


AMERICAN HISTORY 


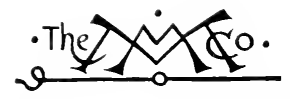

THF, MACMLLAN COMPAXY

NEW YORK - BOSTON - CMICAGO - DALlAS

ATLANTA - SAN FRANCISCO

MACMILLAN \& CO., LiMTED

LONDON - BOMBAY - CALCLTTA

MELBOLKNE

THE MACMLLAN CO. OF CANADA, LtD.

TOKONTO 


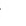




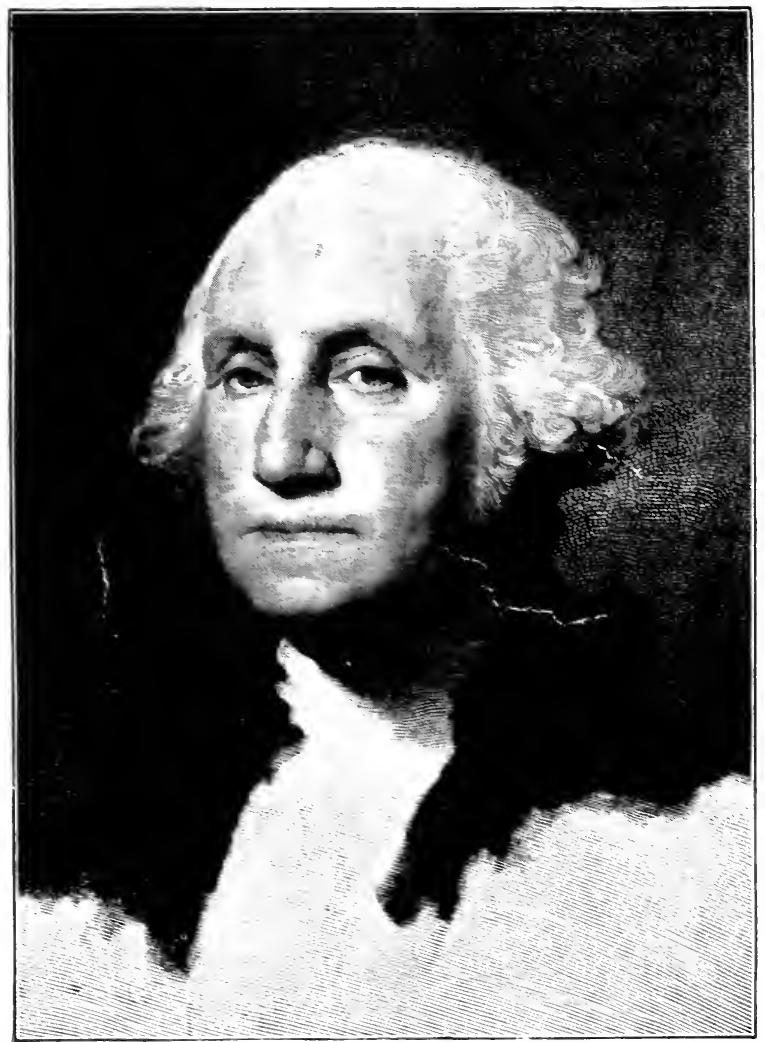

Geurge Washixgtox 


\section{AMERICAN HISTORY}

For Use in Secondary Sibools

\section{BY}

\section{ROSCOE LEWIS ASHIEY}

AUTHOR OF "THE AMERICAN FEINEAL, STATE;"

"AMERICAN GOVERNMENT," ETC.

REITSEI EIDITION

Mrew Mark

THE MACMILLAN COMPANY

LONDON : MACMILLAN \& CO., LTD.

I 9 I

All rights reserved 
COPYRIGHT, I907,

By THE MACMILLAN COMPANY.

COPYRIGHT, I9I4,

By THE MACMILLAN COMPANY.

Set up and electrotyped. Published June, r907 Reprinted September, rgo7: November. Igo8; October, rgo9; May, October, rgro; July, Igrr; January, August, Igr2.

Revised Edition, May, rgr4.

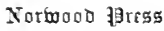

J. s. Cushing Co. - Berwiek os smith Co.

Norwood, Mass., L's.A.

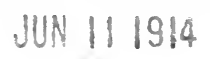

C. CH:3\%1:38:1 


\section{PREFACE}

In this volume the author has treated the topics and suggested the methods that he has found most satisfactory with his own classes. As the development of the nation has been the main theme, many subjects often treated in high school texts have been discarded as non-essential. Many others not connected closely with our national development have been of sufficient interest or importance to 1 ceive attention in separate chapters. In order to make as clear as possible the general course of American development and to explain the character of the principal movement within each short period of the nation's life, the subjects have been grouped under topical heads. The author has hoped to indicate by this means the relation of each historical change to the movement of the times and the relation of this smaller movement to the larger phases of our development which are given in the chapters.

The author regrets that in the preparation of this book he has not been able to consult the later volumes of The American Nation and cannot give references to these volumes. He wishes to express to Messrs. Harper and Brothers his appreciation for the opportunity to examine proofs of two of these volumes, and to Messrs. Houghton, Mifflin \& Company for the use of two maps from Winsor's Narrative and Critical History of America. He takes pleasure in acknowledging the many helpful suggestions and criticisms offered by President Kendric C. Babcock of the University of Arizona, Mr. Haven W. Edwards of the Redlands High School, and Miss Anna V. McNair of the Pasadena High School. 


\section{PREFACE FOR REVISED EDITION}

In this revision no attempt has been made to consider any events except those of the last quarter century. A consecutive account is given of the most important events of the twentieth century, and full recognition is given to important recent movements, political, economic, and social.

PASADENA, CALIFORNIA, February, I9I4. 


\section{SUGGESTIONS}

ON account of the limited time at the disposal of high school pupils, the marginal references have been selected with care. Most of them will be found in the average public library, and a fair proportion in the ordinary high school library. Many of the groups of marginal references can be used for topics to supplement the lists given at the ends of the chapters.

The following lists of books will probably be found most useful in connection with this text. As duplicates are always more useful for class use than even a large number of titles, a large high school library would probably contain a much larger number of books from the first and second lists than from the third.

\section{A SMALI, LIBRARY}

One or more copies of each of the following:Cambridge Modern History', Vol. VII. Coman, Industrial llistory of the Lnited States. MaCDonali1, Select Documents of Linited States History (1 776-186r). Burgess, Middle Period. DODGE, Bird's ty'e Tieze of the Cizil W' Tar. HART (ed.), American History told by' Contemporaries, Vol. IV. American Ilistory I.eafets, Nos. 4, 5, 23, 30.

\section{A MEDIUM-SIZED LIBRARY}

Selected from the books given above and the following:Epochs of American History, 3 volumes.

Channing and HakT, Guide to American History. MacDonald, Select Charters Illustratize of American History. MacDonaln, Select Statutes of United States History.

The American Nation:-

Bourne, Spain in America.

ANDrews, Colonial Self-Government. 
Howard, Preliminaries of the Rerolution.

VAN TYNe, The Ameriall Realution:

McLavghum, confederation and the Constitution.

TURNer, Rise of the l'a' W'st.

HART, Abolition and Sla'e' 'y.

Channinc, Mistory' of the L'nitid States, Vol. I.

Pakknax, Strugurle for a Contine'nt.

Fiske, Critical f'rriod of American History.

AsHler, Amerian Fideral State.

HakT, Actual Gorernment.

HAkT (ed.), American History tolit by Contemporaries, 4 volumes.

American History leaflits.

Old South Leaflets.

Dewer, Financial History of the ("nited States.

Foster, A Century of Amerian Diplomacy.

Jonsston, American Political History, 2 volumes.

Bukless, Midlle Periol.

Burcess, Cizil IV'ar and the Constitution, Vol. I.

Staxwoon, History of the Presidency.

AxDkews, The Lnited States in our Oa'n Time.

LAkxed (ed.), History for Reduly lieference, Vol. VI.

Elson, History' of the L "nitid State's.

\section{A LARGE LIBRARY}

Selected from the books given above and the following:Winson, Varratize and Critical History of tmeria, S volumes.

* The American . Viation, rest of the 27 volumes.

* Fiske, i 3 volumes on American history.

* Senple, Amerian History and its Corgrafic Conditions.

BrighaM, Geografhic Influinic's in theriatn History.

OGe, (ofening of the .Mississiphi.

Egaleston, Begrinnirs of a Viation.

Frothixgham, hise of the Repulic.

Longe, Short Histery of the English Colonies.

Durle, English Colonies, 5 volumes.

Johnston (Woonburi) (eds.), Amerian Eloquence, 4 volumes.

Roosevelt, Winning of the ll'st, + volumes.

*Talssig, Tariff Histery of the L'nitid States.

Schouler, Histoy of the linited Statis $\left(17 S_{j}-16_{5}\right), 6$ volumes.

* McMaster, History of the People of the ("nited States (17 $\mathrm{S}_{3}-\mathrm{IS60}$ )

7 volumes published.

White, .Mone'y and fankingr.

*Rhodes, Histery of the L United State's since the Compromise of 1850 , 
American Statesmen Series; especially volumes on Franklin, *Washington, *Hamilton, *Webster, *(lay, *(alhoun, Lincoln, Benton, Chase, Seward, and Blaine.

American commonitealth Series; especially rolumes on Virginia, Maryland, Connecticut, Missouri, Indiana, Kentucky, Texas, Louisiana, and liansas.

Larned, History for Recady Riference, 6 volumes.

* Sparks, Expansion of the L'nited States.

Blane, Tiuenty lears of (ongress.

Cox, Three Decades of Fedical Legislation.

Burgess, Ciril Ilar and the Constitation, Vol. II.

Johrson, thar of Secission.

Woon-Enmudas, Ciatl II ar in the L'nited States.

Battles and lecaders of the (ivil II'ar, + volumes.

Bukgess, Reconstruction and the Constitution.

Foster, American Diplomacy in the Orint.

Johnson, Amerian Railaiay Transportation.

Those starred in this list should be included in list II if possible. 


\title{
CONTENTS
}

\author{
PART I
}

THE COLONIAL PERIOD (1492-I763)

\author{
CHAP'TER I \\ CONDITIONS AFELCTING COLONIZATION IN \\ AMIERICA. I-23
}

SECTION

I.

Introduction

Geographical Conditions :

2. Geography and American colonization . . . . 2

3. Climate and rainfall . . . . . . . . 3

4. Natural resources . . . . . . . . 5

5. Ceographical divisions of the United States . . . 7

6. Influence of geography on English colonization . . 8

7. Geographical advantages of the French colonies . . ro

The North American Indian :

8. The Inclian tribes . . . . . • • . II

9. Life and character of the Indians . . . . . . I3

10. General relations of Indians and Whites . • . . 14

I I. Help given to the English by the Indians. • • . I5

12. Results of Indian wars . . . . . . . 16

Europe during the Fifteenth Century:

13. Comnection hetween the history of Europe and America - 17

I4. Political Europe after 1450 . . . . . . 18

I5. Tracte with the East before I475 . $\quad . \quad$. $\quad . \quad$. 19

I6. Search for new sea ruutes to India . . . . . 20

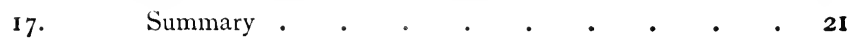

\section{CHAPTER II}

THE FIRST CENTURY (I492-1600). 24-39

The Discovery of a New World:

18. Preparation of ('olumbus . . . • • . 24

19. Columbus's first voyage • • • • • • 25 
SECTION

20. The Pope's division of the earth . . . . . 26

21. Later voyages of Columbus . • • • • • 27

22. The Cabots . . . . . . . 28

23. Vespucius and the naming of America . . . 29

24. The Pacific Ocean . . . . . . . . 30

Explorations in the United States ( $\left.1513^{-1} 543\right)$ :

25. Florida (1513-1536). . . . . 。 30

26. The Southwest (1539-1543) . . . . . • 3 I

27. De Soto . • . • • . • • • . 32

28. Verrazano and Cartier . . . . . . . 32

The Close of the Sixteenth Century:

29. The situation in Europe . • • • • • 33

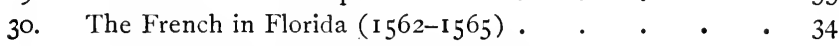

31. The English in the New World (1562-I583) . . . 35

32. The Ralegh colonies (I $584-1590)$. • . . 36

33. The results of the first century . • • • • 37

\section{CHAPTER III}

EARLY ENGLISH COLONIZATION (I600-I660). 40-62

Virginia (1606-1625):

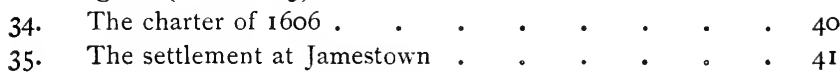

36. The influence of tobacco culture . . . . . 42

37. The first Virginia assembly (1619) . . . . . 43

38. Virginia becomes a royal province (1624). . . . 43

New England before 1628 :

39. The Plymouth Company and the Council for New England 44

40. The English Puritans . . . . . . . 46

41. The Puritans and the English monarchs . . . . 47

42. The Pilgrim migrations . . . . . . 48

43. Early history of New Plymouth . . . . . • 48

Beginnings of Massachusetts Bay (1628-1626):

44. The Massachusetts Bay Company . • • . . 49

45. King Charles and the Puritans . . . . . . 50

46. Character of the Massachusetts Bay colony . . . 5 I

47. Political problems and dangers . . . . . 52

48. Religious difficulties . • • • • • • 53

Expansion in New England (1635-1645):

49. Providence plantations and Rhode Island _ . 54

50. The Connecticut Valley • . • , , 55 
SECTION

PAGE

5I. New Haven . . • . • • . . 56

52. Northern New England • • • • • • 57

53. The New England confederation (I643) • . . 57

Maryland :

54. The charter of Maryland (1632) • • • • . 59

55. The proprietor and the freeman . . . . . 60

56. Religious toleration . . . . . . . . 60

57. Summary . . . . . . . . . 6I

\section{CHAPTER IV}

LATER ENGLISH COLONIZATION (I660-I700). 63-85

58.

Commercial situation of England about 1660 . $\quad 63$

59.

England and the Colonies (1660-1685) • • • 64

New York ( $\left.1609-168_{5}\right)$ :

6o. The founding of New Netherland . . . . . 65

61. The province of New Netherland . . . . . 65

62. New Netherland and its neighbors . . . . . 67

63. Conquest of New Netherland (1664) . . . . 67

64. The English in New York $(1664-1685)$. . . . 68

The Quaker Colonies :

65. New Jersey and the Quakers . • • . . 69

66. Penn and his colony. . . . . . . . 70

67. The government of Pennsylvania . • . . . 7 I

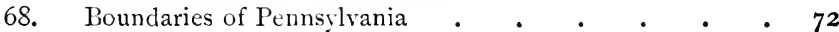

The South after the Restoration (I660-I730):

69. Misgovernment in Virginia (1660-1676) . • • • 73

70. Bacon's rebellion $(1676)$. . . . . . . 74

71. The Carolina charters (1663-1665) . . . . . 75

72. Proprietary government in Carolina (1667-1729) • . 75

New England (1655-I685):

73. Problems of New England (1655-1675) . . . . 76

74. King Philip's war (1675-1676) . . . . . 77

75. Massachusetts and the Crown (1675-1684) • . . 78

The Great Revolution (1685-1700):

76. The Dominion of New England . . • • 79

77. The revolution of 1689 in England and New England . 80

78. Revolutionary movements in the Middle and Southern

Colonies. . . . . . . . 82

79. Results of the revolution in America o . . . 83

So. The colonies in I 700 . . . . . 84 


\section{CHAPTER V}

RIVALRY OF FRENCH AND ENGLISH ( $\left.1689-1 ; 6_{3}\right)$ $\mathrm{SO}-\mathrm{IO}_{3}$

SECTION

SI. Introduction

French Exploration and Settlement :

S2. Founcling of New linance . . . . . . S6

S. Exploration of the llest . . . . . . . S3

S. Louisiana $(1099-1720) . . . . .59$

French and English Colonies (1680-1754):

S5. The Treaty of Ltrecht $(1 ; 13)$. . . . . So

So. Georgia . . . . . . . . . ol

$\mathrm{S}_{7}$. The English colonists and their goremors . . . 92

Ss. Govermment of the French colonies . . . . . 93

So. lreparation for the timal contlict . . . 94

Expulsion of the French $(175+-1703)$ :

9o. The struggle for the upper (Ohio valley. . . . 95

9r. The situation in America and in Eunpe . . . 95

92. The tirst period of the war $(1754-175 ;)$. . . . 97

93. The second period of the war $(1755-1700) .$. os

94. The Peace of Paris $\left(\mathbf{I}_{7}-\mathrm{O}_{3}\right)$. . . . . 99

95. Summiry. . . . . . . . . 101

\section{CHAPTER Yi}

COLONIAL CONDITIONS (1750). IO4-126

Population and socicty:

96. Number of the people . . . . . . . 104

97. Classes of society. . . . . . . 105

gs. Indented serrants . . . . . . . 100

oo. Slavery. . . . . . . . 106

100. Colonial lite . . . . . . . IOS

Occupations:

10I. Agriculture . . . . . . . IIO

102. Commerce and shipping. . . . . . III

103. Industry and labor. . . . . . . I12

104. Colonial currency . . . . . . . . I13

105. The protessions . . . . . . . . IIt

Miscellaneous Conditions:

106. Colonial churches . . . . . . . I15

107. Superstition . . . . . . . . 110 


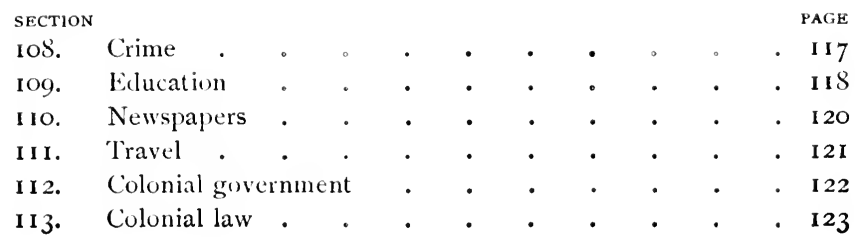

\section{PART II}

\section{THE FORMATION OF A UNION (1763-1789)}

\section{CIIAP'TER VII}

\section{THE BEGINNINGS OF REVOLUTION (1763-1775)

$$
\text { I 27-I } 53
$$

I14. Colonial self-government and English control before

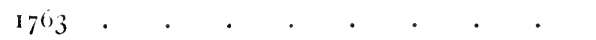

The Old (olonial Policy of England:

I 5. General methods of colonial control

- 28

116. England's interference with colonial government . . I28

117. Lingland's control through colonial officials . . . . I 29

I I8. Control of colonial legislation . . . . . . . Izo

119. Farly acts of tracle $(1660-1696)$. . . . . 131

120. Later Restrictive Legislation (1696-1760) . . . 132

I21. General effect of the commercial system . . . . 133

I22. The writs of assistance . . . . . . . . I 34

The New Pritish Colonial Policy $\left(\mathbf{1}_{7} 6_{3}-\mathbf{1} 76_{7}\right)$ :

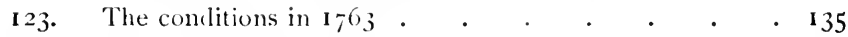

124. George III and his ministers $(1760-1792)$. . . 136

125. The establishment of a colonial army $\left(\mathbf{I}^{6} \mathrm{\sigma}_{3}\right) . \quad$. 137

126. The Sugar Act of 1764 . . . . . . . . I $_{3} 8$

127. The Stamp Act . . . . . . . . . . 139

128. Reception of the Stamp Act . . . . . . . Ifo

129. The Stamp Act congress . . . . . . . IfI

130. The repeal of the Stamp Act. . . . . . I42

131. English and American illeas of representation. . . I43

132. The Townshend Acts $(1767)$. . . . . . 144

Disorder and Organized Opposition (1767-1775):

133. The reception of the Townshencl Acts . . . . 145

134. Growing disorder (1768-1770) . . . . 146

135. The committees of correspondence (1772-1773) . . 147

136. The tea $\operatorname{tax}$. . . . . . . 147 
SECTION

I37. The repressive acts (I774) . . . . . 148

138. The First Continental Congress (1774) . . . . 149

139. The inevitableness of war . . . . . . 150

140. Summary. . . . . . . . . I5I

\section{CHAPTER VIII}

THE REVOLUTIONARY WAR (I775-1783). I54-I88

Revolt and Independence:

14I. Events around Boston (I775).

142. The war on the northern border $\left(\mathbf{I} 775^{-1} 776\right)$. . . I55

143. Change in the theater of war $(1776)$. . . 156

144. The Second Continental Congress (1775-1776) . . 157

145. The movement toward independence . . . . 157

146. The character of the Declaration . . . . . I59

147. The first state governments . . . . . . I60

Conditions Affecting American Success :

I48. The theater of war . . . . . . . . I6I

149. British military organization and policy . . . . I62

I50. The American army . . . . . . . 162

I5I. The loyalists . . . . . . . . . I64

152. The finances of the revolution. . . . . I64

153. Continental currency . . . . • . . 165

The Campaigns of 1776 and 1777 :

154. The movement against New York (1776) . . . 167

155. The Trenton-Princeton campaign . . . . . I68

156. The plan of campaign (I 777), Philadelphia . . . 169

I57. Burgoyne's advance (I777) . . . . . . I7 r

158. The surrender of Burgoyne (1777). • . . . 172

Changed Conditions ( $\left.177^{8-1} 779\right)$ :

I59. French aid before 1778 . . . • . • . I73

160. The French alliance $(\mathbf{I} 778)$. . . . . . 174

I6I. Attempted conciliation by the British (1778) . . . I75

I62. Intrigue and neglect $(\mathbf{I} 778)$. . . . . . I I 6

163. The naval war $(\mathbf{I} 776-\mathrm{I} 782)$. . . . . 176

164. The war in the North and West (1778-1779). . . I77

The Close of the War (1780-I78I):

165. British success in the South (1780) • . . 178

166. The treason of Arnold (1780) . . . . . 179

167. Campaigns in the South (1780-1781) . . . . I80

168. Yorktown $(\mathbf{I} 78 \mathrm{I})$. $. \quad . \quad . \quad . \quad . \quad . \quad$ I 82 
The Treaty of Peace $\left(I_{7} \delta_{2}-I_{7} s_{3}\right)$ :

I69. Conditions affecting the Treaty of Peace. . . . I83

I 7o. Claims and negotiations $(1782) \quad . \quad . \quad . \quad . \quad$ I 84

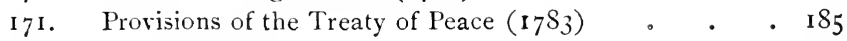

I72. Summary . . . . . . . . 186

\section{CHAPTER IX}

CREATION OF A GENERAL GOVERNMENT (I78II789). I89-2I7

The Articles of Confederation:

173. Formation of the Confederation . . . . . $\quad$ I 89

174. Provisions of the Articles of Cunfederation . . . . I 89

I75. The league of states . . . . . . . Igo

I76. The amendment of the Articles of Confederation . . I9I

The Critical Period $\left(I_{7} S_{I-1}{ }_{7} S_{7}\right)$ :

I77. Critical conditions.

I78. The old soldiers . . . . . . . . . . 192

I79. Land claims of the states . . . . . 193

ISo. Land cessions (I $\left.7 S_{I-I S O 2}\right)$. . . . . . 194

ISI. Ordinances for the government of western territory . I95

IS2. The West and foreign affairs . . . . . . I96

183. Relations with Great Britain . . . . . . 197

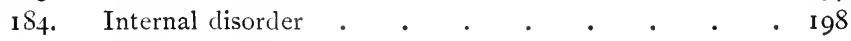

Formation of the Constitution ( $\left.{ }_{7} S_{7}-178 S\right)$ :

I 5 . The Annapolis conference . . . . . . 200

I86. The Connecticut compromise . . . . . . 20 I

I\$7. Later history of the convention . . . . . 202

I88. Feeling of the people . . . . . . 203

I89. Ratification of the Constitution by the states . . . 204

Character of the Constitution :

I90. Dispute over the nature of the Constitution . . . 204

I9I. The nation and the states . . . . . 205

192. Congress . . . . . . . . . 206

193. The president . . . . . . . . . 206

194. The courts . . . . . . . . . 207

195. Amendment of the Constitution . . . . . 207

196. The sources of the Constitution . . . . . 208

The Organization of the New Government (I789):

197. The presidency

I98. Beginnings of the new congress

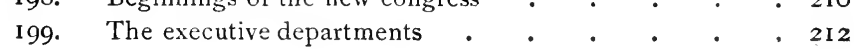


SECTION

200.

The national judiciary .

201.

Summary .

\section{CHAPTER $\mathrm{X}$}

THE ClOSE OF THE XVIII CENTURY. 218-23o

Social Conditions :

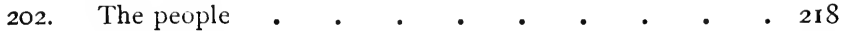

203. The frontier . . . . . . . . . 219

204. The admission of new states . . . . . . 220

205. The movement toward emancipation . . . . $22 \mathrm{I}$

206. The cotton gin and slavery . • . • . . 222

Political and Religious Changes:

207. Voters and officeholders . • . • • • . 223

208. Tendencies toward democracy . . . . . 223

209. Religious freedom . . . . . . . . 224

Economic Conditions :

2 Iо. Commerce • • • • 。 • • 。 . 225

211. Industry . . . . . . . 。 . . 226

212. Currency . • . . . . • • • • 227

213. Improved means of communication. . . . 228

\section{PART III}

\section{DEVELOPMENT OF THE NATION (I789-I843)}

\section{CHAP'TER XI}

FOREIGN AND DOMESTIC PROBLEMS (1789-I8II). 23I-268

214. Problems confronting the new government (1789) . 231

Financial Policy and Political Parties (I 790-1 793)

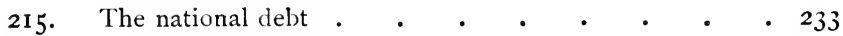

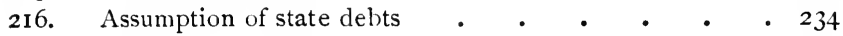

217. New national taxes . . . . . . . . 235

218. The United States bank . . . • • • . 236

219. The formation of political parties . • • • 237

Foreign Affairs (1793-1798) :

220. Difficulties with France (1793) • • • • 238

221. Grievances against England (1794) • • • • 239

222. Jay's treaty (1794). . . . . • • . 240

223. The close of Washington's administration . . $\quad 242$ 
224. Trouble with France (1796-1Soo) • . . . . 243

Federalists and Republicans (I798-1802):

225. The Alien and Sedition laws (179S)

226. The Kentucky and Virginia resolutions (I798-1799) • 245

227. The election of 1800 . . . . . . . 246

228. Jefferson and his party . . • • • • . 247

229. Reversal of Federalist practices . • . . . 249

230. The national courts. . . . . . . 250

Western Problems (ISoo-1So6):

231. Disputes over the lower Mississippi River . • . 252

232. The purchase of Louisiana • • • • • . 253

233. Extent and importance of Louisiana • • • 255

234. The Burr conspiracy (rSo5-1So6) • • • • . 256

Commercial Warfare (1So5-1811):

235. European war and American commerce before 1So6 • 257

236. The impressment of American seamen . • • . 259

237. Orders and decrees (1So6-1So7) . . . . . 260

238. The Embargo (ISo7) . . . . . . . 260

239. Indirect results of the Embargo . . . . . 262

240. The Non-Intercourse Act (ISog) • • • • . 263

24I. The Macon bill No. 2 (ISIO) . . . . . . 264

242. Summary • . • . • • • • . 265

\section{CHAPTER XII}

\section{A NEW NATIONAL SPIRIT (I8II-I824). 269-294}

The Second War of Independence :

243. Events learling to war (18I1-ISI2)

244. Declaration of war (IS12) . . . . 269

245. War in the North (ISI2-ISI3) . . . . . 270

246. The war on the ocean (1812-1814) . . . . 272

247. The last year of the war . . . . . . 273

248. The Treaty of Ghent (1814) • • • • • 274

Changed Conditions after the War of 1812:

249. The new nationality . . . • • • 275

250. Our altered international standing . . . . . 276

25I. Downfall of the Federalist party . . . . 277

252. The tariff of 1816 . . . . . . . . 278

253. The second national bank . • • • • . 279

254. The supreme Court . . . • • . . 280

255. The development of the West . . . . . . 28 I 
SECTION

256. Internal improvements . . • . . . 282

257. Importance of the westward movement . • . . 283

Slavery and Foreign Affairs (I819-1824):

258. The Missouri Bill (ISIS-r\$19) . • • . . 284

259. The Missouri problem . • . • • • . 285

260. The Missouri Compromises (I820-182I) • . 286

261. Florida . . . . . . . • • . 288

262. The Monroe Doctrine (1823) . . . . . 289

263. Summary . . . . . • . • . $29 \mathrm{I}$

\section{CHAPTER XIII}

NATIONAL DEMOCRACY (1824-1843). 295-316

The Triumph of Democracy (1824-1829):

264. The presidential election of $1824 .+. \quad .295$

265. New political parties . . . . 。 . 297

266. The election of Jackson ( $\mathrm{I} S 2 S)$. . . . 298

267. The importance of Jackson's election . . . . 298

268. New political methods . . • • • • . 300

269. The spoils system . • . • . . . . 30I

National Sovereignty versus State Sovereignty (IS26I833):

270. Controversies over Indian lands . • • • 302

27. The Webster-Hayne debate $\left(\mathrm{I}_{3} \mathrm{O}\right)$...$\quad 303$

272. Changes in the tariff $\left(1 \mathrm{I}_{24}-\mathrm{I} S_{32}\right) \cdot . \cdot . \quad 304$

273. The South and the tariff . . . . . . 305

274. Nullification and the compromise tariff . • . 306

Finance and Politics (1829-1843):

275. First attack on the United States bank . . . 307

276. Overthrow of the bank . . . . . . 308

277. Government revenues and the panic of $1 \delta_{37}$. . . 310

278. Administration of Van Buren $(\mathbf{I} 837-\mathbf{I} 84 \mathrm{I}) \cdot . \quad$. 3 II

279. The election of Harrison (IS40) • • • • • 3II

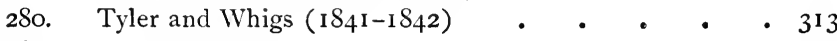

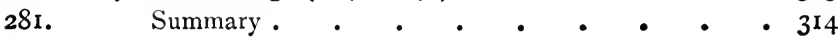

\section{CHAPTER XIV}

A HALF CENTURY OF CHANGES. 317-338

Transportation and Business (I $\$$ I $\left._{5-1} 860\right)$ :

282. The steamboat

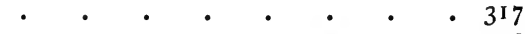

283. The era of canals . . . . . • $\quad 318$ 
SECTION

PAGE

284. Railways . • . • • • • • • • 319

285. Significance of improved means of transportation . . 320

286. The telegraph and other inveritions . • . 322

287. Industrial changes after 1810 . . . . . $\quad 323$

2S8. The era of "free trade" (1846-1857) . • . . 324

Political and Social Changes:

289. Opening of the government lands . • • . 325

290. Development of Democracy . • • • . . 326

291. Changes in the states . . . • • . 328

292. Social legislation . • • • • • • • 329

293. Newspapers and education . • • • • 329

294. American cities . • • • • • • • 331

Free and Slave States :

295. Growth of the United States . • • • • • 33 I

296. Foreign immigration . • • • • • • 333

297. The admission of new states . • • • • 334

298. Early abolitionists . . . . . . . . 335

299. Abolition and petition (1835-1840) . . . 336

\section{PART IV}

THE STRUGGLE OVER SLAVERY (1843-I877)

\section{CHAPTER XV}

SLAVERY IN THE TERRITORIES (1843-1857). 339-365 300. Introduction

Territorial Expansion (1843-1848):

301. Texas before 1843

302. The annexation of Texas (1843-1845) . . . • $34 \mathrm{I}$

303. Oregon territory to 1846 . $\quad . \quad$. $\quad . \quad \cdot \quad \cdot \quad \cdot 343$

304. War with Mexico (1846-1847) . . . . . 344

305. Conquest of California. Peace • • • • • 346

Slavery in New Territory (1848-1853):

306. The Wilmot proviso . . . . • . 347

307. Oregon Territory; election of 1848 . . . . 348

308. California . . . . . . . . . 349

309. The elements of a compromise (1850) . . . . 350

310. Discussion of the compromise . . . . . . $35 \mathrm{I}$

311. Completion of the compromise of 1850 . . . . $35^{2}$ 
SECTION

312. The fugitive slave law

313. Attempts to gain more slave territory • • • • 354

Slavery in Old Territory ( $\left.1 S_{54-1} S_{57}\right)$ :

314. The Kansas-Nebraska bill $\left(1 S_{54}\right)$.

315. Passage of the Kansas-Nebraska Act $\left(18_{54}\right)$. . . 356

316. Reorganization of political parties . . . . . 358

317. The struggle for Kansas $\left(\mathbf{I} \$_{55-1} S_{61}\right)$. . . 359

3I8. The case of Dred $S \operatorname{cott}\left(1 S_{57}\right)$. . . . 360

319. Summary . . . . . . . . 36 I

\section{CHAPTER XVI}

DISUNION AND CINIL WAR (1857-I86I). 366-398

Approaching a Crisis ( $\left.\mathrm{S}_{57-1} 860\right)$ :

320. The situation in $1 S_{57}$

321. Political factions and parties . . . . . .367

322. The Lincoln-Douglas debates $\left(\mathrm{r}_{5} S\right)$. . . . $3^{68}$

323. Union and slavery . . . . . . . 369

324. Influence of John Brown's raid $\left(1 S_{59}\right) \cdot . \quad . \quad$. 370

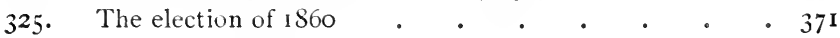

The Secession Movement (IS60-1 S6I):

326. Secession in South Carolina (December, IS60) • . 373

327. Attempted conciliation (December-January) . • . 374

328. The Confederate States of America . . . • 375

329. Close of Buchanan's term . . . . . . 377

330. Fundamental causes of secession . . . . . 378

33r. Slavery and state sovereignty versus nationality . $\quad 379$

Lincoln; "The Three Months' War":

332. Lincoln's policy . . . • . • • . 3So

333. Sumter . . . . . . . . . $.38 \mathbf{r}$

334. Preparation for war. . . . . . . . $33_{2}$

335. The border states . . . . . . . . 383

336. Bull Run • • • • • • • • • 384

Conditions Affecting Union Success :

337. Resources of North and South . • • . . 386

339. The southern armies . . . . . . ${ }^{3} 87$

339. The northern armies . . . • . . . 397

340. The navies; the blockade . . . . . . 3S9

341. Foreign relations (IS6I-IS65). . . . . 390

342. Bonds and a national banking system . . . . 39 I

343. Greenbacks and taxes . . . . . 392 
344. Southern finances and government . . . . 393

345. Critical situation at the North . . . . . 394

346. Summary .

\section{CHAP'TER XVII}

PROSECUTION OF THE WAR (I862-1865). 399-430

Spring and Summer of I $\$ 62$ :

347. Theater of war in the IVest

348. Grant's campaign in the West (to February, I862). . 40I

349. Completion of the Western Tennessee campaign . . 403

350. New Orleans (1S62) . . . . . . . 404

35 i. The theater of war in Virginia. . . . . . 405

352. Monitor and Merrimac . . . . . . . . . 407

353. McClellan's peninsular campaign . . . . . 407

The Middle Period of the War (August, I S62-June, I863):

354. The fall of 1862 . • . . • • • 4 IO

355. Events leading to emancipation . . . . . 4II

356. Emancipation. . . . . . . . . 4 412

357. Chancellorsville; Lee's second invasion . • . . 414

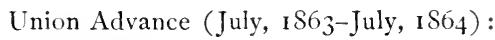

358. Gettysburg . • . . . . • . . 4 45

359. Vicksburg . . . . . . . . . . . . 416

360. Operations around Chattanooga (is63) . . . . 4 I8

36r. Naval operations (1864). . . . . . . 4 49

362. The advance on Atlanta (1864) . • . . . 42I

363. Grant in Virginia (May-July, I864) . • • . 422

The Close of the War (July, I864-April, I 865):

364. The Shenandoah valley; Hood in Tennessee . • • 423

365. Sherman in Georgia and the Carolinas . . . . 424

366. The end of the war . . . . . . . . 424

367. The people and Lincoln's government . • • • 426

368. Summary of the campaigns . • • • • 427

369. Conclusion . . . . . . . . . 428

\section{CHAPTER XVIII}

POLITICAL，RECONSTRUCTION (I865-I877)

$$
43 \mathrm{I}-45^{2}
$$

370. Lincoln, Johnson, and Reconstruction . . . 43 I

Reconstruction ( $\left.1865^{-1} \$ 70\right)$ :

371. The problem of reconstruction 
SECTION PAGE

372. Status of seceding states . . . . . . . . 433

37. Restoration under Johnson (1S65).. . . . . 434

374. Freedmen legislation . . . . . . . 436

375. Civil rights bill and amendment XIV (IS66) . • . 437

370. Military reconstruction $(1 S 0 j-1 S j 0)$. . . . $43 S$

Incidents of the Reconstruction Period $(1 \$ 6 ;-1 S ; 7)$ :

377. The impeachment of Johnson . . . . . . 439

37 S. Carpetbag govermment in the South . . . . 4tI

379. City sovernment and corruption . . . . . + + 42

35o. The administrations of (irant (IS60-1S;7) . . . 443

3 Sr. National political scandals . . . . • . 4t4

3\$2. The disputed clection of 1576 . $. \quad . \quad . \quad 445$

National Changes (1Sor-1ST/):

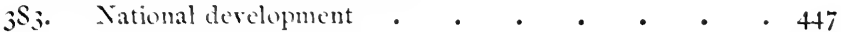

3 S. Changes in the written Constitution . . . . 44S

35. Changes in the unwritten constitution . . . . 4+9

3\$6. The national govermment . • • • • • 449

${ }_{3} S_{7}$. New national industrial conditions . . . . 450

\section{PART V}

\section{THE NEW NATION (IS65-I907)}

\section{CHAPTER XIX}

INTERNAL DEVELOPMENT (IS65-ISS6́). 453-473

$3 S$. Changes following the war

Financial and Industrial Readjustment (IS65-IS79):

3 S9. lionds and taxes after the war

390. The greenbacks . $\cdot 45+$

391. Laws relating to silver . . . . . . . + +56

392. lusiness after the war . . . . . . . + . . . .

39. Agriculture and the West . . . . . $45 \mathrm{~S}$

Transportation Problems (IS65-ISS 7 ):

394. Derelopment of the lliest by means of the railways . 460

395. Railway abuses . . . . . . . . 46 I

396. The granger movement and railway legislation . 462

397. The interstate commerce commission $\left(15 S_{7}\right) . \quad 4_{3}$

Political Changes and Reforms (IS;7-1SSo ): 
SECTION

PAGE

399. The election of Cleveland (1884) • • • • . 465

400. The spoils system and reform . • . . • . 467

40r. Progress of civil service reform since 1883 • • • 468

402. Reform of elections . . . . • . . 469

403. Changes affecting the presidency . • • . . 470

404. Summary . • . • • . • • 47 I

\section{CHAP'TER XX}

THE ENI) OF AN ERA (1886-1897). 405-422

SECTION

PAGE

The Tariff:

405. Proposed reform of the tariff (ISS2-1S88) . . . 474

406. The election of $1888 . .0 . .475$

407. The Mckinley tariff (ISyO) . . . . . 476

408. The Gorman-WVilson tariff; the income tax (I894) , 477

409. Recent tariffs . . . . . . . . 478

The Silver Controversy (1 $\$ 93-\mathbf{1} 897)$ :

410. The Sherman silver act (1890) and the treasury . . 478

4II. The free silver movement in the West. . . 480

412. Election of $1 S 96$. . . . . $4 \$ \mathbf{I}$

413. Republican policies . . . . . 482

Foreign Affairs (I $\$ 65-1895)$ :

414. Disputes with England . . . . . . $48_{3}$

415. Samoa . . . . . . 485

4I6. Ilawaii . . . . . . 486

417. Pan-American Congresses . . . . . . 487

4I8. The Monroe Doctrine and Mexico after the Civil War . 488

419. The dispute over the boundary of Venezuela (r\$95) . 488

420. The settlement of the Venezuela eontroversy . . . 489

42I. The Monroe Uoctrine since I $\$ 95$. . . . . 490

422. Summary . . . . . . . . 491

\section{CHAP'TER XXI \\ EXPANSION (1898-1902). $423-44^{8}$}

423. Fundamental changes in the United States after 1 $897 \quad$ • 493

The Spanish-American War:

42. Our relations with Cuba before $1895 \quad$. . . . 494

425. The United States and Cuban Insurrection (I $895-$ I 896$) 495$

426. Dangers to American interests in Cuba (IS97-IS9S) • 496 
SECTION

427. The spring of $\mathrm{IS} 9 \mathrm{~S}$.

42S. The beginning of war . . . . . . 498

429. War on the Atlantic . . . . . . . 500

430. War finance . . . . . . . . . . 502

431. Army administration and reform . . . . . 503

The Care of Wider American Interests :

432. The problem of the Pacific . . . . . 504

433. The treaty of Paris ( $189 S-1 S 99)$. . . 505

434. Philippine insurrection and election of 1900 . . . 506

435. The development of a colonial policy . . . . 507

436. The Philippines since 1900 . . . . . . 508

437. Alaska . . . . . . . . . . 509

43S. Attempts to secure an Isthmian Canal before 1902 . 510

439. Securing a satisfactory route for the canal . . . 5I I

440. Construction of the canal . . . . . . 512

441. Importance of the canal . . . . . 514

The United States as a World Power:

442. The United States as a world power . . . . 515

443. American influence on world peace . . . . 515

444. Relations with Cuba since r 898 . . . . . 516

445. Relations with Mexico . . . . . . • 517

446. Relations with China . . . . . . . 519

447. Relations with Japan . . . . . . 520

448. Summary . . . . . . • . 522

\section{CHAPTER XXII}

\section{RECENT CHANGES (I9OI-I9I4). $\quad 49-466$}

The Roosevelt Policies (I90I-I909):

449.

Mckinley and Roosevelt

450. Roosevelt's "first term". . . . . . . 527

45I. Foreign affairs under Roosevelt . . . . . $52 \mathrm{~S}$

452. Internal policies of Roosevelt's "second term" . . 528

453. Panic. Election of 1908 . . . . 530

The Rule of the People (1906-1913):

454. The war against political misrule . . . . 530

455. The insurgent movement . . . . . . 53 I

456. Reform of political party methods . . . . 532

457. The initiative, the referendum, and the recall . 533 


\section{Contents}

The Movement toward Economic Reform (1909-1914):

458. The beginning of the Taft administration

459. Reform legislation . . . . . . . . . 537

460. The election of rirs . . . . . . . . 538

46I. Constitutional changes . . . . . . . 540

462. The beginning of the Wilson administration . . 54I

463. The Payne-Aldrich tariff . . . . . . . 542

46.4. Democratic tariff measures . . . . . . 544

465. Other financial reform measures . . . . . 545

466. Summary . . . . . . . . . 547

\section{CHAPTER XXIII}

\section{PROGRESS AND PROBLEMS. 467-486}

Commerce and Inclustry:

467. Industrial progress since I 880 . . . . . 550

468. Anti-trust legislation in the states . . . . . $55 \mathrm{I}$

469. The Sherman anti-trust law of 1890 . . . $55^{2}$

470. Recent anti-trust activity . . . . . . 554

47I. Railway rate regulation . . . . . . . . 555

472. Commerce and shipping. . . . . . . 556

Business and Labor:

473. Prosperity and panics since 1865 . . . . 558

474. Labor unions and strikes $(1877-1$ S94) . . . . 559

475. Recent labor problems . . . . . . . . 560

476. Labor legislation . . . . . . . . 562

Political and Social Changes:

477. Population and race problems . . . . . 563

478. Foreign immigration . . . . . . . . 564

479. Growth of cities . . . . . . . . . 566

4 So. City problems $. \quad . \quad . \quad . \quad . \quad . \quad . \quad .569$

$4 \mathrm{~S}$. Legal rights of women . . . . . . . $57 \mathrm{I}$

4 \&2. The distribution of wealth . . . . . . 573

483. The past and the future . . . . . . . 574

The Nation and its Government - A Comparison:

484. Changes of a century and a third . . . . 575

485. Characteristics of American political development . : 576

486. The people, the nation, and the government . . . 577 


\section{APPENDIX}

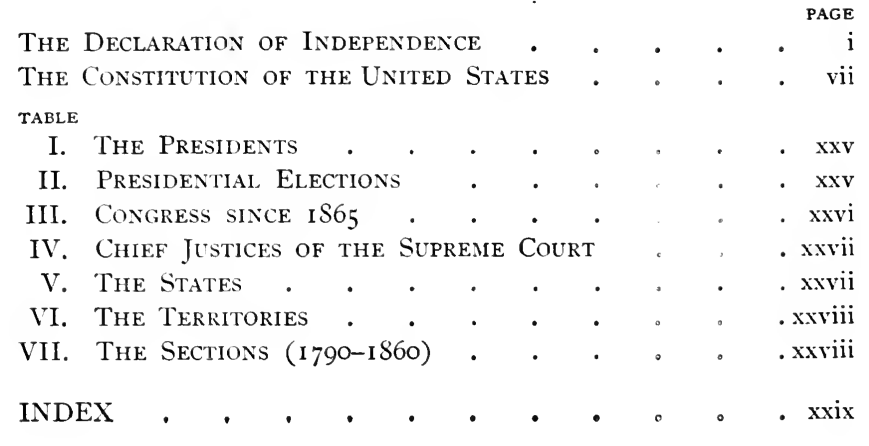




\section{ILLUSTRATIONS}

George Washington

Frontispiece

PAGE

Indians. By MacNeil .

I 2

Columbus

Caravel of Columbus

Sir Walter Ralegh

Captain John Smith

A Puritan. By st. Gaudens

Roger Williams

New York in the Xril Century (New Amsterdam) . . . 66

William Penn

Pine tree shilling. $. \quad . \quad . \quad . \quad . \quad . \quad . \quad . \quad \cdot 77$

Champlain . $. \quad . \quad . \quad . \quad . \quad . \quad . \quad . \quad . \quad . \quad S_{7}$

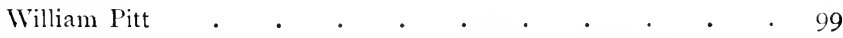

Fireplace in a colonial kitchen. From Mrs. Earle's "Home Life in Colonial Days" . . . . . . . . . . r IoS A colonial hall. From Mrs. Earle's "Ilome Lite in Colonial

Days" . . . . . . . . . . I 109

A colonial church . . . . . . . . . . .

Pillory

Page from an old school book ..$\quad \cdot \quad \cdot \quad \cdot \quad \cdot \quad$ II8

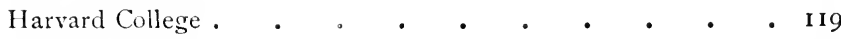

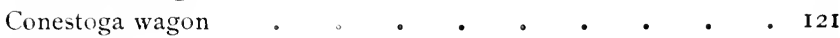

James Otis • • • • • • • • • • . 135

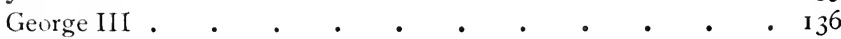

Patrick Henry . . . . . . . . . . 140

The first United States flag . . . . . . . . I59

A Continental bill . . . . . . . . . I66

Benjamin Franklin . . . . • . . • . 174

Nathanael Greene . . . . . . . . . I8I

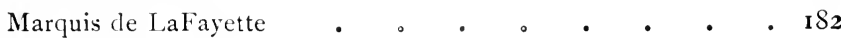

Robert Morris . . . . . . . . . . I9I

James Matison . . . $\quad . \quad$ •

James Wilson . . . . . . . . . . . 202

George Washington. By Savage . . • • • . 2 II

Alexander Hamilton . . . 。 • . . . . 213

An eighteenth century coach . . . . . . . 228

John Jay • • • • • • • • • • • • $24 \mathrm{I}$ 
John Adams

Thumas Jefferson

242

Albert Ciallatin

John Marshall

The Capitol at Washington .

James 1 lonroe

Johu Quincy Alams

Anlrew Jackson .

Martin Van liuren

A log cabin of 1 sto

kailway train in an early day (The Dellitt Clinton engine)

Samuel F. R. Morse and his instrument

249

. 250

$25 \mathrm{I}$

. 273

- 290

- 200

200

- 311

- 312

- 319

Howe's original sewing mathe.

322

William l. lowd ciarrison

- 323

James K. rolk

3.35

Calhoun. Webster, and (lax. He brady.

Stephen A. Douslis

Charles sumuer.

William II. Seward

The rail candidate (carton of ISio).

Jetiersom lowis

Aloraham 1 incoln (the famous braly photograph)

!oseph $1 \%$ gohmston

Salmon l'. Chase.

llysess. Cirant .

kobert k. lee

Geurge B. Miclellin

Antictam bridge.

Fmancipation proclumation (last page)

Themas I. Jackson

Gettysburg Battletich (from I ittle kound Top).

356

- 350

. 370

. 372

. 370

列

. 35

. 392

- 402

- +09

. +10

$+10$

. +13

. +14

William 'T. Sherman

$+15$

Libhe Prison

Andrew Johnson .

Thadileus sterens

The supreme (ourt (ituring the Reconstruction period)

Elwin M. Stanton

- +35

. . . t to

"Who stole the people's money" (Nast's Tweed ring cartoon) $4+3$

Samucl 1. Tiklen

Rutherford li. Haves . . . . • . . . . +46

John sherman

James .1. liarticld

Chester . 1. Arthur

James (i. Haine . 


\begin{tabular}{|c|c|c|c|c|c|c|c|c|c|c|}
\hline Grover Cleveland & . & - & . & - & • & . & . & & . & 407 \\
\hline Benjamin llarrison & - & - & $\cdot$ & $\cdot$ & $\cdot$ & · & $\cdot$ & & . & 475 \\
\hline Inauguration of cleve & lane & $(I S)$ & & . & . & . & . & & . & 479 \\
\hline William J. Bryan & . & . & - & . & . & . & . & & . & $4 S I$ \\
\hline William McKinley & . & $\cdot$ & $\cdot$ & $\cdot$ & $\cdot$ & . & . & $\cdot$ & . & 13 \\
\hline Richard ()lncy & . & . & . & . & . & . & . & • & - & 489 \\
\hline The draine entering 1 & lava & na lia & rloor & . & . & . & . & & - & () \\
\hline Cartom: "lic carcful & & . & $\cdot$ & . & . & . & $\cdot$ & $\cdot$ & . & 497 \\
\hline William 'T. Sampson & - & . & . & - & • & . & - & - & . & 498 \\
\hline The ()rigon & . & . & . & . & . & . & . & & . & 499 \\
\hline (ieorge I)ewey & . & . & . & . & . & . & . & - & . & 500 \\
\hline Signing the peace pro & toc & at 11 & 'aslii & aton. & . & . & . & . & . & 01 \\
\hline Elihu Kont. & . & . & . & . & . & . & . & - & - & 503 \\
\hline A Republican appeal & to $v^{\prime \prime}$ & turs & carte & (1) of & 1900 & & . & . & . & \\
\hline Culelira Cut, l'anama, & beefe & 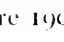 & & . & . & - & $\cdot$ & . & . & 512 \\
\hline John llay . . & . & - & . & . & . & - & $\cdot$ & $\cdot$ & . & 52 \\
\hline Theodore Roosevelt & . & . & . & . & . & . & . & . & · & 526 \\
\hline Water power at Niaga & $\operatorname{ara} 1$ & alls & . & . & . & . & $\cdot$ & . & . & 529 \\
\hline William II. Taft. & . & . & . & . & . & . & $\cdot$ & $\cdot$ & . & 535 \\
\hline Supreme ('ourt in 191 & & . & . & . & . & . & . & $\cdot$ & · & 5.36 \\
\hline Woodrow Wilson & $\cdot$ & $\cdot$ & . & . & . & . & $\cdot$ & . & . & 540 \\
\hline P'resiclent Wilson read & $\operatorname{ling}$ & lis firs & it mes. & sisage th & to & $n g$ & ss & . & . & 543 \\
\hline Lower New lork, sky & $\operatorname{lin}$ & 19) 14 & & . & . & . & . & . & 560 & $-5^{67}$ \\
\hline Thomas A. Flison & . & $\cdot$ & ${ }^{\circ}$ & . & . & . & . & $\cdot$ & $\cdot$ & 568 \\
\hline Main liuilding, Centes & mial & Expo: & sition & 1876 & & . & . & . & $\cdot$ & 68 \\
\hline Court of Ilonor, Chic: & ag(i), & $S 93$ & . & . & . & . & $\cdot$ & . & . & $5^{609}$ \\
\hline (irand basin, Sit. 1، ()ui & $s, 11$ & & - & - & - & - & $\cdot$ & . & . & $57^{\circ}$ \\
\hline Cieneral View, San li & ancis & 1,1 & & . & - & 。 & - & - & . & 571 \\
\hline
\end{tabular}





\section{MAPS AND DIAGRAMS}

Relief Map of the United States. By Howell • • opposite I Isothermal Lines (United States and Europe) . . . . 4 Average Rainfall in the United States . . . . . . 5 Navigable Rivers and Portages of the United States. . . II Location of the Principal Indian Families and Tribes . . . $\quad$ I2

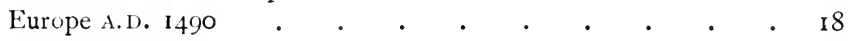
Trade Routes from Europe to the East . . . . . 20 Tuscanelli's Map of the Occident . . . . . 24

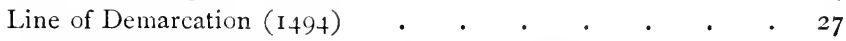
America (1515) (Schoener). Simplified from Winsor's "Narrative and Critical History of America." . . . . . 29 America (I 54I) (Mercator). Simplified from Winsor's "America" 29 Exploration and Settlements before 1600 . . . . . 37 Land Grants under Charter of 1606 . $\quad . \quad$. $\quad . \quad$. 40 Eastern North America (162I). From Dutch map in O'Callaghan collection . . . . . . . . . . . 45 New England Settlements . . . . . . . . . $\quad .58$ Boundaries of Pennsylvania $. \quad . \quad$. $\quad . \quad$. $\quad$. 73 North Atlantic Coast (1650-1695) . . (Colored) opposite 82 Treaty of Utrecht ; Territorial Changes (I7I3) (Colored) " 90 Scene of the French and Indian War (1754-1759) • • • 97 Treaty of Paris; Territorial Changes (1763) (Colored) opposite 100 Density of Population in English Colonies (1750) . . . 104 Boundaries of Quebec (1774) . . . . • • . 149 Boston and Vicinity (I775) . . . . . . 154 Vicinity of New York $(1776)$. . . . . . . . 167 Revolution in the North $\left(1775^{-1} 780\right)$. . . . I70 Campaigns of 1777 in northern New York . $\quad$. . . I72 Revolution in the South $(1778-178 \mathbf{I})$. . . . 180 Boundaries of the United States $\left(\mathbf{I} 779-178_{3}\right)$ (Colored) opposite 185 Western Land Claims . • • • • (Colored) “ 185 Density of Population (1800) . . . . . . . 218 Election of $1800 \quad . \quad . \quad . \quad . \quad . \quad . \quad . \quad . \quad 246$ The United States (ISoo) . . . . (Colored) opposite 252

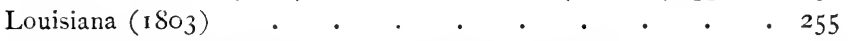
Exports and Imports of the United States (I789-I8II) • . 258 xxxiii 
Scene of War in the North (ISI2-ISI4) . . . . . $27 \mathbf{I}$

British Campaign against Washington (1S14) • • • 272

New Orleans and Vicinity . • • • • • • • 274

Territory affected by Missouri Compromise (IS2O) . . . ${ }_{2} \mathrm{~S}_{7}$

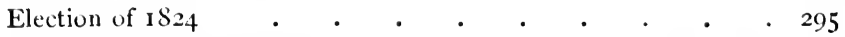

The United States (IS25) • • • • (Colored) opposite 297

Disputed Boundary of Maine . • • • • • • 314

Railroad Construction from 1 \$ 30 to I $\$ 60$. From Coman's "Indus-

trial History of the United states" - (Colored) opposite 320

Adoption of Manhood Suffrage . • • • • • • 327

Density of Population $\left(185^{\circ}\right) \quad \cdot \quad \cdot \quad \cdot \quad \cdot \quad \cdot \quad \cdot \quad \cdot 332$

Election of $\mathrm{I}_{44} \cdot \quad . \quad . \quad . \quad . \quad . \quad . \quad \cdot 342$

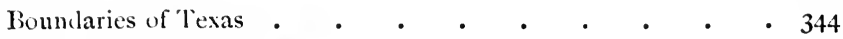

Scene of the Mexican War . . . • • • • • 345

The United States $\left(\mathbf{I} S_{50}\right)$. . . . (colored) opposite 349

Territory affected by the Compromise of $\mathrm{I}_{5} \mathrm{O} \quad$. $\quad . \quad$. 352

Territory affected by the Kansas-Nebraska Act $\left(\mathrm{I}_{54}\right) \quad$. $\quad 357$

Expansion of the Slave Territory $\left(1 S_{44-1} S_{57}\right)$, two maps . $\quad 362$

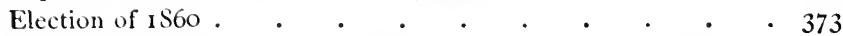

The United States (IS6I), showing first and second secessions of slave states . . . . . . (Colored) opposite

376

Railways and Rivers of the South (1S6I) . . . . . 400

Routes of Invaling Armies (IS62-IS65) • . . . • 40I

Western Kentucky and Tennessee (1S62) . . . . . 403

Theater of War in Virginia. . . . . . . . 406

The York-James Peninsula (rS62) . . . . . . 408

Gettysburg Battlefield $(1 S 63)$. . . • . . . 416

Country around Vicksburg $(1 S 63)$. . . . . . 417

Country around Chattanooga $\left(1 S 6_{3}\right)$. . . . . . . 4I8

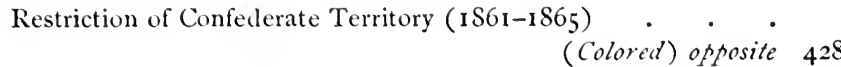

The United States $\left(\mathrm{I}_{75}\right)$ • • . • (Colored) “ 445

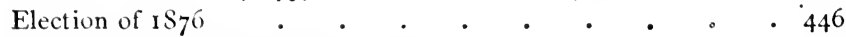

Development of United States (IS70-1905) ...$\quad 448$

Decrease in Railway Rates (1S67-1900) . . . . . 462

Election of $1 S_{0} 6$. $\quad . \quad . \quad . \quad . \quad . \quad .4 S_{4}$

The Ilawiian lslands . . . . . . . . . . 486

(Operations around Santiago de Cuba (ISgS) . . . . 500

Territurial (irowtl of the United States (double page)

Route of the lanama Canal

(Colored) between 508 and 509

$\cdot \quad \cdot \quad \cdot \quad \cdot \quad \cdot 5^{1} 3$

Railways of the United States . . . (Colored) opposite 556

Election of 1912 . . . . . . . . 539 
Wages and Prices, I840-1913, in Gold . . . . 561 The United States (1914) . . . . (Colored) opposite 564 Immigration $\left(\mathbf{I} S 64-19 \mathbf{I}_{3}\right)$. $. \quad . \quad . \quad . \quad . \quad 565$ Total and Urban l'opulation (1790-1910) . . . . . 566 Density of Population (I900) . . . . . 567 



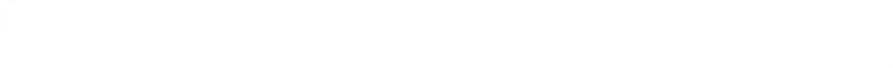




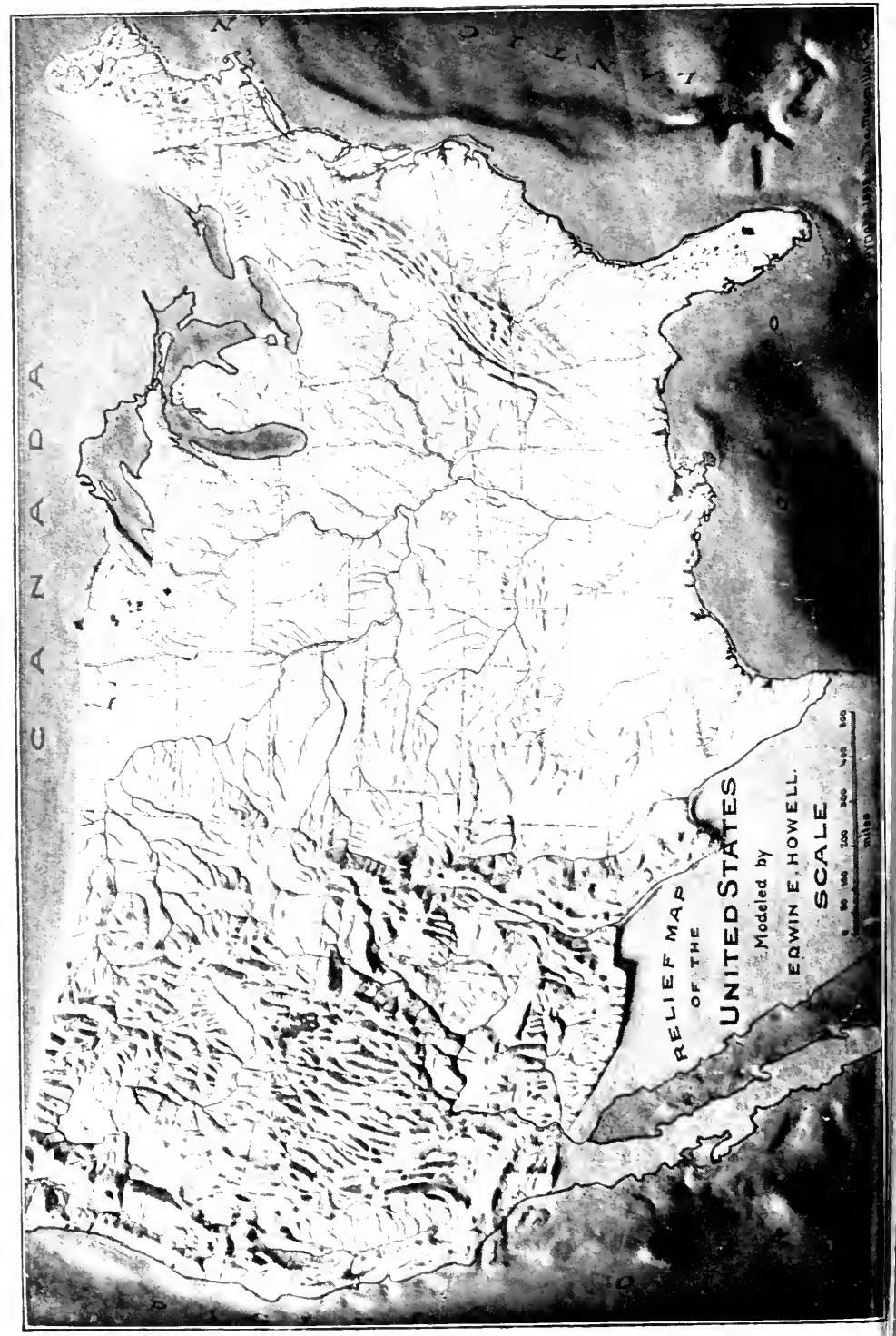




\section{PART I}

\section{THE COLONIAL PERIOD (I492-I763)}

\section{CHAPTER I}

\section{CONDITIONS AFFECTING COLONIZATION IN}

AMERICA

I. Introduction. - Not many years ago the common what is opinion about history was expressed in the words, "happy history? is that people who have no history." To persons holding such a view, history was a record of wars and intrigues, of cruelty, misfortune, and destruction. This opinion of history, common enough a generation ago, is held by few to-day, for we are beginning to realize that history is less a narrative of events than a record of progress - that it should not record the horrors of a nation's life but its achievements. It is hardly necessary to state that this must be quite as much a study of the means used to produce certain results, of the conditions which made possible and necessary certain achievements, as a description of the results themselves; for, after all, the purpose of studying history is not to learn facts, but to understand the causes and results of the great movements in the life of a people.

This task is one of great interest and importance, but it presents many difficulties. We cannot, in a short time and within a brief text, examine very much of the material to be found on this broad subject. We must therefore decide Choice of topics in American history. what phase or phases of history should receive special consideration, and then seek to concentrate our attention on those topics which mark most clearly the path we wish to follow. Since we cannot study all the phases of American development, we shall devote ourselves particularly to the develop- 
ment of the American nation - a subject that is political rather than social - and seek to discorer how the American nation became what it is to-day. Many military events will be examined in the course of this study, for our wars have greatly influenced our national derelopment. Commercial activities and social life will be considered to some extent. because without some knowledge of them we cannot understand certain changes in our country.

Two things to be noted.

In comnection with each subject studied we should note two things: (I) what are the facts resarding the topic under consideration? (2) how is this event connected with other events we have studied? The tirst involves not only an act of memory but discrimination between the details that are more important and those that are insignificant: the second compels us to use the knowledge that we have gained in reasoning out the causes and results of the different movements.

Three condi-

Before taking up in a sytematic way the record of Ameritions affecting can development. We must consider first three things that American history. have influenced our progress greatly, especially during our early years. One of these is the geography of the Lnited States. which has intuenced out history from the beginning and is now a factor of the first importance in determining the character of our life and occupations. The second deals with the original inhabitants, the Indians, whose intuence during colonial times was very great. and the third with the situation in Europe at the time the continent was discorered.

\section{Geographichi Condtions}

Fourimportant seographical infuences.

Winso: (ed.), incisa. IV $\mathrm{x}-\mathrm{xr}$.

2. Geography and American Colonization. - In all ages the geography of different countries has exerted a very sreat infuence on their history. In the development of the United states we can study the influence of physical conditions as. step by step. the territory was explored and opened to settlement. The effect of topography. soil. and climate can be measured. because we have fairly full and exact information of every early attempt to gain a foothold 
on this continent. During the colonial period, the geographical characteristics which affected our history most were four in number: (I) The accessibility of the new continent. Accessibility. Its position with reference to Europe, the character of its coast line, the extent of its water systems, and the navigability of its rivers aided exploration and settlement. (2) The possibility of a food supply. As no colony could continue Food supply. to exist if dependent on Europe or on other colonies for its food, it was necessary that grains and regetables should be raised easily within the colony. Climate, rainfall, the character of the soil, and many other physiographical conditions affected this problem. (3) Its defensibility. The dangers to which a colony was exposed and the ease with which it might be defended were matters of the first importance. If located in the heart of the country, scattered settlements were out of the question. The neighborhood of unfriendly European colonies was also to be avoided, and especial care was necessary to prevent the destruction of a colony through disease caused by extreme heat or cold or by the fevers all too common in the low marshy coastal belt. (4) Its general resources. Permanency depended on the development of certain industries, which would not only General resources. help the colonists to sustain life, but would produce articles which they could exchange for the necessaries that must be procured in Europe. The precious metals of Mexico and South America, the sugar and tobacco of Cuba, and the furs of New France explain the success of Spanish and French colonies. Topography and occupations account to a large extent also for the character of a colony. The compact little hamlets of New England could never have been developed in the broad fertile valleys of the South any more than the system of French trading posts could have been established in the narrow valleys of Massachusetts. After considering some of these physical conditions and the geographical divisions of the United States, we shall note briefly how English and French colonization was affected by them.

3. Climate and Rainfall. - The climate of the United 
Temperature States, while on the whole temperate, presents many variaof the coast and interior. tions. Two things that had a very great influence on our early history should be noted carefully. (I) The temperawinsor (ed.), ture of the Atlantic slope and of the Mississippi basin is America, IV, ii, vi.

Farrand, Basis of much lower than that of Europe in the same latitude, because the warm waters of the Gulf Stream wash the shores of western Europe.

(2) The winters in the northern half of Amer. History, which possesses to a marked degree the characteristics of a I7-2I. continental climate. The earliest American colonies were

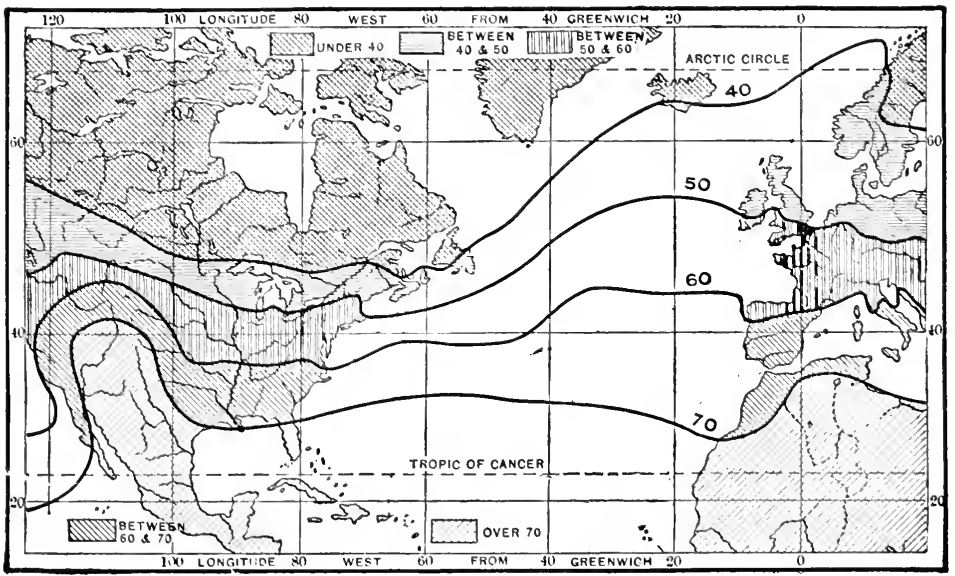

ISOTHERMAL LINES

established below the latitude of Rome and the extreme cold was thus aroided, but most of the English colonists of the serenteenth century settled farther north and found themselves face to face with all the hardships and privations that a long winter would be likely to cause. In several cases the intense suffering led to the complete abandonment of the settlement. This very struggle for existence, however, seems to have benefited those who were courageous enough to attempt or hardy enough to endure the life north of the fortieth parallel. 
The rainfall throughout the eastern half of the United Variations States is sufficiently abundant to insure good crops without in rainfall. being so excessive as to prevent cultivation. It is heaviest on the Gulf slope, but almost as great along the Atlantic border. West of the Mississippi River the rainfall is less Shaler, United States, I, $15^{-20}$. abundant and beyond the one hundred and fifth meridian is too light for the production of most crops. However, the great semi-arid plains of the West form one of the finest grazing regions in the world.

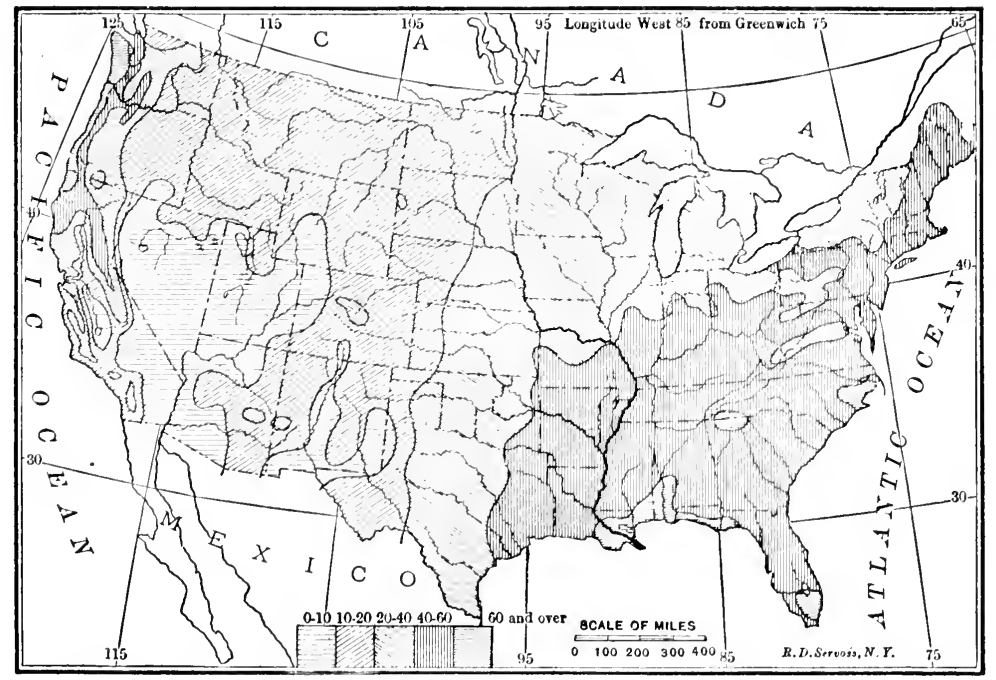

Average Rainfall

4. Natural Resources. - These climatic conditions have made it possible for Europeans to live within the United States. They contributed very largely to the success of the early settlements, because of the ease with which a supply of food could be raised. Without maize or Indian corn Agricultural many of the early colonies would have been complete failures. Being a native product of this continent, maize was found growing wild to some extent. From the Indians who cultivated it in a crude way, all early settlers secured supplies food supplies.

Winsor (ed.), America, IV, xiii-xv. 
by purchase or force, and it remained the chief food of the immigrants during the colonial period. This was largely due to the ease with which it was grown in half-cleared forests where wheat could not be raised, and to the abundance of the crop. As it is sensitive to the cold, it cannot be raised in the North, much to the loss of the colonists in that part of the continent. The early settlers depended a great deal on the pumpkins and squashes grown with the maize in the clearings. In the Great Lake basin wild rice was one of the chief foods for a large part of the population.

Non agricultural foods.

Commercial value of natural resources.

Besides the agricultural productions on which the colonists depended, they used as food the immense supplies of fish and game. Colonization would have been very difficult, perhaps impossible, in New England and around the St. Lawrence, but for the fisheries, the cod particularly being a source of considerable wealth because exported in large quantities. Frontiersmen found it possible to sustain life on the flesh of the animals killed.

Far more valuable to the early settlers was the vast trade in peltries which engaged the attention of a large percentage of the population in New France and New Netherland. This fur trade determined the location of almost all of the frontier towns, which were at the beginning little more than trading posts. In the South the greater productivity of the soil and the mildness of the climate made the question of food supply a less serious one, but the growth of tobacco in Virginia especially and the exportation of rice from the coast plantations aided greatly in the derelopment of colonies in that section. The abundance of excellent timber along the coast furnished material for the construction of homes and stimulated industries like ship building. Although the dense forests interfered somewhat with agriculture, they were a valuable aid to the colonists in other ways, lumber being one of the chief exports of the English provinces.

Influence of natural resources in recent history.

From this fragmentary account we can appreciate perhaps the influence of natural conditions on colonial derelopment. We can understand also how the farorable agricultural 
conditions in this country, coupled with its unexcelled supply of coal, iron, copper, and other minerals, its numerous rivers and excellent harbors, have made it possible for the United States to develop with amazing rapidity since the colonial period.

5. Geographical Divisions of the United States. - The General. topography of the United States is very interesting. On the east and the west are two great oceans, the narrower separating us from those European countries from which almost all American settlers came. One half of the southern border is a great arm of the sea, and nearly one third of the northern boundary is a system of lakes penetrating nearly one half of the distance to the Pacific. Two great systems of mountains divide the country into several distinct geographical divisions. One, the Appalachian, running northeast and southwest, parallel with the Atlantic coast line, is low and comparatively narrow, with passes connecting the East with the West along the Mohawk, in Pennsylvania and at Cumberland Gap. ${ }^{1}$ The second, the Cordilleran system, averages one thousand miles across and is really a high table land fringed for the most part by high ranges on its eastern and western edges.

East of the Appalachian system is the Atlantic slope, narrow and consequently rather steep at the north, giving that section short, rapid rivers, with narrow valleys, and often with numerous water falls; broader at the south, so that the country is more nearly level, the valleys therefore wider, and the rivers slower and navigable for a longer distance. Atlantic slope.

Shaler, United States, I, 53-58, 6I$64,69-74$. Along the coast there are numerous bays and harbors, some of which are particularly fine. On the south Atlantic slope and on the eastern Gulf slope the coast is often marshy for a considerable distance inland.

Between the great mountain systems lies the magnificent Mississippi basin, the river and its tributaries comprising

Winsor (ed.) America, IV, iii-v.

Farrand, Basis of Amer. History, 7-I4.

${ }^{1}$ The highest peaks are but little over six thousand feet. There are two ranges separated from Pennsylvania and North Carolina by a broad, fertile valley. 
Shaler, United nine thousand miles of narigable streams more than three Stutes, I, I02I07, I27-1 30 . feet in depth, draining an area of about a million and a quarter square miles of the finest land on the globe. With a fertile soil and abundant rainfall, except in the West, a climate that is marked by short, hot summers, and in the North by long severe winters, the Mississippi basin is to-day the greatest agricultural region in the world. In colonial times comparatively little use could be made of these characteristics because it was not easily accessible before the days of steam. Mountain ranges shut it off from the Atlantic coast. Falls and rapids in the St. Lawrence basin practically closed that arenue of approach. Access by way of the lower Mississippi was precluded because of the river current and the swamps on either side which made the banks uninhabitable except in places for a long distance from the Gulf. Since the middle of the eighteenth century, however, the Mississippi valley has been the scene of many of the most important conflicts in our history, and it has furnished the issues for numerous great national contests.

Great Lake basin.

North of the eastern Mississippi basin and the Atlantic slope is the basin of the Great Lakes, covering a comparatively small territory aside from the water area. Since it Brigham, was closed to the outside world for one half the year, when Geosraphis Influences, I05-IIt.

Shaler,

Unitid States, I, II9-I 27.

The Atlantic slope. the St. Lawrence was frozen over, and was inaccessible directly because of the rapids in the St. Lawrence River and Niagara Falls, the upper St. Lawrence basin was practically unoccupied during the colonial period. The lower St. Lawrence basin, which is open to sea-going ships as far as Montreal, was the seat of a thriving colony, supported in large part by the fur trade with the interior.

6. Influence of Geography on English Colonization. All of the English colonies proper were confined to the Atlantic slope, which offered many advantages to the settler.

Winsor (ed.), It was the most accessible part of the continent, being almost
-tmcrica. IV, xxiii-xxx. directly across from Europe ${ }^{1}$ and offering shelter to the

${ }^{1}$ On account of the prevailing west winds in the north temperate zone and eastward direction of the north Atlantic currents, however, most of the 
pioneers because of its many harbors. As far inland as the mountains the sloping character of the country, with the numerous short but navigable rivers, gave easy access to a region which was attractive and usually fertile. In the South the Atlantic slope was much broader than in the North. The valleys of Virginia and the Carolinas are broad and fertile. As the climate favored the growing of tobacco, rice, and cotton which can be raised most profitably on large plantations, a scattered agricultural population was inevitable. In New England the stony clay soil of the narrow valleys was not well adapted for agriculture, while the abundance of small but sheltered harbors made it desirable for the people to keep near the coast and give their attention to commerce. The middle section, in this as in most other respects, was a mean between the North and the South and partook of the characteristics of each. The magnificent harbor of New York, at the mouth of the Hudson River and at the eastern extremity of the only low pass from the coast to the West, gave that location advantages over every other, and made it the natural commercial metropolis of the East.

During the colonial period, however, there was little communication between New York and the interior because the Iroquois controlled the Mohawk route and the French occupied that part of the Great Lake basin beyond. Farther south several passes permitted entrance to the Ohio valley, the key to the whole of that basin, the junction of the $\mathrm{Al}$ legheny and Monongahela, lying but a step beyond the last range of hills. Still farther south the great valley between the parallel ranges of the Appalachian mountains, and the gaps from that valley to the fertile region south of the Ohio River, made emigration to the West possible though not easy.

The mountains were of special value to the colonies because they could be crossed only with difficulty. They afforded protection from attack from the interior and allowed

Communication with the interior.

Farrand, Basis of Amer. History, 27-35.

The Appalachian mountains. 
Brigham, Geographic Influences, 76-89.

Semple, Amer. Hist. and its Geographic Conditions, 36-5I.

The great interior basins. Winsor (ed.), America, IV, $\mathbf{x x - x x i i i . ~}$

Hold of the French on the interior.

Farrand,

Basis of tmer. History, 23-27. the English colonies to thrive in comparative peace, expanding with a natural and healthy growth into the foothills without danger of attack from their European rivals. The strength of the English colonies was to a great extent the result of compactness due partly to their agricultural and commercial pursuits, and in part also to the mountain barrier which confined them to the narrow sea border.

\section{Geographical Advantages of the French Colonies.}

The territory occupied by the French presented marked contrast to that of the English. France was fortunate enough to gain possession of the two great basins - those of the St. Lawrence and the Mississippi - which apparently were the gateways to the interior of the continent. Apparently, for it was by no means easy, as we have noticed, to pass from the lower St. Lawrence to the four great lakes beyond Niagara Falls, or to ascend the Mississippi as far as either of its important branches. Had the French been in search of homes, they could not easily have established themselves in the lower St. Lawrence on account of the cold and the sterility of the soil, or have founded extensive colonies in the lower Mississippi valley because of the swampy,malarial condition of the country. Neither could they have penetrated to the interior by either route readily had they been accompanied by their families and encumbered with household necessities.

With the French, however, actual colonization was always subordinate to their real work of exploring, trading, and occupying the country. For this task their geographical position was of the highest value. From Montreal, a trader, with comparatively little difficulty, might reach the ris.ey of the Ohio, the basin of the upper Great Lakes, the Mississippi and its many branches, and the entire system of waterways northwest of Lake Superior, because short portages over comparatively level spaces connected the waters of the three great interior basins of the continent, which two centuries ago formed probably the richest fur-bearing region on the globe. Where the trader might go, the soldier could 
follow. In time, for both commercial and military reasons, posts were established at the points where important waterways or paths joined, giving the French control of the region to which these ways penetrated. The skill shown in the selection of these points is apparent from a glance at the map. Notice the position of Montreal, Fort Frontenac, Fort Duquesne, Detroit, Fort St. Marie, Fort St. Joseph, Fort

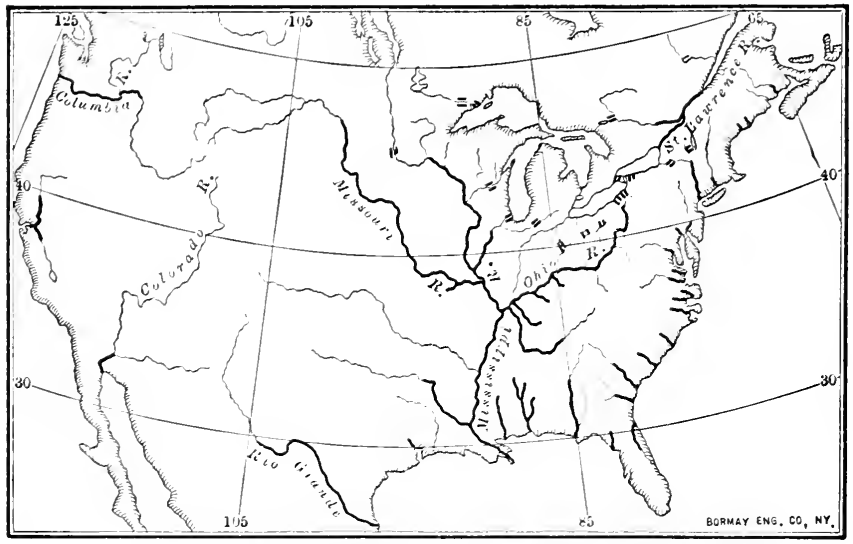

RIVERS AND PORTAges OF THE CNITED STATES

Heary single Lines stow depth of 3 feet or more

Double lines show portages

Chartres, and New Orleans, and we cease to wonder why the French maintained a hold, slight to be sure, on the best part of the North American continent.

\section{The North American Indian}

8. The Indian Tribes. - A second influence during colonial times, less important than physiography, but considerable nevertheless, was that exerted by the native races. There were no early settlers that did not come into contact with the red man, to be helped by him or hindered because of his hostility. These savage hunters were especially numerous along the heavily timbered Atlantic slope, within Numbers, customs, and organization. easy reach of the great supply of fish on the one hand and the animals of the forest on the other. Although they had

Farrand, Basis of Amer. History, 148I75. 
not reached a high degree of civilization, each tribe occupied a fairly definite territory which was rather extended because

Three great families.

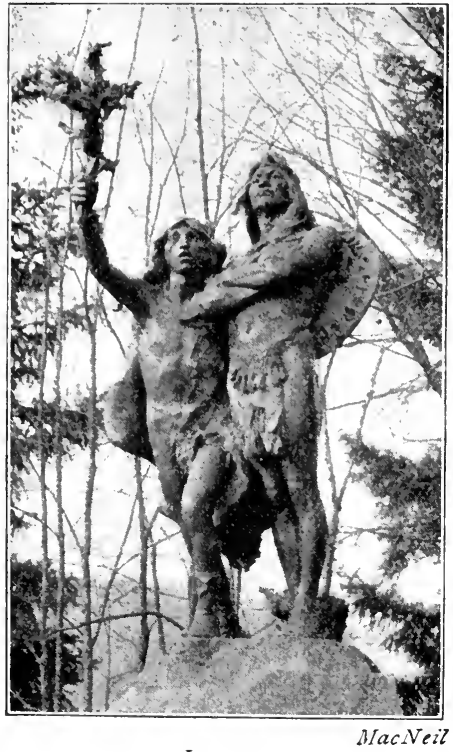

INDIANS of the need of broad hunting grounds. Within the present limits of the United States, they numbered, at the beginning of the seventeenth century, probably not more than a quarter million.

Of the families encountered by the French or English only three were particularly numerous or important. Of these the Algonquins occupied much the largest territory, including most of the seacoast and the larger part of the upper basins of the Mississippi and the Great Lakes. The tribes differed greatly from one another, those of the North and West being, as a rule, fiercer and more nomadic than their kinsmen of the southeast, the Delawares of Pennsylvania and the Powhatans of Virginia, for example. (2) The Iroquois family occupied the basins of Lakes Erie and Ontario and the Mohawk valley, as well as a large district in the southern

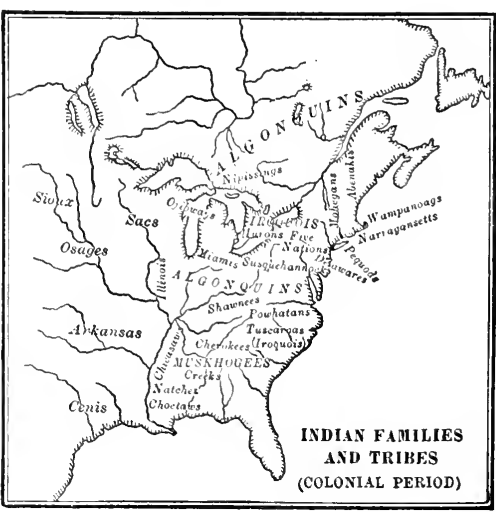


Appalachian region. It included the "Five Nations" of New York whose political organization, the most perfect of any north of Mexico, enabled them to conquer all their neighbors, either Iroquois or Algonquins, so that they often controlled the territory as far south as the Kenawha and as far west as the Wabash. Of great ability and courage unusual even among Indians, the Iroquois have left an impress on our history that is out of all proportion to their number. (3) From the Atlantic to the Mississippi, and from the Tennessee River south to the Gulf of Mexico, dwelt the Muskhogean family, of which the most numerous, ablest, and most civilized tribe was that called Creek.

9. Life and Character of the Indians. - It is no part of Social our purpose to study the life and occupations of the Indian except to appreciate his attitude toward the whites and understand his influence on the colonization of America by Europeans. Living in villages that were often little more than headquarters for hunting expeditions and raids, the Indians were not attached to the soil and removed their wigwams with ease. They found it difficult to fight successfully with the colonists, not alone because bows and arrows were no match for muskets, but because they were seldom united. Each tribe had its own village and lived its own life under chiefs who recognized no higher authority. This separateness prevented concerted movements, except when some great common danger united the tribes for a brief period.

The character of the Indians has never been portrayed better than by the master hand of Francis Parkman. He gives us this picture. "Nature has stamped the Indian with a hard and stern physiognomy. Ambition, revenge, envy, jealousy, are his ruling passions, and his cold temperament is little exposed to those effeminate vices which are the bane of milder races. With him revenge is an overpowering instinct; nay, more, it is a point of honor and a duty. His pride sets all language at defiance. He loathes the thought of coercion, and few of his race have ever stooped

organization.

Parkman,

Struggle for

a continent, $460-464$.

Farrand, Basis of Amer.

History, $215-218$, 240-247.

Stern qualities. 
to discharge a menial office. A wild love of liberty, an utter intolerance of control, lie at the basis of his character, and fire his whole existence. . . With him the love of glory kindles into a burning passion, and to allay its cravings, he will dare cold and famine, fire, tempest, torture, and death itself.

Indian trickiness.

The race and civilization.

\section{Differences} in Indian policy of the Spanish, French, and English.

"These generous traits are overcast by much that is dark, cold, and sinister, by sleepless distrust and rankling jealousy. Treacherous himself, he is alwars suspicious of treachery in others. Brave as he is, - and few of mankind are braver, - he will rent his passion by a secret stab rather than an open blow. His warfare is full of ambuscade and stratagem."

"Some races of men seem molded in wax, soft and melting, at once plastic and feeble. Some races, like some metals, combine the greatest flexibility with the greatest strength. But the Indian is hewn out of a rock. You can rarely change the form without destruction of the substance. Races of inferior energy have possessed the power of expansion and assimilation to which he is a stranger, and it is this fixed and rigid quality which has proved his ruin. He will not learn the arts of civilization and he and his forest must perish together."

I0. General Relations of Indians and Whites. - It was perhaps fortunate for the English that the Indian was incapable of civilization, for it prevented the mixing of the races. The Frenchmen tried intermarrying with the natives, adapting themselves to the standards of the Indians; but the English, a colonizing race, failing to raise the Indian to a level somewhere near their own, treated them always as inferiors. It was as impossible for the Englishman to make a boon companion of the Indian as it was for the Spaniard to respect his rights, so that both were obliged to suffer the loss of his help, which the Frenchman enjoyed. Yet in spite of the difference between the attitude of these three European races toward the red men, it was found that as a rule the Indians responded to the treatment they receired. The old saying that an Indian never forgets and nerer 
forgives is full of meaning in our early history. The Spaniard found to his cost that his cruelty was repaid with usury. He dared not renture into the interior unless his errand was purely one of peace and good will toward men, and it was with difficulty that he maintained on the coast a hold whose military character showed how feeble it really was. The English experienced the result of both kindness and folly. Without the friendship of the Indians some settlements must have perished, and without their hatred others would have expanded with much greater rapidity.

II. Help given to the English by the Indians. - The dependence of the whites on the Indians was especially marked in the early English settlemenis. Time after time, General help given to all of the settlements the settlers would have died of hunger but for the trod furnished by the natives. The first successful efforts of the colonists to raise a supply for themselves were but imitations of the crude Indian methods of agriculture. The Indians showed them how to plant maize in the half-cleared forests, how to fish through the ice, and how to trap game. They taught them to narigate the streams in birch-bark canoes. Clothing was made from skins after the Indian fashion. From the beginning the Indians exchanged valuable furs for trinkets, and the great development of the fur trade, which was a chief source of wealth in more than one American possession, was possible because the Indians brought so many pelts to the traders. Exploration of the interior would have been a very much slower process but for the use made of the numerous Indian trails and the help given by the Indian guides who led the way to the easiest portages.

The Five Nations, or Six Nations as they became in 17 I 5 , exerted an exceptional influence on American history. This was due to their location, their character, and their political organization. Occupying, as they did, the Mohawk valley and the territory south of Lake Ontario, they controlled the southern route from the St. Lawrence River to Aid given by the Six Nations.

Farrand, Basis of Amer. History, the Great Lake basin and the Ohio valley, and the best route I53-162. from the Atlantic coast into the interior. They became the 
persistent enemies of the French, because the French leaders in the St. Lawrence valley found it necessary to ally themselves with the Indians of their section, who were traditional foes of the Five Nations. This made it easy for the Dutch, and later the English, in New York, to gain and retain the friendship of this powerful confederacy. This friendship was exceedingly valuable to the English, because the Iroquois prevented the French from gaining possession of the Mohawk and Ontario valleys and from making inroads on the English settlements during the colonial wars. It also gave the English their first real claim to the land beyond the mountains, for the Iroquois by treaty transferred to the colonists the rights which they enjoyed as conquerors of the territory a long distance to the south and west.

Failure of uprisings against the colonists.

Eggleston, in cintury, XXVI $\left(\mathrm{I}^{8} 8_{3}\right)$, $697-704$.

Contests in the West after I750.
12. Results of Indian Wars. - Many of the other Indian tribes played an important part in the history of several colonies, although none of them exerted an influence equal to that of the "Six Nations" on the great struggle of Europeans for the possession of the continent. All of the English colonies were undoubtedly more compact than they would have been without the danger of Indian attacks. Yet there was never an important contest between the settlers and the natives that was not won by the colonists. In every case the Indians were pushed back from the coast without great loss to the whites, and, in the case of one colony, Connecticut, the only tribe worthy of consideration was practically exterminated during the first five years of the colony. Later Indian uprisings like that of King Philip ( 74 ) were just as disastrous to the natives.

The Indians from the Alleghanies to the Mississippi prevented the rapid settlement of that region. From the time when the French surrendered to the English their claim to the Ohio valley and the basin of the Great Lakes $\left(s_{7} 6_{3}\right)$, it was necessary to establish boundary lines between the territory belonging to the Indians and that opened to settlement. In the terrible war known in history as the conspiracy of Pontiac $\left(1 ; 6_{3}\right)$, during which the frontier suffered terri- 
bly from Maryland to Lake Huron, the Indians were united against the immigrants. During Washington's administration as president, several armies were defeated until General Anthony Wayne won a decisive victory and left the northwest frontier safe once more. The final contests with the Indian tribes came about the time of the second war with Great Britain, when in 181 i General W. H. Harrison quelled the uprising of all the northern Indians under Tecumseh, and in I 8 I $_{4}$ General Andrew Jackson destroyed the encampment of the Creeks in the South. With the removal of the Indians to the Indian Territory soon after 1830 and the occupation of Indian lands in the North $(\$ 27 \mathrm{I})$, the red man ceased to influence the history of the eastern United States. The Sioux and Apaches gave considerable trouble in the settlements of the West, but during the nineteenth century Indian troubles were relatively insignificant.

\section{Europe during the Fifteenth Century}

13. Connection between the History of Europe and America. - It is scarcely too much to say that, during the three centuries which followed the discovery of America by Columbus, the history of America was but a phase of European history. If we wish to know why Columbus set out on his great voyage into unknown waters, why there was so much interest in exploring America, or why certain nations took part in colonizing movements, we must seek our answer in the history of the old world. The differences between the colonies of England and France, the final success of England in the struggle for possession of eastern North America, even the causes and results of both our wars with England, can be understood only when we know the situation in Europe during those years. It is not our desire to treat in this book the history of Europe during those formative centuries. Attention will be called at the proper places to the European events which exerted a direct influence on the development of this country. In these sections we shall consider briefly the situation in Europe during the fifteenth century, so that

Dependence of America on Europe before I750. 
we may appreciate what Europe was like four or five hundred years ago, and know why America was discovered and settled in the way that it was.

The separate nations (I450-I490).

I4. Political Europe after 1450. - The Europe of the fifteenth century was essentially a modern Europe in its awakening tastes and desires, but a mediæval Europe in the degree of its progress and development. The intellectual revival which became prominent after $145^{\circ}$, the renewed

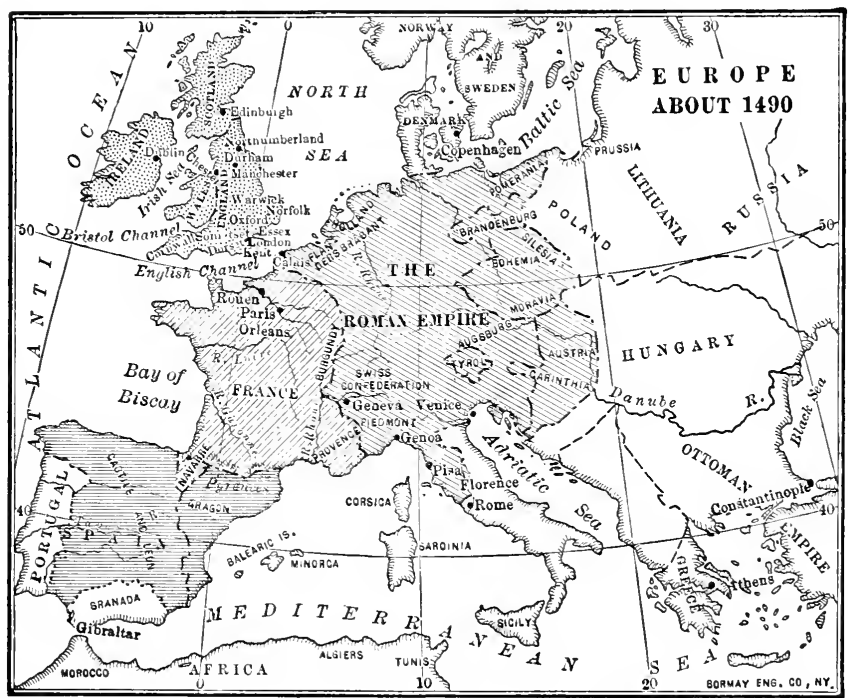

EUROPE A.D. 1490

interest in religious matters that followed in its wake, and the attempts to unite the little feudal dukedoms into which Europe was divided before 1400 were epoch-making movements that could not be completed in a few years. In the half century preceding the discovery of America, France had succeeded in unifying her different feudal provinces under comparatively powerful kings, and all of the little kingdoms of the Spanish peninsula, except Portugal, had been united under the joint rulers, Ferdinand and Isabella. But Spain was too much absorbed in subduing the nobility 
and driving the Moors from Granada to devote much attention to outside interests, and France was more interested in showy conquest than in solid development. The rest of the European countries were still much as they had been. Little Portugal and the cities of Italy were the most enterprising and successful states at that time. Germany was divided into so many petty states that she frittered away her power and failed to exercise the influence which her geographical position and natural resources might have given her. England was still a second-rate power even among the undeveloped nations of that day. Her agriculture was crude, her manufactures and commerce undeveloped, and her kingdom rent by the feuds of nobles until the strong rule of the Tudors established a monarchy worthy of the name. In Italy the pope still claimed the right to exercise temporal power, and his spiritual power was as yet recognized throughout western Europe, although soon to be denied by all of the northern nations.

I5. Trade with the East before 1475. - The intellectual sluggishness and commercial inactivity which were characteristic of the middle ages were giving place in the fifteenth century to a renewed interest in learning, in industry, and in international commerce. The spirit of enterprise thus aroused expressed itself in no way more emphatically than by a desire to trade with the East, for the crusades had given the first insight into the wealth that lay beyond Constantinople and Jerusalem. Marco Polo and other travelers had brought back such glowing accounts of China and India that even the mysteries which seemed to pervade that distant portion of the globe were no longer sufficient to frighten away the timid travelers and merchants. Venice and Genoa, which had created a merchant marine by building ships to carry soldiers to the Holy Land, built up a trade of considerable proportions during the following centuries.

Three routes were used most in carrying on with Asia a large and flourishing business in spices, silks, precious metals, The three trade routes and gems. One of these followed the Black and Caspian

Development of trade after the crusades.

Fiske, Disc. of America, I, $274^{-292 .}$ 
Cheyney, European Background, 22-27.

The route around Africa.

Fiske, Disc. of America, I, 316-334.

seas, a second crossed Syria to the Euphrates, and the third used the Nile and the Red Sea, connecting them by caravan. With the capture of Constantinople by the Turks (I453) and the invasions of those fierce warriors into Syria and Egypt a little later, these routes were closed or made too dangerous for traveling, and trade disappeared; but neither the merchants who carried these precious articles nor the people of wealth who used them were willing to forego the desir-

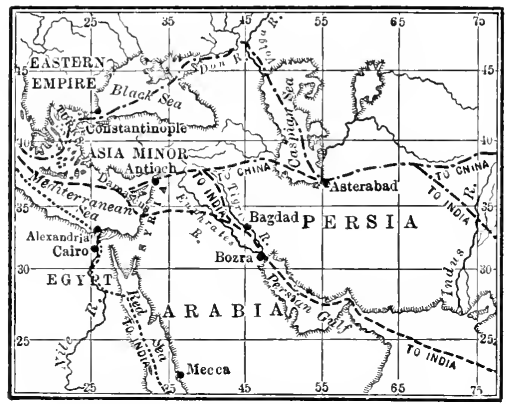

MAIN ROUTES TO THE EAST able and lucrative commerce with Asia. Effort was redoubled to find a new route to India. In this work the navigators trained by Genoa and Venice rendered valuable service in the employ of other countries, since the location of Venice and Genoa made it impossible for them to compete with the nations bordering on the Atlantic.

16. Search for New Sea Routes to India. - Two ways seemed possible to the school of navigators of that time: the one around Africa, the other directly west across the Atlantic. Under the rule of the able Prince Henry of Portugal, the coast of Africa and the islands to the west had been explored by the Portuguese, the belief being that the Atlantic and Indian oceans joined south of Africa, and that if the southernmost point of the African continent were rounded, India could be reached with little difficulty. This was finally proved to be true, but only after great delays. The Cape of Good Hope was discovered by Bartholomew Diaz as late as 1487 , and India was first reached by Vasco da Gama in 1498 .

The route to the West did not attract the same amount of interest or effort because every one dreaded to risk the 
dangers of the "sea of darkness." Many educated persons believed that the earth was spherical, but opinions as to its size and the width of the Atlantic were exceedingly varied. Most of the views in fact were borrowed from, the ancients, many of whose writings, after centuries of oblivion, were published during the fifteenth century. As early as the sixth century before Christ, the Pythagoreans believed in the sphericity of the earth. In the fourth century before Christ Aristotle had held that the earth was round and expressed the opinion that there was probably only one sea between Spain and India. A century later Eratosthenes computed the circumference of the earth at twenty-five thousand two hundred geographical miles and thought that the distance from Europe west to Asia was so great that there might be one or two continents in this unknown region. The great Roman geographer, Ptolemy, came much nearer the fact, estimating the circumference at twenty thousand four hundred geographical miles. These views of the ancients were known during the middle ages or were republished during the fifteenth century. One of the most remarkable of these new books was a kind of encyclopedia of geographical knowledge which was published in $\mathrm{I} 409$ under the title of Imago Mundi, and contained many of the Greek and Roman beliefs. A copy of this book was owned and carefully studied by Christopher Columbus, who accepted the view that the earth was round. But Columbus believed it to be much smaller than it is and thought that the Atlantic Ocean was comparatively narrow.

I7. Summary. - During colonial times three chief Geography. influences on our history were physiography, the Indians, and conditions in Europe. The moderate temperature and adequate rainfall adapted the Atlantic coast and the Mississippi basin particularly to the support of life. Cod and corn were used chiefly as food. The abundance of furs in the interior, and of silver in Mexico, and the ease with which tobacco was grown in Virginia, influenced greatly the permanent settlement in each of those regions. Because of its

Ancient and mediæval views of the sphericity of the earth.

Fiske, Disc. of America, I, 296-300, $368-38 r$. 
accessibility almost all of the early settlements were made on the Atlantic coast, England gaining control of the slope and establishing compact settlements on the harbors or in the narrow valleys of the North and plantations in the broader valleys of the South. The mountains hindered expansion into the interior, but prevented attacks by other nations or the Indians from behind. As the French desired trade, they gained a slight hold on the Mississippi and St. Lawrence valleys by occupying strategic points.

The Indians. The Indians were friendly to most of the early colonists and helped them by giving them food and teaching them how to live in a wilderness. Their hostility at a later time was due either to the cruelty of the settlers or to the encroachments of the whites on their hunting grounds. Only one family, the Iroquois, resisted the advance of the whites successfully. These warriors kept off the French and usually aided the English because the latter did not care to penetrate so far inland.

Influence of Europe.
Until after the Revolutionary War, American history was little more than a phase of European history. At the time America was discovered, Europe was composed of partly united kingdoms like France or Spain or of decentralized feudal states like Germany. The only wealthy countries were those that had engaged in commerce since the crusades. Venice and Genoa were most prominent, but the closing of the eastern trade routes destroyed most of their trade. The future belonged to the nations bordering on the Atlantic, first to Spain and Portugal, which were already aroused to the possibilities of commerce, and later to the more slowly developing French, English, and Dutch nations.

\section{TOPIC}

The Iropuors Confederacy: Larned (ed.), "History for Ready Reference," I, pp. S9-92 ; Fiske, "Discovery of America," I, pp. 6677, II, Pp. 530-531 ; Lee (ed.), "History of North America," II, pp. $143^{-1} 53$.

\section{STUDIES}

I. Western Furope and American exploration. (Semple, "American History and its Geographic Conditions," pp. I-I8.) 
2. Influence of the triangular shape of North America on its exploration. (Cf. Fiske, "Discovery of America," II, Chapter XII.)

3. Fur trade and fisheries. (Weeden, "New England," I, pp. I $29-135$.)

4. The great Appalachian valley. (Semple, "American History and its Geographic Conditions," pp. 5+-6r.)

5. The Hudson-Mohawk route. (Brigham, "Geographic Influences in American History," pp. 3-26.)

6. French use of portages. (Semple, "American History and its Geographic Conditions," pp. 27-3r.)

7. Indian policy of French and English. (Parkman, "Struggle for a Continent," pp. 256-264.)

8. Indian warfare and captives. (Eggleston, Century, XXVI ( $\left.188_{3}\right)$, pp. 704-7I8.)

9. Pontiac's conspiracy. (Parkman, "Struggle for a Continent," pp. 473-5i3.)

Io. Consolidation of France. (Duruy, "Modern Times," pp. 8-26.)

I I. Unification of Spain. (Cheyney, "European Background," pp. $8 \mathrm{I}-96$.)

I2. Commerce of Venice. (Brown, "Venetian Republic" (Temple Primers), pp. 44-65, 75-8r.)

I3. Henry the Navigator. (Cheyney, "European Background," pp. 62-69.)

\section{QUESTIONS}

I. Make an outline showing the character of the soil, temperature, and rainfall of each of the following geographical divisions: lower St. Lawrence, upper St. Lawrence, north Atlantic slope, south Atlantic slope, Gulf region, central Mississippi basin.

2. Make a (companion) outline for the same divisions showing the accessibility, food supply, defensibility, and resources.

3. Mention some of the conflicts of national importance that have taken place in the Mississippi valley. What are some of the national issues furnished by the West?

4. What was the influence of the Appalachian mountains on the expansion of the English colonies and the struggle for the interior?

5. Locate Niagara, Duquesne, Detroit, Ste. Marie, New Orleans. What waterways or trails did they control? What portages made it easy to pass from the basin of the Great Lakes to that of the Mississippi ?

6. Would the task of colonizing America have been easier had there been no native races?

7. Cite at least eight instances before 1775 when events in England influenced American history. Trace the influence. Do the same with three events in America that influenced England. 


\section{CHAPTER II}

\section{THE FIRST CENTURY (I492-I600)}

\section{ENGLISH RULERS}

Henry VII ( $1485-1509$ )

Henry VIII (I 509-I 547)

Edward VI (I547-I553)
Mary $\left(1553^{\left.-155^{8}\right)}\right.$

Elizabeth (1558-1603)
Columbus in Portugal and Spain.

\section{The Discovery of a New World}

I8. Preparation of Columbus. - Christopher Columbus was born near Genoa, before the middle of the fifteenth century. His parents were poor and he had comparatively few early advantages. Before reaching manhood he began

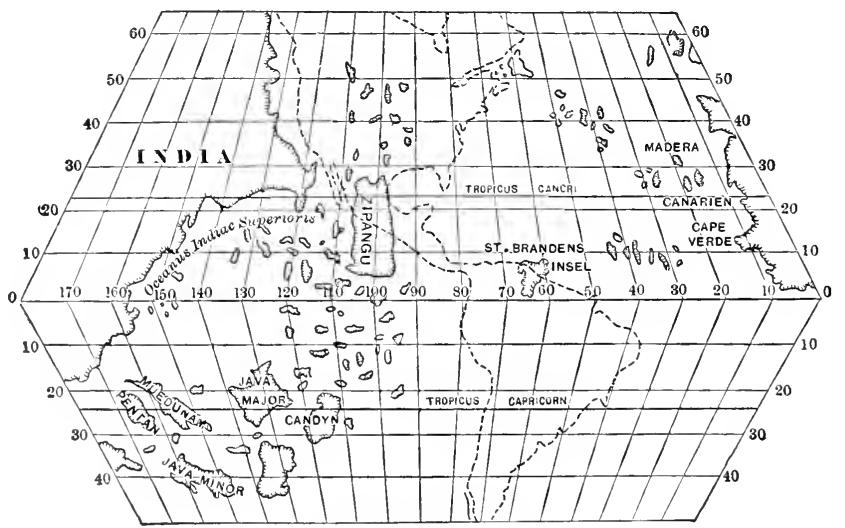

TOSCANELLIS MA

(Showing location of the Americas in dotted lines.)

Channing,

United States,

I, If-2O.

his career as a sailor, spending part of his time when ashore studying navigation or geography and making maps. For several years he resided in Lisbon, the chief center of commercial activity in western Europe. While there he wrote to an Italian philosopher, Toscanelli, asking him for information regarding a direct voyage to India. Toscanelli 
replied, suggesting that Japan could be reached by sailing directly west, and inclosing a map according to which Japan was less than four thousand miles from Spain. Later Columbus asked the king of Portugal to aid him in making this voyage, but the monarch gare him no encouragement. Subsequently Colum. bus entered the service of Spain, endearoring for several years to get governmental aid for his enterprise. But the times were unpropitious, for Ferdinand and Isabella were making a final effort to drive the Moors from the southern part of the peninsula. This was accomplished in $\mathrm{I}_{492}$, and that same year they made an agree-

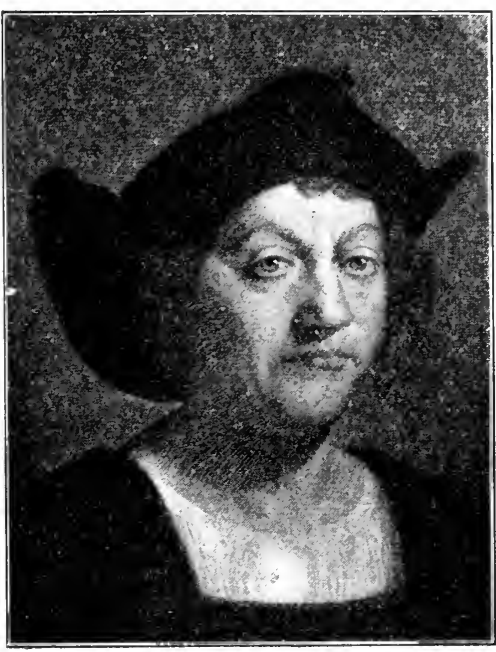

Columbus ment to furnish the ressels for the expedition, to give Columbus absolute power as viceroy over the territories discovered, and to allow him one tenth of all the wealth obtained through his explorations.

I9. Columbus's First Voyage. - On August 3, I492, he set sail from Palos with three caravels, the largest of which was less than one hundred feet in length. After a delay at the Canary Islands, the little fleet started out into unknown waters. In midocean they encountered a vast mass of weeds now known as the "Sargasso Sea." Going to the north of this, they proceeded westward, constantly finding indications of land. Great numbers of birds were seen, and as most of these proceeded southwest, Columbus was persuaded to change his course. In the early morning, October I 2, land

Crossing the Atlantic.

Hart, Contemporaries, I,

No. 17.

Channing,

L'nited States, I, 20-23.

Bourne, Spain in America, 20-23. was sighted, and at daybreak Columbus landed on one of 
Am. History the easternmost of the Bahama Islands. Had he continued Leaflets, No. I. west, he would have been borne still farther north by the Gulf Stream and hare reached the coast of the United States.

The return voyage.

After visiting several islands of the Bahamas, Columbus coasted along the shores of Cuba and reached San Domingo, where his largest vessel was wrecked and a garrison left. The return voyage was marked by a severe storm which

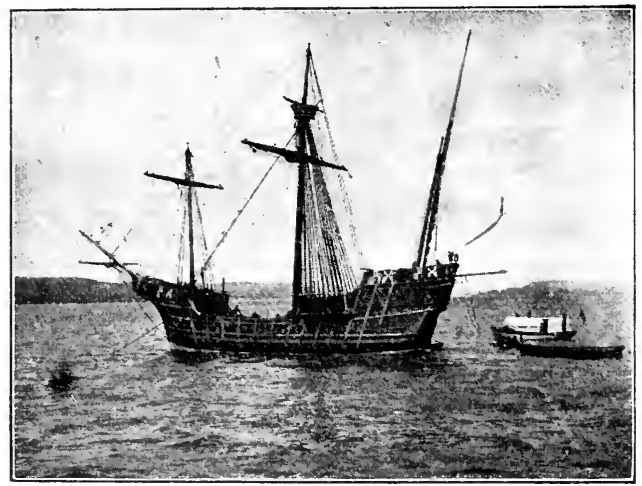

Columbian Exposition Model

A Caravel

Bourne, Spain in

America, $23^{-28}$.

Papal bull and treaty of Tordesillas.

Hart, Contemporaries, I, No. 18.

Bourne, Spain in America, 29-32.

separated the ressels, but, after many experiences, both reached Palos on the same day, March I5, I493. The Spanish monarchs received the discoverer with every mark of esteem and he was treated with almost royal honors.

20. The Pope's Division of the Earth. - As soon as Columbus returned to Spain, King Ferdinand sent at once to Rome and requested that Pope Alexander VI confirm his title to the lands discorered in the west. The pontiff accordingly issued a decree in which he proclaimed that Spain was entitled to the lands lying west of the meridian which was one hundred leagues west from any of the islands commonly called the Azores or Cape Verde. The right to heathen lands lying east of this line was confirmed to Portugal, whose claims to territories discovered in Africa had already been recognized by the Holy See. As Portugal was 
dissatisfied with this division of the globe, negotiations were begun at once with Spain which ended in the treaty of Tordesillas, signed June 7, I494. The line of demarcation was to be drawn three hundred and seventy leagues west of the Cape Verde Islands.

This line did not touch North America, but was not far: east of the country discorered by the Cabots in 1497 ( $\$ 22)$, so that in $I_{500}$ the Cortereal brothers explored the coasts of Newfoundland and Labrador with the hope that they might be claimed by Portugal. On the other hand, a large part of South America lay east of the line, and when in 1500 a Portuguese, Cabral, on his way to the Cape of Good Hope, accidentally sighted the coast of what is now Brazil, the way was open to the establishment of a Portuguese colony in the new world. On the other side of the world Portugal had an undisputed claim to most of the islands, but Spain gained pos-

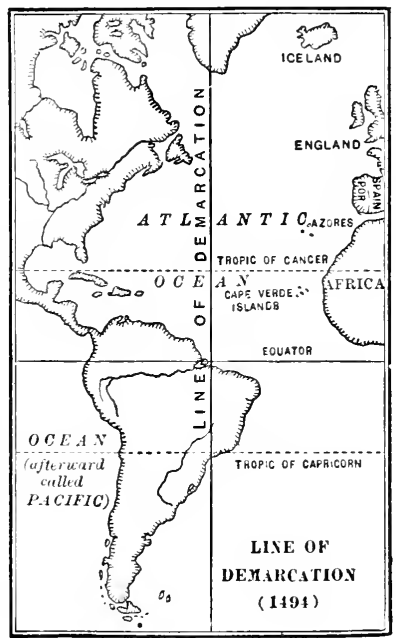

session of the Philippines before it was learned that they were located in Portugal's half of the globe. This papal division was ignored of course by many of the other nations.

2I. Later Voyages of Columbus. - Columbus did not remain long in Spain after his first voyage, because of the danger that Portugal would send out a fleet to seize the lands which he had discorered. The equipment for the second voyage was a marked contrast to that of the first. A large fleet carried nearly fifteen hundred persons, among them many nobles in search of wealth. A number of the West India islands, including Porto Rico and Jamaica, were visited and a Spanish colony established on Hispaniola (San Domingo).
Fiske, Disc. of America, I, $453-460$.

Influence of the division.

Bourne, Spain in America, $63-66,73-75$.

Second voyage.

Larned (ed.): Ready Ref.; I, 50-5I. 
Third

voyage.

Bourne,

shain in

tmerica,

+6-53.

Fiske, Disi.

of America,

I. $+\mathrm{SS}^{-5 \mathrm{O}_{3}}$.

Fourth voyage.

Fiske, Disc. of .tmerici,

I. 503-5I3.

Voyages, I + () $7-1+9$ S.

Am. Histing Leafiets,

No. Q.

Channing,

Cnited States,

I, 33-37.

Bourne,

Stan in

Antericia,

$5 f^{-0 I}$.

( 2, sisto

Learicts,

No. 37 .

Columbus returned to Spain in $1+96$ and did not start on his third royage until two years later. On this expedition he first saw the mainland of South America, near the mouth of the great Orinoco River. Soon after a special envoy was sent from Spain to investigate the charges of misgovernment which had been brought against Columbus as governor, and he was arrested without delay. On his return to Spain in chains, the monarchs disarowed the action of their representative, but Columbus never regained the authority thus taken from him.

His fourth and last royage in 1502 brought him to the coast of Central America, although he still believed he was off the coust of the Indies. His later years were full of bitterness, for he proved to be incompetent for the great task of gorerning a colony, and being harsh in dealing with natives he made enemies who succeeded in stripping him of his honors. He died in I506, obscure and neglected, without knowing that he had led the way to a new world, which was separated from Asia by an ocean larger than the Atlantic.

22. The Cabots were merchants of Bristol, England, at the time news was brought that Columbus had discovered land by sailing west. In I 400 John Cabot obtained from Henry VII a permit to sail westward. The permit was not used until the next year, and it was June 24 , I 497 , when the Cabots sighted land in the neighborhood of Newfoundland. Six weeks later they were back in England, where the king made a gift of Eto "to hym that founde the newe isle." In Ifos a much harger expedition set out. The coast from Labrador to Cape Cod was explored, and many persons believe that the Cabots continued on their southern course until the capes off North Carolina were reached. No attempt was made to follow up these royages, John Cabot probably having died and his son Sebastian having entered the service of Spain. but several generations later, when England desired to establish a legal claim to the eastern part of North America, these voyages of discorery were deemed of the first importance. 
23. Vespucius and the Naming of America. - Americus Vespucius, or Amerigo Vespucci, like Columbus and the Cibots, was an Iialian. In 1504 he wrote a letter telling about "Four royages" that he claimed to have made to the new world while in the employ of Spain. He reported that on the earliest of these (in I 497) he had discorered South America and that on his later voyages he had explored the coast of that region. Many modern investigators consider the claims of Vespucius riliculous, but

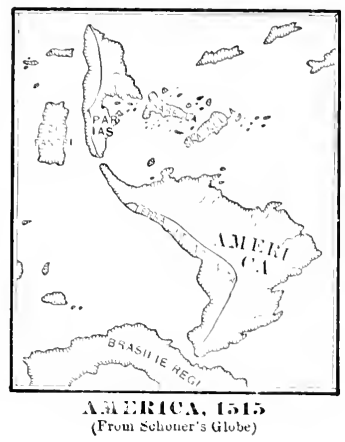

Bourne, Spain $1 n$ America, $8+4-96$.

Old South Leaflets, Nos. 34,90 . it is certain that they were believed by at least some of his contemporaries.

Among these was Martin Waldseemiiller, a professor

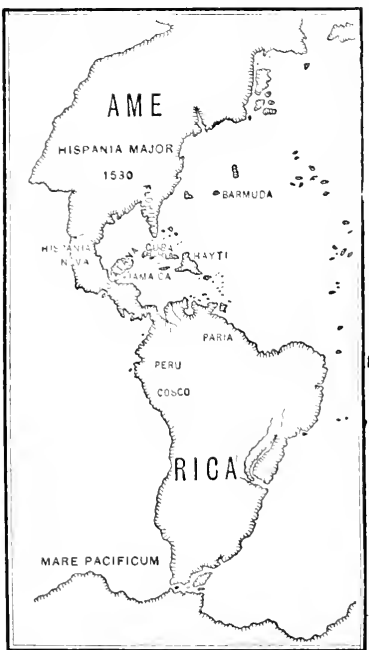

A IIEICA, 1541

(From Mercatur'B Map) of geography at the college of Saint-Die in Lorraine. In I507 Waldseemiiller published a pamphlet entitled Cosmographic Introductio, in which he suggested that the land in the southwest, which did not correspond to any islands on the maps existing before I 492 , and which for several years had been known as Mondo Noro, should be called "America." This name became quite common on maps of the time before it was learned that this southern region formed a continent connected with lands discovered by the Cabots and others at the North.
First use of name America.

Bourne, Spain in tmerica, 99-IO3.

Winsor (ed.) America, II, ${ }^{1}+5^{-1} 5^{2}$.

When this connection was understood, the name America was applied naturally to the whole of the new world. 
Discovery of the Pacific, I5I3.

Channing,

United States, I, 47-5I.

Magellan, voyage around the globe.

Channing, United States, I, 50-54.

Ponce de Leon (I5I3-152I).

Bourne, spain in America, 133-1 36 . Winsor (ed.), America, II, 232-236.
24. The Pacific Ocean. - Little was known yet about this new world, but in the decade beginning with $\mathrm{I}_{5} \mathrm{I} 3$ geographical knowledge of the uncivilized hemisphere was extended greatly. It was in the year $\mathrm{I}^{\mathrm{I}} 3$ that Balboa, an adventurer and a rebel, in search of gold, crossed the Isthmus of Panama and first beheld the waters of the Pacific, which he called the "South Sea," because the shore line runs east and west at this point.

Six years later Fernando Magalhaens or Magellan, a Portuguese nobleman in the employ of Spain, started with five vessels to find a southwest passage through South America to the Indies. In this he succeeded, the strait which he discorered now bearing his name. With but two vessels he proceeded north a long distance, then changed his course to the northwest, and finally to the west, in order not to pass the Molucca or Spice Islands, of which he was in search and whose latitude he knew. After weeks on the quiet ocean, which he named the Pacific, he reached what is probably the Island of Guam, and soon after landed on the Philippines. Here Magellan lost his life, April 27 , I52I. The larger vessel was soon after captured by the Portuguese, but the smaller succeeded in reaching Spain after circumnavigating the globe - certainly one of the most marvelous voyages in history, and one which caused remarkable changes in the geographical ideas of the times.

\section{Explorations in the United States (I5 I3-1543)}

25. Florida (I5I-I536). - For thirty years the Spanish made repeated efforts to explore the southern part of the United States, rumors of gold constantly leading them into the interior. The first to show the way to Florida, a name applied for at least a century to the entire southeastern part of the United States, was Ponce de Leon, who was attracted by the reports of an excellent climate and prospects of wealth. In $I_{5}{ }^{I} 3$ he explored both the east and the west coast of the peninsula and in ${ }^{5} 5^{2}$ attempted a settlement which failed because of the hostility of the Indians. 
In $5^{2} 6$ a much more pretentious settlement was attempted by d'Ayllon. Over five hundred persons, including some slaves, were taken to Chesapeake Bay, but the climate was so unhealthy that they lost their leader and more than onehalf of their men within a year, and the enterprise was abandoned.

The next to search for wealth in Florida was de Narvaez, who landed near Tampa Bay in $\mathrm{I}_{52} 28$. The last survivors of this ill-fated expedition were wrecked some months later on the coast of Texas, where they were held as prisoners for several years. Under the lead of Cabeza de Vaca, who had been employed as a "medicine man," four of them escaped and crossed the plains and mountains to the Spanish settlements on the Gulf of California, bringing with them rumors of large quantities of gems and precious metals to the north of the countries they had traversed and arousing renewed interest in the exploration of the interior.

26. The Southwest (I539-I543). - To ascertain the truth of the reports that the "Seven Cities of Cibola" were possessed of great wealth, Fray Marcos was sent "to spy out the land." He failed to reach the cities, but brought back stories more wonderful than any that had yet been told. In a short time, Coronado at the head of three hundred Spaniards, many of them mounted, and nearly a thousand Indians, set out for Cibola (I 540). The cities proved to be nothing but the unattractive dwellings of Pueblos, but there was said to be a great deal of gold farther north and east. A force was dispatched to investigate a great cañon to the west, - that of the Colorado, - and Coronado's little army then pushed on across the plateau and plains until Quivera was reached, probably in the present state of Kansas. They found immense herds of bison and trackless wastes, but no gold. In disappointment the Spaniards returned to Mexico.

Among the many explorers who at this time were interested in the country north of the Spanish settlements was Cabrillo. Setting out in 1542 with two vessels, he and his Coast of California.

Narvaez and Cabeza de Vaca.

Channing, Lnited States, I, 62-67.

Winsor (ed.). America, I, $240-2+4$. Old South Leaflets, II, No. 39 .

Coronado's ex. pedition (I540I542).

Hart, Contemporaries,

I, No. 24. Channing, Inited states, I, 74-84. Bourne, spain in America, I69-I74. Amer. Hist. Leaflets, No. 13. 
Hittell, Cali- successor Ferrelo examined the western coast beyond Cape fornia, I,73-78. Mendocino with considerable care. Nothing came of this or of the other explorations in the West, and it was a half century before any permanent Spanish missions were established within the United States, and a still longer time before the region proved attractive to less unselfish settlers.

Explorations in the southeast $(1539-15+3)$.

Hart, Contemporaries, I, No. 23 .

Channing, Lnited States, I, 67-72.

Bourne, Stain in America, I62-168.

Winsor (ed.), America. II, $244^{-254}$.

Verrazano's voyage (1524). Bourne, spain in America, I $43-1+5$. Winsor (ed.), America, IV, 5-9.

Cartier's explorations and settiements (1535-154I)
27. De Soto. - The last, and in some respects the greatest, of these early Spanish explorers in the United States was Fernando de Soto. Having served under the Pizarros when they conquered the country of the Incas, he was anxious to gain for himself fame and fortune in Florida, as Cortez had done in Mexico and the Pizarros in Peru. With a wellequipped force of nearly six hundred men and many horses, he landed at Tampa Bay during the summer of I539. The Indians were treated with severity, the chief of each tribe risited being seized and held as hostage until provisions were forthcoming and his country had been crossed. For two years the Spaniards continued their search through the inhospitable country without discovering traces of the wealth they sought and at length crossed the Mississippi. After further wanderings, broken and discouraged, Soto returned to the river to die (May, I $5+2$ ). Nowhere had he found gold or signs of gold, and everywhere the Indians were fierce and hostile. Glad to escape from this land of dangers, the survivors of Soto's party, after several attempts, succeeded in getting out of the Mississippi and reached the Mexican coast settlements.

28. Verrazano and Cartier. - Although far behind the Spanish in a desire to explore and colonize, the French were not entirely inactive. In $\mathrm{I}_{5} 2+$ the French sent cut Verrazano, an Italian like many of the other narigators of that day, who visited the eastern coast of North America and explored from the capes of North Carolina to Newfoundland, probably entering New York harbor.

Ten years later Cartier explored the Gulf of St. Lawrence, returning in 1535 and ascending the river. He penetrated as far as the large island just below the first series of rapids. 
To the height on this island he gave the name Mont Real. ${ }^{1}$ No attempt was made to found a colony at this time, but in ${ }^{1} 540^{-}{ }^{5} 54$ I he and an associate, Roberval, sought to settle on Hart, Contemporaries, the banks of the St. Lawrence. Roberval failed to aid Cartier until the latter had abandoned his settlement, and the French hold on America after this time was represented by a few fishermen's huts on the Atlantic coast.

\section{The Close of the Sixtefnth Century}

29. The Situation in Europe. - During the early part Spain. of the sixteenth century Spain had risen to the position of the first European power. Her king was ruler not only of the Spanish peninsula, but of the Netherlands, the Sicilies, and a large part of America. As he was in addition emperor Schwill, Modem Europe, 59-67. of Germany, the rule of Charles $\mathrm{V}$ was in consequence one of unusual splendor. The immense riches of Mexico and Peru added greatly to this power of Spain, but could not continue to sustain it, for the successor of Charles, Philip II, followed an unwise policy which undermined the sources of national strength. Freedom of thought was crushed by the inquisition, the Netherlands were lost by an unwise religious policy, while the Jews and Moors, the industrial backbone of the nation, were driven from Spain. The decline of Spanish power became evident in the latter half of the sixteenth century, and, after the defeat of the Armada in 1588 , was rapid and continuous.

France was in no position during these years to accom- France. plish much at home or abroad. Torn with the strife between the Catholics and the Huguenots, governed nominally by the worthless sons of Henry II and ruled really by the faction which was temporarily in the ascendant, she followed no fixed policy until the accession of the able Henry IV in 1589 .

England meanwhile under Elizabeth was quietly developWinsor (ed.), America, IV, $47-55$. (1) 
Robinson, Hestern Eurefec, $+5 s-403$.

Port Royal ( 1502 ).

Chamning. Inited Sintes, 1, of $\rightarrow 00$.

Fort Curoline. Menendez.

Chunning

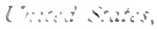
I. $00-100$.

H.xit, contenyand 1. Xio. so.

1. iske, Tisi.

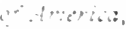
11. 51 2ー521.

Boume. Ex.sin an. tn: cas, I, - ISO. as an international power, inferior to Spain and France, she gave encouragement to the seamen of the southern coast who engaged in trade with the Spanish colonies, and aided merchants who desired to form an East India company to trade with the far East. Elizabeth in fact permitted sir Francis Drake and others to capture Spanish merchantmen and treasure ships in time of peace, thus developing that irregular navy which in Is $\$ S$ harassed and in the end destroyed the unwieldy Spanish Armada. With Spain's nary crippled, the Dutch seized upon the greater part of the carrying trade of Europe.

30. The French in Florida $(1502-1565)$. - Under the anspices of the great Protestant leader, Gasper de Coligny, two settlements were attempted in the southern part of the Lnited states in the land named Florida and claimed by the Spanish. The first of these was made in $r_{5} 62$ by Jean Ribut at Port Royal, a little north of the Saramnah River. but the next year the colonists constructed a ship, abandoned the colony, and reached Europe after a terrible royage.

In 1504 a second settlement was started by Laudonniere on the river of May, now called the St. Johns, where they built a fort named Caroline in honor of their king. Charles IX. Most of the settlers were men of broken fortunes and adventurers. Lntrained to labor and desiring only gold, they quarreled with one another and with the Indians. some of them at length turning pirates and betraying to the Spanish the presence of the little colony. Meanwhile the settlers prepared to abandon the colony, but before they were ready to suil, two flects arrived off the const of Florida: the first. French, under Ribaut bringing relief; the second, Spanish. under Menendez, threatening destruction. Before Menendez, a man of great vigor and earnestness, heard of the French colony, he had been expecting to secure a grant of Florida and colonize that region. When he learned of the Protestant settlement, he applied to Philip II who helped him fit a great expedition for what they considered a crusade. Finding the French fort and fleet too strong to attack, he disem- 
barked his men and constructed a fort which he named St. Augustine ( $\left.{ }_{5} 6_{5}\right)$. The elements now farored him, for Ribaut's fleet was scattered and his ships wrecked by a great storm. Menendez immediately marched overland through the swamps, attacked Fort Caroline, which was practically unprotected, and put the inhabitants to the sword. Three different parties from Ribaut's fleet who had been wrecked on the coast south of St. Augustine were obliged to throw themselves on Menendez's mercy. Most of them were foully slain. This ended the settlements of the French in the southern part of North America, for King Charles of France was not fond of the Huguenots and was completely under the domination of Philip, but it did not close the warfare between the French and the Spaniards, for two years later de Gourgues destroyed the Spanish forts in Florida and hanged the defenders.

\section{The English in the New World ( $\left.5_{5} 6_{2}-\mathrm{I}_{5} s_{3}\right)$. -} Numerous Englishmen were interested in the new world Hawkins and Drake. because of its commercial possibilities. The earliest of these, Sir John Hawkins, engaged in the slave trade with the Spanish West Indies. On the third of these royages his ships were attacked, treacherously he thought, by Spanish officials. With him on this trip was his cousin, Sir Francis Drake, who from this time devoted his life to the injury of Spain. With the consent of Elizabeth, Drake raided the Spanish main and in 1577 sailed into the Pacific Ocean, where he captured treasure ships on the way from Peru to Panama. Continuing northward until turned back by the cold, he returned to a harbor near San Francisco bay, where he refitted his ressel. The western part of the continent he named New Albion, claiming it for England. Returning to England ria the East Indies and Africa, he brought back reports which aroused new interest in finding a northwest passage to the East.

Frobisher had already (1576) searched for a northwest passage and Daris made three royages ( $15^{8} 5^{-1} 5^{8} 7$ ) for the same purpose. The most earnest adrocate of settlement in northern America and of search for a way to Cathay was Sir 
Woodward, British Em. pire, 39-49.

The first colory ( $\mathrm{I}_{5} \mathrm{~S}_{5}$ ).

Channing,

C'nited states, $1,124-128$.

Humphrey Gilbert, who tried to form a colony on Newfoundland in $I_{5} S_{3}$. The attempt was abandoned and on the return voyage Gilbert's vessel foundered.

32. The Ralegh Colonies ( $5_{5} S_{4}-I_{590}$ ). - The next year Sir IValter Ralegh dispatched to America Captains Amadas and Barlow, with instructions to investigate and report the possibilities of colonization. So glowing was their report that Queen Elizabeth named the country Virginia in her own honor. The succeeding spring ( $\left.5 S_{5}\right)$ seren ressels

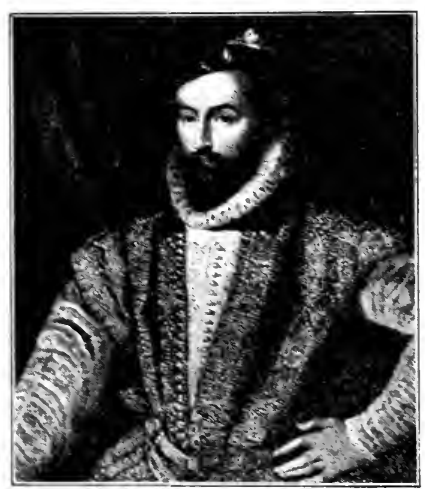

SIR WALTER RALEGH set sail carrying over one hundred settlers, whose leader was Ralph Lane. They landed at Roanoke Island, off the coast of what is now North Carolina, but before the ships returned to England the commander of the fleet maltreated the natives, thus alienating tribes whose friendship would have been of the greatest value. As the colonists would not work, and could obtain no Fiske, ola lir- food from the now hostile Indians, they gladly took adsimia, I, 30-33.

The "lost colony" $\left(I=B^{1}-I \geqslant 00\right)$.

Fiske, Ord l:r. sinia, I, 35-30.

Channing. C"rited stiotis, I. I $28-133$. rantage of the arrival of Sir Francis Drake and returned to England.

Ralegh's derotion to his pet scheme led him to form a company which in $\mathrm{I}_{5} S_{\text {; }}$ sent out a new expedition carrying women as well as men. Their destination was Chesapeake Bay, but they repaired first to Roanoke, where they decided to remain. Governor White of this "City of Ralegh," as the colony was called, returned to England for help later in the summer. but the ships sent out with supplies were used to prey upon Spanish commerce, with disastrous results. Then came the Armada (IjSS) which called forth the naval strength of England. Another year was frittered away by the men to whom Ralegh, now imporerished, 
assigned his Virginia patent, and when in 1590 assistance arrived, no trace could be found of the "lost colony." Thus inauspiciously did the English begin the colonization of the new world.

33. The Results of the First Century. - In the century following the discovery of America by Columbus the advance Discovery and in geographical knowledge had been enormous. The shape of the earth had been proved beyond dispute and its size quite accurately ascertained. There was no longer a sea of darkness, but two immense oceans had been crossed; in the case of the Atlantic, repeatedly. A new continent had been brought to light, of which to be sure little was known except the shore lines. Almost every part of the eastern Atlantic

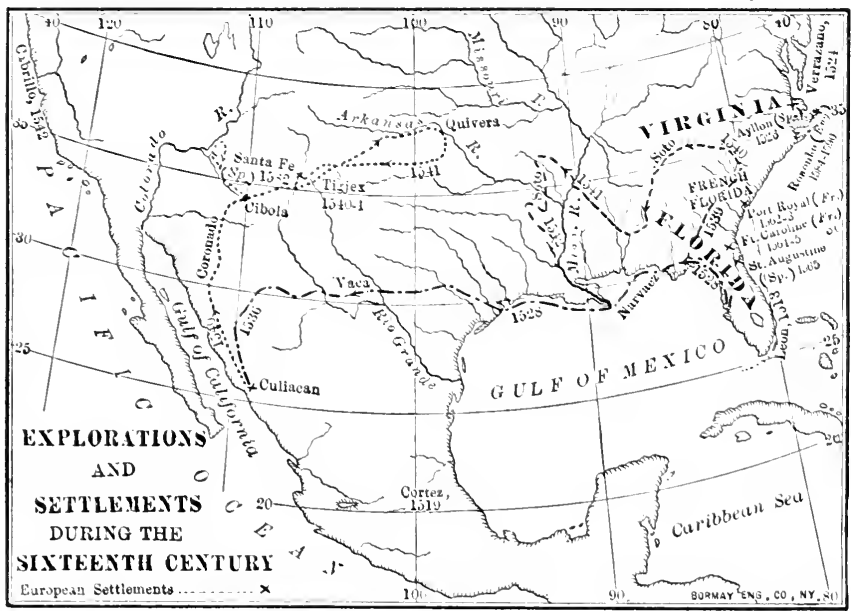

coast had been explored by Europeans and the western coast nearly as far north as the Oregon River had been examined. The interior of the North American continent had been visited by but two leaders - Coronado and Sotoand the heart of the continent was little better known in r600 than a half century earlier. Search had been stimulated, however, because of a desire to find a water passage 
from the Atlantic to the Pacific which would make it possible to sail from Europe west to Asia without going as far south as the Straits of Magellan. More than any other one cause, this desire led in the following century to the investigation of the waterways in the new world.

Attempted colonization.

South of the present limits of the United States, Portugal had established a colony and Spain had taken possession of several islands and many Indian countries. Within the United States the repeated attempts to form colonies had led to the establishment of but two permanent settlements the insignificant Spanish fortifications at St. Augustine and the little frontier mission at Santa Fe. Considering the amount of moner and effort expended, the results were discouraging indeed. In striking contrast to the limited territory occupied by Europeans at the close of the sixteenth century were the sweeping territorial claims of the rival nations. Spain asserted her right to a territory of continental extent. France claimed the northeastern coast and that part of the interior drained by the St. Lawrence River, and England asserted her right to the eastern part of North America, because of the Cabot discoveries, and to the western coast by virtue of Drake's exploration.

\section{TOPICS}

Columbe's Eeforts to chix Help (Ifsf-Ifoz): Adams, "Columbus," PP. Bt-is; Fiske. "Discovery of America," I, PP. 3SI$35 \Sigma, 305-410$.

The Vovage of the CAbots: Winsor (ed.), "America," III, pP. I-; : Fiske. "I) iscovery of America." II. PP. I-Io; Lee (ed.), "History of North America." I. pp. 20;-300.

MAGElAN"s VOYAGE AROTN THE VORLD: Bourne, "Spain in

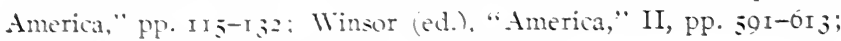
Fiske, "Discovery of America." II, 15

\section{STUDIES}

I. The character of Columbus (rriticisms). (Winsor: "Columbus." PT. 400-5iz.)

2. Origin of the name "America." (Fiske, "Discovery of America," II, PP. 120-I 5.5.) 
3. Cortez in Mexico. (Fiske, "Discovery of America," II, pp. $2+5-293$.)

4. The wanderings of Cabeza de Vaca. (Lummis, "Spanish Pioneers," PP. IOI-I I 0. .)

5. Coronado's explorations. (Johnson, "Pioncer Spaniards," pp. $219-25.3$.

6. Spain's colonial policy. (Bourne, "Spain in America," pp. 202-210.)

7. Spain"s American commercial policy. (Bourne, "Spain in America," pp. 2S2-20S.)

S. Verrazano's voyage. ("Old South Leaflets," No. I7.)

9. Religious wars in France. (Duruy, "History of Modern Times," pp. 2IS-234.)

I0. Destruction of the French colony in Florida ( 1565 ). (Parkman, "Struggle for a Continent," PP. 2-5-54.)

I I. The English in the East (after I5So). (Woodward, "Expansion of the British Empire," pp. 60-85.)

I2. Reasons for English colonization in America. (Hart (ed.), "Contemporaries," I, Ncs. +4-40.)

\section{QUESTIONS}

I. What was the significance of the first royage of Columbus?

2. How did the discoveries of Vespucius and Magellan affect the geographical ideas of the times?

3. What influences were most powerful in leading the Spanish to colonize? What were the chief characteristics of Spain's colonial policy? Was Spain a successful colonizing nation?

4. Why did Soto fail, while Cortez and Pizarro succected? Name several reasons why the Spanish failed to get a real foothold in the United States.

5. How do you account for the comparative inactivity of the French and English during the sixteentli century? 


\title{
CHAPTER III
}

\section{EARLY ENGLISH COLONIZATION (I600-I660)}

\author{
ENGLish RULERS
}

Elizabeth (1558-1603)

Charles I (I625-1649)

James I ( $1603-1625)$

Commonwealth (I649-I660)

\section{ViRginia (i606-i625)}

Virginia company and its sub-companies.

MacDonald, Charters, No. I.

Channing, United States, I, 157-163.

34. The Charter of r606. - During the early years of the seventeenth century several voyages were made to the coast of Virginia by English seamen who brought back glowing reports of the country and its climate. As Ralegh

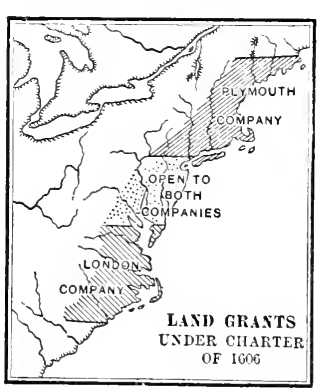
had been imprisoned and his charter annulled by James I, a new company was organized in 1606 for the purpose of making settlements in Virginia. To certain members of this Virginia company, residing in London and usually called the London company, was granted the land lying between parallels 34 and 38. The territory from $4 \mathrm{I}^{\circ}$ north to $45^{\circ}$ was granted to members living in Plymouth, the right to occupy the middle strip from $38^{\circ}$ to $4 \mathrm{I}^{\circ}$ being shared by both sub-companies, provided that neither settled within one hundred miles of the other. The Virginia company was permitted to coin money and to defend its possessions, while its colonists were to have all the rights enjoyed by Englishmen. ${ }^{1}$

${ }^{1}$ There was to be a resident council for the government of each of the two colonies established, and the general direction of the Virginia company's affairs in England was entrusted to a council appointed by the king. 
35. The Settlement at Jamestown. - In December, The first year I606, three vessels fitted out by the London company set (I607). sail for the new world with more than one hundred colonists. According to the custom of those days, they went by way of the Canaries and the West Indies and did not enter Chesapeake Bay until April, I607. As a site for the new settlement, they desired a place not too near the coast which might be fortified easily against the Spaniards, who objected

Eggleston, $B e=$ ginners of $a$ Nation, 25-31.

Channing,

United States, I, 163-170. to English settlements on land which they claimed. A low peninsula half buried at high tide was selected, the name of Jamestown being given to the settlement, in honor of the king. Most of the settlers were "gentlemen" unused to hard labor, so that the work of constructing homes and planting crops progressed slowly. With summer came an epidemic of fever, and within four months half of the colonists had perished. The councilors

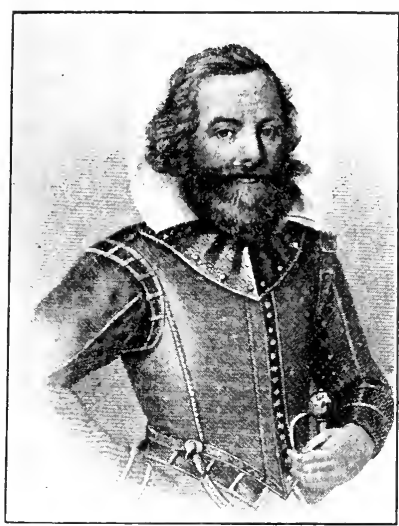

CAPTAIN JohN SMITH who had been sent over to govern the people proved inefficient and quarreled with one another. Famine was averted by securing corn from the Indians and by supplies sent from England, but the communistic system, according to which all labored for the common store, did not encourage industry or thrift in a naturally shiftless set of men.

The real leader of the party was John Smith. Although less than thirty years of age, Smith was a man of varied experiences and of considerable ability. Since coming to Virginia he had made friends with the Indians, and, in an Tyler, England in America, 4I-54. Hart, Contemporaries, I, Nos. 6I-63. open boat, had explored the shores of the Chesapeake Bay, in America, 55-60. making a map of the region which was remarkable for its accuracy. When he was elected president of the council,

Tyler, England

Rule of John Smith. 


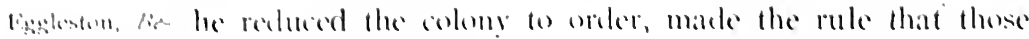

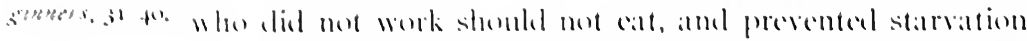
hy scroring fond from the Indians through his skill and holdness.

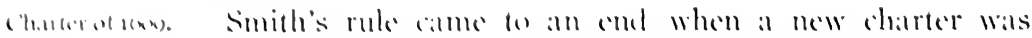
pranted which chamesed the method of gerermment and ex-

$11.11 \cdots \cdots 11,14$,

1 andes.

ㅅ.. 2

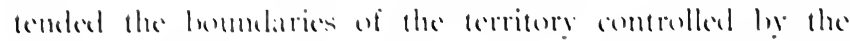

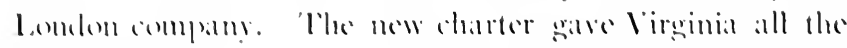
lame for ewo humbled miles morth ame south of loint (ombort

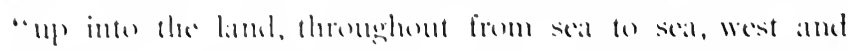
morthwest." licatuse of the word "northwest" Virginia Cinnurrial

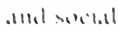
risults. afterwated damed the lerritory in the interior of the conti-

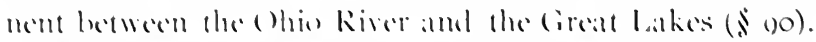

30. The Inthence of Tobaceo Culture. That Virginia

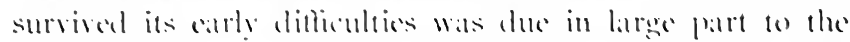
charater of its dirst kathers, especially to fohm smith and

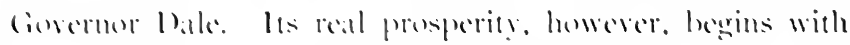
(iml1111, Imitos

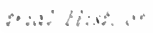
6 ㄴ.

( h. munims: (1). 1. 1050 the cultivation and expertation of tobatcos. for which the soil and climate of the colome were particularly andipted.

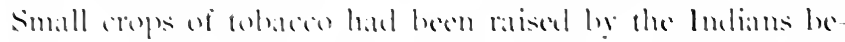
fors the white sethlers came, hut mot antil bale hat put an end to the commmmistic system were plantations started on which the rasing of tohaco beame a regular industry. king James was stromgly appesed to the use of the "tilthy

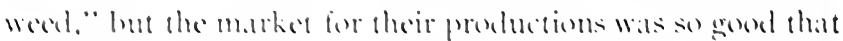

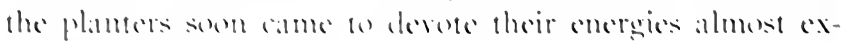

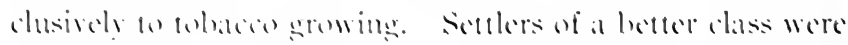

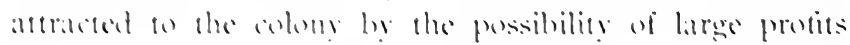

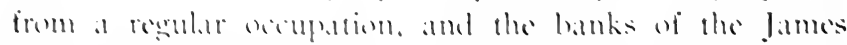

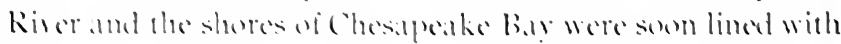

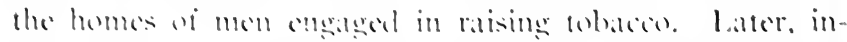

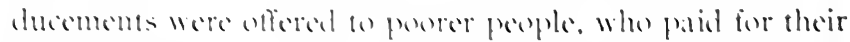
passege the thew world hy several years of service on the

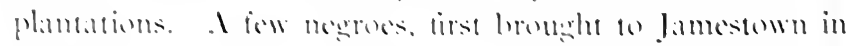
1010 in a Hutch man of watr, were also cmployed at the more menial taskis. Ciratually, as the plamtations became larger and the ticht workers more numerous, the distimetion 
betwèn landowners and laudless became: more marked, the classes of seciety being almost ats wirdely separatrol ats in lingland.

37. The First Virginia Assembly (I6I0). III the years

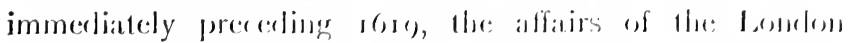
company in lingland and of the Virginia osemists in Amerie a

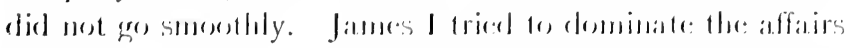
of the omprany by dielating the laws that shemlel be: mate:

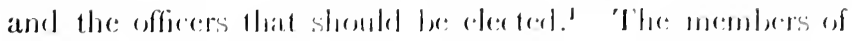
the company olejected naturally, for, by the charter of 1612,

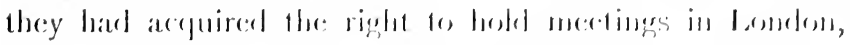
transact gencral business, and gevern the obleny in Amerira.

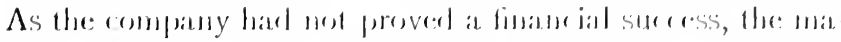
jority of the stock in the lomelem complany hatel comes intos

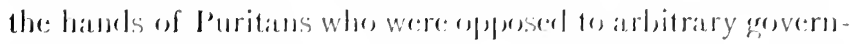
ment in lingland and in Aneriea. Sine the gresermer of Virginia had aremsed the: wrath of the settlers hy his unjust and tyramiand role, the complany, morles lhe laad of

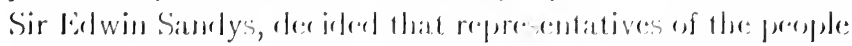

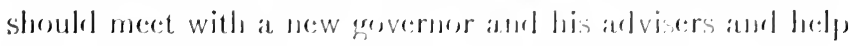
them make the laws. Following his instrue lions, (anvermor Yeardley askeel the freenen in eath of eleven plantations,

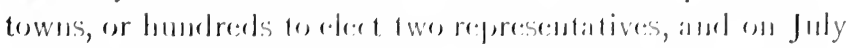

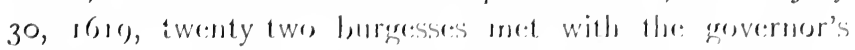
councilors in the first legristature in America. 'J wo years

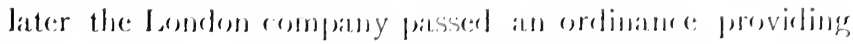
for a regulatr government in Virginia (omsisting of a comme il,

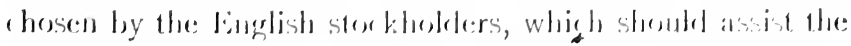
gevernor, and a genceral assembly compesed of the commeilers and ef burgesses elected by the freement. In this way the popular gevernment establisheal in 1610 ly the Jingli h Puritans was marle permanent.

38. Virginia becomes a Royal Province (I624). 'Jlic:

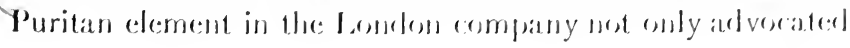

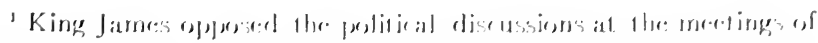

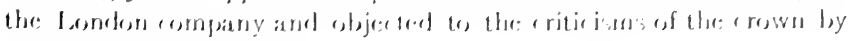
members of the rompany.

Mendings of the: an, $\cdots+m||$,$y .$

$11: 111,10111 / \mathrm{m} / 11-$ fine ilites, $1, N 1,6.5$.

lind int the:

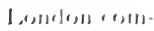
firny': 14: 
Cooke, vir- constitutional government for their Virginia colony, but under ginia, I29-133. their wise guidance hundreds of thrifty settlers were pursuaded to try their fortunes in the new world. The colony Hart, Contem- had a new lease of life, its prosperity far exceeding that of poraries, I, Nos. 66, 67. Indians and in 1622 a terrible massacre occurred, from which Virginia recovered with surprising rapidity. But Tyler, England this uprising furnished the excuse desired by the king and in. America, other enemies of the company in England for the overthrow of the company. This was accomplished in $\mathrm{I} 624$ on flimsy pretexts, and Virginia became a royal province. No change was made, however, in the character of its colonial government, as Charles I, who came to the throne in 1625 , desired to win the faror of his American subjects, and was willing to have assemblies that would provide money for the royal treasury.

\section{New England Before i628}

Plymouth company (1607).

Tyler, England in America, $39-4 \mathrm{I}$.

Council for New England (1620).

MacDonald, Charters, No.4.

\section{The Plymouth Company and the Council for New} England. - The settlements in the northern grant made to men of Plymouth in the charter of 1606 had not prospered like those of the South. During that terrible summer of I 607 when the fate of Jamestown was yet doubtful, over one hundred colonists landed at the mouth of the Kennebec, but the extreme cold of the winter and the death of Sir John Popham, the chief justice of England and the ruling member of the Plymouth company, led to the abandonment of the enterprise.

Nothing further was attempted until in 1620 the company was reorganized ${ }^{1}$ and obtained from King James a patent to the land lying between parallels $40^{\circ}$ and $48^{\circ}$ and extending from sea to sea, with a practical monopoly of the fisheries and fur trade. Various grants of land were made by the company to its members, but few settlements were made, even for purposes of trade, and the credit for establishing

${ }^{1}$ It was now called the Council for New England. 


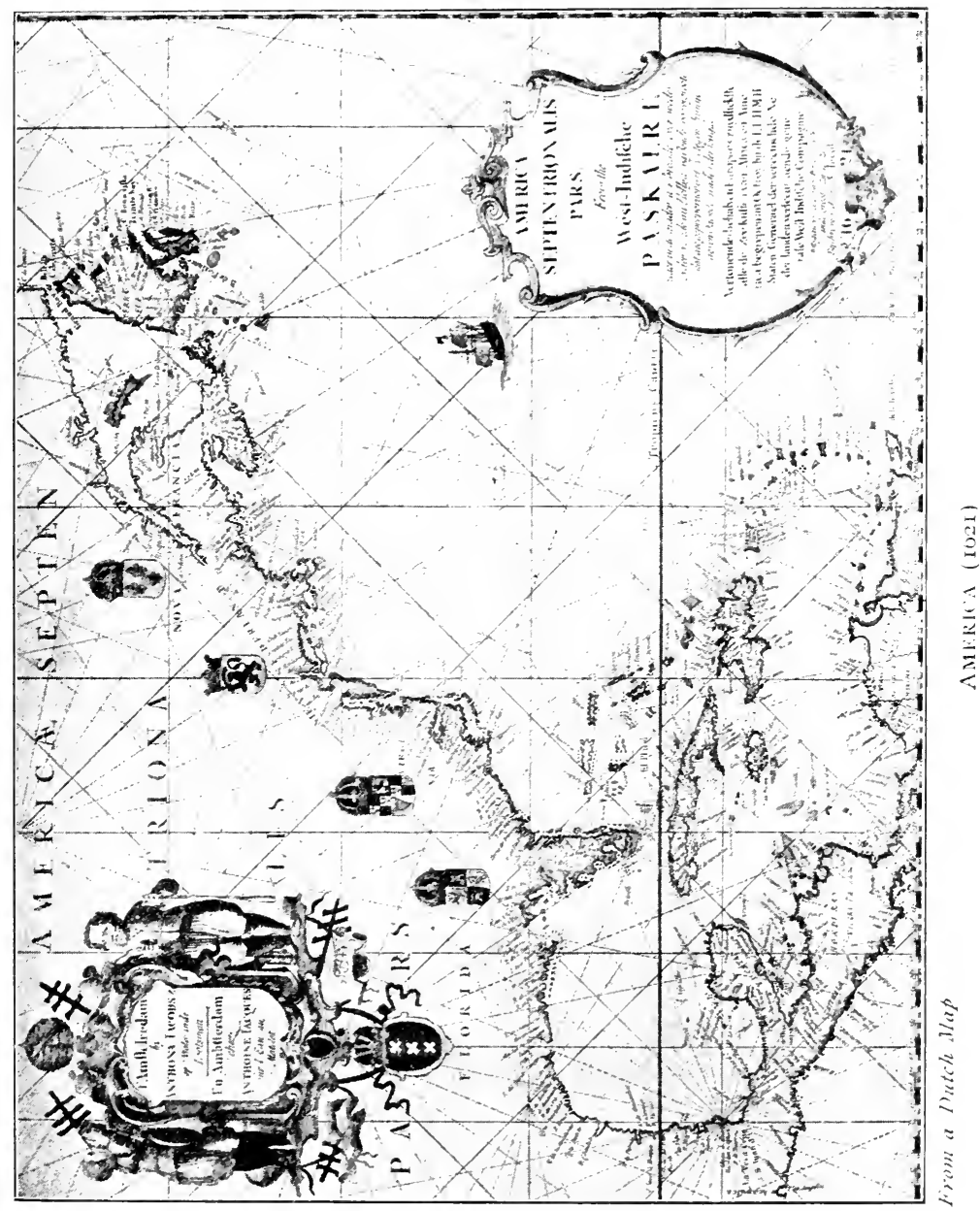


the first homes in New England belongs to some Separatists, usually called the Pilgrims, who located at Plymouth.

Puritan policy. 40. The English Puritans. - To understand the early history of New England, a knowledge of conditions and

Eggleston,

Beginners, IO3-II4. events in England under the first two Stuarts is quite as essential as any information regarding the doings of the early settlers, for the colonization of New England was due directly to the contest which took place between the Puritans and the English kings, James I and his son Charles I. The Puritans comprised a large and ever growing class of the English people who believed that the Anglican church, which had been established by the Tudors in England at the time of the Reformation, retained too many of the old forms of the Roman Catholic church. They desired to purify the church of these "papist" forms and to introduce among the people a higher standard of living. But they stood for more than religious reform. They advocated any scheme or plan that would lead to social or political betterment It would be incorrect to imagine that they formed a sect with well-defined views, for the word "Puritan" three hundred years ago had a meaning but little more definite than that Three classes of "reformer" in our own time. In religious matters alone of Puritans. there was a vast difference between the moderate Puritan who farored a simplification of the church service, but who was nevertheless very much attached to the church, and the radical Puritan who had severed his connection with the established church in England and was known as a "Separatist." Between these two extremes was the liberal Puritan, who desired to remain in the church but wished to introduce radical changes in the church service and to leave the control of all local ecclesiastical affairs, including the selection of a pastor, to the members of the congregation.

Puritan narrowness.

In spite of their desire for reform, the Puritans were often narrow and the importance that they attached to forms is amazing to a person of the twentieth century. Their desire to raise the low moral standard of their time made them go to the other extreme. Their opposition to amuse- 
ments was so rabid that we are tempted to believe the state- Eggleston, ment that they objected to the cruel sport of bear baiting, less because it gave pain to the bear than because it afforded Beginners, I22-I33. pleasure to the spectators. And yet, with all the narrowness which they so often showed, it may well be doubted whether any other political force has exerted as great an influence on America as that of the Puritans.

4I. The Puritans and the English Monarchs. - During the reign of Elizabeth, all of those who did not conform to the practices of the established church, frequently known as non-conformists, were treated with considerable severity. Since the monarch was the head of the church and of the state as well, those who refused to worship as the church prescribed were thought to be guilty of disobedience little less dangerous than treason. For this reason there was no religious toleration in England, and those who were unwilling to conform were punished.

When the throne of England at the death of Elizabeth was left to James VI of Scotland, there was a general feeling among the Puritans that they might obtain some of the religious reforms that they desired, since the established church of Scotland was controlled by the Puritans. James disappointed the reformers very early in his reign, for in a religious conference held at Hampton Court ( 1604 ) he showed very clearly that he believed thoroughly in his divine right to rule both church and state. His experience with the Scotch church had not been especially pleasant and he took occasion to oppose the Puritan requests because they would lead to a church system like that of Scotland, "which agreeth as well with a monarchy as God with the devil." In conclusion he said of the Puritans, "I shall make them conform themselves, or I will harry them out of the land." This policy he followed with constantly increasing vigor, for the Puritan element was gaining in strength year by year. One of the earliest results of James's attitude was to drive from England many Separatist congregations which were no longer allowed to hold meetings, open or secret.

Under

Elizabeth.

Tyler, England in America, I $53-155$.

James I. and the Pulitans.

Eggleston, Besinners, I59-163.

Channing, Lnited. States I, 27 I-284.

Gardiner, Puritan Kevolution. 
In Holland (I608-I6I8).

Tyler, Engrland in America, I 5j-I6I.

Hart, Conte'mforaries, I, Nos. 97-99.

Amer. Hist. Leafits, No. 29.

Voyage to America (I020).

Mayflower compact.

MacDonald, Charters, No.5.

Dangers (I020-IO23).
42. The Pilgrim Migrations. - One of these Separatist churches had been organized in Nottinghamshire by William Brewster and John Robinson. Owing to the persecutions of James I, they Hed in I 608 to Holland, the only country in Europe where relivious differences were tolerated. Making Leyden their home, with many other refugees, they toiled for years without being able to earn more than a bare living. As the prospect was no brighter for the future, and their children were intluenced by the easy-roing Dutch ways, often intermarrying with the Dutch as they grew up, some of them came to the conclusion that their condition might be improved by emigrating to America. The Puritans were now in control of the Virginia company and from them these Separatists obtained liberal concessions and a grant of land in the northern part of Virginia. Lacking the money needed for so expensive a journey, they entered into an agreement with certain "merchant adventurers" of London by which all of the earnings of the colonists should remain joint property, and each atrenturer who contributed ten pounds should, at the end of seren years, have an equal share with each colonist. After many difficulties, including the abandonment of one of their ressels which proved unseaworthy, the Pilgrims set sail in the Mayfouter from Plymouth, September 6, I0zo. Two months later they came in sight of Cape Cod, and after six weeks of search for a suitable place for a settlement landed December 2 I at a harbor which they called New Plymouth.

43. Early History of New Plymouth. - Being far to the north of the territory under the jurisdiction of the Virginia company, the men of the party met in the cabin of the Maylower and drew up a compact organizing themselves into a "civill body politick, for our [their] better ordering $\mathbb{S}$ preservation." and promising "all due submission and obedience" to the "just \& equall lawes" which they should enact from time to time

The first winter, although unusually mild for that section, brought terrible hardships and suffering. One half of the 
colony perished, but the rest kept bravely at their work, Tyler, being aided by a few others who came over from England or Holland. The Indians of the vicinity were friendly, a permanent peace being made with their chief, Massasoit, which lasted until his death forty years later. When the chief of the more distant Narragansetts tried to intimidate them by sending a bundle of arrows tied with a rattlesnake's skin, Governor Bradford returned the skin filled with powder and ball: Soon after the Indian uprising in Virginia (I622), a threatened plot was nipped in the bud by the valiant captain, Miles Standish. By this mixture of diplomacy and force, Plymouth became singularly free from difficulties with the red men.

Even the honest, hard-working Pilgrims could not make a success of communism, and in 1624 an acre was assigned End of communism. to each person as his separate property. Where previously there had been continual danger of famine, now crops were abundant and a surplus remained for sale. Two years later money was borrowed from leading men of the colony, and the interests of the merchant adventurers were purchased for $£$ i 800 .

Plymouth obtained a land grant from the Council of New England in I630 and was allowed to govern itself unmolested. So few were its settlers that until $6_{3} 8$ there was an annual meeting of all the people of the colony, but after that year the example of Massachusetts was followed and a representative assembly was held every year. Plymouth grew slowly, and in I69I was joined to Massachusetts $(\$ 77)$.

\section{Beginnings of Massachusetts Bay (i628-i636)}

44. The Massachusetts Bay Company. -- North of the colony of New Plymouth, a few pioneers began settlements during the years following $\mathrm{r} 620$, making a precarious living usually in connection with the fisheries. One of these, composed of several earnest and religious men from Dorchester, had prospered for a time, only to be practically abandoned later. But this Dorchester venture had awak-

Government before I69I.

Tyler, England in America, $172-182$.

Organization and charter.

Fiske, New

England, 92-97. 
Eggleston, Beginners, I99-209.

MacDonald, Charters, No.8.

Quarrels over political and religious questions.

Robinson, Western

Europe, $478-484$.

Coman and Kendall, Enyland, 296-306. ened the interest of certain Puritan leaders at home, who believed that America offered the best opportunity for the establishment of churches using the simple form of worship which was their ideal. With this in view they obtained (I628) from the Council for New England a patent to the land lying between boundaries three miles north of the Merrimac River and three miles south of the Charles, and extending from sea to sea. A year later King Charles reaffirmed this land grant in a royal charter which created the corporation known as "the Governor and Company of the Mattachusetts Bay in Newe England," with the right to admit new members and to govern its territory, provided that it did not make laws contrary to those of England. The officers were to consist of a governor, a deputy governor, and eighteen assistants, elected yearly by the members of the corporation. No place was designated for the meetings of these officers or of the "general courts" composed of all stockholders in the company, although all previous charters had such a provision. The omission was due probably to the desire of the incorporators to hold their meetings in either London or Dorchester, but there was nothing in the charter to prohibit the company from establishing its headquarters in America.

45. King Charles and the Puritans. - The desire of the Puritans to have a colony in America was due in large part to friction with the king, Charles I, who had succeeded his father in 1625. Charles was a thorough believer in his divine right to rule England, and was less cautious and more obstinate than his father. The Puritan element now controlled the house of commons and forced the king in the Petition of Right (1628) to grant their political demands, but they were unable to obtain any religious concessions. Charles desired a high church ritual with greater uniformity throughout the realm. The commons insisted that a simplified service should be used. The victory remained with Charles, for he had begun to make changes and dissolved parliament before the commons could do more than protest. 
Charles then carried out his plans by enforcing through Archbishop Laud a ritual more elaborate than any used previously in the churches. But Charles's attempt to govern England without parliament $(1629-1640)$ and in opposition to the wishes of a majority of his subjects, his extra-legal

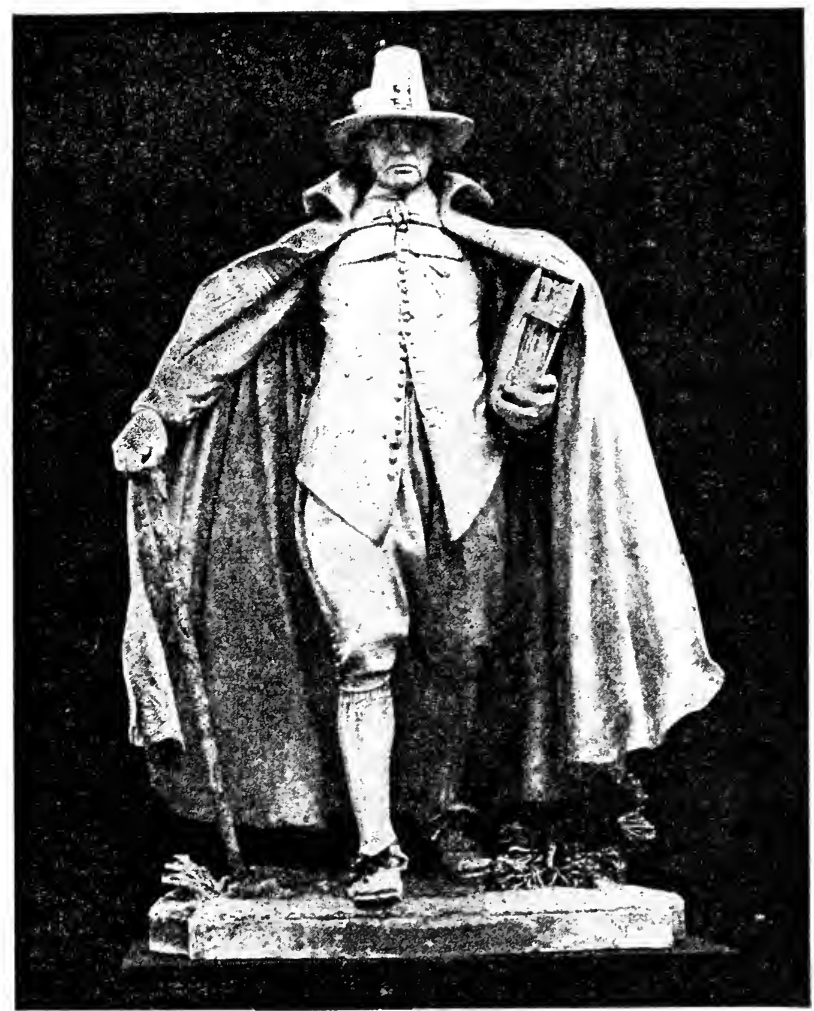

A PURITAN

St. Gaudens

levies of ship money ( 1635 ), and his attempt finally to force the English prayer book on the Scotch church (I637), although apparent evidence of his triumph over the Puritans, were in reality the chief causes of his final overthrow.

46. Character of the Massachusetts Bay Colony. - When the most prominent members of the Massachusetts Bay 
The great migration (1630-I640).

Hart, Contemporaries, I, Nos. 105, 106. Fiske, New England, IOII04, $\mathrm{I}_{37-1} 6$.

Eggleston, Beginners, 209-2I5.

Channing, United States, I, 325-335.

The colony acquires the company's charter.

Channing, Lnited States, I, 340-342.

Contest between the officials and the people.

'Tyler, England in America, 20I-204.

Channing, United States, I, 342-35I.

Hart, Contemporaries, I, No. I07. company left England in 1629, they decided to take the charter with them, intending to transact all their future business where no agent of the king might interrupt. The leading spirit in this movement was the new governor, John Winthrop, a man of exceptional scholarship and very noble character. Winthrop and about one thousand others embarked for their new home during the year 1630 , the first of the eleven years of the "great Puritan migration," for during the time that Charles attempted to govern England without parliament, nearly twenty thousand men, women, and children were transported to the shores of New England. They did not come for religious freedom but with the idea of establishing churches in which they might worship in the way which they preferred.

The transfer of the charter, in itself a most remarkable erent, was the beginning of political changes eren more noteworthy. All church members in the colony were admitted as members of the company. In this way the colony became identified with the company and gained all of the rights that the company had possessed, so that it now had the power, protected by the charter, to govern itself. This change was in fact completed before the king discorered that the charter of the company had been taken from England.

47. Political Problems and Dangers. - Some of the leaders of the Massachusetts Bay company wished to make all of the laws and do all of the gorerning. They persuaded the people to keep them in office without holding elections yearly as the charter directed. The people submitted until the officials began to levy a special tax for a stockade at the most exposed settlement. Then they insisted upon annual elections and the right of every member of the colony to attend the annual meeting and help make the laws. As it was found impossible for the men from distant settlements to leare their homes for this annual meeting, they began in ${ }^{6} 6_{3}$ to send representatives who helped the governor's assistants to make the laws. In 1644 a dispute over a stray 
pig led to the separation of the assistants and the representatives, thus organizing the first bicameral legislature in America. The democratic faction protested against the Donald Charters, No. 17. powers which the officials still exercised by interpreting as they pleased the laws which were unwritten. The people demanded a bill of rights and a written code. In I64I the officials yielded and passed a very complete and very liberal code of laws known as the Massachusetts Body of Liberties.

The Massachusetts Bay company treated its neighbors so arbitrarily that some of them complained to the king. King Charles realized that the colony was governing itself in opposition to his wishes, so that steps were taken to revoke the charter. Preparations were made to defend the colony against attack, but the king was too busy carrying out his policy at home to give the matter his attention.

48. Religious Difficulties. - Quite as serious as the threatened attacks made by England were the dangers arising in Massachusetts from religious differences. Massachusetts was a distinctively Puritan commonwealth. The church was not only closely connected with the affairs of state, it was the foundation on which the political and social organization rested. Partly for this reason, partly because the Puritans were by nature intense, sincere, but narrow, and partly because every nation of that time except the Dutch loathed the idea of religious toleration, the government of Massachusetts exercised a very strict supervision of church affairs. Although themselves non-conformists with the established church in England, the Puritan emigrants followed toward the irregulars the policy of James I toward themselves. Those were banished who insisted on worshiping according to the rites of the Anglican church or in other non-Puritan ways.

The most famous of these early dissenters was Roger Williams, an able, large-hearted but eccentric clergyman. He wrote a pamphlet claiming that the king had no right to issue land patents, for all the land belongerl to the Indians. Williams' crowning offence was the assertion that no magis-

Roger

Williams.

Fiske, New

England, II. -I I6. 
Tyler,

England in

America.

212-218.

Channing,

United States,

I. 362-368.

Anne

Hutchinson.

Fiske, Neze

England,

II6-II9.

Eggleston,

Beginners,

329-339.

Religious

policy.

Channing,

United States,

I, 393-398.

Hart, Contemporaries,

I, No. II5.

trate should exercise any control in religious matters, such as enforcing Sunday laws or requiring an unconverted person to take an oath, which he considered a religious act, but that affairs of state should be separated from those of the church. ${ }^{1}$ He was tried (1635) and ordered to leave for England, but was permitted to make his way south, where he founded Providence ( 1636 ).

Williams had exercised great influence, but had no large personal following, as was the case with Mrs. Anne Hutchinson whose teachings in 1636 threatened to disrupt Massachusetts. The entire population of Boston was divided into two hostile parties favorable or unfavorable to Mrs. Hutchinson. The opponents of Mrs. Hutchinson finally triumphed and that lady with her followers was banished (1637). Some went north to New Hampshire, but the larger number settled on Rhode Island in Narragansett Bay.

\section{Expansion in New England (i635-I645)}

49. Providence Plantations and Rhode Island. - Settled by persons who had been driven from Massachusetts because of their religious views,

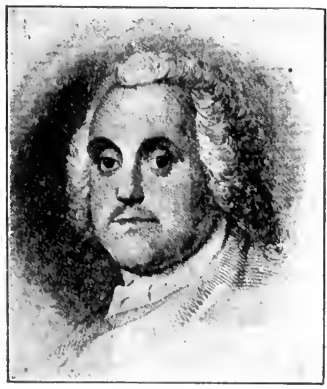

ROGER WILLIAMS Providence and the Rhode Island towns were drawn together by bonds of sympathy, but remained politically separate until in 1644 Roger Williams obtained from a parliamentary commission a semicharter by which the towns around Narragansett Bay were united and authorized to govern themselves. The policy of Providence from the beginning and of the united towns after I644 was one of perfect religious liberty. Liberal Puritans were welcomed, but freedom of thought was per-

${ }^{1}$ When supplying the pulpit at Salem, his extreme views gave offense. He was held responsible when one of his supporters, John Endicott, cut out from the British flag one arm of the cross which 
mitted to Catholics, Jews, Quakers, and atheists as well. Williams insisted that a man should be protected by the government without regard to his religious views. Through his influence Rhode Island became the first community in the modern world where there was perfect religious liberty. Yet the earliest results of this policy were somewhat disastrous. Not only those with real depth of religious feeling made Rhode. Island their home, but many whose views on all subjects were unusual.

The colony grew but slowly, making up in the eccentricity of its people what it lacked in numbers. As the first semicharter had been issued irregularly and did not define the territorial limits of the colony, Charles II was persuaded in I663 to grant a charter which gave the people complete powers of self-government, subject to the one limitation that the laws conform as near as might be to the laws of England. Perfect religious freedom was permitted, so that no change was made in the policy of the colony.

50. The Connecticut Valley. - We have already noticed ( $\$ 47$ ) the antagonism existing in Massachusetts between those who favored an aristocratic government and those whose ideal was democratic. Although certain concessions were made to the liberals, several of the towns were still dissatisfied, as they desired to abolish the religious qualifications for voting. Another cause of discontent existed in the sterility of the soil, which they had found unsuitable for agriculture. Learning of the fertile Connecticut valley in the west, several hundred people set out in ${ }^{6} 636$. The Dutch had already built ( 1633 ) within the present limits of Hartford a fort which they did not abandon for several years. The mouth of the river was seized by the English, who erected a fort, from which the Dutch made a halfhearted attempt to drive them. Their real foes were not the Dutch but the Pequod Indians, who ruled the territory

Endicott declared was a symbol of popery. This act the magistrates felt might be construed in England as an insult, and they forced from Endicott an apology.

Settlement, Dutch and Indians.

Channing United States, I, 398-404.

Fiske, New England, I23-I33.

Eggleston, Beginners, 316-324. 
from the Hudson to Narragansett Bay with severity. Difficulties arose almost at the start, and were increased by savage actions on both sides. In $1_{37}$ the people resolved to put an end to these outrages. One of the Pequod camps west of Narragansett Bay was attacked by less than a hundred men under Mason and Underhill. The attack was a complete surprise, the wigwams were set on fire, and several hundred Indians slain. The remaining Pequods were relentlessly hunted out of the country, and for many years there was peace and prosperity.

Constitution of 1639 .

Channing, United States, I, 404-407.

MacDonald, Charters, No. I4.

Johnston, Connecticut, $59-64,75-79$.

Connecticut charter (I662). MacDonald, Charters, No. 24. Johnston, Connecticui, I67-I73.

Theocratic character.
As the people of Connecticut were outside the jurisdiction of Massachusetts and unwilling to have that colony extend its authority over them, they met and drew up a set of fundamental laws for their government (I639). The constitution which was adopted in 1639 established a government similar to that of Massachusetts, with a governor, magistrates, and deputies, who looked after common interests. Unlike Massachusetts, Connecticut did not restrict the privilege of roting to those who were church members, and she left with the towns a much more complete degree of self-government than had been enjoyed in the parent colony. This set of laws, remarkable for its democratic character, is still more remarkable because it is the first written constitution compiled by a people for their own government.

This very liberal political system was recognized and continued in the charter which Connecticut obtained from Charles II in r662. The new colony, however, included not only the Connecticut valley settlements, but New Haven as well, and extended from the Pawtucket River to the Pacific. Under this charter, slightly modified when Connecticut became a state in 1776 , the people lived until 1818 .

5I. New Haven. - Strangely enough the later colony and state of Connecticut was composed of two quite different elements: the Connecticut valley settlements, the most liberal, and the New Haven settlements, the most conservative, of those made by the New England Puritans. The 
founders of New Haven desired to establish a town ruled according to Scripture, which to them meant the Mosaic code. Other towns were founded by their friends, and in I643 these were united in much the same way as those of Connecticut under the constitution of 1639 . In New Haven only church members might vote, and the general court enacted rather searching laws regulating religious and other matters. These were caricatured soon after the Revolutionary War by a loyalist, Peters, whose book on the "Blue Laws of Connecticut" was supposed for many years to be historically correct.

52. Northern New England. - A number of attempts had been made to colonize the coast north of Massachusetts. Several grants of land were issued by the Council for New England, notably that to Mason and Gorges. In I629 these men divided their territory, Mason taking that between the Merrimac and the Piscataqua, to which he now gave the name New Hampshire, and Gorges that from the Piscataqua to the Kennebec, a district known as Maine. Large sums were spent by both, but their settlements were little more than fishing hamlets. At the beginning of the Civil War in England, Massachusetts annexed the New Hampshire towns on the ground that her charter of 1629 gave her all territory east as well as west from a point three miles north of the source of the Merrimac River, but the towns were allowed to govern themselves and to send representatives to the general court of Massachusetts until in I679 New Hampshire became a royal province. During the Commonwealth Massachusetts extended her jurisdiction over most of the towns in Maine also, and although obliged by a commission from England (I665) to relinquish her control temporarily, she reasserted her authority until Maine was purchased from the Gorges heirs by Massachusetts (1678). The territory east of the Kennebec River was granted to several court favorites, but was practically unoccupied because of the opposition of the French.

53. The New England Confederation (1643). - Between

Fiske, New England, I34-I37.

Tyler, England in America, 260-264.

Channing,

Lnited States,

I, 407-4II.

Settlement.

Relations with Massachusetts.

Tyler, England in America. 266-276, 279$28 \mathrm{I}$. 
Origin.

Fiske, New England, $155^{-1} 5^{-8}$.

Government

Fiske, Vew England, I5 8 -I 6 I.

Channing, Cribted States, I, $+\mathrm{I}_{5}-42 \mathrm{O}$.

several of these New England colonies there was a pronounced unity of feeling. Though representing different types of Puritan sentiment, the ideals in Massachusetts Bay, New Plymouth, Connecticut, and New Haren were much the same. Some of these colonies had acted together in more than one undertaking, but no formal union had been considered wise, perhaps for the reason that it would have

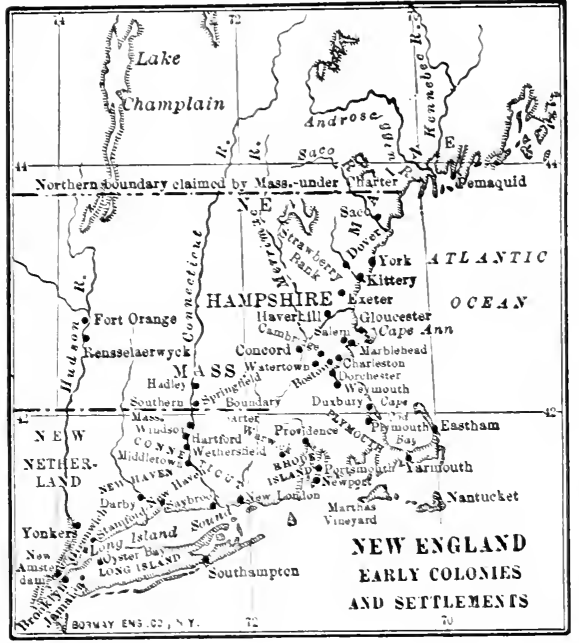
made supervision by the royal government so much easier. In $16+3$, the Civil IVar in England removed this obstacle and these four little Puritan communities united to form the New England Confederation, chiefly for the purpose of better. defense against the Dutch,the French, and the Indians. Maine, a settlement alien in its origin and customs, was not admitted, nor was heretical Rhode Island, which wished to join the league, its lack of stable government being assigned as the excuse for refusal.

The Confederation carefully avoided interference with the local gorernment of each of its members. Two commissioners were selected by each colony for the transaction of league matters. Any six of these had power to determine questions of peace or war, deciding how many men each colony was able to contribute for purposes of defense. Intercolonial disputes were to be settled by the commissioners. A sort of intercolonial citizenship was established and servants or criminals escaping from one colony to another 
were to be surrendered. The authority of the commissioners was more apparent than real, but the Confederation was of great value in dealing with both the Dutch and the Indians. The injustice done to Massachusetts, which was larger than the other three together, and the desire of that colony to manage the affairs of the Confederation, caused its decline, but it remained in existence until 1684 .

\section{MARYLAND}

54. The Charter of Maryland (I632). - While the Puritan emigration to New England was taking place, a A proprietary colony. colony of a new type was being founded in the region north of Virginia. The land was granted and the power to govern the colony assigned to a proprietor, who controlled the affairs of the colony in accordance with a charter given to him by the king. This proprietary form of government, although modified in many ways, was the one used after this time in the establishment of new English colonies in America.

The founding of Maryland was due to the personal ambition of George Calvert, Lord Baltimore, an enterprising Catholic nobleman who had long enjoyed royal favor. He was anxious to establish in the new world a place of refuge for Catholies and to build up for his family a semi-feudal estate. Before his conversion to the faith of Rome, he had started a settlement on Newfoundland, which was soon abandoned. He next tried Virginia, but the governors of the colony would have none of him. He then obtained from the king a charter which gave him title to the land from the Potomac to the fortieth parallel and from Delaware Bay to the meridian passing through the head waters of the Potomac. Over this domain he was to exercise almost regal Calvert and his charter.

MacDonald, Charters, No. I2.

Fiske, Old lirginia, I, 255$256,261-274$. powers, sending to the king two arrows yearly as a recognition of royal suzerainty. He was free from taxation by the authorities at home, which were not allowed to interfere in other ways with his government. With the consent of the freemen, he might make the laws, which should not be contrary to those of England. 
Contest over the right to propose laws.

Channing, L'nited States, I, $265^{-267}$.

Browne, Maryland, $35-37,4 \mathrm{I}-47$.

Religious classes. Law of I649.

MacDonald, charters, No.2I.

Eggleston, Reginners. $242,250-257$.
55. The Proprietor and the Freeman. - Interest in the early history of Maryland centers around two things, the religious conditions and the development of democratic institutions. George Calvert died before the charter was granted and his work was undertaken by his eldest son, Cecil, who remained in England and exercised his functions as proprietor through a resident governor. Being at such a distance, he was unable to meet with the freemen for the purpose of making laws, and the earliest laws which he proposed for the colony were rejected by the first assembly of freemen ( 1635 ), who claimed that they had the right to propose laws. This claim was not accepted by the proprietor, who in turn rejected the laws suggested by the freemen. Matters remained in this chaotic state for four years, each side refusing to yield, but in $6_{39}$ Baltimore gave his consent to a very full and cumbersome code of laws enacted by the assembly, at the same time instructing his governor to claim the power of veto only. Calvert could well afford this concession, because his authority over the colony was very great, and the legislature was composed of councilors selected by himself as well as the freemen who represented the people or were summoned to the assembly by the proprietor. The later history of the colony is largely concerned with the attempt on the part of the freemen and of the proprietor to extend their legislative influence at the expense of the other.

56. Religious Toleration. - From the first the majority of the settlers in Maryland were Puritans, the proportion increasing with great rapidity during the closing years of the Civil War in England, especially when Virginia in 1648 drove many Puritans from its borders. As the proprietor could not establish Catholicism as a state religion, and would not permit an established church of any other faith, there had been little interference on account of religious beliefs during the early history of Maryland. Foreseeing that the Catholic majority in the legislature could not be maintained on account of the Puritan immigration, Baltimore proposed 
to the freemen a law giving religious toleration, and at the same time sent over a Protestant governor. The legislature rejected Baltimore's law because it denied to the proprietary the right of initiation, but the next year ( 1649 ) passed a somewhat similar law. This famous "Toleration Act" provided the death penalty for those who blasphemed or denied any person of the Trinity, but declared "that noe person or persons ... professing to beleive in Jesus Christ, shall from henceforth bee any waies troubled, Molested or discountenanced for or in respect of his or her religion."

57. Summary. - After a half century of successful colonization we find the English in possession of the Atlantic coast from the Kennebec nearly to the Hudson, and from the northern part of Chesapeake Bay to Cape Fear River. The intervening territory was occupied by the Dutch, who had lately conquered the tiny Swedish settlement on the Delaware. To the south, though separated by an extensive wilderness, were the Spanish, while but little closer neighbors on the north were the French. In 1660 the English settlers lived in eight distinct colonies, two of which, Miassachusetts and Virginia, included more than one half of the total population. The emigration to the American provinces of England had been almost exclusively from the mother country, most of the settlers coming between the years i6ra and 1640 , although a large number of cavaliers sought Virginia when the fortunes of Charles I declined. As the majority of these settlers were hard-working, courageous men and women whom the dangers of the forest could not daunt nor the hardships of the frontier discourage, the future of the colonies was assured. With increasing prosperity and continued expansion, the Dutch settlements would of necessity have become less endurable, and the first opportunity was therefore embraced to conquer them.

\section{TOPICS}

I. Virginia under the Commonwealth: Fiske, "Old Virginia," II, pp. I-I8: Doyle, "English Colonies," I, pp. 21 2-229; Bancroft, "United States." 
2. The Puritans: Ellis, in Winsor, "America," III, pp. 2 I9-244; Palfrey, "New England," I, pp. IOI-132; Osgood, in Political Science Quarterly, VI (IS9I), pp. I-28, 201-23I ; Borgeaud, "Democracy in America."

3. Pilgrim Migrations: Fiske, "New England," pp. $7 \mathrm{I}-82$;

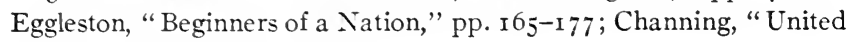
States," I, pp. 293-307.

\section{STUDIES}

I. Agricultural difficulties and problems in early Virginia. (Bruce, "Economic History" of Virginia," I, pp. I\$9-226.)

2. Smith in Virginia. ("American History Leaflets," No. 27)

3. Virginia under Charles I. (Cooke, "Virginia," pp. 4 I-I57.)

4. First weeks at Plỵmouth. (Bradford, "Plỵmouth Plantation.")

5. Early emigrants. (Hart (ed.), "Contemporaries," I, Nos. 555s.)

6. Winthrop's account of Massachusetts. ("American History Leatlets," No. 3I.)

7. Earliest New England code of laws. ("American History" Leaflets," No. 25.)

8. Pequod VTar. (Doyle, "English Colonies," I, pp. I6o-I -8.)

o. Roger Williams and his work. (Eggleston, "Beginners of a Nation," pp. 266-306.)

10. General character of the English colonies. (Mace, "Method in History," pp. S6-104.)

I . Charter land grants. ("American History Leaflets," No. I4.)

\section{QUESTIONS}

I. What was the significance of the settlement at Jamestown $(160 \%)$ ? of that at Plymouth (I620)? of that at Salem (I628)?

2. Compare the Virginia charters of 1606,1609 , and 1612 as to territory and government.

3. What influence did tobacco have upon (a) the growth of Virginia, (b) the social classes, (c) the establishment of the county systems of government, $(d)$ the relations of Virginia to England $(36)$ ?

4. Did the Puritans believe in religious toleration? How did the Puritan spirit show itself in the dealings of Massachusetts with Roger Williams and with England? Was their course justified?

5. In the contest between the aristocrats and the liberals in Massachusetts between $I_{3} 0$ and $I 641$, which gained the greater victories in determining the character $(a)$ of the government, $(b)$ of the suffirage, $(c)$ of the code of laws?

6. Define the term "charter." Give the distinction between a charter and a constitution. In what respects was the constitution of Connecticut different from the Massachusetts charter of I629? 


\section{CHAPTER IV}

\section{LATER ENGLISH COLONIZATION (I660-I700)}

\section{ENGLISH RULERS}

Charles II (1660-1685)

James II (I685-I688)
IVilliam III ( $1689-\mathrm{I} 702)$ and Mary (I689-1694)

58. Commercial Situation of England about I66o. - The English year I660, during which the Stuarts were restored to their position as kings of England, marks the beginning of a new epoch from the standpoint of the colonies. This was due to a large extent to the interest taken by the able advisers of Charles II, Clarendon and Shaftesbury, in the expansion of the British domains, and the desire of those statesmen colonial and commercial policy.

Andrews, Col. Self-Gov't. $5^{-13}$

to bring the existing English colonies into closer and more satisfactory relations with the mother country. It was due in part also to the anxiety of England to compete with Holland, which had become the first commercial nation of Europe. ${ }^{1}$ Cromwell had sought to injure Dutch commercial supremacy by securing a law (165I) which compelled all English merchants to import and export goods in English ships only. This had led to a war with Holland in which the advantage remained with the English.

This policy of British trade in British ships only was reaffirmed by the new Stuart government after the Restoration by the passage of the very important navigation act of 1660 . Not only were England and the English possessions to allow only English or colonial vessels entrance to their ports, but certain articles produced in the colonies, including sugar

Early navigation acts.

Andrews, Col. Self-Gor't., I3-2r.

${ }^{1}$ The Dutch had not only gained extensive possessions in America, with the control of most of the East India trade, but in 1650 they controlled nine tenths of the carrying trade of England and practically a monopoly of that of continental nations. 


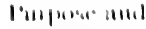
16. Norigatlon A.t.

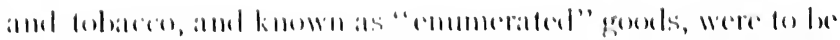

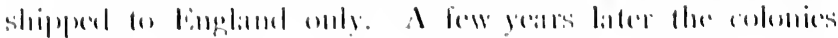

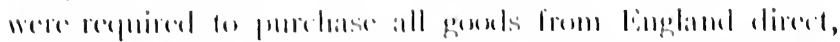

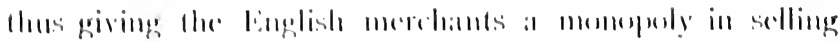

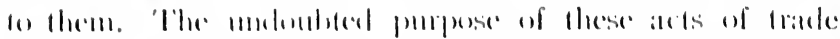

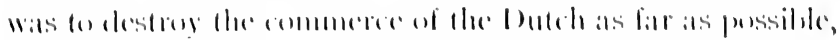

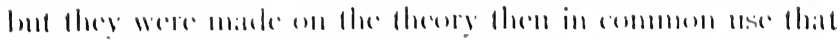

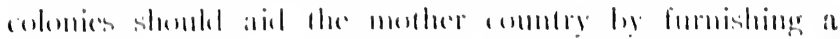

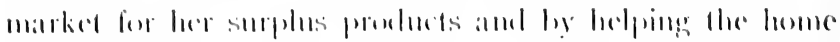

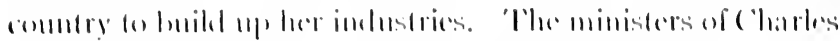

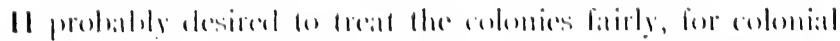

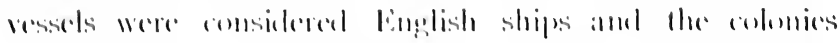

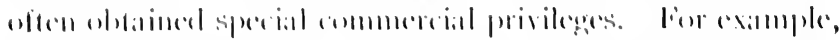

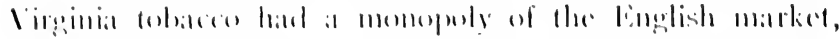

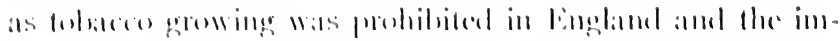

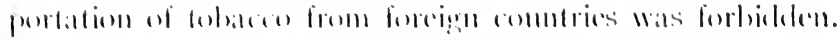

Kengsumization of colomices.

\section{England and the Colonies (1660 1085). 1)ur-}

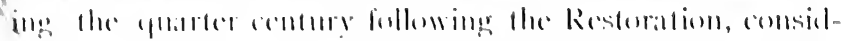

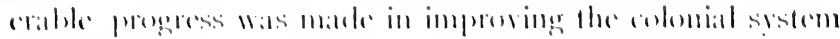

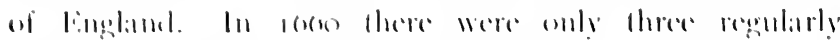

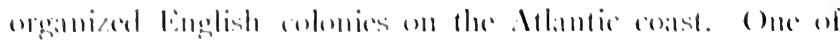

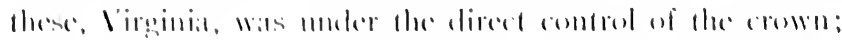

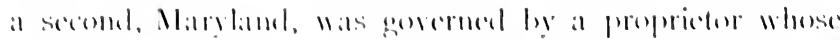

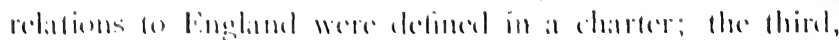

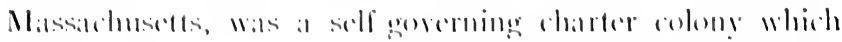

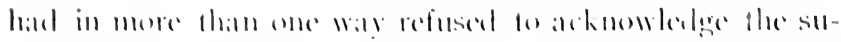

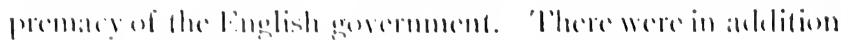

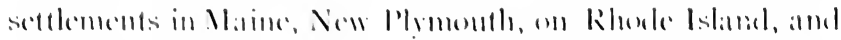

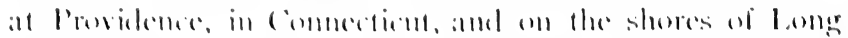

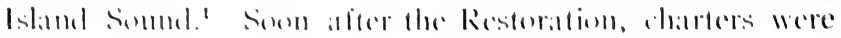

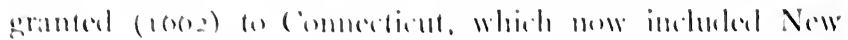

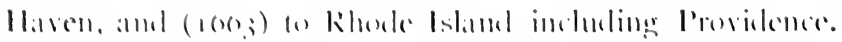
Atlompts were mole also to hring Matssidhusetts inte sub-

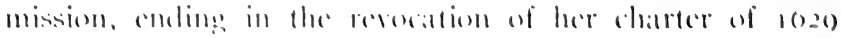
in the veit 10 s.

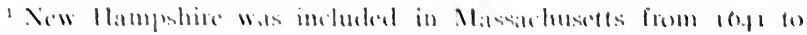
1030 .

$2 \mathrm{~s} \leqslant 5.75$. 


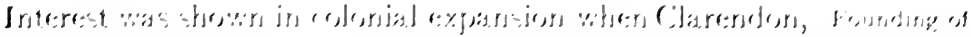

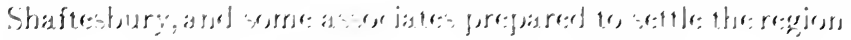

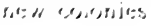

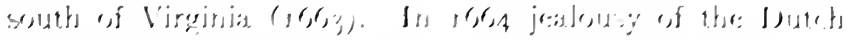

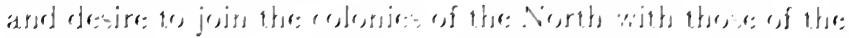

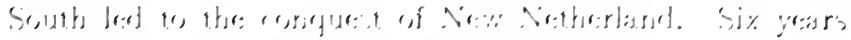

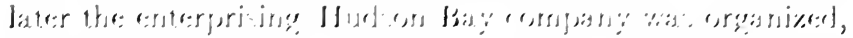

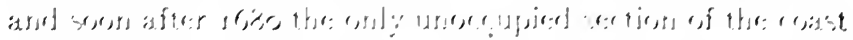

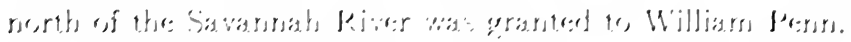

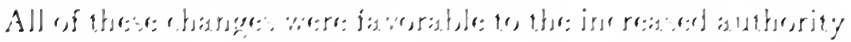

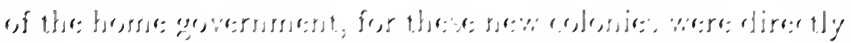

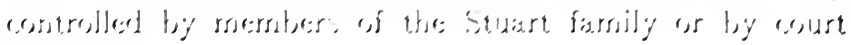

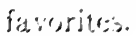

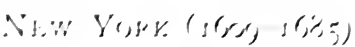

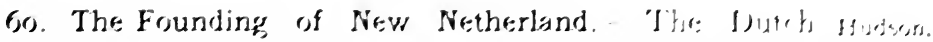

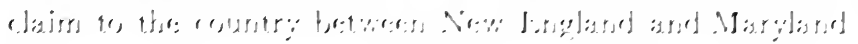

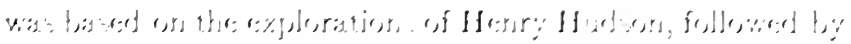

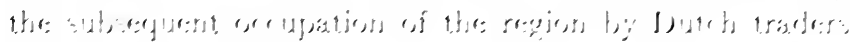

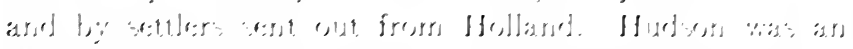

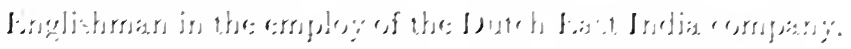

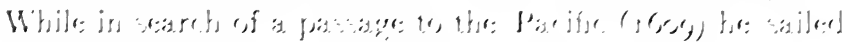

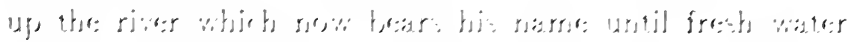

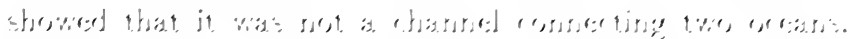

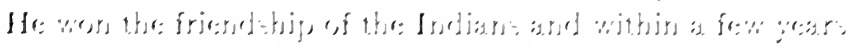

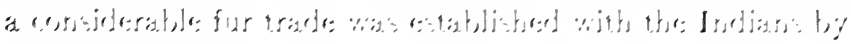

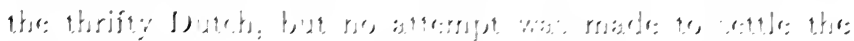

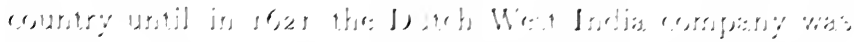

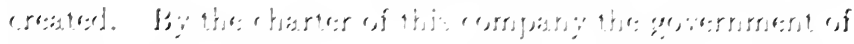

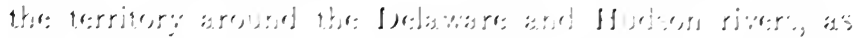

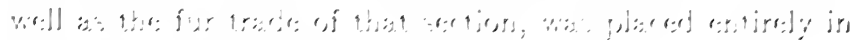

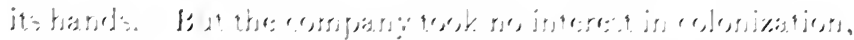

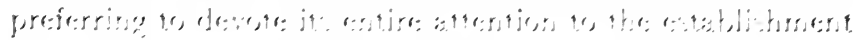

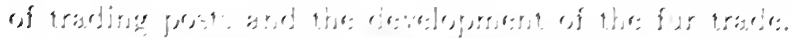

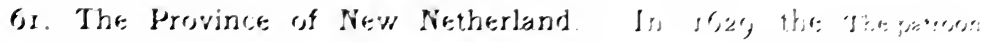

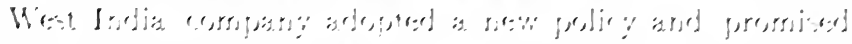

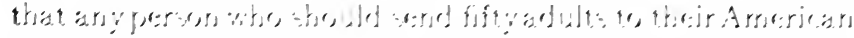

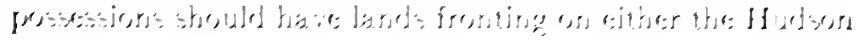


Channing, United States, I, 446-449.

Fiske,

Dutch and Quilier Cols., I, 133-I40.

or the Delaware, sixteen miles on one bank or eight miles on both and extending into the interior. This liberal domain the patroon, as he was called, was to rule as a feudal lord, with power to make laws and hold court for the trial of offenses. All corn was to be ground at his mill and no one should hunt or fish on his domain without his consent. This feudal system appealed to many wealthier members of the company and large landed estates were established along the Hudson. Of these the most extensive was that of the

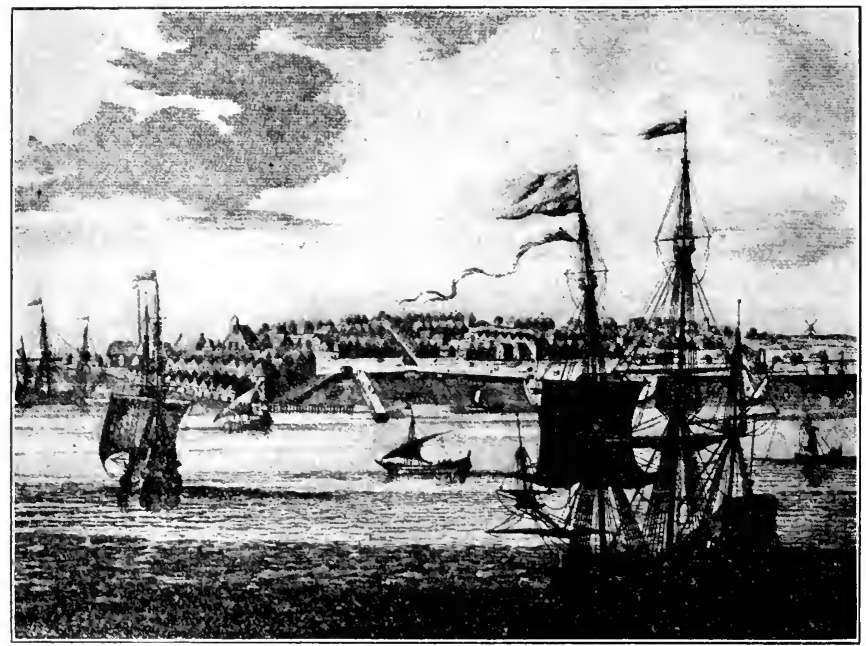

NEW AMSTERDAM

Van Rensselaers, in which the custom of paying feudal rents persisted until the tenants rebelled about 1840 and gained the right to purchase their lands.

Dutch

governors.

Channing,

United States, I, $450-472$.
Governors were sent out by the company to administer its affairs, which they did in a quite unsatisfactory manner. The early governors found it difficult to maintain the authority of the company against the patroons, who were practically independent within the limits of their patroonships. The people of the principal city, New Amsterdam, and in the rest of the colony protested also against the arbi- 
trary rule of the governors, and demanded a share in the government. The last and the ablest of the Dutch governors, Stuyvesant, was forced to give New Amsterdam a more liberal government with nine men to advise him, but he made more promises than reforms, and to the last the rule of the Dutch was narrow and arbitrary.

62. New Netherland and its Neighbors. - The location of New Netherland between jealous and comparatively powerful English colonies and its proximity to the most powerful Indian tribe on the continent, the Iroquois, made its position one of no little difficalty. The Dutch avoirled conflict with the Iroquois by preserving the friendship established with those Indians by Hudson. This afforded them protection from attack and benefited their trade in fur. Unwise treatment of the Indians near Manhattan Island, however, led to a disastrous war, in which most of the settlements near New Amsterdam were destroyed (I64II643).

On the south the Dutch came into collision with the Swedes, who had made a few settlements on the shores of Delaware Bay. The Dutch claimed the land and warned the Swedes to leave, but no action was taken before i648, partly because of the governors' indifference and partly because Sweden had aided Holland during the Thirty Years' War which closed that year. After the Peace of Westphalia made all the nations guarantee the independence of Holland, the new governor, Stuyvesant, proceeded against the Swedes and in $6_{55}$ New Sweden was brought under Dutch rule.

63. Conquest of New Netherland (1664). - By the English the Dutch had been consiciered intruders from the beginning, because England laid claim to the entire coast on the basis of the Cabot voyages. Aside from the feeling against Holland that sprang from commercial rivalry, England desired to seize the Dutch possessions for several reasons. Dutch occupation of the region between the thriving provinces in New England and in the South was not pleasing to her, their extensive fur trade was an object of envy, and the

Relations with the Indians.

Channing, United States, I, $45+-458$.

Conquest of New sweden $(1555)$.

Channing, United States, I, $475-477$.

English motives and early attempts.

Andrews, Col. Self-Gov't, 74-78. 
Hart, Contem- Dutch gave offense by helping the colonies to evade the poraries,

I, No. 155 .

Fiske,

Dutch and

Quaker Cols., I, 248-269. navigation acts. Before 1650 the Dutch had been driven from the valley of the Connecticut by the settlers near Hartford $(\S 50)$, and several English settlements on Long Island had restricted their territory in that direction. When war broke out between England and Holland during the Commonwealth, steps were taken toward conquering New Netherland, but peace was declared before the expedition was ready.

Conquest and reconquest.

Andrews, Col. Self-Gov't, 78-82, 89.

Fiske,

Dutch and Quaker Cols., I, 277-292.

The people and their government.

Andrews, Col. Self-Gov't, 82-IOO.
A few years later, the English government decided to take the initiative against Holland by seizing her North American possessions. All of the territory from the Delaware to the Connecticut, and from the Kennebec to the St. Croix, was granted by the king to his brother James, the Duke of York. A fleet was dispatched to New Netherland under the command of four commissioners, who were also to bring Massachusetts to terms ( $\$ 73$ ). New Amsterdam surrendered at once because the citizens refused to fight, much to the disgust of the wrathy governor, Stuyvesant, and the rest of New Netherland surrendered without delay. Several years later, during another war between England and Holland, New Netherland was recaptured by the Dutch, but after a brief period was returned to the English by the Treaty of Westminster ( 1675 ).

64. The English in New York (1664-1685). - A large percentage of the inhabitants of New Netherland in 1664 were English, so that the transition from Dutch to English rule was not difficult. A great many laws in force in New England were introduced, but most of the Dutch practices also were recognized. The local government was reorganized so as to give the people a slightly greater share in its work, but the Duke of York would not allow an assembly to be called. Many of the English settlers demanded a representative government, the Puritans on Long Island being particularly insistent, but no action was taken until 1684. In that year the first assembly of the colony distinguished itself by passing a charter of franchises and liberties 
which provided for religious toleration, allowed all freeholders to vote, and permitted no taxation without the consent of the people's representatives. This charter was ratified by the Duke of York, but was rejected by him later when, on the death of Charles II, he became king of England with the title of James II. In the year I 684 also Governor Dongan negotiated with the Iroquois a treaty which gained for the English the friendship and help of those able warriors in the long contest with the French which began soon after.

\section{The Quaker Colonies}

65. New Jersey and the Quakers. - Before the conquest of New Netherland, the Duke of York granted the territory between the Hudson and the Delaware to two of his favorites, Sir George Carteret and Sir John Berkeley. They were liberal to the colonists, and the inhabitants, many of whom were immigrants from New England, enjoyed a large degree of religious and political freedom, but they quarreled with the proprietors over the making of laws and the payment of land rents, and in 1674 Berkeley sold his share of New Jersey, the western half, to a Quaker who was probably acting for many others of his sect.

The society of Friends, or Quakers, had been organized in England by George Fox just before the middle of the seventeenth century. The Quakers believed that a person should be guided chiefly by his conscience and not by the dictates of church or writings. For others as well as themselves they claimed the right of worshiping in the way they pleased, so that they were always in favor of religious toleration. They advocated the doctrine of the fellowship of man and carried their belief in equality so far that they refused to remove their hats even in the presence of the king. Desiring to found in the new world a colony in which they might carry their principles into effect, the Quakers made settlements on the east bank of the Delaware and established an extremely liberal government which they were never able

The two Jerseys.

Andrews, Col. Self-Guv't, IOI-III.

The Quakers. West Jersey.

Andrews, Col. Self-Gov't, II3-I 24 .

Fiske, Dutch and Quaker cols., II, Io9II3, I4O-I 47 . 
to put into practice effectively. The success of the Quakers in gaining first West Jersey and later control of East Jersey was due principally to the interest and ability of William Penn.

Pennsylvania charter (I68r). MacDonald, Charters, No. 38.

66. Penn and His Colony. - Because Penn found it impossible to carry out his ideas regarding society and government in New Jersey, he asked the king for a grant of land west of the Delaware River. As he was a man of high rank,

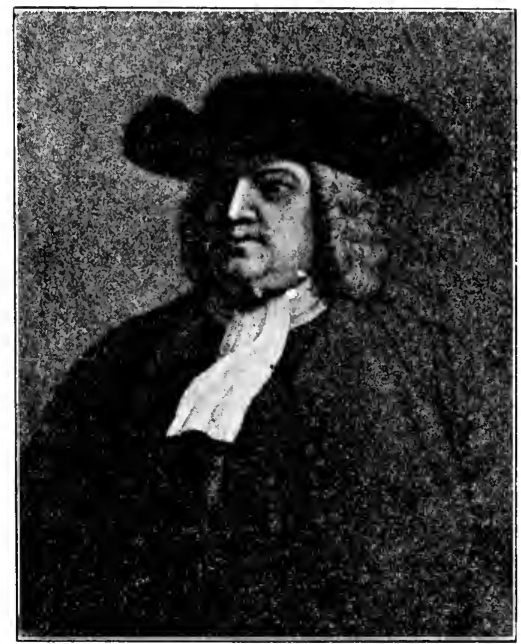

WILLIAM PENN the son of an admiral to whom Charles II was indebted in several ways, and a friend of James, Duke of York, he had no difficulty in obtaining from the king a charter which gave him a large territory beyond the Delaware and made him proprietor of that region with the right to govern it, provided that all laws should be made with the consent of the freemen and sent to England

Andrews, Col. Self-Gov't, I65-169, 175177 .

Fiske, Dutch and Quaker Cols., II, $\mathrm{II}_{4-}$ II 8, I47-I 53 . Growth and inhabitants.

for approval. Parliament, however, had the right to levy taxes within the colony and the proprietor was obliged to appoint an agent through whom the English government might exercise some control over the affairs of the province. It will be seen that the home government had profited by the rather bitter experience it had had with those colonies that refused to recognize its authority over them.

Not only were Penn's religious views advanced, but he had long held political ideas which were extreme in the opinion of men of that time. His colony during its early years showed in marked degree the impress of his personality, and under 
his wise and able guidance, grew as no other had done. Andrews, At the end of four years it contained eight thousand inhat,itants, and Philadelphia had become the third city on the continent. English Quakers came in large numbers, but there were numerous Englishmen of different denominations, and many Swedes, Hollanders, Germans, Frenchmen, and Scotchmen. Mrost of these were attracted by the wellknown liberal ideas of Penn and his promise of religious freedom and political rights.

67. The Government of Pennsylvania. - Penn did not disappoint his colonists, for as early as 1682 he issuerl a Frame of Government by which he shared with the people the powers of government granted to him as proprietor. At the same time he announced laws which assured a larger number of individual rights than were enjoyed then in any other colony in America. At first the government was composed of a governor and of two large unwieldy houses called the council and the assembly, both of which were elected by the freemen. All laws were proposed by the governor and council, the assemtsly having no authority except to ratify or reject bills under consideration.

This cumbersome legislature did not work well, and in I 7or Penn gave the colony a new "Charter of Privileges." This reaffirmed religious liberty to all who believed in God, and declared that any one who believed in Jesus Christ as the Savior of the world was qualified to hold office. The charter provided that laws should tse made by an assembly, and left the local gorernment in the hands of the persple. The charter might be amended fy the grovernor and six serenths of the assembly. Cnder it, until I $7-6$, Pennsylvania and Delaware hard separate legrislatures, although ruled by the same governor.

In his dealings with the Indians, Penn was just and fair. His famous treaty of I 682 under the "Penn elm" was said by Voltaire to be "the only treaty between savages and Christians that was never sworn to and that was never broken." Like Roger Williams and many other early

Col. Self-Gou't. IEg-IgI, and Greene, Provincial America, 230-234. Fiske, Dutch and Quaker Cols., II, I53$\mathrm{I} 58,320-329$.

Eariy governmeni.

MacDonald, Charters, Nos. 40, 4I, 44. Andrews,

Col. Self-govit, IE2-184, IgI14.

Minsor (ed.), America, II I. $4 \Sigma_{3}-489$.

Charter of Privileges (ITOI).

Macdonaid, Charters, No. 45 .

Fishe, Quaker Cols., II, 309-3II.

Penn and the Indians.

Hart, Contemporaries.

I, No. I5z. 
Fiske,

Ouaker Cols., II, I 58-I66.

Colonial boundary disputes.

Greene, Provincial Amer'ica, 190-I92.

Andrews

Col.Self-Gov't., I7 I-I 75.

Hinsdale, Old Northivest, 98-I04, I08IIO. settlers his aim was to pay the red men a reasonable sum for the lands occupied.

68. Boundaries of Pennsylvania. - The exact boundaries of the land granted to Penn in his charter were long in dispute because his territory conflicted with that already granted to several of the other colonies. Pennsylvania was not alone in this heritage of boundary disputes because grants overlapped; but, as the latest of the northern colonies, her boundary difficulties affected more provinces than those of almost any other colony and may be considered in some degree typical of the boundary wars waged by most of the seventeenth-century pioneers. It would naturally be supposed that as late as $168 \mathrm{I}$ the geography of the Delaware and Susquehanna regions would be known accurately, Penn's grant. but such was not the case. Penn's grant was to extend $5^{\circ}$ west from the Delaware River and $3^{\circ}$ north and south along that river. ${ }^{1}$ Penn, having acquired Delaware in ${ }_{1682}$ and having several settlements in Pennsylvania south of the fortieth parallel and desiring a port on Chesapeake Bay, argued that the "beginning" of the fortieth parallel, which, according to the charter, was the southern boundary of Pennsylvania, must have meant the southern boundary of the zone which was the fortieth from the equator, that is, parallel 39. This claim he could not establish, as the northern boundary of Maryland was $40^{\circ}$ also, and it was not until I760 that the English government decided the controversy by locating the dividing line between the two colonies at $39^{\circ} 42^{\prime}$. The boundary was surveyed by two skilled mathematicians, Mason and Dixon, from whom

${ }^{1}$ Its southern boundary was a semicircular line drawn from twelve miles north and west of New Castle "unto the beginning of the fortieth degree of northern latitude and then by a straight line westward." The northern boundary was the beginning of the three and fortieth degree of northern latitude. As the fortieth parallel had been given as the northern boundary of Maryland ( $\$ 54)$, the expression, the "beginning" of the fortieth degree probably meant the same as the fortieth parallel of Baltimore's grart, but as a matter of fact, the fortieth parallel is much more than twelve miles north of New Castle, so that it would be impossible to survey such a line as Penn's southern limit called for. 
it has since been known as "Mason and Dixon's Line," a name applied later to the boundary between the slave and the free states.

On the north there was doubt about whether the boundary was the forty-third or the forty-second parallel. New York, wishing to retain as much territory as possible and unwilling to grant Pennsylvania any jurisdiction over the six Iroquois nations, contended with success for the lower boundary. When this boundary was decided upon finally, there was no longer any conflict with Massachusetts, which did not claim land south of $42^{\circ}$. The dispute with Connecticut under her sea-to-sea charter involved an at tempt on the part of Connecticut to settle the northern part of Pennsyl-

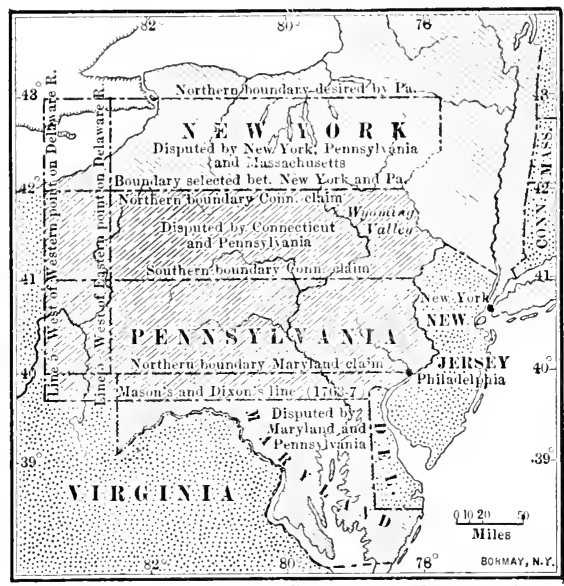

BOUNDARY DISPUES OF PENNSYLANIA vania, especially Wyoming valley, but the whole territory was assigned to Pennsylvania by the Congress of the Confederation soon after the Revolutionary War.

\section{The South after the Restoration (i660-i730)}

69. Misgovernment in Virginia (I660-1676). - For several years during the Commonwealth the people of Virginia attempted in an irregular way to govern themselves, but with the restoration of Charles II the old order was reestablished. During the years following the Restoration, Sir William Berkeley was governor of Virginia. Of a Political grievances. despotic temper, he used his office to the personal advantage of himself and his royal master, appointing worthless

Andrews, Col. Self-Gov't, 207-2I4. 
Dovle,

Eng. Cols., I, $230-245$.

Economic grievances.

Fiske, Old lir- and hard times prevailed. As though this were not enough, ginia,II,46-54. Charles, in 1673 , rented Virginia for thirty-one years to two of his favorites, Arlington and Culpepper. They received the right to make grants of land, had the absolute control of the important local offices, and appointed all pastors. Fortunately most of these privileges were surrendered in return for a duty on tobacco, showing that the patentees were chiefly interested in the revenue to be obtained from the colony.

Bacon and Berkeley.

Larned (ed.), Ready Ref., V. $3^{6} 3^{2-36} 34$.

Andrews, Col. Self-Gov't, $215-226$. 7o. Bacon's Rebellion ( 1676$)$. - The discontent of the Virginians was brought to a head by Indian massacres on the frontier. Governor Berkeley had erected forts for the protection of the outlying settlements and refused to send troops or grant commissions to raise troops. Thereupon Nathaniel Bacon, a young and headstrong but able planter whose overseer had been murdered, gathered a force, and, defying Berkeley's orders, marched into the Indian country. The colony was now in great disorder and demanded a new election of burgesses. This was held, Bacon being among those chosen. The new legislature repealed the restrictive suffrage law and enacted other laws granting greater civil and political liberty. Bacon and Berkeley made their peace, which was broken soon, as neither had confidence in the other. During the civil strife that ensued, Jamestown was burned and Bacon died, the rebellion collapsing with 
his death. Berkeley, again supreme, hanged the leaders of the rebellion and secured the repeal of many liberal laws which had been passed in $1676 .{ }^{1}$ Unfortunately the rebellion deprived the colony of a very liberal charter which lacked only the king's signature at the beginning of the disturbance.

7x. The Carolina Charters $(1663-1665)$. - The interest taken in colonial matters during the years following the Restoration is shown clearly in the early history of Carolina. Several of the most prominent courtiers, including Clarendon and Shaftesbury, obtained from Charles in 1663 a charter which made them proprietors of the land lying south of Virginia and extending from sea to sea. Over this vast domain the absolute power of the proprietors was limited only by the provision that the laws should be made with the consent of the freemen represented in an assembly and that "the faith, allegiance and sovereign domain" due to the crown should not be impaired. Perhaps the most notable clause of the charter was the one permitting the proprietors to grant perfect religious freedom to such of the loyal settlers as they desired - a clause of which we are glad to say advantage was taken. Two years later the limits of the colony were extended still further south and one half degree farther north, making the boundary between Virginia and the new colony of Carolina practically the same as the present southern boundary of Virginia.

72. Proprietary Government in Carolina (I667-1 729). For the government of their Carolina province very elaborate "Fundamental Constitutions" were drawn for the proprietors by the philosopher, John Locke. This rumbersome document provided for a feudal system in which the chief landowners were the proprietors and nobles whom they appointed. No land was to be sold after forty years, so as to make this mediæval system permanent. The government was to be in the hands of the proprietors and nobles,

Provisions of the two charters.

MacDonald, Charters, Nos. 26, 32.

Andrews, Col. Self-Gov't, I3O-I38.

Locke's

Fundamental Constitutions (I669).

MacDonald, Charters, No. 33.

${ }^{1}$ King Charles II is reported to have said of Berkeley: "That old fool has hanged more men in that naked country than I have done for the murder of my father." 
Andrews, Col. Self-Gov't, I39-I4I.

Fiske, Old lirginia, II, 272-276,

Social and political changes (I670-I729).

Winsor (ed.), America, V, 3II-3I6, 322-327.

Quakers in Massachusetts (I655-I660).

Hart, Contemporaries,

I, Nos. I4O-I 42.

Doyle,

Eng. Cols.,

III, IOO-II4. although there was to be a parliament for members of which all freeholders owning estates of fifty acres might vote. A degree of religious liberty was permitted to churches of at least seven members, though not to separate individuals. It is needless to say that these constitutions never went into effect. The proprietors waited until the development of the colonies should warrant their use, but that time never came.

The growth of Carolina was by no means rapid and few settlements were added in northern Carolina to those existing when the proprietors received their patent. In southern Carolina Charleston was founded in 1672 and a few other towns begun by the English. A large percentage of the inhabitants were Scotch highlanders and French Huguenots drawn thither by the promise of religious freedom. Political liberty also was enjoyed to an unusual degree, for the people exerted a great influence in local government and their representatives chose part of the council or upper house of the legislature. The time came when the voters believed that the proprietors were selecting more than their share of the councilors. A rebellion followed (I7I9), with an overwhelming victory for the people, who selected a governor and asked the king to accept South Carolina as a royal province, which he did. Ten years later all rights of the'proprietors were extinguished by purchase.

\section{New England ( $1655^{-1685}$ )}

73. Problems of New England (1655-1675). - During the later years of the Commonwealth the Puritan colonies had considerable trouble with the Quakers, who were driven out from England by harsh measures. Severe laws were made by the colonies in the New England Confederacy, particularly against those who returned after being sent away. Massachusetts in $165^{8}$ made it a capital offense for any Quaker to return to the colony. This law was opposed by a large part of the population and when it was enforced by putting to death three Quakers, the protests 
were so lourl that the law was changed. In fact after i 660 the colony was much more liferal in its treatment of nonPuritans than it had been before.

Soon after Charles II came to the throne in I 660, he united the colonies of Connecticut and New Haven by giving a charter to the former, as New Haven had incurred the royal displeasure by harboring judges who had condemned to death Charles I. Rhode Island and Providence also receiverd a charter in $I f f, 3$.

A number of complaints harl been marle against Massachusetts at this time, because she hard been domineering in her treatment of her weaker neightorss and on accrunt of New charters. her independent spirit. Cnder the Commonwealth, e.g. she hard crined "pine tree shillings," thus exercising a sovereign prower, and in Iffli she had issued a declaration of rights. Nevertheless the charter of Massachusetts was confirmed by Charles in I662, on condition that the colony acknowledge the supremacy

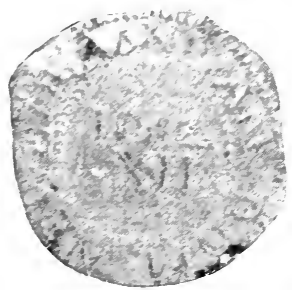

PRE TREE SHILLN, of England and grant to members of the Anglican church freedrom of worship and the right to vote on the same terms as Puritans. In from Massachusetts complierl with Andrews Cul. Self-groo't $47-4 \overline{3}, 75-72$. these requests which affected so deeply her religious and political prolicy, fut no change was made in her relations with England, and, as her ministers alone registered those eligible to vote, members of the church of England did not often enjoy a share in the government. In I6f, the commissioners who had charge of the expedition against New Netherland $(6,3)$ were instructed to investigate affairs in New England also. These men complained that Massachusetts was not fulfilling the condition: improsed by the king in I662, but the home grovernment was tor, much interested in other matters to correct her refractory colony until ten years later.

74. King Philip's War (1675-1676). - The constant en- 
Events and croachments of the English settlers on the lands of the Inresults. dians made collision inevitable. Under the lead of Philip, chief of the Wampanoags, these Indians agreed with other Andrews, tribes to exterminate the whites. The first blow was Col. Self-Gov't, struck in June, 1675 , at Swansea in Plymouth, near the

Hart, Contemporaries, I, Nos. I33,I34. Rhode Island border. Other towns were burned and the inhabitants were slain, the war parties retiring before help could come from other settlements. After six months of this horrible border warfare a thousand men were sent against the stronghold of the Narragansetts, which was captured Larned (ed.), after severe loss and completely destroyed. From this time Re'ady Ref., III, 23 IO-23I3. the warfare increased in bitterness on the one side and barbarity on the other until in August, r676, Philip was killed and the last Indian braves were hunted from their retreats. Many of the luckless survivors of this struggle, including women and children, were sent to the West Indies to be sold into slavery. $\mathrm{By}$ this pitiless course all danger from the red men was removed, but the colonies were left in an exhausted condition. Many of the towns had been entirely destroyed, hundreds of men had been killed, crops had been burned so that famine was narrowly averted, and trade had almost ceased.

Complaints against Massachusetts.

Andrews, Col. Self-Gov't, $256-262$.

75. Massachusetts and the Crown (I675-I684). - Matters had now reached a crisis in the Bay colony. The indifference of Massachusetts to the demands of the English government and her arrogance in her treatment of those with whom she had dealings, especially in New Hampshire and Maine, culminated in a series of complaints so serious that definite action was taken against Massachusetts. Among the more serious charges were: (I) her disregard of the rights of the Mason and Gorges heirs along the coast to the north; (2) the failure to give political and religious rights to non-Puritans in accordance with the requests of the king (I662); (3) the evasion of the acts of trade which forbade commerce with nations other than England; and (4) the general independent attitude of the colonists shown in their separate coinage of money, their refusal to allow 
appeals from colonial courts to those of the king, and their neglect to send to England an agent through whom the colony might be controlled.

The case of New Hampshire was settler by making the colony a royal province. Massachusetts tried to end that of Maine by purchasing the rights of the Gorges heirs, but as this was done without the knowlerlge or consent of King Charles, it aroused still greater feeling against . Iassachusetts. During this period the business of the English government in the colony was intrusted to Edward Randolph, an honest but exceedingly narrow man and a partisan of Massachusetts' enemies, who used his authority in such a way as to widen the breach between the mother cruntry and the none too conciliatory Puritan leaders. Although Massachusetts, taking alarm at last, agreerl to yield on every question, the king was in no mord for hali measures and in 1587 the charter of the colony was annulled. At this time Charles had come very largely under the influence of L France, and was showing himself a monarch fond of absolute government. Not only did he deprive Massachusetts of her charter, with good reason it must be admitter, but he proceeded also against the charters of London and other English cities, and before his death prepared to annul the charters of the inoffensive colonies of Rhode Island and Connecticut.

\section{The Great Revoltition (i685-i;00)}

76. The Dominion of New England. - Before I 685 many English merchants and officials harl farored the consolidation of the northern colonies under a single governor who could then govern them more perfectly in the interests of England. The death of Charles II in I685 leit the execution of this plan to James II who was more opproser to popular gorernment than his brother hard been. Tnder the name of the Dominion of New England, James uniterl all the colonies from Acadia to the Delaware, naming Sir Edmund Andros as governor. The difficulty causer by

Revocation of the charter $\left(I \leqslant 8_{4}\right)$.

Anciews, Ciol. Self-Gi't $252-255$.
Consolidation of the rortitem coionies.

Andrews, Col. erfolgoit, $25 j-2 ; 2$.

\section{Fisine.} Vew England, $257-272$ 
Doyle,

Eng. Cols., III, 234-236, 242-249.

Government of the Dominion.

Doyle,

Eng. Cols., III, 234-239.

Changes affecting church and society.

Doyle, Eng. Cols., III, 239-243.

the existence of charters in Rhode Island and Connecticut was solved by demanding the surrender of those documents. Rhode Island agreed to submit and Connecticut did not hold out, although she failed to part with her charter, tradition asserting that when Andros sought to obtain it, the charter was spirited away and hidden in the "charter oak."

Full and arbitrary instructions were issued to Andros by the king. The governor, who was a soldier rather than a politician, obeyed the letter of his instructions, carrying out the wishes of James with such care and so little tact that the period of his rule is often referred to as "the tyranny of Andros." During his term no popular assembly was called nor was any town allowed to hold town meetings except once a year. Laws were made and taxes levied by the governor and councilors appointed by Andros, being executed by agents of the governor. There were no courts except those held by judges whom the governor selected. No papers or books were printed unless they first received the approval of James's representatives.

This arbitrary government was of course offensive to people who were sticklers for their political rights, but it caused even less opposition to the new administration than certain acts which affected religious prejudices and the rights of property. Preference was given now to the Anglican church and services were held according to the rites of the church of England in the Old South meeting house. Marriages could be celebrated only by an Anglican clergyman, and as there was but one in the colony all persons who wished to marry must journey to Boston, a trip as tedious as the service itself was distasteful. Many who held lands with titles in dispute were obliged to prove their rights at great cost, the impression being general that no one's land was safe from attack. Under these circumstances there was little wonder that in Massachusetts at least the caldron of revolution was on the point of boiling over.

77. The Revolution of 1689 in England and New England. - This happened when news was brought in April, 
I689, that William of Orange had landed in England and that James had fled from the kingdom. During the three years of his reign James had incurred the displeasure and Causes and results in England. aroused the opposition of class after class of the population. His claim that he might suspend any law he pleased, coupled with his attempt to control the courts for his own benefit, his open help to Catholics, and his utter disregard for the civil rights which the people had wrested from his father and brother, united the nation against him. So long as the people expected that at his death the crown would pass to his daughter, Mary, and her husband, his nephew, William of Orange, they remained passive, but when a prince was born who would probably be brought up a Catholic, a number of leaders invited William to come to England and help them preserve their liberties. With the flight of James and the selection by the people's representatives of William and Mary as the rulers of England, the long contest between parliament and the king ended in the complete supremacy of the former. The principal results of the revolution were embodied in the Bill of Rights (r689) and in several supplementary acts. They assured the frequent meetings of parliament, and control by that body of taxation, the army, and other important subjects; they guaranteed freedom of the press and religious toleration for all Protestants; and they prevented the king from setting aside laws or removing judges at his pleasure.

When news of James's flight reached Massachusetts, the frigate in the harbor and all fortifications about Boston were seized, Andros and other officials were imprisoned, and a temporary government similar to that under the old charter was established. There was no bloodshed, but the overthrow of the government of Andros was complete. Rhode Island and Connecticut resumed the use of their charters, which they had never surrendered, but Massachusetts did not have a regularly organized government until in r6gr a new charter of a semi-popular type was issued by William and Mary. To Massachusetts Bay Colony

Reëstablishment of charter government in New England.

MacDonald, Charters, No. 42. 
Hart, Contem- were added Plymouth and the islands south of Plymouth, poraries, I, No. 136.

Fiske, New England, $272-278$.

Leisler's as well as the English provinces beginning with Maine eastward to Acadia, which was included. The people were allowed to resume the government of their towns by town meetings and were also permitted to elect an assembly, the assembly in turn choosing the governor's council. The governor, the lieutenant governor, and the secretary were appointed by the crown, as in New York and Virginia. Under this quite liberal charter Massachusetts was governed until her separation from Great Britain (I776).

Rebellion.

\section{Revolutionary Movements in the Middle and South-} ern Colonies. - In New York (the lower part of the Dominion of New England) Andros's lieutenant, Nicholson, Andrews, attempted to maintain his authority after news had been Col. Self-Gov't, received that James had been driven from England, and
$283-287$.

Hart, Contemporaries, I, No. I57. that Andros was a prisoner at Boston. Taking advantage of this, the opponents of Nicholson, led by a merchant, Jacob Leisler, gained possession of the province. The new monarchs were proclaimed, an assembly was called, and for nearly two years the laws were administered by Leisler, whose authority was not recognized officially. When a governor was finally sent over, Leisler, now cordially hated by a large part of the population, yielded of necessity. $\mathrm{He}$ was tried on the charge of treason and condemned, being put to death when his successor, while intoxicated, was induced to sign his death warrant. This unwise and unjust "judicial murder" involved the colony in serious internal dissensions. "Leisler's Rebellion," however, had shown the strength of the popular party and from that time New York enjoyed a fair degree of self-government.

Results in Maryland.

Maryland failed to proclaim the new monarchs because the messenger whom Baltimore had sent with instructions to recognize the new government died before reaching the Andrews, $\begin{array}{ll}\text { Col. Self-Gov't, } & \text { colony. The anti-Catholic party took advantage of this } \\ 79-283 . & \text { neglect, captured the officials who favored Baltimore, and }\end{array}$ Browne, Maryland, $\mathrm{I}_{47-156 .}$ claimed the province for William and Mary. The monarchs decided to keep the government of Maryland in their own 


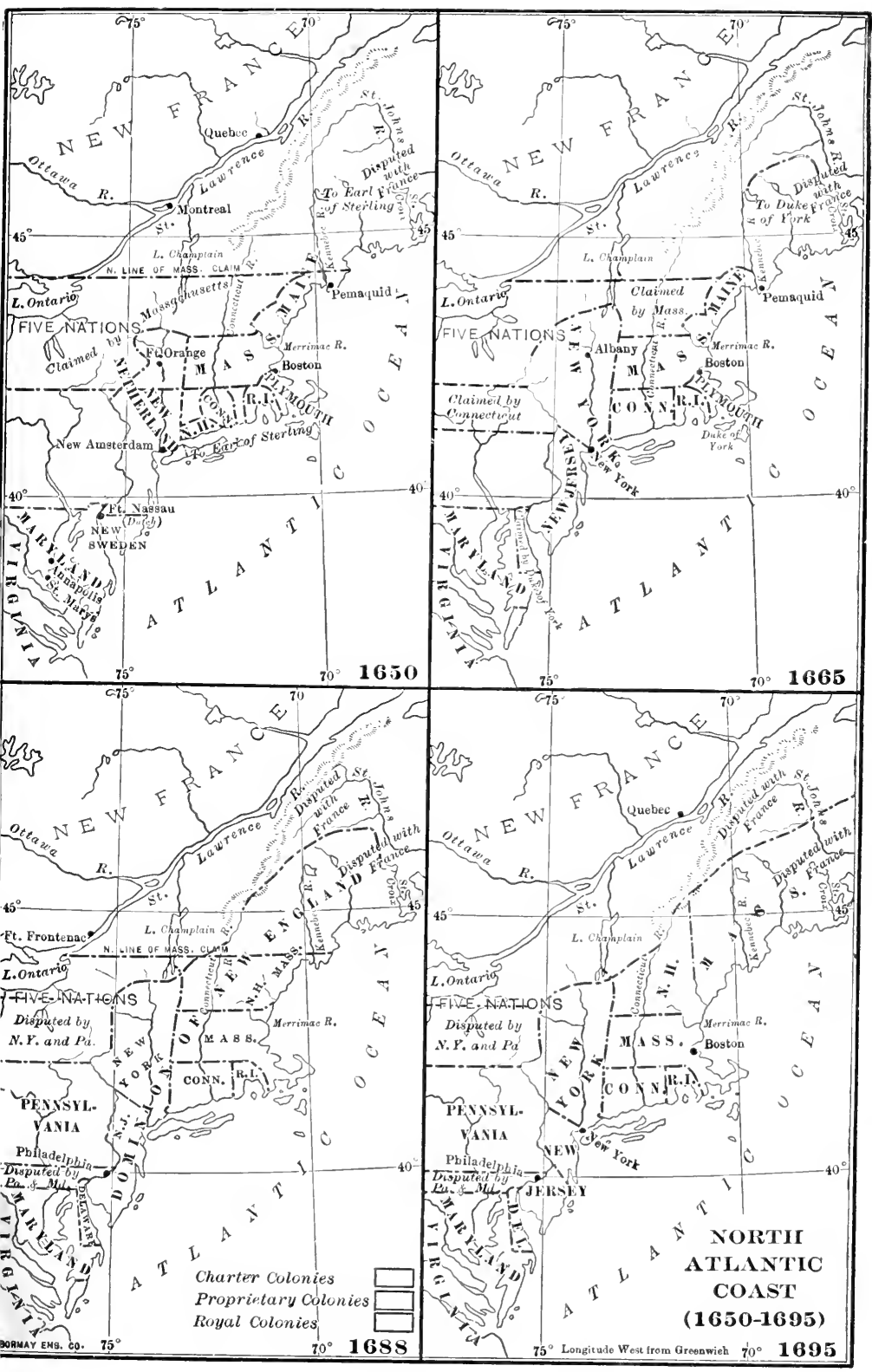



hands, although they did not interfere with the revenues or Doyle, land rights of Baltimore, but it was a quarter century before another and Protestant Lord Baltimore regained politiEng. Cols., I, 264-274. cal control of the colony.

79. Results of the Revolution in America. - It will be noted that the changes in America following the Revoluticn of 1689 were of the first magnitude. It will be noted also that they were not the results simply of the revolutionary movement in England, but of several minor revolutions in this country, which were due to causes exclusively American, although the expulsion of James furnished the occasion for the overthrow of arbitrary rule in the colonies. ThroughReestablishment of separate charter governments. out the Dominion of New England the arbitrary govern-. ment established by James was replaced by constitutional government. Connecticut and Rhode Island resumed the use of their old charters. Massachusetts secured less complete self-government than she had enjoyed before I684, but in New York there was a great advance over the system in use at all former times. A second result of considerable importance was the failure of the scheme for the consolidation of the colonies. Union, even under the later kings, would have been injurious, for the colonies owed a very large amount of their experience in self-government and their numerous political privileges to their separateness.

In some ways the reign of William III was not especially favorable to colonial liberty. The king expressly and emphatically denied to the colonies the rights which the Bill of Rights guaranteed throughout the length and breadth of England. Religious toleration of all except Catholics was extended to the colonies, but if any colonies enjoyed freedom of the press and the privilege of the writ of habeas corpus, it was because the charters of the Colonial policy of England after I689.

Greene, Provincial America, $3^{0}-3^{8}, 4^{6-62}$. colonies made it impossible for the monarch to control their policy in those matters. The increase of the power of parliament due to the Revolution led to the reënactment of the old laws of trade and the passage of several laws prohibiting colonial manufactures $(\$ \mathrm{I} 20)$. During this period also

Greene, Provincial America, 17-24. 
the English government perfected means for controlling the colonies by establishing a permanent "Board of Trade and Plantations" (I696), whose members were popularly called "the Lords of Trade." This board gradually took charge of almost all matters referring to the colonies, including the right to decide all matters which had been adjudged in the highest court of any colony, if either party wished to appeal from the decision of the colonial court.

Territorial changes (I660-I700).

Colonial policy after 1660 .

8o. The Colonies in I70o. - It may be well to consider for a moment the changes in the extent of English territory and in the relation of the colonies to the mother country that had taken place in the last four decades of the seventeenth century. At the time of the Restoration there had been two well-defined groups of colonies, the New England group, extending as far north as the Kennebec, and the southern colonies, with their frontier settlements a short distance south of the James. By the conquest of New Netherland, England came into possession of the intervening territory and by settlements in Carolina had extended the frontier almost to the Savannah River. Although the settlers had continued to push into the interior, the frontier line was but little farther from the coast in 1700 than in I660. Immigration from England had been fairly extensive and the population of the colonies, estimated at 60,000 in 1660 , had become 250,000 in 1700 .

Before 1660 England had no colonial policy. Since the Restoration it had organized the colonies, brought many of them directly under the royal authority, and had created a board which had charge of all colonial affairs. It had passed numerous acts of trade which regulated the commerce of the colonies, primarily in the interests of England, but not always to the disadvantage of the colonies.

\section{TOPICS}

I. The Beginning of Pennsylvania: Fiske, "Dutch and Quaker Colonies," II, pp. I47-I67; Bancroft, "United States," I, 552-573; Winsor (ed.), “America," III, pp. 476-495. 
2. Boundary Difficulties of Pennsylvania: Hinsdale, "Old Northwest," 98-r I9; Fisher, "Making of Pennsylvania," pp. 318354 .

3. Bacon's Rebellion: Fiske, "Old Virginia," pp. 45-107; Doyle, "English Colonies," I, pp. 230-257; Cooke, "Virginia," pp. 2 I 6-297.

4. King Philip's War: Bancroft, "United States," I, 382-394; Fiske, "New England," pp. 2 I I-24I ; Doyle, "English Colonies," III, pp. I 53-I 8 9.

5. Massachusetis and the Crown, during Reign of Charles II : Bancroft, "United States," I, 367-38I, 395-406; Doyle, "Colonies," III, pp. I30-I52, I90-208, 2 I $_{4}-226$; Palfrey, "New England," II, pp. 28-36, 56-63: 7 I-80, 2 I $0-260$.

\section{STUDIES}

I. Early navigation acts. (Winsor (ed.), "America," VI, pp. 5-ro.)

2. The patroon system. (MacDonald, "Charters," No. 9.)

3. Wars of England and Holland. (Griffis, Motley's "Dutch Republic," pp. 832-847.)

4. Evolution of New York. (Janvier, "In Old New York.")

5. Early history of Wall Street. (Goodwin et al. (eds.), "History of New York," I, pp. 77-Ii8.)

6. Character of IVilliam Penn.

7. Overthrow of proprietary government in South Carolina. Doyle, "English Colonies," I, 376-38o.

8. Puritans and Anglicans after the revolution of r689. (Greene, "Provincial America," pp. 83-105.)

\section{QUESTIONS}

I. What degree of self-government had the people of New Netherland gained under Dutch rule? What were the lasting results of Dutch occupation? Compare the situation in New Netherland in I663 with that in the South African Republic in I 898.

2. Compare fully the powers of Penn as proprietor with those of Baltimore. In what respects was Pennsylvania at an early date more like the states of to-day than any of the other colonies?

3. What were the real causes of Bacon's rebellion? What were the results and the real significance of this movement?

4. On what grounds might a colonial charter be amended? be revoked? Should Massachusetts have been allowed to retain her charter after I664? Compare the complaints after I 660 with those after ${ }_{1676}$. Were the latter more serious?

5. Compare the period i6 $18-1640$ with that from i 660 to 1682 as to $(a)$ interest in colonization, $(b)$ causes of colonization, $(c)$ number of colonies established, and $(d)$ total settled area at close of the period. 


\section{CHAPTER V}

\section{RIVALRY OF FRENCH AND ENGLISH (I689-I763)}

\section{FRENCH KINGS}

Henry IV (I589-I6ro)

Louis XIII (I610-I643)

Louis XIV (I643-I7I5)

Louis XV (I7I5-I774)

\section{ENGLISH RULERS}

William III (I689-I702)

Anne

(I 702-I7I4)

George I (I $\left.7 \mathrm{I}_{4}-\mathrm{I} 727\right)$

George II $(1727-1760)$

George III ( $1760-1820)$
Wars between France and England.

Seelye, Expansion of England, Chapter II.

8I. Introduction. - The year $\mathrm{I} 689$ is notable for the changes which it wrought in the internal development of England and the English colonies, but is almost as important in the intercolonial history of America, because it marks the beginning of a long conflict between the provinces of England and France in the new world. During the years from I689 to $175^{\circ}$ the European wars in which these two countries engaged were accompanied naturally by military engagements in the colonies, although these were of minor significance. About I750 began the real contest between the two powers for the control of the continent - a struggle short and really one-sided, which ended in the complete supremacy of the English and the expulsion of the French from North America. In this chapter we shall consider not only the more important events in the intercolonial wars and study the progress of both French and English colonies after I689, but shall take up briefly also the earlier history of the interesting ventures of the French in America.

\section{French Exploration and Settlement}

France under Henry IV.
82. Founding of New France. - With the accession of Henry IV (1589), there came a new era of prosperity in France. Deadly civil and religious wars ceased, commerce 
revived, and industry received new impetus. Interest in Adams, colonization kept pace with the development in other directions, and several settlements were attempted in Acadia. French Nation, I77-188. One of these under the lead of De Monts was established at Port Royal (i604) and proved successful temporarily.

Among the companions of De Monts was a young man of great energy and foresight, who believed that the St. Lawrence basin offered a better location for trading, exploration, and permanent settlement. This man, Samuel de Champlain, founded Quebec in 1608 and soon perceived that his only hope of holding the country and gaining the interior was to make friends with the Indians of the St. Lawrence valley. But the Algonquins living on the St. Lawrence and the Ottawa rivers, together with the Huron Indians to the west, had for many years waged almost incessant war

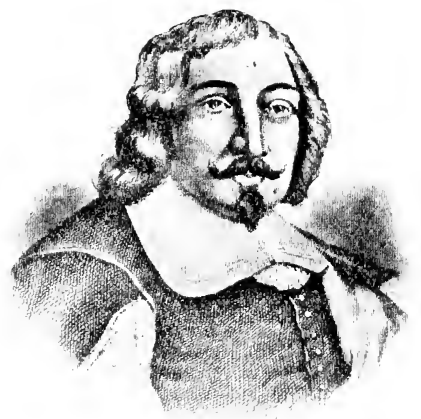

Champlain with the Five Nations of the Long House in central New York. The allies of Champlain persuaded him therefore to join them in expeditions against the Iroquois. The first of these in 1609 brought him to the shores of the lake now called by his name, where a single well-aimed shot from his arquebus put to flight the Mohawks who opposed him and brought upon the French the enmity of the most powerful Indian confederacy in North America. A few weeks after this momentous battle, Henry Hudson entertained some Mohawks at a point near the present city of Albany, only a little over one hundred miles away, and gained the goodwill of the Iroquois. Although he was responsible for this disastrous hostility of the Iroquois to the French, Champlain deserves all the credit for the success of New France, for he

Champlain in the St. Lawrence valley (1608-1635).
Hart, Contemporaries, I, No. 39 .

Thwaites, France in America,16-22.

Parkman, Struggle for a Continent, 88-106, I2O-I24. 
took part in numerous exploring expeditions and kept the sickly little hamlet alive through his unflagging zeal and unwearied efforts. In I629, however, Quebec was captured by the English with the help of some French Huguenots, and it was returned to France at the close of the war only through the influence of Richelieu, who had recently interested himself in France's American possessions. In I635 Champlain died and so little did New France prosper that a half century after Quebec was founded there were only about two thousand persons in the colony.

Classes that extended

French sway.

Parkman, Strussole for a continent, I30-I34, I8O-IS5.

Early explorers.

La Salle.

Fiske, Disc of America, II, $53-58$.

Hart, Contemforaries, I, No. +3 .

83. Exploration of the West. - The work of extending French influence in the West was carried on by three different classes: (I) the Jesuit missionaries who, before the middle of the serenteenth century, had established missions as far south as the Iroquois country, and as far west as Sault Stc. Marie; (2) the fur traders who found they could make greater profits by risiting the more distant tribes; and (3) the explorers who desired to extend the political sway of France rather than her religious or commercial interests.

The earliest of western explorers, Nicollet, launched his canoe on a tributary of the Mississippi about 1640 , but it was not until 1673 that Marquette and Joliet explored that river, which they descended as far as the Arkansas. The work of these men was completed by the greatest American explorer, Robert Cavelier, Sieur de La Salle, who proposed to gain possession of the whole interior and maintain this hold by means of a chain of forts situated at strategic points. In spite of almost orerwhelming odds and amid the greatest difficulties, he clung to his single purpose of making New France the strongest colony in America. His explorations began in 1669 with a trip via Lake Erie to the Ohio River. Ten years later he sought to explore the Mississippi to its mouth. After two futile expeditions filled with difficulties, his third expedition met with success and on April 9, I6S2, La Salle planted the standard of France where the Mississippi River pours its vast volume into the Gulf of Mexico and claimed the whole territory drained by it for 
Louis XIV. He next proceeded to France, told the king his plans, and asked permission to settle at the mouth of the Mississippi, to build a chain of forts from this point to the colony of Canada, and to drive out the Spaniards who claimed the country. An expedition was fitted out, but by accident came to Texas. Here La Salle was shot in 1687 by one of his own men.

84. Louisiana (I699-I720). - La Salle's plan was not abandoned, although nothing further was done until after the first intercolonial war. In I699 a settlement was made at Biloxi, but it was abandoned, the colonists moving to Mobile in r7or. Both the English and the Spanish protested against this occupancy of the gulf region, the former on the ground that this land was covered by previous grants made by English kings, the latter because of her discoveries and explorations and her settlements in Florida and on the Mexican coast. The Spaniards had in fact occupied the best harbor on the coast, that of Pensacola, as early as 1696 , in the hope of preventing further French attempts at colonization. Louisiana did not grow rapidly, but in i 7 is New Orleans was founded and forts were placed at commanding points on the Mississippi and Red rivers, so that all other nations were effectively excluded from the Mississippi basin. About this time attention was called to the Louisiana settlements by the speculations in the stock of the French Mississippi company under the manipulations of the Scotchman, John Law. The bursting of the "Mississippi Bubble" did much in the end to injure the colony.

\section{French and English Colonies (i689-i754)}

85. The Treaty of Utrecht (I II3). - Before the French had gained a foothold at the mouth of the Mississippi, the colony of New France became engaged in two conflicts with the English on the Atlantic coast. These wars were of European origin, caused by differences between France and England. The first followed the Revolution of $\mathrm{x} 689$ and the attempt made by Louis XIV to regain the throne of England

Early settlement.

Hart, Contem* poraries, II, Nos. I09, I Io.

Thwaites, France in America, 72-88.

Ogg, Mississippi, 169-204.

Parkman, Half Century, I, 288-3I4.

Beginning of the hundred years' war (1689-1697). 
for James II. For the French, the contest in America was ably conducted by the most capable of a long line of able governors, the Count of Frontenac. At the close of the war the French retained the territory draining into the Hudson Bay and all lands occupied by them at the beginning of the conflict. ${ }^{1}$

War of the Spanish Succession

(I7O2-1713).

Treaty of Utrecht (I713).

MacDonald, Charters, No. 47 .
But five years elapsed before the ambitions of France again involved that country in a European conflict, ${ }^{2}$ when Louis XIV sought to place upon the throne of Spain his grandson, Philip of Anjou, to whom the late Spanish king had left his scepter. The coalition against France was remarkably successful during the long war that followed, and in America the English colonists gained possession of territory in Acadia, Newfoundland, and farther north.

The war was brought to a close in $17 \mathrm{I} 33$ by the Treaty of Utrecht. England was able to make peace on very favorable terms because of her successes everywhere. She allowed Philip to retain his position, but only on condition that the two thrones of France and Spain should never be united. While France was permitted to keep Canada and Louisiana, England gained possession of the entire area draining into Hudson Bay, the whole of Newfoundland, and Acadia according to its most ancient limits. This last provision was to be a bone of contention for fifty years, as France wished to restrict England to the peninsula called Nova Scotia and England claimed Cape Breton Island and the mainland to the north and west as far as the St. Lawrence and the Penobscot. According to the treaty the French were allowed to catch fish off Newfoundland, with the privilege of drying their fish on parts of the island, the earliest attempt to regulate by treaty the rights of different nations in the fisheries. ${ }^{3}$

1 The Treaty of Ryswick ( 1697 ) brought to a close this war, known in colonial history as King William's War.

2 In the colonies this war was called Queen Anne's War, in Europe it was known as the War of the Spanish Succession.

${ }^{3}$ The treaty stated also that France should never molest the Five Nations "subject to the dominion of Great Britain." France of course 


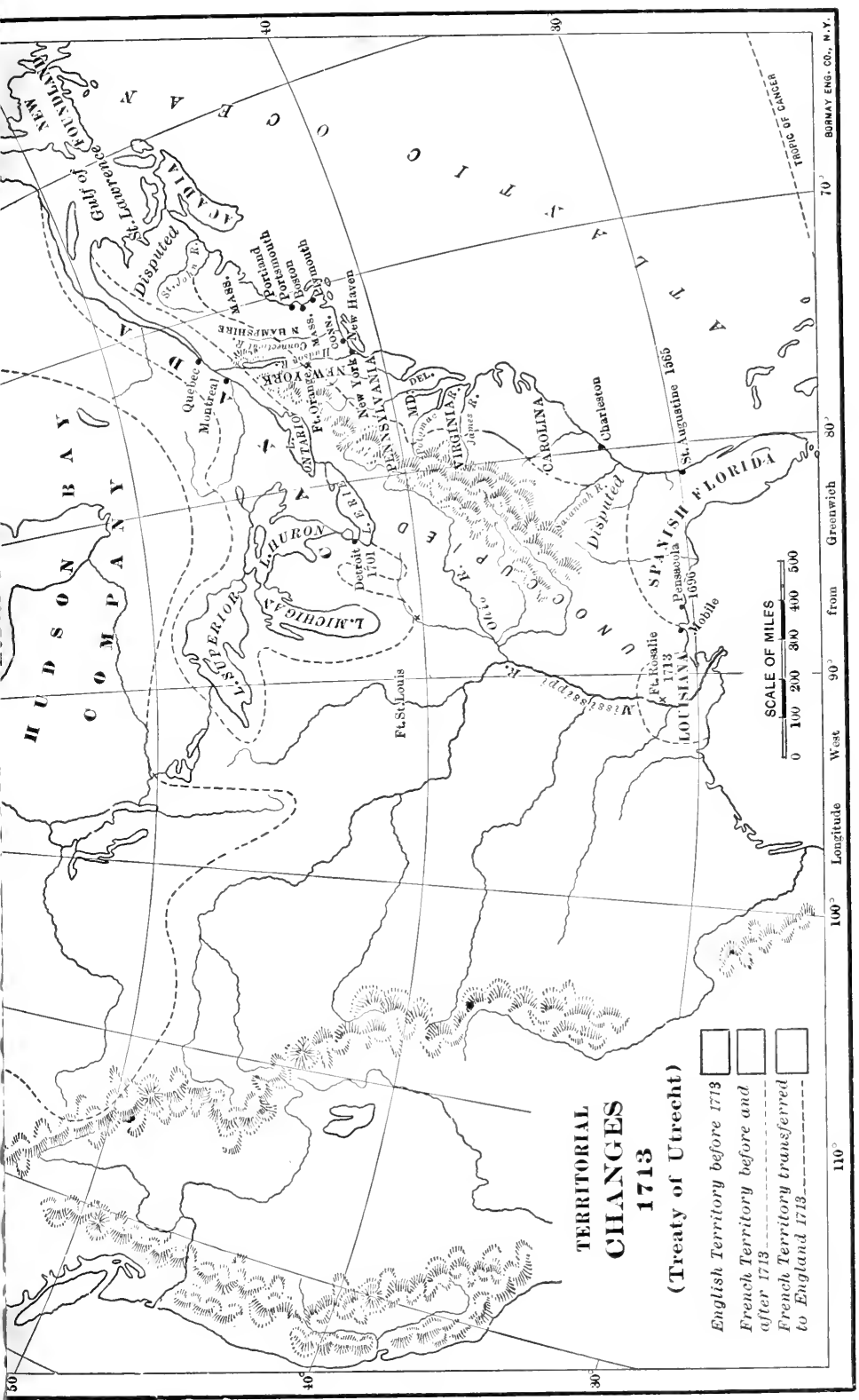



86. Georgia. - The thirty years between the Treaty of Utrecht and the third war between England and France was a period of expansion and development for both parties. With both it was a time of preparation for the conflict which was to determine the possession of the continent, but the preparation of the French, carefully planned as it was, proved to be less perfect than the growth of the sturly English colonies which were less conscious of the impending crisis and apparently did nothing to make realy for it. The two historical events of the period which particularly deserve attention were the settlement of Georgia and the conflicts between the governors and the assemblies in at majority of the colonies.

Georgia was founded by James Edward Oglethorpe and several associates who desired to establish a colony in which Georgia (1731-1752). debtors might get a new start. They obtained from the king a charter to land from the Savamnah to the Altamaha rivers and westward to the Pacific. This was to be governed by a council in which the people had no choice. 'The inhabitants, except Roman Catholics, were to have religious freedom and all were to enjoy the rights of Englishmen. The trustees of the colony sought to prevent the growth of large plantations by forbidlding negro slavery and restricting the amount of land held by one person. They expected to make great fortunes by producing raw silk and wines. Almost without exception, their plans came to naught. The settlers proved to be inefficient, save for a few bands that were not sent over by the trustees. Slaves were hired from the people of Carolina and later regular slavery was introduced, and the agricultural schemes of the founders entailed such losses that they were abandoned. The colony prospered after a fashion, but was so much exposed to Spanish attacks and so greatly handicapped by its start that it did not develop at all rapidly.

claimed that while these Indians might be subjects of England, the territory of the Iroquois and of their tributary tribes was still free. England, however, claimed territorial as well as personal dominion. 
The colonies under the first Hanoverians.

87. The English Colonists and their Governors. - Meanwhile the older English colonies were growing more rapidly than at any previous time. Large numbers of immigrants, most of them of other nationalities than English, flocked to America. These new settlers, with the more adventurous of the native-born inhabitants, pressed into the interior. Commerce and industry were expanding with considerable rapidity, notwithstanding the laws which were made by the English government to control these occupations, for these laws were not enforced. ${ }^{1}$ Under the first two Hanoverians the colonial governments were allowed by the authorities in England to do much as they pleased, and they pleased to run their own affiars. The principal obstacle in the way of their complete management of American affairs they found in the governors who were sent over to look after the interests of the crown, in the roval colonies, or of

Victories of the assemblies over the governors.

Thwaites, The colonies, is $\mathrm{I} 23-\mathrm{I} 20$.

Greene, Provincial tmiriica, I9t-200. the proprietors, in the proprietary colonies. These gorernors were intrusted with powers so important that they often controlled the situation theoretically. But custom frequently prevented them from exercising these powers fully. There were often important men or interests to be consulted and a new governor was obliged to use his powers with caution. If, as was often the case, he was a pleasureloving court favorite, he followed the line of least resistance, and yielded to the assembly (the lower house of the legislature, which was always elected by the people) most of its demands as the price of peace. By using this method, which was sneeringly called a process of "bargain and sale," the assemblies in most of the colonies paid the governors' salaries and allowed them to perform their duties unhampered only when the governors in turn kept their hands off the business of the assemblies. These contests between the governors and the assemblies were the most marked characteristic of English colonial history during the first half of the eighteenth century. The almost unvarying success of the assemblies left the colonies to a large extent 
self-governing and did much to give the colonial learlers confidence in their ability to protect themselves from interference on the part of the home government or its representatives.

88. Government of the French Colonies. - The French colonies were governed very differently. No representative of the people had a share in making the laws. The king appointed directly all of the chief colonial officials. There was a gozernor who had control of military affairs, who executed the laws, who, in fact, had more influence than any one else in making the laws. These governors held office as a rule for a longer time than the governors in the English colonies and exercised powers that were immeasurably greater. But every governor had at his elbow an official called an "intendant," who was appointed by the king to spy upon the governor and report to the king what the governor did. Naturally he acted as a check on that official, but this dual system resulted in constant misunderstandings and bickerings. The real legislative head of the French colonies was a superior council appointed by the king. This council made laws, established courts, and formed a final court of appeal.

Such an absolute government of council, governor, and intendant made it possible for the French colonies to concentrate all their strength in carrying on war and seizing territory, much to their advantage. But the French rule was not fitted to develop strong, populous, self-reliant colonies. The government established a paternalism which sought to aid the colonies, but which succeeded only in weakening them. Commercial monopolies interfered with individual enterprise, immigration was restricted by the ardor of the Jesuit priests who kept out Protestant settlers, while feudal estates and privileges placed barriers in the way of social progress. For the protection of the fine territorial domain that she had securerl, France at the middle of the eighteenth century could muster only eighty thousand inhabitants, while the rival British possessions boasted

Results of the French colonial policy.

Parkman, Struggle for a Continent, 314-3I8.

Thwaites, France in America, 132-I42. 
nearly a million and a quarter. Little wonder that the court of that pleasure-loving monarch, Louis $\mathrm{XV}$, with its shortsighted, blundering policy in Europe, Asia, and America, was unable to retain its hold in America!

IVar of the Austrian Succession (I $\left.7 f^{-I} 7 t^{8}\right)$.

Fiske, New France and Neav England, 249-256.

French forts in the West.

Parkman, Struggle for a Continent, $1_{5} 6-$ $264,297-300$.

Parkman, Half Century, I, 63-77.
89. Preparation for the Final Conflict. - Great Britain and Spain had been at war for sereral years before the war of the Austrian succession, which involved nearly every country of Europe, spread to America in 1744 . Only one important military event distinguished this third intercolonial war. The great fortress of Louisburg on Cape Breton Island, which commanded the entrance to the St. Lawrence and threatened the English colonies of Newfoundland and Acadia, was reduced by William Pepperell and a force of New England farmers and fishermen almost unaided by the British nary. Much to the indignation of the colonists, this advantage was lost by the treaty of Aix-la-Chapelle $(\mathrm{I} 7+8)$, since Louisburg was returned to the French in exchange for Dutch fortresses that they gave up.

As this treaty of Aix-la-Chapelle was considered by all parties a mere truce - a temporary lull in the storm - each side was busy making preparations for the real struggle to follow. France had already made considerable progress in the occupation of the West, having gained control of the principal avenues of communication by establishing forts at strategic points like Frontenac, Detroit, Sault Ste. Marie, and Chartres before 1720 . When the English sought to secure a large share of the fur trade by building a trading post at Oswego in 1722 , the French tried by establishing forts at Crown Point and Niagara to gain control of Lake Champlain and to recover the trade they had lost on Lake Ontario. At the close of the third intercolonial war, the French governor of Canada strengthened the chain of forts from Montreal to New Orleans, and in order to gain the goodwill of the western Indians by impressing them with the power of the French, he buried leaden plates inscribed with the arms of France and the claim that France was the sole ormer of the country west of the mountains. 


\section{Expulsion of the French (I754-I 763 )}

9o. The Struggle for the Upper Ohio Valley. - In I 753 the French extended their system of forts to the valley of the Allegheny River, with the intention of keeping the English from the upper Ohio region. The English had already secured from the Iroquois a claim to this territory, but the first real interest in the country beyond the mountains was developed in Virginia, which claimed that section

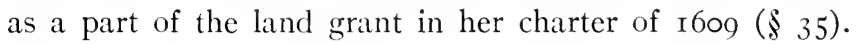
Grants of the land had been made to companies by Virginia before $175^{\circ}$, and, when the French began building forts south of Lake Erie, Deputy Governor Dinwiddie of Virginia sent George IVashington, then a stalwart youth of twenty-one, to warn the French that they were trespassers.

Acting on Washington's report, a force was dispatched the next spring ( 1754 ), to occupy the rocky promontory at the junction of the Allegheny and the Monongahela Rivers, which was the real "gateway of the IVest." Before their arrival the French descended the Allegheny in force, drove away the traders who had a post at that point, and built a strong fort that they called Duquesne. A scouting party from this fort was sent to watch the movements of the vanguard of the Virginia detachment under IVashington and was attacked by him, all of the Frenchmen being killed or captured. Of course this was an act of war, but both France and England desired to maintain peace as long as possible, and it was two years before war was declared, although waged during the interval in America and India. After the first skirmish Vashington was obliged to fall back, but later was himself captured with all of his troops by a French force much larger than his own.

9I. The Situation in America and in Europe. - That an actual battle between armed forces of the two countries did not lead at once to a break in their friendly relations was due to the state of European politics. The treaty of Aix-la-Chapelle had seated Maria Theresa firmly upon the

French forts and Virginia land grants.

Hart, Contemporaries, II, Nos. 123-124.

Collision between the French and Washington.

Parkman, Struggle for a Continent, 333-337.

Fiske, Neze France and New England: 269-276.

Thwaites,

France in America, I 57-I68.

Complications of European politics. 
Hassall, Bal- throne of Austria, after nearly a decade of fighting. So ance of Power, 224-240. anxious was the whole of Europe for a respite, that not even the struggles between France and England in India, which had continued after war ceased in Europe, proved sufficient cause for an open renewal of hostilities. But when affairs reached a crisis in India; when Austria and France united for the dismemberment of Prussia, with whom England was in sympathy; when French and English vessels were scouring the seas for the merchantmen of the other; and when a half-dozen armies were actually fighting for America, the facts could no longer be ignored, and war was declared (I756). This "Seven Years' War," as it is called in European history, exerted a greater influence on the destinies of both France and England than almost any other war in their history. The phase of it in which we are most interested, the contest in America, best known as the "Old French and Indian War," decided the future of half a continent.

Comparison of the combatants in America.

Parkman, Struggle for a Continent, 314-328.

Avenues of English attack.
For the first time both England and France were almost as much interested in the war outside of Europe as in the war on the continent, and each gave to her colonies all the forces that she could spare. In America the resources of the contestants were far from equal. The population of the English colonies was nearly fifteen times as large as that of the French provinces. On the other hand there were two highly centralized French provinces, in which a semi-military government could bring every able-bodied man into the field at short notice, and fourteen disconnected British colonies more or less jealous of one another, and practically without experience in acting together. Nothing but a great common danger could make the English colonies forget their differences, and the distrust shown by the assemblies toward their governors made them unwilling to vote men and supplies for an army which might be directed by the governors.

As the strength of the French was greatly disproportionate to the territory that they held, it was natural for them to await the attack of the English. The English in the mean- 
time prepared for invasion along four principal avenues. First, they followed the seacoast and the St. Lawrence, using Boston and Halifax as the bases of operations. Then came the Champlain route, and the one through the Mohawk valley and Lake Ontario. Last of all was that leading straight to the ground especially in dispute by way of Fort Duquesne.

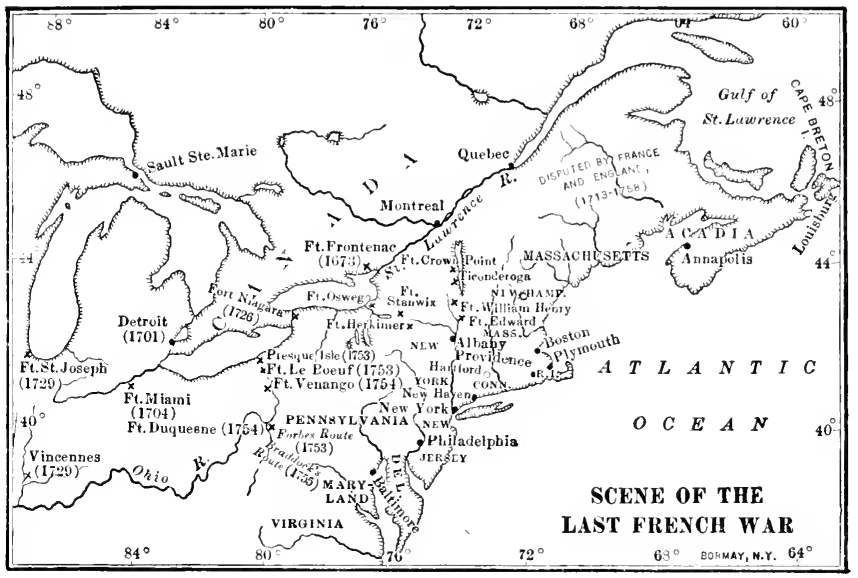

92. The First Period of the War (I 754-I757). - In order to secure the coöperation of the Indians west from Lake Champlain, the French had made repeated efforts to gain the friendship of the various tribes. So great was their success that even the Six Nations, ${ }^{1}$ which had remained neutral during the third intercolonial war, were brought under French influence. To cnunteract this impending danger, a congress was called to meet at Albany, New York (I754), for the purpose of renewing treaties with the Iroquois. The Six Nations were persuaded easily not to cast in their lot with the French in the conflict that had begun already, but the congress proceeded to adopt a remarkable plan of military union for the colonies, which had

The Iroquois and the Albany Congress (I754).

Hart, Contemporaries, II, No. 125 .

Thwaites, France in America, I68-I72.

1 The Tuscaroras had joined the Five Nations in 17 I 5 . 
Larned (ed.), been proposed by Benjamin Franklin of Pennsylvania. Ready kef., V, 3175-3178. It contemplated a president general appointed by the English king, who was to be commander in chief of the colonial army, and an assembly which was to have charge of all financial matters. This plan was disapproved in England as too democratic, and in the colonies because it centered too much power in the hands of a royal representative.

French victories

$\left(\mathrm{I} 755^{-\mathrm{I}} 757\right)$.

Hart, Conte'mforaries, II, Nos. $120-127$.

Parkman, Struggle for a continent, $3+3-355$.

Campaigns of $175^{3}$.

The first real campaign of the war was that of Braddock, who attempted with a force of provincials and regulars to capture Fort Duquesne ( 755 ). His overwhelming defeat was all the more humiliating because of the numerical inferiority of the French and Indians. The same year occurred the expulsion of the Acadians, a cruel act, justified on the ground of political and military necessity. While the English commanders remained inactive the next two years or wasted thcir time in vain demonstrations against the great fortress of Louisburg, the French general, M[ontcalm, gained absolute control of Lakes Ontario and Champlain. The first period of the war had revealed the utter incapacity of most of the English commanders, while an almost uninterrupted series of French victories had extended still further the limits of the vast territory claimed by France.

93. The Second Period of the War (I 758-I 760). - When William Pitt became prime minister of England ( $15 \%$ ) the tide turned. He immediately formed plans for the active prosecution of the war by sending to America a stili larger number of troops, by arousing the colonists to active cooperation with the regular army, and by appointing competent commanders. An expedition was fitted out to follow each route. Louisburg, Frontenac, and Fort Duquesne fell into the hands of the English, the first after a siege that was serere though short. The French line would have been cut up even more had it not been for the remoteness of Niagara and the presence of a skillful leader, Marquis de Montcalm, at Ticonderoga. With his departure to defend 
Quebec the next season (I 759), Lake Champlain too became English.

The great expedition of the year, and in fact of the war, Capture of was that against the city of Quebec. Occupying commanding heights that were directly approachable from one side only, with mighty fortifications against which artillery thundered in vain, defended by a large army under the command of the ablest French general, Quebec seemed impregnable. For the capture of the city a fleet and an army were dispatched early in I759 under James Wolfe, whose diseased frame housed an indomitable spirit. After months of fruitless siege Wolfe was able to lead one half of his army by night to the plains of Abraham on the unprotected side

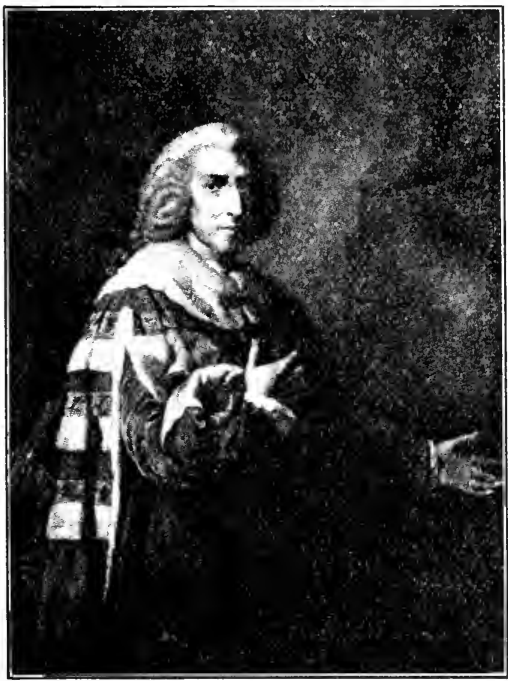

William PITT Quebec (1759). of the city. Montcalm gave battle, in which both commanders were killed, and a few days later the city surrendered. This glorious victory left to the French only Montreal, which was captured the next year, and the territory in the West. It really settled the fate of the French empire on the continent of North America. John Fiske believed that "the triumph of Wolfe marks the greatest turning point as yet discernible in modern history."

94. The Peace of Paris (I 763). - For nearly three years after war ceased in America, the two countries continued the great conflict elsewhere. During this interval Spain formed an alliance with France and assisted her in

Fiske, New France and New England; 349-359.

The situation in 1762 . 
the contest. But England continued to gain victories. She became mistress of the important island of Guadaloupe, as well as most of the other French possessions in the West Indies. Havana and part of Florida had fallen into her hands. As she had been the acknowledged ruler of India after the battle of Plassey (I757), she was not to be satisfied with the territory for which she had fought, not even when Canada was included. The war had proved a colonial death struggle, from which France emerged with scarcely a trace of the magnificent possessions she had claimed at the beginning.

Provisions In the Treaty of Paris ( 1763 ) all of the claims of France of the Treaty of Paris (I763). MacDonald, Charters, No. 54 . Thwaites, France in America, 266-279.

Territory west of the Alleghany mountains.

MacDonald, Charters, No. 55 . to the territory east of the Mississippi, except the little island on which New Orleans stands, were transferred to England. ${ }^{1}$ Only two little islets south of Newfoundland were kept for fishing stations, and they were never to be fortified. England's territory was rounded out by the exchange of Havana for the Spanish Floridas. Spain had already been compensated for her losses when France gave her the isle of Orleans and all Louisiana west of the Mississippi River.

Many of the Indian tribes of the West protested against the transfer of their territory to English rule and united under Pontiac in one of the greatest Indian uprisings in history. Attacks were made on all the western forts and settlements from the Virginia frontier to the Great Lakes. As the colonial assemblies neglected or refused to furnish troops, regulars were sent to relieve the besieged garrisons, but the insurrection was not broken completely until r765. Meanwhile, in order to appease the western Indians, George III issued a proclamation ( 1763 ) reserving the lands beyond the Alleghanies for the Indians and prohibiting the colonies from making grants of lands or settlements in that region.

' France was allowed to retain either Guadaloupe or Canada. While Canada was poor and had been a source of continual expense, Guadaloupe was rich and had given substantial aid to the French treasury. So the chance of future dominion was sacrificed to present gain. 


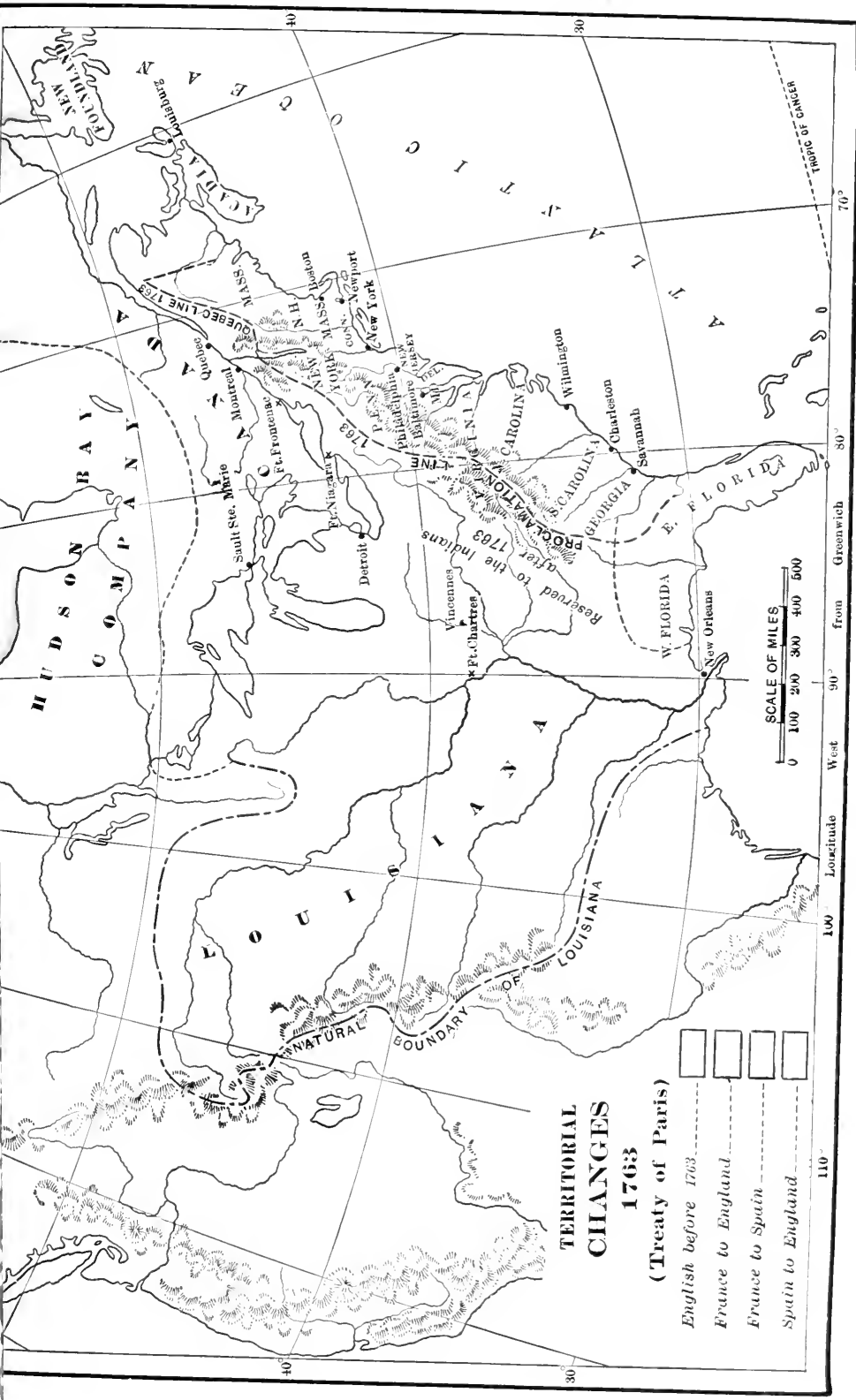


95. Summary. - The French were not good colonizers and were hampered by the paternal attitude of their home government. Three colonies were founded in North America : Acadia south of the St. Lawrence, New France or Canada in the St. Lawrence basin, and Louisiana in the lower Mississippi basin. French explorers, traders, and priests penetrated the interior, but France planted no colonies inland. She maintained a hold on the interior, however, by connecting Canada with Louisiana by a chain of forts at strategic points. Her great rival meanwhile was neglecting the eleven colonies which had been planted on the Atlantic coast during the seventeenth century. But the colonies prospered, large numbers of immigrants being received from Ireland, Scotland, France, and Germany as well as England. Their gain during the three quarters of a century following the revolution of r 688 was not only in population, commerce, and wealth, but in culture, selfreliance, and a greater desire for self-govermment.

With the expulsion of James II from England in 1689 began the second "hundred years' war" between France and Great Britain. The first four conflicts in this series, lasting until $\mathrm{I}_{7} 6_{3}$, involved the colonies of these nations in America, and were accompanied by all the horrors of border Indian warfare. The first substantial gain was secured in the Treaty of Utrecht ( I $_{3} 3$ ) by which England gained control of all Newfoundland, the territory drained into Hudson Bay, and Acadia with its ancient limits. The last war, begun in $\mathrm{I} 754$, was a contest at the beginning for the control of the upper Ohio valley, but, when Pitt became prime minister in England, it became a struggle for supremacy in America which ended in the capture of Louisburg, Quebec, and all other important French strongholds. At the close of the war France transferred her territory west of the Mississippi to her ally, Spain, and surrendered to the English Canada and the eastern Mississippi basin. England rounded out her possessions by acquiring from Spain both Floridas. 


\section{TOPICS}

I. Champlain: Fiske, "New England and New France," pp. 39-42, $5^{8-7 \text { I }, 80-93}$; Parkman, "Struggle for a Continent," pp. $S_{3-124}$; Winsor (ed.), "America," V, pp. I03-I 30.

2. Capture of Quebec ( 1759$)$ : Thwaites, "France in America," pp. 239-254; Sloane, "French War and Revolution," pp. $78-98$; Parkman, "Struggle for a Continent," pp. $3 \delta_{2-44} 6$.

\section{STUDIES}

I. France under Henry IV. (Wakeman, "Ascendency of France," pp. It $_{4} 3 \mathrm{~S}$.)

2. French search for a western passage. (Parkman, "Struggle for a Continent," pp. IO;-I I3.)

3. Iroquois and the French.

4. Character of La Salle. (Parkman, "Struggle for a Continent," pp. 220-222.)

5. Early Indian attacks during the second intercolonial war. (Drake, "Border Wars of New England," I53-i 66. .)

6. Acadia after 17 I3. (Parkman, "Montcalm and Wolfe," I, 9o$\mathrm{I} 27$.

7. How the people controlled their governors. (Fisher, "True American Revolution," pp. 2I-32.)

S. England and France in the eighteenth century. (Parkman, "Struggle for a Continent," pp. 30I-3 3 .)

9. Early colonial plans of union. ("American History Leaflets," No. I4.)

ro. The contest over India. (Woodward, "Expansion of the British Empire," pp. I96-205.)

Ir. Montcalm. (Parkman, "Montcalm and Wolfe," I, pp. 356380.)

\section{QUESTIONS}

I. Show how political changes in France influenced the course of events in the French colonies. Was the colonial policy of France wise? (Consider political, commercial, and religious regulations.)

2. Make an outline on the French in America, giving (a) method used to gain possession of the country, $(b)$ three classes that extended French sway, $(c)$ extent of French possessions (I650, I 7 IO, I755), $(d)$ causes of French success, (e) causes of French failure.

3. Make a table showing the chief events during the three periods, I600-I660, I660-1;00, I;00-1;63, under the following heads: England, New England, middle colonies, southern colonies, the French and English, everts of continental Europe. (Keep events of the same date on same horizontal line.) 
4. Compare the land claims of the two countries to the Ohio valley ( 1754 ). What had each done to explore or occupy that region before that date.

5. To what extent did the colonial wars create a spirit of unity among the colonies? Name several reasons why Franklin's plan of unity met with disapproval.

6. Was the expulsion of the Acadians necessary? Give reasons for your answer. Could it have been accomplished in a different way?

7. Why might Fiske have believed that "the triumph of Wolfe marks the greatest turning point as yet discernible in modern history"? 


\section{CHAPTER VI}

\section{COLONIAL CONDITIONS (I750)}

\section{Population ANd Society}

96. Number of the People. - At the middle of the eigh-

Population of the sections.

Race elements of the population.

\section{Thwaites,} Colonies, 97. I8O-I8I, 220-222.

Greene, Provincial America, $22 S-236$.

Lodge, Eng. Colonie's, 66, 227-229, +06- +09 . teenth century the population of the thirteen colonies that afterward united to form the United States was probably less than a million and a quarter, distributed fairly erenly between the three sections, New England, the Middle colonies, and the South. The most populous of all the colonies was Virginia, with Massachusetts and Pennsylvania occupying second and third places.

With the exception of about three hundred thousand negroes all of the inhabitants were white, but perhaps not more than three fourths of these were of English descent. The New England colonies were settled almost exclusively by English Puritans and Virginia had few white inhabitants in the eastern part who were not English. A large percentage were of that sturdy yeoman stock which has been the backbone of the English race for several centuries. A few came from the higher social ranks but some were the dregs of English society. Among the non-English peoples, 
the Scotch-Irish predominated, large numbers of that intense and intelligent race having emigrated from the north of Ireland during the first half of the eighteenth century. Most of these Scotch-Irish settled in the interior, along the foothills of Pennsylvania and the Carolinas particularly. Aside from the English Puritans, this race has furnished the largest number and most influential of our public men. Many Huguenot families emigrated to America after the revocation of the Edict of Nantes in 1685. A larger proportion of these desirable citizens settled in South Carolina than in any other colony. In the middle colonies there was a larger number of foreigners than elsewhere, for not only were the Scotch and French numerous in that section, but there were also the original Dutch and Swedish settlers, besides a great number of German settlers who are known best as "Pennsylvania Dutch." Probably one quarter of all the colonists were of nationalities other than English.

97. Classes of Society. - In all the colonies there was social classes a marked distinction between the social classes, least pronounced in Pennsylvania and New England, most noticeable in South Carolina. In the North, the aristocracy was one based to a great extent on family, but men often attained social standing by exceptional learning or unusual business success. In the South, family and the possession of landerl estates counted for most. The middle class of independent farmers or merchants was largest in New England, for in that section there were few dependents and practically no slaves. In Pennsylvania also the middle class was very numerous, although there was the greatest difference between the prosperous farmer of the eastern valleys and the rough ignorant frontiersman of the interior. In most of the other colonies the middle class was comparatively small.

As a rule these people of the colonies were rough, kindhearted, industrious, and frugal. Their manners were often crude, and their ideas on social and political subjects undeveloped, but their courage was never open to question, and their love of liberty unquenchable. Although they

Thwaites,

Colonies,

$\S \$ 42,93$.

Lodge,

Eng. Colonies, 7 I $-73,327-329$. $445^{-} 44^{8}$.

Character of the people.

Wilson, Washington. 
drank overmuch and often engaged in pastimes that do not appeal to a more highly organized people, they rarely had distorted views of right and wrong.

Two kinds of indented servants.

Andrews, Col. Self-Gov't, 290-293.

Lodge, Eng. Colonies, 69-7I, 125-126.

Eggleston, in Century, Xxill (I884), 853856 .

Treatment of indented servants.

Eggleston, in Century, XXVIII (I884), 856858 .

Blacks in the North and the south.
98. Indented Servants. - There existed in all of the English provinces a class of white servants who were bound to their masters for a term of years. Of these there were two distinct kinds - one consisting of convicts who were sent to America to serve their sentences, and the other "indented" servants who bound themselves to work for a period of five years, usually, in payment of their passage to the new world. Many of those belonging to the second class were worthy, hardworking, but unfortunate individuals who secured farms of their own after the expiration of their terms of service, and became valuable citizens. The majority of the "indented" servants, however, were indolent and shiftless, so that an immense number of ne'er-do-wells were imposed on the colonies, especially from New York to North Carolina. Still more burdensome were the released convicts whose lawlessness and viciousness were a menace to the peace and order of the colonies.

During the terms of service these servants were controlled absolutely and often treated harshly by their masters. Attempts to escape were punished severely, and added to the time of servitude. In some colonies a second attempt was punishable by branding on the cheek and a third attempt by death if desired by the master. Frequently the condition of these servants was much better than might be expected, comparing farorably with that of farm hands in England. Sometimes convicts who were political exiles occupied clerical or business positions of importance.

99. Slavery. - African slavery existed in New Netherland and in the South almost from the beginning. It never attained prominence in New England, for the occupations of the people and later a growing sentiment against human bondage prevented its derelopment. The few slaves, as in most of the other northern colonies, were house servants who were treated usually with a great deal of consideration. 
From Pennsylvania south, the blacks were, of course, very much more numerous, in Virginia nearly equaling the whites in number, and in South Carolina forming about three Coman, Induse trial Hist., 43-45. fifths of the population. All of the menial domestic duties were performed by slaves, but in Maryland and Virginia most of the blacks were employed as field hands on the large tobacco plantations, while in the extreme South the work in the rice fields was done by bands of fierce, ignorant slaves, under cruel overseers.

During the seventeenth century white servants were preferred to African slaves, in almost all of the colonies, and the laws regarding slaves were comparatively lenient. Later, with the development of slavery and attempted insurrections, laws of great severity were passed. Slaves were not allowed to leave their plantations without permission and might be put to death if they attempted to escape or injured their masters. Meetings of slaves were forbidden and their quarters were searched frequently for hidden arms. Intermarriage between whites and blacks was forbidden under very heavy penalties. Many legal obstacles were placed in the way of emancipation. These laws were not enforced in Maryland and Virginia, for most of the blacks in those colonies were native born, living their entire lives on a single plantation, and consequently known personally to the master and mistress. As a rule they were well fed, well clothed, and treated humanely.

In the South, on the contrary, there was little difference between the letter and the spirit of the law. Many of the blacks were barbarous Africans, trapped by slave dealers and brought to America by Spanish or New England slave traders. On the rice or indigo plantations little attempt was made to civilize them. Slaves were cheap and their labor so profitable that it was more economical to work them , hard and buy new slaves when they were worn out than to spare them. Small wonder was it that the badly treated blacks hated their masters and overseers and were kept in subjection by an iron rule.

Laws regarding slaves.

Eggleston, in Century, XXVIII (1884), 86I865.

Lodge, Eng. Colonies, 67-69.

Enforcement of slave laws in the extreme South.

Lodge, Eng. Colonies: 181-183. 
The cities.

roo. Colonial Life. - Although nearly all of the people lived within one hundred miles of the seacoast, there were

Eggleston, in Century, XXIX (1885), 873$88 \mathrm{I}$. only four places that deserved to be called cities - Boston, Philadelphia, New York, and Charleston - and comparatively few large towns. Boston and New York were the centers of a thriving commerce. In Charleston lived most of the planters of South Carolina who found life unendur-

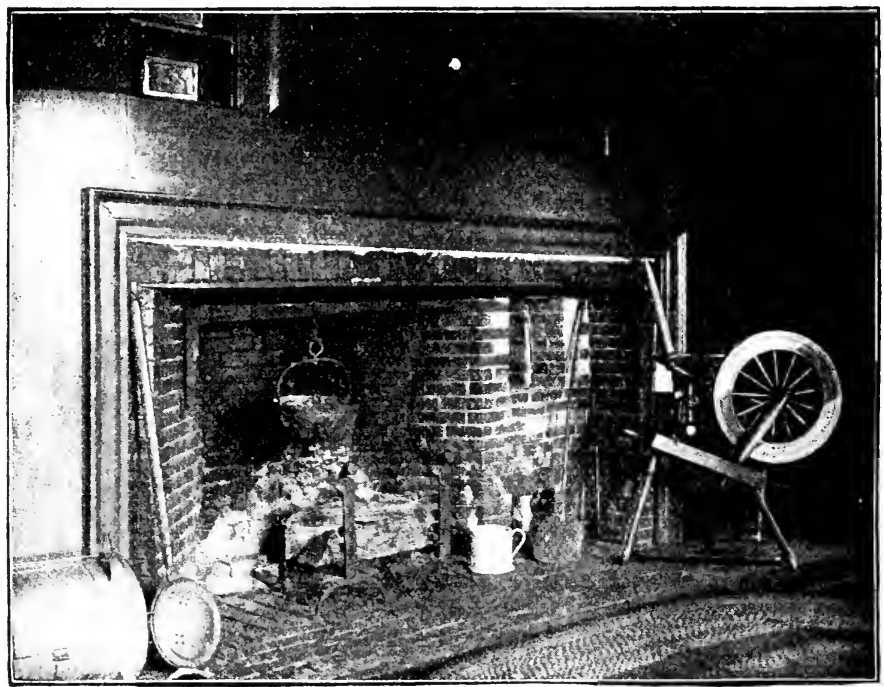

A Colonial Kitchen

Lodge,

Eng. Colonies, I03, 237-240, 258-262, 333337,45 I-46I. able on the hot, swampy plantations. These cities and some of the towns were compact little burgs, not overciean, with narrow winding streets - except Philadelphia - numerous small shops, and well-built houses usually of brick and stone. Few of the inhabitants were wealthy, but the majority were in fair circumstances. Few of the streets were patrolled or lighted at night, there was no uniform water supply or proper sanitation. Most of the houses had several balconies, and were backed if not surrounded by attractive gardens. Some of them were comfortably furnished with chairs, tables, and draperies purchased abroad. 
In the country the log cabins which had been the rule everywhere in the early days were to be found only on the frontier or in the poorer districts. With the advent of the sawmill, they had been replaced by frame houses of several rooms which were rude structures tied together with wooden pins, for iron was scarce. The doors were hung on leather hinges and fortunate indeed was the farmer who substituted glass brought from England for the oiled paper which was

Life in the country.

Earle, Home Life in Colonial Day's, $4^{-16}, 22-27$, $52-75$.

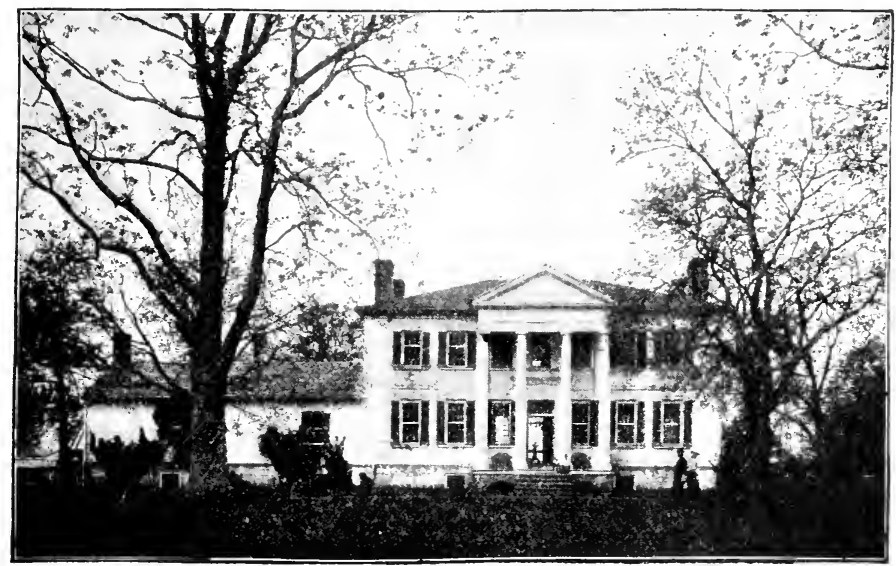

A Colonial HaLL

almost universal outside of the towns. In most of the farmhouses the spacious kitchen was the most attractive room. At one end was a great fireplace with large pots and kettles suspended from a horizontal rod - for stoves were practically unknown in 1750 . There was a large dining-table and a few rude chairs or benches. Around the glowing fire the family gathered at night, and the kitchen was frequently the scene of jolly neighborhood gatherings. The loneliness of country life was relieverl by occasional house raisings and by frequent quilting bees and corn huskings. In a few districts in rural New England, along the Hudson, and from the Delaware to the Carolina borler, the country homes of the landed gentry were very fine examples

Lodge, Eng. Colonies, 76-82, $248-252,329-$ 33 I, $448-45$ I.

Country homes of the gentry. 
of the beautiful type of architecture which we call colonial. These were seen at their best on the broad tobacco plantations of Virginia. There the spacious "halls," ever open to visitors, with the numerous barns and other farm buildings and rows of slave cabins, formed miniature colonies in themselves.

\section{OCCUPATIONS}

Difficulties in preparing the land.

Winsor (ed.), America, IV, Intro.

Agricultural products and exports.

Coman, Industrial Hist., 47-6o.

Eggleston, in Century, XXVII (I884), 435-442. ror. Agriculture. - Most of the colonists depended on agriculture for their support. At first each colony sought to raise simply the necessaries of life - a supply of food which would keep them from starring. Conditions were not especially favorable for agriculture at the beginning, because of the dense forests. The task of clearing the land was so arduous that the early settlers contented themselves with the Indian method of girdling the trees so that they died. Corn and pumpkins were then planted among the lifeless trunks. In New England, further difficulties were added by the stones with which the prehistoric glaciers had sown the land. The fight with the wilderness was long and intense.

In the northern colonies all of the farms were small, as the narrow valleys precluded cultivation on a large scale. Great care was necessary to insure even moderate crops, except in the valley of the Connecticut. There were very few communities in New England that raised articles for export. In the middle section a surplus supply of wheat was grown, so that wheat and flour were shipped to the West Indies and Europe. In Maryland and Virginia agriculture absorbed the entire attention of the people. This was due to the profitableness of the tobacco industry, for at different times the planters neglected food supplies in their mad desire to gain wealth by raising tobacco to be sold abroad. It was necessary to make laws compelling every planter to devote a certain area to corn. Even with this restraint, the over-production of tobacco caused a great decline in the price. After the passage of the Navigation Act, which 
forbade the sending of tobacco to other countries than England, the price became still lower, but the raising of tobacco remained the chief source of wealth in those colonies until the revolution. South Carolina made a specialty of rice during the eighteenth century, and indigo was produced in large quantities after I745. Some cotton also was grown in the low lands along the coast.

ro2. Commerce and Shipping. - The colonies were dependent on England for many manufactured articles. At the beginning it was impossible to produce these things in America, and after I660 the home government aimed to prohibit manufacturing in the colonies, at the same time compelling the colonists to purchase everything they needed from England rather than from her continental rivals. Since the commercial laws of England were not enforced strictly, the colonies enjoyed a large though legally forbidden trade with the West Indian possessions of France and Spain and with Holland, France, and other European countries. ${ }^{1}$

From the northern ports a comparatively large trade was carried on, especially with England and the British West Indies. It is estimated that salted cod and mackerel worth $£ 250,000$ were exported annually from New England. Large quantities of lumber and dried fish were sent to the West Indies every year, where they were exchanged for molasses, from which was distilled rum that was in turn exported. Nevertheless, the imports of New England were four times as great as its exports. In Virginia and North Carolina, owing to the lack of towns and harbors, the skippers of the small sailing vessels ascended the numerous rivers of those colonies, exchanging their fine cloths and other articles at each plantation for the products of the country.

A large part of the shipping was in the hands of New Englanders, since the colonists were allowed by the navigation acts to trade on the same terms as native-born Englishmen. Shipbuilding had become an important indus-

${ }^{1}$ On the laws of trade, see $\$$ I I9-I II.

Coman, Indus. trial Hist., 77-83.

General exports and imports.

Coman, Indus. trial Hist., 75-77.

Ship building and shipping. 
Wright, Industrial Evolution of $U . S_{.}, 28-42$.

Piracy.

Hart, Contemporaries, II, No. 85 .

Colonial manufactures.

Coman, Industrial Hist., 62,72 .

try in the northern colonies, as lumber was cheap, and the ressels built in the New England shipyards were superior to those constructed in Europe. The fisheries formed a training school of the best kind for a race of hardy, daring sailors who gained a reputation in later naval wars. Probably one hali of the population in New England depended on the sea for a living.

Commerce in colonial times was attended by dangers that no longer exist. There was always risk of capture by privateers of unfriendly nations. Pirates were numerous, successful, and often unpunished. At one time North Carolina harbored a great many, at another New York and Newport gained an unpleasant reputation for giving them aid. The government sought to suppress piracy, sending out privateers to capture them. Among those commissioned to destroy pirate ships was the notorious Captain Kidd, who turned pirate as soon as he was out of sight of land, but afterward suffered death for his crimes. In spite of harsh measures, regular commerce was not free from perils of this nature until comparatively late in the eighteenth century, and many passengers and crews were obliged to "walk the plank."

103. Industry and Labor. - The colonies were in no true sense manufacturing communities. A new country is not well adapted for those industries which require a large supply of raw materials and an abundance of labor. Because of the lack of laborers and the higher wages paid in America, it was cheaper to ship the raw materials to England and purchase the finished products from the mother country. Yet there was a large amount of manufacturing done in the colonies on a small scale. Practically all of the household furniture was made at home. Almost every family had its spinning wheel and hand loom. Few of the colonists used anything but the coarse "linen" made from the hemp and flax that they prepared, or dressed in anything but homespun woolen clothes, but the wealthier farmers or merchants imported their broadcloth and their 
hats. The building of ships was undoubtedly the foremost industry of the colonies, three hundred and eightynine being constructed in a single year. ${ }^{1}$ Many of these were built for English owners, or were sold abroad later with their cargoes.

Although the hours of labor were very long, and the wages paid, two or three shillings a day for skilled labor, seem ridiculously small, the laborer in the colonies was undoubtedly better paid and better treated than in any part of Europe. The agricultural laborer was free to sell his labor to the one who would pay the most for it, instearl of being tied to a certain farm, as in most countries across the Atlantic. The man who wished to learn a trade served a shorter apprenticeship, and was freer in every way than a fellow workman in England. There were numerous attempts during colonial times to regulate the price of wages or of commodities, in the interest usually of those wealthier classes which controlled the government, but these proved ineffective.

s04. Colonial Currency. - Most of the colonial business consisted simply in the exchange of one commodity for another. Corn, sheep, and cattle were the ordinary media of exchange in several colonies, the value of a sheep in shillings often being designated by law. This enabled debtors to pay their creditors in the poorest animals they owned. In Virginia and Maryland, tobacco was used as currency, articles being purchased and wages paid in tobacco.

As the people bought abroad more than they were able to sell it was impossible to secure or retain any large quantity of gold or silver. Most of the silver coins in circulation were dollars or smaller coins bearing a Spanish stamp, which had been obtained in trade with the West Indies. Almost every colony placed a different valuation on the Spanish dollar. In one colony it was considered worth five English shillings, in another six, in another eight. This naturally added confusion to the existing monetary difficulties.

${ }^{1}$ i 769 , the only year for which full statistics are available.

Commodities as money.

Colonial coins.

Dewey, Finan. cial Hist. of U. S., I8-2I. 
Paper money. Massachusetts was the first colony to attempt a solution of the currency problem by issuing paper money, but other Coman, Indus- colonies were not slow to follow this apparently easy method trial Hist., 83-86.

Hart, Contemporaries, II, Nos. 88,89 . of paying private and public debts. ${ }^{1} \quad$ New York and Pennsylvania were more careful than the other colonies to pro vide a safe system of redeeming this paper, thus escaping the evils of depreciation and business depression that followed in the other colonies. In several colonies so-called "banks" were allowed to issue paper money, with results disastrous to all but the promoters of the scheme. A large part of the paper money in circulation became worth less than fifteen per cent of its face value. Interference with business was so great that at length parliament forbade ( $755^{\mathrm{I}}$ ) the issue of paper money in New England and ( $76_{3}$ ) extended the prohibition to all of the colonies.

Medicine, teaching, and the laws.

Greene, Prorincial therica, 317-319.

Lodge, Eng. Colonies, $232,236-237$.

105. The Professions. - Very few persons were trained carefully for professional work. There were in I750 but four colleges, most of which had been founded with an idea of fitting men for the ministry, but there were no theological seminaries or other professional schools. Consequently few physicians were to be found in the colonies, and of these the majority were men of little learning and less skill. Medicine as practiced was neither an art nor a science. Most of the teachers were either clergymen who gave part of their attention to private classes or incompetent individuals who had failed of success in other occupations. Although few men deroted their attention exclusively to the law, most educated men in the colonies were rersed in the law and were prepared to argue cases if necessary. Pennsylvania alone furnished many able lawyers for other colonies, and the saying "as smart as a Philadelphia lawyer" became almost a proverb.

The ministry. As more care was taken in preparing clergymen for their work than with the other professions, the Congregational colonial minister was the best educated, and probably the

${ }^{1}$ Before $1 ; 50$, all of the colonies except Virginia and Georgia had issued bills of credit. 
ablest man in his community. Looked up to for his char- Lodge, acter and learning, his influence enabled him to direct Eng. Colonits, public opinion and settle private controversies. Many of 423-425. the men appointed to livings in the Anglican church in America as in England were ignorant and corrupt, although the pastors of most independent churches and of regular parishes were men of high moral character.

\section{Miscellaneous Conditions}

ro6. Colonial Churches. - In most of the colonies there was a church supported at public expense, the union of

Puritan churches.

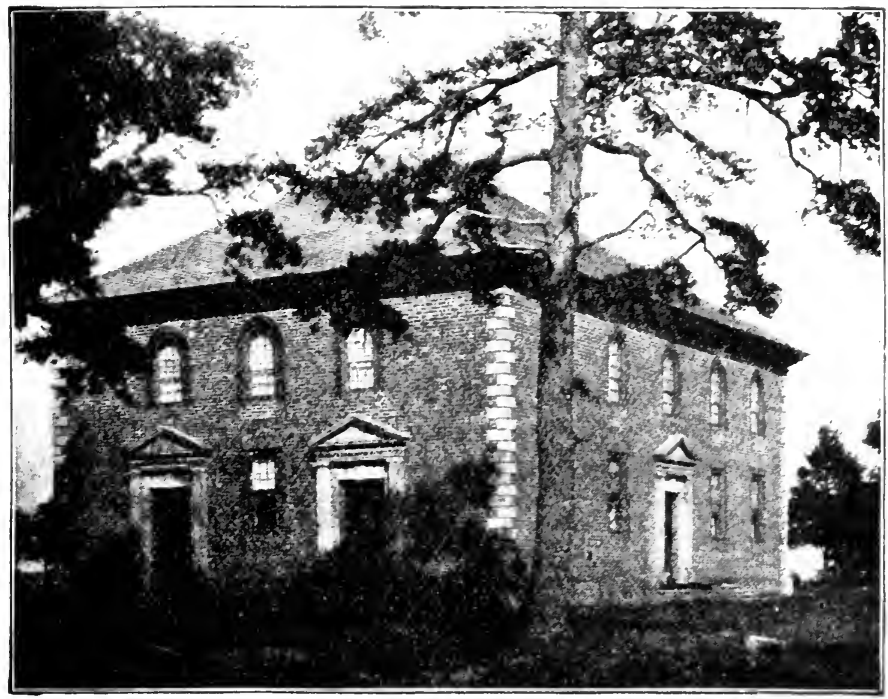

A Colonial ChURCH

church and state being common. In the New England Lodge, colonies, except Rhode Island, the Congregational church had been established by law, all other denominations being Eng. Colonies, $425-434$. excluded so far as possiłsle from erecting buildings or even holding services. The Sabbath was observed very rigidly. No one traveled except to church, cooking was a voided, and the day given over to religious worship. Attendance at 
church service was compulsory, absence being punished by fine or the stocks. The services were always long and sometimes tedious, the hourglass being turned once during the "long" prayer, and usually twice during the sermon. The straight-backed uncushioned seats did not make it easier for the attendants to listen to the long, dry arguments or fierce declamation on future punishment, especially in winter when the meeting houses were unheated and even footstoves were considered effeminate. Puritan austerity could scarcely devise harsher means of mortifying the flesh, or better tests for self-control and endurance.

Anglicans and dissenters.

South of New England the Anglican church had been established by law except in Pennsylvania, but church Andrews, attendance was irregular and very little attempt was made Col. Self-Gov't, to prevent dissenters from holding services of their own, 304-3II.

Eggleston, in Century, although Catholics had churches in Pennsylvania only. XXVI (1883), I07-116.

Superstition in custom and law.

Lodge, Eng. Colonies, $253^{-254}$, $424-436$. In South Carolina, western Virginia, and Pennsylvania, the Presbyterians were numerous, while Rhode Island was controlled by the Baptists. In Rhode Island and Pennsylvania alone was there anything like real religious liberty.

ro7. Superstition. - Superstition was much more common in the seventeenth century than it is at present. This was due not simply to the greater ignorance of that day, but particularly to the survival of beliefs in signs and in the existence of evil spirits, witches, the evil eye, and other evidences of Satan's control of mortals. These beliefs were much less common in England than on the continent, and less common here than in England, although the non-English immigrants were very superstitious. ${ }^{1}$ This superstition not only influenced the habits of the people, but also affected their laws.

Only once did superstitious fear lead to a wholesale punishment of witches. This was in the terrible witchcraft

1 There are a few isolated instances of witches being put to death in the colonies before 1602 and after the witchcraft episode. In England and on the continent hundreds of thousands of witches were condemned to death, five hundred being burned in a single year in the city of Geneva. 
delusion at Salem, Massachusetts, in I692. The epidemic started when a number of "afflicted children," under the morbid training of some ignorant colored servants, accused eccentric people in the village of having bewitched them. A special court was organized for the trial of these cases, and persons were condemned on absurd testimony by conservative judges like Samuel Sewell. Excitement ran so high that many people accused their enemies of witchcraft, and no one could condemn the so-called trials without danger of being considered a witch. ${ }^{1}$ After several women of unusual standing and virtue had been accused, the eyes of the people were opened; not, however, until a number of persons had been put to death.

108. Crime.

The death penalty was used much more commonly in colonial times

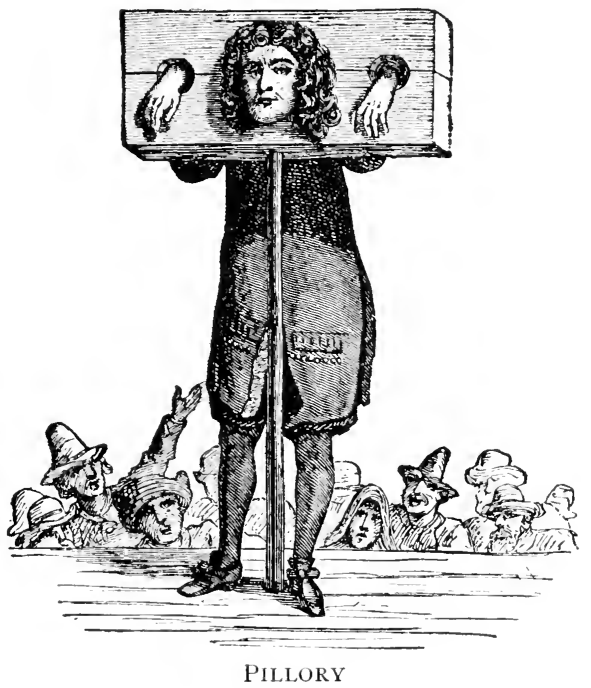

PILLORY

than at present. $^{2}$ In one colony, Pennsylvania, an attempt was made at the beginning to abolish it except for murder, but so great a departure from the customs of the times was abandoned after a few years. In Massa-

1 A common way of deciding whether a woman was a witch was to cast her into the water. If she failed to sink, she was proved to be a witch.

${ }^{2}$ In England during the seventeenth century over one hundred crimes were punishable by death, the number increasing instead of diminishing during the eighteenth century. Frequently juries would acquit a man where the evidence showed him guilty, because they were unwilling to punish him by death for a minor offense. 
chusetts, as we noticed ( $\$ 73$ ), Quakers who had been banished, but insisted on returning, were hanged. Yet executions were not common in colonial times, although so many offenses were punishable by death. In fact, in all well-settled communities, crime was by no means general. On many frontiers, and in a few older sections, there was considerable lawlessness. Imprisonment was

Man and Horse. Mad Bull.

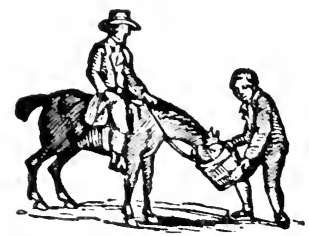

A Horse drinking.

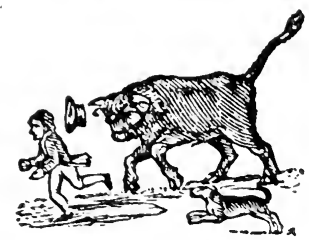

Boy in danger.

Children should be careful not to provoke a bull, or get over into the field where one is. Alas! for that little boy that is running with all his might: see his hat flying behind him, and the mad bull close at his heels.

PAGE FROM AN OLD SCHOOL BOOK

used comparatively little as a punishment and the prisons were few in number and of a low order. In a conspicuous place in each town stood the whipping post, at which runaway slaves and criminals were lashed upon bare backs, and the stocks and pillory, in which offenders were locked for from one to four hours, the pain of their cramped position being augmented by the jeers of the spectators and the mud thrown by rowdies. Ducking stools were used occasionally for scolding wives even in the eighteenth century.

109. Education. - Outside of New England there was schools. practically no public education, but east of the Hudson almost every town boasted a grammar school and practi- 
cally every county had a Latin school which prepared students for college. To the Puritans, ability to read the Bible was a necessary part of the preparation for life. Except in parts of Rhode Island and on the Maine frontier no illiterate persons could be found in New England at the middle of the eighteenth century. The middle colonies paid comparatively little attention to education, although there were

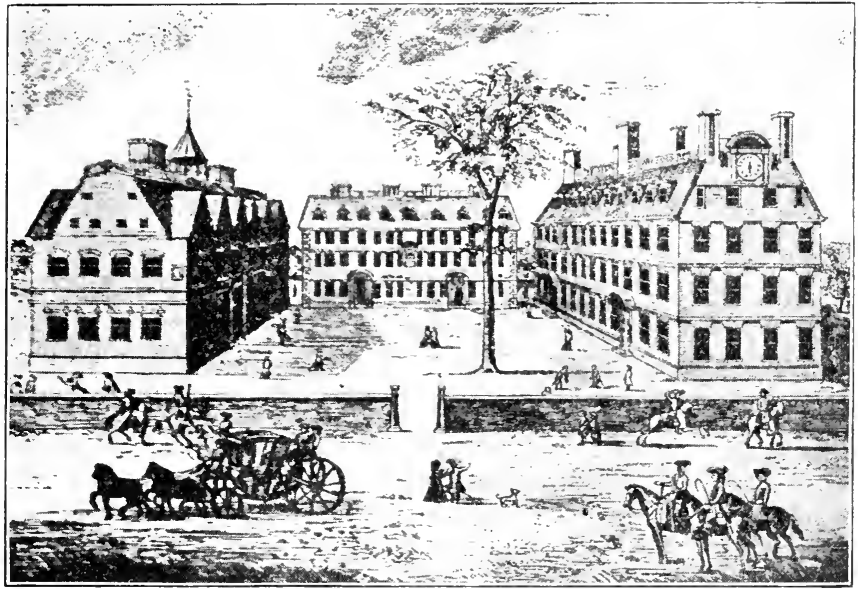

First Harvard Hall Governor's Coach First Stoughton Massachusetts Hall

HARVARD COLlege

a few excellent private schools in New York, Philadelphia, and a few other large towns. South of Mason and Dixon's line education was systematically neglected. The oftquoted comment of Governor Berkeley, in which he thanked God that there were no free schools or printing presses in Virginia, expressed the sentiment of the ruling class. Tutors were employed by some of the wealthier planters, and a few sons of prominent families in Virginia and South Carolina were sent to England for a college education.

The most famous and the most influential of the early colleges was that established at Cambridge in 1636 , and Colonial colleges. named after John Harvard; William and Mary college 
Greene,

Prowinial?

America,

$304-3$ II.

Newspapers and the government.

Wright, Industrial Eiciution, $03-60$.

was founded in Virginia, just before the close of the serenteenth century, and Yale College at New Haven in r 70 . About the middle of the eighteenth century renewed interest in higher education led to the establishment of three colleges in the middle colonies: Kings (afterward Columbia) in New York. Princeton in New Jersey, and the Lniversity of Pennsylrania at Philadelphia. The latter, through the influence of Benjamin Franklin, developed rapidly, gaining a reputation for its standing and for the number of its courses and students within a few years.

I Io. Newspapers. - New England established its primacy in literary enterprise and attaimments as in other lines, although it must be admitted that there was very little printing and less literature in the colonies before 1;50. No newspaper was published in this country prior to $1 ; 04$, when the Boston Vous Letter was started. At the middle of the century there were less than a dozen newspapers printed in all of the colonies, none being published daily. The attitude of the government toward the printers was by no means fivorable. No books or pamphlets could be printed without a special license. When an attempt was made in Boston (1600) to start a newspaper called Public Oecurronces, it was suppresied.

The Zenger case $\left(1 / 3^{0}\right)$.

Hart, cinte'tforaries, II, Nio. 72 .

Real freedom of the press was not recognized until after the fimous Zenger case had been decided in New York in I ; 36. Zenger was the publisher of the New York Weckly Journal. In a controversy between the governor of the colony, Cosby, and the president of the colonial council, Zenger supported the president. Van Dom, and was in consequence imprisoned and tried for libel. His lawyer, Andrew Hamilton of Philadelphia, argued that Zenger had published only facts and claimed that his client had the right to state the truth so long as it was not done maliciously. Influenced hy his reasoning and eloquence, the jury found Zenger not guilty. This verdict had a wholesome intluence not alone in New York, but throughout the colonies, in freeing the press from the trranmy of the government. 
II I. Travel. - As most of the settlements were near the seacoast or on rivers, it was possible at first to travel from town to town or from plantation to plantation by water. Birch bark or "dugout" canoes were used on the rivers, sailing vessels on the ocean. As the colonies developerl, travel by land became unavoidable. U'ntil roads were constructed, Indian trails and bridle paths served the settlers, most of whom were obliged to journey on foot. Later the highways were improved, and horses were more numerous,

Travel in an early day.

Earle,

Home Life,

325-332.

Hart, contemporaries, II, No. So.

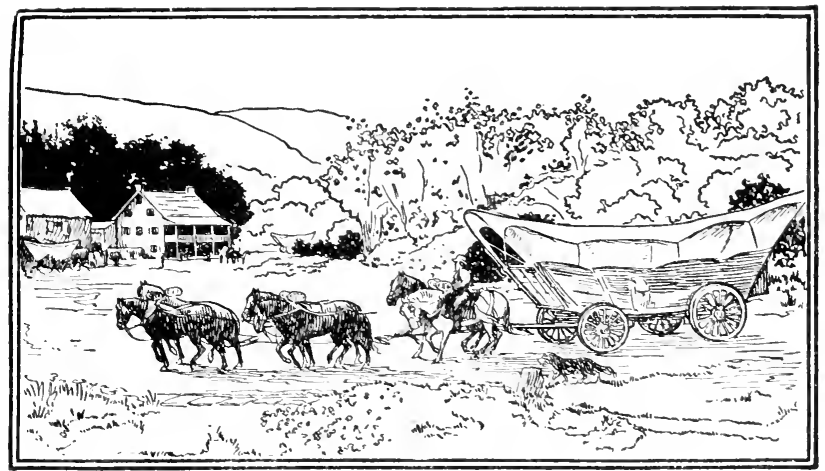

CONESTOGA WAGON

so that comparatively few of the planters or their families ever traveled except by boat or on horseback. Roads were still few, however, and bridges almost unknown, the numerous rivers being forded at convenient points. Settlers in the North rode to church, usually with their wives on a pillion, or cushion, behind them.

The eighteenth century saw considerable improvement in the colonial highways and in the methods of travel. Roads connected all of the towns of importance but were few and poor in colonies with few villages. The use of two-wheeled chaises had replaced horseback riding to quite an extent in the North, although they were less common in Maryland, Virginia, and the Carolinas. Coaches were kept by most of Roads, coaches, and wagons, eighteenth century. the wealthy families, who put on considerable style with

Eggleston, in Century, XXX (1885), $3^{87-389 .}$ 
Earle, Home Life, 335-344.

Irregular stage lines.

Mail service.

Earle, Home Life, 332-335.

Democratic character of the local government.

Hart, Formation of Union, $\$ 6$.

Lee (ed.), 1. America, VI, 66-72. their liveried coachmen and outriders. The roads were primitive, however, and comparatively little used for the transportation of merchandise. Most articles were carried on packhorses, but in Pennsylvania commodious farm wagons, known as Conestoga wagons, were coming into extensive use.

Before 1750 there were no regular stage coaches in the colonies. Stages were run between certain towns regularly in the summer, and at irregular intervals throughout the year, connecting the larger cities. A journey by stage from Boston to New York took a week and was an exceedingly uncomfortable trip. From three in the morning until nine at night the lumbering vehicle jolted its passengers orer the rough roads, leaving them a few hours' fitful slumber in the none too comfortable beds of the wayside taverns. The smaller streams were forded, the larger crossed by ferry, sometimes in detachments. When the stage stuck in the mud, the passengers were obliged to alight and put their shoulders to the wheel.

\section{There was no mail service worthy of the name before $175^{\circ}$.} The mails were irregular, costly, and unsatisfactory. When a postrider had enough letters to justify a trip, he set out, carrying numerous parcels on his own account. ${ }^{1}$ The mail was left at some public house to be hauled over by every comer until claimed and paid for by the person to whom it was addressed.

II2. Colonial Government. - The governments of the American colonies were notable as being far more democratic than any others then in existence. This was true especially of the local governments in the northern and middle colonies. In New England every town was governed by a town meeting composed of all roters in that town, and by officials chosen by popular election in those town meetings. In New York most of the town officials were chosen by the people, although much of the work of governing was done by county officials appointed by the governor. Pennsylvania chose her own county officials. In Virginia and the

${ }^{1}$ Only letters could be sent by government post. 
South there were no officials for districts smaller than the county and these officers were selected by the governor, so that the people had little share directly in their local government.

In every colony there was an assembly chosen by the voters. This assembly, together with a "council," made the laws subject to the approval of the governor. It also controlled almost exclusively the raising of money by taxation. The council was selected by the governor in all but three colonies, ${ }^{1}$ and as the governor was himself chosen by the people in only two colonies, there was in theory very little popular colonial government, although in fact the people's influence over the governor was very great. ${ }^{2}$ In two colonies the governors were selected by the proprietors, in two they were elected by the people, and for the others were appointed by the king. Courts of justice existed in every colony, but no judge of colonial times was chosen directly by the people, even in the two little democracies of Connecticut and Rhode Island.

The suffrage laws of the colonies, although narrow from our point of view, were exceedingly liberal when compared with those of foreign countries. Every landowner with property of a certain value in the North, or of a certain size in the South, was allowed to vote. It is true this excluded about ninety-five per cent of the population, but many who could not vote on colonial affairs were allowed to take part in local government.

I13. Colonial Law. - Although the laws varied consicierably from colony to colony, there was a uniformity that is remarkable considering the differences between the people and the occupations of the various sections. All of the colonies had transplanted the English system of common law with such modifications as the peculiar conditions in each colony required. Many of the laws made by the colonial legislatures were merely reënactments of English statutes. In fact, the laws were few

${ }^{1}$ See Connecticut, Rhode Island, and Massachusetts. ${ }^{2}$ See $\$ 87$.

Suffrage laws.

Hart, Contemporaries, II, No. 6r.

English common law in America. government of the colonies.

Ashley, Am. Gov't, $\S \S$ III2-II5.

Lee (ed.), N. America, VI, 57-66. 61. 
in comparison with the volume of state legislation at the present time.

Land laws of the colonies.

Coman, Industrial Hist. $3^{2-3}$.

Eggleston, in cintury, Xivili $\left(\mathrm{ISS}_{4}\right)$, $8_{4} \mathrm{~S}^{-8} \mathrm{~S}_{2}$.

Inheritance laws.

The system of land laws in use in America illustrates how the English system was modified to meet colonial needs. Land was considered the property of the king, the name real estate, or royal estate, emphasizing this fact. The king made grants of land to companies and individuals, so that in America the legislature of the charter colonies or the proprietor of the proprietary colonies had the right to regrant land, and in the royal colonies the governor, as the direct representative of the king, had the right. Grants were made to individuals with a lavishness that amounted to recklessness, for land was plentiful and cost the grantor little or nothing. Not only were large estates numerous, but the number of small landowners was very great, as most heads of families owned their own farms. Because so many people owned land, and because speculation in land was common even in colonial times, the slow and cumbersome English system of transferring land was altered so that it was easy to sell or buy real estate.

The American inheritance laws were borrowed from England except in the Puritin and Quaker colonies. Elsewhere the estates or farms descended to the eldest son, because primogeniture was recognized in New York and the South. In New England, Pennsylvania, Delaware, and New Jersey a double share went to the eldest son, but the other children, including the daughters, had an equal share in the property of the father when he died without making a will.

\section{TOPICS}

Colonial MaNefacteres: Coman, "Industrial History of the United States," pp. 02-72; Wright, "Industrial Evolution of the United States," pp. 23-60, So-103; Beer, "Commercial Policy of England toward the American Colonies," 66-00.

Colonial Paper Money: Dewey, "Financial History of the United States," pp. 2I-30; White, "Money and Banking," I03II 4 ; Sumner, "History of American Currency," It- +3 ; Bullock, "Monetary History of the United States," I, Chapter IV. 


\section{STUDIES}

I. Conditions in Germany that led to emigration to America. (Bittinger, "Germans in Colonial Times," pp. I I-24.)

2. German redemptioners. (Bittinger, "Germans in Colonial Times," pp. 215-229.)

3. Maryland society in the seventeenth century. (Browne, "Maryland," pp. I $57-183$.)

4. Life in Virginia two centuries ago. (Fiske, "Old Virginia," II, pp. I 74-269.)

5. Conditions in the English colonies (I688). (Andrews, "Colonial Self-Government," pp. 293-304.)

6. The true Captain Kidd. (Champlain, in Harper's Magazine, Io6 (1902), pp. 27-36.)

7. Meat and drink in colonial times. (Earle, "Home Life in Colonial Days," pp. 1 $42-165$.)

8. Dress of the colonists. (Earle, "Home Life in Colonial Days," pp. 281-299; Eggleston, in Century, XXIX ( $188_{5}$ ), pp. 882-892.)

9. The colonial theater. (Eggleston, in Century, XXX (I885), pp. 403-407.)

10. Church and meeting house before the Revolution. (Eggleston in Century, XXXIII (1887), pp. 901-912.)

II. Sunday in the colonies. (Earle, "Home Life in Colonial Days," pp. $\left.3^{6+-3} 87.\right)$

I2. American prose $(1701-1764)$. (Trent, "American Literature," pp. $9^{8-1} 3$ o.)

I3. The colonial governor. (Hart (ed.), "Contemporaries," Nos. $54^{-60 .)}$

I4. Local government in the southern colonies. (Fiske, "Civil Government," pp. $7 \mathrm{I}-78$.)

15. Middle colonies in colonial times. (Lee (cd.), "North America," VI, pp. 29-39.)

\section{QUESTIONS}

I. Show how physical conditions, climate, and rainfall affected slavery in the North, in Virginia, and in South Carolina. What advantage did the South derive from slavery?

2. To what extent were the colonies alike in $\mathbf{I} 75^{\circ}$ ? Why did they remain isolated? What was the result of their separateness on their dealings with Great Britain?

3. What are the chief differences between the houses, food, dress, and manner of living in $175^{\circ}$ and to-day? Name several conveniences that are now considered necessaries which were unknown in $175^{\circ}$.

4. Explain why England and the colonies each took the course 
they did in reference to paper money? Was paper money necessary? What influence did it have on the opening of new lands, commerce, on business in general?

5. Note the important changes, political, legal, social, and industrial, that have taken place in America in the last century and a half.

6. In what respect had the colonists more or less political liberty than the English? Why did the local governments of the colonies influence our later history more than the central colonial governments? 


\title{
PART II
}

\section{THE FORMATION OF A UNION ( $7763-1789)$}

\section{CHAPTER VII}

\section{THE BEGINNINGS OF REVOLUTION ( $1763^{-1775)}$}

\author{
ENgLish KING \\ George III ( $760-1820)$
}

I14. Colonial Self-Government and English Control be- Leniency of fore I763. - The Seven Years' War, which added to Great English conBritain immense possessions in America and gained for her the control of India, may be said to mark the real beginning of the British empire and of a new colonial policy. Previously, the American colonies had been governed according to no uniform rule, but in the most diverse ways. As they had been founded at different times and under different conditions, each had developed a government more or less different from that of its neighbors, and had political traditions to which it was greatly attached. Owing to the condition of affairs before $1_{7} 6_{3}$, the colonies had been left much to their own devices, and the political changes under the Stuarts and the early Hanoverians had accordingly been favorable to colonial self-government. Practically all the contests between the governors and assemblies $(\$ 87)$ had resulted in victories for the latter, and the colonists had come to look upon Great Britain as the power which protected them from foreign nations, which passed laws for the regulation of external commerce, and which, in some cases, selected their administrative officials. 


\section{The Old Colonial Policy of England}

Four possible methods of control.

Board of 'Trade and colonial secretary.

Larned (ed.), Ready Ref., V. 3r72.

Control of charters.

Hart, Contemporaries, II, No. 48 .
II5. General Methods of Colonial Control. - There were four ways in which the king or parliament might control the colonies: (I) by changing the internal government of any province; (II) by exercising a general oversight of legislation and the administration of laws within a colony; (III) by the regulation of colonial trade and industry; and (IV) by levying internal taxes. Not all of these means had been used by Great Britain previous to $176_{3}$, and in fact internal taxation had never been considered seriously. The few regulations that did exist were of a very mild description, and were enforced laxly.

As it was necessary to have some set of English officials who should give especial attention to American affairs, a board of commissioners was selected from among the king's private councillors. ${ }^{1}$ This Board of Trade was required to correspond with the colonies so as to keep in touch with them and informed about colonial affairs, to hear appeals and complaints, and to set aside laws that were repugnant to the laws of England or distasteful to the crown. In addition there was a British secretary of foreign affairs, who devoted a large part of his attention to colonial matters. Most of the colonies also maintained in London agents who looked after their respective interests.

In order to learn the extent of the supervision exercised by England, especially through the Board of Trade, let us examine a little more in detail the regulations belonging under the first three heads enumerated above.

I I 6. England's Interference with Colonial Government. (I) To a certain extent the king was able to control most of his American provinces through the right to alter their governments. In $\mathrm{I}_{7} 6_{3}$ seven of the colonies were under the direct supervision of the crown, i.e. were royal colonies, whereas only six retained their seventeenth-century char- 
ters. ${ }^{1}$ These charters were forfeitable to the crown if violated by the colonies, but could not be revoked except upon clear proof that the colonies had failed to keep their charter agreements with the king. Indeed, to modify an article of a charter which would interfere with a colonial right was to exercise a power that had been unused since the days of Andros and James II, and one that no wise monarch would lightly undertake.

The alteration of the government in a royal colony was a different matter. New instructions were issued to each governor and the installation of a new governor would seem to be a favorable opportunity for strengthening the king's authority in America. On the contrary, the appointment of a governor was almost invariably the signal for a renewed effort to increase legislative power at the expense of the executive. Fully occupied with their efforts to maintain their influence at home, the ministers of the first two Georges gave their governors but a half-hearted support and allowed the assemblies to encroach on the powers of the royal representatives, until in practically all of the colonies a serious attempt to curtail popular privileges had become a dangerous experiment.

II7. England's Control through Colonial Officials. (II) Colonial administration and legislation could be controlled in part through the power of the crown to select for most of the colonies the governors who in turn might appoint the members of their councils, the judges, the county sheriffs, and many other officials. These governors not only selected persons for most of the appointive positions, but commanded the military forces of the colony, had charge of public lands, and pardoned offenders. The legislatures were convened and adjourned at their wish, and all bills passed by those bodies failed unless approved by the governors. Many of the governors and a few others were bankrupt English nobles, but the majority of the officials appointed by the governors

1 Not counting the continental colonies conquered from the French and Spanish, or the insular colonies.

\section{Control}

through executive officials.

Hart, Contemporaries, II, Nos. 51, 65, 66 
belonged to the aristocracy of the colonies. Loyalty to the king and a unity of interest made these officeholders a class of no mean importance in upholding within the colonies the authority of the English government. The influence of these officials was at all times considerable because of the great power conferred upon them, although the assemblies frequently hampered their work by refusing to vote money for their salaries.

Colonial

judges.

Howard,

Preliminaries of Revolution, $85-87$.

The judges, like the other appointed officials, were dependent on the assemblies for their salaries, but, as the judges were selected for life, and not during good behavior, as in England, this dependence was more apparent than real. To remove the judges entirely from the control of the people, the crown decreed in I76r that they should be paid out of the king's land revenue. These instructions were resisted by the legislature of New York and disregarded by the governor of New Jersey. In both of these colonies a spirited contest ensued.

The "Parson's

II8. Control of Colonial Legislation. - Although the Cause" $(1763)$. people's representatives might manage the governor and his appointees, their laws might be set aside by the Board of Howard, Revo- Trade on the ground that they were unwise or contrary to lution, go-ror. Tyler, Henry, 32-49. the laws of England. A prominent instance of this use of the veto power is furnished in connection with the pay of the Virginia clergy. According to the law of that colony the clergymen were paid in tobacco, but, in 1755 and again in ${ }_{175} 8$, tobacco being very scarce, the Virginia legislature gave the people permission to discharge all debts payable in tobacco at the rate of two pence of currency for each pound. This made it possible for a person to pay his debts at a small percentage of their real amount. The parishes accordingly took advantage of the law in paying their pastors. On complaints of the clergymen, the Board of Trade set aside the law of ${ }_{1758}$ and announced that thereafter no law which repealed or altered an existing colonial law should go into effect until actually approved by the Board - a process that would take months at least and often two or 
three years. The clergy at once began suit for the extra pay due them. One case was argued ( $1_{7} 63$ ) for the people by a hitherto unknown lawyer, Patrick Henry. In an eloquent appeal, Henry pressed the claim that the king, "by annulling or disallowing acts of so salutory a nature, from being the father of his people, degenerated into a tyrant, and forfeits all rights to his subjects' obedience." Persuaded by his eloquence, the jury fixed the amount of the damages at one penny. This was one of the first conspicuous denials of the right of England to control colonial legislation through the power of vetoing bills.

Laws passed by the colonial legislatures might also be annulled because they were superseded by an order issued by the Board of Trade or by a law enacted in parliament for the benefit of the colonies. For example, in I 75I, parliament prohibited the issuance of paper money in the four New England colonies, and in I 763 extended this prohibition to all of the colonies. Before those dates the people had insisted on the need of a cheap currency, and when the governors, in accordance with instructions from the Board of Trade, vetoed the paper money bills passed by the legislatures, the assemblies retaliated by refusing to vote money for necessary expenditures, thus forcing the governors to sign the bills. The parliamentary law prevented the issuance of more paper money, but was a source of considerable irritation to the colonists.

I19. Early Acts of Trade (I66o-I696).-(III) Although there had been laws relating to American trade before the Restoration (I660), the system of restrictions on colonial commerce really dates from the accession of Charles II. It was the purpose of this system to develop English trade and industry, and indirectly to aid those occupations of the colonies which did not interfere with similar interests in England. The first of these navigation acts, that of I66o,

\section{Dewey, \\ Financial Hist.} §II.

Law of 1660 . restricted colonial importations and exportations to ships built in Great Britain or the colonies, two thirds of whose crews were English subjects. This was in many ways an

Howard, $\cdot$ Rer'o.
lution, $50-54$.

Howard, $R$ Rev'
lution, $50-54$.

MacDonald, Charters, Nos. 23, 25. 
Winsor (ed.), advantage to the people of America, because it stimulated America, VI, 5-8. ship-building to such an extent that eventually more vessels were built in the northern colonies than in England. The law of 1660 also gave a list of articles which could be exported from the colonies to England alone, the most important of these "enumerated articles" being tobacco. Although American tobacco enjoyed a practical monopoly of the English markets after $I 66_{3}$, as the growth of tobacco in the British Isles was prohibited and very heavy duties were levied on foreign tobaccos, this limitation of its market greatly reduced the price in Virginia and was injurious to that colony.

Laws of 1663 and 1672 .

MacDonald, Charters, Nos. 28,34 .

Andrews, Col. Self-Gov't, I9-2I.

General character.

Howard, Revolution, 57-6r.
The law of $166_{3}$ was a much less reasonable act, passed for the benefit of English exporters. The colonies were no longer allowed to import goods direct from the continental European countries, even in English ressels. All products of these nations needed in America must first pass through the hands of English merchants, who shipped them to the colonies after adding their own profits to the original cost. The British government soon found that these acts of trade were being evaded by the shipment of enumerated articles to colonies in which they could not be produced, and exportation from ports of the latter direct to continental Europe, from which goods were invariably brought back. In I672, therefore, a law was passed by parliament forbidding free trade between the colonies in the enumerated articles by lerving duties on intercolonial trade at the place of export.

r20. Later Restrictive Legislation (I696-1760). - After the Revolution of 1689 had settled the dispute between the Stuarts and parliament, more attention was given to colonial affairs. Few important alterations were made in the navigation acts, but the list of enumerated articles was lengthened and colonial manufacturing was in several instances prohibited for the benefit of British merchants or manufacturers. In order to make this policy seem less one-sided, bounties were offered for certain articles which England used but did not produce in sufficient quantities.

One of the most important of the additions to the enu- 
merated articles was that of rice. Before the colonists had been obliged to ship all of their rice to England, the rice of South Carolina had control of the European market, but the extra freight required upon reshipment from England destroyed the profit and practically ruined the rice plantations of the South. After thirty years the law was repealed partially so as to allow the exportation of rice to countries south of Cape Finisterre.

Restrictions on colonial manufactures were not numerous because manufacturing never reached an advanced state in the colonies, but those that existed were unjust and oppressive. To protect the wool growers and weavers of England, the exportation of colonial manufactures of wool to England or to other colonies was forbidden. For the benefit of English hat makers, no hats could be shipped from the colonies. None but the crudest forms of iron might be produced in America, although the colonists were encouraged to send large quantities of bar iron to the mother country.

One of the most offensive acts of trade was passed for the benefit of the planters in the English West Indies, and required that the continental colonies should import no molasses from French or Spanish possessions unless they paid almost prohibitive duties. As Nerv England used large quantities of molasses, principally in the manufacture of rum, it was unwilling to give the increased prices that the Jamaica planters were able to ask for their molasses, and systematically brought from the French and Spanish islands large quantities on which it paid no duties.

I2I. General Effect of the Commercial System. Unpleasant as this system of restrictions certainly was to the colonists, it was much less arbitrary and oppressive than similar colonial regulations made by France and Spain for their American possessions. At that time colonies were expected to aid the mother country in disposing of her surplus products and in developing her resources or industries. Although the acts of parliament were often selfish and

Rice as an enumerated article.

Restrictions on manufactures.

Larned (ed.), Ready Ref., $\mathrm{V}, 3^{\mathrm{I}} 73$.

Coman, Indus. trial Hist., 65-72.

Lee (ed.), N. America, VI, 83-88.

Molasses Act (I733).

MacDonald, Charters, No. 5 o.

Coman, Industrial Hist., 82-83.

Disadvantages and advantages to colonists.

Lecky, Am.Revolution, $42-46$. 
Larned (ed.), unjust, they did not prevent the development of the English Ready' Ref., V. 3180-318I. provinces except along certain lines. Probably one half of the carrying trade between Great Britain and America was in colonial ressels. Most of the productions of the North could be exported to any part of the world, and the ships never returned empty. A profitable commerce was permitted with the French West Indies. Bounties were paid for masts, naval stores, indigo, and a few other articles sent to England. Duties at English ports of entry were often reduced for the benefit of American productions, and, in some cases, as that of tobacco, the colonists enjoyed a monopoly of the home market.

Smuggling. Of greater real significance than the favorable provisions of these laws of trade was the lax way in which they were Coman, Indus- administered. At first there were no custom houses, but trial Hist., 82. even after these were established, the laws were not enforced. In spite of the provisions that the customs officials should be appointed by the governors or king, that they should not be dependent on the colonial assemblies for their salaries, and that revenue cases should be tried ir special admiralty courts, the collectors of customs permitted the most open violation of the acts. The smugglers were sometimes permitted to land dutiable goods upon payment to the customs officials of an insignificant sum. During the administrations of Walpole and Newcastle in England, covering most of the reigns of George I and George II, there had been almost no interference with American commerce, and the expansion of colonial trade had been very great. Nevertheless the abuses of the system were often serious, and could not be overlooked entirely by the successors of Newcastle.

Otis's plea against the writs.

Amer. Hist. Leaflets, No. 33 .
I22. The Writs of Assistance. - It was especially necessary to prevent smuggling because the people of New England had been persistently furnishing supplies to the French in Canada during the Seven Years' War. The prime minister, William Pitt, ordered the customs officials to stop this practice, but they found it impossible with the means at 
their command. The collectors of revenue at Boston Tudor, Otis, therefore applied ( $176 \mathrm{r}$ ) to the Superior Court of Massachusetts to grant them "writs of assistance" - general search warrants which did not name the accused person nor describe the goods to be seized. A protest made by the merchants of Boston against the issuance of these writs was argued for them by James Otis, who resigned his position as advocate general of the colony for that purpose. Otis not only claimed that the writs violated those rights to which the colonists were entitled "by the British constitution, as well as by the laws of nature, and their own provincial charters," but went so far as to deny that parliament had any right to pass an act of trade which levied a tax on the colonies. This argument created a profound impression. John Adams declared that it "breathed into this nation the breath

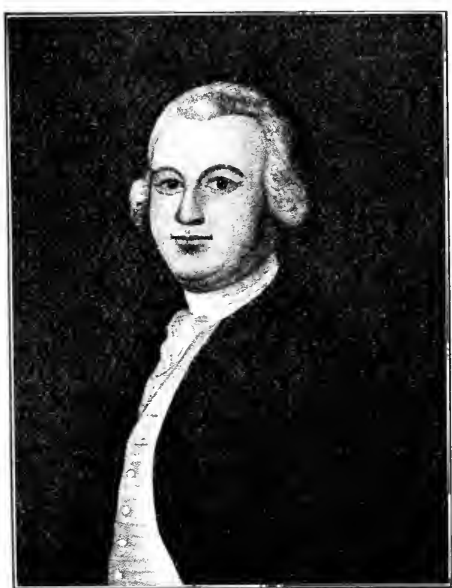

JAMES OTIS 52-88.

Howard Revolution, 70-83.

Cambridge Mod. Hist., VII, $177-181$ of life." The court, however, held that the writs were not unconstitutional, but in order to remove possible doubt parliament in 1767 legalized the issuance of writs of assistance.

\section{The New British Colonial Policy (i $763^{-i} 767$ )}

123. The Conditions in 1763 . - As already stated, the close of the war with France and the transfer of Canada was the beginning of a new era. The enlargement of the British iempire made the adoption of a new imperial policy ineritable, and this policy would almost of necessity include some imeans of reforming the irregularities in the older American colonies and the removal of the grossest abuses of colonial

Imperial policy and opposition.

Lecky, Am.Revolution, I-I 2 . 
Lee (ed.), N. Ameraca, VI, 3-8.

administration. But howerer opportune colonial reform might be from this point of riew, it was eminently unwise from two others. (I) It could not be carried into effect without arousing opposition in the colonies, as we can perceive easily from the preceding sections. The right of the English government to use writs of assistance had been ques-

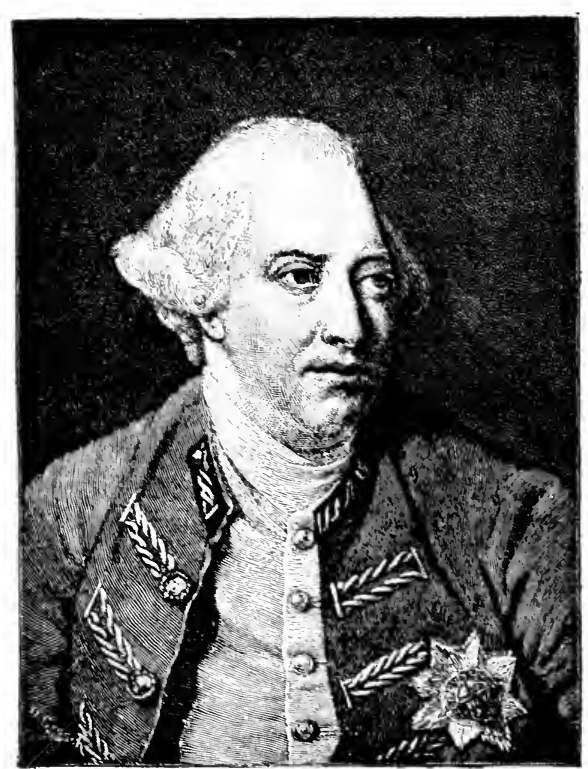

GEORGE III tioned by Otis as early as $\mathrm{I} 76 \mathrm{I}$ and Henry only roiced the wish of large numbers of colonists when he claimed that no colonial law could be set aside by the imperial authorities. (2) As the chief danger to the colonies the presence of the French in Canada-had been removed by the war, colonial opposition was likely to derelop into a serious breach with the mother country. Discerning statesmen, especially among the French, did not hesitate to predict that the acquisition of Canada by Britain would mean the loss of her older colonies.

George III and the " King's Friends."

Howard, Re'elution, 25-32.
124. George III and his Ministers (I760-I 782). - The character of the new king, George III, was farorable alike to a new policy and its unsuccessful administration. He was upright, sincere, and earnest, but without tact, narrow, and exceedingly obstinate. Coming to the throne ( 1760 ) with the determination that he should be the real ruler of Great Britain, he found it necessary to remove from power 
the Whig aristocracy which hail gained the ascendency during the reigns of his predecessors. To do this he gathered a party of adherents who were known as the "King's friends" and who were sufficiently servile to do his bidding. During the first decade of his reign, party lines were almost destroyed by this policy of the king. In consequence, at a time when "great wisdom, moderation, and tact were needed if healthy relations were to be established between England and her colonies, unfortunately these qualities were conspicuously absent from English councils." 1

In England from $1_{7} 65$ to I $_{73}$, a small minority were striving continually to prevent the king and his friends from reëstablishing the supremacy of the crown over parliament. At first they seemed to fail, for the ministry and parliament were the tools of the king. Their final success was due, in large measure, to the failure of the king and his friends to carry through their colonial policy in America.

125. The Establishment of a Colonial Army (I763). In 1763 the affairs of England were in charge of a cabinet whose chief was George Grenville, an industrious statesman and a careful financier, withal a firm believer in the supremacy of the empire. In accordance with plans formulated by the brilliant Charles Townshend and others of the king's friends as early as $\mathrm{I} 762$, he first induced parliament to establish twenty regiments, with a total of ten thousand men, in America for the purpose of protecting the colonies from any possible uprising of the French or the Indians and of looking after imperial interests in the new world. The expense of this undertaking was at this time to be paid from the British treasury, with the understanding that it should be borne later in part by the colonies themselves.

England had increast her debt during the war from $£ 70,000,000$ to $f_{140,000,000}$ and was heavily burdened iwith taxes to pay the running expenses of the government fand the interest on the debt. It seemed only just therefore that the colonies should pay at least a share of the cost of

Contest over supremacy of the king.

Plans for establishing an army.

Winsor (ed.), America, VI, I5-I7.

Need of regular army.

Lecky, Am. Revolution, 57-59. 
this army. To the ministry, an army appeared necessary as no dependence could be placed on the colonial militia except within a colony actually threatened with danger. This opinion was probably correct, for during the conspiracy of Pontiac $(1 ; 63)$, when the whole western frontier was threatened, only a few colonies could be induced to furmish troops.

American dread of an army.

Purpose, provisions, enforement.

MacDonald, chartis, No. $5^{\circ}$.

Coman, Industhial Hist., $00-92$.

Howard, Rezolution, 102-120.

But the Americans, having roted money and men without stint during the war, opposed a military establishment for two reasons. They wished to aroid the expense, and they hated the thought of an English army in America. They believed that the militia could be called out at a moment's notice and served every purpose. An army was in their opinion much less necessary for their protection than before the late war, when raids by the French and Indians were constantly to be dreaded. In short the army itself, although located in the recently acquired provinces, was offensive as a possible means of repressing colonial liberty, and colonial distrust was intensified by the methods used for its payment.

I26. The Sugar Act of I764. - Grenville intended to pay part of the expenses of this army by the more rigid enforcement of the laws of trade (S I I , I 20), and later by a tax on the colonies. After investigating the subject of customs administration in America, he learned that the custom houses cost five times as much as the total revenue from duties. Accordingly he arranged first that all naval ressels of Great Britain should aid the customs officials in enforcing the unpopular narigation acts. Later he secured the passage of a new Sugar Act which reduced the duties on molasses imported from non-English colonies to three pence per gallon and on sugar to two and one half shillings per hundred pounds. hoping thus to discourage smuggling and secure large revenues. To counteract the opposition to this measure, a practical monopoly of the whale tisheries was given to American seamen, and bounties were offered for the cultivation of flax and hemp. The enforcement of the 
act would have interfered greatly with the trade in fish which New England carried on with the West Indies, would have reduced the supply of specie which the shippers always brought back with them, and would have increased the price of liquors distilled from molasses so that the rum industry of the northern colonies would have suffered greatly. The opposition that was aroused in New England by these threatened dangers may be imagined easily.

127. The Stamp Act. - Grenville relied much more on a stamp tax for the necessary revenue. In 1764 he proposed a tax similar to one then in use in England, giving the colonies until the next session of parliament to suggest a better means of raising the money. He was not left long in doubt as to the feelings of the colonists. Neither king nor parliament had previous to this time attempted to levy an internal colonial tax for any purpose, and the colonies claimed that one of the fundamental rights of Englishmen, to which they were entitled, was the exclusive right of the people's representatives to raise revenue through taxation. In one colony, Pennsylvania, the charter gave parliament the power of taxation, but this had never been exercised. Walpole had been wise enough to reject a proposal that he tax the colonies. He is reported to have said, "I have old England set against me by this measure, and do you think I will have new England, too?" But Grenville, more financier than statesman, was blind to the consequences of taxing America. Protests came in from several of the colonial assemblies, but this he expected. The colonial agents in London met the prime minister, and Benjamin Franklin requested him to make requisitions of the colonies for the sums needed. "Can you agree," asked Grenville, "on the proportions each colony should raise?" As the agents were unable to give a satisfactory reply, Grenville clung to his original plan.

The Stamp Act for the purpose of "defraying the expenses of defending, protecting, and securing" the colonies was passed by parliament practically without opposition in March,

Proposal and protest.

Lecky, $A m$. Revolution, $67-73$.

Howard, Revolution, I 2 I-I35 
MacDonald, Chartirs,

No. 57 .

Howard, Re'inlution, 135-139.

Quartering Act ( 1705$)$.

MacDonald No. $5^{8}$.

Protests and mob violence.

Hart, ContemAcruries II, No. I30.

Lecky, $A^{4 m}$. Racolution, $79-8+$.

Howard, Rei'sIution, If I5- 54 .

I $755 .{ }^{1}$ It required that all pamphlets, newspapers, deeds, wills, licenses, court papers, and many other legal documents should be printed or made out on stamped paper, sold by distributers appointed for the purpose. All cases arising under the act were to be tried in the admiralty courts without juries.

A month later parliament passed the Quartering Act, which supplemented the Stamp Act as a measure for meeting military expenses, by

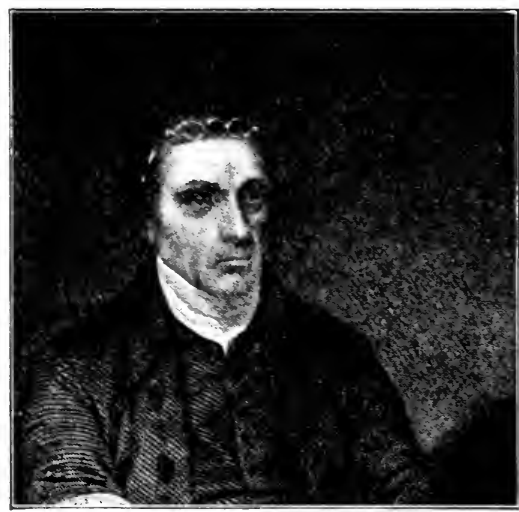

PNRlK HENKI compelling the colonists to supply the troops with quarters, and with bedding, cooking utensils, fire, candles, vinegar, salt, and beer.

I28. Reception of the Stamp Act. - As the stamp Act did not go into effect until November I, there was at first comparatively little excitement. Late in Mar, however, Patrick Henry, who had won considerable local fame in the "Parsons Cause" (S IIS), introduced in the Virginia legislature several resolutions asserting that the general assembly, subject to the veto of the crown, had the exclusive right of taxation. These resolutions were adopted after a heated debate. Other assemblies roiced their opposition, but quiet reigned for two months, until the names of the stamp distributers were amnounced. Then the storm broke. Mob violence compelled most of the distributers to resign. In Boston the people destroyed the homes of Oliver, secretary of the province and distributer in chief, Hutchinson, the lieutenant governor, and of several others. Whenever

1 The rote in the House of Commons was 205 to 49. 
ships arrived with stamps and stamped paper, these were seized or destroyed. In all of the northern colonies the younger element organized for active resistance under the name of the "Sons of Liberty," with the motto, "Liberty, Property, and no Stamps." When the first of November came there were neither stamps nor officials for their distribution in any colony. Newspapers, which were supposed to bear stamps, appeared with a death's head in the place left for stamps. Business was at a standstill. Even the governors and the courts soon realized that the law was a dead letter, and accordingly official documents were drawn up by government employees on ordinary paper, as no stamped paper could be obtained.

129. The Stamp Act Congress. - Meanwhile the colonies had been protesting against the Stamp Act in a much more dignified and lawful way. Early in June the Massachusetts legislature had asked the other colonies to meet in Congress and consider the best means of solving their difficulties. On October $7,1_{7} 65$, delegates from nine colonies held sessions in New York and adopted a Declaration of Rights which denounced the Stamp Act as illegal. After asserting their allegiance to the king and "all due subordination to that august body, the parliament of Great Britain," they claimed for themselves the rights of Englishmen, including the one "that no taxes be imposed on them but with their own consent, given personally, or by their representatives." They asserted further "that the people of these colonies are not, and, from their local circumstances, cannot, be represented in the house of commons in Great Britain. That the only representatives of the people of these colonies are persons chosen therein by themselves, and that no taxes ever have been, or can be constitutionally imposed on them, but by their respective legislatures." They claimed also right of trial by jury and protested against the injustice of the acts of trade. Several days later the Congress approved petitions to the king and to the houses of parliament. 
Reasons for repeal.

Debate on repeal.

Hart, Contemporaries, II, Nos. I42-I 44 .

Howard, Revolution, 158-173.

Lecky, $A m$. Revolution, 84-94.

Declaratory act (I766).
130. The Repeal of the Stamp Act. - The colonies further expressed their objections to the Stamp Act by refusing to order goods from England or pay their debts to English merchants, on the ground that the Stamp Act had interfered seriously with business. When parliament assembled in December, I 765, therefore, very great pressure was brought to bear on that body. The protests of the colonies were presented, the absolute impossibility of enforcing the act was emphasized, and the requests of the British merchants for its repeal were considered.

During the summer of $\mathrm{I}_{7} 65$, the ministry of Grenville had been superseded by an opposition cabinet under Rockingham. ${ }^{\mathbf{1}}$ The majority of this cabinet favored repeal, but hesitated to weaken British authority in America by granting the colonial claims. They finally advocated repeal. When the question came up in parliament, the late prime minister, Grenville, argued strongly that if the colonists objected to internal taxation because they were not represented in parliament, they would soon refuse to pay external taxes in the form of navigation duties. Later they would deny the right of parliament to make any laws whatever for them. If England yields now, he said, she will never be able to regain her authority in America. The colonial position was upheld by Pitt, who had already asserted the right of the colonies to tax themselves. "I rejoice," he said, "that America has resisted." For several weeks the debates continued, and during this time Franklin was examined in the house of commons concerning the state of affairs in America. His answers probably had a very decisive influence because they showed the impossibility of enforcing a stamp act.

When the Stamp Act was repealed in March, I766, parliament passed the Declaratory Act which asserted that the colonies are "subordinate unto, and dependent upon the imperial crown and parliament of Great Britain, and

1 The Stamp Act had nothing whatever to do with this change of ministries. 
that the King's majesty, by and with the advice and consent of the lords spiritual and temporal, and commons of Great Britain, in parliament assembled, had, hath, and of right ought to have, full power and authority to make laws and statutes of sufficient force and validity to bind the colonies and people of America, subjects of the crown of Great Britain, in all cases whatsoever."

131. English and American Ideas of Representation.During the discussions on the Stamp Act in America and England, the differences between the English and American ideas of representation were brought out with considerable clearness. It will be well to examine the question because the Americans claimed that they were being taxed without representation, while the English denied that the Stamp Act provided "taxation without representation." At this time the house of commons was composed of over five hundred members from England and Wales, less than one hundred of whom were elected by the counties, the remainder being chosen from boroughs. These boroughs had gained centuries before the right to elect members and at least one half were at this time unimportant. ${ }^{1}$ For this reason a large proportion of those composing the house of commons were appointed practically by a few hundred persons of wealth and influence. Most of the others were chosen by a very limited number of voters, for the franchise in the boroughs was very restricted, and in the counties, none but landowners - at this time a very select class - enjoyed the elective franchise. Moreover the new towns of the North were totally unrepresented.

According to the English view, every member of parliament represented the entire empire, the colonies as well Virtual representation. as the British Isles. During the debate on repeal, this

${ }^{1}$ Several attempts were made soon after to abolish the rotten boroughs and reform the representation in parliament, but even in 1832 , when the great Reform Bill was under discussion, the suggestion that representation should be territorial and according to population was scorned as an "American idea." 
Lecky, $A m$. Revolution, 75-79.

Territorial representation in America.

Provisions.

Macdonald, Charters, Nos. 6I-64. view was stated by Mansfield, the able chief justice. There can be no doubt "that the inhabitants of the colonies are as much represented in parliament as the greatest part of the people of England are represented, among nine millions of whom there are eight who have no votes in electing members of parliament." He claimed that there was no difference between "virtual and actual representation," and that any attempt to make such distinction would alter the British constitution.

The American idea of representation was entirely different. The colonial assemblies were composed of representatives from towns, in the North, or counties, in the South. No territory was thought to be represented unless it actually elected and sent to the assemblies members chosen by popular vote. The franchise - although limited to landowners and very restricted according to our present notions -1 was much more liberal than that of England because in America most of the heads of families owned land.

132. The Townshend Acts, I767. - For nearly a year the relations between England and the colonies were almost cordial. Then a new series of measures for colonial control were introduced by Charles Townshend, an ardent advocate of imperial supremacy and the ruling member of the new ministry to which that of Rockingham had given place. (I) The first of these laws provided for duties on glass, lead, painters' colors, paper, and tea. Townshend hoped, by avoiding any form of internal taxation, to gain a revenue without arousing colonial opposition. ${ }^{1}$ (2) All revenue raised under this customs law was to be used for the purpose of paying the governors and judges in the colonies in order that they might be independent of the assemblies. In a day, therefore, the colonies lost a right for which many

1 This act was connected with one reducing the land tax in England from four shillings to three shillings a pound. Merchants exporting tea to America were allowed for five years a drawback of the shilling a pound paid at English ports of entry, so that tea was sold cheaper in America than in England. 
of them had contended a half century $(\$ 87)$. (3) For the proper enforcement of this act, writs of assistance were legalized. (4) A board of commissioners was appointed to supervise the administration of all navigation acts. (5) About the same time the assembly of New York was forbidden to make any laws until that province complied with the terms of the quartering act of $I_{7} 65$ ( $\$$ I 27$)$, which it hitherto had refused to do.

In the fall of ${ }_{1} 767$ Townshend died, but the ministry maintained his policy, and the cabinet changes that took place were favorable to the full maintenance of imperial authority. In I 770 Lord North, an amiable and peace-loving man, but a willing tool of the king, became prime minister, a position which he held until the close of the Revolutionary War (I 782 ).

During the years from ${ }_{1} 763$ to ${ }_{7} 767$ a new colonial system had been created. This was not so much the result of a definite fixed policy as the outgrowth of the spasmodic attempts on the part of the English ministers to make the colonies pay a part of the expenses incurred for their protection, with a general intent to strengthen British authority in America. Marked by an invasion of the rights which the colonists held most dear, this new colonial system must be considered most unwise. Possibly any attempt to reform the abuses of colonial administration would have ended as disastrously, but certainly care should have been taken to avoid antagonizing the colonies by selecting the least objectionable instead of the most offensive measures.

\section{Disorder and Organized Opposition (i $767-$ I 775 )}

133. The Reception of the Townshend Acts. - As might easily have been foreseen, the Townshend Acts were not acceptable to the colonists. The old distinction between external and internal taxation was now ignored; the colonists supported the view that all taxation for the benefit of England was unjust and unconstitutional. In most of the

Cabinet changes $(1767-1782)$.

Summary of the new colonial system.
Change of colonial views.

Howard, Revolution, 185-I92. 
colonies organizations were suggested for the non-importation of British manufactures.

Circular letter of Massachusetts.

MacDonald, Charters,

No. 65 .

Fiske,

tm. Kin'olution, I, $47-50$.

Frothingham, Renublic, 2 II-23I.

Boston "Mrassacre" (I/70).

Lecky, .tm. Reiolution, IIS, I $20-13 \mathrm{I}$.

Howard, Rea'intion, I $y_{3}-1,3$, 202-205.

Fiske, $t m$. Rer-

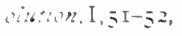
$57-50,00-72$.

Non-importation agreement $(1 ;-\infty)$.

Howard, Keiv¿atin, I IS-20I.
The Massachusetts assembly, which was now for a number of years under the influence of that adroit leader, Samuel Adams, issued in February, 1768 , a circular letter to the colonies, asking their coöperation in protesting against the Townshend acts, and sent a petition to the king and addresses to the people of Great Britain. The circular letter was so offensive to the British government that all of the governors were instructed to prevent their assemblies from giring it consideration and Massachusetts was ordered to rescind it. BY a rote of ninetr-two to serenteen the house of representatives in Massachusetts refused to rescind, and was immediately dissolved, as were the assemblies in several other colonies.

I34. Growing Disorder (1768-I 770). - For the purpose of enforcing the Townshend Acts and other narigation laws in Massachusetts, troops were now sent to Boston. Before their arrival, the customs officials seized $(1 ; 68)$ the sloop Liberty whose officers were accused of smugrling. The ressel was rescued by a mob and two additional regiments were ordered to Boston. Disputes arose regarding the quartering of these troops. In March, $1 ; 70$, the citizens and some soldiers came to blows in the streets of Boston. The soldiers at length fired upon the citizens, killing five and wounding six others. A meeting was called at once, and at the request of Samuel Adams. Gorernor Hutchinson removed all the regiments to a fort in the harbor. Several of the soldiers were tried in a local court, being defended by John Adams and Josiah Quincy. All were acquitted but two.

The result of this trial is the more noteworthy because of the furore produced in $1-60$, after the Liberty affair, by the attempt of the British govermment to revire an old law of Henry VIII, according to which crimes committed outside of the realm should be tried in England. When the house of commons farored this, the Virginia burgesses 
protested against it and persuaded the legislatures in several other colonies to do the same. The non-importation agreements were renewed in several colonies and this boycott exerted a considerable influence on the repeal of the Townshend revenue act $(1770)$.

I35. The Committees of Correspondence (I 772-I773).For two or three years comparative quiet reigned in America. ${ }^{1}$ In 1772 , however, a British revenue cutter, the Gaspee, whose commander had been enforcing the navigation laws in Narragansett Bay with far more zeal than judgment, ran aground near Providence. The citizens of that town immediately seized and burned the ship. Enraged by this act the British government appointed a commission to investigate the Gaspee affair. According to a law passed early in 1772 , any person who destroyed imperial property was guilty of treason. Under this law the offenders if captured were to be taken to England for trial.

In Massachusetts, Samuel Adams had already organized a number of tow'n committees of correspondence which were keeping alive the spirit of opposition. As soon as the instructions of the Gaspee commission became known, the Virginia house of burgesses adopted resolutions proposed by Thomas Jefferson, for the appointment of colonial committees of correspondence. Rhode Island, Connecticut, New Hampshire, Massachusetts, and South Carolina responded by appointing similar committees, the beginning of an intercolonial organization that was of the highest value in the perfection of a colonial union.

I36. The Tea Tax. - Influenced by the petitions of English merchants whose business had suffered from the non-importation agreements of $I_{7} 67$ and 1769 , and by the lack of revenue produced by the Townshend act, parlia-

1 This was not true of North Carolina. Some frontiersmen called "regulators," who believed that justice had been denied to them, refused to pay taxes and attempted to gain their asserted rights by force of arms. They were finally defeated by Governor Tryon in the battle of the Alamance ( 1774 ). 
Howard, Revo- ment had in 1770 repealed all of the duties except that on lution, 266-269. tea. This was maintained for the purpose of asserting the right of parliament to tax the colonies, but it was valueless

Cambridge Mod. Hist., VII, I57-I59.

Boston Tea Party (I773). Hart, Contemporaries, II, No. I52. Frothingham, Republic, 303-3I2. Old South Leaflets, No. 68.

Punishment of Massachusetts.

MacDonald, Charters, Nos. 68-7I.

Howard, Rerolution, 272-279.

Lecky, $A m$. Recolution, I64-I70. as a source of revenue, because the colonists either refrained from drinking tea or smuggled it from Holland. In I 773 the East India company, being in financial straits, asked parliament for permission to send tea direct to America, paying the colonial tax of three pence per pound only, and being relieved of the one shilling tax at English ports of entry. When this was granted, tea was immediately shipped to Boston, New York, Philadelphia, and Charleston.

At Boston meetings were held to prevent the landing of the tea, and when the ships arrived, a number of patriots were placed on guard over the ressels. As the ships remained in the harbor and it was the intention to land the tea December $I_{7}$, on the preceding evening a band of about fifty men dressed as Indians boarded both ships and threw the tea into the water. There was no tumult and no attempt to prevent this action. At Philadelphia, and later at New York, the vessels were sent back to England at once. The tea was landed at Charleston, only to be sold after the outbreak of war for the benefit of the patriots.

137. The Repressive Acts (I774). - The rejoicing in America and the indignation in England on account of the Boston Tea Party were alike universal. On both sides of the water the people were becoming more united. Within a few months several measures were passed by parliament for the purpose of punishing Massachusetts, but with the result of uniting the colonies much more firmly. (I) The first of these was the Boston Port Bill which closed Boston harbor to commerce and made Marblehead the port of entry for the colony. (2) The most important of these acts was that altering the charter of Massachusetts. The council was in future to be chosen by the crown, and all local executive or judicial officers were to be selected by the gorernor or the highest judges. Sheriffs, themselves appointees of the governor, were to choose jurymen, and no 
town meetings were to be held without the consent of the governor, except for the annual election of town officers. (3) All persons in government employ who were charged with murder were to be tried in another colony or in Great Britain. (4) Troops were quartered on the inhabitants of Boston. (5) By the new Quebec Act the boundaries of that province were extended to the Mississippi, on the west, and the Ohio on the south, and the allegiance of its inhabitants was strengthened by reviving the old French civil law and granting new privileges to the Catholic church.

\section{The First Con- tinental Congress (I774). - This coer-} cion of Massachusetts

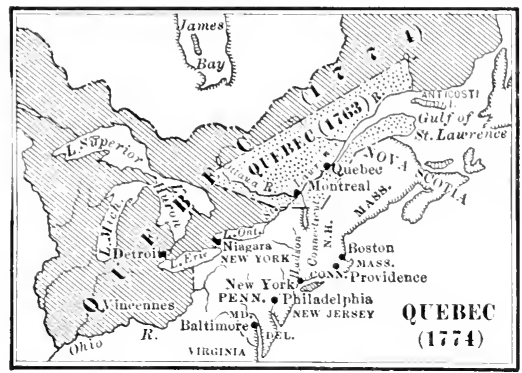

(17it) had been attempted in the belief that severe measures were needed and that the opposition to British authority was confined almost solely to that province. The falseness of this impression was soon evident. Sympathy and offers of help came to Boston from all quarters. Delegates for a continental Congress were chosen by the assemblies or committees of correspondence in all of the thirteen colonies except Georgia. On September 5, I774, the Congress met at Philadelphia with fifty-three delegates present, among them the ablest of the American leaders. ${ }^{1}$

The Congress adopted a Declaration of Rights asserting that as the colonies are not, and cannot be, represented in parliament, "they are entitled to a free and exclusive power of legislation in their sereral provincial legislatures, where their right of representation can alone be preserved, in all

Work.

Wilson, Am. People, II, 193-199.

Howard, Revolution, 280-287.

MacDonald, Charters, No. 72 .

- 1 These included John and Samuel Adams of Massachusetts, Roger Sherman of Connecticut, John Jay of New York, George Washington, Patrick Henry, Peyton Randolph, and Richard Henry Lee of Virginia, and John Rutledge of South Carolina. 
Hart, Contemporaries, II, No. 153 .

Howard, Revolution, 287-294.

American

Association.

MacDonald, Charters,

No. 73 .

Hart, Contemporaries, II, No. 154 .

Concluding work.

Continued policy of coercion.

cases of taxation and internal polity, subject alone to the negative of their sovereign, in such manner as has been heretofore used and accustomed." The Congress conceded, however, the right of parliament to regulate external trade if no duties were levied.

A little later the members of the Congress organized an “American Association," to carry out non-importation agreements. A committee was to be selected for each town which should supervise the action of all citizens and organize resistance to British domination. The union of the colonies was accomplished at last.

Having drawn up a petition to the king and addresses to the colonists, to the Canadians, and to the people of Great Britain, the Congress made provision for another Congress to meet in May, I775, and adjourned.

139. The Inevitableness of War. - News of the opposition to the acts of parliament and warlike preparations in New England created a profound impression in Great Britain. With the exception of the small body of Whigs who had consistently supported the colonial position, the country was overwhelmingly in favor of punishing the refractory spirit among "our subjects in America." George III probably voiced the popular belief in his words, "I have not the smallest doubt, when once vigorous measures. appear to be the only means left of bringing the Americans to a due submission to the mother country, that the colonies will submit." Parliament refused to consider the petitions of Congress to the king, repeatedly roted down concessive measures proposed by the Whigs, shut New England off from the fisheries, which had been an important source of revenue to the people, prohibited the New England colonies, and afterward most of the others, from trading with Great Britain or her other colonies, declared Massachusetts in rebellion, and voted six thousand additional men for suppressing this rebellion.

North's plan of Parliament was persuaded with difficulty to indorse Lord conciliation.

North's suggestions for conciliation. By the prime minister's 
plan, England agreed to forego the taxation of America except by commercial duties, so long as each colony contributed a fixed amount satisfactory to parliament for the support of the army and colonial officials. At the same time, North informally suggested to Franklin that the English government might be willing to repeal the tea tax and the Boston Port Bill, but not the Massachusetts Government Act.

Lord North's plan met with no favor in America, and his suggestions drew immediately the reply from Franklin:"The people of Massachusetts must suffer all the hazards and mischiefs of war, rather than admit the alterations of their charter and laws by parliament." Massachusetts had already held a provincial congress, which was a revolutionary body because it was not chosen according to the new government act, and had made careful preparations for defense by organizing the militia and gathering munitions of war. A few of the other colonies as well made rcarly for hostilities, and it was generally believed that war was inevitable, though little had been said on the subject, when, in March, I 775 , Patrick Henry startled the people of the colonies by his public declaration, "We must fight! I repeat it, sir, we must fight! An appeal to arms, and to the God of hosts, is all that is left us."

140. Summary. - Before $\mathrm{I}_{7} 63$ the English government had done very little toward controlling her colonies in America. A few officials were approinted to represent Great Britain in the colonies. In many instances colonial laws had been set aside and parliament hard made special laws regulating the trade or industry of the American provinces, but this supervision or control did not interfere seriously with government by the people in most of the colonies. After I 763 the English statesmen desired to regulate American affairs by compelling the colonists to pay part of the expense incurred for their defense. First by the Sugar Act $(1 ; 64)$ they aroused New England by interfering with business in that section. Then the Stamp Act brought all of the oller colonies into direct opposition to the English government.

Lecky, Am. Revolution, Ig $8-200$.

Frothingham, R'epublic, 4 II-4I3.

Preparation for war.

Frothingham, Kepublic, 4I3-4I9.

American Eloquence, I, 18-23.

Winsor (erl.), America,

$\mathrm{VI}, \mathrm{II}_{4}-\mathrm{I}_{22}$.

Contrast between the old colonial policy and the new. 
The crisis precipitated.

Repeal of this act was followed by a milder method of taxation, by which the friends of the king sought to gain a more perfect control of American affairs.

Both the English and the colonists had gone too far now to withdraw easily. When the people of Boston protested against the attempt to enforce imperial control through the sale of tea, and the English government sought to punish the city of Boston and the colony of Massachusetts, the union of the colonies was assured. Unwise counsels overruled conciliatory plans, and feeling both in England and America became so bitter that a clash was avoidable only through the complete surrender of one side.

\section{TOPICS}

r. Character and Policy of George III: Hart, "Contemporaries," II, No. I30; Fiske, "American Revolution," I, pp. $3^{8-45}$; Lecky, "England in the Eighteenth Century," III, pp. II-25; Trevelyan, "American Revolution," I, pp. 30-33, 85-90.

2. The Repressive Acts of r $77+$ : MacDonald, "Charters," Nos. 68-7r ; Frothingham, "Rise of the Republic," pp. $317-327,344^{-}$ $35^{8}$; Trevelyan, "American Revolution," I, pp. $175^{-203}$.

\section{STUDIES}

I. Union before $175^{\circ}$. (Frothingham, "Rise of the Republic," pp. rog-I 20.)

2. Otis's speech on the writs of assistance. (Johnston (Woodburn) eds. "American Eloquence," I, pp. II-I 7 .)

3. Chatham's speech on Taxation of America. ("British Orations," I, pp. 98-IIg.)

4. Mansfield's speech on Taxation and Representation. ("British Orations," I, pp. I $50-\mathrm{I} ; \mathrm{r}$.)

5. Franklin's examination before the house of commons ( 1766 ). (Larned, "History for Ready Reference," V, pp. 3192-3201.)

6. Dickinson's Farmers Letters. (Tyler, "Literary History of American Revolution," I, pp. 234-239.)

7 . The West during the period of $1 ; 67$ to 1775 . (Howard, "Preliminaries of the Revolution," pp. 222-2+1.)

8. The North Carolina regulators.

9. Lord Dunmore's War. (Roosevelt, "Winning oi the West," I, Chapters VIII and IX.) 


\section{QUESTIONS}

I. What was the European idea of a colony? (Thwaites, "Colonies," \$ I \$-22). Compare with the Greek and the Roman ideas. Compare the English rule with Spanish rule (Moses, "Spanish Rule" pp. I 7-26).

2. What were the chief political features of the old colonial system, in royal colonies? in other colonies? To what extent were the colonies actually governed by England through the different means enumerated in $\$$ I I5-I I 8 ?

3. What were the principal commercial features of the old colonial system? Was the system theoretically unjust? Was it oppressive in practice?

4. Why was a new colonial system adopted during the period I $763-1767$ ? How was the Sugar Act of 1764 different from the earlier laws of trade, in its purpose and in the methods proposed for its enforcement?

5. Had the colonies a legal right to exemption from taxation by parliament? Explain your answer and state as fully as possible the American claim.

6. What provisions of the Townshend Acts violated American principles of government, and in what ways?

7. Did the English government have sufficient cause for passing the repressive acts of 1774 ? Which was the most offensive of the acts? Why? Why did they influence the action of the other colonies if they applied only to Massachusetts?

8. Compare the congresses of $I_{7} 65,1774$, and 1775 as to reasons for which they were called, number of colonies represented, method of choosing delegates (see Howard, "Revolution," pp. I 54, 282 ), degree of unity shown, work of the congress, and influence on permanent union. Make table.

9. What is a revolution? Show the difference between a social revolution and a political revolution? (Ashley, "American Federal State," § 36.) Is it true that a "revolution is a successful rebellion"?

Io. What was the fundamental cause of the revolution? Name the successive changes in British policy which led directly to separation from England, showing how each change marks an advance on the policy in force previously. 


\section{CHAPTER VIII \\ THE REVOLUTIONARY WAR (I775-I783)}

Revolt AND INDEPENDENCE

Lexington and

Concord.

Fiske, $A m$. Revolution, I, II7-I27.
I4I. Events around Boston (I775). - In the spring of I 775 General Gage, governor of Massachusetts, determined to capture the military stores which had been gathered at various points near Boston by the companies of militia, "minute men" as they were called. Early on the morning of April I 9, eight hundred men were dispatched secretly to Concord, sixteen miles from

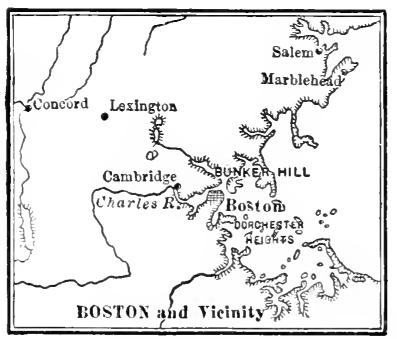

Boston. But the Americans were on the alert and Paul Revere aroused the "minute men," about seventy of whom met the British vanguard at Lexington. Upon this company the regulars fired, killing seven - the first bloodshed of the war. Marching on

Lodge,

Story of Rev., I, 25-52.

Hart, Contemporaries, II, No. I9I.

Bunker Hill. to Concord the British seized the town and the bridge, at which a skirmish was fought, but most of the stores were remored, and finally the soldiers were obliged to retreat before the ever increasing number of militiamen. Although reënforced at Lexington, their retreat was humiliating and disastrous, as the "minute men" fired at them from behind every tree and fence. Within a short time, a force of fifteen hundred Americans had gathered around Boston.

In order to protect Boston more adequately, General Gage decided to fortify the hills on Charlestown peninsula which commanded both the city and the harbor. Before this could be done, Colonel Prescott, with six cannon 
and a force of about fifteen hundred, seized Breed's Lecky, Hill on the night of June I6, I775, and threw up earthworks. At daybreak the war vessels in the harbor began bombardment, and General Gage, ignoring the possibilities of cutting off the American retreat, ordered Howe to make a front attack with three thousand soldiers. When the Am. Revolution, 202-205 British charged up the sides of the hill, the militiamen reserved their fire, their supply of ammunition being limited. A first time and a second the British line withdrew from the withering fire, but the Americans' ammunition was already giving out, and the third assault was successful. Fortunately the militiamen were able to withdraw in fair order though with considerable loss across Charlestown "neck." The British force lost over a thousand men, killed and wounded, and General Howe, who was soon after made commander in chief for America, ever after displayed particular fondness for flank attacks. The moral effect of this English victory was undoubtedly with the American side, for it showed the ability of raw troops to meet a much larger number of regulars, and was correspondingly encouraging to the colonists and disheartening to the British.

142. The War on the Northern Border (I775-1776). As soon as the news of Concord and Lexington reached the "Green Mountain Boys" in Vermont, they attacked and easily captured the important forts of Ticonderoga and Crown Point on Lake Champlain (May ıo, I775).

Later in the summer an invasion of Canada was planned. One expedition under Richard Montgomery proceeded up Lake Champlain, captured Montreal, and united before Quebec with a division under Benedict Arnold, which had forced its way, after almost inconceivable hardships, through the woods of Maine. An attack upon Quebec in a snowstorm, December 3 I, I775, resulted in the death of Montgomery and consequent confusion and defeat. The failure fof the expedition against Canada, much as success might have encouraged the colonists, was not an unmixed misfortune. With their imperfect military organization and lack

Ticonderoga

Fiske, $A m$. Revolution, I, I 29-I32.

Invasion of Canada.

Fiske, $A m$. Rerolution, I, I65-169

Larned (ed.) Ready Ref., $\mathrm{V}$, 3228-3229. 
of munitions of war the Americans were iily prepared to assume the offensive and could not afford to separate their forces. With the coming of summer, moreover, the energetic governor of Canada, Carleton, made a determined effort to gain control of Lake Champlain and recapture Ticonderoga and Crown Point. His plans were foiled by Arnold, who with skill and foresight as remarkable as his resources were limited, collected a fleet and delayed Carleton so that the doughty governor, victorious in a naval battle and yet baffled, was obliged to withdraw to Canada without capturing the forts.

Siege of

Boston.

Van Tyne, Revolution, 42-49.

Lecky, $A m$. Revolution, 226-234.

Old South Leaflets, No.86.

Capture of Boston.

\section{Lodge,} Story of Rev., I, IIO-II7.

Carrington, Battles, I47-I54.

War in the South (I776).

143. Change in the Theater of War (I776). - The summer and autumn of 1775 passed without any movement on the part of the British army in Boston which was now commanded by Howe. Washington, who had been appointed commander in chief through the influence of John Adams, maintained his lines about the city, although the terms of enlistment for his soldiers expired. He himself commented on the inactivity of the British. "It is not in the page of history, perhaps, to furnish a case like ours: to maintain a post within musket-shot of the enemy for six months together without powder, and at the same time to disband an army and recruit another within that distance, of twenty odd English regiments." But at length he was able to assume the offensive.

During the winter of $1775^{-1776}$ many of the cannon captured at Ticonderoga were dragged over the snow to Boston. With these in his possession, Washington fortified Dorchester Heights, about two miles south of the city. Owing to a storm, Howe was unable to attack. Not daring to remain in Boston, he now evacuated that city, carrying his ten thousand soldiers and marines besides many loyalists to Nora Scotia.

Part of this army, greatly reënforced, made an attack on New York during the middle of the summer (\$ I 54). Another part under Clinton, joining with a fleet from Ireland, sailed against Charleston, South Carolina. In view 
of the large number of loyalists in the southern colonies, this seemed to be a wise move. Yet it failed. The fleet was much injured, and effectually repulsed by the batteries of Charleston harbor, June ( 1776 ), and after several weeks of inaction the British abandoned attacks upon the South until late in the war.

I44. The Second Continental Congress (I775-I776). On the day that Ticonderoga was captured (May Io, I 775) the members of the second Continental Congress met in Philadelphia. As hostilities had begun already, the Congress did not devote itself to discussions only, as had its predecessors, but proceeded to act. Without great delay it organized a continental army, borrowed money, issued bills of credit, and drew up a second petition to the king. When news was received in October, I775, that the king's answer to their petitions was a proclamation declaring them rebels and providing for the suppression of rebellion in America, Congress moved with much less caution. A navy was authorized and privateers fitted out, a committee was selected to correspond with other nations, the ports along the Atlantic were thrown open to the commerce of the world, reversing the policy of the navigation acts, and preparations were made for declaring the United States independent of Great Britain.

During the six years that elapsed before the completion of a confederation, the Continental Congress was the only central government existing in America. It was composed of delegates elected at first by assemblies, conventions, or committees of correspondence, but after 1776 by the state legislatures. At no time did it possess any legal authority for the exercise of the powers of sovereignty which it actually used. Such rights as it had were derived from the instructions given by the states to their delegates, the unquestioned need of a central government, and the hearty approval of, and public acquiescence in, the acts of Congress.

145. The Movement toward Independence. - The majority of the members of Congress were unwilling to consider Authority of Congress.

Lodge, Story of Rev., I, I26-I35. Carrington, Battles, I85-190.

Acts of Congress (I775).

Lecky, $A m$. Revolution, 205-209.

Hart, Contenporaries,

II, No. 185 .

Frothingham, Republic, 428$437,450-45$ I. Congress. 
Hart, Contem- the question of independence from Great Britain, for the poraries, II, No. 186.

Van Tyne, Revolution, 50-7I.

Lodge, Story of Rev., I, I46-I55. people of the United States dreaded separation. Memorials came from several patriotic organizations before the close of $\mathrm{I} 775$, but they received scant attention until the king proclaimed the Americans to be rebels and news was received that several thousand Hessians had been hired to reduce the colonies to submission. Early in January, I776, there appeared a pamphlet entitled Common Sense, written by an English immigrant, Thomas Paine, and emphasizing the necessity and the benefits of independence. At this time the sentiment in favor of separation was pronounced only in New England, while the middle states and the South looked with abhorrence on such an action. Gradually a change took place in the feelings of the people. They had gone too far to draw back. The king stubbornly refused concessions, and there was no alternative but complete submission or independence. Congress recognized this sooner than most of the people, and on May Io, I776, urged the colonies to form state governments, adding five days later as justification for this step a resolution that the British government had withdrawn its protection and that the people must look to themselves.

Resolutions for

When this resolution became known, the legislatures of independence. all but one of the colonies instructed their delegates to vote for a declaration of independence. Meanwhile, on Van Tyne, Revolution, 7 I-78.

Fiske, $A m$. Revolution, I, I83-I92. June 7 , Richard Henry Lee introduced his famous resolutions "that these united colonies are, and of right ought to be, free and independent states, that they are absolved from all allegiance to the British Crown, and that all political connection between them and the state of Great Britain is, and ought to be, totally dissolved," and "that a plan of confederation be prepared and transmitted to the respective Frothingham, colonies for their consideration and approbation." A comRepublic, 513-532. mittee of five, composed of Thomas Jefferson, John Adams, Benjamin Franklin, Roger Sherman, and Robert R. Livingston, was appointed to draw up a declaration and a committee was chosen, June I 2, to prepare articles of confederation. 
The report of the committee on independence, written principally by Jefferson, was debated in Congress for two days, altered in some of its details, and finally adopted by Congress, July 4, 1776 . The committee on confederation reported July I2, but no legal union was formed until long after ( $\$$ I 73).

146. The Character of the Declaration. - Independence of Great Britain had been asserted because the colonies believed that they had a right to govern themselves in their own way, and the mother country had not permitted them to do this. We can perhaps see most clearly why our forefathers took this stand if we examine certain parts of the Declaration. The second paragraph, for example, gives some of their views upon government. "We hold these truths to be self-evident, that all men are created equal, that they are endowed by their Creator with certain unalienable rights, that among these are life, liberty, and the pursuit of happiness. That to secure these rights, governments

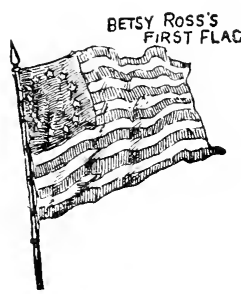

FIRST U. S. FLAG are instituted among men, deriving their just powers from the consent of the governed. That/ whenever any form of government becomes destructive of these ends, it is the right of the people to alter or to abolish it, and to institute new government, laying its foundation on such principles and organizing its powers in such form as to them shall seem most likely to effect their safety and happiness." After enumerating a long list of acts of George III which had aimed to overthrow these rights, the signers "in the name and by authority of the good people of these colonies, solemnly publish and declare, that these united colonies, are, and of right ought to be, free and independent states, that they are absolved from all allegiance to the British crown, and that all political connection between them and the state of Great Britain is, and ought to be, totally dissolved; and that, as free and independent states, they have 
full power to levy war, conclude peace, contract alliances, establish commerce, and to do all other acts and things which independent states may of right do."

Disorder of the state governments (1775).

Hart, Union, i 39 .

Frothingham, Republic, 49 I- 496 .

Congressional resolution of May 10, 1776.

Frothingham, Republic, 496-499.

Van Tyne, lierolition, I36-I+2.

Composition.

Van Tyne, Revolution, I $+2-152$.
147. The First State Governments. - IThile the colonies collectively were declaring their independence of Great Britain, the colonial governments were being replaced by separate state governments. As the war spread, the royal governors and their assistants and the judges frequently found it wise to leave the country. This left only a part of a government in several of the colonies, in some of which the assemblies asked Congress what they should do. In July, I775, Massachusetts had been advised to use her old charter and to disregard the governor. In the following November, New Hampshire had been urged to call a convention representing the whole people in order to frame a state constitution, which she did gladly.

On May io, I 7 ; , Congress took a great step forward which marked a new era in the history of independence, union, and constitutional development. It recommended that each colony "adopt such a government as shall in the opinion of the representatives of the people best conduce to the happiness and safety of their constituents in particular and of America in general." This suggestion was quickly followed by Virginia, which in convention adopted a constitution embodying not only a plan for the state government, but also a bill of rights. Connecticut and Rhode Island merely continued their charters, which were to all intents and purposes republican constitutions, while most of the other states called conventions for the purpose, but only Massachusetts submitted the constitution framed by her convention to the people for ratification.

These governments were similar in form to those of the colonies, but now both houses of the legislature were chosen by the people and the governors were elected by the legislatures, except in New England and New York, where they were chosen by popular vote. The powers of the legislatures were increased greatly at the expense of the executive, the 
governors being deprived of the reto, for example, in almost all of the revolutionary governments.

\section{Conditions affecting American Success}

148. The Theater of War. - Whatever may have been General. the purpose of the patriot leaders before 1776 , there was now no doubt that the struggle was one which would admit of no compromise. Let us consider therefore the conditions that were farorable or unfavorable to the American cause.

The thirteen colonies that revolted against British rule extended along the Atlantic coast orer a thousand miles and inland usually two or three hundred. This was in some respects an adrantage to the British, because they at all times controlled the ocean and by seizing one or two seaports might transport their armies to any part of the coast they pleased. But the hold on a few seaport towns was in itself of very little importance to the English government. Unless the English generals could gain control and retain possession of the interior, their attempt to subdue the colonies would fail. Movements on land from one colony to another were prevented by the numerous rivers which flowed at right angles to the coast line. Moreover, any invasion of the interior was disastrous, because the American armies could withdraw easily to the frontier, being augmented by the militia which was always most patriotic in the inland counties. The British, unable to maintain direct water communication from the ocean to their armies, found it practically impossible to maintain an adranced position for any length of time.

In one quarter only did circumstances seem to be in their favor. The island of Manhattan with its magnificent harControl of bor could not be defended by the Americans, and was seized therefore and held by the British, who might proceed up the Hudson to Albany. On the north they controlled Montreal and the outlet of Lake Champlain as well as Lake Ontario. But even here the almost unbroken wilderness between the head of Lake Champlain and the Hudson River and be- 
Possible policies.

British and Hessian troops.

Lecky, Am. Revolution, 240-244.

Van Tyne, Revolution, 96-ror.

tween Lake Ontario and the Mohawk valley was an ally of incalculable benefit to the patriots.

\section{I49. British Military Organization and Policy. - To} insure success the British needed either to exclude the colonies from communication with the outside world until they were willing to make terms, or to gain control of the territory as far inland as the mountains. The first, which might have been accomplished by an effective blockade, they did not attempt, probably on account of the numerous harbors. The second required a large army skillfully led, and the second was the policy followed.

Supported at all times by a large fleet, which remained inactive, the British army in America numbered, during the first half of the war, about forty thousand, and during the second half, about twenty-five thousand men. Most of these were experienced soldiers, but many of them were not English. Finding it difficult to enlist the necessary soldiers at home, George III hired from the dukes of the small German states, especially Hesse Cassel, about eighteen thousand veterans. The employment of these "Hessians" undoubtedly intensified the feeling of the colonists, not alone because the king was willing to use those so-called mercenaries for their subjugation, but on account of the many outrages perpetrated by the Hessian troops.

British leaders. The soldiers of the British army on all occasions proved their courage, but were unfortunate in their leaders. Appointed from a certain class of the nobility without reference to military fitness, the English generals and other officers, with notable exceptions, exhibited an incapacity for their duties that is appalling and is perhaps the chief cause of the complete failure of the English plan of subjection.

Native leaders. 150. The American Army. - Our military leaders represented the two extremes of superior ability and extreme incapacity. They were appointed by Congress and were often selected for reasons other than proved ability. For- 
tunately George Washington was chosen as commander in chief. Hampered as he was by the unwillingness of Congress to give him full direction of affairs, and constantly handicapped by the lack of trained soldiers, he was without question chiefly responsible for the final establishment of American independence. Although at the time of his appointment he had seen comparatively little fighting, this Virginia planter proved himself an able general and a skillful strategist - much more than a match for any of his English antagonists. He could strike hard when his chance came, but he could also wait, and a waiting policy was usually his only hope of success, because of the superiority of the British in numbers and discipline. Moreover, his foresight, generosity, and broadmindedness united the factions at home - foes more dangerous than the foreign armies. Among his assistants Nathanael Greene is accorded the highest place, although many others, like Benedict Arnold and Daniel Morgan, exhibited, within a more limited radius, conspicuous ability.

Many of the highest offices in the army were bestowed upon foreigners who had not resided long in America or Foreign leaders. had come here after the beginning of war. Some of these men, like LaFayette, Steuben, and Kosciusko, were heartily and unselfishly in sympathy with the revolution; others, like Conway and Charles Lee, were adventurers who imposed upon Congress and interfered with American chances of success.

One of the chief difficulties encountered by the Americans was their inability to maintain a permanent army. At the American soldiers. beginning, enlistments were for a term of one year or less. As the troops were poorly fed and clothed, paid in depreciated currency or not at all, most farmers objected to leaving their crops during the summer campaigns when the grain would suffer greatly. Later in the war soldiers of the "continental line" enlisted for three years. Although few in number they formed the nucleus of a regular fighting force. They were the only well-trained American soldiers.

Fiske, Am. Revolution, I, I33-I36, $148-152$. 
Because of the short terms of the others, it was often impossible to obtain men enough to oppose the advance of the enemy, although in times of great danger many joined the army for a few days or weeks. Except at these intervals the number of American soldiers in the field was smaller than that of the British.

Numbers and elements.

Winsor (ed.), America, VII, 185-I92.

Loyalists and patriots.

Hart, Contemporaries, II, Nos. I66-169.

Van Tyne, Revolution, 265-278.
151. The Loyalists. - As we noticed in a previous section ( $\$$ I 45), a large part of the population agreed to a declaration of independence from the mother country with great reluctance. Another part was never convinced of the wisdom of the step and remained throughout the war loyal to Great Britain. Many of these loyalists simply refrained from taking sides, but many others were active in their opposition to the patriot party. Few of them were found in New England and Virginia, but in the other states they probably included one half of the population, being especially numerous and virulent in New York, Georgia, and the Carolinas. The inhabitants of the large towns, the officeholders, the clergy in the Anglican church, the members of the professions, most of the merchants, and owners of large estates usually cast in their lot with the loyalists rather than with the patriots.

The persecution of the loyalists began before the outbreak of war, an effort being made by the use of tar and feathers and by similar outrages to intimidate the wavering, and make open espousal of the English cause unpopular. After the establishment of the state governments, the more prominent loyalists were deprived not only of political and civil rights but often of their estates as well. Where they were sufficiently numerous the loyalists retaliated with spirit, outdoing the patriots in brutality. In South Carolina and in some other states a partisan warfare of extreme bitterness was kept up even after the close of the war. In these fierce contests hundreds of persons were killed, the innocent and defenseless suffering quite as frequently as the guilty.

152. The Finances of the Revolution, - The difficulties 
of achieving independence were financial rather than mili- The problem tary. The lack of an established central government with well-recognized means of raising money for the payment of war expenditures caused continued anxiety to the American leaders. Without a certain minimum of congressional revenue the prosecution of the war was impossible. But how was this to be obtained? The states were of course unwilling that Congress should exercise the right of taxation, for after 1777 Congress enjoyed almost as little confidence as parliament had done before the war. Few would lend to Congress because it had no definite sources of income, no legal status, no international standing, and therefore no credit. Nothing was left but for Congress to issue paper money on the credit of the United States and to ask the states for annual contributions with which to pay its most pressing needs. As the states were getting deeply into debt on account of their own war expenses, these requisitions were usually ignored. Paper money was in consequence the chief reliance of Congress.

During the most trying years of the war, Congress opened loan offices through which the people loaned to the government over $\$ 10,000,000$. Foreign nations, especially France, helped us some, but most of the foreign loans were made after the victory at Yorktown, so that they were not of direct value in conducting the campaign.

I53. Continental Currency. - When Congress began printing paper money in June, I775, it was expected that after a few issues the presses would be stopped. But on account of the difficulties of raising a revenue from other sources, the issues grew constantly larger. By 1779 the face value of the bills printed amounted to nearly $\$ 250,000$,$\infty)^{\circ}$, although they had been worth to the treasury less than one fifth of that amount in cash. Congress had provided for the payment of the bills by pledging the credit of the United States and apportioning to each state the share it should redeem, but on account of repeated issues and little other revenue, depreciation was inevitable. Congress

Dewey, Financial Hist., $\S \mathrm{I} 4$.
Loans.

Dewey, Financial Hist., $\oint \oint 19,20$.

Issues and depreciation.

Lecky, $A m$. Revolution, 287-292.

Dewey, Financral Hist., \$\$ I5, I6.

White, Money, II5-I26. 
sought to prevent this by fixing the prices which should be paid for commodities, naturally without effect. Before the last year of fighting a hundred dollars in continental currency would purchase less than one dollar in silver. A little later continental bills were used jokingly for papering rooms and for suits of clothing. It is not strange that toward the close of the war valueless articles were said to be "not worth a continental."

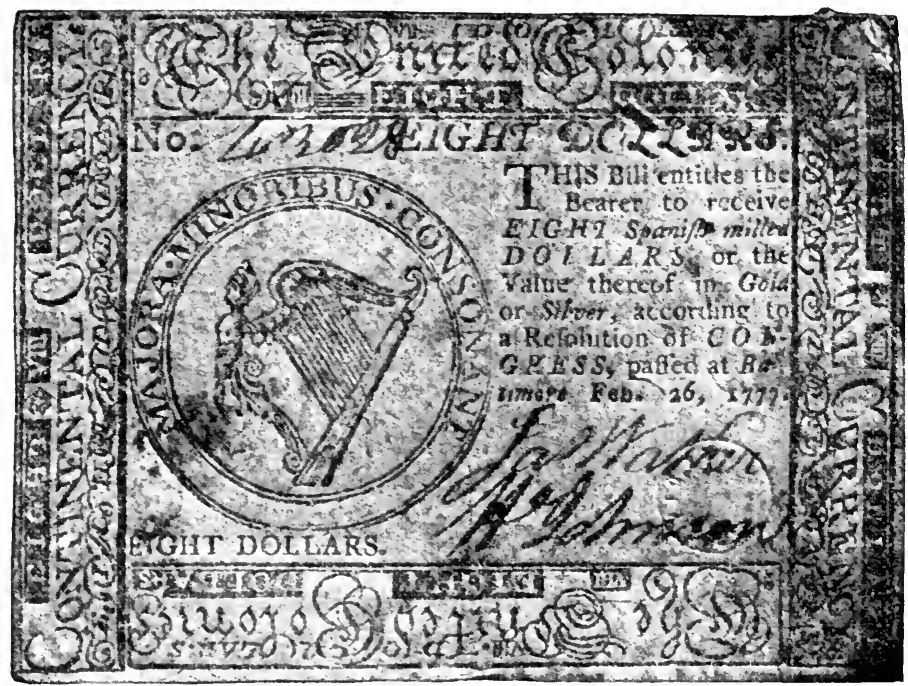

A Continental Bill

Justification.

An attempt was made to justify the issuance of paper money on the ground that it was a form of tax which could

Dewey, Finan- be escaped by no one who did business. But it imposed a cial Hist., $\S 17$.

White,

Hiney, I $20-129$. most unfair burden on those least able to bear it, and was not only a most unjust tax, but a serious injury to business enterprise. If justified at all, it must be as a military necessity, for the states refused to pay the requisitions made on them by Congress, and that body should not be blamed for using the only practicable means it had for continuing the war. 


\section{The Campaigns of I 776 and I 777}

154. The Movement against New York (I776). - The Plan of eighteen months following the declaration of American inde- campaign. pendence witnessed the most active campaigns of the entire war. The British government had already resolved to make an attack upon the middle colonies with a large army, seize New York, gain possession of the Hudson and Lake Champlain, thereby cutting off New England from the other states, and subduing the middle states, which they considered an easy task because of the large number of loyalists.

Late in June, 1776 , General Howe landed at Staten Island and was soon joined by his brother, Admiral Howe, with a fleet and

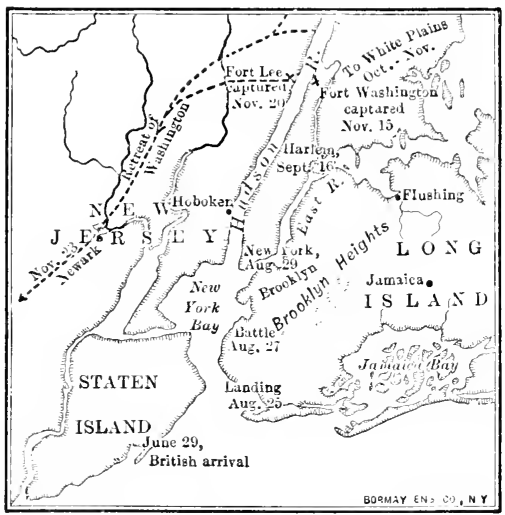

NICINITY OF NEW TOLK

$(1 ; 76)$

reënforcements. To the British army of over thirty thousand regulars Washington was able to oppose a force but two thirds as large, few of whom were well armed or experienced. His was indeed a most difficult task. Public sentiment demanded that he should not abandon New York without a contest, although it was absolutely indefensible against the larger force and fleet, which could cut him off easily from retreat. Moreover he was obliged to fortify and hold Brooklyn Heights, which commanded the city but was exposed to a combined land and water attack. For nearly two months the British allowed him to strengthen his position. Howe then landed twenty thousand men at the southern end of Long Island, and by concerted movements overpowered the eight thousand men

Campaign on Long Island.

Van Tyne, Revolution, I02-IO8.

Fiske, Am. Revolution, I, 204-2I2.

Lodge, Story of Rev. I, 184-I95. 
left by Washington, captured General Sullivan with one thousand men, and drove the remainder back to the East River. From this position Washington was fortunate enough to extricate his men before the fleet cut off his retreat.

Retreat from New York.

Van Tyne, Revolution, I $18-128$.

American difficulties (Dec., 1776).

Fiske, $A m$. Revolution, I, 227-229.

Capture of Trenton (I776).

Lodge, Story of Rev., I, 207-2I5.
By two other flank movements Howe compelled Washington to abandon first New York and later Harlem Heights. Then the American army was withdrawn to White Plains, where an indecisive battle took place. When Howe captured the two forts, Washington and Lee, on opposite sides of the Hudson, Washington retreated skillfully through New Jersey, destroying bridges as he went. Seizing all the boats on the Delaware, he placed that river between himself and the enemy, and blocked their advance to Philadelphia.

155. The Trenton-Princeton Campaign. - The American cause seemed now almost hopeless. In spite of Ar-

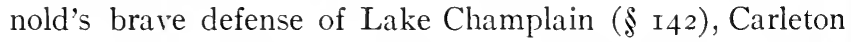
had gained control as far south as Ticonderoga. Newport had been captured by the British fleet in December, I776. The army under Washington, having sereral times barely escaped destruction, had been driven from New York and New Jersey. Large numbers had taken. the oath of allegiance to Great Britain and apparently the backbone of the revolution had been broken effectually.

As the terms of enlistment for most of his soldiers would expire the first of January, Washington decided to assume the offensive - apparently a most foolhardy attempt. But as usual the British were their own worst enemies and had left their vanguard scattered at a half-dozen posts. The advance at Trenton was held by Colonel Rahl and a body of Hessians. On Christmas eve Washington crossed the Delaware, and attacked this force in the midst of their festivities. With the loss of two men killed and two wounded he captured over a thousand prisoners, only two hundred escaping. 
The effect of this victory was instantaneous. The soldiers reënlisted. Hundreds of militiamen joined Washington, and the people of New Jersey, aroused by the brutality of the British and Hessian soldiers, again gladly espoused the American cause. Meanwhile Washington, who had withdrawn to Pennsylvania, returned to Trenton, disputing the advance of Lord Cornwallis and his greatly superior force. As the Americans occupied a fairly strong position and as night was at hand, Cornwallis postponed his attack until morning, only to find that Washington had slipped Washington in New Jersey (I777).

Van Tyne, Revolution, I3I-I35. away in the night, leaving his campfires burning. Washington had in fact marched around Cornwallis's main army and had attacked three regiments stationed at Princeton, routing them without great difficulty. He then retired to the foothills in the northern part of New Jersey, compelling Cornwallis to abandon the western part of the state. In the face of defeat Washington had outmaneuvered a force several times as large as his own and regained most of the ground he had lost. Frederick the Great, one of the highest military authorities in Europe, is said to have called this the greatest campaign of the century.

I56. The Plan of Campaign, I777; Philadelphia. - In Plan to I 777 the English government, still believing that the opposition outside of New England was half hearted, determined to put an end to the war by gaining control of the Hudson and separating New England entirely from the southern and middle states. For this purpose Sir John Burgoyne was selected to lead the northern army down Lake Champlain to Albany, coöperating with Howe, who was to ascend the river and rnake the separation of New England complete. This plan had been outlined the previous year separate New England,

Van Tyne, Revolution, 157-I59. and did not meet with the full approval of Howe. By some inexcusable carelessness, the instructions to Howe were mislaid in a pigeonhole by the English colonial secretary, Lord Germain, and did not reach New York until August i6. Long before that date Howe had left New York, intending to capture Philadelphia, the "rebel capital."

Fiske, $A m$. Revolution, 260-268. 
Accordingly he failed to coöperate with Burgoyne, and the latter was unable to carry out his plans.

Capture of Philadelphia.
Washington supposed that Howe's destination would be Philadelphia, but held himself in readiness to move to any point threatened. Howe appeared first off Delaware Bay, but did not ascend that river on account of the forts erected

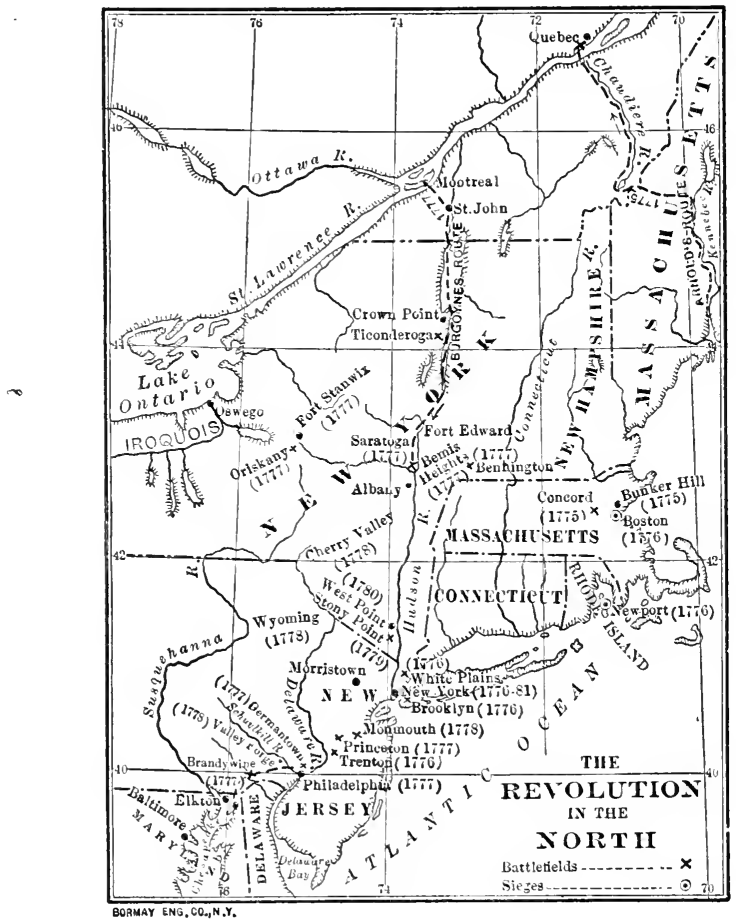

Lodge, Story of Rev., I, 280-302. below Philadelphia. Late in August he landed at the head of Chesapeake Bay. At Brandywine Creek his way was blocked by Washington, who had sent some of his best troops to the north. A flank attack made by Howe across the fords above Washington's main body was successful on account of the overwhelming superiority of the British in numbers and discipline The way now lay open to Phila- 
delphia, which gave Howe a cordial welcome. But Washington was not content, and on October 4 attacked the British army, now stationed at Germantown, but without success. Howe captured the forts below the city, although they were defended with great skill. The British then gave themselves up to the enjoyment of winter festivities, while Washington went into winter quarters at Valley Forge only a short distance up the Schuylkill River.

I57. Burgoyne's Advance (I 777). - Early in the summer Burgoyne had left Canada with about ten thousand English regulars, Hessians, Canadian militia, and Indians. His advance down Lake Champlain was undisputed until he reached Ticonderoga. By seizing some commanding heights that were left undefended he compelled the abandonment of that fortress without serious fighting, the garrison joining another detachment under General Schuyler. Realizing that his opportunity lay in the comparatively unsettled region between Lake Champlain and the Hudson River, Schuyler withdrew slowly, felling trees across the roads or converting them into swamps, destroying bridges, making the way impassable to an army encumbered with baggage and artillery. He accomplished his purpose admirably, for Burgoyne spent fifty days covering seventy-five miles. The American army meanwhile was strengthened daily by arrivals from New England and the Hudson valley.

Having reached the Hudson and being short of provisions, Bennington. Burgoyne sent Colonel Baum with six hundred Hessians into what is now Vermont. To the support of this division he dispatched another four days later. The first was met near Bennington, August I6, by John Stark and a body of New Hampshire farmers. Stark attacked the Hessian camp, capturing practically the entire force. Barely was this engagement finished when the second detachment arrived. This was beaten off after hard fighting. Burgoyne had gained nothing and had lost a thousand men.

At this time Colonel St. Leger, who had advanced from Defeat of Lake Ontario in order to move down the Mohawk valley St. Leger 
Lodge, Story of Rev., I, $236-2+2$.

and coöperate with Burgoyne, was besieging Fort Stanwix near the western end of the valley. Herkimer, with some Dutch settlers, attempted to raise the siege, but was a mbushed and driven back; but when news came that Arnold was approaching with another force, the siege was raised, and St. Leger retreated. In this way, Burgoyne was left to meet the constantly increasing American army without hope of support from any quarter.

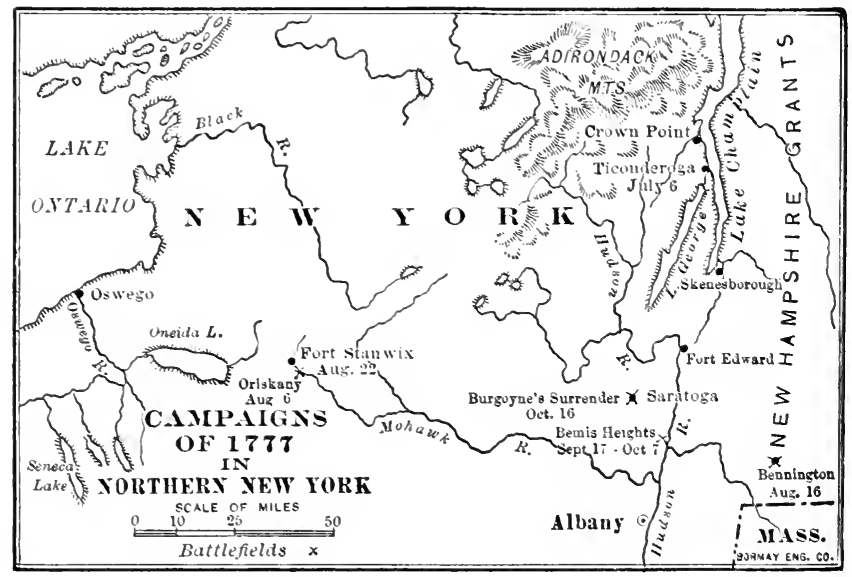

Battles of Bemis Heights.

Winsor (ed.), America, VI.

Fiske, Am. Revolution, I, 325-334.
158. The Surrender of Burgoyne (I777). - The command of the American army which faced Burgoyne had been transferred from Schuyler to General Horatio Gates, who was more popular among the New England soldiers. Gates was not an experienced commander, and took very little part in directing the campaign. He drew up his army at Bemis Heights directly in the line of the British advance. In this neighborhood two engagements were fought. The first, on September I9, was indecisive, but in reality an American victory, as the British advance was practically checked. As the news of this battle brought still larger numbers of farmers to the American ranks, and as Burgoyne's communications were threatened by the American com- 
mands in his rear, he undoubtedly would have retreated but for the news that Clinton was ascending the Hudson with aid. On October 7 an attempt to reconnoiter brought on another battle. Arnold, although deprived of his command, and Morgan, broke the British line and made Burgoyne's position untenable.

He attempted to withdraw, but was surrounded by the American forces, which outnumbered him three to one. Finally October I6, at Saratoga, he agreed to surrender his army, now diminished to 579 soldiers and camp attendants. These were to be sent back to England on condition that they should not serve again in America, but Congress kept them as prisoners of war, because the claim was made that the British had broken the Saratoga Conventiou. Thus the general who had boasted that he would never retreat yielded the last of his army of veterans to a temporary force of militia and farmers called together by the attempted invasion, and directed by an inefficient commander. This was really the turning point of the war, for the victory at Saratoga had momentous consequences in America and Europe.

\section{Changed Conditions (I 778-i 779)}

I59. French Aid before I778. - The most important result of Burgoyne's surrender was the open alliance of the French and Americans. France, keenly alive to the disgraceful defeats of the last war with England, was anxious to improve the first opportunity of injuring her old enemy. Turgot, the comptroller general, realizing the financial condition of the country, advised King Louis to hold aloof from interference, but a more active party under the lead of Vergennes, minister of foreign affairs, urged that help should be given to the United States secretly. This was done as early as 1776 , but American interests were not managed well until the appointment of Benjamin Franklin to the court of France.

Franklin is one of the most extraordinary men of our entire history. Of unaffected manner and a most practical

French hatred of England.

Lecky, $A m$. Revolution, 296-3I I.

Van Tyne, Revolution, $203^{-217}$

Larned (ed.), Ready Ref., $\mathrm{V}, 324 \mathrm{I}-3244$. 
Benjamin Franklin.

Appleton, Cyclopedia of Am. Biog.

mind, he was an astute philosopher and a far-sighted statesman. His contributions to the cause of education and science entitle him to a high position among the leaders in those branches, and as a diplomat he is unexcelled among Americans. Beginning life as a journeyman printer in Boston, he had run away to Philadelphia, established a paper of his own, founded the Lniversity of Pennsylvania, and brought the administration of the municipal gorernment in his

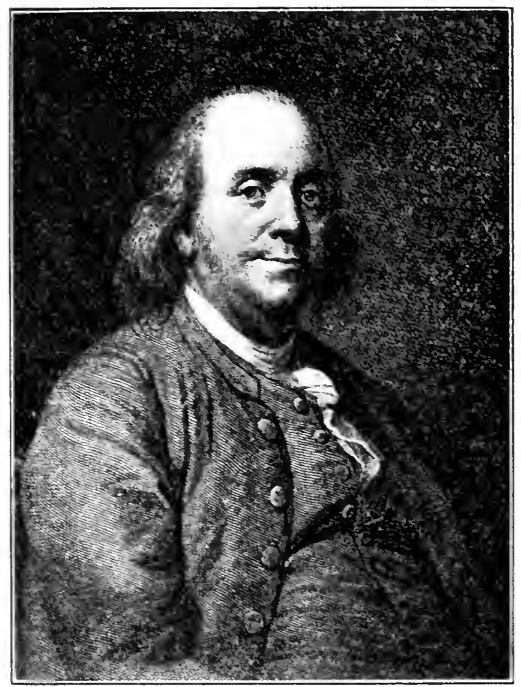

BENJAMIN FRANKLIN adopted city to a high state of efficiency. He had gained a world-wide reputation for his discoreries of electricity, had been assistant postmaster-general for the colonies, and during the trying period immediately preceding the war had rendered invaluable service to the colonies as a colonial agent in London. No one had done more than he to promote colonial union, and when the Declaration of Independence was drawn up, he was one of those selected for the task. His appointment to France was wise beyond expectation, for no one could have foreseen that his services to America in the next six years would be the most valuable of his remarkable career.

Terms of the alliance.
I60. The French Alliance (I778). - Franklin was very popular in France, and would probably have secured an alliance because of the bitterness toward England. After Saratoga, however, his task was extremely easy, and on February 6, $\tau_{7} ;$, a treaty of alliance was signed by which 
France agreed to aid the United States in order to maintain her "liberty, sovereignty, and independence, absolute and unlimited." France renounced all possessions on the mainland of America, but was to retain any islands in the West Indies captured from Great Britain. The allies were not to make peace or "lay down their arms until the independence of the United States shall have been formally or tacitly assured by the treaty or treaties that shall terminate the war." On the same day a commercial treaty was signed.

The French Alliance and the subsequent war between France and England had a threefold influence on the contest in America. (I) It brought us substantial help in the form of a fleet and regular bodies of troops. (2) It also compelled the British to withdraw from the United States a large number of troops. This crippled the English and made extensive operations difficult, so that the fighting was thereafter more desultory, except in the South during I 7 So and $I_{7} S_{I}$. (3) As there were no invading armies to oppose and no possibility of driving the British from the few seaports that they held, the Americans took less interest in the war, and depended more on their French allies.

I6r. Attempted Conciliation by the British (I778). - Another result of Saratoga was the attempt made by the British government to end the war by conceding all American demands except that of independence. In 1776 Admiral Howe had been instructed to offer pardon to all who would return to their allegiance, but he had failed through unwillingness to recognize Congress as an American government. The full effect of Burgoyne's defeat may be apparent if we notice the offers which were made by Lord North in February, 1778 , a few days after the treaty with France was signed, but before England knew of the alliance. The tea act and the Massachusetts government act were repealed, and the right of parliamentary taxation renounced except for duties on commerce, the revenue of which was to be expended by each colony for itself. The peace commissioners were to have power to treat with Congress, grant

Results of the alliance.

Lecky, Am. Revolution, 398-399.

Terms proposed by Eng land.

Tan Tyne, Revolution, 227-233. 
pardons, and suspend all colonial laws passed by parliament after I $_{7} 63$. In short, England agreed to return to the oid colonial system if her former American possessions would resume their colonial relations.

Rejection of peace.

The Conway cabal.

Fiske, $A m$. Revolution, II, 32-46.

Inefficiency of Congress.

Fiske, $A m$. Revolution, II, 26-32.

Larned (ed.), Ready Ref., $\mathrm{V}, 326 \mathrm{I}-3263$.

Hart, Contemporaries, [I. I9o, I98.
These efforts came to naught. Had the same offers been made even two years earlier they would have been accepted gladly, but now independence alone was satisfactory to the United States. Congress rejected all offers made by the commissioners, who returned to England, after announcing that thenceforth a war of destruction would be waged.

I62. Intrigue and Neglect (I778). - A third, though much less important, result of Saratoga was the attempt to remove Washington from his position as commander in chief. The repeated defeats which he had sustained during the fall of 1777 contrasted strangely with the victory in the North, and, to persons unacquainted with the facts, seemed proof that Gates was the greater general. In November, I777, a war board had been appointed with Gates at the head. An Irish adventurer, named Conway, who had seen some service in France, and whose promotion Washington had opposed, thought this a farorable moment to intrigue against the commander in chief. With Gates and a few others he sought to gain control of Congress; but the plot was exposed, Conway resigned from the army, Gates was detailed to the forts on the Hudson, and Washington enjoyed even greater confidence than before.

Congress meanwhile found itself incapable of meeting the situation. Paper money was almost worthless, and there was no proper organization to care for the army. The soldiers were not only unpaid, but unprovided with clothes and food. The suffering at Valley Forge during the winter of 1778 was extreme and inexcusable. Many of the men went barefoot in the snow, but, in spite of obstacles, under the supervision of Steuben, a small force of regulars was being trained that was to form the nucleus of the army during the uninteresting campaigns that followed.

163. The Naval War (I776-I782). - At the beginning 
of the war the United States had no fleet and little attempt Lack of a navy. was made to create one. There being no fleet to oppose, comparatively few English men-of-war were sent to America, although Admiral Howe and others advocated a strict blockade of our coasts as the best and quickest means of bringing the colonies to submission.

Numerous privateers were fitted out to prey upon English commerce, an undertaking that was considered perfectly proper, and was highly profitable. Several American captains inflicted great damage on the shipping of the British Channel and the North Sea. Among these was Paul Jones, who in the Bon Homme Richard ( 1779 ) engaged in a fierce and bloody contest with the Serapis, conquering his antagonist but losing his own vessel.

After 1778 the war on the ocean assumed a different character on account of the French. Possessed of a powerful navy, she joined to this the navy of Spain, making an alliance with that nation for the purpose of expelling the English from Gibraltar, and invading the British Isles. A year later England declared war against Holland, because that country had indirectly given sympathy and aid to the United States. The war against these three continental countries England carried on principally through a naval contest aimed at their colonies in the West Indies.

164. The War in the North and West (I778-1779).While at Philadelphia, Howe was superseded by Sir Henry Clinton. As his army was reduced to provide troops for the West Indies, and as the possession of the "capital" was of no value, he withdrew in June, I778, to New York. At Monmouth courthouse, he was attacked by Washington. The American van, led by General Charles Lee, an Englishman who had been highly honored by Congress, retreated at the beginning of the battle, and, but for the personal efforts of Washington, the army. would have been badly disorgan ,ized. As it was, the chance of victory had been lost and Clinton reached New York in safety. A little later an elaborate attempt to capture Newport ended in a fiasco.

Hart, Contem-

poraries,

II, No. 194 .

Victories of

Paul Jones.

Fiske, $A m$.

Revolution,

II, I2O-I3O.

Naval war after I 778 .

Fiske, $A m$.

Revolution,

II, I3O-I 62 .

Withdrawal from Philadelphia.

Lodge,

Story of liev.

I, 316-324. 
Minor events. During these years occurred the revolting massacres at Fiske, $A m$. Wyoming and Cherry valleys, perpetrated by Indians and Revolution, II, loyalists. Clinton began also a series of raids along the 85-90, 109-115. coast, burning and destroying the seaports. Brilliant and Larned (ed.), successful but comparatively valueless assaults were made Ready Ref., V, 3258-3200. by General Wayne and Major Lee on Stony Point and Paulus Hook.

Clark's conquest of the Northwest.

Van Tyne, Revolution, 280-284.

Ogg, Mississippi, $35+-367$.

Lodge, Story of Reu., II, 7-28.

The region directly west of Virginia and North Carolina and beyond the mountains had been settled gradually by pioneers led by Boone and Robertson. These had successfully repelled Indian attacks made upon them in the first half of the war, but they did not assume the offensive until I 77 S. In that year George Rogers Clark, with the sanction and aid of Virginia officials, descended the Ohio, surprised and captured Fort Kaskaskia near the Mississippi, and marched overland to Vincennes. Hamilton, the British commander in the West, with headquarters at Detroit, had already attached the Indians to the English cause. $\mathrm{He}$ again gained Vincennes, but Clark, after a heroic march in melting snow, recaptured the fort (February, I779), broke up the Indian confederacy, and established American rule over the entire Ohio valley.

\section{The Close of the IVAR (I;SO-I $7 S_{\text {I }}$ )}

Capture of Charleston $(1780)$.

Van Tỵe, Rezolution, 293-299.

Winsor (ed.), America, VI, $+69-475$.

Lodge, story' of Rev', II, $29-+2$.

165. British Success in the South ( 1780 ). - During the year $177 S$ Sarannah had been captured by the British and the strongly loyalist state of Georgia had been overrun. Clinton now decided that the chief hope of success lay in following up the British victories in the South. Taking most of the men at his disposal, he adranced from Sarannah to Charleston, to which the American commander, Lincoln, retreated, foolishly attempting to defend the town. In May, I 7 So, Charleston surrendered with its army of about five thousand, a blow that was especially serious because there was no other organized American force in the southern states. Clinton at once occupied the strategic points in the interior and threatened confiscation of 
property to all who did not take the oath of allegiance. He then left Cornwallis with about half of his army to hold the country. A violent contest broke out between the patriots and the loyalists, as the latter were now strong enough to retaliate. The American guerrilla commanders, Sumter and Marion, kept up their annoying attacks, but the British had good reason to feel that Georgia and South Carolina had been completely subdued.

A new southern army was being collected by de Kalb, who had some of I'ashington's continental soldiers and was joined by militia from North Carolina and Virginia. The command of this force was intrusted to Gates, the inefficient, although Washington wished to have Greene chosen for the position. Gates moved against Camolen, where he was met by Cornwallis (August I 5, i 780 ). Each general had attempted to surprise the other by an early morning attack. The continentals stood their ground, but the militia fled at the first fire, and the battle ended in the complete rout of the patriot army. The prospects of the Americans were indeed dim, and this time is called quite appropriately "the darkest hour of the Revolution."

I66. The Treason of Arnold (I780). - A disaster greater than the capture of Lincoln or the defeat of Gates was narrowly averted a month after Camden. Had Benedict Arnold's plan to betray West Point succeeded, even Mashington might not have been able to save the North from the fate that threatened the South. West Point was the best fortified and much the most important of the forts constructed by Washington to hold the Hudson. It had a garrison of three thousand men, and had been commanded by Arnold since July, izSo. Arnold was a brave, energetic, and efficient officer, but of overbearing manner, extravagant ways, and an unfortunate tendency to make enemies. He earned the cordial dislike of most persons with whom he associated, and had, perhaps for this reason, been promoted very tardily by Congress. In ${ }_{7} 7 S$ as commander at Philadelphia, he had indulged in a number of sharp practices

Arnold's career and failure.

Larned (ed.), Ready Ref., $\mathrm{V}, 3272-3273$.

Lecky, . $1 \mathrm{~m}$. Revolution, 403-419. 
which led to an investigation, and finally a court-martial, in both of which he was acquitted. He had already made overtures to Clinton before applying for the position at West Point. Command was given to him gladly by Washington, who believed him ill treated. The plot to betray the fortress came to light, as is well known, through the capture of Major Andre, Clinton's aid. Arnold fled and

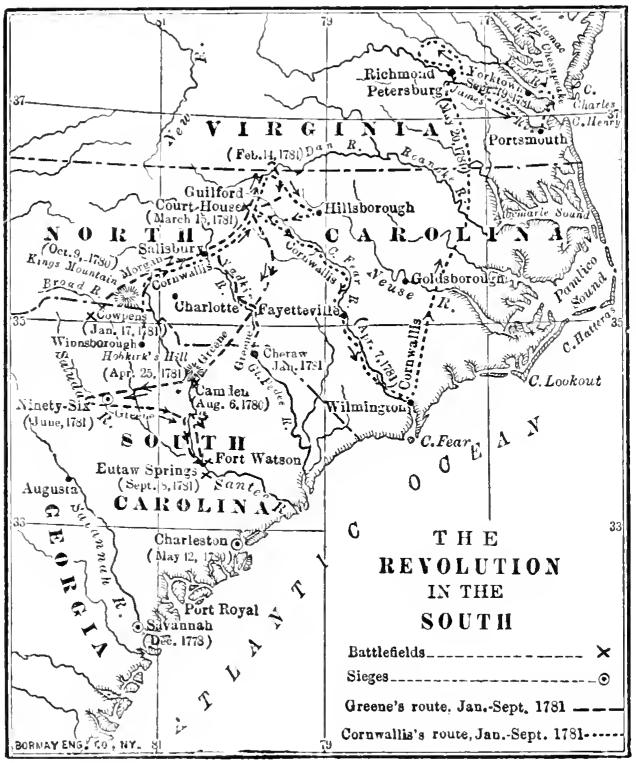

was afterward employed by Clinton in attacking and burning sea-coast towns. Andre was tried as a spy, convicted, and hanged.

Kings Mountain (I780).

Carrington; Battles, 520522 .
167. Campaigns in the South (I78o-I78I). - The tide of British success was now at its flood, but Cornwallis was destined to lose two divisions in the Carolina foothills during the six months following Gates's defeat. The first of these was a body of loyalists and regulars under a skillful partisan leader, Major Ferguson. Penetrating too far into the uplands, he was surrounded at Kings 
Mountain by several bands of patriots, who captured the British force.

Nathanael Greene was now placed in command of the The Cowpens southern army, part of which under General Morgan was widely separated from his own force. Thinking to destroy each section separately Cornwallis sent Colonel Tarleton against Morgan, who was at the Cowpens near Kings Mountain. By skillful flank movements and sharp fighting Morgan surrounded Tarleton and captured or destroyed over three fourths of his men (January I 7, I $78 \mathrm{I}$ ). Cornwallis was rapidly losing the army that he needed for the occupation of the South.

Morgan did not remain at the Cowpens, but marched north rapidly in order to join Greene. Cornwallis followed with all speed, aiming to strike before they united. He even destroyed his heavy baggage, but, as the rivers were swollen

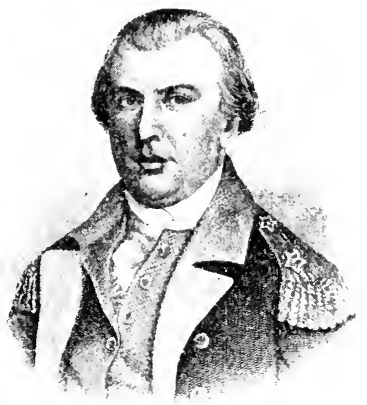

NathanaEl GReEne
(I78I).

Fiske, $A m$. Revolution, II, 252-255.

Maneuvering in North Carolina.

Fiske, $A m$. Revolution, II, 256-26I.

Winsor (ed.), America, VI, 482-487.

Reconquest of South Carolina.

Fiske, $A m$. Revolution, II, 26I-268. left by Cornwallis, but compelled the abandonment of that important center by cutting his opponent's communications. 
Winsor (ed.), In September he engaged the British in another battle at Atmerica, VI, $487-494$.

Cornwallis in Virginia.

Lecky, .tm. Kevilution, $44^{S-45 I}$.

Fiske, $f m$. Rciolution, II, 208-272.

Surrender of Cornwallis.

Leckr, tm. Rowithon, $+51-450$.

Fiske, $4 m$. Reriblats?, II, $273-286$.

Larned (ed.), keariz key. ㄱ. 327\%-3279.

Mahan,

Itutuence of Sia Puret, $35 ;-392$.

Eutaw Springs, much nearer Charleston. Again he could claim no victory, but the British as usual found it necessary to withdraw.

I68. Yorktown ( $178 \mathrm{I})$. - Meanwhile Cornwallis had reached Vircinia, where he found himself opposed by a much inferior force under LaFayette. After endeavoring in vain to bring on an engagement, since he found the people actively hostile, he withdrew to the seacoast in order to be

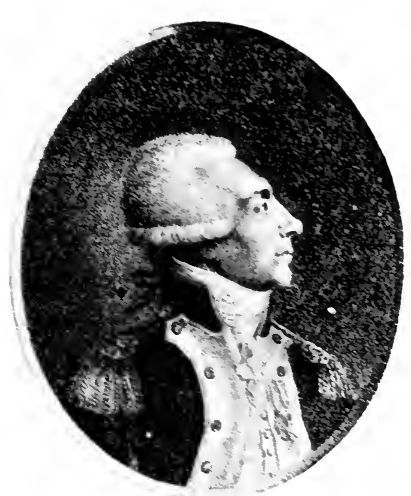

L.F.MFTRE ready to cöpperate with Clinton. Cornwallis's position on York peninsula was defended quite easily from land attacks, and seemed a safe one because the English had never been prevented from moring their armies by water whenever they pleased.

But the British commanders failed to take into consideration the French fleet under de Grasse which had been in the West Indies, but now sailed for Chesapeake Bay. Washington so deceived Clinton that he expected an attack on New York by the combined French and American armies, coöperating with the French fleet. Too late Clinton discovered that most of Washington's army was well on its way to Virginia. A fleet was sent to aid Cornwallis, but was met near the entrance to Chesapeake Bay and compelled to retire after a short naval engagement. Retreat from Yorktown was shut off now on all sides. Daily the American lines on the peninsula were brought nearer the fortifications of the enemy, and, on October If, the British outworks were taken by assault. October I Cormwallis surrendered, and two dars later his army of over seven thousand men marched out while the the band played the old English tune, "The World turned Cpside Down." 


\section{The Treaty of Peace ( $782-1783$ )}

169. Conditions affecting the Treaty of Peace. - The Problems of victory at Yorktown made further prosecution of the war England. impossible. Lord North, who, as prime minister, had carried on the war since 1778 against his own personal wishes, resigned, and Rockingham formed a new ministry on condition that the independence of America should be acknowledged. His cabinet was confronted with a very difficult task. England was at war with four countries, the United States, France, Spain, and Holland. In almost every quarter her enemies had been successful, most of all in America. England's sole hope of success lay in persuarling either France or the United States to make a separate treaty, ${ }^{1}$ as she would then be in a better position to rlictate to the others. For this separate treaty the ministry labored unceasingly.

For the United States the negotiations were conducted by three of her ablest statesmen, Benjamin Franklin, John Jay, and John Adams. They were bound by the French treaty not to conclude peace with Great Britain without the consent of France, and were seriously hampered by the instructions of Congress to do nothing without the "knowledge and concurrence" of the French king "and ultimately Van Tyne, Revolution, 309-316, 319$320,328$. to govern yourselves by their [the French ministers'] advice and opinion." As France had agreed in the treaty with Spain (I779) to continue the war until Gibraltar should be captured, and to share the American fisheries with Spain alone if Newfoundland were reduced, these instructions were in the interest of France and not of the United States. Furthermore there is no doubt that the French government

${ }^{1}$ Even with the separate treaty, success could be attained by England only with a united ministry, yet the negotiation of the treaties with the continental nations was intrusted to the foreign secretary, Charles Fox, and of that with the United States to his political and personal enemy, the colonial secretary, Lord Shelburne. To complicate matters still

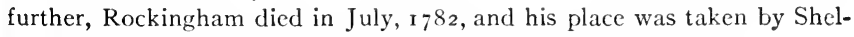
burne, who did not enjoy the full confidence of his associates. 
desired to have the Lnited States weak enough to be dependent on France for continued aid. ${ }^{1}$

American claims.

English cisims.

Negotiation of the préliminury treaty.

Lecky, tim.

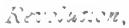
$400-4$, $4+-4=2$.

Larned ed.). ín

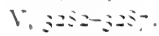

Lotge.

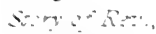
11. $200-213$.

MrLang:in. comeserasen, II - S.
I7o. Claims and Negotiations $(\mathbf{1 7 8 2})$. - The claims seriously presented by the American commissioners were four in number: ( I) complete recognition of American independence; (2) the Mississippi River as a western boundary, and on the north the Great Lakes or a line through Lake Nipissing to the source of the Mississippi; (:) the right to fish off Newfoundland; and (t) the navigation of the Mississippi River.

The English, on the other hand, wished to have the Alleghanies as the western Bundary of the United states, and did not care to share the tisheries with the Americans. They insisted that there could be no peace until the Lnited States agreed to pay all debts due to British merchants in I $_{\text {is }}$ and to compensate the loyalists for losses sustained during the war. They intended to acknowledge American independence, but held the acknowledgment in reserve with the hope of trading it for valuable concessions. With remarkable skill and good fortune. Franklin opened the negotiations for peace by peruading the English secretary, Lord Shelbume, to select as England's representative, Richard ()wald, an unsuspicious, open-minded man, easily intuenced by the great philosopher. Through $\mathrm{O}$ swald he succeded in obtaining recosmition of almost all the American clams before the arrival of fay from Matrid in July. Iタ:. On account of his experience in Spain. Jay hat grown distrustiul of all Europeans, and declured that he would not proced until the independence of the Cnited states was acepted as the bas of the treaty rather than as one of its provisions. Shelburne expressed his willingness to do this. on condition that we make a separate treaty. When Franklin asked Jay if he would break his instructions (1) follow the advice of the French ministers. Jay replied, "as readily as I break this pipe." throwing the fragments

Brance also which to have the American boundaries limited to the Alleghanies. See map oggosite g. Is. 


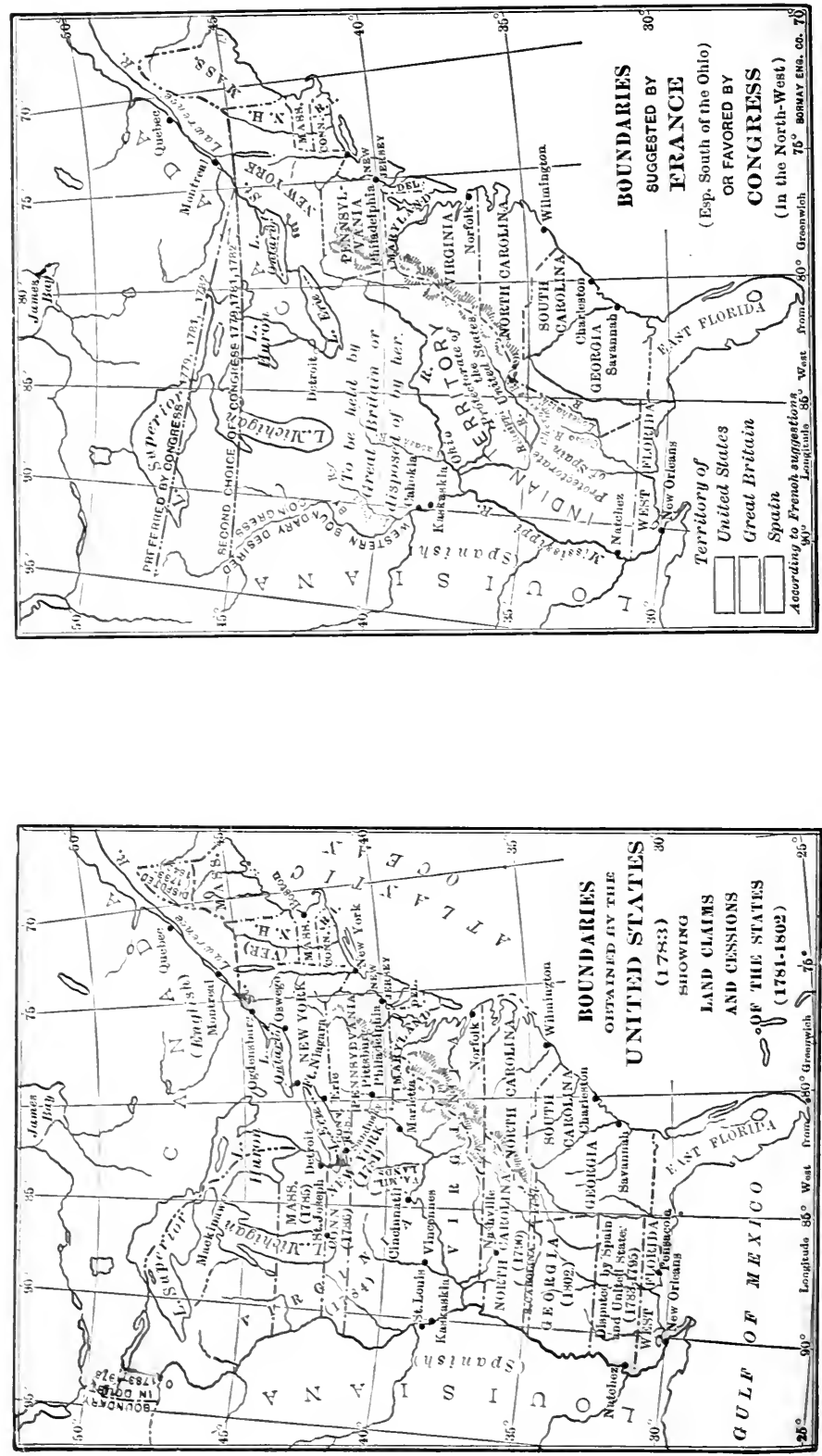
into the fire. With the aid of Adams, who became the champion of the American fisheries, negotiations now proceeded, and a preliminary treaty was signed November 30 , I782, without the knowledge of the French. This was, however, to become operative only when accepted by parliament and when the French and the English agreed upon terms of peace. Although rejected by parliament, on September $3, I_{7} 8_{3}$, a new treaty almost identical with that of 1782 was signed at Paris.

I7I. Provisions of the Treaty of Peace (I783). - In the opening section of the treaty, Great Britain acknowledged the independence of the United States. The boundaries agreed upon were as follows: on the north from the mouth of the St. Croix to the source of that river, north to the highlands that separated the rivers flowing into the St. Lawrence from those flowing into the Atlantic Ocean, along those highlands to the Connecticut River, parallel 45 to the St. Lawrence, the middle of the St. Lawrence and the Great Lakes to the Lake of, the Woods, and thence to the source of the Mississippi, ${ }^{1}$ on the west, the Mississippi River to parallel 3 I , and on the south parallel $3_{1}$ to the Chattahoochie River, and along the present north boundary of Florida to the Atlantic Ocean.

The people of the United States were to have the right to fish off Newfoundland. Creditors were to be paid bona fide debts in sterling money. Congress was to recommend to the state legislatures restitution of all estates, rights, and properties to loyalists, and the treaty declared that there should be no further persecution of that class. The British armies were to be withdrawn at once from all posts in the United States, no negroes being taken with them. Finally, the navigation of the Mississippi was declared to be free to subjects of both countries. The greatest victory of the Revolution had been won, not by armies in America, but by statesmen in Europe.

1 "A due west course to the river Mississippi." It was supposed at that time that the source of the Mississippi was north of the latitude of the Lake of the Woods. Later it was discovered that it was almost directly south. 
Problems of union and independence.

First period of the war $\left(1775^{-1777)}\right.$.

Second period of the war $(1778-1783)$.
I72. Summary. - The war between the colonies and Great Britain made independence inevitable during the second year of the conflict. Although the colonies were united from the beginning, the union was represented until I 78 I solely by Congress, which exercised less authority year by year. With a large percentage of the people loyal to Great Britain, the political leaders were obliged not only to form a national government but to organize state governments, create an army on limited financial resources, secure recognition of the United States abroad, and finally make peace on farorable terms.

During the first year of the war all battles were confined to New England or the northern border. When in the summer of 1776 the theater of action was transferred to the middle states, the English armies began a serious struggle for the control of the Hudson, and incidentally the Delaware. Gaining a foothold on New York, which was maintained to the end of the war, the British occupied New Jersey until repulsed by Washington, and sought in 1777 to gain control of the Hudson and of Philadelphia.

With the failure of these plans and the French alliance, the English generals began active campaigns in the South. Although attended by success at first, they lost gradually all the southern colonies that they had occupied until, after Yorktown, they held only Charleston and Savannah. When peace was made, everything seemed to favor the American commissioners, who gained extensive territories in the West, besides the concession of almost all other demands except those relating to commerce with Great Britain.

\section{TOPICS}

I. The Loyalists: Winsor (ed.), "America," VII, pp. I852I4; Van Tyne, "Loyalists in the Revolution;" Flick, "Loyalism in New York."

2. Burgorne's Campaign (I7/7): Fiske, "American Revolution," I, pp. 262-3+3; Lodge, "Story of the Revolution," I, pp. 228278 ; Carrington, "Battles of the Revolution," pp. 303-354. 
3. The Treaty of Paris ( $\left.{ }_{7} \delta_{2-\text { I }} \delta_{3}\right)$ : Winsor (ed.), "America," VII, pp. 89-165; Lee (ed.) (Veditz and James), "North America," VI, pp. 423-442; Bigelow, "Franklin," Part III, Chapters III-V; Pellew, "John Jay," pp. I 44-228.

\section{STUDIES}

I. Loyalists at the beginning of the Revolution. (Howard, "Preliminaries of the Revolution," pp. $313-326$.

2. Struggle for Lake Champlain ( 1776$)$. (A. T. Mahan in Scribners, XXIII (I898), pp. I47-I60.)

3. New York and the independence movement. (Van Tyne, "Revolution," pp. 88-95.)

4. Battle of Long Island. (Carrington, "Battles of the Revolution," 199-219.)

5. Finances of the War. (Lee (ed.) (Veditz and James), "North America," VI, pp. $4+33^{-456 .)}$

6. The genius of Franklin. (W.MacDonald in Atlantic Monthly, Vol. 96 (1905), pp. $450-462$.

7. Arnold's career $\left(I_{j} \gamma^{-1} \boldsymbol{I}_{j} \mathrm{~S}_{\mathrm{I}}\right)$. (Fiske, "American Revolution," II, pp. 206-239.)

8. Battle of Kings Mountain. (Lodge, "Story of the Revolution," II, 56-66.)

9. French influence over Congress. (Pellew, "Life of John Jay," I $24^{-1} 27$, I $50-165$.)

ı. Jay's suspicions of France. (Pellew, "Life of John Jay," pp. I 79-200.)

II. The military ability of Washington. (Ford, "True George Washington," pp. 27t-292.)

I2. Meaning of the Revolution. (Lodge, "Story of the Revolution," II, pp. $224^{-2+8}$.)

\section{QUESTIONS}

I. Why did the Americans desire to gain possession of Canada? What plans were suggested to that end? Why was the failure of the expedition of I 775 not an "unmixed misfortune"?

2. Were the Americans fighting the battles of English freedom? Was independence inevitable? How far had the desire for separation spread by April, I 775 ? by July, I 776 ? What effect did the Declaration have on parties in the United States? on our standing abroad?

3. Make a study of the Declaration. What do you think of the bases of the argument in $\$ 2$ ? of the argument itself? Point out what reasons were illegal in English law; which were contrary to colonial practices before $1_{7} 63$ ? Did the Declaration make the states independent individually, or collectively? 
4. What was the importance of the first state governments (a) in our constitutional history? (b) in reference to independence? Why were the legislatures predominant during the quarter century following $17 ; 0$ ?

5. What does the proportion of the loyalists show as to the feeling of the colonists regarding the war? What rights had the Tories? Was the policy of the states toward the loyalists after I-S I wise?

6. Name the different sources of congressional revenue during the war. Why did not Congress lery duties on imports? What difficulties did it cncounter in borrowing? Discuss the wisdom of issuing continental currency.

7. What causes produced the French alliance? What obligations were imposed on each side by the alliance? What was the difference in the conduct of the war, feeling of the people, and theater of action before the alliance and after?

s. Of what value to the British was the control of the Carolinas and Georgia? What territory was controlled by the British, March I, $\mathrm{I}_{7} \mathrm{~S}_{1}$ ? Nowember $\mathrm{I}$ of the same year?

o. Compare the reasonableness of the British and American claims. Compare the claims with the provisions of the treaty. How do you account for American success?

10. Give in outline a history of the international changes of territory from 1054 to $\mathrm{I}_{i} \mathrm{~s}$ 


\section{CHAPTER IX}

\section{CREATION OF A GENERAL GOVERNMENT $\left(\right.$ I $\left.78_{\text {I }-I} 789\right)$}

\section{Articles of Confederation}

173. Formation of the Confederation.-In June, I776, when the movement for independence was well under way, Congress appointed a committee of one from each state to draft articles of union. The first report of this committee was made by the chairman, John Dickinson, on July i 2, I 776 , but the question of completing a confederation was treated with indifference by most of the delegates, and it was not until November, I777, that Congress agreed upon Articles of Confederation.

These articles were to go into effect when ratified by all of the states, but three and a half years elapsed before the last of the states gave her consent. During this interval the old Congress, with its powers undefined, and its authority growing less year by year, cared as best it could for the interests of the United States. By February, I 779, however, only Maryland had neglected to sign, and for two years the little commonwealth refused until Virginia promised that her claims to the land northwest of the Ohio River ( $\$ 180$ ) should be surrendered to the central government.

I74. Provisions of the Articles of Confederation.--The government of the United States under the Articles consisted of a Congress composed of not less than two nor more than seven delegates from each state. There was no separate executive or judiciary. Congress had the right to make treaties, and in fact took charge of all foreign affairs, but it had no authority whatever to enforce any article of a treaty which a state refused to respect. Congress was per-
Proposal in Congress. Van Tyne, Revolution, I $83-186$, $198-202$.

Amer. Hist. Leaflets, No. 20 Ratification by the states.

Curtis, Const'l Hist., I, 86-97.

Composition and powers of Congress.

Fiske, Critical Period, 93-98. 
MacDonald, Documents, No. 2, Arts. V, VII-X.

State and interstate regulations.

Nature of the Confederation. Fiske, Critical Period, 98-ror.

Curtis, Const'l Hist., I, 98-I03. Hart, Contemporaries, III, Nos. 39-4I.

Importance of the Confederation. mitted to declare war and make peace, to construct a navy, to organize an army, to borrow and issue money, and to make requisitions on the states for sums sufficient to pay all current expenses. When a vote was taken, each state had one vote, and the support of nine states was required for all measures of importance. Congress was also the court of final resort in interstate disputes.

The attempt was made by the framers of the Articles to render these powers effective by prohibiting to the states the sending of ambassadors, the making of treaties, the laying of duties which violated any treaty of the United States, and the making of war. One especially valuable article provided for the establishment of an interstate citizenship, making it possible for a citizen of one state to become a citizen of another by a bona fide residence in the latter.

I75. The League of States formed under the Articles of Confederation was in no sense a nation. The states were as yet unwilling to establish a true central government or give Congress the powers necessary to secure an international standing and to gain respect at home. The union was crude and unsatisfactory. As has been well said, the Confederation seemed to have been designed to accomplish a minimum of result with a maximum of effort.

Jealousy of any government which exercised its rule beyond the limits of any one state led the states to assert their separate sovereignty and independence. In every way the union was sacrificed to the states, because of their deep-seated dread of a government that was not local. Yet when we consider the situation, the intense spirit of localism, the narrowness that marked many of the political actions of the people, the fear of oppression through union which was constantly present during colonial times, and the inexperience in forming a legal union of the states, we cease to wonder that the Confederation was so imperfect. Indeed, if we compare the Congress of the Confederation with the Second Continental Congress, considering that the latter was exercising war powers without any direct legal 
authority, - powers that in time of peace might disappear entirely, - we can realize perhaps that the Confederation was a more perfect union than the one existing in 1776 .

I76. The Amendment of the Articles of Confederation. No amendment of the Articles was to become a part of that document until ratified by all of the states. For this reason the imperfections which were inevitable in any first government, and especially marked in the Confederation, could not be eradicated easily. The Confederation was in consequence short-lived.

Since no government can long maintain its authority on an insufficient revenue, the most serious need of amendment was noticeable in connection with the finances. Congress had exhausted its paper money early in the war ( $\$$ I 53). It was not allowed to levy taxes, and was able to borrow very little abroad ( $\S$ I $\left._{52}^{2}\right)$. Prac-

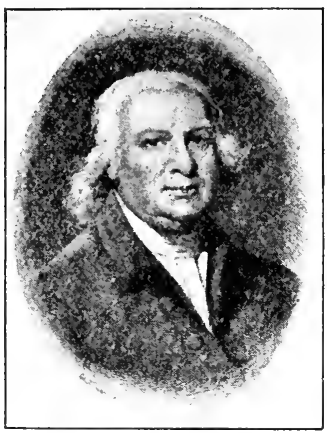

ROBERT MORRIS tically therefore its sole resource was the requisitions made on the states. As these were paid with increasing reluctance and in decreasing proportions, Congress tried twice to amend the Articles. On February 3, I78I, it asked that Congress be allowed to collect a five per cent ad valorem duty on imports to be used exclusively for the interest and principal of the public debt. To this all consented except Rhode Island. The second proposed amendment, accepted by Congress April 30, I 783 , provided for a duty for twenty five years of five or more per cent on seven enumerated articles, to be applied to the interest only of the public debt. It took four years to gain consent of twelve states, and the thirteenth, New York, finally refused to ratify the amendment.

If it was impossible to obtain a legal change in the Articles when the need was so great, we can see that the Articles

Dewey, Finan. iial Hest.,

$\$ \$ 21,22$.

Curtis, Const'l Hist., I, I57 I67.

Amer. Hist.

Leaflets, No. 28.

Financial amendments. 
Temporary character of the Articles.

Dangers and problems.

McLaughlin, Confederation, $39-46,55-60$.

Fiske, Critical Period,

142-147, I89.

Complaints of the soldiers.

Fiske.

Critical Period, IO5-IIt.

McLaughlin, Confederation, 59-68. were unsuitable for a permanent constitution, and would of necessity be replaced by a more satisfactory document in the course of a few years.

\section{The Critical Period ( $778 \mathrm{I}-\mathrm{r} 787$ )}

I77. Critical Conditions. - The period following the establishment of the Confederation has very properly been named "the critical period of American history." The union produced by the struggle for independence was to be tested by the much more trying problems of peace. Jealous of one another, yet not daring to separate; burdened by debts, with resources greatly impaired by the war, the states were forced to make good their claim that they were capable of the self-government they desired - a task that was especially difficult because the revolt against British domination had developed a spirit of protest against authority of every kind. Still more serious were the refusal of the states to subordinate their interests to those of the Union and the difficulties of coöperation among the states. Foreign powers refused to treat with a people who formed "one nation to-day and thirteen to-morrow." The vast territory beyond the Alleghanies, in which the claims of the states overlapped, was a perpetual menace to continued harmony. Trade between the states was in a most chaotic condition, since each regulated its commerce to its own advantage. With good reason might European statesmen believe that the new republic would be dissolved within a few years.

178. The Old Soldiers. - Not the least of the dangers feared by the people at the close of the war was the continental army. To us these fears seem almost without foundation, but there was a chance that in the disordered condition of affairs, the army, which was the only well-organized body in America, might seize the reins of power. The soldiers felt that they had been treated badly and were dissatisfied on account of the failure of Congress to pay them promptly. In $I 7 \delta$ I two regiments had revolted because 
they thought Congress had broken faith with them, and Congress was driven from Philadelphia in June, $I 783$, by a company of half-drunk and mutinous soldiers. To this was added the popular distrust caused by the Newburgh address - an anonymous appeal to the officers of the army to seek redress for neglect and wrongs. Although this came to nothing, on account of the tact and wisdom of Washington, it increased the dread of military interference.

The army was disbanded in June, $\mathrm{I}_{7} 8_{3}$, the soldiers being paid in paper money. Before separating, the officers orSociety of the Cincinnati. ganized a society called the order of the Cincinnati, very unwisely providing that at the death of any member his place should be taken by his eldest son. So great was the indigHart, Contemporaries, II, No. 218. nation manifested everywhere at this attempt to establish a so-called aristocracy that the objectionable feature was soon dropped. In point of fact the organization does not seem to have exerted a very marked influence over the politics of the succeeding years.

I79. Land Claims of the States. - During the period of the Confederation the West exerted a constant influence on the policy of the United States. Although by the Proclamation of I $_{7} 6_{3}(\$ 94)$ settlements had been prohibited west of the mountains, and by the Quebec Act (I 774) (\$ I 37 ) the territory northwest of the Ohio River had been granted to the province of Quebec, no less than seven states laid claim to western lands." By virtue of "sea to sea" charters, four of these, Massachusetts, Connecticut, North Carolina, and South Carolina, claimed the western belts included between their northern and southern boundaries prolonged to the Mississippi. Virginia asserted her title not only to the lands west of her but north of the Ohio as well, because her charter of I609 included the phrase "from sea to sea, west and northwest."

New York claimed the territory between the Ohio and the Great Lakes, because the Iroquois, who kept in subjection

Fiske, Critucal Period, I I4II9.

Claims based on charters.

Fiske,

Critical Period, I89-I9I.

Hinsdale, Old Northwest, I 88-196.

Donaldson, Public Domain, $30-55$.

${ }^{1}$ The map opposite p. 185 indicates these claims more definitely and accurately. 
the Indians of that region, had by treaty conferred upon New York their claims to its jurisdiction. Georgia asserted her right to the Southwest because in 1764 royal instructions had extended her jurisdiction over this region.

Validity of the claims.

Attitude of Maryland.

Amer. Hist. Leaflets, No. 22, I- 8 .

Fiske, Critical Period, I9I-I93.

Donaldson, Public Domain, 6o-63.

Hinsdale, Old Northivest, I97-2I7.

Cessions by the states.

The validity of these claims was questioned with good reason by the states that held no western lands. Not only had the charters been granted in ignorance of the geography of America, but with a single exception, that of Connecticut, these charter grants had been revoked. Moreover, Great Britain, by the Quebec Act (I 774), had shown that none of the older colonies could claim jurisdiction of any western lands in the North.

I80. Land Cessions (I78I-I802). - As early as I778 Maryland protested against the recognition of these claims, which she deemed extravagant and unjust. New Jersey and Delaware, when joining the Confederation, expressed the hope that the large states would be willing to curtail their western boundaries, but Maryland waited for the states, especially Virginia, to give up their claims before she signed the Articles. She felt that her future was jeopardized by her neighbor's ability to sell cheap lands and thereby reduce Maryland's population, which would be drawn off by the low taxes of Virginia or to the fertile valleys of the West. She took the broad, patriotic view that the western lands "if wrested from the common enemy by the blood and treasure of the thirteen states, should be considered as a common property, subject to be parcelled out by Congress into free, convenient, and independent governments." To meet the objections of Maryland, and to remove the very serious dangers arising from interstate strife over conflicting claims, Congress, on September 6, I 780, urged the states to transfer their western land claims to the United States. When assurances were given that this would be done, Maryland joined the Confederation, March I, I $78 \mathrm{I}$.

That same day New York ceded her western lands to the United States, and three years later Virginia gave up all claim to territory northwest of the Ohio except for certain 
military lands along the Ohio River. In I 785 Massachusetts yielded her claims to lands beyond the present western boundary of New York, and the next year the Connecticut cession was completed, a strip along Lake Erie, known in history as the "Connecticut Reserve," being retained by the state until I80o. South Carolina ( ${ }^{7} 787$ ) gave up her claim to a belt about thirteen miles wide, and in I 790 North Carolina yielded to the United States the jurisdiction of what is now Tennessee, most of the lands having already been granted to private parties. Not until I 802 did Georgia formally cede the last of her western lands, the delay being caused by disputes over certain "Yazoo claims," lands irregularly granted by the Georgia legislature.

I8I. Ordinances for the Government of Western Territory. - Long before these cessions were completed, Congress adopted, April 23, I784, resolutions proposed by Thomas Jefferson for the government of all the western territory ceded or to be ceded by the various states. Small states were to be formed and admitted to the Union as soon as their population equaled that of the least populous among the original states. They were to have republican governments and were to remain forever a part of the United States. ${ }^{1}$ No attempt was made to put this plan into operation, and the real territorial system of the United States dates from the much more famous Ordinance of 1787 . In that document are contained the principles of territorial government which the United States has used with slight modifications from that day to this. The territory was to be governed temporarily in one or two districts by a governor, a secretary, and judges selected by Congress, but when each district

Amer. Hist.

Leaflets,

No. 22, 9-37.

Fiske, Critical

Period,

193-196.

King, Olio, I67-I72.

Hinsdale, Old Northaest. 218-246.

Donaldson, Public Domain, $65-88$.

Ordinance of I784.

Fiske, Critical Period, 196-199.

McLaughlin, Confederation, IIt-II7.

Alner. Hist. Leaflets, No. 32. Ordinance of I787.

Fiske, Critical Period, 203-207.

McLaughlin, Cunfederation, I $18-122$.

1 These resolutions followed in the main the suggestions made by a committee of which Thomas Jefferson was the leading member. Although the resolutions applied to all western territory, it was quite evident that only that in the Northwest was contemplated seriously, since names were puggested for states in that region alone. These names were finally mitted from the resolutions, as was also a clause prohibiting slavery in Ill the western territory after 1800 , this antislavery clause being favored y only six out of the ten states represented in Congress. 
contained five thousand free male adults, there should be a representative assembly. Not less than three nor more than NacDonald, five states were to be formed from the territory, as soon as Documents, No. 4. each contained not less than sixty thousand free inhabitants. None of these states were to be separated from the Union, perfect religious liberty was guaranteed, and civil rights were assured the inhabitants. Most interesting of all, there was to be "neither slavery nor involuntary servitude in the said territory, otherwise than in the punishment of crimes, whereof the party shall have been duly convicted" - a phrase that was to become famous in American history. By this article and one which provided for a land system much simpler than that of colonial times, the Ordinance of I 787 exerted an inestimable influence on the later development of the Northwest and of the nation.

Siavery in the Southwest.

Donaldson, Public Domain, I6I-I63.

Settlement of the West.

Fiske, Critical Period, 199-202.

McLaughlin, Confederation, 128-I37.

Navigation of the Mississippi.

Fiske,

Critical Period, 207-2II.
Jefferson was unable to extend his liberal antislavery ideas to the territory southwest of the Ohio, for, when Congress accepted the cession of North Carolina (I790), it agreed that "no regulations made, or to be made, by Congress shall tend to emancipate slaves." Except in this particular, the Ordinance of ${ }_{7} 787$ was extended to the public domain in the South.

182. The West and Foreign Affairs. - In the years following Yorktown there had been a great exodus through the passes of the Alleghanies into the fertile valleys of eastern Kentucky and Tennessee. These hardy pioneers had a thinly veiled contempt for the inefficient Congress, and when, in I784, North Carolina offered to cede Tennessee to the United States, the settlers took the law into their own hands and organized the state of Franklin. North Carolina thereupon withdrew her offer, and after two years of fighting reëstablished her control in eastern Tennessee.

The same spirit that opposed government by a Congress which could give no protection led those westerners to resent interference by Spain with the free navigation of the Mississippi. Spain was displeased with the extension of United States territory to the Mississippi, and had just cause for 
complaint in the restriction of the West Florida boundary to the thirty-first degree. ${ }^{1}$ Spain now closed the entrance to the Mississippi, and seized the stock of an American trader who had descended the river as far as Natchez. The story of his loss aroused the rough and ready pioneers, who sought to retaliate. Their anger was inflamed still more when they learned that John Jay, the secretary for foreign affairs, had agreed that the Mississippi should be closed for twentyfive years in return for a commercial treaty with Spain which would open to our ships a profitable trade with the West Indies. The South heartily espoused the cause of the West against the commercial North, and the treaty was never completed.

183. Relations with Great Britain were strained during the Confederation because of commercial difficulties and the failure on both sides to carry out the treaty of peace. The English army had carried off many negro slaves and refused to surrender the forts south of the Great Lakes, as British fur traders were unwilling to give up the lucrative trade of that region. On the other hand several states passed laws which prevented British creditors from collecting debts incurred before the war. A larger number took especial delight in persecuting the loyalists who remained in the United States or sought to return. Many loyalists were disfranchised. Estates which had been left untouched in the war were confiscated, and damages were sought for the property of patriots which had been in the possession of the enemy in New York and other places. In South Carolina loyalists were compelled to emigrate, and many who

Failure to observe treaties.

Cambridge Mod. Hist., VII, 307-308.

Fiske, Critical Period II $9-133$.

Van Tyne, Revolution, $256-268$.

Hart, Conteme poraries, III, Nos. 47,48 .

${ }^{1}$ In the preliminary treaty of peace ( 1782 ), Great Britain and the United States agreed in a secret article that if Great Britain retained West Florida, the northern boundary of the province should be the parallel passing through the mouth of the Yazoo River as theretofore; but if it was trans'ferred to Spain, the boundary should be parallel $3 \mathrm{r}$. At that time this intermediate territory was controlled absolutely by Spain. When the secret article became known, Spain was greatly incensed; but in 1795 she agreed to the thirty-first degree as the boundary between the United States and Florida. 
refused were kifled. Probably one hundred thousand persons left the country for Lingland or the British colonies during the wat and the years succeding. As these refuares were unable to secure compensation from the state legistatures for their losses, the british government appropriated a large sum of money for them, besides giving them help in ofher walys.

A(tompt to) secolto at commercist treaty.

rizmbidse 1hit. Hist. VII. $3(x) \leqslant 10$.

Mal anshlin, cimticterasm, II) $=107$.

liske,

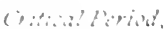
I 3 - 14 t

H.unt. (int:mA

$111, x 0 s .50-53$.

Puper money

lickitl :

Wiedin (1-50).

(a) a is 18: Has. 111, 312-313. Fiske,

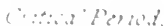
$10=-102$, $108-1,7$.

These violations of treaty obligations and acts of violence not only caused ill focling, but stood in the way of a commerial treat! with Great Britain which we desired greatiy. In making the treaty of peace in $17 S_{3}$, no commercial agreements were made hy the two nations. In consequence lingland prohibited trate with the British West Indies eveept in English ships and also restricted a large part of the commere with the british Isles to English ships. This policy she would not change because her minister claimed that we could make no concessions of value to them. Before 1,70 we had protested against the British navigation acts bealuse they prevented our colonial trate with foreign countrics: after that date we objected to them because they interfered with tratde between the United States and British dependencies. Many Americans desired by retaliation to force (ireat britain into granting us trade advantages, but this wats impossible, for Congress had no power to place restrictions on English commeree that would be uniform throughout the United States, and several of the states sought to attack English trate by lerving duties on goods brought from Great Britain.

I84. Internal Disorder. - Although times were fairly prosperens in spite of state jealousy and foreign difficulties, most of the rash had heen exported to pay for goods bought abroal. There hat been so much speculation following the chese of the war that debts were heary and discontent rife. For relief the debtors demanded issuance of large sums of paper money. This was granted in seven states. Of necessity the currency depreciated, and aggravated the crils. In Rhode Island the legislature passed an 
act forcing men to take the almost worthless pajer. A butcher named Weerlen refused to do this and appeaterl to the courts, which declared the force art unconstitutional (I786). Amid great excitement, at a special scosion, the legislature removerl the olmoxious jurlges. 'This was the first conspicursus case in which a cosurt rlectared null and voirl an aret of a legislature.

In Massachusetts the hard money party prevailerl, but the advocates of a pajer currency attarkerl the lawyers and closed the courts that harl been instrumental in enllect ing detsts. Led by I aniel Shays, formerly a captain in the American army, the rirters gained prostessiron of Worcester and towns to the west. At length, being short of arms ard ammunition, they attacked the arsenal at Sipringfielrl. They were finally defeated by the militia under (jeneral Lincroln ( 1787 ).

Meanwhile, the states were beroming more and more in. censerl with one another on account of commercial differculties. These that hard seaperts torek unfair ardvaritageof their neighbrors, levying unjust and unneressary duties. New Jersey was compared to a cask tapperd at broth ends. Connertirut was on bard terms with forth Massar husetts and New Yort.. Some of the states impresed speerial restrictions on forcign commerce, some inviterl foreign trade hy removing all duties. Affairs were in a chartic condition and becoming worse.

All of this disorder convincerl jeesple who harl hitherter been indifferent that the authority of the state government: must be uphelel in enforcing the law, and that a stronger central government was absolutely necessary. The country was in a prosperous condition on the whole; the people were becoming more united and realizing their dejendence on one another, the churches were taking stejs toward perfecting national organizations, but a new government was required for the United States, and many believerl that the Articles of Confederation should not be allowed to stand in the way.

Shays's

Rerter:Hiren.

Hart, cistemporares,

III, is. $5 \%$

Me. J aughtion.

confoderalesn, $157-167$.

Iriterstate traele revienteros.

ritive,

crelecalleresd $144^{-1.47}$

Nefest of a strengg uniron.

Hart, Conlemforarle: III, Nos, 54, $55.57,55$. 


\section{Formation of the Constitution ( $1787-$ I 788 )}

Meeting of the 185. The Annapolis Conference. - As nothing could conference. be done under the existing Confederation toward remedying these defects, an earnest attempt was now made, under

Fiske,

Critical Period, the lead of Alexander Hamilton and James Madison, to 213-218.

obtain new articles of union. Their opportunity arrived when in 1786 Virginia and Maryland were discussing a

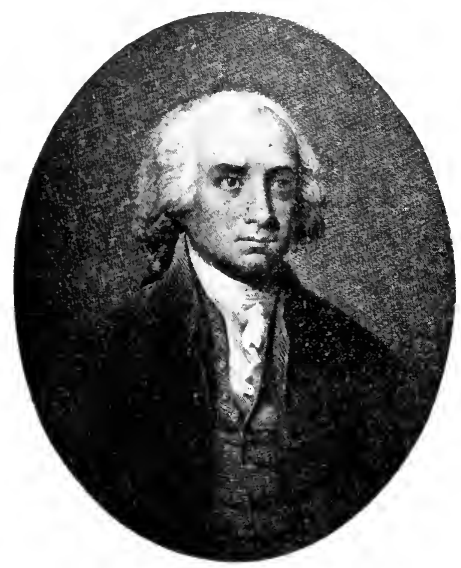

JAMES MADISON system of tolls and commercial agreements for the Potomac River. Delegates from all of the states were invited to join representatives from these two at Annapolis, Maryland, and discuss ways of improving commerce between the states. Nine of the states appointed ccmmissioners, but only five were represented at the conference. Unable to transact any business of importance, and believing

McLaughlin, that the time had come for decisive action, these men Confederation, I72-183.

adopted a resolution offered by Hamilton urging the state legislatures to select delegates for a constitutional convention which should revise the Articles of Confederation.

Spring of I787.

Congress was asked to indorse this convention, but refused. Without waiting for the sanction of that body, the state legislatures began to appoint representatives. When

Fiske, Critical Period, a majority of the states had taken this step, Congress yielded 220-222. so far as to call another convention to meet at the same time and place. During this winter of $\mathrm{I}_{7} 86-\mathrm{I} 787$, the defeat

Curtis, Const'l Hisl., I, I75-I85. of the second amendment of the Articles ( $\$ 176)$, and the anarchy accompanying Shays's rebellion, roused people to the need of a new and better constitution, so that the sum- 
mer of 1787 was a propitious time for changing the fundamental law of the United States.

I86. The Connecticut Compromise. - At the old statehouse in Philadelphia, where the Declaration of Independence had been signed, the delegates to the convention gathered in May, I787. Many leaders of the revolution were there, among them Washington, Franklin, John Rutledge, Charles and C. C. Pinckney, Roger Sherman, and Robert Morris. But the work before them was performed to a greater degree by younger and perhaps less known men. James Madison, the author of the first outline, and Gouverneur Morris, the writer of the final draft, of the Constitution, were among the younger members, as were also Alexander Hamilton and James Wilson, the most ardent advocates of a strong government in America. It is probably the ablest body of men that ever assembled in this country. Its members represented many views and classes. A few placed local interest and state pride before all else, a small number would have sacrificed every hope of a better government because too narrow-minded for such a great undertaking, but the majority earnestly strove to subordinate personal preferences for the public good.

Before many sessions had been held, the delegates began to arrange themselves in two groups or parties. The larger of these favored a new Constitution, with a Congress of two houses, a separate executive and judiciary, and a very great increase of national power. The other wished to revise the Articles of Confederation, giving Congress power to levy duties and internal taxes, and allowing that body to appoint an executive and judiciary. The latter group was composed chiefly of delegates from the small states who feared that concentration of power in the central government would be a great advantage to the larger states and correspondingly dangerous to themselves.

As the advocates of the national government were in a majority, the small-state party consented to frame a new Constitution, and began a contest for equal representation

Parties in the convention.

Cambridge Mod. Hist., VII, 2.46-249.

Fiske, Critical Period 235-250.

McLaughlin, Confederation, 192-220.

Compromise over representation. 
Fiske, of the states in the new Congress. The "national" party Critical Period, (the delegates from the large states) wished to have the rep250-255.

McLaughlin, resentation in both houses according to the population of Confederation, tion adopted a compromise, usually known as the "Con221-235.

Three fifths compromise.

Melaughlin, confederation, 257260. necticut Compromise," because proposed by the delegates from that commonwealth. Each state was to have two members in one house - the Senate - and to be represented

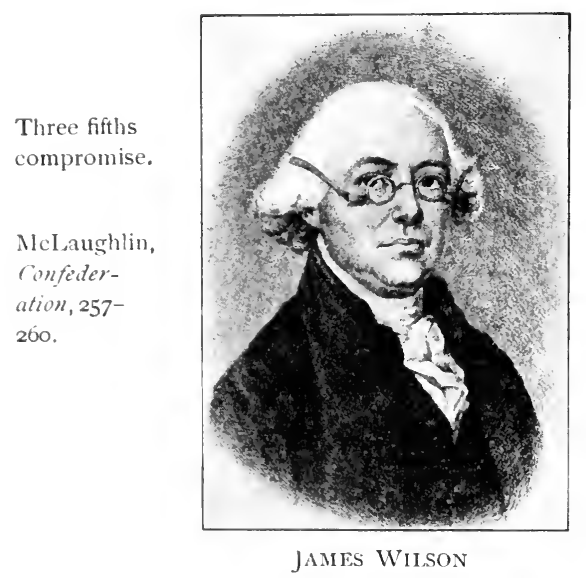
according to population in the other - the House of Representatives.

187. Later History of the Convention. - With the adoption of the Connecticut Compromise came a new arrangement of parties, for the support of the small states to the Constitution was now fully assured. Since the most important subjects over which there was serious dispute were concerned with slavery, the new parties were almost sectional, as the Fiske, North was already quite opposed to the extension of the criticalperiod, system. The first question that came up was about the 255-262.

Cambridge Mod. Hist., III, $264-269$. counting of the slaves. An enumeration of blacks was necessary for representation in the lower house of Congress and for the levying of direct taxes, which the states were to pay according to their population. As the South wanted slaves counted for representation, and the North wanted them counted for taxation, it was decided for purposes of enumeration to call five blacks equal to three whites.

Third great compromise.

A little later New England clashed with the extreme South orer the questions of navigation acts and the slave trade. The southern states, fearing that their agriculture would be sacrificed for the commerce of the North, were unwilling to give Congress the power of enacting navigation 
laws except by a two thirds vote. They likewise wished to Fiske, prevent Congress from forbidding the slave trade. The North opposed both of these measures. As Gouverneur Morris said, this was a chance for a "bargain among the northern and southern states." A compromise was finally adopted which declared that the foreign slave trade should not be forbidden before $1808,{ }^{1}$ prescribing no special majority for navigation acts, and forbidding the taxation of exports.

These compromises closed the most heated sessions of the convention, but did not lessen the interest with which for four months the members grappled with the problems before them. Finally on the $1 ;$ th of September, ${ }_{7} 8_{7}$, the completed draft of the Constitution was signed by delegates from all the states except Rhode Island, and the first and most important stage in this momentous work was completed.

I88. Feeling of the People. - The Constitution was to go into effect when ratified by conventions chosen by popular vote in the states. If accepted by nine of them, it was to be establisher "between the states so ratifying the same." But the people did not fully appreciate the evils of the Confederation, and dreaded the creation of a "consolidated" government. They feared that the president would become a dictator, and thought that the national courts would be an instrument of tyranny, especially as the Constitution contained no bill of rights, protecting the liberty of the individual. Others declaimer against the power of Congress over both the purse and the sword, urging, as did Richard Henry Lee, that they preferred a rope of sand to a rod of iron, but theșe "Anti-Federalists," although numerous, were not united.

Fortunately the advocates of the Constitution included most of the able political leaders, whose zeal never flagged until eleven states had indorsed the new Lnion. They had the sympathy and help of the commercial and conservative

Conditions favorable to ratification.

'So strong was the sentiment of the people against the foreign slave trade that action was taken long before $180 \%$, prohibiting that slave trade in that year.

ritucal Period $252-257$.

McLaughlin, Confederation, $250-255$.

Cambridge Mod. Hist., VII, 278-283.

Completion of the work.

Fiske,

Critical Perrod $301-305$.

Objections to the Constitution.

McLaughlin, Confederation: 277-2ह1, 287288. 
McMaster, classes, which were disgusted with the inefficiency of the l'nited states, I, $454^{-472}$.

Curtis, cinst'l Hist., $1,023-640$.

Final adoption. Confeclerate Congress. Among the officers of the continental army, even before the close of the war, the favorite toast had been "A hoop to the barrel." Now arose a demand for a "new roof." Processions were held and popular interest aroused in favor of the Constitution. Thinking men were convincel of the need for a new government by the able papers written by Hamilton, Madison, and Jay, which were published under the title of The Federalist. But prejudice against centralization of power was deep seated, and the Constitution was truly "drawn by grinding necessity from a reluctant people."

Schouler,

L'nited states, I, $65-79$.

McLaughlin, Confederation, $28_{3}-317$.

Compact theory.
189. Ratification of the Constitution by the States. The ratification beg:in in December, ${ }_{7} 787$, with a unanimous vote in little Delaware. With the exception of Rhode Island the small states fell into line rapidly, showing that they were satisfied with the Connecticut Compromise. In Massachusetts, Virginia, and New York fierce contests were waged. Objection was made to the "consolidated" government and to the lack of a bill of rights, but Patrick Henry argued with ability against the absolutism of the president. These states and three others proposed amendments to the Constitution when giving their consent, but the ratifications were to stand eren if the amendments failed. By the first of $\mathrm{Au}-$ gust, I 788 , all of the states had ratified except North Carolina and Rhode Island, which became members of the Union in November, I789, and May, I790, respectively. ${ }^{1}$ But Congress did not wait for them, and in September, 1788 , selected the first Wednesday, January, i 789 , as the day for the appointment of presidential electors, and the first Wednesday in March for the first meeting of the new Congress.

\section{Character of the Constitution}

190. Dispute over the Nature of the Constitution. From the very first there were differences of opinion regard-

${ }^{1}$ Rhode Island did not finally join the Union until the Senate had passed a bill prohibiting commurce with that state. 


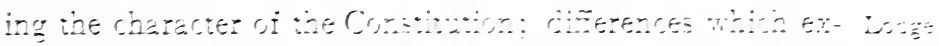

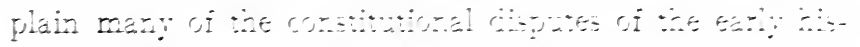

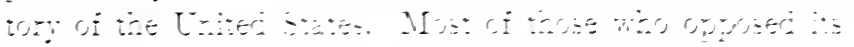

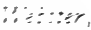

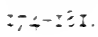

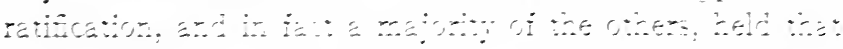

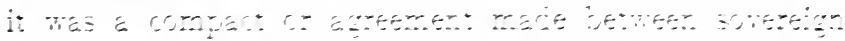

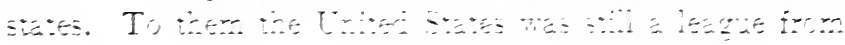

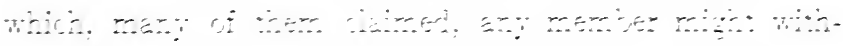

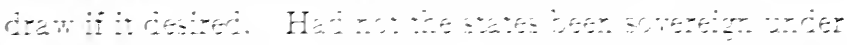

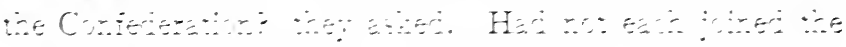

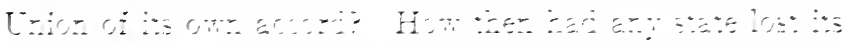

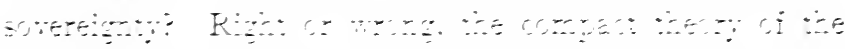

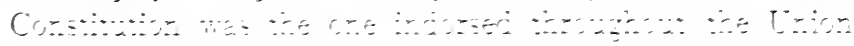

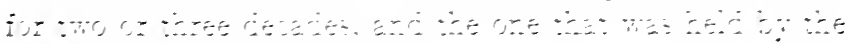

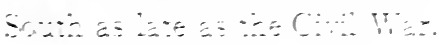

A: z, :

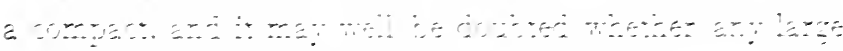

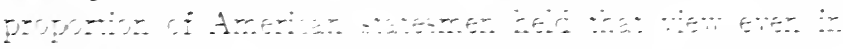

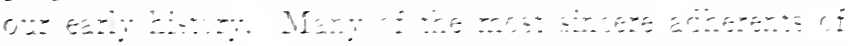

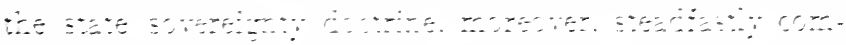

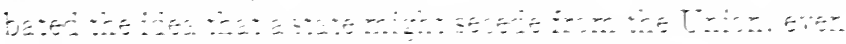

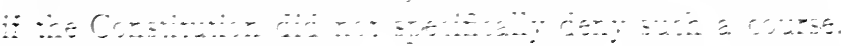

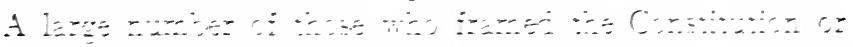

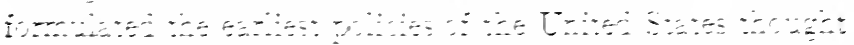

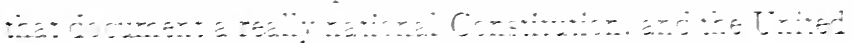

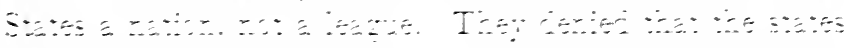

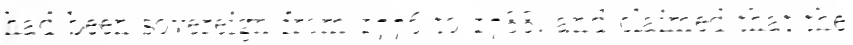

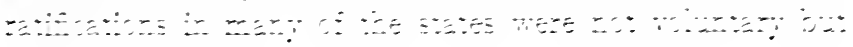

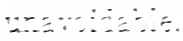

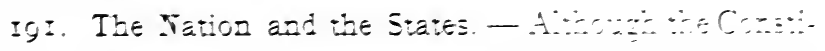
…

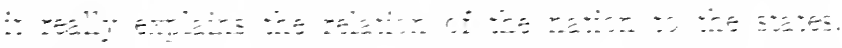

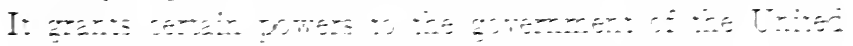

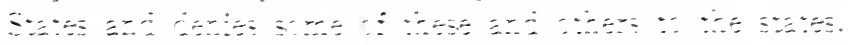

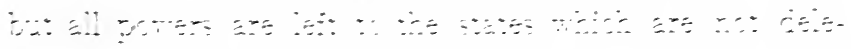

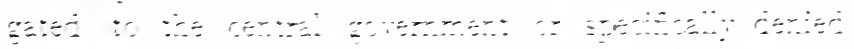

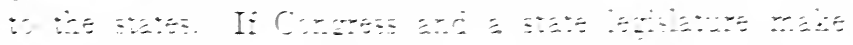

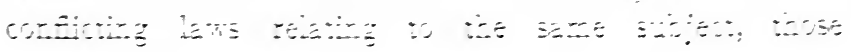

$\because=\because 2=\sum$ $\therefore=: \because$

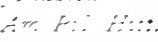
$\therefore \equiv \equiv-5$

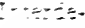

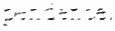

$\therefore \therefore \div$ $\therefore \because \quad \therefore$ : $2 \vdots 3-2 \%$

$\Xi \because \div \therefore$ $\therefore m, r+x=2$

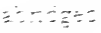

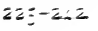


enacted by Congress prevail, for the Constitution says that the Constitution, the national laws, and treaties shall be the supreme law of the land. Yet the nation and the states are dependent on each other. The two together form a whole - each by itself an incomplete part. Neither state law nor national law alone is sufficient for our government. Ours is "an indestructible union composed of indestructible states," as Chief Justice Chase said at the close of the Civil War.

Composition.

192. Congress. - The legislative body under the Constitution is called Congress as formerly, but is composed of

Ashley, $A m$.

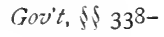
$340,3+7-35 \mathrm{I}$.

Powers of Congress.

Ashley, Am. Fed. State, $\$ \$ 301-325$.

Election.

Stanwood, Presidency, I-9. two houses, one supposed to represent the states and the other the people. For the smaller, the Senate, each state legislature elects two members for a term of six years, one third of the senators retiring every second year. Each state has at least one member in the House of Representatives chosen every two years, but its number depends on its population.

The new Congress obtained the right to make laws for all subjects which the convention thought could not wisely be left to the states, because of the disastrous effect of conflicting legislation on these topics. It has power to levy different kinds of taxes, borrow money, and regulate foreign and interstate commerce. It cares for some foreign relations of the United States, has the right to declare war, and raise an army and nary. It may coin money, make a rule for naturalization, establish post offices, grant patents and copyrights, and perform other acts permitted by the Constitution. In order that it might not be hampered by too narrow an interpretation of its powers, it has the right "to make all laws which shall be necessary and proper for carrying into execution the foregoing powers, and all other powers vested by this Constitution in the government of the United States, or in any department or officer thereof."

193. The President. - After protracted debate, the convention came to the conclusion that the president should be chosen for a term of four years and be reëligible to the office. Various methods of election were considered, 
direct popular election meeting with no favor, and election Ashley, by Congress being rejected as likely to make the executive dependent on the legislative department. The choice was given finally to electors, equal in number to the senators and representatives from each state, who are chosen in whatever way the states prescribe. It was intended originally that these electors should exercise independent judgment when casting their votes, but before many years electors found themselves obliged to vote as they were directed by the parties from which they were chosen.

The powers intrusted to the president are sufficiently great to make his position an important one and to show that Henry did not fear a dictatorship needlessly. Besides the right to execute laws in general, the president has command of the army and navy, the right of sending ambassadors, of making treaties and appointing officials with the consent of the Senate, the right to veto bills passed by Congress, and many other less important duties.

r94. The Courts. - Under the Confederation, Congress was the court of last resort in interstate disputes. It had the right also to appoint judges who might try prize cases, but there was no regular judicial system for the United States. The Constitution changed all this by providing for a Supreme Court, and permitting Congress to erect such inferior courts as became necessary. The judges in all these were to be selected by the president and Senate, holding their offices during good behavior. The jurisdiction of these courts covered cases arising not only under the national laws and treaties but under the Constitution as well, thus allowing the Supreme Court to interpret finally the meaning of any clause in the Constitution. Cases affecting states or arising between citizens of different states or between an American and a foreigner as well as cases affecting national representatives or the United States itself were to be tried in the courts of the nation.

195. Amendment of the Constitution. - The failure of the Confederation was due in great part to the necessity of a

Am. Gov't, $\oint \oint 359-365$.

Bryce, Am. Commonwealth (abridged), 22-36.

Powers.

Ashley, Am. Gov't, iई $370-382$.

Judges and jurisdiction.

Ashley, Am. Gov't, $\oint \oint 4$ II -422

Bryce, Am. Commonwealth (abridged), I67-I77. 
Method of amendment.

Meigs, Growth of Const., $272-277$.

National bill of rights (1791).

Schouler, l'nited state's. 1, $113^{-1} 15$.

Colonial and state models used.

uninimous rote of the states for all changes in the Articles. A different scheme was adopted for amending the Constitution - one which at that time seemed too flexible if anything, but which has proved much too difficult a process for ordinary use. Amendments may be proposed by two thirds of each house af Congress or by a convention called on the application of two thirds of the states. These become parts of the Constitution when ratified by the legislatures or conventions in three fourths of the states.

This method was used at once in fulfilling the promises made by the friends of the Constitution that a bill of rights should be submitted to the states. The amendments proposed by the ratifying conventions in the states were considered carefully and revised in the first Congress, twelve heing alopted hy that boly. Two of these were rejected by the states and the other ten were declared in force as part of the Constitution, December 15, 1791. The first eight enumerate rights of the individual with which the national government is not to interfere, and the tenth declares that all powers "not delegated to the United States by the Constitution, nor prohibiterl by it to the states, are reserved to the states respectively or to the people."

196. The Sources of the Constitution. - This bill of rights was to a large extent copied from those found in the state constitutions of that time, and is similar to the bills of rights of to-day. The govermment established under the Constitution proper was likewise in great measure an adaptation of a state govermment to the needs of a federal union. The president was in many ways "an enlarged copy of the state governor." His military powers, the right of appointment and of reto, followed the best practices in the commonwealths. Congress was composed of two houses like the legislatures in ten of the states. The House of Representatives was chosen by popular vote from districts, on a plan similar to that used by the assemblies even in colonial times. The plan of a continuous senate had been tried

\footnotetext{
${ }^{1}$ Ashley, "American Federal State," $\$ 55+-567$.
} 
successfully in New York, Delaware, and Virginia. The national courts, with their great power of interpreting the Constitution, were not unlike those of the states, which in several cases harl exercised the right to set aside unconstitutional laws. ${ }^{2}$ These similarities are not accidental. Most of the members of the constitutional convention had already sat in state constitutional conventions and had seen that those parts of the state constitutions workerl best which followerl the usage of the time. 'They drew constantly upon the experience of theirown states, anrl even the method of electing a presirlent was suggester by a practice employed when chorsing senators in Maryland.

In one respect at least the members of constitutional " conventions were obligerl to consider the needs of the situation without experience to hely them; namely, in recirling the relation of the states to the nation. It is true they ransacked history from the time of the Amphictyonic league to that of the Swiss Republic for help in solving this problem, but without result. In creating a ferleral system they did the only wise thing jossible, and adopted the only system that could reconcile conflicting interests at the same time that it establisherl a stable government. We owe much to the men who, with the wish of experimenting as little as possible, laid a permanent foundation for a new and better union.

\section{The Organization of the New (jovernment (i 780 )}

197. The Presidency. - On the first Merlnesrlay in January, $178 \%$, presidential electors were chosen by all the states then in the Union with the exception of New York. In most of the states the chojec was left with the legislature, but in Virginia and Maryland the people were allowed to voste for electors. A month later the electors met at their respective capitals and cast two votes for their candirlates, one of whom could not be a resident of the same state with themselves. The result was of course a foregone conclusion.

"Original" features.

J. H. Robinson, in Annals Am. Acad. I'ol. and Social Science, I, 203-243.

Election of Washington.

Mc:Masti:r, reople of cimited States, I, 525-53').

Stanwerd, I'residency, 20-3I. 
Washington was chosen unanimously for the presidency, John Adams being selected as vice president.

Washington as President.

L.odge, Washington, II, 47-63.

Washington's inauguration.

McMaster, United States, I, $53^{8}-540$.

Elections and first meeting.

McMaster, United States, I, 530-534.
At this time Washington was fifty-seven years of age, and without doubt the foremost man in America. Yet his victories had been almost exclusively on the field of battle, and as an administrator he was practically without experience. On this account he took particular pains in the selection of his advisers, surrounding himself with men of exceptional ability. In the solution of the many problems of domestic and foreign affairs with which the new government was compelled to grapple, his sound judgment and lofty patriotism were of the highest value, and the interests of the United States and her people were protected during his administrations as they could have been under few other presidents, however skilled they may have been in affairs of state.

Washington's first inauguration occurred in New York City, April 30, 1789 , after a triumphal journey from his home at Mt. Vernon, Virginia. The oath of office was administered on the balcony of Federal Hall, in Wall Street, the populace shouting their approval: "Long live George Washington, President of the United States." Washington then retired to the Senate chamber, where he read his inaugural address to the houses of Congress.

198. Beginnings of the New Congress. - The Congress of the Confederation had appointed March 4, 1789, as the date upon which its successor should begin business, but on that day only a few members had reached New York. Congressional elections had been held quite late, and in many sections no representatives had been chosen by the beginning of March. New Jersey, for example, kept the polls open for three weeks, and in many of the New England districts two elections were necessary since the state laws required a majority vote before certificates of election were issued to the successful candidates. Moreover, bad roads delayed some, for it took many of the members three weeks to reach New York from their own homes. More than all else, the 


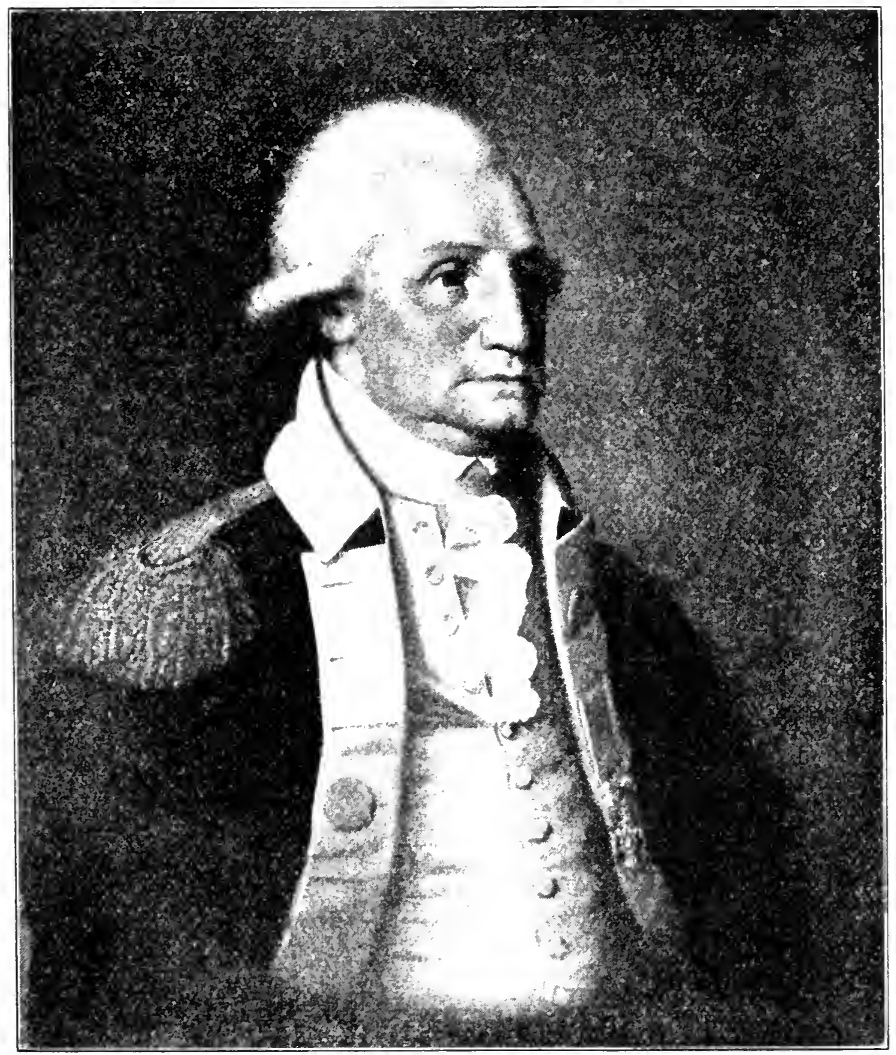

GEORGE WASHINGTUN 
example of procrastination and inaction set by the Confederate Congress exerted a pernicious influence in making the congressmen indifferent and dilatory.

First tariff act ( 1789$)$.

Dewey, Financial Hist., is 35-36.

McMaster, United States, I, 545-550.

Coman, Industrial Hist., I38-144.

Tonnage act.

Coman, Industrial Hist., I30-I34.

The problem of organization.

Schouler,

United States, I, 104-106.

At length, on April 6, a quorum was present in both houses. As the government was in pressing need of revenue, Congress did not wait for the inauguration before beginning business. James Madison immediately introduced a tariff bill in the House, which had exclusive right to originate measures relating to revenue. Then followed weeks of debate in which the representatives sought to increase the duties upon articles manufactured by their constituents, or to lower those which might interfere with their agricultural interests. Few changes were made in the Senate and the bill became a law on July 4, I789. It provided for ad valorem duties of from five to fifteen per cent, and for specific duties on many articles. As a source of revenue it was a complete success - although the rates were raised afterward - and it contained the germ of our present system of protection to American industries.

A few days later, Congress passed a tonnage act which imposed a small tax on American vessels engaged in commerce, and a much heavier tax on all foreign vessels.

199. The Executive Departments. - The next task of Congress was that of providing the new government with machinery for the administration of the laws. Although the Constitution mentions the executive departments, it makes no provision for their organization and powers. Two important questions were left therefore to the decision of Congress: (I) what departments were necessary and what duties should be assigned to each; (2) should the work of each department be performed by boards or under the supervision of superintendents or secretaries? The first question was settled by creating the three departments of state, the treasury, and war, and arranging for an attorney-general and a postmaster-general in addition. On the second there was little difference of opinion, for the board system had been used without great success under the Confederation, and 
the majority favored heads of departments. Four of these, the secretaries of state, treasury, and war and the attorneygeneral, were to form a cabinet or advisory body for the president. This cabinet was essentially different from that of England, for the English cabinet at that time was the real executive of Great Britain, whereas the American cabinet was solely an advisory body, which was in fact not called together during the first administration of Washington.

Washington did much to insure the success of the new government by the selection of his assistants. The ablest of these were Thomas Jefferson, who became secretary of state, and Alexander Hamilton, who was chosen for the treasury portfolio. All the members of the cabinet were in fact men who enjoyed

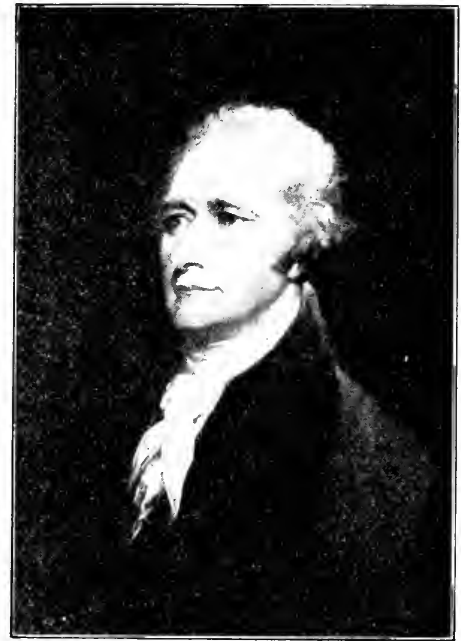

ALExander HAMILTON the confidence of the people, in addition to being earnest supporters of the Constitution. The one on whom the heaviest burden fell, Hamilton, although but thirty-four years of age, had already rendered valuable services to this country during the Revolutionary War, and in securing the adoption of a stronger government than that of the Confederation. Particularly versed in the financial methods of his time, he was well fitted for the task of establishing and strengthening the public credit. As a political manager he had few superiors, but he made the great mistake of distrusting the people, for he favored a central government that was almost monarchical, which looked to the aristocracy for its support. For this reason he was never 
popular with the masses and much of his effort was spent in trying to stem the rising tide of popular government.

Judiciary Act of 1789 .

Schouler, L'nited States, I, $107-108$.

Willoughiny, supreme Court, 22-26.

Justices of the Supreme Court.

Pellew, Jay', $35 t-366$.

Need of Union. I)efects of the Confederation.
200. The National Judiciary. - The last step in organizing the new government consisted in passing the Judiciary Act in September, I789. According to the Constitution there was to be a Supreme Court and such inferior courts as Congress might create. Congress decided that there should be a chief justice of the Supreme Court, with five associate justices. It divided the United States into three circuits, a northern, a central, and a southern, but it did not provide for any separate circuit judges. Sixteen district courts were created, one for each of the thirteen states, besides Vermont, Maine, and Kentucky. To each district was assigned a district judge, an attorney, and a marshal. The jurisdiction of these courts was clearly defined, and elaborate provision was made for the appeal of cases from state to national tribunals. This judiciary act, largely the work of Oliver Ellsworth, was so nearly perfect that it is still the basis of our judicial system, although enlarged by the addition of the circuit courts of appeals in I 89 I.

For chief justice, Washington appointed John Jay, a man of great learning and sound judgment. His colleagues also were able jurists and strong Federalists. At first their duties were comparatively light, and it was many years before people began to realize what an important work had been given to the national courts. In fact it was not until the nation became more united after I 8 I 5 that the court was able to strengthen the central government greatly (\$254). 201. Summary. - Separation from Great Britain forced the colonies to decide whether they would unite or be separate from each other. Although union was the only attempted solution of the problem, the states were unable and unwilling to form a strong confederation. The chief defect of the Confederation - the fact that the states were sovereign - made it impossible for Congress to raise money for its needs, to enforce the laws that it made, or to regulate commerce for the general good. Coupled with these spe- 
cific defects was the provision of the Articles that they could be amended only with the consent of all the states. The states were in danger of drifting into commercial warfare and anarchy unless a substitute for the Articles could be devised.

When the need of a new constitution was recognized, The new and a convention was called to revise the Articles of Con- Constitution: federation, most of the leaders desired a national Constitution. They did not insist on that form of union, because they feared that it would be rejected by the states, but a compromise plan was adopted by the convention at Philadelphia and ratified by conventions chosen for that purpose in the states. This federal union bound the states closely together without consolidating them under a centralized government. Such a federal republic was different from any that had existed before, so that there were numerous heated controversies during the period following 1787 regarding the powers of the national government and the rights of the states. The success of the new government was due in large part to the farorable circumstances under which it began its work in 1789 .

\section{TOPICS}

i. Developient of the West: "American Nation Series," VIII, pp. 222-24I, IX, pp. 269-288, X, pp. I28-I3i; Roosevelt, "Winning of the West," I, pp. I $22-22$ I (to I7/7); Morre, "North West under Three Flags," pp. 333-355 (after $1-87$ ); Winsor, "Westward Novement," pp. 43-62, 7i-100.

2. Finarcial Conditios of the Limed States $(1-81-1 ;-87)$ : Sumner, "Histcry of American Currency," pp. 43-57; Bancroft, "History of the Constitution," I, pp. 3I-45, 76-7I, 228-24I; Curtis, "Constitutional History" of the Cnited States," I, PP. 45-I34, I57185.

3. The Ordnalice of $7_{7} 8 ;$ : Johnston, "American Pclitical History;" I, pp. 95-105; Dunn, "Indiana," Pp. I7--218; Hinsdale, "Old Northwest," 255-2f, ; Sato in "Johns Hopkins University Studies," IV, pp. 88-I20.

4. The Conectict Compromise: "Cambridge Modern History," pp. 25I-264; Curtis. "Constitutional History of the Lnited States," I, pp. 365-706; Bancroft, "Hiztory of the Constitution," II, pp. $36-67$. 


\section{STUDIES}

I. Importance of the Articles of Confederation.

2. Treatment of the loyalists. (McMaster, "People of the United States," 1, Pl]. 107-130.)

3. Reception of first American minister by George III. (Hart, (ed.), "Contemporaries," III, No. 53.)

4. Paper moncy in the states under the Confederation. (McMaster, "People of the United States," I, 28I-305, 331-355.)

5. Defects of the Confederation. (The Federalist, XV-XVIl.)

6. The movement toward a better union. (Curtis, "Constitutional History of the United States," 1, pp. 221-232.)

7. The Virginia plan. (Madison, Journal of the Constitutional convention, Tuesdiay, Maty 29.)

8. Ilamilton's proposed plan of Union. (Madison, Journal, Monday, June is.)

7. Means to prevent legislative corruption considered by the convention. (Mcigs, " (rrowth of the Constitution.")

10. Report of the Committee of Details. (Madison, Journal, Mondliy, August 6.)

11. Election of schators. (Meigs, "Growth of the Constitution," Pp. 68-So.)

12. Opposition of Henry to the Constitution. (Tyler, "Patrick Henry.")

13. Defects in the methods of amendment. (Burgess, "Political Science and Comparative (onstitutional Law," I, pp. I+3-I54.)

If. Methods used to obtain ratification. (McMaster, "People of the United States," I, PP. $+5+-46$ I.)

15. Madison's view of the Constitution. (The Federalist, No. 39.)

\section{QUESTIONS}

I. What one underlying principle of the Confederation was of greater importance than any others? Name four specific defects of the Articles. Was there a greater degree of real union in this country in 1777 or in $17 S_{2}$ ? (Give reasons in full.)

2. Give your opinion of the course taken by Maryland ( $177^{8-}$ $\left.{ }_{I} \mathrm{~S}_{\mathrm{I}}\right)$. How did the surrender of the land claims strengthen the Union?

3. What constitutional right had Congress to pass the Ordinance of $I_{7}>7$ ? To what extent were the provisions of the Ordinance in sympathy with the times? ahead of the times? What influence did they have upon the United States then? upon our policy and history later? 
4. Was the period from 1781 to 1787 a critical period? Why? Do "hard times" have anything to do with cheap money agitation? Prove your answer from American history. Show how the commercial selfishness of the states produced a spirit of disunion and at the same time a spirit of union.

5. State clearly who were the parties in each of the compromises adopted by the Convention. Tell what each party desired in each case and show which party won in each compromise. Were the compromises necessary? Did they pave the way for eivil war?

6. Why were not the Articles of Confederation amended as they provided? What right had the Convention to proprese a new constitution? Was not the process revolutionary? What was the status of North Carolina and Rhorde Island between 1788 and the dates at which they ratified the Constitution? (Johnston, "American Political History," II, pp. 336-3+3.)

7. Compare the Articles of Confederation and the Constitution in regard to real character, form of government, prowers of Congress, prohibitions on the states, and methods of amendment.

8. From our standpoint was it a disadvantage that the Articles of Confederation could be amended only by a unanimous vote? Is the Constitution amended tor easily? What features of the Constitution are based on previrus experiments of the states? What features were borrowed directly from other countries? What features are "original"? 


\section{CHAPTER X}

\section{'THE CLOSE OF THE EIGHTEENTH CENTURY}

\section{Social Conditions}

Number.

Provincial characteristics.

202. The People. - Although there had been little emigration from Europe to America during the last half of the eighteenth century, the increase in population had been more than fourfold,

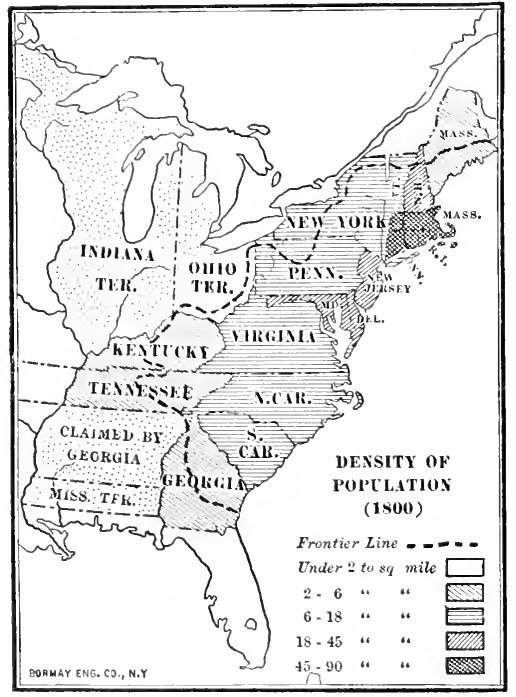
since the population in 1800 was over $5,000,000$. The white population was, moreover, fairly homogeneous, as all of the foreign peoples were being assimilated gradually into a race that was not English, though predominantly Anglo-Saxon.

There was still a marked difference between the sections as there had been at an earlier time; for, although the people of I 800 were more liberal in their views and less restricted in their occupations than their grandparents, the sections lost their colonial characteristics slowly. Yet with all their differences of temperament, religion, and pursuits, the people of the various states were alike in their preference for their own states, and in their prejudice in favor of local customs. The American republic was still essentially a nation of farm- 
ers, energetic and enterprising, but rude and rather narrow. ${ }^{\mathbf{1}}$ Not many had traveled beyond the limits of the county in which they were born, and few indeed had visited other states, except during the war, which had brought into contact men from distant sections. With the development of commerce and improved means of communication, it was only a question of time before many of the barriers between remote states would be broken down, since they had grown out of isolation and were fostered by local prejudice; but it was several decades before most of the people considered the interests of the whole country as important as those of their own state or locality.

Most of the people in I 800 lived within a short distance of the seacoast, but the cities were not numerous and had grown slowly except during the last decades of the century. Only two cities, Philadelphia and New York, boasted over 50,000 inhabitants and only two others, Boston and Baltimore, had more than 20,000 . There had been some improvement in the character of the shops, in the paving of the streets, . and in the town houses, but a half century had not altered essentially the manner of living, nor brought many additional comforts.

203. The Frontier. - A few pioneers began crossing the mountains before the close of the last French war, and Western settlements. the emigration to the West continued in spite of the king's proclamation $\left(\mathrm{I}_{7} \mathrm{6}_{3}\right)$ reserving that country to the Indians

McMaster, United States, I, I I-I6, 55-60, $64,83$.

1 McMaster gives the following description of the Massachusetts farmer: "The Massachusetts farmer who witnessed the revolution plowed his land with the wooden bull-plough, sowed his grain broadcast, and, when it was ripe, cut it with a scythe, and thrashed it on his barn-floor with a flail. His house was without paint; his floors were without carpet. When darkness came on his light was derived from a few candles of home manufacture. The place of furnaces and stoves was supplied by large cavernous fireplaces which took up one side of the room, and, sending half the smoke into the room, sent half the heat up the chimney. His food was of the simplest kind, was served in the commonest of dishes and eaten with the coarsest of implements. Beef and pork, salt fish, dried apples and vegetables, made up the daily fare from one year's end to another." "History of the People of the United States," I, p. I8. 
Dangers from the Indians.

Coman, Industrial Hist., 158-r66.

McMaster, United States, I, 596-604.

Sparks, Expansion of tim. People, 88-103.

Life on the frontier.

Sparks, Expansion, I $49-158$, $23^{8-24^{8}}$.

Problems to be settled.

Madison, Journal of Const'l Conv., $298,312,327$, $345,44^{8}, 460$.
(\$ 94). At the close of the Revolutionary War there was an exodus from the Atlantic slope to the fertile valleys of Kentucky and Tennessee, which no dangers from savages seemed able to check. These emigrants followed the trails through Cumberland Gap and the passes farther south, although some went by way of Pittsburg and the Ohio River. North of the Ohio, the Indians were in undisputed posses sion until I794. In I79I they had defeated and almost destroyed an army under General St. Clair which had been sent against them. Encouraged by the British, who still held many posts in the Northwest, the Indians demanded that the Ohio be the limit of the western settlements. After their army had been destroyed by General Anthony Wayne, they agreed to a compromise line across Ohio. This line was removed farther at later dates.

After 1795 the settlers poured into Ohio rapidly. In I 800 there were nearly 50,000 in the present state of Ohio, and over 400,000 west of the Alleghanies. Villages were - few and small. Cincinnati contained but a hundred houses, and Pittsburg, the largest town, had less than 2000 people. Most of the pioneers lived on separate farms, often near a blockhouse or stockade for protection. Their houses were invariably of logs and their clothes of skins or coarse homespun cloth. Many reckless men found their way to the frontier, but the people, as a rule, were honest and hard-working, with the love of justice which equaled their arclor for liberty.

204. The Admission of New States. - We have noticed already at some length the cession of western lands by the states to Congress and some of the western problems which Congress was asked to solve ( $\$$ I $\left.79^{-1} 82\right)$. Many people had thought it unwise to extend the boundaries of the United States beyond the Alleghany mountains because of the diffi. culties in maintaining a Union which included two diverse sections, one of which was interested almost solely in Atlantic seaboard affairs, while the other belonged to a remote and separate region with interests of its own. The wiser 
counsels prevailed when they sought to obtain from England this territory. But the problems of controlling this territory became prominent. The people of the frontier insisted that they should manage their own affairs either as an independent nation or in states of the Union. Many on the seacoast, especially in New England and Pennsylvania, protested against the admission of new states west of the mountains, because of the danger that in time the new states would outnumber the old and control the destiny of the country. Again wise counsels prevailed, and the Congress of the Confederation agreed that the new states to be organized in the West should not be small as suggested at first ( $\$$ I8I), but should be large and should be admitted on an equality with the states already in the Union.

When the Constitution was adopted, Congress was al- Three new lowed to control the admission of new states in this way. ${ }^{1}$ It adopted a liberal plan at the beginning, for three states were admitted before I797. The first of these, Vermont (I79r), comprised lands in dispute between New York and New Hampshire. Kentucky (I792) had been settled by Virginians and was until her admission a part of Virginia. Tennessee (1796) had been settled by the people of North Carolina, but was the first state organized in the territory controlled by Congress.

205. The Movement toward Emancipation. - One of the most beneficial results of the Revolutionary War was the attempt to free the slaves or ameliorate their condition. It was only natural that fair-minded men who had for years insisted on the rights of man, who indorsed the view that all men are created equal, should take some steps toward abolishing human bondage. An attempt had been made in Virginia before the war to discontinue the slave trade, but the king had aroused the wrath of the people by vetoing the law passed by the colony. After they became independent, Delaware and Virginia prohibited the slave trade within their boundaries, and Pennsylvania provided for gradual states (I790I796).

Emancipation in the states (I776-I800). 
emancipation. In ${ }_{7} 73$ Massachusetts abandoned the system of slavery entirely, since her judges held that slavery had been abolished by the provision of the state constitution which declared that all men were born free and equal. Other states followed the lead of these, those in the middle South by preventing the further importation of slaves and those in the North by voting for gradual emancipation. In I800 New Jersey was the only state north of Mason and Dixon's line in which negro children could become slaves.

Slavery petitions in Congress.

Bassett,

Federalist

System,

186-r89.

Schouler,

United States, I, $156-163$.

Renewed demand for slaves.

Hart, Siavery and Abolition, 53, 59-62.

Turner, New West, $46-50$.
In this antislavery agitation the Quakers had taken the most active part, ably seconded by that earnest apostle of democracy, Thomas Jefferson, and by leading New England Puritans. The Quakers scarcely waited for the new Constitution to go into effect before petitioning Congress (I 790) to abolish slavery. After several bitter speeches, resolutions were adopted to the effect that Congress could not interfere with slavery in the states, but that Congress might control the slave trade absolutely.

206. The Cotton Gin and Slavery. - The enthusiasm for emancipation which had developed during the Revolution and was noticeable as far south as the Carolinas died out gradually. A counter movement in favor of slavery began when, in I793, a young New Englander of inventive mind, Eli Whitney, perfected a machine for separating cotton seeds from the fiber. Whitney's gin enabled a negro to clear of seeds as much cotton as a thousand negroes had been able to do by hand. It gave an impetus to cottongrowing, then an unimportant industry, which made cotton the most important product in all the states south of North Carolina. It created a demand for slave labor on the cotton plantations which made the institution of slavery much more valuable and desirable in the South. Not only did it create in the extreme South a stronger proslavery sentiment than before, but it converted the lukewarm Virginians and Marylanders into ardent advocates of slavery, because it gave them a market for their surplus slaves. Interest revived in the slave trade, which was forbidden by the Con- 
stitution after I 808 , and many merchantmen engaged in the vile traffic. Even after that date, Africans were smuggled into the United States after a voyage of horrors.

\section{Political and Religious Changes}

207. Voters and Officeholders. - It is easy to orerestimate the influence which the Revolution exerterl directly upon the suffrage. The leveling influences of the Revolution did affect the right to vote; but they did not abolish, they only modified, the property qualification which had been universal in colonial times. In a few states taxpayers as Tasks allotted to the voters. well as owners of land were allowed to vote, but man as man had not yet established his right to a share in the government. Yet the quarter century following the Declaration of Independence brought a much greater share in the work of governing to those that were voters. The constitutions of the states were framed by conventions chosen by the people for that purpose, just as the Constitution of the United States was ratified by similar conventions. Numerous officials were chosen by popular vote and in two states the people ratified the constitutions. The belief that the people should rule was gradually gaining headway.

Everywhere the old demand that no one should vote unless he held certain religious views was discarled, so that Catholics and Jews voted on the same terms as Protestants. 'The same liberality was not shown to officeholders, for it was thought that only men of property and certain religious views were competent to direct affairs of state. The Ordinance of 1787 and the Constitution of the United States dir not permit any discrimination in regard to religion for national or territorial officials.

208. Tendencies toward Democracy. - In other things than politics the tendency toward democracy at the close of the eighteenth century was noticeable. After the war the term "gentleman" came into disfavor and was userl little even by those who believed with John Adams in the rule of "the rich, the well-born, and the able," because public

Qualification of voters and officeholders.

Fiske, Critica! Period, 69-70.

Ashley, $A m$. Fed. State, $572-576$.

Disuse of distinctions in dress and rank: 
sentiment was a growing force which no public man could afford to ignore. When the first Congress was seeking a title for the president, popular opposition to anything savoring of rank was so pronounced that " his excellency" seemed the only title not odious to the people. Men whose ancestors had been proud to recognize the superiority of the gentry insisted on their right to a position of social equality. Slowly but surely the old order of society was passing away. Distinctions in dress were less conspicuous than in an earlier day. The aristocrat was obliged soon to keep his cocked hat, his wig and queue, his knee breeches, his silk stockings, and low silver-buckle shoes for dress occasions. A plainer, more useful costume was becoming universal for everyday business.

Abolition of special privileges.

\section{Fiske, Critical} Period, 70-7 I.

Disestablishment of state churches.

Fiske, Critical Period, 76-83.

Many of the special privileges enjoyed by the proprietors of the great estates in New York and Maryland were abolished. Primogeniture had been formally set aside in all of the states, and in the national territory laws had been enacted before 1800 giving the children equal shares in the property of a father who died without will.

209. Religious Freedom. - The movement for religious liberty was the most complete of all those accompanying the Revolution. Before the war the Anglican church was established in seren colonies, the Congregational in three, while three did not sanction a state church. Except in Pennsylvania and Maryland Catholics were not allowed to vote or to hold religious services. As already noted (\$ I06), many dissenting congregations were allowed to hold services which were of course illegal. Virginia signalized her independence by freeing dissenters from paying taxes to support the established church $(\mathrm{I} 776)$, and a few years later, after a memorable contest, largely through the influence of Jefferson and Madison, passed an act establishing complete religious freedom. Outside of New England, the other states disestablished their state churches during the revolutionary period, but in Massachusetts, Connecticut, and New Hampshire the union of church and state survived 
until the nineteenth century, although members of other denominations were no longer expected to attend the Congregational service. In fact there was no other part of the country in which greater real liberty of religious thought existed than in New England.

During the Confederation there were meetings of clergymen connected with all of the prominent sects in America. National churches were organized by the Episcopalians, the Methodists, and the Presbyterians before the adoption of the Constitution. In some cases these organizations held meetings of the governing body of the church. Thus organized and strengthened, the churches were able to secure better men for their noble work.

\section{Economic Conditions}

2 10. Commerce. - Before I 789 the commerce of the Commerce United States did not thrive. The disputes with Great before 1789. Britain before the Revolutionary War, and the attempt of the mother country to enforce the navigation acts, prevented a free exchange of commodities with other countries. The war and the Confederation made matters worse for a time, because England closed the ports of the British West Indies, at which so much of our colonial trading had been done, and refused to allow commerce on advantageous terms with Great Britain, while other nations were not anxious to trade with states that followed no regular commercial policy. During this period it is true we had made commercial treaties with France, Holland, and Prussia. New avenues of commerce had been opened in hitherto forbidden parts of Europe and America. Enterprising Yankee skippers had rounded Cape Horn and crossed the Pacific to China, bringing back precious and profitable cargoes besides large amounts of silver. Yet the total amount of commerce was small and the quantity imported was much in excess of that exported.

Under the new government came a radical change. The Commerce prosperity which followed the adoption of the Constitution

National

churches.

Fiske, Critica

Period, 83-87. 
Coman, Indus- was noticeable at once in the very great increase in our extrial Hist., 130-138. ports. Laws were passed in 1789 which regulated the imports ( $\$$ I9\$) and gave an advantage to American vessels over foreign vessels engaged in trade. Shipbuilding received a new impetus, especially after I793. Even Great Britain was eager to trade with us and made a fairly favorable treaty in I794 (\$222). With the outbreak of war between France and England (I 793), American ships enjoyed a still larger carrying trade, and the American flag was seen on every sea. In I 800 the exports of the United States were three times as large as the entire commerce of the country twelve years earlier.

Industry before 1789 .

Hart, Contemporaries,

II, No. 20.

Industry after 1789.

Hart, Contemporaries,

III, No. 22.

Coman, Industrial Hist., I38-I5I.
2II. Industry. - Although there had been little change in the industrial methods and little industrial advance before I $_{7} 89$, separation from Great Britain had compelled us to manufacture many articles that we had imported previously from England. As the states were free from the prohibitions which had been placed upon manufacturing by the English government, the people now turned their attention to the production of iron and steel articles and to many branches of industry unknown before 1776 .

To no person did the adoption of the Constitution prove a greater boon than to the manufacturer. Before $I_{7} 89$ he had labored at a very great disadvantage. In a new country where raw materials and labor were higher than in the old world, he found it difficult to compete with the merchants of Europe. He needed protection of some kind and this help he obtained from Congress, for the new government left no doubt as to its policy by passing as its second law an act in favor of protecting home industries from foreign competition. Two years later appeared Hamilton's famous report on manufactures which exerted an inestimable influence. With the' stimulus of a slightly protective tariff industry expanded, although manufacturing was on a small scale and made slight headway until the opening of the nineteenth century, because there was no improved machinery. England took precautions to prevent the ex- 
portation of the inventions which were made by her citizens, including Watts's steam engine, Arkwright's and Hargreave's spinning machines, and Cartwright's power loom.

212. Currency. - The year i789 marks an epoch in the history of currency in the United States, for the Constitution gave Congress complete control of the money system and forbade the states to issue bills of credit or make anything but gold or silver a tender for payment of a debt. There was need of these provisions. It was essential that there should be a uniform standard throughout the country, and there was need of a stable as well as a uniform currency. A repetition of the business confusion and distress which followed the experiments of the states with paper money during the Confederation ( $\$$ I 84 ) was to be avoided at all costs. This could be done only by leaving the question of money to Congress alone. But if Congress were to issue continental money, the situation would be little better than under the Confederation. Many members of the constitutional convention of $\mathrm{I} 787$ wished to prohibit Congress from issuing bills of credit. After a discussion, in which the members showed how little they favored a national paper currency, the convention decided not to place the prohibition on Congress for fear that at some future time the need might be very great, and the issuance of paper money might be not only necessary but wise. But for this far-sightedness the nation could not have issued "greenbacks" during the Civil War, nor could we have these notes for use to-day.

During the Confederation, Congress adopted a decimal system of coinage based on suggestions made by Robert Morris and Thomas Jefferson. No coins were struck at that time, nor until after an act was passed ( I 792) establishing a bimetallic system of money with a legal ratio of $I_{5}$ to $\mathrm{I}$, that is, with fifteen times as much pure silver in a silver dollar as there was gold in a gold dollar. At that time the business of the country was done by means of Spanish and English coins, much of the small change consisting of quarCurrency legislation (1792I799).

Dewey, Finan cial Hest., $\$ 44$.

Coman, Indus trial Hist., I5I-154. ters and eights of the Spanish dollar. These foreign coins 
McMaster, C'nited siates II, 72-74, $360-363$.

Highways, wagons, traveling.

Hart, cintemporaries, III, Nos. 21, 35 .

Adams, Inited States, 1, 5-I5.

McMaster, Cinited states, I, $+4-53$. II , 560-565.

were usually old and worn and often clipped, but it was necessary that they be legal and accepted even by the government in payment of taxes, for very little gold and silver was brought to the mint for coinage into American money. Several times Congress designated a date at which these foreign coins were no longer to be used, but in each case the lack of a national currency made it impossible to carry the act into effect. In fact foreign coins were used ex-

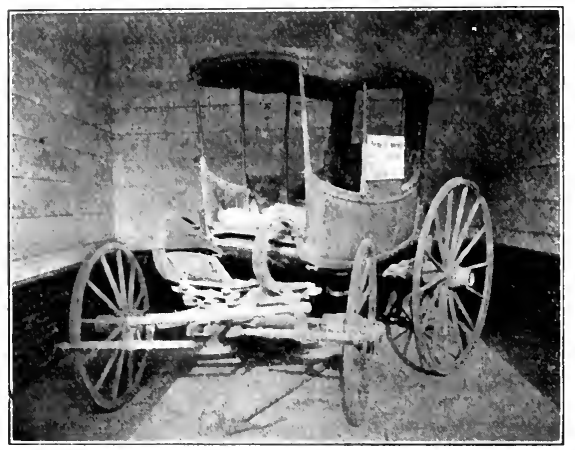

An EIGHTEentI Century CoACH tensively in the United States until the Civil War.

\section{Improved Means of Com-} munication.-The last half of the cighteenth century witnessed important im provements in the means of communication but very little in the methols. In the older sections, the highways of ISoo were superior to those of I 750, although in the spring the ruts were deep and the mud appalling. Many trails had been widened into wagon roads and several important highways leading to the West had been cut through the forests. In the most enterprising states, turmpike companies had been organized for the purpose of improving the roads, defraying their expenses by charging tolls of all travelers. Bridges were little more common than fifty years earlier, but the ferries were more numerous and much better. Freight was carried by wagon rather than on horseback. A large coasting trade gave employment to numerous swift packets which usually carried passengers. Between all of the large cities regular stagecoach lines plied throughout the year, but the journey was not much more comfortable than at an earlier day. 
The stages were cumbersome, the roads far from smooth, and the taverns lacking in comforts. The man who demanderl clean sheets in a room by himself was considered an aristocrat. Although these coaches ran at least fifteen hours a day, it took two days to go from Philadelphia to New York and at least five from New York to Isoston.

Meanwhile the mail service had been brought to a fairly high state of perfection. Under Benjamin Franklin, who was postmaster for the colonies after I753, routes were established and a few regular post offices created. Real improvement, however, rlates from the inauguration of Washington. The postmasters-general of our first two presidents saw the number of post offices increased from seventyfive in 1790 to nine hundred and three in 1800 . 'The rates for letters, the only articles carried before this time, were fixed ( 1792$)$ at from six to twenty-five cents a sheet accorrling to the distance. Thereafter newspapers, the best of which were small four page sheets, were inclurled in the posts at the rate of one cent or a cent and a half a copy. Two years later, magazines were taken also, but the rates were almost prohibitive.

\section{TOPIC}

I. The Frontier: Sparks, "Expansion of the American People," Pp. i 8-i 48; Hart, "Contemporaries," III, Nos. 31, 32, 35; Mc.Master, "People of the United States," III, Pp. 450-486, 521-54.3; Thorpe, "Constitutional History of the American People," I, Chapters VIII-IX.

\section{STUDIES}

I. Social conditions. (Hart, "Contemporaries," III, Nos. I I-I5.)

2. The "middle passage" on a slave ship. (Spear, "The Slave Trade in America.")

3. An early trip to Chicago. (McMaster, "People of the United States," I, IP. 259-262.)

4. Hamilton's report on manufactures. (MacDonald, "Documents," No. 12.)

5. Tripon the Mississippi. (Hart, "Contemporaries," III, No. 34.)

6. Theater in the later eighteenth century. (McMaster, "I'eople of the United States," I, PP. 84-95.)

Me.Master,

United States,

I, 4O-44,

II, 58-67. 


\section{QUESTIONS}

I. What causes were of greatest importance in the western movement? Why did the people of the western settlements have interests different from those living on the seacoast? In what respects did Congress and the constitutional convention follow a wise western policy?

2. Compare the sentiment in opposition to slave trade in $I 790$ with that before the Revolutionary War. Explain how Whitney's cotton gin affected slavery in the states that could not raise cotton.

3. Show how the leveling influences of the Revolution affected civil, religious, and political rights. Which class of rights was granted first? most tardily?

4. To what extent did the organization of the government under the Constitution affect the stability and success of the state governments, popular rights, our international standing, foreign and interstate trade, industry, and business in general? 


\title{
PART III
}

\section{DEVELOPMENT OF THE NATION ( $789-1843$ )}

\section{CHAPTER XI}

\author{
FOREIGN AND DOMESTIC PROBLEMS (I789-I8II)
}

PRESIDENTS

George Washington (1789-1797) Thomas Jefferson (1801-1809)

John Adams (I 797-I 80I) James Madison (1809-1817)

214. Problems confronting the New Government, I789. Although the adoption of the Constitution had removed the most serious danger to the continuance of the American Republic, there was still doubt concerning the efficiency of Organization and efficiency of the new government. the new government. Was the new Union after all to be but an improved Confederation, with the states disunited, with a central government incapable of protecting national interests, commanding respect neither at home nor abroad? The Constitution seemed to prepare the way for a government capable of solving these problems, but the adoption of a paper constitution was a simple matter compared with the creation of a government which should be completely organized and whose parts should work in harmony. The organization of the executive departments was the first thing to be done, and the success which attended this work, joined with the wisdom in the choice of the men who should manage affairs of state ( $\$$ I99), left no doubt that the paper constitution would become the real Constitution.

While the organization of the departments was being completed, the new government was obliged to provide itself with a revenue that should be permanent and adequate. 
Financial, commercial, and foreign problems.

Western questions.

Changed conditions after I793.
With money for its current needs, it could then attempt to establish the credit of the United States which, during the Confederation, had been practically nil. The debt was large, interest had not been paid, and the ordinary certificates of the United States were worth only one seventh of their face value. It was necessary to reëstablish harmony among the states, which had waged on one another for years a species of commercial warfare. Foreign trade must be protected and extended, the nations which had injured us commercially during the Confederation being compelled to treat us fairly because the loss would be theirs if they refused to do so. National prestige must be created by showing foreign powers that we constituted a nation deserving of consideration and respect, that we were not to be the tool of France or England or any of the other European nations. ${ }^{1}$

In the central West the new government had yet to gain the real allegiance of the settlers who could be held in the Union only by gaining control of the entire Mississippi. In the Northwest the British still kept several posts in the territory which had been granted to us in $\mathrm{I}_{7} 83$, and dominated the Indians of that region. In the Southwest, Spain, which refused to recognize our right to territory around Natchez, refused to give up her forts or make any concessions which would give a satisfactory outlet to the Gulf. Moreover, both France and England desired to possess Louisiana, and were intriguing to gain possession of the territory, which, as the colony of a powerful nation, would be a menace to all of the United States west of the Alleghany mountains, and would effectually prevent the expansion of the nation beyond the Mississippi River.

Some of these difficulties were removed easily, but many of them proved serious. Because of the conflicts that began in Europe in 1793 and continued almost without interruption until I815, some of the problems existing in 1789 were ag-

${ }^{1}$ Fortunately, at this crisis, Europe was at peace and the United States had proved conclusively its right to an international pasition before, in I 793, foreign problems became serious (\$§ 220-224). 
gravated greatly, while a number of others were presented which seriously affected the stability of the new nation. In fact, American affairs during most of these periods were dominated by conditions in Europe, until the nation finally began war rather than submit to the humiliations forced on us by the great powers of Europe.

\section{Financial Policy and Political Parties (i 790-I 793)}

215. The National Debt. - The first session of the first Hamilton's Congress had performed valuable services in equipping the new government for its work. Its successors, following suggestions of Hamilton, by strengthening the public credit, made it possible for that skillful pilot to steer the Ship of State clear of the financial rocks and shoals upon which the governmental vessel of the Confederation had been wrecked. No sooner had Congress met in January, I790, than Hamilton submitted his first report on the public credit. This called attention to the public debts of the United States, consisting of the foreign debt and the domestic debt, and urged that they be funded at their face value. In addition Hamilton proposed that the debts incurred by the states for the common defense during the Revolutionary War should be assumed by the national government and paid from the treasury of the United States.

There was no opposition to refunding the debt which we owed abroad. A different feeling was noticed in connection with the payment of the domestic debts. These consisted principally of certificates of indebtedness which had been issued to individuals and which, by act of Congress, were transferable. Before Hamilton's report was submitted they had been worth about fifteen cents on the dollar, but as soon as his suggestions were made public, the market price became nearly three times that figure. Speculators took advantage of the ignorance of the people in remote districts and purchased large numbers of these certificates before the holders learned of this rise in value. Congress found it

MacDonald, Documents, No. 6.

Lodge, Hamilton, 85-96.

Funding of foreign and domestic debts.

Dewey, Financial Hist., $\{39$.

Schouler,

United States, I, I44-I49.

McMaster, United States, I, 568-578. necessary to answer two questions.

(I) Shall the certifi- 
cates be paid at their face value? Madison voiced the general feeling when he said, "the debt is the price of our liberties, and cannot be diminished a farthing." So it was agreed wisely that the national government should not follow the vicious custom of the old Congress in repudiating a part of its debts. (2) The second question produced a long debate. Was the total amount of a certificate to be paid to the present owner if that person was not the original holder of it, or was the present owner to receive the market value and the balance to go to the original holder? Madison advocated the second alternative, but the policy of discriminating between earlier and later holders of certificates met with little favor. Hamilton's argument that the people must learn not to part with government securities and that the administration should therefore deal with the present owners only, finally prevailed, and Congress authorized new loans, at a rate of practically five per cent, to pay the old certificates.

Compromise over assumption and nationai capital.

Lodge, Hamilton, I 2 I-I 29.

McMaster, L'nited States, I, 580-583.

Dewey, Financial Hist., \$ to.

Hart, Contemporaries, III, No. 80 .
216. Assumption of State Debts. - The House of Representatives was divided about equally on the question of the assumption of state debts, most of the northern members favoring the measure, while the majority of those from the South were opposed to assumption. Some of the southern states, among them Virginia, had reduced their war indebtedness, and others were opposed to a measure which they believed favored the commercial classes at the expense of the agricultural sections. "State-assumption" had a very small majority, however, until the representatives arrived from North Carolina, which had recently become a member of the Union. In order to obtain the votes necessary to carry the measure, Hamilton and Jefferson came to an agreement at a dinner given at the latter's home. Jefferson promised that two Virginia congressmen should support assumption, if Hamilton would assure the location of the national capital upon the banks of the Potomac. There had been heated discussions over the question of the location of the capital, for the northern men wanted it in Pennsyl- 
vania and the southern representatives desired the Potomac. Jefferson's offer was accepted, and the state debts were assumed by the national government. 'The seat of government was to be Philadelphia for ten years, and after that a district not exceeding ten miles square on both sides of the Potomac. As a result of the compromise, the national government temporarily gained the ill will of a large part of the South. Three quarters of a century later, the location of the capital on the border of the Confederacy was a menace to the Union and an important influence in prolonging the Civil War. On the other hand the assumption of these debts did much to strengthen the central government at a time when its continued existence was still a matter of some doubt.

217. New National Taxes. - Since the government of the United States was already undertaking with vigor the duties conferred on it by the Constitution, the revenue obtained from customs was needed for expenses other than the payment of interest on the state debts. Hamilton therefore recommended an excise tax upon whisky, which was adopted in March, I79ז. This tax was very unpopular, especially in the mountains of North Carolina and Pennsylvania. In parts of these states there occurred riots similar to those caused by the Stamp Act, and the collectors appointed by the treasury department were compelled to resign. When, in I 794, the government attempted to collect delinquent taxes in western Pennsylvania, and there was again disorder accompanied by meetings of armed men who defied the authority of the United States, Washington called out fifteen thousand militiamen. At the approach of this army, the rioters dispersed and the insurrection was ended. Although only a few ringleaders were punished, the lawless elements feared thereafter to oppose the enforcement of national law.

As a revenue measure this excise tax was not a marked Other taxes. success, nine tenths of the government's income still being derived from the customs duties. The rates upon imports

Excise tax (I79I) and whisky rebellion (I794).

Dewey, Finan cial Hist., $\$ 45$

Bassett, Feder alist System, I06-I I2.

McMaster, United States, II, I89-203. 
Dewey, Finan had been increased, and, because of the development of cial Hist., $\$ \$ 46-48$.

foreign commerce which the new Constitution had brought, the revenue for 1793 amounted to twice that obtained for the six years from $\mathrm{I} 783$ to $\mathrm{I} 789$ by the Confederate Congress. Yet the prompt payment of interest on the public debt and the proper administration of the new laws of the United States demanded a still larger sum. In I794 taxes were levied upon carriages, auction sales, and certain manufactures, so that people became accustomed to a still further extension of federal authority. Later, in I 798, a direct tax was levied upon houses, lands, and slaves.

Discussion in Congress (I79I).

Dewey, Financial Hist., $\S_{43}$.

MacDonald, Documents, No. 9 .
218. The United States Bank. - In I791 Hamilton suggested a national bank, which would strengthen the public credit, provide a uniform currency, and aid the government in its financial operations. A bill creating such a bank passed the Senate without opposition, but was immediately assailed in the House on the ground that it was an unconstitutional measure. Madison claimed that as the Constitution did not give Congress in explicit language the power to incorporate a bank, it was not constitutional unless the founders of the government approved such an act. On the contrary, he said, the Convention of ${ }_{1} 787$ believed that the national government had no authority to grant articles of incorporation. He was answered by Fisher Ames, who showed that Congress had already exercised many powers not directly conferred on it by the Constitution. Ames urged that "Congress may do what is necessary to the end for which the Constitution was adopted, provided it is not repugnant to the natural rights of man, or to those which have been expressly reserved to themselves, or to the powers which are assigned to the states." By a sectional vote of thirty-nine to twenty, the bank bill was passed by the House, more perhaps because it appealed to the commercial interests of the North than because of constitutional arguments.

Washington submitted the bill to Jefferson and Randolph for their opinions, and then sent those opinions to Hamilton 
for his consideration. Jefferson argued that the bank was not a "necessary and proper" 1 means of carrying into effect the financial powers of Congress, and claimed that if that body could adopt any means it thought necessary and proper, it would invade the sphere of the states and destroy their rights. Hamilton's reply was logical and convincing. He stated that the states and the nation have different spheres of activity, and that the United States is sovereign within its own sphere. He asserted that not only the "express" or enumerated powers of Congress were delegated, but those that were "implied" as well, and showed that the use of an implied power to supplement an express power could not injure a state provided the object for which both were used was one not reserved to the states. Washington accepted the view of Hamilton and signed the bill, and the use of implied powers was not again questioned while the Federalists remained in power.

2I9. The Formation of Political Parties. - During the three years that had elapsed between the inauguration of Washington and the creation of the bank, the revival of business, the continued prosperity in every line, popular confidence in Washington, and national pride in the growing prestige of the American people, had undermined all the old opposition to the Constitution which had been voiced by the Anti-Federalists. But as Hamilton had seen his financial plans enacted into law and had attached to the new government the classes interested in commerce and manufactures, he had aroused an opposition among those devoted to agriculture which had grown stronger year by year. The leader of this opposition was Jefferson, who fought the policy of Hamilton in the cabinet, and began organizing his followers in the country.

The party of Hamilton, the members of which called themselves Federalists, included the majority of the aristocracy in the United States chiefly because the party believed in government by the "well born." All the moneyed men as

Reorganization.

Johnston. Am. Pol. Hist. I, 206-2II.

Bassett, Federalist System, 42-55.

Federalist party.

Lodge, Hamilton.

1 The Constitution, Art. I, $\S 8, \mathrm{cl}_{2} \mathrm{I} 8$. 
Johnston, Am. Pol. Hist., I, 220-223.

Republican party.

Johnston, tin. Pol. Hist., I, 208, 21 5-220.

Hart, Contemporaries, Nos. $85-88$.

McMaster, C'nited sitates, I I, IIO-II2, $249-255$. 296-306.

Proclamation of Neutrality.

MacDonald, Documents, No. I3.

Foster, $A m$. Diplomacy, I53-156. well had profited by the strong policy of the government under which business had improved so greatly, and were therefore realdy to accept Hamilton's doctrine of implied powers. In the North and in South Carolina, the Federalists were in a decided majority.

Although an opposition party, the adherents of Jefferson, known as Republicans, had well-defined views on public questions, modeled after those of their leader. Their chief doctrine was the restriction of the powers of the central government in order to protect the states from the aggressions of Congress. Coupled with this was a belief that the country should be ruled by the common people for the benefit of the agricultural classes.

Each of these parties employed newspapers in which appeared partisan articles supporting their respective claims. In time the criticisms of the administration in the Republican papers degenerated into personal attacks upon Washington, the war of these pamphlet writers being scurrilous beyond belief. At one time Washington was nicknamed "the step-father of his country." At another he was accused of stealing from the public treasury. Driven to desperation he said that he would rather be in his grave than in the office of president.

\section{Foreign Affairs (I 793-I 798 )}

220. Difficulties with France (1793). - Fortunately for the United States the new government was established quite firmly before it was obliged to deal with any important foreign problems. But during the period from 1793 to 18 I5, there was scarcely a year that did not bring fresh difficulties. The revolution which had broken out in France in $\mathrm{I} 789$ had in 1792 led to the establishment of a republic, and in January, I793, to the execution of Louis XVI. Early in April news was brought that France had declared war against England. Washington without delay called his cabinet together and asked the members whether the French treaty of ${ }_{1778}$ was still binding upon us, and whether he 
should declare the Uniter States neutral. Hamilton and Knox held the treaty tro be withrut effect, and all agreed that the United States shrould take no prart in the war, fout should Lordge,

Wastington, II, I3:-I receive a minister from the French Republic, thereby recognizing that grvernment. This wise froliry of refraing from a contest which lasted two decarles was adrofted, and Washington on April 22, I-93, issued his famous Proclamation of Neutrality waming citizens of the Lrited States to aroid all acts that were not strictly neutral in character.

Two weeks earlier, a French minister, Ermund Charles Genet, had landerl at Charleston. Young, ardent, ard irrespronsible, a fit represertative of the (jirrorlists who then governed France, (jeret lid not wait to be accredited by rur groferment, but began fitting out priateers. Proceerling leisurely orerland he ewherl great enthusian iror the French cause. Hi= treatmert of Washirgton, whe rlid not in the lea-i alter his determination to keEp the cruntry neutral, was at first cresl ard then rure. Stranegely enrugh, Genet lid not ask us to carr: out the treaty ri I to deiend the French West Indies against Englard fecause he hroped tr make a rew treaty in which we wosld agree to help France regain Lowisiana. Being called to account for his virsations of interrational lan, he stirrerd up opprsition to the groverment, urged the ismation of sorieties on the mordel oi the French Jacotsin cluts: ard at lesergth declarerl that he wruld arpeal irom the Presicent tr, Crongress. Hitherto propular ieeling had been iery bitter againd Wathington ior not iavoring the French openily. but as foret became more indiscret. a reaction set in whirh leit the ardministration more propular than eifer. A redues: for forets recall was honored at once. as the Girondists were ro, loneger in prower. and an epiorde that might have harl serious conseruences but ir the recklesness if (jenet, ro longer arouserl gereral interest.

221. Grievances against England ( 794 - F sllk, wing close uron the excitement wer French actions. came an outburst of wrath against the ageressiors of freat britain.

Trouble with Gens:

Is,igen, Hi:hent:n,

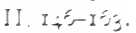

Jetroven, Am. Fil. Hi:t I $I 3 I-I \leqslant 4$.

Hicss:" , Federah:t

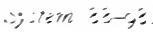

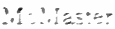
Inoted ante: II, yz-:5 IIJ, IET-Iษ2.

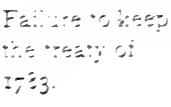


Johnston, There had been some bad feeling between the two countries Am. Pol. Hist., I, $144^{-147 .}$ because of the failure on each side to observe features of the treaty of $I_{7} 83$. As ten years earlier, Great Britain still retained the military posts in the Northwest and was accused of inciting the Indians of that region. No compensation had ever been made for the negroes carried off by the English in I $_{73}$. On the other hand England was offended that obstacles had been placed in the way of collecting debts due to her merchants and complained because the states had refused absolutely to compensate the loyalists for injuries sustained during the war.

Interference with American commerce.

Johnston, Am. Pol. Hist., I, I $47-150$.

McMaster, United States, II, I65-I68.

Negotiation and provisions.

When war began between France and England in I793, each used all possible means of injuring the other's commerce and eventually of damaging the enemy by interfering with neutral trade, England being the chief offender because she was more powerful on the ocean. American vessels were seized if found carrying goods of the enemy or when they had on board contraband of war, the latter being held most unjustly to include provisions destined for a French or British port. Great Britain also began to reënforce the Rule of ${ }_{7} 756$, which declared that neutrals should not enjoy during war a commerce with colonies that were closed to them in times of peace. Ships trading with the French West Indies were therefore subject to capture. English war vessels further exercised the privilege of stopping American ships and impressing sailors who were thought to be British citizens. Many of these had no doubt sought employment in a neutral marine to avoid service in the British nary, but a larger number were American-born or naturalized American citizens. ${ }^{1}$

222. Jay's Treaty (1794). - Aroused by these outrages, Congress declared an embargo on all vessels or ports of the United States, and roted a large sum for harbor defenses. But Washington desired a peaceful solution of the differences

${ }^{1}$ England claimed that no English citizen could ever forswear his allegiance to her, on the principle of once an English citizen always an English citizen. 
with England, and appointed John Jay as special envoy Johnston, to the court of St. James. Jay was well received by the English ministry, and concluded a treaty covering some of Am. Pol. Hist. I, I50-I55. the points at issue. Each nation was allowed to trade with the other on the most favorable terms given to any other power. The northwest posts were to be evacuated in I796, and compensation was promised for any merchantmen unlawfully seized, but the subject of impressment was not mentioned. The United States agreed to pay all of the debts which British creditors could not collect. By Article XII trade was permitted with the British West Indies during the war with France, and for two years thereafter, in vessels of less than seventy tons, provided that no molasses, sugar, coffee, cocoa, or cotton was to be carried in American vessels to any part of the world.

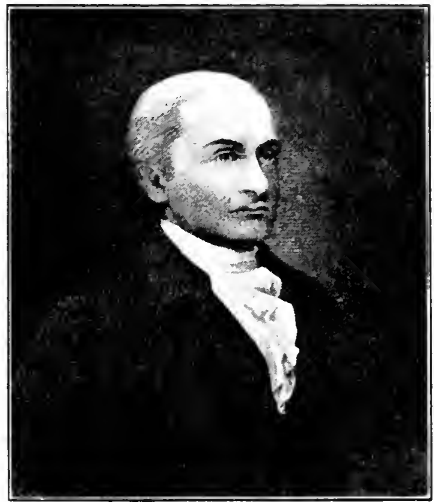

JOHN JAY
Pellew, Jay, 294-313.

This treaty was submitted by Washington to a special session of the Senate, which debated it in secret and ratified by a two thirds vote after striking out the objectionable twelfth article. A few days later, the text of the treaty was made public for the first time. From all parts of the country arose a storm of protest. Jay, Washington, and the Federalist senators were accused of betraying the country and were subjected to criticism more virulent than that of two years before. Opposition meetings were held in all of the large cities, Jay was burned in effigy at various places, Criticism and adoption.

Lodge, Washington, II, I8I-I94, 20I-207.

McMaster, United States, II, 2I2-2I6, $245^{-255}$. and Hamilton, attempting to speak for the treaty, was stoned by a mob in New York City. Nevertheless the treaty was signed by Washington and went into force without the offensive article on West Indian trade. 
Importance of he treaty.

Farewell address.

Old South

Leaflets,

No. 4.

Election of 1796.

Bassett, Federalist System, $\mathrm{I}_{4} 2-\mathrm{I}+6$. II, $29 \mathrm{I}-307$.

Although this treaty was in many ways unsatisfactory to the nation, it postponed war with Great Britain for several years and placed us upon a friendlier footing with that power. Considering the circumstances it was probably as favorable a treaty as a young though growing nation could expect to make with the chief maritime power of the world, which was at that time using every means to crush a formidable antagonist.

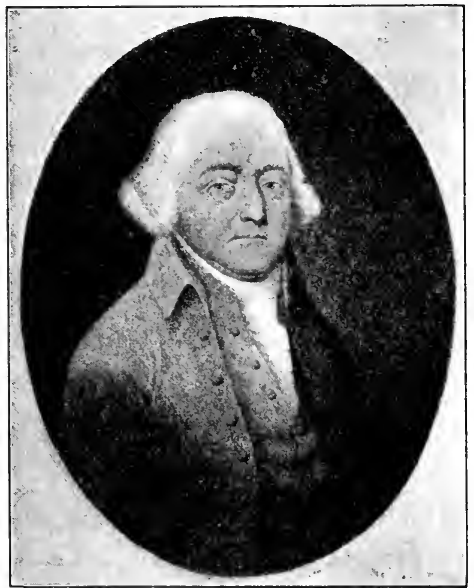

JOHN ADAMS Its real importance is shown clearly by the objections made to it by France $(\$ 224)$ and by the concessions which we were able to obtain from Spain at this time (\$23I).

223. The Close of Washington's Administration. - Washington declined to accept a third term as President, glad to escape the cares of the office and the abuse of his enemies. Before the election of his successor was held, he issued a farewell address to the people of the United States, urging them to avoid geographical parties and foreign entanglements.

Jefferson was the natural candidate of the Republican party, but the Federalists knew that it was hopeless to attempt the election of their leader, Hamilton, and selected Vice President Adams as the most available man. Interest in the election centered in the effort of Hamilton to have Adams again chosen as vice president, and to secure the selection of Thomas Pinckney as president. Party lines were not drawn closely and the result was most peculiar. Pinckney did not obtain the full support of the Federalists 
in the North, and received fewer votes than Jefferson. Adams had a majority of but three over Jefferson, so that, according to the Constitution, Jefferson, a Republican, became vice president, and Adams, a Federalist, was chosen president - " the president of three votes," as he was sometimes called.

Adams was an exceptionally honest and able man, but so conceited and overbearing that his undoubted merits were often overlooked. In the revolutionary Congress he hat been one of the most active and efficient workers. He has the honor of being the chief author of the only revolutionary state constitution - that of Massachusetts - which is still in use. Although blunt and outspoken, he had rendered valuable services abroad under the Confederation, and, as vice president for eight ycars, he had gained the good opinion if not the cordial support of the moderate Federalists.

224. Trouble with France (I796-I800). - Jay's treaty was even less palatable to the French than to the United States. Even so imperfect an understanding with England was held to have abrogated the treaties of amity and commerce made in $1778 .^{1}$ Coupled with the recall of James Monroe, who, as minister at Paris, had sought to curry French favor by the neglect of his duties, the Directory refused to receive the new minister, C. C. Pinckney. A year Character of Adams.

Appleton's Cyclopedia of Am. Biog.

Schouler,

United States, I, 505-512.

Quarrel

(I797-I798).

Johnston, Am. Pol. Hista I, 163-168.

Foster, $A m$. Diplomacy, I72-I77. later three special envoys were sent to settle matters peacefully if possible, John Marsnall and Elbridge Gerry being selected to act with Pinckney. As soon as the Americans attempted to present their claims, the secret representatives of the Directory made certain demands, including one for a loan and $\$ 240,000$ for the personal use of the directors, the last-named sum to be paid at once. The agents intimated that if this bribe was paid and the loan promised, their claims against us would not be pressed. After months of effort that was fruitless because the French marle the payment of the bribe a prerequisite to all negotiations, the envoys departed.

1 Officially the treaties were still in force, however. 
X.y.Z.papers. Meanwhile, the dispatches of the envoys reached America with the insulting demands of the French agents. These Johnston, Am. Pol. Hist., I, I68-I75.

McMaster, Lnited States, II, 374-385.

Naval war, and treaty of I 800.

Bassett, Federalist System, 237-25I. papers were submitted to Congress and in a ringing message President Adams urged preparations for the national defense. The enthusiasm of the people was intense, and in addition to the appropriations made by Congress for the equipment of men-of-war and the raising of an army, popular subscriptions were raised for the arming of privateers.

The next year ( I 799) one French frigate was captured, and another greatly injured in the West Indies, but the contest with France was brought to a close when Adams sent three commissioners to Paris in opposition to the wishes of his own party. In I 800 a treaty was concluded with Napoleon, now first consul, and the real head of the French government, who desired to acquire Louisiana and wished first to regain the friendship of America. This provided for peace, declared the alliance of 1778 dissolved in exchange for the surrender of our claims for damages done to our commerce by the French, and gave guarantees that as neutrals we should thereafter be free from arbitrary interference with legitimate commerce.

\section{Federalists and Republicans (I 798-I802)}

Anti-alien laws. 225. The Alien and Sedition Laws (I798). - The publication of the insulting "X. Y. Z. letters," and the popular MacDonald, Documents, Nos. I7-I9.

Johnston, Am. Pol. Hist., I, $18 \mathrm{I}-\mathrm{I} 84$.

Bassett, Federalist System. 252-259. enthusiasm in favor of strong measures against the French, caused the Federalists to pass three acts aimed ostensibly at aliens, but really designed to silence the vicious attacks upon the administration made by Republican journalists who were of foreign birth. The Naturalization Act provided that no alien could become a citizen until he had resided in the United States fourteen years. By the Alien Act the president might for two years order all aliens whom he considered dangerous to the United States or engaged in secret machinations against the government to leave the country. ${ }^{1}$

\footnotetext{
${ }^{1}$ An Alien Enemy's Act was passed a fortnight after the first Alien Act. In case of war or invasion, the president might order the arrest of any adult male citizen of the nation with whom we were at war.
} 
Many foreigners, fearing that the government might apply this law strictly, left the United States of their own accord.

The Sedition Act was much more drastic. ${ }^{1} \quad$ It provided Sedition Act. fines and imprisonment for any person guilty of impeding the enforcement of national law or for any one who might "write, print, utter, or publish any false, scandalous, and malicious writing or writings" against any national officials with intent to defame them or bring them into contempt or disrepute. Under this act, the Federalists attempted to prevent the reëlection of Representative Lyon of Vermont. Lyon was arrested, tried, and sentenced to imprisonment for four months and the payment of a fine of \$1000. His fine was paid by friends, and his district reëlected him to Congress. The Sedition Act stirred up more hatred than it suppressed, and reacted upon the Federalists, in the end destroying the popularity caused by the war excitement. Such arbitrary government was not possible in a free and enlightened republic.

226. The Kentucky and Virginia Resolutions (I798I799). - The Republican leaders quickly took advantage of these Federalist blunders and strengthened their organization, especially in the South and West. Among the means used for undermining Federalist power were protests issued by certain legislatures against the anti-foreign laws enacted during the summer of $\mathrm{I} 798$. The first of these resolutions was suggested by Jefferson to the Kentucky legislature, and is a truly remarkable document. It asseried that the central government was created by a compact of the states for special purposes only, "and that whensoever the general government assumes undelegated powers, its acts are unauthoritative, void, and of no force." It maintained that the government of the United States is not the judge of the powers that are conferred in the Constitution, but that each state " has an equal right to judge for itself, as well of infractions as of the mode and measure of redress." The violations of which complaint was made were discussed at

1 The Sedition Act expired by limitation March 4, r8or.

MacDonaid,

Documents,

No. 20.

Johnston, Am. Pol. Hist. I, I84-I88.

Bassett, Federalist System, 259-264.

McMaster, United States, II, 396-404.

Principles announced.

MacDonald, Documents, Nos. 21-23.

Bassett, Federalist System, 265-27r. 
some length. These resolutions, adopted in November, I 798, were submitted to the legislatures of the other states, seven of which in their replies distinctly denied the right of the states to nullify a national law. Virginia protested in resolutions drawn up by Madison against the Alien and Sedition acts as "palpable and alarming infractions of

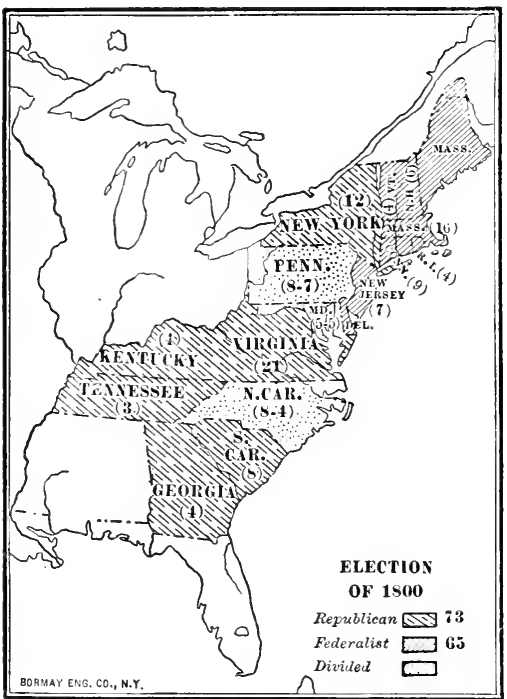
the Constitution," although the tone of the Virginia resolutions was much milder than that of those adopted in Kentucky. With these replies before it, the next legislature of Kentucky declared its attachment to the Union, reaffirmed its previous assertions, and added that, as the sovereign states have the unquestionable right to judge of any infraction of the Constitution, " a nullification by those sovereignties, of all unauthorized acts done under color of that instrument, is the rightful remedy."

Candidates and campaign.

Morse,

Jefferson, 195-200.

McMaster, United States, II, 493-508.
227. The Election of 1800 . - The presidential election of 1800 was interesting and exciting. Parties were much better organized than four years earlier, and the electors were now required to vote in accord with instructions rather than to follow their own judgment. The candidates were again Adams and Jefferson, the Republicans uniting upon Aaron Burr of New York for vice president, and the Federalists selecting C. C. Pinckney of South Carolina for the second place. Adams had not added to his popularity during his four years of office. He had made the mistake 
of retaining Washington's cabinet, dismissing the members who opposed him only a short time before the election of I800. The breach with Hamilton had been widened, and Adams was obliged to shoulder responsibility for the odious anti-foreign laws of 1798 .

Nevertheless the election was not one-sided. Jefferson Election. and Burr received seventy-three votes each, Adams obtained sixty-five, and Pinckney sixty-four. As the electors, according to the Constitution, did not designate which candidate was to be president and which vice president, the House of Representatives, voting by states, was obliged to select the chief executive. None questioned for an instant that Jefferson was the real candidate of the Republicans, but the House was Federalist and for a time it looked as though the Federalists in their chagrin would rote for Burr. Fortunately, Hamilton used his influence in faror of Jefferson, and on the thirty-sixth ballot Jefferson was chosen president. Three years later Congress proposed as a twelith amendment to the Constitution that the electors designate the office of the candidates for whom they roted. This was adopted without delay, and is the method used at the present time.

Finding that the election had gone against them, the Federalist Congress passed a Judiciary Act providing for circuit judgeships which Adams filled with members of his own party. With unseemly greed the Federalists seized upon every office that was vacant in order to reduce the patronage of the new administration; but at midnight, March 3, I80I, this work of spoliation was checked by Jefferson's attorney-general, who entered the office of Secretary of State Marshall, and stopped the signing of commissions.

228. Jefferson and his Party. - The inauguration of Inauguration. Jefferson was marked by a simplicity lacking in those of his predecessors. Without parade, in the dress of an ordinary citizen, he proceeded to the capitol and delivered an inaugural address, noteworthy for its breadth and moderation.

Federalist appointments.

Schouler, L'nited States, I, 500-504. The most skillful partisan leader of his time, he decried

Schouler,

United States, II, I-6. 
Adams, United States, I, $185^{-208 .}$

Views of Jefferson.

Hart, Contemporaries, III, No. 106.

Johnston, Am. Pol. Hist., I, 253-258.

The man Jefferson and his advisers. party animosities. "Every difference of opinion is not a difference of principle. We are all Republicans - we are all Federalists." In eloquent language he summarized the principles on which our government is based - equal and exact justice to all men, "peace, commerce, and honest friendship with all nations, entangling alliances with none," the support of the state governments in all their rights, the preservation of the general government in its whole constitutional vigor, a jealous care of the right of election by the people, the supremacy of the civil over the military authority, economy in the public service, and the maintenance of individual freedom.

Thus auspiciously did the members of Jefferson's party come into control of the national government, a position which they held with few interruptions for sixty years. Although their views and practices changed greatly during those six decades, they followed in the main the lines laid down by their great leader. Jefferson had something of the demagogue in his disposition, and had no scruples against reversing his previous policies if anything was to be gained, but he was consistent in his desire to make the United States a democratic nation, and in that consists his greatest service to his country. Under the Federalists the central government had been strengthened, so that its permanence was assured, but it was out of touch with the people and distrusted by them. Jefferson, rightly reading the future, foresaw that the nation would become democratic and that our governments must become so. More than any one else he aided in this movement of extending power to the masses. He trusted the people and sought in every way to give every man equal opportunities and equal privileges.

At the time of his election Jefferson was in his fifty-ninth year, and had devoted half his life to public affairs. As the writer of the Declaration of Independence, he had gained an international reputation early in life. During the Confederation he had rendered inestimable services in the cause of freedom in his own state and in the West. He had served 
abroad, and had been secretary of state under Washington, but had not made a brilliant diplomat. Tall and ungainly in appearance, rather eccentric in manner, and given to an ostentatious simplicity of dress, he nevertheless possessed a bright, pleasant way which made him extremely popular. In the direction of national affairs he called to his aid, among others, James Madison, who was secretary of state, and Albert Gallatin, who was placed in charge of the finances. By these three able and patriotic leaders were the interests of America considered and protected amid the many difficulties that beset Jefferson's two administrations.

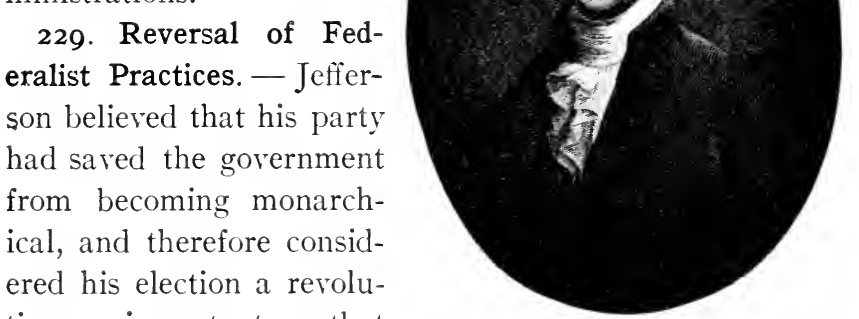
tion as important as that of 1776 . In point of fact

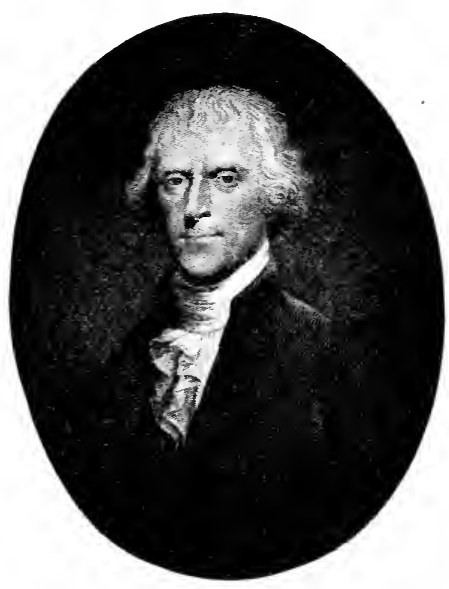

THOMAS JEFFERSON few policies of the Federalists were reversed, although some of their practices were changed, and the most objectionable of their laws were repealed. For purely personal reasons Jefferson, who was a poor speaker, did not address the houses of Congress after the manner of Washington and Adams, but sent to them a written message - a custom followed by all of his successors.

At the time of his inauguration, most of the offices were held by political opponents, whom he retained, except in a few cases. Resisting the clamor of his friends for recognition, Jefferson made few removals except for incompetency and gave some of the positions made vacant to moderate Federalists.

Channing, Jeffersonian System, 4-10.

Jefferson's general policy.

Attitude toward removals.

Channing,

Jeffersonian

System, IO-I7.

McMaster, United States, II, 583-588. 
Financial, military, and naval policies.

Dewey, Finaniall Hist., 8) $5 t-57$.

'The financial policy of the administration was outlined by Gallatin, the secretary of the treasury. Under the Federalists taxes had been multiplied, and the revenue had increased constantly, but expenditures had increased in even greater proportion because the Federalists believed in a comparatively large army and navy, and desired the expansion of national authority regardless of expense. The national debt was, in consequence, eight millions more in ISor than in I79I. This debt Gallatin planned to pay within

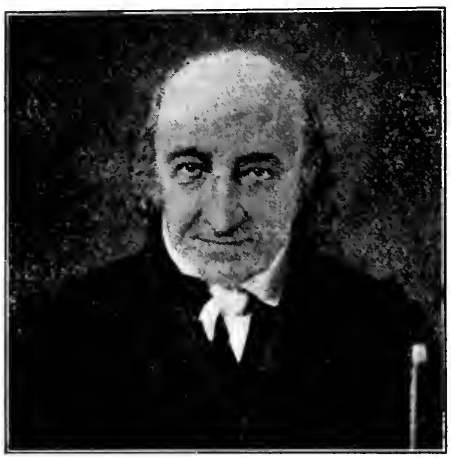

Albert GallatiN less than twenty years, principally by reducing military and naval expenditures. At his suggestion and in accordance with the wishes of the President, the army was reduced to three thousand men, and many of the naval vessels were placed out of commission, the protection of the coasts being left to tiny "gunboats" which were as inexpensive as they were ineffective. At the same session of Congress, the internal revenue taxes, which had been from the beginning odious to the Republicans, were repealed, the loss of income from this source being comparatively slight.

Changes in the judiciary.

Schouler, United States, II, 25-27.

McMaster, United Stiztes, II, 607-6I 2 .
230. The National Courts. - The Republicans attempted to undo the work of their predecessors by attacks upon the courts. The scandalous Judiciary Act of $\mathrm{I} 80 \mathrm{I}$ which created unnecessary circuit judgeships, and provided berths for many partisans whose terms of office were expiring, was repealed in ISO2. Other acts were passed which reduced greatly the number of cases likely to be brought before national tribunals. No change was made, however, at this time in the Supreme Court, to the chief justiceship of which 
John Marshall had been appointed by President Adams six weeks before the close of his term.

This great jurist, for over thirty years the head of the high- John Marshall est court of the United States, exerted an influence upon the development of a strong national government within the United States which was second to that of no other man. By force of intellect he dominated the court long after the Republicans had gained a majority of the places on the bench, and in a series of decisions marked by unanswerable logic (\$254) made the powers of the Constitution so real that even his political opponents accepted his views and used in the most liberal

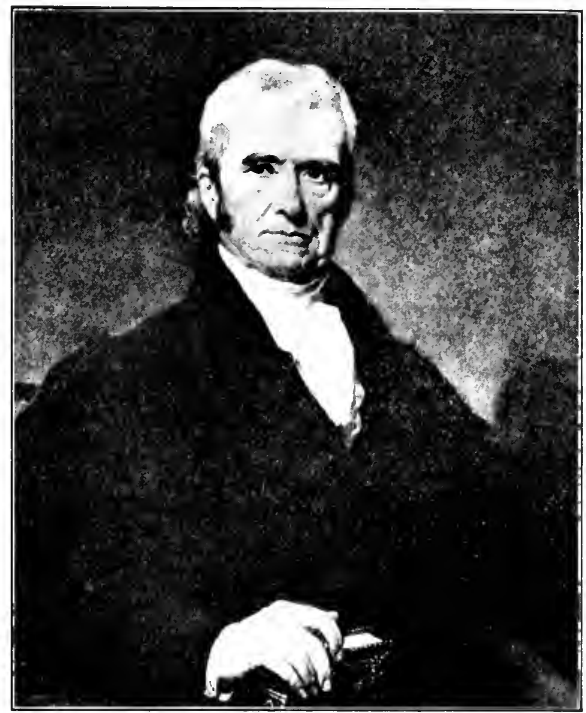

JOHN MARSHALL, way the powers

Willoughby, Supreme Court 89-9o.

Lodge, Fighting Frigate, 25-64 conferred on the national government by the Constitution.

The Republicans showed their distrust of the courts also in attempting to remove a number of judges. In PennImpeachment of judges. sylvania most of the judges in the highest court were impeached, but retained their positions because the moderate Republicans believed that conviction for partisan reasons Schouler, United States. II, 86-89. was a menace to free government. United States District Judge Pickering was impeached and found guilty, though not for political offenses. Much the most conspicuous case was that of Justice Chase of the Supreme Court. Although a man of parts, he had aroused the animosity of his oppo- 
nents by his biased conduct in one or two semi-political trials and by offensive remarks in a political speech. His prosecution before the Senate was conducted by John Randolph, a most eccentric individual whose conduct of the case was absurdly incompetent. Chase was defended ably and was acquitted. These impeachments, although undertaken for partisan reasons, had a wholesome influence in preventing further abuses of judicial privileges. The acquittals likewise were most fortunate, for they insured the protection of the courts against unjust attacks by their enemies.

\section{Western Problems (i800-i 806 )}

Importance of the river to the West.

Hart, Contemporaries, III, No. III.

Disputes before I800.

Turner, F. J., in Review of Reviews, XXVII $\left(\mathrm{I} 90_{3}\right), 578-58 \mathrm{I}$.
23I. Disputes over the Lower Mississippi River. - The most momentous question that arose during Jefferson's first administration was concerned with the purchase of Louisiana. This important addition to our territory was the outgrowth of controversies over the navigation of the Mississippi River and the right of deposit at the mouth of that river. Before I 800 Spain controlled the western bank of the river as well as the eastern bank for two hundred miles from its mouth. But the inhabitants of the region west of the Alleghanies needed both the navigation of the river - their natural means of communicating with the outside world, since it was extremely difficult for them to carry their products across the Alleghanies - and a right of deposit near the mouth for goods to be shipped abroad.

We noticed $\left(\S_{1} 8_{2}\right)$ the storm of protest that greeted the proposal to close the Mississippi for twenty-five years at a time when the West was settled very little. In the absence of treaty agreements, however, Spain had not been punctilious about interfering with our western trade until in I795 Thomas Pinckney concluded a treaty with that power. Alarmed by Jay's treaty $(\$ 222)$ and by the prospect of an alliance between Great Britain and the United States, Spain recognized the thirty-first parallel as the northern boundary of West Florida, opened the Mississippi to our commerce, 


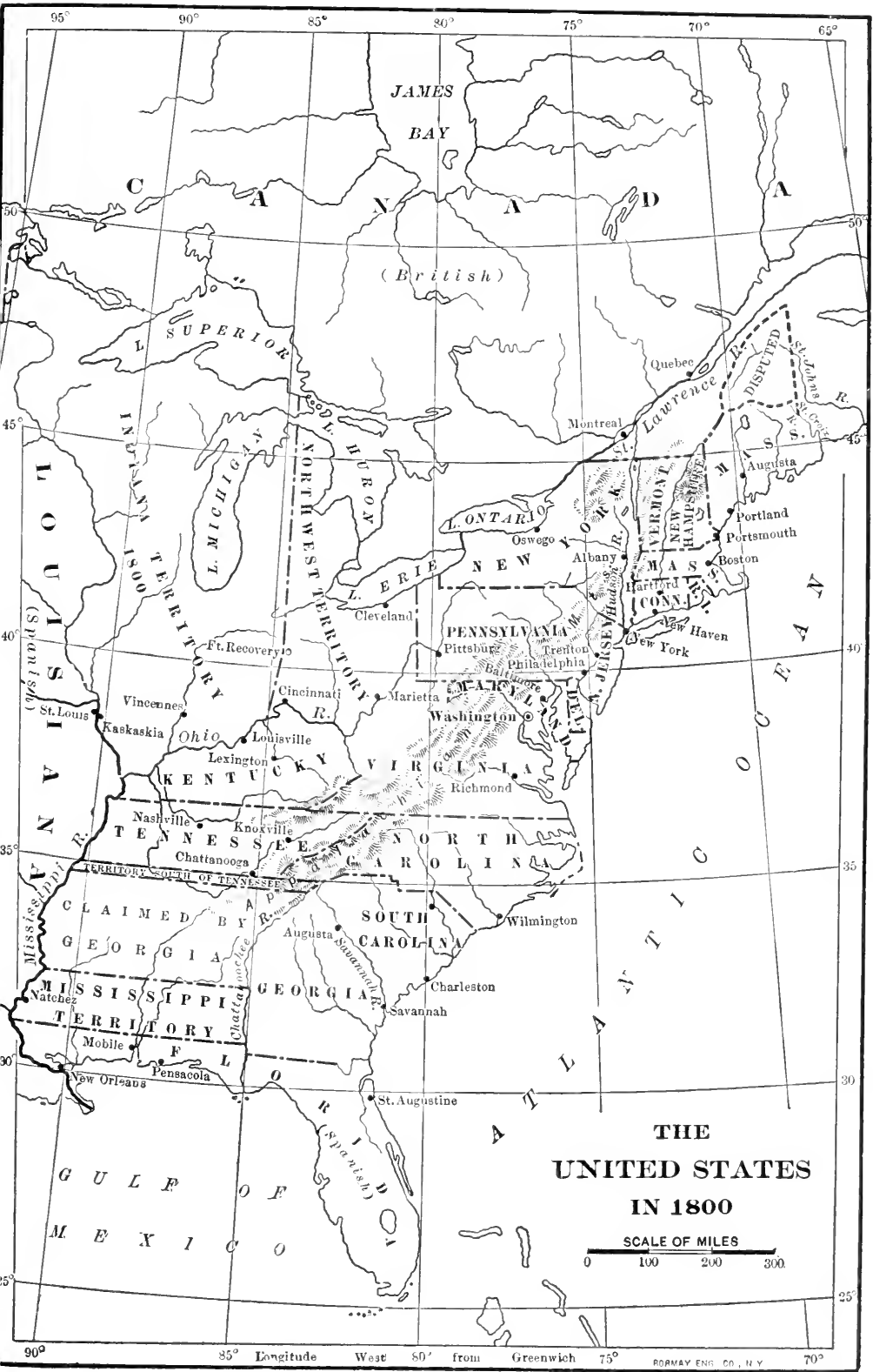



and gave us a right of deposit at New Orleans. Spain was Ogg, Missisthe more willing to make these concessions in order to gain the goodwill of the United States, because France was very anxious to regain Louisiana and Great Britain was willing to intrigue for its possession, and at this time the United States was less grasping than either of the great European rivals.

In I 800 Napoleon, now first consul of France, forced the king of Spain to sign the treaty of San Ildefonso, and to cede him Louisiana, on the express stipulation, however, that it should never be transferred to any other power. When this treaty became known in America the next year, Robert R. Livingston, our minister to France, was instructed to purchase if possible the Isle of Orleans, upon which New Orleans is located, and West Florida, so as to give us control of the entire east bank of the Mississippi. Soon after, and before the actual transfer of Louisiana to France, the Spanish officials at New Orleans took away our right of deposit, thereby arousing a demand for war throughout the West. The importance of the Mississippi to the West and to the country at large, and the danger to the United States of having a powerful nation in control of the mouth of the Mississippi, may be appreciated from the emphatic language of Jefferson, whose sympathies before that time had been distinctly French. "The day that France takes possession of New Orleans ... we must marry ourselves to the British fleet and nation." "By uniting with Great Britain, we must make the first cannon which shall be fired in Europe the signal for the tearing up of any settlement she [France] may have made."

232. The Purchase of Louisiana. - The purchase of Negotiations. New Orleans, and if possible West Florida, was desired so much that James Monroe was selected to act with Livingston, who had already been authorized to expend $\$ 10,000,000$ for these few thousand square miles of swampy land. ${ }^{1}$ But

Louisiana (I800-I803).

Channing, Jeffersonian System, 5I-64.

Adams,

United States, I, 352 et seq.
Hart, Contem poraries, III, No. II2.

${ }^{1}$ The instructions to Livingston emphasized more than anything else the need of control by the United States of the east bank of the Mississippi; 
Channing, effersonian System, 64-72,

McMaster, United States, I, 625-63I.

Ratification of he treaty.

Hart, Contemboraries, II, No. II3.

McMaster, United States, II, I-9.

Jgg, Missisippi, 543-558. just as Monroe reached Paris, after Livingston had spent several months negotiating in vain for the east bank of the Mississippi, Napoleon offered to sell all of Louisiana. He had hoped to make this vast region the foundation of a colonial empire, but the army which was needed to hold it had been destroyed in insurrections in San Domingo, war was soon to begin in Europe, and the maritime superiority of England left all of the French colonies exposed to her attacks. Although our representatives at Paris were not authorized to purchase so vast a region, they did not hesitate long, and after some haggling over the price, on April 30, I803, Louisiana became ours for the paltry sum of $\$ 15,000,000 .^{1}$ As Talleyrand, the French minister of foreign affairs, said, we had made a " noble bargain." In the words of Livingston, "We have lived long, but we have this day done the noblest work of our lives."

Jefferson believed that the Constitution did not authorize such an action as this purchase and would have preferred to wait for an amendment to that instrument giving him unquestioned authority. But time was all important. Napoleon might repent, England was likely to be jealous, and Spain sure to protest. Jefferson's cabinet advised ratification at once, and his friends persuaded him that the power to make treaties gave him the right to acquire territory. Congress was called for an early date, and, as the purchase was very popular, the Senate ratified the treaty after a comparatively brief debate. Public sentiment had changed so that no one now considered the annexation of Louisiana by treaty to be unconstitutional; but the Federalists, who feared that the West might come to dominate the East, claimed that no states could be admitted from this territory. In this

if France would sell us West Florida and New Orleans, we agreed to guarantee to her the west bank of the Mississippi, and if France refused our request, arrangements were to be made for an alliance with Great Britain.

1 Sixty million francs in 6 per cent stock of the United States and twenty million francs to be paid by the United States to our citizens for damages done by French men-of-war before I 800 . 
they were opposed by the Republicans who had completely abandoned their strict constructionist views, and from this time made a fairly liberal use of "implied powers." When the first state, Louisiana, was admitted from this territory (I8I2), however, several Federalists maintained that it was sufficient cause for secession from the Union.

233. Extent and Importance of Louisiana. - The boundaries of this immense region were intentionally left indefinite. The Louisiana treaty copied the words of the treaty of I 800 between France and Spain, which were, "Louisiana with the same extent that it now has in the hands of Spain, and that it had when France possessed it " before I762. But these limits never had been determined. ${ }^{1}$ Livingston claimed that they included West Florida, but Napoleon

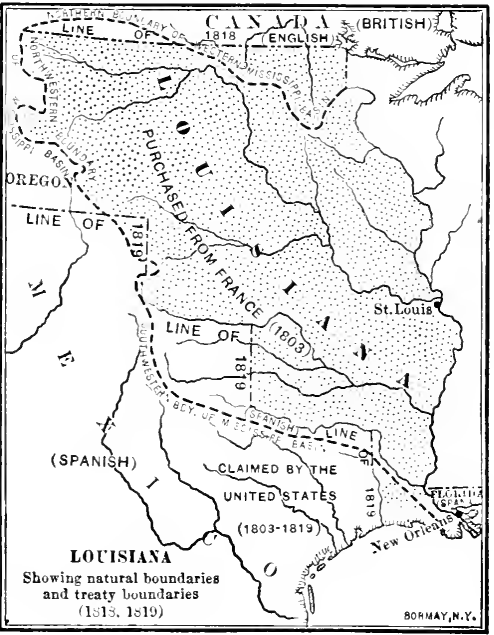

Indefinite boundaries. West Florida

McMaster, United States III, 3I-34, 37 I- 375 . would not support his claim, and we know now that, although Napoleon coveted West Florida, he did not consider it a part of Louisiana. Nevertheless, the doubt regarding the southeastern boundary and our former desire to obtain West Florida, led the United States to seize the disputed strip before the beginning of hostilities with Great Britain in $18 \mathrm{r} 2$.

${ }^{1}$ In order to explore parts of the new territory, parties were sent respectively to the source of the Mississippi, up the Missouri and across by the Arkansas to the Rocky Mountains, the summit of which was thought to be the limit of Louisiana on the northwest. The expedition under Lewis and Clark crossed the Rockies (1805) and descended the Snake and Oregon rivers, thus giving us a better claim to the Oregon country. (See $\S 303$. ) 
Texan

roblem.

Channing, Jeffersonian System, 77-79.

Significance of he purchase.

Plot and trial.

Hart, Contemporaries, III, No. Iog.

Sichouler,

United States, II, 68-74.
On the southwest a much larger, if at that time less interesting territory, was claimed by both the United States and Spain. Spain would have restricted us to the Mississippi basin, with scarcely any of the Gulf coast, but many Americans believed the Rio Grande to be the dividing line between Louisiana and Mexico. In I8I9 this country gave up its claim to all land west of the Sabine River in return for the cession of East Florida ( $\$ 26 \mathrm{I}$ ).

The purchase of Louisiana had a very great influence on the future of the United States. It doubled the area of the United States, giving us complete control of the entire Mississippi basin and permitting expansion to the Pacific. It removed obstructions to commerce in the western states and prevented international complications with the nations that held or sought to seize Louisiana. It compelled the Republican party to abandon its old strict construction position, and increased the power of the national government by giving it control of a vast region. In the territory acquired at this time a true democracy and a national spirit were developed which influenced the rest of the people. In this territory occurred the great struggle between the forces favoring the extension or exclusion of slavery, which ended in civil war. Finally, the great West has contributed in innumerable ways to the economic development of the greatest agricultural and commercial nation of the world.

234. The Burr Conspiracy (I805-1806). - Soon after the annexation of Louisiana the West became the scene of a remarkable conspiracy formed under the leadership of Aaron Burr. This was one of the last of the numerous attempts to separate the West from the East and organize the West under a distinct government, because the two sections had so little in common. In I804 Vice President Burr, failing of election as governor of New York largely through the efforts of Alexander Hamilton, challenged the latter to a duel, which resulted in the death of Hamilton. Burr was obliged to flee from the East and devoted his attention to the formation in the Southwest of a confederacy 
to be ruled by himself. It is generally supposed that Burr wished to detach the western states from the Union and then conquer Mexico. Burr's movements were reported at Washington, but for a long time nothing was done, although Burr had the support of a large part of the IVest and was in secret correspondence with General IVilkinson, the commander of the army at New Orleans. Burr was arrested at length and brought to Richmond, Virginia, where he was tried in the Circuit Court on the charge of treason, Chief Justice Marshall presiding. President Jefferson was summoned to appear at the trial with papers, but refused, although the papers were sent. The evidence being insufficient, Burr was released after a tedious trial lasting six months.

Commercial Warfare (i 805 -I 8 it)

235. European War and American Commerce before 1806. - The wars waged by England and France between Our neutral I793 and I8I5 made possible an abnormal development of American commerce. Because of the naval superiority of Great Britain, France and her allies had been unable to Commerce, I789-I8II. trade with her colonies and had accordingly opened her colonial ports to neutral trading vessels. In spite of the attempt made by Great Britain to apply the Rule of $175^{6}$, which prevented our carrying goods directly between a colony and a mother country, our foreign commerce had increased threefold between I792 and I796 and had nearly doubled between 1796 and 1805 . But the risks incurred increased with the amount of the traffic. Both Great Britain and France exercised the right of seizing goods of their enemies on neutral ships, notwithstanding the American claim that "free ships make free goods." Contraband of war was forfeitable if discovered, and neutral ships carrying it were often confiscated as aiding the enemy. This would have been a fair practice had the term " contraband of war " been defined justly; but when it was held to include breadstuffs, the most important of American exports, the United States had just cause for complaint. 
lew interpreition of Rule f 1756 .

IcMaster, Inited States, II, 220-228.

Still more serious was the interference with neutral trade because of a new interpretation of the "Rule of 1756 ." Before 1805 , American vessels had been permitted to obtain a cargo in the French or Spanish West Indies, sail to a port of the United States, remove their cargoes, and give bonds that their goods would be reëxported, and, after reloading, sail for continental Europe. In May, I805, the

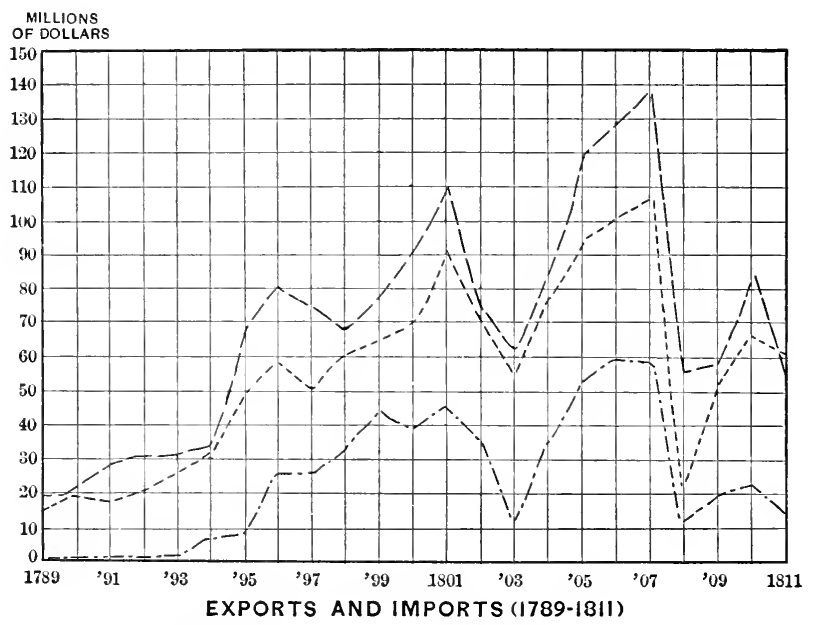

Imports-- Exports-....-
Goods imported and reëxported at once---
(It was to this latter trade that England objected after 1805)

highest British court of Admiralty decided that this practice was an evasion of the "Rule of $175^{6}$ " and as such must be stopped. This was the beginning of a carnival of confiscation that lasted for several years. Rather than give up the lucrative trade between Europe and the West Indies, the American vessels took their chances of capture. No company of underwriters would insure ships or cargoes engaged in this perilous trade, but profits increased with the risk. Great fortunes were made although many shippers became bankrupt because of the wholesale seizures made by English cruisers. 
236. The Impressment of American Seamen.-This growing trade, attencled by such personal perils, caused a marked rise in the wages of ordinary seamen. Naturally from American vessels. many English sailors were employed in this business, and as wages continued to rise, hundrerls of men from the British war vessels deserted and applied for positions in our merchant marine. In many cases these deserters were able to buy papers declaring that they were American citizens. To seize these traitors and to impress all the British sailors possible, the English cruisers now redoubled their efforts in searching American vessels. Every harbor on the coast of the United States was watched and every outgroing vessel searched. On the theory that "once a British citizen, always a I3ritish citizen," thousands of naturalized Americans were carried off. Hundreds of native Americans were impressed, as it was often difficult to ristinguish between American and British-born seamen. The government of the United States offered to see that all deserters were returnerl if England would give up the claim to search American ships, but to no avail, and the ill feeling against Great Britain deepened.

An opportunity now came to the English ministry to gain the goordwill of the United States. Jay's treaty harl expired, and Jefferson was anxious to make a new treaty dealing with the questions of impressment and neutral trade. But so little would the English government yield that the treaty dirl not mention impressment and was not even submitted by the Presirlent to the Senate.

A little later, in June, 1807 , war between the two nations seemed imminent. The warship Leopard remanderl from the Chesapeake the surrender of three deserters, two of whom were American-born and harl been forcerl into the British navy. When the rlemanrl was unheeded, the Leopard, the more prowerful brat, firer on the Chesapeake, killing three and wounding eighteen of her crew. This outrage causerl intense excitement, but was quickly disavowed hy the finglish government. Four years later reparation was marle Hart, Contempararies,

III, iro, Ilg.

McMaster. Imled Stales, III, $240-245$.

Hart, romlemporaries, III, Nos. 116-118.

Attempted treaty $(18,6)$ ).

McMaster,

Iniled States, III, 249-253.

Chesapeake affair ( 1807$)$.

Schoruler, United States, II, If $3-1+5 x_{\text {, }}$. 
by appropriating money for the families of those slain or injured, but in the meantime Great Britain exercised with the greatest freedom the "wrong of search."

Earlier orders and decrees.

Hart, Contemtoraries,

III, No. I20.

McMaster, L'nited States, III, $24^{8-250 .}$

ater restrictions on trade.

McMaster, L'nited States, III, $273-275$.

Johnston, Am. Pol. Hist., $1,289-296$.

237. Orders and Decrees (1806-1807). - The victory of the English fleet under Nelson over the combined fleets of France and Spain at Trafalgar in I $\mathrm{SO}_{5}$ definitely settled the supremacy of England on the sea. The years i 805 and I 806 saw Napoleon master of all western Europe after the humiliation of Austria at Austerlitz and of Prussia at Jena. As neither foe could strike the other directly, Napoleon now attempted to crush England by shutting off her trade with the continent, on which her prosperity depended to a large extent, while England tried to prevent the French and their allies from receiving supplies from their colonies and from neutral nations. Napoleon made the first move by closing the ports of Prussia to English ships. England responded by an order in council (May, ISo6) blockading the coast from the Elbe to Brest. Napoleon in his Berlin decree (November, I 806 ) announced a blockade of the British Isles and declared all English merchandise subject to confiscation. These blockades were not enforced, but English cruisers seized neutral ships on the way to the forbidden continental ports, and the French did not hesitate to appropriate American vessels that were carrying British exports to the continent.

Much more drastic were the proclamations issued the next year. British orders in council adopted in November, I $\mathrm{SO}_{7}$, demanded that all neutral vessels bound for a port of the enemy must first touch at an English port, and pay duty or be liable to confiscation. When Napoleon heard of these orders, he immediately issued his Milan Decree, declaring that all ships were forfeited which traded with Great Britain or stopped at an English port on their way to the continent and paid duties. Between the millstones of English greed and French spite, American commerce was likely to be ground to destruction.

238. The Embargo ( 1807 ). - Congress was in session 
when news was brought of the orders in council of November, 1807. President Jefferson suggested an embargo and Original Emwithin four days the act became a law, December 22, 1807. The general feeling is expressed in the words of John Quincy Adams, who took this opportunity to identify himself with the Republican party. "The President has recommended the measure on his high responsibility. I would not consider, I would not deliberate, I would act." No vessel was allowed to leave the United States for a foreign port, and no ship could engage in the coasting trade unless it gave bonds for twice the value of the ship and cargo that the goods it carried would be landed in the United States. The law, made more specific in supplementary acts, was not enforced easily. Along the northern borler a large amount of smuggling was done. So clever were many of the evasions that at length it was necessary to demand that all vessels be laden under the supervision of a revenue officer.

President Jefferson, once the strictest of strict constructionists, was obliged to use autocratic powers. Our foreign commerce disappeared. The ships which were abroad when the embargo was laid stayed away, only to be seized by Napoleon, who said he would be glad to aid us in enforcing the embargo. In New England business was at a standstill, most of the capital being tied up in the ships which were rotting at the wharves. Nor did shipowners submit without a murmur. Protests came to the President constantly. On the anniversary of the passage of the embargo, processions with ships draped in black paraded many of the seacoast towns. Popular discontent was so great that in the fall of 1808 the Federalists carried several hitherto Republican states. Yet the Congress which met immediately after, advocated the reverse of repeal, and on January 9, I 809, passed a force act making it a crime to export anything from the United States, giving collectors the power to seize wagons or boats headed toward the boundary and articles that they thought might be intended for export. The president was authorized to employ the army and navy in enforcing the

Enforcement and repeal.

Hart, Contemporaries,

III, No. I22.

Johnston, Am. Pol. Hist, I, 297-300. 
law. The scenes that followed in New England brought back the days of the Stamp Act. Collectors resigned, meetings were held, protests and memorials were sent to Washington, committees of safety were formed, militiamen to enforce the law were refused, and even secession was suggested. The embargo majority in Congress was swept away by this storm, and the embargo acts were repealed on the first of March, isog.

iffect abroad.

239. Indirect Results of the Embargo. - Foreign trade had been prohibited with the expectation of starving Europe into submission to our demands. The total cessation of the chief neutral carrying trade was undoubtedly a loss to the wealthy European colonies in the IVest Indies and a deprivation to the continental countries, but the chief damage was to America, as noted in the preceding section. As Armstrong, our minister to France, wrote, "We have somewhat overrated our means of coercion. Here it is not felt, and in England . . . it is forgotten." It had at least one good influence abroad, however, in showing that the United States, though unwilling to try the fortunes of war, was ready to undergo unusual hardships rather than submit to the humiliating proclamations against neutral trade. Furthermore, had there been no embargo, the enforcement of the last orders in council and the Milan Decree might have led to a war more futile, more prolonged, and more annoying than that which broke out four and one-half years later.

In one sense the embargo marks the beginning of the United States as a manufacturing nation. Cut off as we were from the importation of manufactured articles that had formerly been brought from Europe, especially England, a large amount of homespun cloth, steel goods, furniture, and other articles was produced, particularly in New England, where the capital formerly devoted to trading was now in many cases used in manufacturing.

From a constitutional standpoint also, the influence of the embargo was important. The Constitution allows Congress to regulate foreign commerce, but nowhere au-

Constitutional results.

United States, IV, $274^{-284}$ V, If-20. 
thorizes the prohibition of all trade with other countries. The passage and enforcement of the embargo involved therefore a much more liberal use of the implied powers of Congress than had been undertaken by the Federalists. Jefferson and his party had abandoned, without hope of return, their former position as really strict constructionists of the Constitution.

240. The Non-Intercourse Act (1809). - The repeal of Provisions. the embargo acts was accompanied by the passage of a law providing that there should be no commercial intercourse with either England or France so long as their orders and decrees remained in force. If these were revoked, the president had the right by proclamation to renew commerce with the nation that had withdrawn its objectionable restrictions on our trade. This discretion was to be exercised by James Madison, who took the oath of office as president three days after the law had been signed. A sincere lover of peace, and a student of politics rather than a practical politician, Madison could be counted on to prevent actual hostilities if possible, as he had done during his eight years of service as Jefferson's secretary of state.

England's minister, Darid M. Erskine, was as desirous as Madison to reëstablish cordial relations between his nation and the United States. Accordingly he offered to have the orders in council withdrawn on the Ioth of June, 1809 , if the United States would cease to discriminate against MacDonald, Documents, No. 28.

English commerce. ${ }^{1}$ Amid the general rejoicing over this settlement of difficulties with Great Britain came news that Erskine had been recalled and his acts disavowed, and, after a brief interval, the orders in council were enforced with greater vigor. The United States had added another failure to her already long list in her attempts to protect our trade abroad.

'In doing this Erskine undoubtedly exceeded his instructions, but Medison, glad of the opportunity to discontinue so large a part of the commercial warfare we had been waging, did not wait to learn whether Erskine's action would be endorsed by the English ministry, and proclaimed that trade with England would be resumed June ro. 
French

rotests.

Schouler, ('nited States, II, 335-340.

Provisions.

Napoleon's trickery.

McMaster, Inited States, II I, 368-394, $424-426$.
Napoleon was no more submissive to the Non-intercourse Act than was Great Britain. As the act prevented trade with France and threatened confiscation to any French ships found in American ports, Napoleon retaliated with spirit by scizing and selling all the American ships that entered ports of his allies. This policy of confiscation he strengthened by issuing in March, I 8 so, the Rambouillet Decree, by which all American ships trading with France or countries subject to France were to be sold and the proceeds placed in the " chest of death." Within two months one hundred and thirty-four ships had been confiscated, making a total of \$10,000,000 obtained by Napoleon from American spoliations since the passage of the Non-intercourse Act.

24I. The Macon Bill, No. 2 (18Io). - Non-intercourse, as embolied in the bill of 1809 , was seen to be unsatisfactory. A substitute was adopted finally by Congress on May I, ISIO. This provided for a renewal of trade with all countries, but, if either France or Great Britain should withdraw her proclamations against American commerce, our government should give the other three months in which to withdraw her decrees. If the latter still continued to discriminate against our trade, we should revive non-intercourse with that nation.

Napoleon saw that his chance had come to embroil the United States with Great Britain, to his own advantage. With half promises that restitution should be made to America for the ships he had seized, he agreed that on November I, IS Io, he would revoke the Berlin and Milan decrees if England would recall her orders in council, or if the United States would compel Great Britain to respect our rights on the ocean. Our government consequently sought in every way to secure the revocation of the English orders in council, but in vain. On November 2, therefore, President Madison proclaimed that if the orders were not withdrawn by February I, I8 I r, non-intercourse should go into effect again with Great Britain. The tricky emperor, without compensating American merchants for losses at his hands, by a halting and par- 
tial removal of restrictions on our trarle, had skillfully marle the Uniter States an instrument for injuring liritish rommerce, at the same time that he harl causerl England to seem the chief offencler. For Great Britain, claiming that the French decrees were still in force, refused to morlify her orders, and on March 2, I 8 I , Crongress passerd the last of its commercial acts designed to maintain peace, and prohibiterl all trarle with England in British ressels.

242. Summary. - Fortunately the chief problems of Financial internal organization had been completed before we became involved in the contests of Eurojee after I 793. Mrst and party probjems. of the pressing jorollems of finance had been solved by the adoption of Hamilton's plan for a complete system of taxes, for reducing the dekt, and the assumption of state detsts. 'The ardoption of this financial prolicy was the cause of disputes between two sets of people who in time organized prolitical parties with definite views regarding the respective powers of the national and state governments, on European questirns, and on popular participation in the work of gosernment. Under the aristrocatic Federalist jarty, the national government was placerl upon a firm basis, but the Ferderalists ruled arbitrarily and jermitter their opjornents to gain control. This democratic Republican jarty kejt itself in prower because every tendency of the times was in farror of government by the persple.

We were drawn into foreign disputes hecause, as neutrals, we enjoyed a large part of the carrying trarle carried on before I 79.3 by one of the crombatants, and because several of the nations engager in the Eursjean war controlled or desired territrry adjacent to the Cnited States. O) chief complaints were against (jreat Britain, who objecterl to our carrying gords directly or indirectly between French colonies and France or her allies in Europe.

Although we tried to arrid any part in these European wars, our treaty of $1,7-8$ with France caused difficulty at first, and oup understanding with England in Jay's treaty Foreign protsleerns after 1793 . (I794) completely altered our relations with the chief nations

Successful treaties $(1734-1803)$. 
at war. The misunderstanding with France which followed Jay's treaty was terminated by the treaty of 1800 . In $\mathrm{ISO}_{3}$ Napoleon helped us to solve difficulties in the West by ceding all of Louisiana, which affected American development in innumerable ways and to a very great extent.

Commercial discriminations (I8O5-I8II).

The last phase of the European contest during this period in which we were interested was a species of commercial warfare in which France tried to cripple England by cutting off English trade with the continent, and England aimed to destroy the trade of France with the outside world. The United States suffered especially and tried to protect herself by passing embargo and non-intercourse acts which destroyed most of our commerce without injuring the European nations particularly. Having exhausted every peaceable means to obtain relief from commercial discrimination, there seemed to be no honorable course but to declare war in order to protect our rights.

\section{TOPICS}

I. International Interests in the IVEST (I790-r8oo): Roosevelt, "Winning of the West," VI, chap. II; Turner, F. J., in Atlantic Wonthly, 93 (I904), pp. 676-69I, 807-8I7; Ogg, "Opening of the Mississippi," pp. 410-494.

2. Kentuchy and Virginia Resolutions: Johnston, "American Political History," I, pp. ISS-202; Von Holst, "Constitutional History," I, pp. I+2-I67; Powell, "Nullification and Secession in United States," pp. 50-9I.

3. BurR's CoNspiricy: Roosevelt, "Winning of the West," IV, pp. 2SS-307; McMaster, "People of the United States," III, pp. 5t-SS; Adams, "History of the United States," II, pp. 394-409, III, 290-34t; McCaleb, "Aaron Burr Conspiracy."

4. Opposition to the Embargo: McMaster, "People of the United States," III, Pp. 270-307, 323-335; Adams, "History of the United States," IV, pp. 240-2So, 339-360; Benton (ed.), "Debates of Congress," III, 677-707, IV, pp. 5-3I.

\section{STUDIES}

I. Difficulties with the Indians in the Northwest. (King, "Ohio," Pp. 24I-26I.)

2. The situation in Europe ( $7_{7} \mathrm{~S}_{9-\mathrm{I}} \mathrm{SO}_{\mathrm{I}}$ ). (Adams, "European Historv," pp. 427-444.) 
3. Washington's Farewell Address. (Larned (ed.), "History for Ready Reference," V, pp. 3308-33r4.)

4. Debate on the "X. Y. Z." correspondence in Congress. (Benton (ed.), "Debates of Congress," III, pp. 225-242.)

5. Jefferson's first inaugural address. ("American Eloquence," I, pp. $155-163$.)

6. Fisher Ames on Jay's treaty. ("American Eloquence," I, pp. I I 2-I 30.)

7. Jefferson's views on the constitutionality of Louisiana. (Jefferson, "Writings" (Monticello ed.), X, pp. 407-420.)

8. Significance of the Louisiana purchase. (Turner, F. J., in Review of Reviews, XXVII (1903), pp. 578-584.)

9. Napoleon's "Continental System." (Andrews, "Historical Development of Modern Euroje," I, pp. 49-62.)

I0. English customs followed in 1789 . (Ford, "American Politics," Chapter VI.)

\section{QUESTIONS}

I. How had the state debts been incurred? Should the difference between the net amount of the northern and southern debts have affected the payment? Was assumption necessary? Was it wise? What influence did the financial measures of Hamilton exert on the national government?

2. What is the difference between strict construction in $\mathrm{I} 79 \mathrm{I}$ and at present? What is meant by implied powers? Could the Constitution have survived without the use of implied powers? Mention several duties now performed by the national government which involve the use of implied powers.

3. Could the organization of prolitical parties have been prevented? Explain. Show the position of the parties on democracy, constitutional questions, foreign affairs, other matters. Why did the Federalist party go to pieces after 1800 ? What part of its work was permanent?

4. Why was the Proclamation of Neutrality in 1793 a wise measure? Show how the year 1795 marks a turning-point in the history of our international relations. Did our standing abroad improve during the rule of the Federalists?

5. Was the election of Jefferson (1800-180I) a political revolution? To what extent was the policy of the national government really changed? Were Jefferson's administrations successful?

6. What was the influence of the Louisiana purchase on territorial expansion, construction of the Constitution, development of nationality, changes in favor of democracy, economic development, the problem of slavery, settlement of international disputes, general progress of the United States? 
7. Define the American view of the Rule of $175^{6}$, the English view. Was impressment from American vessels justifiable? Was there any reasonable excuse for the orders and decrees of 1806 and 1807 ? Be specific.

8. On what constitutional grounds might an embargo be declared? What was the effect of the embargo on England? on France? on American commerce? How did the embargo influence the investment of capital within the United States? Give some idea of the real importance of the embargo.

9. Explain each of the problems confronting the national govern. ment in 1789 and note those developed later. In what way was an attempt made to solve each? With what success? Give fully. 


\section{CHAPTER XII}

\section{A NEW NATIONAL SPIRIT (I8II-I824)}

\section{Presidents}

James Madison ( $1809-1817)$

James Monroe (1817-1825)

\section{The Second War of Independence}

243. Events Leading to War (I8II-I8I2). The feeling toward England, already bitter, was increased during the years I $8 \mathrm{II}$ and I8I 2 by three unfortunate events. In May ô I8I I the Little Belt, one of the British vessels occupied in watching our coasts, by some mischance was engaged in action by the President, which was a much larger ship. The Little Belt was completely crippled, but an investigation freed the American government from blame for the affair, and there was general rejoicing that the Chesapeake had been avenged.

Six months later, Governor William Henry Harrison attacked a force of Indians gathered at Tippecanoe creek in Indiana Territory, defeating them with great slaughter and burning their principal town. Under the lead of a Shawnee chieftain, Tecumseh, a confederation of all the Indian tribes in the West had been formed for the purpose of expelling the whites. This movement, it was thought, had received the support of the British in upper Canada.

The third cause of ill-feeling was the publication in March, I8I2, of letters sold to our government by an adventurer, John Henry, who claimed to have been sent in I8ro on a secret mission to New England with the intention of learning whether that section would desert the United States in case Little Belt affair.

McMaster,

United States, III, 402-406.

Victory at Tippecanoe.

Babcock, Am. Nationality, $3^{2-36}$.

Schouler, United States, II, 366-370.

The Henry letters.

McMaster, United States III, $444^{-447}$. of a war with Great Britain.

244. Declaration of War (I8I2). - Prevention of war 
Clay and the New Republicans.

Schurz, Clay, I, 77-88.

War declared.

MacDonald,

Documents,

Nos. 29, 3 .

McMaster,

Inited states, III, 449-452. $454^{-458}$.

Beginning of the conflict.

Babcock, Am. Nationality, 69-83. had now become an especially difficult task, for the control within the Republican party had passed from the older and more conservative leaders to a set of young, energetic men who believed further submission to be debasing. Among these young Republicans Henry Clay of Kentucky was the most prominent figure. Brilliant rather than deep, an eloquent speaker, with a rare capacity for making friends, he was a remarkably successful leader. He and his "warhawks" aroused such an enthusiasm for war that President Madison, desiring a second term, was induced to support their policy.

An increase in the army and navy was voted early in January, ISI2. Later, an embargo of ninety days was declared as a preparation for war, and on June I, i 8 I 2 , the President's confidential war message was submitted to Congress. Three grievances against England were mentioned: impressment, sham blockades, and intrigues with the western Indians. With but a few days' delay, Congress voted for war, the South and West being almost unanimous for action, while the Northeast voted against the measure, thirty-four of the minority going so far as to issue an unpatriotic manifesto assailing the administration's position.

War was declared June $I$, and on June the orders in council were withdrawn by England. Had a telegraphic cable been in existence, war might have been avoided. Before this news could reach America, the government had made preparations for increasing its army and building new frigates, and the nation could not easily be dissuaded from the invasion of Canada which had been planned. In New England, the governors refused to furnish troops who should fight outside their respective states, but elsewhere enlistments went on rapidly. With light hearts the people began war on the most powerful nation of Europe. Considering the distance between the continents and the difficulties of the war with Napoleon which had taxed England's resources to the utmost, the disparity was not great.

245. War in the North $(1812-1813)$. - The invasion of 
Canada, so much desired, especially by the West, and repeatelly attempted during the first two years of the war, was a complete and humiliating failure. At the beginning of hostilities, General Hull, having crossed into upper Canada, was forced to retire, and, without a blow, surrendered Detroit and all Michigan to the English. Following this came counter invasions of the British into Ohio, and the horrible massacre of the wouncled by the Indian allies of the British at the River Raisin, the cry of "Remember the

I oss of the Northwest (1812).

Larned (ed.), Ready lief., $\mathrm{V}, 3340-3344$.

Babcock, $d m$. Nationality, $84-98$.

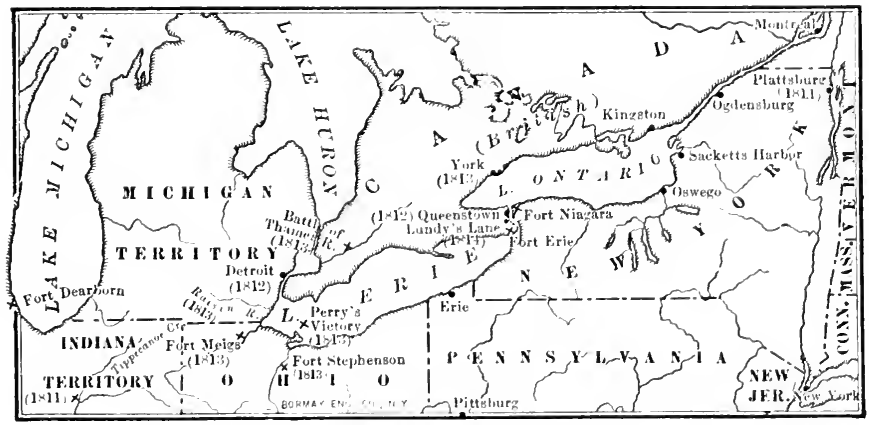

SCENE OF WAR IN THE NORTH

River Raisin" being thereafter the slogan of the western troops.

In the fall of 1813 the tide turned in the Northwest. Oliver H. Perry, having by remarkable efforts completed a fleet on Lake Erie, met and captured a somewhat inferior fleet commanded by an officer who had served under the greatest of British admirals, Nelson. This great victory was announced in the laconic dispatch, "We have met the enemy and they are ours." It was followed by the transfer of Harrison's army to the north shore of Lake Erie and the unequal battle on the Thames River, in which the Indian warrior Tecumseh was slain. This double victory freed the entire Northwest from English control.

Elsewhere on the northern border success dirl not attend American arms. On the Niagara frontier operations dur-

McMaster,

United States,

and the River 'Thames (1813)

IV, 32-4I. 
Failures in northern New Iork $($ I8I3).

McMaster, United States, IV , 4 I-56.

Successful naval duels.

Larned (ed.), Ready Ref., $\mathrm{V}, 33+3-33+4$.

Babcock, $A m$. Nationality, IO6-I I4.

Losses to commerce.

MicMaster, I'nited States, IV, IO4-II6.

ing the summer of $\mathrm{I}_{\mathrm{S}} \mathrm{3} 3 \mathrm{had}$ been conducted with more than usual inefficiency by our commanders, and at York (Toronto) the parliamentary buildings had been burned. The St. Lawrence and Champlain basins also had been the scenes of disgraceful mismanagement. Projected invasions of Canada had failed ignominiously, owing to the incapacity of the American generals and their failure to coöperate with each other.

246. The War on the Ocean $(1812-1814)$. - There is no brighter chapter in American history than the one devoted to the records of the American

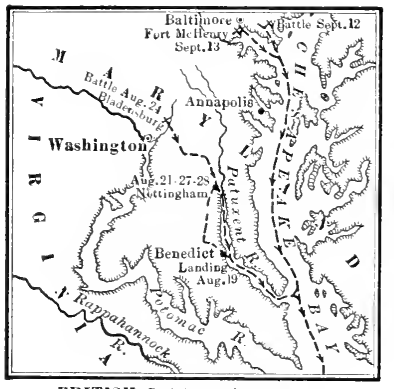

BRITISH CAMPAIGN AGAINST WASHINGTON, 1814 navy during the War of I8I 2. Our ships were unable to engage the enemy except in rare instances, but the duels fought between single frigates were in most cases signal victories for the American vessels. During the first year of the war the Constitution captured $\mathrm{t}$ wo frigates after short, decisive engagements, the superiority of the Americans being chiefly in seamanship and gunnery, but partially in heavier armament. Especially during I8I 2 and I ${ }_{I} 3$ did the nary distinguish itself, for, with the progress of the war, the coast was blockaded so carefully that once in port an American frigate could not escape easily. Great damage was also inflicted on British commerce by vessels of the navy and privateers. The Essex made numerous captures on the Pacific, and the privateers are said to have made prizes of fifteen hundred English merchantmen, a larger number than had been confiscated by Great Britain during the years preceding the war. ${ }^{1}$ On the other hand, American commerce was practically destroyed by the war, it being unsafe for our merchant marine on the

${ }^{1}$ Nearly one half of these were recaptured on their way to American ports. 
high seas and all but impossible to evade the strict blockades of the coasts.

247. The Last Year of the War. - With the capture of Paris in I8r4 and the subsequent banishment of Napoleon to Elba, England was able to spare many veterans for the war in America. These aided the Canadian militia in the North and took part in the expeditions against Washington and New Orleans. Yet this accession of strength brought Niagara and Lake Champlain. the English few successes, for during the rest of the war the

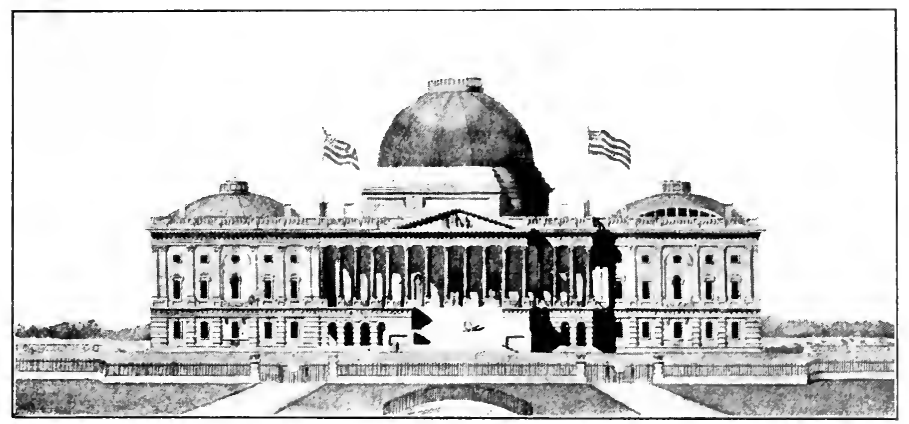

The Capitol, Washington

Americans were nearly everywhere victorious. During the summer of I8I4, General Jacob Brown restored American prestige at Niagara by winning the battles of Chippewa McNiaster, Cnited States, IV, 56-69. and Lundy's Lane. In the fall of that year an invasion of Lake Champlain was attempted by the Canadians, a large land force being supported by a hastily prepared but by no means insignificant fleet. Their progress was checked at Plattsburg by young Captain Macdonough, who so arranged and managed his vessels that he crippled the superior fleet of the enemy and compelled the withdrawal of both land and naval forces into Canada.

During the first two years of the war, rairls had been made at various points along the coast in which several towns Washington and Baltimore. were burned and considerable shipping destroyed. These were supplemented in I8I4 by an expedition against Wash- 
Schouler, C'nitid states, I. $450-455$.

3abcock, $4 \mathrm{~m}$. Viationality, $3^{2-I}+3$.

New Orleans I8I5).

ington and Baltimore. As the capital was practically undefended except by forts on the Potomac, the British advanced without opposition to Bladensburg, where they put to flight a motley force gathered to protect the city. The capitol, Ihite House, and other public buildings were burned, but all of the government officials, including President Madison, made their escape. Advancing toward Baltimore by water, the British were unable to capture Fort McHenry, its chief defense, and withdrew without further successes. The bombardment of this fort by night was the

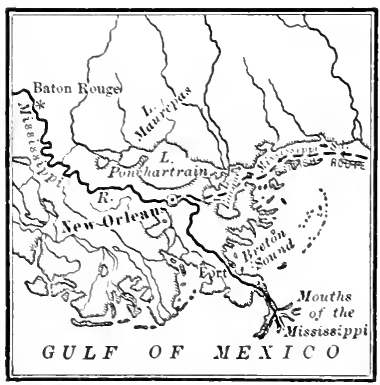

NEW ORLEANS AND VICINITY occasion for the writing of "The Star Spangled Banner." Being desirous of capturing New Orleans and thus gaining possession of the valuable territory of Louisiana, the English sent a large army against that city late in $\mathrm{I}_{\mathrm{I}} 4$. Its defense was intrusted to Andrew Jackson who had already distinguished himself by his vigor and energy in the deLarned (ed.), struction of a hostile force of Creek Indians, and by the Ready Ref.,

V, 3358-3359.

Babcock, $4 m$. Niationality, I 28-I 32, $\mathrm{I}_{44^{-I}}+\mathrm{g}$.

McMaster, L'nited States. IV, I60-I7I. I80-I9o. seizure of Pensacola, which the Spanish had allowed the British to use as a base of operations. With comparatively few regulars, but with large numbers of frontiersmen, Jackson skillfully blocked the efforts of the English general, Pakenham, to reach the city by a flank movement. Pakenham with his veterans then advanced to a front attack along the narrow strip of land between the Mississippi and extensive swamps. The first assault took place on January 8 , I 8 i 5 . Of the Americans, but seren were killed and six were wounded, while the English lost at least twenty-five hundred in their vain attempt to take the American position. This remarkable victory produced general rejoicing and made Andrew Jackson a conspicuous personage.

248. The Treaty of Ghent (I8I4). - Two weeks before 
the battle of New Orleans, a treaty of peace had been signed Negotiations. at Ghent in Belgium. Negotiations for peace had in fact been attempted in 1813 when the Czar of Russia offered his services as mediator. The United States accepted his offer and appointed commissioners, but Great Britain refused to be a party in such an arrangement. The following summer (August, 18I4), negotiations were finally begun at Ghent, the United States being represented by three very able men, Albert Gallatin, John Quincy Adams, and Henry Clay, who unfortunately did not agree on the best terms to be marle with England. As the British armies had been in the main victorious to that time and as the blockade of our coast was quite effective, her commissioners made several demands, among them the establishment on our northwest frontier of a permanent belt of Indian . country under British protection.

The English finally agreed to give up all their demands and to return territory that had been seized, namely, parts of Maine and Oregon, when our representatives promised that they would not mention the subject of impressment and would not require compensation for ships and cargoes confiscated before 1812. With these terms the commissioners were content, because the conflict between England and France had already ceased and the British navy needed no more sailors. $\mathrm{By}_{y}$ the American people the treaty was hailed with delight, for they ignored our failure to obtain any of the objects of war, in the general rejoicing over the restoration of peace.

\section{Changed Conditions after the War of i8i 2}

249. The New Nationality. - The close of the second war with England marks the beginning of a new epoch in America. Aroused by the commercial discriminations of the leading European nations, the people had become united as never before to uphold the honor and preserve the rights of the American people. Throughout the country there Terms of the treaty.

MacDonald, Documents, No. 31 .

McMaster, United States, IV, 270-276.

Independent spirit of the people.

Babcock, Am. Nationality, I9I-I95. was a feeling of loyalty to the nation, a national pride, a 
belief in the oneness of the nation and the unity of interests which had never existed before that time. Not only had barriers between the states been broken down, but there was widespread desire to cast aside old forms and customs which had been in use since colonial times and which most people now thought to be outgrown. The new nation had found itself and insisted on doing its work in its own way, not looking to Europe for the policies it should pursue nor slavishly following the paths laid down by preceding generations. On this account the War of $\mathrm{I} 8 \mathrm{I} 2$ is often called rightly the second war of independence.

Changed conditions after 1815.

Reasons for improvement.

War with Algiers (I8I5).
Of the conditions which were changed after the war five deserve especial attention: (I) our altered international standing, (II) changes in political parties, (III) changed economic conditions, (IV) the new policy of the courts, and (V) the development of the West and the demand for internal improvements. All of these reflect the new national spirit of the people and most of them show that a new national policy was being adopted by the central government.

250. Our Altered International Standing. - (I) In I 8 I 5 war ceased in America and in Europe. After the battle of Waterloo France and England no longer found it necessary to injure one another directly or through acts that affected the trade of neutrals. Our ships were not stopped on the high seas, and our commerce was free from interference as it had not been before for a score of years. Aside from these immunities we were treated abroad with a respect that cannot be accounted for on the ground that the return of peace made it unnecessary to fear us as neutrals. Foreign nations realized that the United States must no longer be treated as a third-rate power. This improvement in our international standing was due in part to the fact that the United States had now come to recognize itself as a nation. It was due still more perhaps to the determination of the United States to protect its rights by force if necessary. It was influenced undoubtedly by the promptness with which, at the close of the war with England, our navy compelled 
the heads of the Barbary powers to make restitution for injuries committed during the war, and to renounce all claims to tribute which had been paid theretofore by us and McMaster, United States IV, 35I-356. which was still being paid by European states.

The increased respect which we commanded abroad is shown by the greater eagerness with which foreign nations sought our favor, and the more satisfactory terms which we were able to make with them in various treaties. Probably the best proof of our real independence was the willingness to announce so bold a policy as that embodied in the Monroe Doctrine ( $\$ 262)$, and the influence which the announcement of that doctrine had in Europe.

25I. Downfall of the Federalist Party. - (II) Political conditions were radically different after I8I5. With the close of the war the Federalist party practically disappeared, leaving only the Republican party. As far as there were any issues separating the factions of this party, they dealt with domestic affairs exclusively. Nothing more was heard of the French party and the English party, for with the wai had passed the dominance of Europe in our politics. Because of the war and their unpatriotic action during that conflict, the Federalists ceased to exert even the minor influence they had possessed before i 8 I 2 .

They had opposed the war from the beginning and in several instances had acted in opposition to the administration. Several state legislatures issued protests against the continuance of the war. All but one of the New England governors objected to the use of the militia in other states for the purpose of carrying on offensive war. Merchants in the Northeast furnished the enemy with a large part of their provisions. New England capitalists, who had most of the specie in the United States, refused to aid the government in its attempts to sell bonds. On the other hand, the national government made no attempt to protect the New England states and adopted several measures particularly injurious to that section.

The Federalist opposition to the war culminated in the

Reasons for Federalist downfall.
Beginning of domestic political parties.

Evidence of a better international position.

.


Iartford onvention I $\left.8 I_{4}\right)$.

Babcock, th. iationality. $00-107$.

Icdaster, "nited states, V, $247-252$, 75.

Beginnings of hanufacturing.

ichouler.

C'nited states, I, $243-246$.

raussig.

Tariff Hist., $7-19,27-29$, 99.50 .

Difticulties of the minuacturers (ISI5-ISI6).
Hartford convention, in which three states were represented. Their enemies claimed that in these secret sessions the members were considering plans for secession from the Union, but that was not true. The real purpose of the convention was to protest against the war and unite on certain measures for the protection of the sectional interests of the New England states. ${ }^{1}$ Several amendments to the Constitution were proposed that would, if accepted, safeguard their interests. The report of the convention was adopted by the legislatures of Massachusetts and Connecticut and was carried to Washington so that it might be laid before Congress. Unfortunately for the Federalists, it reached the national capital at the same time as news that peace had been made, and that the British had sustained an overwhelming defeat at New Orleans. The return of peace remored the cause of the Federalists' grievances and produced such a reaction against that opposition party that it was never afterward a serious factor in our political life.

\section{The Tariff of 1816 . - (III) Shut off from Europe by} embargo and war during most of the years following $\mathrm{ISO}_{7}$, the people of the United States were deprived of the use of articles that they had imported formerly except so far as crude substitutes were manufactured in this country. So great was the impetus given to manufacturing during this period that the real industrial beginnings of the United States may be said to date from the great embargo.

After Napoleon was orerthrown at Waterloo ( 1815 ) and Europe was at peace for the first time in twenty years, the continental nations revived their old tariffs in order to prevent England from sending them so many manufactured articles. Deprived of this market for their goods, the Eng-

${ }_{1}$ The members of the convention occupied much the same ground taken by Kentucky and Virginia in their resolutions of 1708 and 1790 . They claimed that in case of deliberate, dangerous, and palpable infractions of the Constitution affecting the sovereignty of a state and the liberties of the people, "it is not only the right but the duty of such a state to interpose its authority for their protection in the manner best calculated to secure that end." 
lish merchants shipped immense quantities of manufactures to America. Prices fell immediately, and the American manufacturers found that they could not compete with their English rivals. Unless Congress gave them relief from this deluge of foreign goods, the factories started during the previous decade would be obliged to close, as the comparatively high tariff of 1812 , passed for the purpose of giving revenue, was not really protective and was to continue only a year after peace was marle.

Numerous petitions were sent to Congress asking that body to raise the duties on wool and cotton manufactures. Henry Clay, distinguisherl throughout his career as the great champion of protection for American manufactures, gave the proposed tariff his ardent support. John C. Calhoun made a speech in its fa vor that was remarkable for itsbrearth. Daniel Webster and the New England contingent hesitated to support a policy that threatened to injure the commerce of that section. Many in the South saw only danger in protection, but a fair minority were won over by the tariff on cotton imports which would benefit indirectly the planters in the cotton belt. In its final form the tariff of 1816 , the first really protective tariff in our history, provided for a twenty-five per cent ad valorem duty on cotton and wool manufactures, thirty per cent on some forms of iron manufactures, a specific duty of three cents a pound on sugar, and lower rates on a few other articles. In some respects it was the most national tariff ever enacted in Congress, as it received some support in every section of the country.

253. The Second National Bank. - The change in the national sentiment of the people and in the willingness to intrust a greater amount of power to the central government is more striking in the case of the national bank than in that of the tariff. The first national bank had been ol)liged to discontinue its operations as a national corporation in 18 i when Congress refused to renew its charter. The opposition to the bank among the Republicans was quite strong because they felt that there was considerable doubt

Need of a national bank.
MeMaster, I'nitid States, IV, 319-326.

Tariff of 1816.

Dewey, Financial Ilist., $\$ 73$

labeock, $\mathrm{dm}$. Nationality, 235-242.

Burgess, Middle leriod, 8-13. . 
as to its constitutionality, and because many believed that the influence of the bank had been exerted for corrupt ends. Nevertheless the bill to renew the charter in I $\mathrm{I}_{\mathrm{I}}$ was lost by the casting rote of the vice president in the Senate. During the war with England, the dilatory policy of the government in raising taxes, coupled with the great increase of paper money issued by the local banks that had sprung into existence after the discontinuance of the national bank, caused great confusion in the currency and left both the government and the country in a serious financial condition.

The second Jnited States ank.

lacDonald, locuments, To. 33.

Dewey, Finanial Hist., ई 67.

Ic.liaster, 'nited states, V, 309-3I4.

iupport given o the central overnment.

lagruder, Iarshall, Chapter X.
It was believed quite generally that a national bank would be of the greatest service in aiding the national government and in remedying the currency ills of the country. As very little doubt existed now as to the constitutionality of a national bank, there was little difficulty in passing an act for a second national bank. ${ }^{1}$ This bank was chartered for twenty years and was to have a capital of $\$ 35,000,000$, of which one fifth was to be subscribed by the national government. Most of the remainder was to be in bonds or notes of the United States. It was to aid the government in conducting its fiscal operations. Unlike its predecessor, the stock for which had been owned almost entirely abroad, the bank was supported by American capitalists, the number of those owning stock being very much larger than those interested in the earlier bank. Although the bank did relieve the financial situation somewhat, it was managed badly for several years and did not prove a great success at the beginning.

254. The Supreme Court. - (IV) The influence of the Supreme Court in strengthening the national government at this time can hardly be overestimated. On account of the national sentiment among the people during the period following the war, the court was allowed to render and enforce several decisions which defined more clearly the work

${ }^{1}$ Most of the opposition came from the Federalists, whose anti-national attitude at this time was followed by their complete disappearance soon after. 
which Congress might do and enlarged the sphere of duties left to the government at Washington. In this task of increasing the authority of the national government, the influence of the Chief Justice, John Marshall, was preëminent, although the other justices held very liberal views. 'There were two ways in which the court gave its support to the national government: ( 1 ) by interpreting in a liberal way that clause of the Constitution which gives Congress the right to use all means which are necessary ard proper for carrying into execution the powers specifically conferred on the national government by the Constitution, thus indorsing the right of Congress to use "implied" powers, ${ }^{1}$ and (2) by preventing the states from interfering with the work of the central government. ${ }^{2}$

The right of Congress to use implied powers was expressed most emphatically in the case of $I^{\prime} C$ ulloch v. Maryland (18I9), when the court declared that Congress harl the right to charter a national bank, although the Constitution does not mention such a right in the list of enumerated powers. Marshall admitted that the powers of the national government were limited, but claimed that Congress harl the right to use its discretion as to the means which it might employ in performing its duties. "Let the end be legitimate, let it be within the scope of the Constitution, and all means which are appropriate, which are plainly adapted to that end, which are not prohibited, but consistent with the letter and spirit of the Constitution, are constitutional."

255. The Development of the West. - (V) Undoubtedly the most important of the changes which took place luring this period was the westward movement by which the eastern Causes of migration to the West. half of the Mississippi and Gulf basins was peopled, leading directly to the admission of several new states and indirectly to a great development in the democratic and national

${ }^{1}$ Constitution, Art. I, $\$ 8, \mathrm{Cl}$. I 8 .

2 The court also limited the powers of the states in the interests of individual rights, as in the famous Dartmouth College case, in which the right of a state to alter a charter was denied. 
spirit of the people (S 290, 297). The war had served to awaken the nation. Thousands became dissatisfied with the old hundrum life of the eastern border, and turned to the West - the land of enterprise, of opportunity, of wealth. Before the war the emigration to the West had been considerable, after I $S_{1} 3$ it became rapid, and by I $\&_{1} 5$ it was little less than marvelous. The stagnation in the coast cities due to the blockade maintained during the war and the limited market for farm products had much to do with the exodus. The richness of the soil, the liberal land policy of the government ( $\left.2 S_{9}\right)$, and the greater political rights enjoyed in the West (\$290) were not the least of the inducements in the country beyond the mountains.

Extent of migrations.

Turner, Niow $\|{ }^{e s t,} 67-\delta_{3}$.

MeMaster, Linted states, IV, $3 \mathrm{SI}-390$.

Cumberland road.

Sparks, Existinsion, $250-264$.

Several of the southern coast states considered measures for preventing further emigration to Mississippi, Alabama, and Tennessee, the population of which expanded amazingly in the years following the destruction of the Indian strongholds by forces under Jackson. But the growth of the South did not equal that of the North. The roads to the West were one succession of emigrant wagons carrying families and houschold goods. At one point in Pennsylvania five hundred wagons were counted in a single month. Nearly fifty thousand persons moved into Indiana in the single year ISI6. Villages sprang up as if by magic. Speculation in town lots and farm lands became common. Everywhere the country teemed with life and excitement. Nor did expansion stop with the Mississippi River. Into the trackless wastes beyond the Father of Waters poured the pioneers, closely followed by the farmers with their families.

256. Internal Improvements. - Most of the states west of the Alleghany Mountains desired to improve all possible means of communication, because they were essential to their development. They expended large sums of money for roads and canals, granted privileges and gave bonuses to private companies engaged in improving highways and waterways, and sought from the national government aid in constructing roads. When the state of Ohio was admitted 
into the Union ( 1803 ), Congress agreed to spend the proceeds arising from the sale of certain public lands in building a national road which should connect the state with the seacoast. Naturally the states west of Ohio insisted on a continuance of this highway. The route selecterl was from Cumberland, through Maryland, Pennsylvania, and Virginia to Wheeling on the Ohio, and west through Columbus and Indianapolis to Vandalia, Illinois, beyond which nothing was done. Work on this "Cumberland roatl" progresserl slowly, although Congress began at an early date to make appropriations supplementing the land funds, thus establishing firmly as at governmental policy that system of internal improvements which has done so much for the commerce of the United States both foreign and inland.

After the war with England, Congress took up in carnest the question of internal improvements. ${ }^{1}$ Under the learl of Calhoun, Congress discussed a system of roatls aturl canals similar to the famous plan proposed by Allert Gallatin, secretary of the treasury, in 1808 . There were to be canals connecting all of the important bays along the $\Lambda$ tlantic coast in order to permit communication by inland waters from one part of the coast with another in time of war, a national road from Maine to Georgia, several roads to the West, and military roarls on the frontiers. The money paid by the national bank for its charter was voted by Congress for the partial improvement of these roarls and canals, the rest to be appropriated by the states, but the bill was vetoed by President Marlison (18I7), who favored the scheme but could not overcome his constitutional scruples. The national government afterward built several military roads, which were located, however, in such a way as to be of comparatively little value to commerce and interstate migration.

257. Importance of the Westward Movement. - The part which the West took in the development of the nation in the years following the second war with England can be

Internal Improvement [si'] (1817).

IIart, contempuraries,

III, No. I3I.

Burgess,

Middle f'eriod $14-18$.

McMaster, Uniled States, IV, $411-415$.

New national type: in the West.

${ }^{1}$ Appropriations had been made before that time for post roads and for harbors and lighthouses as an aid to commerce. 
appreciated in part from the preceding sections. But the growth of the West did much more than awaken the people and present new problems for the nation to solve. It changed, gradually of course, the point of view of the whole population, for in the West much sooner than in the East the people came to look upon things from a national, not from a local standpoint. The emigrants from the Atlantic states who settled in the Mississippi valley had no local traditions in their new settlements and forgot their pride in their former state. More than one western state was settled by people from a dozen other states who lost quickly most of the characteristics that continued for two generations in the old home. In the cosmopolitan West a new race was dereloped that was a blending of the colonial types which still existed on the Atlantic border. Here was the beginning of the really new nation, the American people.

Four things of the first importance the IVest was doing at this time which the whole people adopted later. (I) The American type was developed - a race that blended many of the characteristics of the eastern people from whom it sprang, uniting with them a vigor, an enterprise, a broadmindedness that was its own. (2) The West riewed things from a national rather than a local or sectional standpoint. (3) In the West, legal and political equality was developed much earlier than in the older parts of the country. (4) The West presented many political and social problems for the entire nation to solve, and itself decided the solution of many of those problems, because the IVest was progressive and united.

\section{Slateri and Foreign Affairs (isig-i824)}

258. The Missouri Bill (I8I8-1819). - The growth of the West in the period following I I $_{5}$ was so remarkable that territories were prepared for statehood with amazing rapidity. Although the growth was greater in the Northwest than in the Southwest, care was taken to preserve the balance between the free states and the slave states. Indiana (I8I6) was followed by Mississippi ( $\left.\operatorname{I}_{1}{ }_{7}\right)$, and after Illinois was 
admitted (1818) the application of Alabama was considered favorably. All of these states were located east of the Mississippi River and were in territory set aside as free or slave years before.

The situation was radically different in Missouri, which applied for admission as a slave state in I8I8. Missouri was in territory that had been acquired after the Constitution had been adopted, and Congress was free to adopt such a policy as it wished in this region. There was a growing sentiment in parts of the United States against slavery extension, and, although slavery had existed in Missouri from the time of French rule, there was considerable opposition to the continuance of slavery in that region, especially as Missouri was almost entirely north of the line of the Ohio River, which in the middle West marked the boundary between the slave and free states. On this account, when the House of Representatives began consideration of the bill to admit Missouri as a slave state, James Tallmadge of New York offered an amendment that all children born in the state after its admission be free at the age of twent $y$-five years. After an extended debate the House adopted the Tallmadge amendment by a majority of four votes, but the Senate refused to agree and passed the bill admitting Missouri as a slave state without the Tallmadge amendment. Nothing further could be done that session, for neither chamber would recede from its position.

259. The Missouri Problem. - The reason for this deadlock between the houses of Congress is interesting. As the states are represented equally in the Senate, and the slave states were as numerous as the free states, the pro-slavery leaders controlled the Senate because the senators from the slave states were united in favor of admitting Missouri with slavery, whereas the northern members were divided in sentiment. In the House, however, since representation was based on population, and five negroes were counted as equal to three whites for purposes of representation, the northern members outnumbered those from the South by

Different viev of Senate and House. 
twenty-five. Although the southern representatives were united closely by their slavery interest, they could not gain the support of enough members from the North to give them a majority in the lower house.

Tiews of the eople.

IcMaster, Inited States, V, 576-58o.

The MaineGissouri bill.

Jart, Contemporaries,

II, Nos. I35, 36.

3urgess, fiddle Period, 7-87.

Discussion of compromise.
Before the new Congress met in December, I8I9, the sentiment of the country had been expressed fully and clearly on the Missouri question. Meetings had been held in most of the large northern cities and resolutions had been adopted in public gatherings, in town meetings, and in state legislatures, which requested Congress to forbid the further extension of slavery beyond the Mississippi. From the South came numerous petitions asking that Missouri be admitted with slavery.

Before the Missouri bill came up in earnest, however, the House passed a bill admitting Maine as a free state. When the Maine bill reached the Senate, the Missouri bill with slavery was attached to it. Several weeks were spent by both houses in discussing the Missouri question. The arguments presented at this session were similar to those used during the preceding year. Most of those who wished to have Missouri admitted with slavery did not attempt to deny that slavery was an evil, but argued that its diffusion over a greater area would lead to its extinction sooner than restriction within a limited territory. They claimed that Congress had no right to impose important conditions like that which prohibited slavery within a state on its admission to the Union. Their opponents maintained zealously that slavery was a curse which should not be allowed to expand; that it was more wasteful and dearer than free labor. ${ }^{1}$

260. The Missouri Compromises (1820-1821). The debate in the Senate on the Maine-Missouri bill was con-

1 They pointed to the conditions in Louisiana at the time of its admission and to the conditions prohibiting slavery that had been exacted from the states formed out of the "Northwest territory" to show that Congress had the power to regulate important matters for states on their admission to the Union. The proslavery debaters claimed that Congress could not have forced these states to accept that condition, but that they had done so freely. 
cluded by the adoption of an amendment to that dual Schouler, measure, proposed by Senator Thomas of Illinois, which prohibited slavery forever within the territory acquired from France north of $36^{\circ} 30^{\prime}$ except in the state of Missouri. But the House refused to concur. It passed a Missouri bill of its own with a clause prohibiting slavery, but after a conference the House yielded, and the first Missouri compromise was completed.

Missouri was admitted without mention of slavery, but slavery was thereafter prohibited north of $36^{\circ}$ $30^{\prime}$ in the rest of the Louisiana purchase. Maine was admitted separately as a free state. A year later it was found that the new Missouri constitution did not allow free

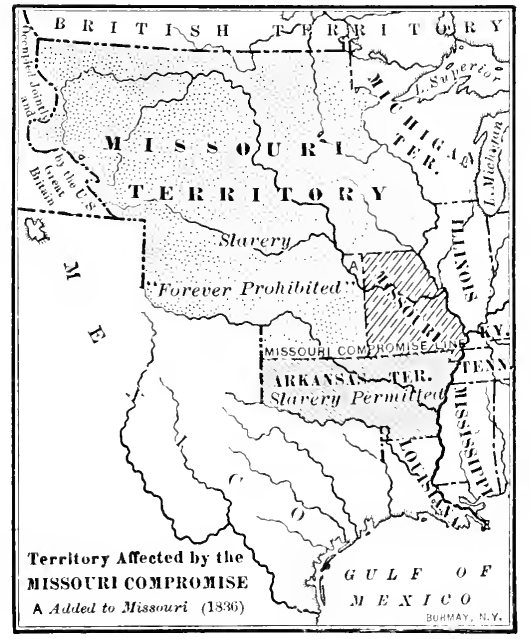

blacks or mulattoes to settle in the state. A sectional clash on this provision was settled by a second compromise, engineered by Clay, which provided that the Missouri constitution should never be construed so as to prevent citizens of other states from migrating to Missouri.

In this way did the statesmen of that period settle the first important slavery controversy under the Constitution. From a legal point of view the result was wise and satisfactory. The right of a state on its admission to the Union to decide questions that were left to the states which were in the Union was affirmed, as well as the right of Congress to control absolutely the national territory before it was erected into states. As slavery had existed in the Louisiana territory from the beginning and had never been prohibited in any
United States I I I, I6I-I65.

MacDonald, Locuments, Nos. $37,3^{8}$.

Provisions of the compronises.

MacDonald, Locuments, Nos. 39-4I.

Burgess, Middle' Peric 87-IO3.

Significance of the compr mises.

Burgess, Middle' l'erio 103-107. 
part by Congress, the prohibition of slavery from the vast region between parallels $30^{\circ} 30^{\prime}$ and $49^{\circ}$ and between the Mississippi and the rilges of the Rockies was a distinct advance, as so little territory wats left open to slavery. As a means for allaying sectional feeling and preventing strife over the question of slavery, it was a decided success, for in the forty years that elipsed before the North and South finally resorted to arms to settle this problem, the antislavery section had developed much more rapidly than the region dependent on slivery.

lorida and the nited states $\left.\mathrm{SO}_{3}-18 \mathrm{I}+\mathrm{B}\right)$.

urgess, lidalle Piriod, 33

abcock, $t m$. ittionality, -20, $128-130$, $1-28_{3}$

26r. Florida. - After the acquisition of Louisiana in ISo,3. Spain retained the Floridas in the southeast and Mexico in the southwest. Between our territory and these Spanish possessions, no deinite boundary lines had been established. We claimed the western part of the Floridas as part of Louisiana ( 23,3$)$, but failed to gain this region until ISI, when disorder in that section led President Madison to extend the authority of the United States over the territory as far cast as the Perdido River. During the war with England the rest of the Floridas was used as a base of operations by the British, and became the home of slaves and criminals who escaped from the states. Spain was unable to control the territory or to prevent rumaways from making it a place of refuge. When these ditticulties were aggravated by Indian disturbances which threatened our borders, General Jackson invaded Florida, captured Pensacola and other towns, and hanged the British subjects, Ambrister and Arbuthnot, who had stirred up the Indians. ${ }^{1}$

${ }^{1}$ Crawford, Clay, and Calhoun criticised Jackson's action and an attempt was made to have him censured by Congress. This failed miserably. Only one member of the cabinet, Adams, defended Jackson; but Jackson, supposing that Calhoun was his defender, was bitter toward Adams, especially after $1 \$ 25(\$ 264)$. When ten years later he learned that Calhoun had worked arainst him at this time, his friendship for Calhoun was changed into the harshest emmity. These enmities which grew out of the attempt of jealous politicians to discredit a general who was becoming very popular had a great influence on the history of the next twenty years. 
Spain and Great Britain protested, but Spain, finding that she could not control the territory properly and that it would be seized by the United States if she dirl not cede it peaceably, agreed to transfer it to the United States in return for $\$ 5,000,000$. The treaty also defined the southwestern boundary between the United States and Mexico, ${ }^{1}$ yielding the whole of Texas which the United States desired but could not claim justly. ${ }^{2}$ This treaty of $\mathrm{I} S \mathrm{I} 9$ was not ratified by the Spanish and two years elapsed before a similar treaty was concluded with slight morlifications in favor of the United States. In this way the United States rounded out her territory so as to attain a natural boundary on the southeast. Hat Spain refused to sell us Florida, we should have been forcerl to seize the peninsula to protect our interests. The limitation of the western boundary was a grievance to the expansionists, for Americans were already making their way to 'Texas.

262. The Monroe Doctrine (1823). - Soon after the settlement of the Florirla difficulty the Uniterl States was confronted by a very much more serious problem growing out of the inability of Spain to control her American colonies and the attempt on the part of an alliance of four European powers - Russia, Austria, Prussia, and Irance - to reconquer for Spain her colonies that had revolted. ${ }^{3}$ This alliance had been formed originally in ${ }_{1}{ }_{1} 5$ by the emperors of Russia and Austria and the king of Prussia, under the name of the Holy Alliance, for the real purpose of upholling the rights of monarchy against the democratic movements which had broken out in different parts of Europe, especially during,

1 For this line of 1819 , see map page 255.

2 Many authorities believe that Texas was part of the I.ouisiana purchase, and there is no doubt that Napolcon would have insisted on the Rio Grande as the southwest limit of the territory.

${ }^{3}$ Most of Spain's possessions in this hemisphere had established separate governments during the years following a 80 S when Napoleon attempted to rule Spain. They had returned to their allegiance after the Spanish monarchy was reëstablished, but even before the revolutionists gained the upper hand in Spain again in $\mathbf{8} \$ 20$ the colonies declared their independence. 
the disorders of the Napoleonic wars. All attempts to gain a greater degree of self-government within their dominions were suppressed by force. In I 820 the people of Spain and some other countries revolted against the arbitrary rule of their monarchs, revolutionary governments being established. The Alliance directed France to suppress the Spanish revolution. The Holy Alliance then announced that the Spanish-American states were to be conquered for Spain.

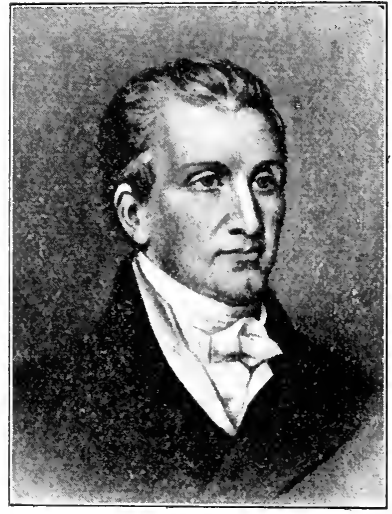

James Monroe

As England desired the trade of these new republics, her prime minister, Canning, immediately suggested that the United States should join her in a protest against this reactionary step. President Monroe sought the advice of Jefferson, Madison, and his cabinet. All agreed that the threatened attack of the Alliance must be averted, but through the influence of Secretary of State Adams, Great Britain and the United

States decided to make separate protests against the reestablishment of Spanish rule over the states that had declared their independence.

In his regular message to Congress in December, I823, Monroe announced the famous doctrine since known by his name. ${ }^{1}$ He declared that we had never interfered in

${ }^{1}$ He declared that "we owe it, therefore, to candor and to the amicable relations existing between the United States and those powers [the Holy Alliance], to declare that we should consider any attempt on their part to extend their system to any portion of this hemisphere as dangerous to our peace and safety. With the existing colonies or dependencies of any European power, we have not interfered, and shall not interfere. But with the governments who have declared their independence, and maintained it, and whose independence we have, on great consideration, and on just principles, acknowledged, we could not view any interposition for the pur- 
distinctively European affairs and had no intention of doing so. We could not permit the Alliance to reduce these states again to the position of colonies. In another part of his MacDonald, Documents, No. 43. message Monroe considered a similar question: the aggressions of Russia on the northwestern coast. "The occasion has been judged proper for asserting as a principle in which the rights and interests of the United States are involved, that the American continents, by the free and independent condition which they have assumed and maintain, are henceforth not to be considered as subjects for future colonization by any European powers." In this way and at this time was announced formally a policy which the United States had maintained almost from the beginning and which she has developed with our needs into the great American doctrine.

263. Summary. - The protest against the commercial discriminations of France and England was one of the chief causes which aroused the national spirit of the American people. Comparatively unimportant as the military events of the war must be considered, the war really compelled the people to depend on themselves for many things that had been furnished formerly by Europe; it made them unwilling longer to follow the lead of the European nations in matters of internal political policies, and it united the people as they were not united even at the beginning of the conflict.

The new national spirit which grew out of this second war for independence was especially noticeable in the consideration of distinctively American political questions, in the adoption of a national protective tariff, and a new United States Bank that was at once national and democratic, in increased centralization through the greater powers exercised by Congress and indorsed by the Supreme Court. National unity in its turn gave us a better international position, so that we may be said to have risen from a third-

pose of oppressing them or controlling, in any other manner, their destiny, by a European power, in any other light than as the manifestation of an unfriendly disposition toward the United States."

Causes of the new national spirit.

Results of the new national spirit. 
class power to one of the second rate. In connection with the adoption of the policy now known as the Monroe Doctrine we gave proof that we were no longer subservient to any of the great nations of Europe.

The West and its problems. Democracy.
The events of the period from isi i to I8IS, the latter part of which was a time of very great prosperity, were favorable not alone to the development of a national spirit and the extension of national authority but to an expansion which made the West and western questions of the greatest prominence. In this large and rapidly growing region, with nine states to fifteen on the Atlantic border, there were developed more democratic institutions than those of the East. As the tendency of the century was toward political equality, the West simply accelerated the movement toward democracy, so that before 1850 practically the entire nation had abandoned class rule and many social inequalities. The growth of the West compelled the nation to solve many problems, among them that of slavery extension. In connection with the admission of Missouri, the first great contest occurred between the forces which favored the extension of slavery and those that opposed its adoption in new states and territories. The compromise was chiefly important in postponing the inevitable conflict between the forces of free labor and of slave labor.

\section{TOPICS}

I. The Career of the Constitution: Roosevelt, "Naval War of ISI2;" Maclay, "History of the United States Navy," I; Mahan, "War of i $8_{12}$."

2. Treaty of Ghent (i $\mathrm{S}_{4}$ ): Stevens, "Albert Gallatin," pp. 312-337; Morse, "John Quincy Adams," pp. 75-98; Schurz, "Clay," I, pp. roo-I25; Adams, "United States," VII, Chapter XIV; VIII, Chapters I-II.

3. Tariff of isi6: McMaster, "People of the United States," IV, pp. 319-3+5; Taussig, "Tariff History of the United States," pp. I6-67; Stanwood, "Tariff Controversies of the Nineteenth Century," I, pp. I28-I 59.

4. The Missouri Compromises: Johnston, "American Political History," II, pp. IIO-I20; Von Holst, "Constitutional History of 
United States," I, pl). $35^{6-3} 8_{1}$; Burgess, "Middle Period," Pp. 6II07; Schouler, "United States," III, pp. 99-103, I47-186.

\section{STUDIES}

I. Perry's victory on Lake Erie. (Mahan, "War of I812," Chapter XI.)

2. Financial problems of the war. (Dewey, "Financial History of United States," Pp. I $28-1+2$.)

3. Disorders of the currency which influenced the crisis of 1819 . (McMaster, "People of the United States," IV, pp. 280-318.)

4. Building the Cumberland Road in the West. (Hulbert, "Cumberland Road," pp. 7I-90.)

5. Character of the West $\left({ }^{2} 81_{5}-1830\right)$. (Turner, "Rise of the New West," pp. 8+-1 Io.)

6. The Far West. (Turner, "Rise of the New West," pp. IIII33.)

7. Diverse interests in the South (1820). ('Turner, "Rise of New West," pp. 45-66.)

8. William Pinckney on the Missouri controversy. (Johnston (ed.), "American Elorjuence," II, pp. 63-ror.)

9. Relations of Spain and the United States around the Gulf of Mexico (1 $\left.78_{3}-\mathrm{I} 82 \mathrm{I}\right)$.

10. Authorship of the Monroe Doctrine. (Ford, IV. C., in American Historical Review, 7 (1901), pp. 676-696, 8, pp. 28-52.)

\section{QUESTIONS}

I. Summarize the grievances of New England. To what extent were they real grievances? What just complaint did the administration have against New England? What were the results of New England's course during the war on the war itsclf? on the Federalist party? on the influence of New England later in the councils of the nation?

2. Why did we declare war against Great Britain? How many of our grievances were removed during the war? by the treaty of peace? How many of the grievances existed after the war? what new international complications?

3. Compare fully the changes which followed the Revolutionary War and that of I8I2. To what extent were the movements begun during the period of the Revolution completed at this time?

4. What justification do you find in the Constitution for a protective tariff, a national bank, internal improvements? Did the Republican party favor a looser construction of the Constitution in 1816 than in 1792 , in 1803 , in 1808 ? 
5. Was slavery principally a political or an economic issue? Compare the advantages won by each side in the Missouri compromise. What were the constitutional results of the compromises? the political results?

6. Just how did the decisions of the Supreme Court strengthen nationality? Was the court sufficiently conservative? Would its permanent influence have been greater by following a different policy? If so, what policy?

7. What was the purpose of the Holy Alliance? What had been done by the Alliance in Europe? What was the attitude of England toward the Alliance before 1822 ? after 1822 ? What was the relation of the Alliance and Russia in Alaska to the Monroe Doctrine? 


\section{CHAPTER XIII}

NATIONAL DEMOCRACY (I824-I843)

\section{Presidents}

John Quincy Adams (1825-1 829)

Andrew Jackson (1829-1837)

Martin Van Buren (1837-I84I)
William Henry Harrison

$$
\text { (I } 84 \text { I-I } 84 \text { I ) }
$$

John Tyler (I84I-I 845)

\section{The Triumph of Democracy (1824-1829)}

264. The Presidential Election of $\mathbf{1 8 2 4}$ marks the begin- Candidates. ning of the transition from the old order to the new. According to the custom that had been followed at preceding elections the secretary of state was considered the "heirapparent," but considerable opposition was developed in 1823 to John Quincy Adams, who had directed foreign affairs for Monroe. Previously nominations had been made by a caucus of congressmen.

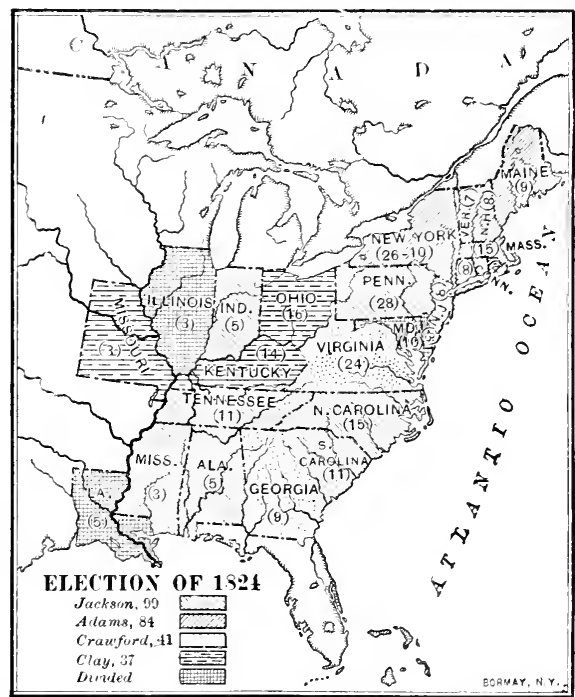

As there was but one party now, the Burgess, desire for a caucus was slight, since all of the candidates would be Republicans. However, a caucus was held, about one fourth of the congressmen attending, and 295
Middle Feriod, I3I-136. 
Peck, Jacksomian Epich.

Elections ISz+ and IS25).

William H. Crawford of Georgia, then secretary of the treasury, was nominated. The other candidates were Henry Clay, the most popular speaker the House erer had, and Andrew Jackson, the " hero of New Orleans," who had emerged from the Florida imbroglio with added reputation. Although he had been senator from Tennessee twice and hald held other public offices, he was considered by the people as

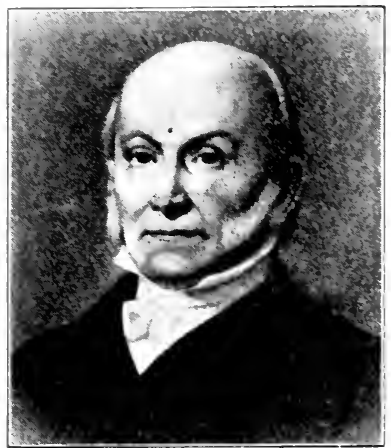

JOHN QUNT AnAMS entirely difierent from the officeholding candidates whom he opposed.

The election was not decided in Norember as is usually the case, for no one had a majority of the electoral votes. Jackson receired 90. mainly from the South and West, Adams st. principally from the Northeast, Crawford stood third with +1 , and Clay fourth with 37 . As the Con-

Burgess,

Mididle Firial I $360-14+$

MeMaster,

Lintel states,

$1,72-S \mathrm{I}$.

Stanwood,

Presidency, Chapter XI.

Character of J. Q. Adams.

stitution requires the House of Representatires to select the president from the three candidates having the largest number of votes. whenever the electoral college fails to give any one a majority, Clay held the balance of power. His infuence was thrown to Adams, who was, like Clay, a believer in the liberal construction of the Constitution, a protective tariff, and internal improvements. But when Clay was selected as Adams's scoretary of state, followers of Jacksori cried out that a "corrupt hargain" had been made between Clay and Adams. Jackson never forgare Adams for "cheating" him out of the presidency, and his dislike for Clay was intensified by the latter's preference for his rival.

Austere, painstaking. and impartial, Adams made few friends and won over no enemies, by settling all questions and making all appointments on their merits. His personal enemies fought him at every turn in Mashington, and the people turned from him and his policy to more popular men 



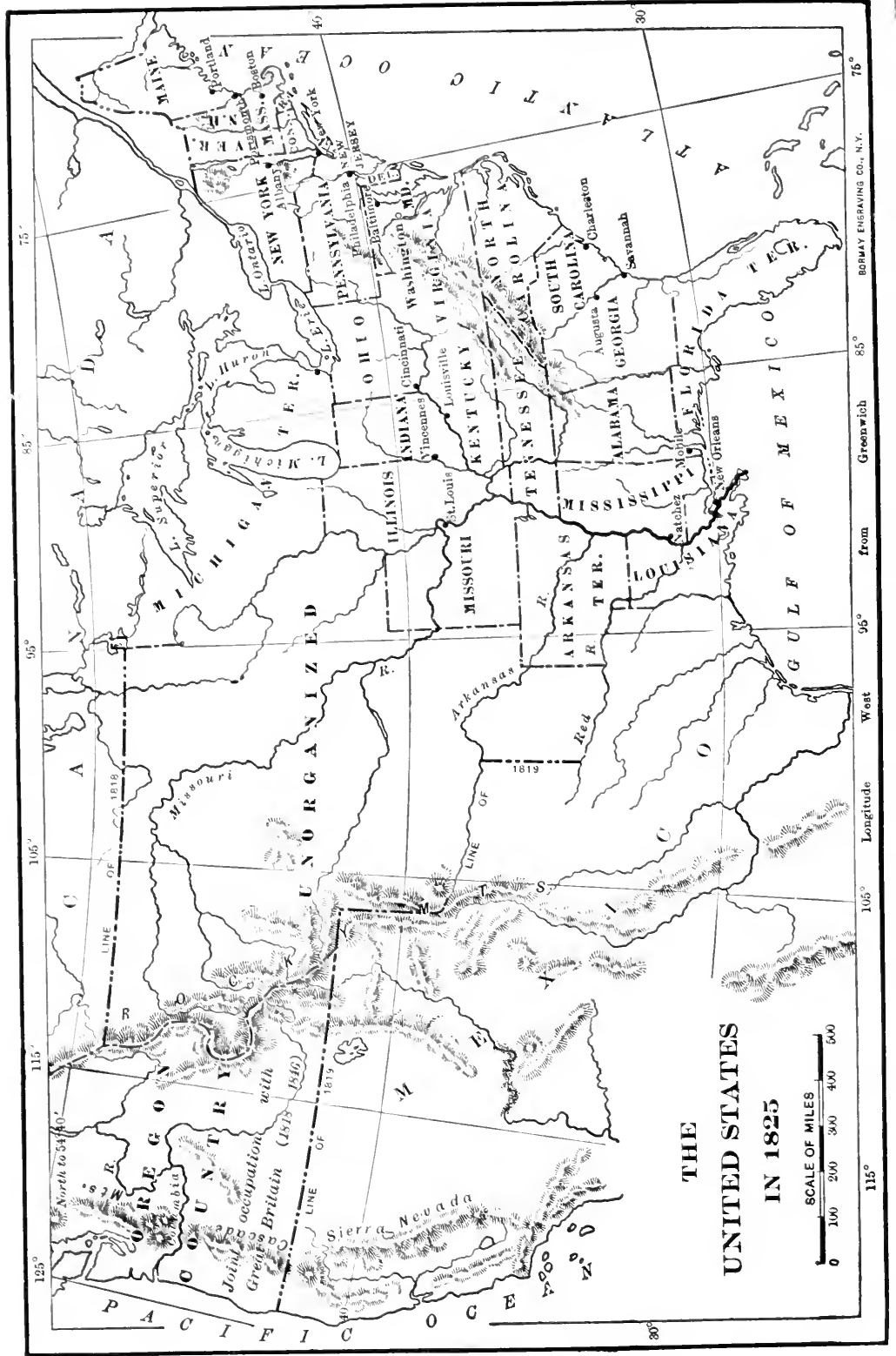


and measures. The last president of the old régime, Adams failed because the country had outgrown the aristocratic system which he represented and had become democratic.

265. New Political Parties. - The presidential election of $1824-1825$ and the subsequent formation of factions, composed on the one hand of supporters of the administration the Adams and Clay men - and on the other hand of the Jackson men, marks the beginning of a permanent break in the old Republican party. Although in large part these factions represented personal views and antagonisms, they held essentially different views on questions of public policy. Both Adams and Clay were ardent protectionists and believed in a broad construction of the Constitution which would extend the powers of the national government. They adopted therefore the name of "National Republicans," although in the course of a few years the name "Whig" was used more commonly.

Their opponents, who gradually rallied around Jackson as the coming man, were as a rule strict constructionists. Aithough not at the beginning supporters of popular government, in time they came to adopt the views of their intense domineering leader. on that question. Jackson ardently advocated the right of the people to rule untrammelled by traditions which had been established by conservative aristocrats. The party of Jackson, known as "Democrats," occupied a rather unusual position. While they believerl in a strict construction of the Constitution, they asserted Jacksonian Democrats.

Johnston, Alil. H'ol. Hist. II, I78-198.

MacDonald, Jacksonian Democracy. $306-315$. with Jackson that the will of the people should decide how the powers of the general government should be used. Unlike their predecessors, the Jeffersonian Republicans, who opposed centralization and favored the rights of the individual and the expansion of state powers, the Jacksonian Democrats believel in the supremacy of the nation. This peculiar combination of contradictory opinions was due to the personal preferences of "Old Hickory," a man of great simplicity of mind, who cared neither for political theories nor political consistency. Because the nation was young, 
hopeful, confident of itself, and charmed by the personal magnetism of Jackson, the Democratic party gained control of the affairs of the nation and retained that control almost without interruption for three decades.

Interest in Jackson's candidacy.

MacDonald, Jacksonian Democracy, 28-37.

Peck, Jacksonian Epoch.

Campaign and election.

Stanwood, Presidency, Chapter XII.

Imperfect development of a national spirit before I829.
266. The Election of Jackson (1828). - The Democratic party came into power with the first election of Jackson (1828). Since the House of Representatives had been called upon to choose a president and had passed by the " hero of New Orleans" for Adams (I 825), the Jackson men had not ceased to cry out against the injustice done to their leader. The will of the people has been defeated, they claimed. Continued agitation of Jackson's candidacy, the resolutions passed by numerous legislatures in his behalf, and the gradual abandonment of the old undemocratic method of choosing electors through the legislatures tended to arouse among the people for the first time a real interest in a presidential election. Heretofore the officeholders had decided what candidates should head each ticket and officeholders had elected the president. But the times were changing. In response to a strong popular demand, the suffrage laws had been made more liberal, so that nearly twice as many people could vote in 1828 as in 1824 .

Aside from the deeper reasons for Jackson's success, the conduct of the campaign is interesting. The tariff was an important issue, on which Jackson skillfully avoided committing himself. Aided by Martin Van Buren, the ablest politician of that period, and by most of the southern leaders, Jackson captured the vote of every western and southern state, besides that of Pennsylvania and scattering votes throughout the North. In the electoral college the vote stood I $_{7} 8$ for Jackson to 83 for Adams.

267. The Importance of Jackson's Election. - In the history of the United States at this time, and in fact throughout the first half of the nineteenth century, there were two movements of very great importance. The first of these was the development of a national spirit and a real national unity among the American people; the second, the spread of 
democracy, the belief in the right of the people to rule. Turner, As we noticed in the last chapter $(\$ \$ 249-257)$, the national spirit developed rapidly between I $8 \mathrm{I} O$ and $\mathrm{I} 820$, but it had New V'est, 300-309. not produced a great change in the central government. To be sure factional strife ceased to some extent and the national government was treated with greater respect than before. But as the enthusiasm created by the war died out, the people remembered again their local jealousies and the central government was in danger of losing most of the powers that it had gained.

In the two decades preceding

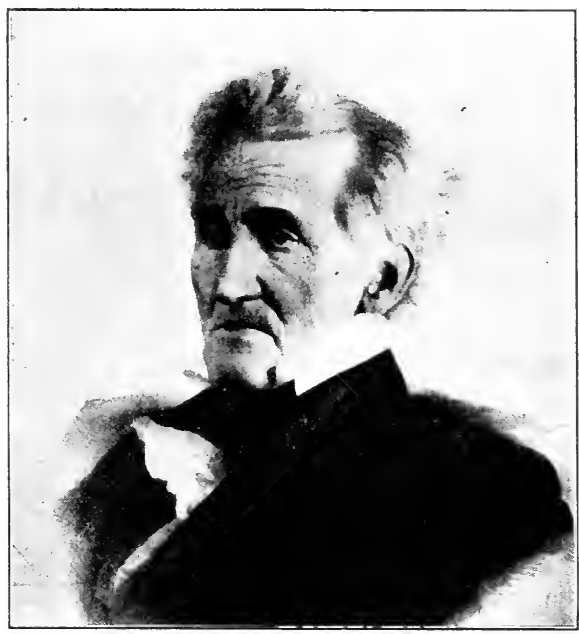

ANDREW JACKSON the election of Jackson, democracy had been gaining a real foothold in the states. Not only was a much larger number of pecple allowed to vote than before, but the voters enjoyed an infinitely greater share in public affairs $(\$ \$ 290$, 29I). This has been shown to some extent in preceding paragraphs. But this almost universal change in the policies of the states and the localities had produced before 1828 no change in the conduct of affairs at the national capital. There the rule of the old-time politician was supreme. Offices were acquired and held according to the length of time the candidate had been in the public service. The Democracy in the states and in the nation before 1829 .

McMaster, United States, $\mathrm{V}, 3^{80-394 .}$ nation was ruled really by a clique of men who kept themselves continually in office.

Jackson made the central government of the United

Schouler, Const'l Studies $23 \mathrm{I}-245$. 
National and democratic changes after 1829.

Mace, Manual of $\mathrm{Am}$. Hist.. I92-20I.

Ford, Am.

Politics,

Chapter XIX.

Nominations by conventions.

Stanwood, Presidency, 166-I77.

The campaign and the party "machine."

Ford, Amer. Politics, I44-I 49 .
States both national and democratic. Under him it responded to the demand of the people that they should be allowed to govern and to the wish of the people that the United States should be recognized as a real nation. Jackson considered himself the representative of the nation, and, by the fearless use of his position as president, he increased greatly the power of the chief executive. In some ways his election deserves to be considered, as many have called it, "the revolution of i 829 ."

268. New Political Methods. - Since the people were much more interested in government than formerly, they were not satisfied simply with electing officials; they demanded the initiative in political affairs. Formerly the politicians in power had been in the habit of holding a caucus for the nomination of candidates for their party. This kept them and their friends in power and preserved a class rule which was distasteful to the masses. Parties out of power, who had no officials, adopted first a method that afterward came into general use. From each district in a state representatives were chosen to a state conrention, which nominated party candidates. The first national convention was held by the Anti-Masonic leaders who wished to perfect their organization throughout the United States. This example was followed quickly by the older parties, who, in many cases, adopted resolutions stating their policy. From this custom there was developed in time the platform, now an indispensable part of the work of every national and many state conventions.

As each party was bidding for popular support, every effort was made to obtain votes. Two of the most important methods introduced were the campaign and machine organization. In the first, voters were to be attracted by the popular love of display and by "stump speaking." The later presidential elections of $\mathrm{I} 8_{40}$ and $\mathrm{I} 844$ were the best examples of this. Even more reliance was placed on more perfect party organization. The "machine" was not a new thing, for Tammany Hall had used methods like those 
of the present many times since it was formed in $7_{7} 8$, but now the party "boss" became a recognized power in political circles, while federal and state patronage were used to control votes. Bribery was used more frequently, and the wretched system of the open ballot boxes marle intimiclation of voters and "stuffing" of the boxes not only possible, but quite common. The political products of democracy were as yet of the crudest kind, and it required years to sift out the good and to reject the less perfect.

269. The Spoils System. - Jackson introduced into the national government a system which was at that time used extensively in the states and known best as the "spoils system." This consisted of filling the offices with party friends on the principle that " to the victors belong the spoils." Jackson firmly believed that he could not do his cluty as president if his sulordinates were political enemies, who woukl not work with him. IIimself a fierce hater, he expected nothing but opposition from those who had not favored his election and took the first opportunity to remove his enemies from office. Thousands of his party followers, knowing his loyalty to his friends and already acquainted with the spoils system at home, thronged to Washington. This horde of officeseekers and their friends pressed into the White House at the time of the inauguration, climbing on the chairs and behaving in such a way that the older politicians bewailed the arlvent of "mob rule." Giving Jackson no rest, they importuned him day after day for positions. They were the first of a throng of office-seckers who have infesterl the capital at every inauguration from that day to this.

Many of them were disappointed, but in less than a year Jackson had removed from office fifteen hundred persons, about ten times as many as had been removed in the preceding forty years. No reasons were given for removals and no attempt was marle to appoint men except as a rewarl for party services. The Presilent not only abandoned precedent by adopting the spoils system, but he also followed a new plan of seeking advice from a set of men who were not his calinet

Jackson's attitucle regarding appoinfments

Wilson, I)io. and reunion, \$S I4-I9.

MacDonald, Jacksomian L)emocracy, 54-63.

Removals and kitchen cabinet.

MacDonald, Jacksomian lemocracy, 47-54, 60 , $63-66$. 
officers. These advisers were known as his "kitchen cabinet." Before long Jackson abandoned this method of securing help in administering the duties of his office. It is scarcely necessary to state that his successors made very little use of such an unofficial cabinet, although they were careful to follow his policy of making appointments to office for partisan reasons only.

\section{National Sovereignty zersus State Sovereignty} (is26-i 833 )

Georgia and he Indians.

IacDonaid, acksonian Democracy, $69-173$.

Controversy vith the ational sovernment.

Burgess, Viddle Period, io-220.

American Vation, XIV, 309-3I3, XV, $73-180$.
270. Controversies over Indian Lands. - During the administration of Adams and the first term of Jackson the national government was brought into conflict with the state of Georgia. The difficulty arose over the Indian lands, which settlers wished to occupy, and over which the government of Georgia desired to extend its jurisdiction. These lands in IS 25 covered about fifteen thousand square miles. ${ }^{1}$ By law the Indians were under the control of the United States, which had promised Georgia long before that their lands should be acquired. The promise had been kept in part only, because it was customary to treat the tribes as separate nations.

In I \& 6 Georgia attempted to occupy forcibly some Creek lands which the United States was then seeking to acquire. The United States troops were ordered by President Adams to maintain the rights of the Indians, and an armed conflict was a voided narrowly (I826). A few years later Georgia passed a law extending her jurisdiction over the Cherokee lands. The Cherokees appealed to the United States courts, which upheld the Indians by declaring the Georgia law null and void. When the state proceeded to enforce the law, President Jackson, whose sympathies were naturally not with the Indians, refused to interfere, declaring, it is said, "John Marshall has pronounced his judgment, let him enforce it if he

${ }^{1}$ In the southern states east of the Mississippi, excluding Florida territory, in 1825 the Indians controlled an area larger than the state of New York. 
can." So the state continued to disobey the decree of the court.

Most of the Indians east of the Mississippi were persuaded to exchange their lands for territory west of the river, chiefly in the district set aside as Indian territory. In Florida a few Seminole chiefs resisted the removal and jn Iowa Black Hawk sought by war to regain lands that had been ceded already.

27I. The Webster-Hayne Debate (1830). - In connection with the proposed opening to settlement of public lands in the West and South, the year following Jackson's election, there occurred the interesting debate between Webster and Hayne of South Carolina, regarding the nature of the Union. Webster replied to Hayne's earlier argument by declaring that the Constitution had been adopted by the people of the United States in the aggregate. A real union had been established by that Constitution, ( 1 ) because the Constitution and laws made in accordance with it were declared to be the supreme law of the land, ${ }^{1}$ and (2) because the Constitution itself provides that the national courts shall decide whether a certain power was given to the national government or withheld from it. ${ }^{2}$ He maintained that to acknowledge the right of nullification by any state would reduce the Union again to a " rope of sand," as under the old Confederation.

In reply Hayne argued that the states had been sovereign before the Constitution was adopted, and claimed that they Argument of Hayne. had acted in their sovereign capacity when agreeing to that "compact." He denied that the clause relating to the supremacy of the Constitution and of national laws transferred sovereignty from the states to the nation. According to Hayne,

MacDonald,
Documents,

MacDonald, No. 48 . when a question arose regarding the power conferred on the central government by the Constitution, "resort must be had to their common superior (that power which may give any character to the Constitution they may think proper) viz.: three fourths of the states."

Both speakers used the words "sovereign" and "sover-

${ }^{1}$ Constitution, Art. IV.

${ }^{2}$ Constitution, Art. III, $\S 2$, cl. I.

MacDonald, Documents, Nos. 47,49 .

Argument of Webster.

Nos. 47.49 .100 No.

Removal of

MacDonald, Jacksonian Democracy. 180-182. 
he theories om an historiland a practistandpoint.

odge,

cobster, $4^{-180 .}$

acDonald, ucksonian e'mocracy', -III.

esire for rift changes 8I6-1824).

ewey, Finanal Hist., \$ 78 .

the tariff 1828 .

dewey, Finanial Hist., 79.

eignty" in a careless way, but even when allowance has been made for this laxity in expression, their views of the Union were seen to be diametrically opposed. According to the one, the people of the nation were sovereign; in the opinion of the other the states were sovereign. Hayne's view was undoubtedly the one held by the great majority at the time the Constitution was adopted, but in the interrening forty years so strong a national sentiment had been developed that in $I S_{3} 0$ the majority accepted Webster's position. Hayme stood for a past that was being outgrown rapidly; Webster for the present and the future of a growing nation.

272. Changes in the Tariff $(1824-1832)$. - Opposition to a protective tariff was responsible in a large part for the position taken by Hayne and other southern leaders. On account of the numerous and rapid changes in the industrial conditions within the United States after the close of the war with England, several changes were made in the tariff schedules after i $S_{1} 6$. New industrics that were protected inadequately desired help which they found the general gorernment was willing and able to give to favored interests, especially during the hard times which began in i 8 ig. However, the tariff of IS 6 stood until I $S_{24}$ with but slight modifications. In that year the rates were increased on most articles protected formerly, protection was granted to a few manufacturers not aided in the earlier tariff and duties were placed on some raw materials, especially hemp and wool. By this time the South had become fully convinced that a protective tariff was interfering with her agricultural interests and her general development. Joining with Maine, New Hampshire, and Malssachusetts, the South strove, though without success, to defeat the tariff of $I_{2} 4$.

Adams's administration was marked by continued agitation: in the North, for additional duties; in the South, for an abandomment of the protective principle. In ${ } S_{27}$ a convention of protectionists called by the wool growers brought pressure to bear on Congress for a higher tariff. 
As a presidential election was approaching in which Adams, Clay, and Jackson were likely to be candidates, the coterie that had for years opposed the administration and its protectionist policy, now sought to discredit it by proposing a tariff which the followers of Clay and Adams could not accept. With this in view they framed a tariff bill which carried high rates on manufactured articles, but more than nullified the protective duties that were desired in the states in which Adams and Clay had the largest following, by placing very high duties on the raw materials to be used by the manufacturers in those states. This political deal failed miserably because the manufacturers accepted the tariff, hoping to obtain later the changes they desired.

This high tariff, with its many irregular duties, was not Tariff of 183 distinctively a protective measure and was known commonly as the "tariff of abominations." In spite of its serious defects it was retained until 1832 . The tariff of that year removed most of the objectionable high rates, replacing them by uniformly protective rates. Because of the lower duties, many of the southerners voted for the measure, but in the lower South the opposition was very active because Congress practically had accepted protection as a policy of government.

273. The South and the Tariff. - The first organized opposition of the South to the protective system was noticed in connection with the "tariff of abominations" in 1828 . After the passage of that act several state legislatures adopted resolutions denouncing the tariff. South Carolina, the first to take this action, indorsed papers prepared by John C. Calhoun and best known as the "South Carolina Exposition." Calhoun maintained that the general government had no constitutional right to pass a protective tariff. He argued that the tariff was oppressive to the South and tended to create sectionalism.

In the opinion of the southern political leaders, the policy of protection was undermining the industries of the South and building up those of the North at the expense of the

Dewey, Fin cial Hist., \$

Opposition the "tariff ol abomination

MacDonald, Documents, Nos. 44,45 .

McMaster, United State $\mathrm{V}, 256-267$.

The South a the question protection. 
urner, 'ew II est, -63 , $39-24^{2}$.

ullification ider the lead Calhoun.

eck,

acksonian

poch.

ullification dinance.

acDonald, acksonian emocracy, $4^{-159}$ slave states. High tariffs were valuable only for manufacturing districts, they said, and as the slave labor in the South could not be used in manufacturing and kept out free labor, the South could not devote herself to industry. Moreover, Southerners claimed that protection interfered with commerce by limiting exports, that it increased the price of all manufactured articles, and reduced the demand for labor. The wealth of the South depended on the sale of her surplus cotton, tobacco, and other agricultural products. Her exports were at this time much greater than those of the North, but the South was obliged to buy elsewhere what she needed, chiefly in the North, so that a protective tariff was a distinct disadvantage to her. Naturally in South Carolina and in some other states there was a growing sentiment that the Constitution did not give Congress the right to pass a tariff which protected one section only.

274. Nullification and the Compromise Tariff. - When the southern opponents of protection failed to defeat the tariff of $183_{2}$, they sought to apply the doctrine of nullification which Calhoun and Hayne had announced and explained. Calhoun was really the leader in this movement, for before I 832 he had advocated actual nullification of the tariff unless it was revised by eliminating the most protective features. But Calhoun's leadership of the nullification forces caused Jackson to consider the action of South Carolina in a personal light, for in 1830 he had discovered that Calhoun, as secretary of war in I8I8, had wished to censure him for his actions in Florida ( $\$ 26 \mathrm{I})$. This made him Calhoun's most bitter enemy, ready to attack Calhoun on the slightest provocation.

A convention was called by the South Carolina legislature in October, $18_{32}$, for the purpose of nullifying the tariff of that year. Before it met Jackson had issued instructions to the revenue officers in South Carolina that would insure the collection of the tariff. But the convention proceeded to declare the tariffs of $I_{2} 88$ and $\mathrm{I} 832$ null and void, prohibited the payment of duties after February I, I 833 , and declared 
that the state would secede if force were used to collect the duties.

A few days later Jackson issued a proclamation written undoubtedly by his secretary of state, Edward Livingston, which made plain two things. (I) It contained an elaborate argument on the nature of the Union and declared that nullification is " incompatible with the existence of the Union, contradicted expressly by the letter of the Constitution, unauthorized by its spirit, inconsistent with every principle on which it was founded, and destructive of the great object for which it was formed." (2) Jackson's attitude toward South Carolina was stated clearly. "The laws of the United States must be executed. I have no discretionary power on the subject. My duty is emphatically pronounced in the Constitution. Those who told you that you might peaceably prevent their execution deceived you; they could not have been deceived themselves. Their object is disunion, and disunion by armed force is treason."

During the weeks that followed, South Carolina prepared to enforce her nullification ordinance; the President took every precaution to enforce the collection of the tariff in that state, and Congress discussed possible modifications of the tariff. February I brought no change, the duties being collected as formerly and a force act for their collection being authorized by Congress, March 2, because a change in the tariff seemed probable. Congress agreed finally to a "compromise tariff," proposed by Henry Clay. This provided for a gradual reduction of all duties which were in excess of twenty per cent until a uniform rate of twenty per cent was attained in $1842 .^{1}$

\section{Finance and Politics (I829-I843)}

275. First Attack on the United States Bank. - Perhaps the most prominent feature of Jackson's administrations The bank and was the war which he waged on the second national bank. its enemies.

${ }^{1}$ A hout one half of this reduction was to be made during the years I $84 \mathrm{I}$ and 1842 . 
Burgess, Jackson looked upon the bank as a great monopoly, conMiddle Period, trolled by his political opponents and capable of dominating
rgo-Ig8.

McMaster, United States, VI, I-IO.

politics because of its resources and its influence in the world of business. At the time of Jackson's first inauguration few persons considered the bank a public menace, although its conservative methods had made it unpopular in the South and West. Business men as a rule placed great confidence in the bank, for although it had been mismanaged during the first five years of its existence, it had been reorganized and well managed for several years. Jackson's attention was called particularly to the bank in June, I829, when some of his followers asked for the removal of the president of the branch bank at Portsmouth, New Hampshire. This was refused by the bank officials on the ground that the man was capable and had not been selected for partisan reasons.

Jackson's attack.

Election of I832.

MacDonald, Documents, Nos. $46,50-52$.

McMaster,

Inited States, VI, I33-I4O.

Dewey, Financial Hist., $\oint \oint 86,87$.

Amer. Hist., Leaflets, No. 24 .

Removal of the deposits.

The following December, in his first annual message, Jackson attacked the methods of the bank and its constitutionality, although the latter had been affirmed by the Supreme Court. ${ }^{1}$ As Congress approved of the bank, nothing was done until, two years later, the President said he would leave to the people the question of rechartering a bank. The bank at once applied to Congress for a new charter, and its cause was championed by Clay, who was the candidate of the National Republicans or Whigs for the presidency. The bank bill was passed by both chambers by fair majorities, but was vetoed by the President, and failed to obtain the two thirds necessary to make it a law. In the election of 1832 the chief issue was that of the bank, but the campaign was really a personal contest between Jackson and Clay. Jackson was so popular that the people reëlected him by a large majority, the electoral vote being 2I 9 for Jackson to 49 for Clay.

276. Overthrow of the Bank. - Jackson considered his reëlection as an indorsement of his bank policy, and began a much more active campaign against the bank. He wished

${ }^{1}$ In M'Culloch vs. Maryland (I \&19) (\$ 254). 
first to remove the government money, which had been deposited in branches of the national bank. This could be done only through the secretary of the treasury. As Jackson's secretary was unwilling to do this without the authority of Congress, his place was filled by William J. Duane who refused finally either to remove the deposits or resign. $\mathrm{He}$ was dismissed and his place filled by Roger Taney, who carried out the President's plan. For removing the deposits the President was censured by the Senate, the resolution remaining on the journal until expunged two years later.

The government money at this time was deposited in state banks which were known popularly as "pet banks." There was considerable rivalry among the banks in order to secure a part of the funds, which were increasing constantly on account of the very great amount of surplus revenue. The system provided was so unsatisfactory that in 1840 an independent treasury was established by the Democrats $(\$ 278)$. This was abolished by the Whigs (r84r) who desired another national bank, which they failed to get on account of President Tyler's opposition. When the Democrats again gained control of the government (i 845 ), they reëstablished the independent treasury, which has been developed into the system that we use at the present time.

Jackson's second term was a period of unusual, in fact unhealthy, business activity. Speculation was very common, and a wild scramble began for government lands, which were sold on easy terms ( $\$ 289)$. The national bank, with its currency accepted at the same value everywhere and its conservative methods of making loans, had acted as a check on the smaller state banks and on business in general. But when it became apparent in 1834 that it would not be rechartered and the public moneys were deposited in the "pet banks," there began an era of "wild cat" banking unequaled during earlier periods. Bank notes were issued in immense quantities and loans were made on securities which

Results of the overthrow of the bank.

Wilson, Div. and Reunion, $\$ \$+5,46$.

McMaster, L'nited States, VI, 336-358. 
possessed very little real value. Every one bought on credit, "boom" towns were started throughout the middle West, and land values rose to an absurd figure.

Extra revenue.

Distribution of the surplus.

Dewey, Financial Hist., $\oint \oint 92-94$.

Schurz, Clay, I I, I I3-I 27.

The panic of 1837 .

Dewey, Financial Hist., is 96-98.

Hart, Slavery and Abolition, 298-305.

McMaster, United States, VI, 390-4I5.
277. Government Revenues and the Panic of 1837 . - So much public land was sold that the revenues from that source increased to nearly $\$_{15,000,000}$ in 1835 and nearly $\$ 25,000,000$ in $\mathrm{IS}_{3} 6$, in the latter year for the first and only time in our history being the chief source of government revenue. The expenses of the government did not increase as rapidly as the income, but the compromise tariff of $\mathrm{I}_{33}$ could not be changed and the public debt was extinguished in 1835 . Strange as it may seem, a treasury surplus, especially when a nation has no debt, is a serious menace to business. In this case it was decided by Congress that the surplus should be distributed to the states in proportion to their representation in Congress. As objection was made that this would not be constitutional, the distribution was called technically a loan. As matter of fact, only three quarterly distributions were made, for the revenues fell off rapidly in $s_{37}$, when the panic began.

The real cause of the panic of $8_{37}$ was the unwise speculation culminating in ${ }_{1} 8_{3} 6$ and ${ }_{1} 8_{37}$, but the government helped to bring on the crisis not only by destroying the national bank, but in two other ways. (I) Because many of the notes issued by the western "wild cat" banks were of little or no value, Jackson issued through the treasury department in $I_{3} 6$ the famous "specie circular," requiring those who bought public lands to pay in cash. Almost all purchasers of government land had bought on the installment plan. There was very little specie in the West. Crops in $I_{35}$ had been a failure and the farmers could not obtain the little cash in circulation. The entire West was upset by this change. (2) When the pet banks were requested to turn over to the states the surplus which had been deposited with them, the banks were compelled to sacrifice their securities in order to obtain the money. In some cases banks were obliged to suspend payments on their notes. 
The failure of western banks was followed by failures elsewhere of banks and later of business houses until the business depression was complete throughout the United States.

278. Administration of Van Buren ( $1837-184 \mathrm{I})$. - During Van Buren the speculative excitement of 1836 , Martin Van Buren of New York, the Democratic nominee, was elected president over William Henry Harrison of Indiana. ${ }^{1}$ Van Buren had been known as a crafty politician before he became Jackson's secretary of state. His skill as a diplomat increased his reputation appreciably, and he undertook now to carry out Jackson's policy under very trying circumstances. During the business crisis of 1837 and the years that followed he exhibited firmness and good judgment in trying to save the government from financial difficulties, although he did not show those qualitics of leadership which would have been invaluable to his party.

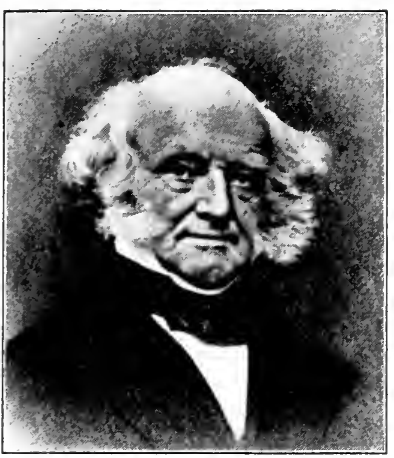

MARTIN VAN BUREN
Van Holst, Const'l Hist., II, I $47-15^{8 .}$

When it was found that the system of deposits with "pet banks" was unsatisfactory in almost every way, President Van Buren recommended to Congress, in 1837 , the establishment of an independent treasury which would render the government independent of any banking institution. Subtreasuries were to be established at convenient places for handling government funds and the government was to conduct its fiscal operations without depositing its money with the banks. Congress debated the question for over two years before passing the act in 1840 .

279. The Election of Harrison (I840). - Van Buren had not gained in popularity during his term, partly because of the hard times and his unwillingness to compromise in

${ }^{1}$ His popular majority was 24,893 , but the electoral vote was $I_{77}$ for Van Buren, 73 for Harrison, and 57 for other Whig candidates. 
ichouler, United states, V, 327-335.

itanwood, residency, thapter XV.

any way with the opponents of hard money, but he was renominated by the Democrats without opposition. The Whigs began and continued the campaign with the determination to win. Instead of nominating Henry Clay, the real head of the party but a man whose political views were obnoxious to many voters, they selected William Henry Harrison, whose services during the war of i $\delta$ i 2 had been only less conspicuous than those of Jackson. For vice president they chose John Tyler of Virginia, an anti-administration

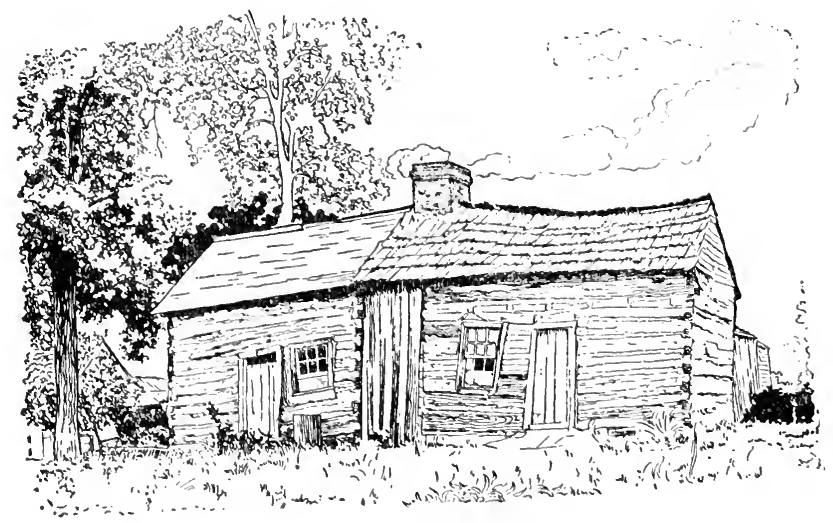

A Log CABIN

McMaster, United States, I, $55^{\circ-}-55^{8}$

72.

New election nethods.

Schouler, L'nited Stute's, IV, 335-3+I.
Democrat who was expected to bring the ticket many voters from Democratic ranks. Fearing that a definite statement of their policy would be a disadvantage, they adopted no platform, although Harrison made clear his preference for a national bank and a more liberal national currency and was outspoken in his opposition to the arbitrary executive rule of the last three terms.

Not content with the natural advantages which hard times gave them, and an almost perfect union of all elements of the party, the Whigs introduced into the campaign methods that would appeal to the roters. Stump speaking was used very extensively. Great mass meetings were held, attended in at least one instance by one hundred thousand persons. 
Processions paraded the streets, displaying banners, and drawing vehicles on which were log cabins or great casks of cider. Harrison was lauded as a plain citizen, a man of the people; Van Buren derided as an aristocrat who favored hard money and ignored the suffering caused ly hard times. "Tippecanoe and Tyler too" was the cry of the IThigs. Against this campaign of enthusiasm and appeal to popular fancy, the Democrats, with their old-fashioned methods, could make no headway. When the votes were counted, it was found that Harrison had carried nineteen states to seven for his opponent and that his electoral vote was 234 against 60 for Van Buren. By the same election the Whigs gained control of the Senate and the House of Representatives.

280. Tyler and the Whigs (I84I-I842). - Exactly a month after Harrison was inaugurated, he died, and John Tyler became president. Tyler was known to be a strict constructionist and an opponent of a national bank, but a special session of Congress hard been called by Harrison to consider the question of a bank, and that body proceeded at once to repeal the independent treasury act and pass a bill creating a "fiscal bank," which was little different from the second national bank. This bill Tyler vetoed because it created branch banks in the states. Congress at once passed a new bill chartering a "fiscal corporation," a term preferred by Tyler, which was supposed to embody the views of the President. Either because Tyler would not sign any bank bill or because he hoped to bring the Whig learlers in Congress into submission to himself, Tyler vetoed this bill also. The members of his cabinet resigned at once, with the exception of Webster, secretary of state, who was negotiating with Great Britain a treaty to define the northeastern boundary of the United States. The break between Tyler and the Whigs was complete.

The northern boundary of Maine had been in dispute since the treaty of 1783 . At that time the line was designated as the highlands that separate the rivers that flow into the St. Lawrence from those that flow into the Atlantic Ocean. As

WebsterAsliburton

treaty $(18+2)$.
McMaster, United States, VI, 562-595.

Quarrel over a bank.

Dewey, Financial /list., § 103 .

Wilson, Div. and K'eunion, $\$ \$ 68-70$.

MeMaster, United States, VI, 628-637. 
MacDonald, Documents, No. 70.

Lodge, $\mathrm{Heb}^{\mathrm{e}}$ ster, 252-26o.

Garrison, Westzuard Expansion, 67-84.

Democratic changes (I829).

State and national sovereignty. the St. Johns River empties into the Bay of Fundy, England maintained that the valley of the St. Johns did not belong to the United States. Naturally we claimed all that part of the valley west of the eastern boundary of Maine. An attempt was made to submit the dispute to the king of the Netherlands as arbitrator ( ${ }_{1827}$ ), but he proposed a compromise line which neither party would accept. On account of an insur-

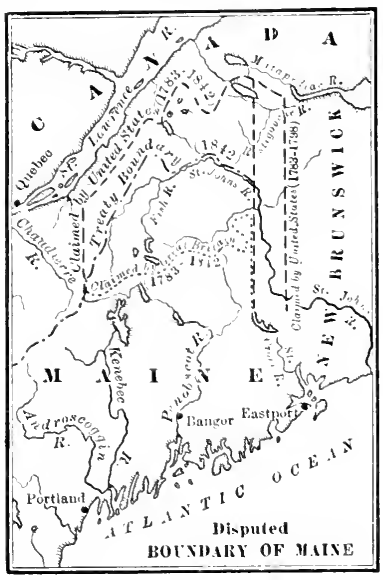
rection in Canada in 1837 and bad feeling over the dispute, some decision became necessary to aroid worse troubles. England sent a special envoy, Lord Ashburton, and a compromise line was agreed upon, the United States yielding some of her claims in the St. Johns valley and Great Britain receding from most of her claims in Maine and practically all in northern New York. ${ }^{1}$

28r. Summary. - The democratic movement which had made fair headway before I 825 in the states, especially in the Mississippi basin, was responsible for the election of Jackson to the presidency in I829. At this time numerous democratic changes were introduced in the policies of the political parties and the national government. A system of nominating conventions came into use. Appointments to office were made for partisan reasons more than at any other time. The national government responded readily to the will of the people, because both political parties favored a fairly strong national government and Jackson believed thoroughly in a national democracy.

National development caused controversies with the states over the rights of the states and of the national government. In the Webster-Hayne debate especially the issue

${ }^{1}$ As to the location of the boundary supposed to be parallel 45 . 
between national and state sovereignty was clearly defined. The old theory in favor of the states was upheld by the older sections of the Union, especially the South, whose agricultural progress seemed to be threatened by the protective system adopted by Congress. Although South Carolina tried to nullify the tariffs of 1828 and 1832 , the state did not attempt to enforce its nullification ordinance and Congress yielded to the extent of passing the compromise tariff of 1833 .

Financial questions engaged a large share of attention Financial during the administrations of Jackson and Van Buren. problems. Jackson's attack on the United States bank on the ground that it enjoyed a political monopoly caused the overthrow of the bank and led to the establishment of very many "wild-cat" banks. Speculation in lands by the people and immense issues of paper by the banks culminated in 1837 in a panic, the business depression lasting about six years. The hard times reacterl against the Democrats, but the Whigs failed to gain a real victory because Harrison's death depriver them of the presidency. Even during Tyler's term the question of slavery was obscuring the factional quarrels which filled most of the years before 1843 .

\section{TOPICS}

i. Beginnings of the Nominating Convention: Ford, "American Politics," Chapter XVI; Dallinger, "Nomination for Elective Office," pp. I3-45; Woodburn, "Political Parties and Party" Problems," pp. I5I-I 74; Ostrogorski, "Democracy and the Organization of Political Parties," II, pp. 39-79.

2. Nullification by South Carolina: Johnston, "American Political History," I, pp. 42I-437; Burgess, "Middle Period," pp. 220-24I ; McMaster, "People of the United States," VI, PP. I $48-$ I 75 ; Schouler, "United States," IV, IP. 85-1 I I Von Holst, "Constitutional History of the United States," I, pp. 495-505.

3. The Second Bank of the United States: Von Holst,

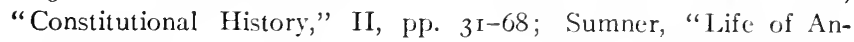
drew Jackson," pp. 25t-276, 29 I-3 I0; Burgess, "Middle Period," pp. 190-209, 278-284; White, "Money and Banking," PI. 291-312. 


\section{STUDIES}

I. Protection and the tariff of abominations. (Taussig, "Tariff History of the United States," pp. 68-ro8.)

2. Webster and Hayne on national and state sovereignty. ("American History Leaflets," No. 30.)

3. The election of $\mathrm{I}_{32}$. (Stanwood, "History of the Presidency," Chapter XIII.)

4. Banking and internal improvements in a western state. (Cooley, "Michigan," pp. 25t-293.)

5. Foreign affairs under Jackson and Van Buren. (Foster, "Century of American Diplomacy," pp. 273-28r.)

6. The Seminole War. (McMaster, "People of the United States," VI, pp. 329-334, 463-466.)

7. The expunging resolution. (Benton, in "American Eloquence," I, pp. 320-336, and in Benton's “Thirty Years," I, pp. 528-550.)

\section{QUESTIONS}

I. Could political class rule have been abolished during this period except through the convention and by the use of the "machine"? Was the new system preferable to the old? Give reasons for your answer.

2. Compare the "political revolution" of I $\$ 29$ with that of I 80 I. Consider character, change from former system, and influence of each.

3. State the difference between Jeffersonian Democracy and Jacksonian Democracy. Where were the Democrats strongest? Why was the Democratic party successful almost without interruption until is6o?

4. Explain the differences between nullification in Kentucky ( 1799 ), that in New England ( $1 \delta_{14}$ ), and in South Carolina ( 1828 and $\left.{ }_{1} S_{32}\right)$. How was the attitude of Georgia in regard to the Indians unlike that of South Carolina on the tariff?

5. Did Webster or Hayne occupy the more correct position, historically? State your objections to the arguments of each. How was the question of national or state supremacy decided in the nullification controversy of $\mathrm{I}_{32}$ and $\mathrm{I}_{33}$ ?

6. Had the national bank failed to establish a uniform and sound currency, as Jackson claimed? Was the bank dangerous because of its influence in elections?

7. What were the most important political doctrines of the Whigs? To what extent was their comparative failure due to the unpopular issues they indorsed? to unwise political deals (as in 1840 )? to other causes? 


\section{CHAPTER XIV}

\section{A HALF CENTURY OF CHANGES}

\section{Transportation and Business (I8I 5-i860)}

282. The Steamboat. - The first half of the nineteenth century is notable not alone for the remarkable development of the spirit of nationality within the United States. It is Progress during the haif century. almost as noteworthy for the great advance made in the ideas of political and social equality, for the numerous mechanical improvements which brought in an age of machinery, and most of all perhaps for the changes in the methods of transportation by land and water which have revolutionized traveling and commerce within the boundaries of the United States.

The steam engine was used for water transportation twenty years before the first steam railways were operated. Experiments with steamboats had been made during the later years of the eighteenth century, but it was not until I 807 that Robert Fulton constructed a steamboat that was an unqualified success. After Fulton's Clermont made the trip from New York to Albany in thirty-two hours, and began a little later to carry passengers and freight regularly, steamboats were built on many of the rivers and lakes east of the Mississippi. Before 1825 there were several plying on the Mississippi and its tributaries and a few employed on the Great Lakes and for the coasting trade. In I8I9 a vessel, the Savannah, crossed the ocean in twenty-five days by using steam and sails, although it was 1838 before the first ocean steamer made that voyage. About the same time Ericsson invented the screw propeller, which was very much more satisfactory than the old side-wheels used in the steamers of an earlier day.

The earlies' steamers.

McMaster, United States III, 486-494.

Marvin, Am. Merchant Marine, 395-402. 
Jse of the teamboats in he West.

Fparks, Expanion of. $\mathrm{tm}$. Desple, 270-274.

McMaster, I'nited State's, V, 397-407.

nterest in the ubject.

ohnston,

Pailiziay

Transportation. $4^{-19 .}$

IcMaster, Cnited States, II, 47 I- 480 .

Erie canal.

IcMaster, Inited States, $\mathrm{V}, 4 \mathrm{I} 5^{-4} \mathrm{I} 8$, , $132-136$.
Steamboats were especially valuable in the West. Before this time it was easy to descend the Cumberland, the Ohio, or the Mississippi by barge or raft, but little progress could be made against the current. The trader from Kentucky or the prairie country could carry his wares to Natchez or New Orleans, but was obliged to return home by horseback over the western trails or go by ship to Philadelphia and come west by road. During the War of I $\delta_{1} 2$ the first regular steamboat began to ply between Pittsburg and New Orleans, and from that time communication between different parts of the great western basin was comparatively easy.

283. The Era of Canals. - Improved means of communication by river undoubtedly gave an impetus to the building of canals, in which many people were interested before the steamboat was invented. Among others Washington formed a plan for the construction of a series of canals to cross the numerous peninsulas of the Atlantic coast or to connect the eastern cities with the Mississippi basin. The original cost of constructing a canal was a serious obstacle, but the great reduction in freight charges and the greater ease of traveling would, it was thought, justify a considerable outlay. Gallatin and others tried to interest national officials in plans for interstate canals, but Congress did not appropriate money for them as it did for the Cumberland road $(\$ 256)$. The credit for the canals which were constructed in such numbers between I 8 I 5 and ${ }_{1} \delta_{35}$ belongs to individuals or to far-sighted state officials.

The earliest of the canals built on a large scale was the Erie canal which connects the Hudson River with Lake Erie. By following the Mohawk River this canal was built across the only low pass through the Appalachian range of mountains. This was a state enterprise which was completed in I 825 largely through the efforts of DeWitt Clinton. The canal was much narrower and shallower than it is to-day, but it shortened the journey from Albany to Buffalo several days and it reduced the price of freight many times. From 
the beginning it was a financial success and the profits repaid the cost of the canal within ten years.

Pennsylvania was almost as much interesterl in canals as New York, but accomplished less because of the mountains in the western part of the state. This difficulty was solver] by building canals as far as possible from the east and from the west and connecting them by a "portage railway," over which the canal boats were carried. Other states, east and

Canals in other states.

Coman, Industrial Hist., $205-211$.

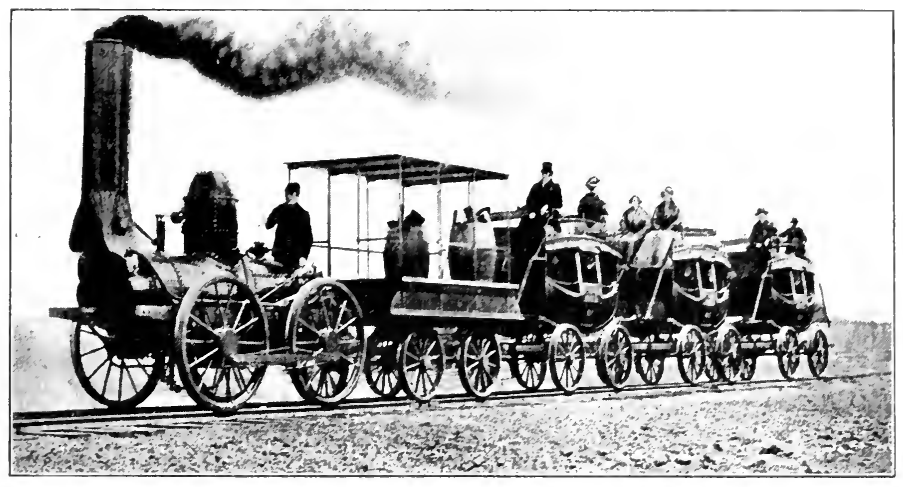

The De Witt Clinton

RAILWAY TRAIN IN AN EARLY DAY

west, began to build canals because of the great profit marle by New York, but because of geographical difficulties or sparseness of population, most of these were not financial Me.Master, United Stutes, $\mathrm{V}, \mathrm{I}_{3} \mathrm{f}_{-} \mathrm{I}+3 \mathrm{3}$. successes.

284. Railways. - Interest in the cronstruction of canals almost ceased when the railway came into use between I 8,30 and 1840 . The cost of laying a railway track was less than the cost of digging a canal. Railways could be built on grarles instead of nearly level areas and railways could be operated the entire year, so that they were preferable in almost every respect to artificial waterways. The earliest railways were practically horse-car lines of no great length. Alorut the time that Jackson was inaugurated, the perfection of Stevenson's Rocket showed that locomotives were better than any

First railways. Coman, Industrial 1fist., $235^{-241}$. Johnson, Kailway

Transportation I8-24, 34-4. McMaster, Lnited States, VI, 85-93. $342,35 \%$. 
other motive power, and, within a few years, railways were operated from Boston, New York, Philadelphia, Baltimore, and Charleston to neighboring towns, as well as between smaller cities that were farther apart.

Government and early railways.

Hart, Slav'ery and Abolition, $39-45$.

Johnson,

Railway

Transportation, 308-3II.

Railway development ( $1830-1860$ ).

Johnson, Railiay Transportation, $24-27$.

Smith, Parties and Slavery, ;9-67.

Semple, Geographic Conditions, $37 \mathrm{I}-3^{8} 9$.

mportance of neans of comnunication for large country.

These railways were built principally by private capital, but in Michigan and a few other states they were public enterprises. Subsidies were granted to a large number of railways by different states and cities during this period, and public money was invested in railways on every side. The results were disastrous, as the public roads could not pay expenses and were sold after a few years. Very little of the capital contributed by the states was ever returned to them. After I850, however, the states gave to the railways large bonuses of public lands which had been contributed by Congress for that purpose.

Although in $I_{3}$ o there were less than twenty-five miles of steam railway in use in this country, the mileage had increased to nearly 3000 in I 850 and to more than 30,000 at the beginning of the Civil War. Before 1840 there was no line roo miles in length. In that year there were eleven distinct railways connecting Albany with Buffalo. These were finally consolidated into a single railway system soon after ${ }_{1} 8_{5}^{\circ}$, but it was not until ${ }_{1} S_{5} S$ that cars ran on the track of a single company from New York to Buffalo. About the same time the first series of railways connected New York with the Mississippi River. This policy of consolidation, which made rapid progress during the decade before the Civil War, aroused most serious opposition. Politicians sought to make political capital out of the threatened dangers of monopoly, and the mass of the people would have prevented continued consolidation had it been in their power.

\section{Significance of Improved Means of Transporta-} tion. - The transformation wrought by these changes on land and water were greater than might be apparent at first. In a country covering so vast a territory as ours, with the limited interstate trade or travel and the comparative lack of common interests among the people of the states which 


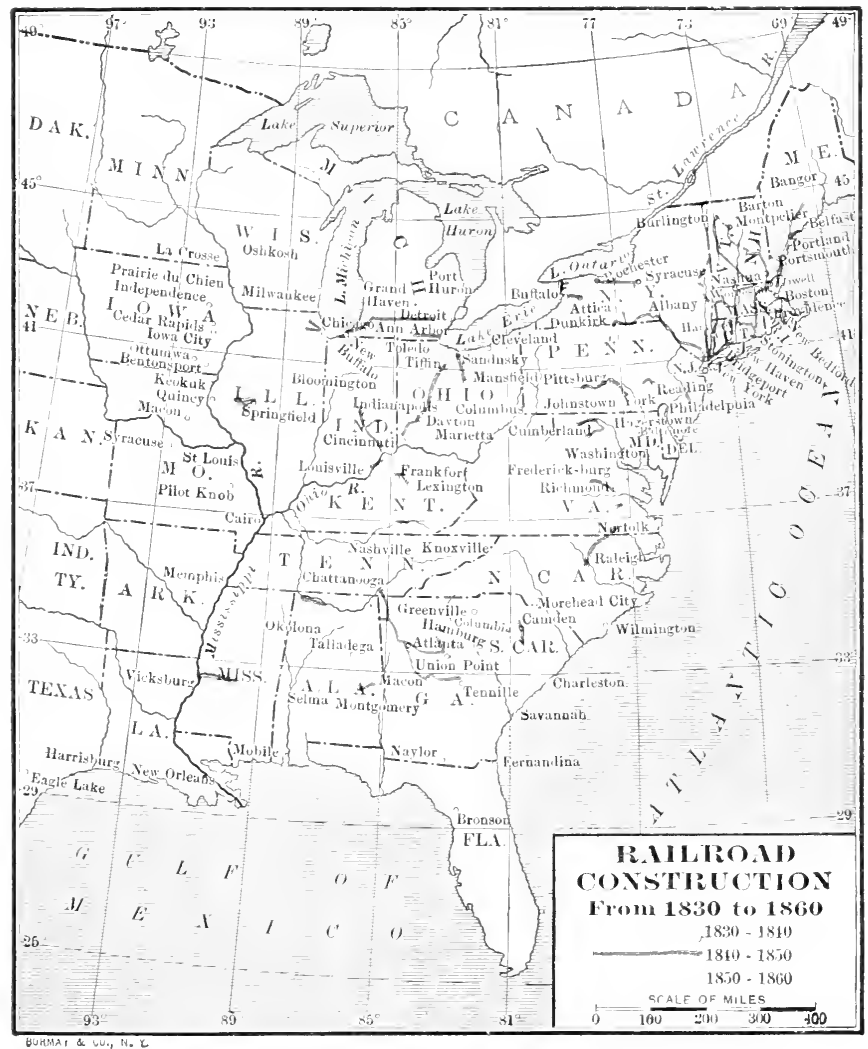



existed three quarters of a century ago, real union was impossible except through the use of goorl means of communication. There were very few goorl roarls in the United States at that time. Some turnpikes had been constructerl, usually within the limits of a single county, lut the condition of the rest of the roads was deplorable in the spring or in rainy weather. Moreover, with the exception of the Cumberland road and a few others, the letter highways never crossed state bounclaries. Emigrants userl the trails or hastily constructed roads and followerl the rivers, of which there were a large number in the West; but trarlers found it impossible to transport goods a great distance on land, or even on water unless they were going downstream. 'The early settlers were forced to live near rivers if they raised articles for a market other than that of their own locality.

By the use of the steamboat passengers and merchandise were transported easily and rapidly from the cities of the Atlantic borrler and (iulf to the upper waters of the coast rivers or those of the Mississippi system. A large interstate trade was developerl on the Mississippi and its tributaries which had been impossible before excejt downstream. Rivers of the western basin that hitherto hard been inarcessible were reached without difficulty. J)istricts listant from the rivers were penetrated by the canals that were built to connect large rivers or important bodies of water. This Value of waterways after 1815.

Turner, New West. $\left.3^{2}-38,(f)-1,6\right)$

Semple, Amer Ilist. and its Geosraphic condlions. $252-278$. opened large territories to cultivation and was an important cause of the great development of the midllle West during the quarter century following the second war with England. The reduction in freight rates over the canals gave a tremendous impetus to the industries of the towns and valleys that could now find a market for their productions. This commerce was especially valuable to the eastern cities, for the canals diverted trade from the earlier channels of the western rivers so that the exports of the prairie states nolonger went through New Orleans exclusively. New York owed a large part of her commercial supremacy after 1820 to the Erie canal. 
Development y means of ailways.

As the railway superseded the canal, the social expansion and industrial development begun by the improved means of communication by water was extended many times. Trips that in 1800 took a month and, in I825, weeks, could now be made in as many days. The railways went everywhere, not only bringing new settlers and increased business,

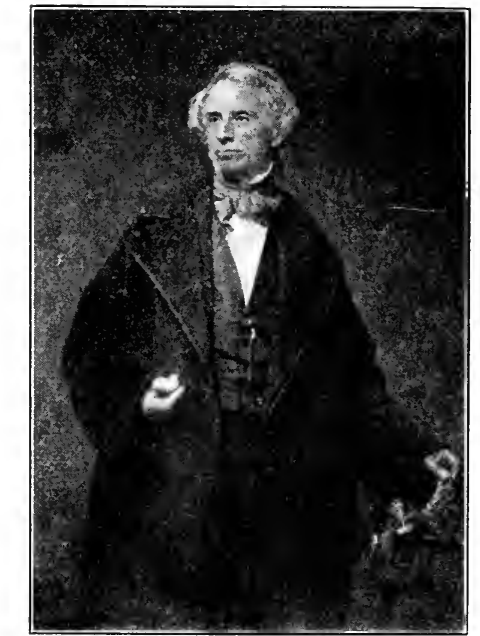

MORSE AND HIS INSTRUMENT

but giving improved mail service and permitting the interchange of new ideas and methods. Chicago was in 1860 as near to New York in time as Philadelphia had been a century earlier. The South lost most of the trade from the Middle West, but the Northeast and Northwest were united by closer commercial ties than formerly, so that the whole North was united as never before.

\section{The Telegraph}

irst telegraph ine and cable.

3ryn, Progress flnvention, $5-22,32-35$. and Other Inventions. - Annihilation of distance by steam was little less noteworthy than the infinitely more rapid transmission of news by electric telegraph. The perfection of the first successful transmitter and the operation of the first satisfactory telegraph line were due to the genius and persistence of Samuel F. B. Morse. Morse had made use of crude telegraphic apparatus as early as I 832 , but was not able to construct a line until Congress appropriated $\$ 30,000$ to build a line from Washington to Baltimore. The first important news sent over this line told of the proceedings in the Democratic nominating convention of 1844 . Before the Civil War all important cities and towns in the countrv were reached by the wires of some 
telegraph company, and an Atlantic cable had been laid. This cable was not successful, and in 1866, through the efforts of Cyrus W. Field, a new cable connected Europe with America. Perhaps we can get some idea of the value of the telegraph if we note its use in conducting a single business like that of a railway, in transmitting general news, and in dealing with questions of international importance which require prompt attention.

The period following I 8 I 5, especially after I 829, witnessed a revolution in the methods of production due to changes in the machinery used. Among the inventions which affected industry or increased the comfort of the people may be mentioned the improvements in plows, the invention of reapers and binders and threshing machines, improved cooking stoves, the first successful sewing machines, and rotary printing presses. The process of making vulcanized rubber was perfected, the first friction matches were used,

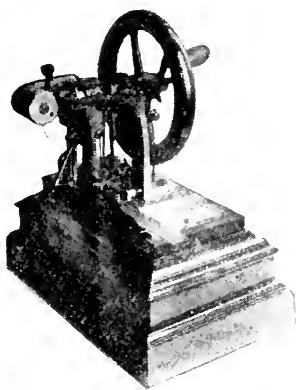

HOWE'S ORIGINAL SEWING MACHINE the earliest daguerreotypes taken at this time. Illuminating gas began to come into common use. In I860 people lived in much greater comfort than in 1830 and they purchased most articles of common use at a much smaller price.

287. Industrial Changes after i8io. - On account of the improved machinery used after $\mathrm{I} 8 \mathrm{~s}$, a change occurred in the methods of manufacturing. Until about i8 io most articles had been produced in small shops or in the homes of the workers. Soon after i8 io machinery came into general use for the weaving of cotton and woolen cloth and in Use of machinery.

Wright, Indu trial Evolutio II7-I3I. other industries. Large foundries, using anthracite and bituminous coal, displaced the smaller foundries and forges in use at an early day. Manufacturing under the factory system was much more economical than the older methods, and the value of the products very much greater. 
Degree of idustrial evelopment.

Vright, Indusial Evolution, $3^{2-I} 42$.

rosperity nd panics $1815-1843)$.

Tariff of 842.

Dewey, Finanial Hist., I02.
The industrial development between the second war with Great Britain and the Civil War was rapid, but not greater than the increase in agriculture and commerce. There were many difficulties to be overcome in starting these "infant industries." Aid was given by the national government in the tariff of I 8 I 6 and for about two decades following, but the system of protection was practically abandoned during the quarter century preceding the Civil War. Manufacturing was a much less essential part of the nation's life than it has been since the war between the North and the South. Very few products of the factories were exported and only four per cent of the people were employed in manufacturing.

During the period from I $S_{5}$ to ${ }_{1} S_{43}$ the country passed through several periods of prosperity and depression. The excessive activity following the war of ISI 2 ended in ISI9 in a panic which affected business in general and the new cotton and woolen industries especially. The hard times of that period reacted on the people, many of whom were less in favor of the expansion of national authority than at the close of the recent war $(\$ 249-257)$. The return of prosperity before the election of Jackson restored confidence and enthusiasm for national expansion, and culminated finally in more radical speculation than had ever been tried before $(\$ 276)$. The panic of ${ }_{1} S_{37}(\$ 277)$ put an end to "wildcat banking," to the "booming" of town lots and public lands, and to unwarranted business ventures, ending as it did in the greatest business depression suffered by the people to this time.

288. The Era of "Free Trade" (1846-1857). - The country had not recorered from the hard times which followed the panic of $18_{37}$, when the compromise tariff of $18_{33}$ was completed by the final reduction of duties in 1842 to a level of twenty per cent. As the government obtained insufficient revenue from the duties on imports, a new tariff was proposed by the Whigs and passed in 1842 which restored the policy of protection, with rates averaging about the same as those in the tariff of $I_{8} 8_{2}$. 
Opposition to protection developed again as soon as good times returned a year or two later. The Democrats, successful in the election of 1844 , made their plans for a freetrade tariff. Articles were classified in schedules, with rates from five per cent to one hundred per cent, and many articles on the free list. All rates were levied on the value of goods for the first time, and a great amount of fraud resulted because importers undervalued their goods.

Because of the reaction from the depression which lasted from 1837 to 1843 , the decade following 1846 was one of unProsperity $\left(1845^{\prime}-1857\right)$ usual prosperity. Our foreign trade, which in 1846 amounted to $\$ 227,000,000$, hald increased in 1857 to $\$ 642,000,000$. Large numbers of immigrants came from Europe every year. Crops were large, prices were high, and business of every kind active. Immense amounts of gold had been taken from California since its discovery in $\mathrm{I} 848$, so that money was plentiful. Capital was invested recklessly, especially in real estate and in railways.

Since the government revenues exceeded the expenditures which the conservative politicians in control of Congress believed it to be wise or constitutional to make, a new tariff act was passed in 1857 , reducing the rates on articles imported. Scarcely had this been done when excessive speculation led to a panic which affected business in general, and the railways in the interior particularly. Failures were numerous and the government kept getting deeper into debt during Buchanan's administration, although business revived more rapidly than is usual after a depression.

\section{Political ani Social Changes}

289. Opening of the Government Lands. - The rapid development of political and social democracy during the first half of the nineteenth century was due especially to the growth of the West. The population of the Mirllle West increased from less than five hundred thousand inhabitants in 1800 to more than seven and one half millions in $185^{\circ}$.

Dewey, fïna cial Mist.,

$\oint \oint$ IIO-II2.

Rhodes,

United States

III, 14-27.

Tariff and panic (1857).

Dewey, fïna, cial llist., $\S 113$.

Rhodes, Linited States II $1,44-56$.

I and systems before 1820 .

Turner, New llest, $84-87,135$, I $40-143$. This expansion was influenced not alone by the improved 
means of communication in the Mississippi basin, but by the liberal land policy of Congress. When the states ceded to Congress ( $178 \mathrm{I}-\mathrm{I} 802$ ) their claims to lands in the West, Congress gained the title to all unoccupied lands in that region. A system of surveys was begun in 1785 , following after I 796 a plan similar to that used at present. ${ }^{1}$ Congress expected to derive from the sale of these lands considerable revenue, of which it was greatly in need, but the profits during the Confederation were slight. After other sources of national income had been devised under the Constitution ( $\$$ I 98,2 I 7 ), Congress in I 800 decided to sell lands in blocks of 320 or 640 acres at $\$ 2$ per acre, payable in installments. Later laws made it possible to purchase for cash public lands in still smaller lots, usually i 60 acres, a quarter section, the price being reduced somewhat, especially for actual settlers.

Extensive ale of lands.

Hart, Practical issays, $39-2+4$.

MacDonald, racksonian Democracy, $76-285$.

Jonaldson, ublic Domain, oo-2o8.

Universal novement oward lemocracy.

Many of these lots were taken by speculators, who secured the choicest sections in the fertile valleys and expected to sell them at a great advance. Most of the sales were to actual settlers, except during the years from I 834 to 1837 , when a mania for speculation in lands and the subdivision of districts into town sites reached its maximum. During the first forty years of the century an area was sold equal to that of the three states of Illinois, Wisconsin, and Iowa. Such reckless disposal of the best lands in the finest agricultural region on the globe was unfortunate except when the lands were taken by actual settlers. Yet the impetus which it gave to immigration into the West and the influence which the sale of lands in small blocks had upon the democratic character of the western states, makes the subject one of the greatest importance.

290. Development of Democracy. - The democratic spirit which developed rapidly after I 8 I 5 affected the national government much less than it did the states, especially in the West. Frontier life, with its crude conditions, its lack of huge estates or great fortunes, is a social leveler. Men are

${ }^{2}$ See Ashley, "American Government," \$299. 
judged on their merits, not by the standards of money or Turner, former social position. In the West accordingly democracy, political and social, was perfected at an earlier date than Frontier in History. elsewhere. But the changes in the West affected the East, whose people protested against the old inequalities which kept many men from voting and gave more legal rights to some than to others. This democratic movement was more

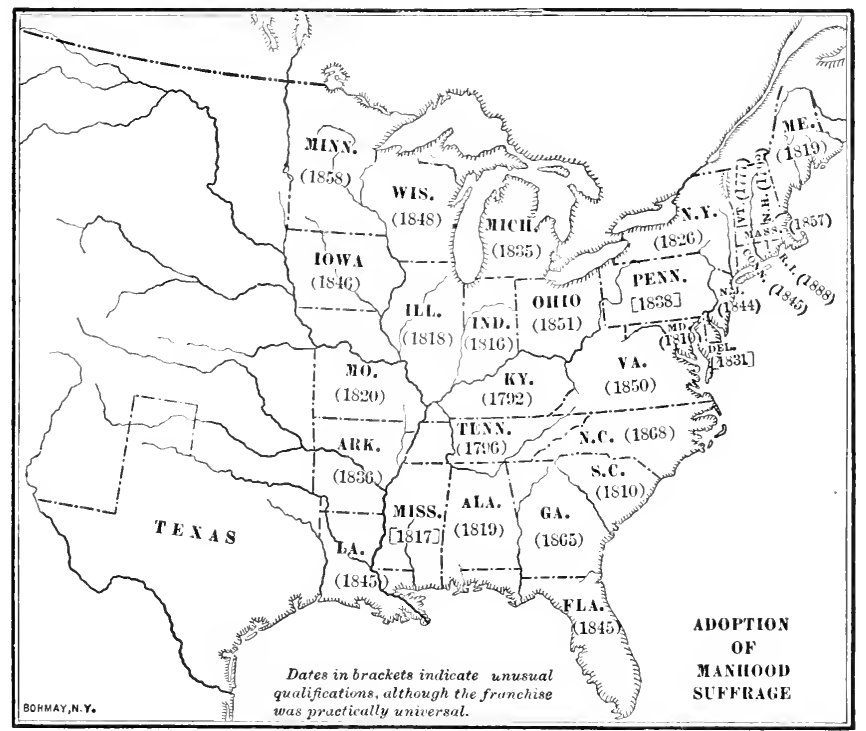

pronounced in this country than elsewhere, but the same spirit produced in Europe reform movements or revolutions which sought to abolish class rule and secure justice for the masses. These culminated in the widespread revolutions of $\mathrm{I} 848$.

In the United States the demand of the people for a share in the government produced, first of all, changes in the Changes in the franchise. suffrage. In I 8 I 5 only three or four states along the Atlantic border allowed all men to vote, although most of those in the Northwest and Southwest had very liberal qualifications for voters. Thirty years later practically all of the states

Thorpe, Const'l Hist. of Am. People II, $476-482$. 
McMaster,

Inited States,

V. 380-394.

Schouler, Const'l Studies, $23 \mathrm{I}-248$.

\section{Popular par-} ticipation in government.

Thorpe, Const'l Hist., I I, 426-428, $45^{8-476 .}$

Schouler, Const'l Studies, $267-292$.

Distrust of the legislatures.

Thorpe,

Const'l Hist., II, 4I3-4I9.

New activities of the states.

Thorpe, Const'l Hist., II, $429-446$. allowed white men to vote without other restrictions than citizenship and a short period of residence in the state. New York permitted blacks to vote if they owned property, but, as a rule, the laws of the period restricted rather than increased the voting privileges of free negroes. Many of the western states tried to attract immigrants by allowing those who intended to become citizens the same privileges as citizens, and two states allowed all adult male residents to exercise the elective franchise.

291. Changes in the States. - Popular demand for a share in the work of governing affected much more than the right to vote. Formerly, most officials had been appointed, the governor being the only state official chosen before this time by the people in all of the states. Local sheriffs and city officials were no longer appointed. Even the judges in most of the states were chosen by popular vote. Moreover, after I 820 the people insisted that their state constitutions should be submitted to them after they had been drafted by the conventions chosen for that purpose.

Popular distrust of the officials chosen even at general elections was shown by the great number of subjects that were included in the state constitutions. The legislatures, which in 1776 by general consent had held almost continuous sessions, were forced to be content with sessions of about sixty days once in two years. Many powers were taken from the legislature, so that the people should not suffer too severely from the bane of overlegislation, which had afflicted more than one of the states.

Nevertheless the people of the states were willing to try new experiments. They undertook the construction of numerous canals $\left(\$_{2} 8_{3}\right)$, voted public money as bonuses for roads, and invested state funds in speculative enterprises which promised to develop the resources of the state, but resulted in nothing but the exploitation of the public treasury. Permission was given to numerous "wild-cat banks" which issued notes practically without limitation and on very limited credit or capital. Yet the enterprise and spirit which 
prompted all of these movements resulted in wonderful changes in the condition of those whose rights had been denied before that time.

292. Social Legislation. - It was inevitable that sooner or later class privileges should disappear. We have noticed already that religious qualifications for the franchise had been the first to go, and that property was not required of voters to any extent. Laws of inheritance no longer gave the eldest son a special share. Imprisonment for debt had been discontinued gradually after $\mathrm{I}_{776}$, and was used very little in I840. The newer states were beginning to make homesteads exempt from seizure by creditors. Through constitutional provision or statute some states were following the example of the national government which in 1840 made ten hours a day's labor for its employees, but most changes of this character came later, after the Civil War. In some cases the constitutions expressly stated that married women might hold property in their own names, and gave them certain other specific rights before the law and in inheritance. The movement in favor of equalization among white men was almost universal, though less pronounced in the older and more conservative sections.

An instance of the humanitarian changes of the time is furnished by the prisons. The prisons of the eighteenth century were of the worst description, the prisoners being herded together irrespective of age, offense, and other conditions, sometimes kept in cellar dungeons or in damp, unventilated mines. Little improvement was made until, about I830, a few model prisons were built, in which prisoners were allowed to work under sanitary conditions, and decent food and shelter were provided.

293. Newspapers and Education. - The same causes which gave the people so much power in political affairs were influential in the extension of systems of free education. Not only did people begin to realize that it was necessary to be trained for their civic duties, but they felt that the state owed every child the opportunity of a good education. Under the

Equalization of rights.

Cleveland, Democracy, $359-363$, $379-385$.

Beginnings of prison reform

McMaster, United States, I, 98-IO2, IV, 532-549, VI, 96-99.

New public school system.

McMaster. United States, V. 343-372. 
lead of Mann and Barnard, New England built upon her old foundation of belief in common schools a far more perfect free system than had yet existed. In the West democracy insisted upon education as a right. As all of these states had once been parts of the public domain, each had an educational fund of one section, or, after I848, of two sections, in each township. This greatly lightened the burden of the local school taxes, and thus gave the West decided advantages over the East.

Cheap daily newspapers.

Hapgood and Maurice, Bookman It (I902), $567-584$.

Improved mail service.

Harrison, This Country of

Ours, 233-240.
One of the greatest educational forces of that day and the era since that time has been the modern newspaper. The newspapers of the eighteenth century usually contained four small pages with comparatively little news and very little advertising. As better presses were invented, the New York Sun and other papers were published at one cent ( $18_{33}$ ), the first modern newspapers at a popular price. These papers, especially in New York, were developed into bright, interesting sheets, with valuable editorial comment on public questions. Soon there were very few villages which did not have a local newspaper. Everywhere these papers exerted a tremendous influence on public sentiment. It is said that the feelings of a large class were expressed by the old farmer who was asked his opinion on some public question and replied, "I don't know. The Tribune has not come yet." 1

The national government helped to bring this education to the people by revising its postal system. It adopted adhesive stamps and reduced letter postage from twenty-five cents for all distances over four hundred miles to a uniform rate of three cents per half ounce for all distances less than three thousand miles. On newspapers and other periodicals rates were lowered later to one cent per pound, if sent direct from the publishers. For a long time this involved considerable loss, and in fact the receipts do not equal the expenditures to-day; but this loss, most of which comes from the transportation and delivery of periodicals, is justified on the ground that it is a public service of exceptional value.

1 The New York Weekly Tribune, edited by Horace Greeley. 
294. American Cities. - No part of the nation grew with greater rapidity during the first half of the nineteenth century than the cities. In I 800 only four contained as many as ten thousand inhabitants, but in 1850 the number of cities of that size was $4 \mathrm{I}$. In the half century the urban population had increased more than three times as rapidly as the population of the entire United States. The largest city, New York, was a thriving metropolis of over a half million, just beginning the decade of most rapid growth in its history. Many of the Irish who came to America between I846 and I 860 settled in these bustling centers of population, and thousands of farmer boys and girls left the country yearly for the more active life of the railway centers or the factory towns.

Most of the cities abandoned the old undemocratic government that they had used during the colonial and early national periods. In adopting a more popular system the cities showed most of the faults with few of the excellencies possible in popular rule. In them the "spoils" system was brought nearest perfection, and "boss" rule was developed most easily. This demoralizing state of affairs was probably due to two things. (I) The growth of the cities was quite rapid, and a large part of the new population was foreign. As suffrage was universal, and a declared intention to become a citizen often gave an ignorant immigrant a vote, the elections were decided by an element easily led and corrupted. (2) The rapid growth made extensive improvements necessary. This expenditure acted as a temptation to certain of the lower classes to take part in city government, and, as the money was expended by these persons, it tended to increase the evils already existing. So democracy in the cities came near being mob rule.

\section{Free and Slave States}

295. Growth of the United States. - In I 800 the United States extended from the Atlantic to the Mississippi River and from the Great Lakes to the Floridas. In 1850 its

Changes in government.

Fairlie, J. A., in Municipal Programme, II-I7.

Fairlie, Mun Administration, 77-85.

Territorial expansion (1800-1850). 
arrison, Vestzoard xtension, 42.

western boundary was the Pacific Ocean. Louisiana, with its indefinite western boundary, had been acquired from France in 1803 . The Floridas had been ceded by Spain in I8I 9 , and our title to Oregon from $42^{\circ}$ to $49^{\circ}$ became clear in 1846 . In I $8_{45}$ we annexed the republic of Texas $(\$ 302)$, and when Mexico objected, we made war on her and seized the territory from the Rio Grande to the Pacific. In a half

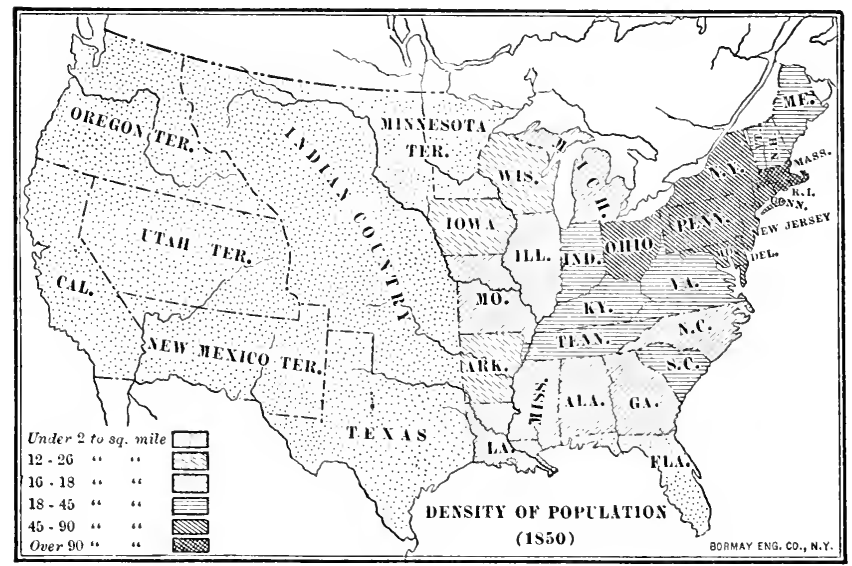

century the United States had grown to more than three times its original size, had acquired a natural boundary on the southeast, and had gained a seacoast more than one thousand miles long on the Pacific - a magnificent domain, symmetrical, productive, with unlimited natural resources, and located midway between the well-developed nations of Europe and the older civilization of the Far East.

The population meanwhile had doubled every twentyfive years. From only 5,300,000 inhabitants in I 800 , the number had increased to $23,000,000$ in ${ }_{1} S_{50}$ and more than tarrison, Hestaward Extension, $-21$.

ncrease in opulation. $31,000,000$ in 1860 . But the growth was not uniform throughout the country. The population of the older states had not increased as rapidly as that of the West, although in I850 nearly one half of the people lived east of the Alleghany 
mountains. The cities had grown more rapidly than the country, although more than eighty-seven per cent of the people still lived on farms or in villages. The South had not kept pace with the North, for, although they started together in I 800 , the free states contained 4,000,000 more people than the slave states in 1850 , and in 1860 were nearly $7,000,000$ in advance of the southern states.

296. Foreign Immigration. - A considerable part of this increase was due to the very large immigration from Europe which followed the Irish famines after I 845 and the failure of the revolutions in Europe in 1848 . About two and one half millions came during the first half of the nineteenth century and as many more landed at the ports of the United States during the decade from I 850 to 1860 . Most of these were Irish or Germans, people of unusual intelligence and energy who threw in their lot with the people of the United States and discarded to a large extent all their former social characteristics. Many of the Irish settled in the cities where they interested themselves particularly in the work of city government, often complicating the problems that the cities were forced to solve during this transitional period of their existence. Many of the other immigrants went directly to the West, where they obtained government lands. Almost without exception they settled in the North in order to avoid competition with slave labor.

Had it been impossible for the United States to assimilate so large a body of foreigners, their great numbers would have been a decided menace to our institutions. Yet nowhere did they retain their old national characteristics of race, language, and customs, for, even if the first generation failed to become truly American, it was never so with the second. As they were industrious and thrifty, they increased the wealth and producing power of the nation. Moreover, they, consciously and unconsciously, aided in the development of a national spirit and gave their support in favor of a strong central government. The Irish and the Germans, at least, had struggled for the perfection of na-

National influence of foreigners. 
tional unity in their former homes and were in sympathy with the similar movement in this country. They were drawn to the United States as the land of the free, but they knew little and cared less about the states. Directly and indirectly they were a great help in developing a national sentiment in the North.

States admitted (1820-1850).
Attitude of the new states toward the national government.
297. The Admission of New States. - In spite of the much more rapid development in the North than in the South, Congress had preserved the balance of the states until I850. After the struggle over the admission of Missouri $(\$ 260)$, no state was admitted for fifteen years. Then Arkansas and Michigan were admitted. Later Texas and Florida were followed by Iowa and Wisconsin. When California was admitted as a free state, the balance was broken, for there was no territory in the South between Texas and California that was well settled. Even in this territory the people were opposed to the system of slavery, for in New Mexico in 1850 the vote was nearly Io to I in favor of asking for admission as a free state. The Northwest, on the contrary, was growing rapidly and in the natural course of events would be divided into free states.

It is interesting to notice that so far in our history, except in the disputes arising over the navigation of the Mississippi River, all of the tendencies toward disunion and most of those favorable to state sovereignty came from the older commonwealths. The reason for this is evident. The old states looked upon the Union as their creation; the new considered the nation their creator. Nearly all of the territory formed into states after 1789 has been at some time under the absolute control of the national government. When these new states were admitted to the Union, the old states apparently had nothing to do with the change. Congress passed the enabling act, Congress imposed conditions, if such there were. The new commonwealths had no local traditions, no revolutionary claim to sovereignty, no institutions productive of either particularism or sectionalism. They favored a strong government for foreign affairs and for 
internal improvements, and only in the few matters directly antagonistic to their interests did they disapprove of national authority.

298. Early Abolitionists. - Not only were the slave states behind the more progressive free northern commonwealths, but they found that their institution of slavery was threatened by the growth of a new and practically worldwide movement in favor of universal freedom for blacks as well as whites. The abolition movement became prominent in the United States about I83 I. Before that time all of the northern states had made provision for the emancipation of their slaves, and a few of the southern states had looked with favor on some form of gradual emancipation. In 183 I William Lloyd Garrison established in Boston his paper called "The Liberator" which was thenceforth devoted with unlimited zeal to the cause of negro ireedom.

Unfortunately in the same year there was an insurrection of blacks in Virginia led by a negro, Nat Turner. Before this could be suppressed, over sixty whites, most of them women and children, lost their lives. Severe laws were enacted against the blacks in several states and further consideration of emancipation in the South ceased. Many people, North and South, believed that Turner's insurrection had been produced by the abolitionists, and so great was the feeling aroused against Garrison and his followers that abolition meetings were broken up, speakers were mobbed in almost every northern state, a large amount of property was destroyed, and a few of the more radical leaders, like Lovejoy in Illinois, put to death. The movement grew slowly. In 1833 a national anti-slavery convention was

Progress of the abolition movement.

Schouler,

United States, IV, 210-216, 296-300. 
held, but before 1835 very few people had identified themselves with the abolitionists, although in 1840 they claimed about two hundred thousand members in various abolition societies. Public sentiment changed gradually toward the abolitionists so that after I 840 they suffered comparatively little from mob violence in the North, although they did not control the sentiment of many states except possibly in parts of New England.

\section{Congress's} attitude toward abolition.

Burgess, Middle Period, 254-273.

Hart, Slavery and Abolition, 256-275.

299. Abolition and Petition (I835-I840). - Since the beginning of the national government petitions had been presented in Congress requesting the abolition of slavery in the District of Columbia. At first the Quakers were the only persons interested, but after ${ }_{1} \delta_{3}$ o the abolitionists circulated and presented numerous petitions. In ${ }_{3} 8_{35}$ the radical members of the House became engaged in a contest over these petitions which had a very momentous result. After several months of bitter debate, the House adopted a "gag-resolution" by which all anti-slavery petitions were to be laid on the table, with no further action whatever to be taken on them later. The Senate adopted rules which prevented the consideration of similar petitions in much the same manner. Nothing else could have brought before the attention of the people the cause of the abolitionists as had this debate. Instead of reducing the number of petitions, the agitation continued to spread until the House, thinking to rid itself of this question, was persuaded by the southern members to go one step farther. "After $\mathrm{I} 8_{4} \mathrm{O}$ no petitions are to be received by this House or entertained in any way whatever." In short, the House had denied to large numbers of citizens their constitutional right of presenting petitions. ${ }^{1}$ In seeking to injure the anti-slavery movement, the radical congressmen had given the abolitionists definite legal grounds for opposing slavery. The pro-slavery leaders had shown that in their opinion they must protect slavery even though they interfered with the rights of other citizens, certainly a fatal mistake.

${ }^{1}$ Constitution, Amendment $\mathrm{I}$. 


\section{TOPICS}

I. Land Policy of the United States: Hart, "Practical Essays on Government," No. ro; Willoughby, in "Johns Hopkins University Studies," Sato, S., in "Johns Hopkins University Studies," IV, Nos. vii-ix.

2. Anti-Slavery Movement: Burgess, "Middle Period," pp. 2ł2-277; Hart, "Contemporaries," III, Nos. $17+-18_{4}$; Von Holst, "Constitutional History of United States," II, pp. 80-I39, 219-292; Hart, "Slavery and Abolition," pp. I 52-275.

\section{STUDIES}

I. Spread of population in the Mississippi valley as affected by geographic conditions. (Semple, "American History and Its Geographic Conditions," pp. I 50-I 77.)

2. Local influences of the Erie canal. (Hulbert, "Great American Canals," II, pp. I $5^{2-1} 77$.)

3. Government of democracy in America. (De Tocqueville, "Democracy in America," I, pp. 19 $8-238$.)

4. "Who reads an American book?" (Hart (ed.), "Contemporaries," III, No. I52.)

5. American poets of the Middle Period. (Trent, "American Literature," pp. 393-460.)

6. An Englishwoman's view of a western town. (Mrs. Trollope, "Domestic Manners of the Americans," I, pp. 6I-I3I.)

7. Removal of the Indians east of the Mississippi. ("The American Nation," XIV, zro (maps), XV, Chapter X.)

8. People without a Country. (Thorpe, "Constitutional History of the United States," I, pp. 356-399.)

9. Economic character of slavery. (Hart, "Slavery and Abolition," pp. 49-66.)

10. The slave market. (Hart, "Slavery and Abolition," pp. I23-I 35 .)

I I. Slavery agitation in Congress. (Benton, "Thirty Years in Senate," I, pp. 576-588, 600-623.)

I2. J. Q. Adams on constitutional war powers over slavery. (Johnston (ed.), “American Eloquence," II, pp. I I 5-I 22.)

\section{QUESTIONS}

I. Compare the internal improvements made by the national government with those undertaken by the states. Was there any difference between the character and extent of the improvements made by the eastern and by the western states? 
2. Give a full comparison of the ways of transportation in $\mathbf{I} 75^{\circ}$, I 800 , and 1850 . What changes or improvements coincided with the close of the first war with Great Britain? the second war with Great Britain? the election of Jackson?

3. Make a table showing in one column the periods of prosperity and business depression since ${ }_{1} 8_{15}$; in a second the wars, movements of population (indicated by new states, etc.), and extension of territory; in a third very important laws or acts of the national government.

4. During the first half of the nineteenth century what changes occurred in the franchise, in popular participation in government, in laws regarding debt, imprisonment for debt and methods of punishment, in civil rights in general?

5. Trace the changes from i $; 80$ to the present in our Indian policy; in our postal service; in our public land system.

6. Compare the United States in 1850 with the United States in I8oo. Note area, population, percentages of rural and urban population, occupations, culture, degree of national unity, and changes considered in 2 and 4 above. 


\section{PART IV}

\section{THE STRUGGLE OVER SLAVERY$$
\text { ( I 843-I 877) }
$$

\section{CHAPTER XV}

\section{SLAVERY IN THE TERRITORIES (I843-I857)}

300. Introduction. - The period between I 843 and $\mathbf{1} 877$ is concerned principally with questions arising out of slavery. This system, which had once been universal in this country, had been superseded gradually in the North by free labor. The reasons for this are topographical, economic, and social. We have noticed already the decay of slavery in the North and the spread of an abolition sentiment throughout that section. ${ }^{1}$ In the South, on the other hand, since the invention of the cotton gin ( $\$ 206)$, there had been a great and constantly increasing demand for slaves, who could be employed profitably on the large cotton plantations. ${ }^{2}$ After 1830 the cotton industry dereloped with especial rapidity, so that long before i 860 it had become the chief occupation of the South, and of value to the whole country, furnishing as it did two-thirds of the exports of the United States.

So important was this industry, so essentially a part of the life of the South, so valuable was cotton in our foreign commerce, that almost every one believed "Cotton was King." Not only did it make slavery more necessary to the South, but, through its demand for slave labor, it helped to uphold that patriarchal plantation system that was the chief characteristic of the Old South. Throughout the
Slavery and the South.
Influence of cotton. 
southern states there was preserved until the coming of war a life of social pleasures, of large-hearted hospitality, which even cotton could not make commercial. These plantation owners were men of high ideals who opposed democratic innovations and considered manual labor degrading, who had no sympathy with the bustling, energetic, commercial North, and were particularly anxious to protect and extend the institution of slavery.

The nation and slavery.

Naturally the South desired more territory in which new plantations might be started; to which the institution of slavery might be extended. As there was no possibility of reëstablishing slavery in the North, the South turned, of course, to territories south and west of the slave states. The southern leaders desired more than new territory suitable for slavery, for they insisted that slavery must be established and maintained in these lands. The South had not grown as rapidly as the North, so that unless new slave states were added soon to the Union, the political balance between the free and the slave states would be broken forever. But the extension of slavery, in fact even the maintenance of slavery, was at this time threatening the completion of that national development which had been the chief result of our history to this time. ${ }^{1}$ Although slavery tried to prevent the completion of nationality, in the end the nation conquered and destroyed the institution.

Four periods in the contest between the nation and slavery.

The struggle between these two forces covers four periods: (I) The attempt to acquire more territory and extend slavery to all of the territories controlled by Congress; (2) the attempt to protect slavery by means of secession and civil war; (3) the triumph of the Union orer secession; and (4) the reconstruction of the states that attempted to secede. We shall consider in the following chapters these four phases of the slavery contest, which covered a third of a century and assured the future success of the republic.

${ }^{1}$ On the incompatibility of slavery and nationality, consult $\S \S 33^{\circ}, 33^{\mathrm{I}}$. 


\section{Territorial Expansion (1843-1848)}

30r. Texas before 1843. - Soon after the United States The settleabandoned its claims to Texas in the treaty of I8I9 (\$26I), Mexico revolted against the rule of Spain and established her independence. One of the states of the new republic was that of Coahuila-Texas, the eastern part of which, as far as the Nueces River, was called Texas and was settled almost exclusively by immigrants from the United States. These Texans had nothing in common with the Mexicans of the Coahuila part of the double state, but the Mexicans were so much more numerous that they ruled the state. Opposition to Mexican rule culminated in an attempt to gain independence for Texas. This succeeded practically when, in I 836 , General Sam Houston defeated at San Jacinto an army much larger than his own under President Santa Anna, capturing the Mexican general and a large force of men. Early the next year the independence of Texas was acknowledged by the United States and by foreign powers.

From the beginning the Texans had desired annexation to the United States. This was not farored by either Jackson or Van Buren, but was discussed somewhat in Congress and throughout the country. As early as i $8_{3} 6$ Calhoun announced in the Senate that he considered the annexation of Texas necessary to preserve that balance between slave and free states which alone would preserve the Union. Others at this time opposed the annexation for exactly the same reason, but it did not become a sectional question until much later.

302. The Annexation of Texas (I843-1845). - President Tyler desired annexation, but was unable to accomplish anything in this direction until Webster resigned his position as secretary of state in 1843 . Plans for a treaty of annexation had been almost completed when Calhoun accepted the portfolio of state in 1844 . The Texas treaty was rejected in the Senate by an emphatic vote, probably less because the senators opposed annexation than because they lisliked the

Proposed annexation.

Burgess, Middle Period, 295-302.

Annexation treaty $(1844)$.

Rhodes, United States, I, 78-82.

Burgess. Middle Period, 302-310. 
way the President dictated to them. Some feared also that the annexation of Texas with a claim to the Rio Grande rould involve us in war with Mexico.

Election of IS+H.

Scarcely had the Senate rejected the Texas treaty when conventions met to nominate candidates for the presidency. The Whigs adopted a short platform in which Texas was not mentioned. They nominated Henry Clay. In the Demo-

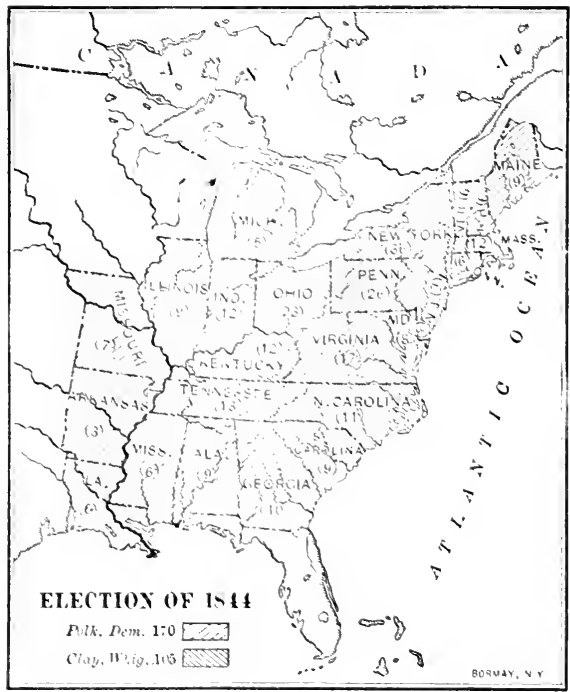

Schouler, I nitid states IN, $405-4$ SO.

S:anwood, l'isting, $20 y-225$. cratic convention there was a contest between the friends and enemies of Vin Buren. His friends had a majority of the delegates, but could not muster the two thirds necessary for the nom in a tion. James K. Polk of Temnessce, formerly speaker of the house, was selected finally. The platform stated that "the reoccupation of Oregon and the reannexation of Texas at the earliest practicable period are great American measures which this convention recommends to the cortial support of the Democracy of the Union." Under the name of the Liberty party, the abolitionists took part in this campaign as in that of isfo. At first Clay emphatically opposed the annexation of Texas on the ground that it would involve us in war with Mexico, but, as the campaign progressed he wrote to a friend in the South that he farored annexation if it could be done "without dishonor, without war, with the common consent of the Union, and upon just and 
fair terms." This attitude alienated enough of his supporters in New York so that Polk carried that state and the election. ${ }^{1}$

When Congress met in December, 1844 , resolutions were introduced for the annexation of Texas by joint action of the houses of Congress. These were adopted and signed by President Tyler, March 1, 1845. Mexico threatened war if Texas accepted the offer to enter the Union, but the state adopted a constitution and was admitted in December of that year. ${ }^{2}$

303. Oregon Territory to 1846 . - In the campaign of I 844 the desire for territorial expansion had been roiced not simply by the desire to annex 'Texas, but by the demand for "the whole of Oregon." This was expressed in the campaign motto "54-40 or fight." Since i 8 i 8 the Oregon territory from $42^{\circ}$ to $54^{\circ} 40^{\prime}$ had been helel jointly by Great Britain and the United States. Spain had surrenderel to us her claims to land north of the forty-second parallel in the treaty of I8I9. Russia had agreed to remain north of $54^{\circ}$ $40^{\prime}$. The question to be settled was therefore the boundary line between British Oregon and American Oregon. 'This remained in abeyance until 1844 .

American claims to the Oregon country were based upon the discovery of the Columbia River in 1792 , the Lewis and Clark explorations in I804-1806, settlements and trading posts established at the mouth of the Columbia before the second war with England, Spanish claims which had been transferred to us, and actual settlement of the territory by missionaries and others, most of whom went to Oregon after I835. Great Britain based her claims on the explorations of Vancouver and others before $\mathrm{I} 800$, the acknowledgment of her territorial rights by Spain in I 790, and the many posts established by the Hudson Bay company. In I 844 none

1 The vote was $1,337,243$ for Polk, 1,288,062 for Clay, and 62,300 for Birney (Liberty party). The electoral vote was 170 for Polk and ro5 for Clay.

2 The United States did not guarantec the Rio Grande boundary nor assume the public debt of Texas exceding the sum of $\$ 10,000,000$. 
of these claims were of the least value except those based on actual occupation. In that respect England had the advantage if we consider areas, for the Hudson Bay company had been very active in extending its tracle. On the other hand the Americans were much truer settlers and had a much more valicl claim in the territory which they held.

Oregon reaty $(\mathrm{I} 846)$.

Foster, Amer. Diplomacy, 3о7-313.

Schouler, United States, IV, 5II-5I4.

Hostilities on the Rio Grande.

Burgess, Middle Period, $327-33 \mathrm{I}$.
About $\mathrm{I}_{2} 25$ the United States had desired a division of Oregon by extending the line of $49^{\circ}$ to the Pacific. Great Britain wished to have the Columbia from its mouth to parallel $49^{\circ}$ and then use that line to the Rockies. No agreement was reached and little interest was taken in Oregon by the people of the United States. ${ }^{1}$ In 1846 England agreed, however, to a treaty which extended to the Pacific the existing line between Canada and the United States east of the Rockies, $49^{\circ}$.

304. War with Mexico (I846-I847). - Before the Oregon treaty had been signed, hostilities with $\mathrm{M}$ Iexico had begun in April, IS46. The republic of Texas had claimed the Rio Grande as its western boundary, and, although at the time of annexation the United States had not agreed to retain this boundary line, there is no doubt that the people of the nation beliered the Rio Grande to be the rightful boundary.

1 Some suggested that the Rocky mountains formed our natural boundary on the West. Interest in Oregon was renewed after I $S_{4} 0$, especially by Marcus Whitman and other settlers who realized its value. England was very anxious to gain a foothold in California and so declined to recede from the line of the Columbia until the intensity of feeling in the United States thoroughly convinced her statesmen that if she did not accept the line of $49^{\circ}$ the United States would insist on a still larger share of Oregon. 
Moreover the desire among the people to possess on the Pacific coast a territory much greater than that of Oregon made them willing to have the war which Mexico claimed she would wage if we annexed Texas. To be sure, a powerful and active minority, especially in New England, opposed this policy of aggression because it would extend the power of slavery. War began when United States troops under General Zachary Taylor were ordered by President Polk to occupy the disputed territory between the Nueces River and the Rio Grande. The Mexicans ordered Taylor to withdraw. When he failed to do so, they crossed the Rio Grande, but early in May were defeated by Taylor and driven back across the river.

Congress immediately voted

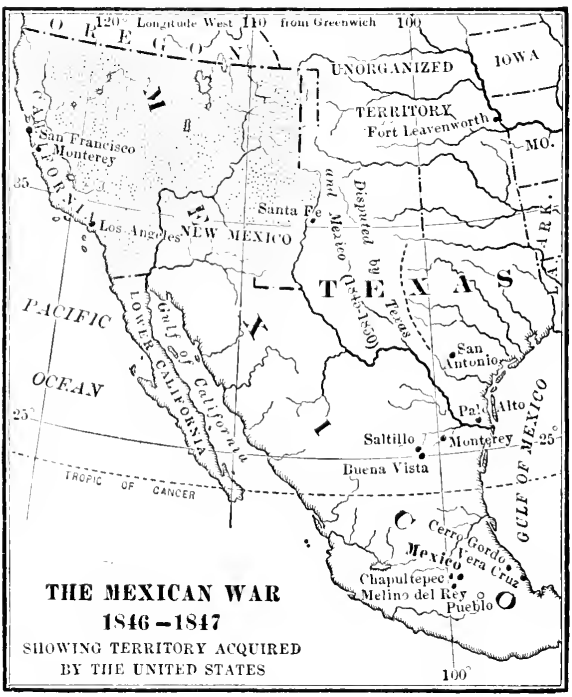

men and money for the prosecution of an offensive campaign. ${ }^{1}$ Plans were made at length for Taylor to advance into northeastern Mexico and for General Scott to seize the city of Mexico. Taylor had no difficulty in capturing Monterey, the largest city in his route. When he advanced farther into Mexico, he encountered at Buena Vista an army four times as large as his own under Santa Anna, who had again become dictator of Mexico. So stubborn
Schouler, United States, IV, 52I-528.

Hart, Contemporaries, IV, Nos. 8-II I5.

Taylor and Scott in Mexico.

Burgess, Middle Period 33I-334.

1 Delay was caused by the desire to give the chief command to a Democrat, as both Taylor, known as "Old R"ough and Ready," and Winfield Scott, who was nicknamed "Fuss and Feathers," were Whigs. 
was the resistance of the Americans that they defeated the enemy with great loss. Santa Anna now returned to the defense of the capital which was threatened by General

Garrison, Westward Extension, $2+5-25$ I.

Contest over California.

Garrison, Westward Extension, 230-239. Winfield Scott. Scott was obliged to capture first the seaport of Vera Cruz which many considered impregnable. Crossing a range of mountains by means of the national road, Scott defeated the Mexicans at every point and came at length in sight of the city. Here he abandoned the road, both sides of which were for-

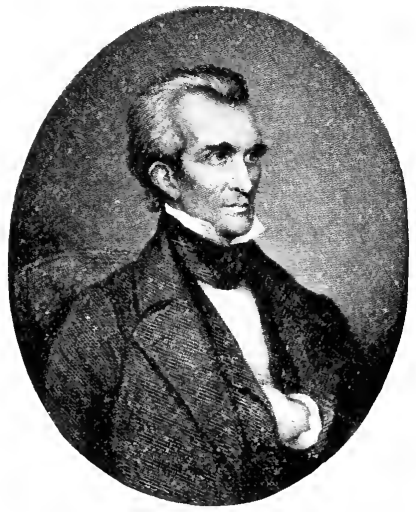

JAMES K. POLK tified, and cut his way over lava beds to the rear of the city, where the capture of the fortress at Chapultepec forced Santa Anna to surrender the city.

305. Conquest of California; Peace. - When the United States became involved in war with Mexico, steps were taken to secure possession of California. For years Great Britain had looked longingly at this region, hoping to gain this territory peaceably by treaty with Mexico or wrest it from her when she was engaged in difficulties with the United States. Our government had offered to buy California in order to avoid such a catastrophe, but Mexico was unwilling to part with her northern possessions to either England or the United States. As soon as news reached the Pacific coast that war had been declared, Captain John C. Frémont seized some of the towns in the interior and Commodores Sloat and Stockton occupied Monterey, the northern capital of California. A bear flag was raised by the people of Sonoma and for a short time the "Bear-Flag Republic" was proclaimed. The conquest of California was completed by the coöperation of the American inhabitants and the United States forces during I847. 
The United States had been making plans for negotiations Treaty of as early as 1846 . The important point with the administration and the public seems to have been the cession of at least part of upper California. The instructions issued when the first envoy was sent in 1847 included the line of the Rio Grande, New Mexico, both Californias, and a right of way Guadalupe Hidalgo(I848) across the isthmus of Tehuantepec. As Scott had not captured the city of Mexico at this time, the Mexicans would yield very little and negotiations were broken off. During the months which followed the capture of the Mexican capital public sentiment in the United States changed. President Polk claimed that but for his influence the members of his cabinet would have insisted on the acquisition of all Mexico. ${ }^{-1}$ The public heard rumors of this, and, not desiring the destruction of Mexico or so great an extension of territory in which slavery might be established, opposed the scheme. The Mexican politicians finally became alarmed and agreed to yield all upper California and New Mexico and acknowledge the Rio Grande boundary for Texas on the payment of a sum of $\$_{15}, 000,000$. The first Mexican cession was supplemented in 1853 by a strip south of the Gila River known as the Gadsden Purchase. ${ }^{2}$

\section{Slavery in New Territory (i 848 -i 853 )}

306. The Wilmot Proviso. - In August of s 846 , when the war with Mexico had been in progress three months, President Polk requested Congress to grant him \$2,,00, to be used in negotiating a treaty of peace. It was generally believed that the government wished this money in order to purchase from Mexico a large strip of territory. Wilmot of Pennsylvania therefore proposed in the House of Representatives as an amendment to the appropriation bill that slavery should not be permitted in any territory acquired from Mexico. The bill was passed twice by the House with the Wilmot proviso; but in the later session the

Contest between the House and Senate.

Hart, Contemporaries, IV, No. I6.

Burgess, Middle Period, 335-337. 
Johnston, House rescinded its action when the Senate refused to concur. Am.Pol.H ist., The southern members of Congress voted solidly against the II. $84-87$. proviso in both houses and many northerners opposed it on the ground that agitation of the slavery question at that time would hamper the administration in its prosecution of the war and in concluding peace.

Contest over organizing Oregon Territory.

Burgess, 307. Oregon Territory; Election of I848. - The question of organizing the Oregon country as a territory with or without slavery was brought up at the same time as the Wilmot proviso (August, I846), but was not settled until Middle Period, not prevent the prohibition of slavery in Oregon, but hoped 340-347. to gain certain concessions in return for a few necessary votes. A determined attempt was made to extend the Missouri Compromise line $\left(36^{\circ} 30^{\prime}\right)$ to the Pacific and to connect the question of organizing Oregon territory with the organization of territorial governments in California and New Mexico, so that slavery should be permitted in the latter if forbidden in the former. These attempts failed and the Oregon bill was passed (I848) prohibiting slavery in that territory.

Presidential In the election of 1848 the question of slavery in the terelection(1848). ritories was ignored by the Whigs and the Democrats. The Whigs nominated General Zachary Taylor of Louisi-

Stanwood, Presidency, 226-243. ana and Millard Fillmore of New York. They adopted no platform whatever. The Democratic nominee was Lewis Cass of Michigan who believed that the question of slavery in the territories should be decided by the voters of each territory for themselves, a view afterward known as " popular sovereignty," or "squatter-sovereignty." Those who favored the principle of the Wilmot proviso united to form a new party, known as the Free Soil party, and nominated ex-President Van Buren, whose reputation added greatly to their strength, so that the party polled over a quarter of a million votes. Taylor carried a majority of the states North and South as well as most of those in the Northeast, obtaining I63 electoral votes to 127 for Cass. In the same election the 



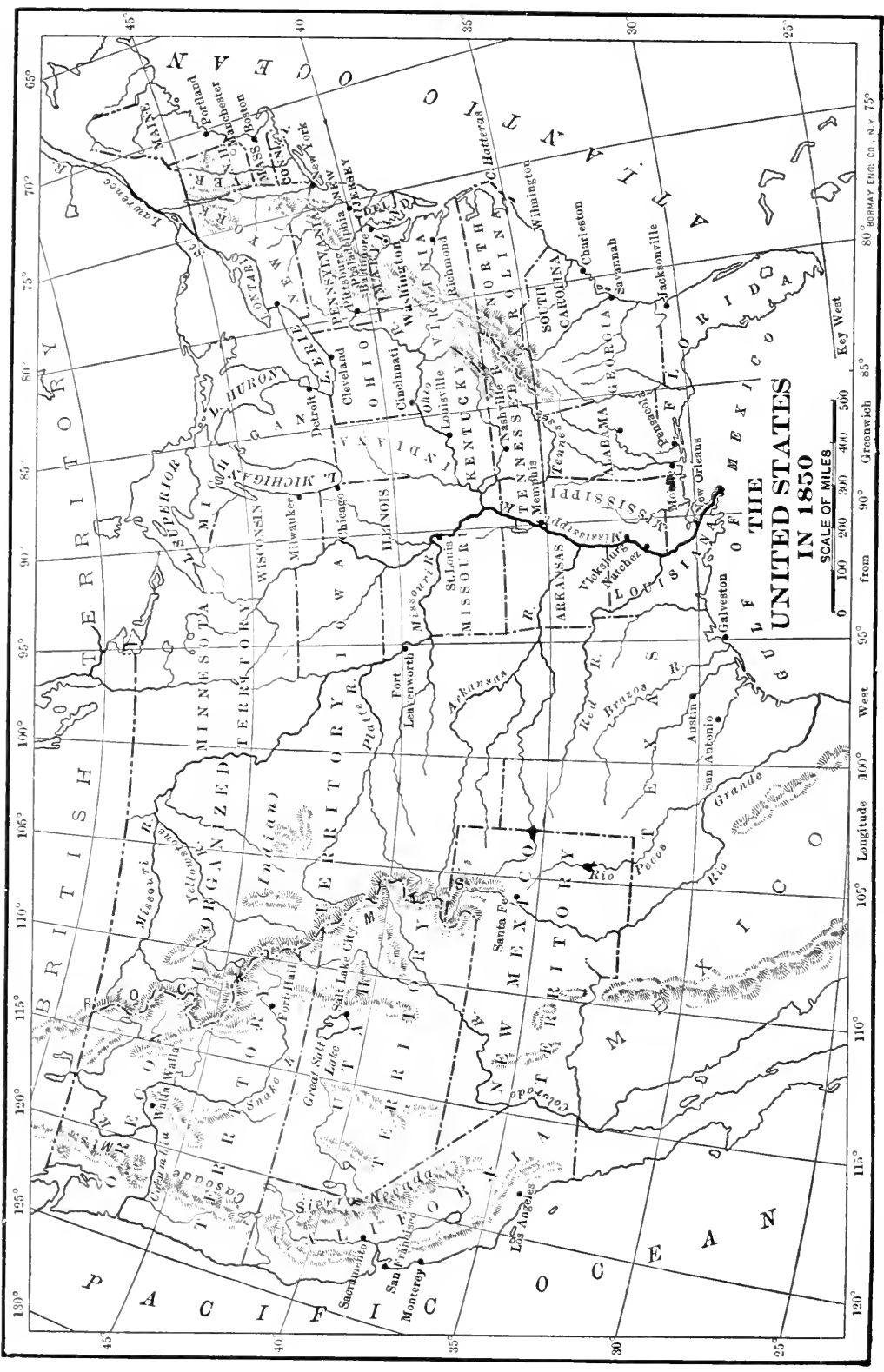


Free Soilers elected thirteen congressmen who held the balance of power in the new House of Representatives.

308. California. - In the interval between the election of the thirty-first Congress and its first meeting in December, 1849, great changes had taken place in the territory acquired from Mexico. The discovery of gold in California by John Marshall in January, I848, had brought to the Golden Gate tens of thousands from all parts of the world. Caravan after caravan of "forty-niners" crossed the plains and the mountains. Many proceeded via the Isthmus of Panama and large numbers sailed around Cape Horn. The slave states were represented as well as the free states, but the people of the southern states brought few slaves with them, for California at that time had little use for slave labor. ${ }^{1}$

When a constitutional convention was held at Monterey, a constitution was framed by which slavery was prohibited within the state. All delegates to the convention, whether from the North or the South, supported this anti-slavery provision. With this constitution California applied for admission to the Union as a free state, to the dismay of the

California's application for admission.

Schouler,

United States, $\mathrm{V}, \mathrm{I}_{4} 2-\mathrm{I}_{4} 6$. pro-slavery advocates. Since there were already as many free states as there were slave states, the admission of California would disturb forever the equality between the sections which had existed since the formation of the Constitution. Not only was a large part of California south of the line of $36^{\circ} 30^{\prime}$, but it was understood that in the territory east of California and south of that line the prevailing sentiment was opposed strongly to slavery. Unless something were done to protect slavery interests it would be only a question of time before the Senate - heretofore the stronghold of the slavery interests - would be controlled by the opponents of

${ }^{1}$ As Congress had neglected to pass a territorial act, there was no government in that region other than the provisional one under General Riley, the military commander of California. To President Taylor, who was accustomed to direct methods, it seemed as though California should apply at once for admission to the Union without going through the territorial stage. He accordingly dispatched an agent to the Pacific coast in order to learn whether the population justified this step. 
slavery. The admission of California as a free state seemed therefore to the less conservative southerners a menace to their prosperity and development and a sufficient reason for secession from the Union.

Diverse views on political questions.

Johnston, Am. Pol. Hist., II, 9 I-95, 122-123.

Rhodes, United States, I, IO4-IIO, 130-136.
309. The Elements of a Compromise (1850). - The admission of California with the constitution which she had adopted was recommended by President Taylor to Congress in his message, December, I849. No action was taken at once, but a number of questions regarding slavery and connected especially with the subject of slavery in the territory ceded by Mexico were discussed at Washington. Among these were the admission of California, the organization of territorial government for the rest of the Mexican cession, the dispute over the boundary between Texas and New Mexico, slavery and the slave trade in the District of Columbia, and the problem of returning fugitive slaves to their masters under the law of I793. The majority of the people in the North undoubtedly believed that the further extension of slavery should be discouraged, and felt that the United States could not afford to take a backward step by opening to slavery the new lands in the Southwest, in which slavery had been prohibited by Mexican law. A large and active minority in the North desired the exclusion of slavery from all new territory and the abolition of slavery as well as the slave trade in the national capital. Many, South and North, would have preferred to leave the question entirely alone, or, if this were impossible, settle the question in such a way that the Union would be preserved. To Clay it seemed that disunion might be prevented and the slavery question might be settled for all time by combining these measures before Congress and asking both sections to make concessions in a great compromise. ${ }^{1}$

1 It was Clay's suggestion that California be admitted as a free state, the territories of New Nexico and Utah be organized without restrictions as to slavery, Texas to be asked to relinquish her elaims on New Mexico for a money consideration, the slave trade but not slavery be prohibited in the District of Columbia, and a new fugitive slave law be enacted. 
3ro. Discussion of the Compromise. - For six months Senatorial Congress discussed the measures proposed by Clay. The weightiest speeches were delivered in the Senate where the great triumvirate, Webster, Clay, and Calhoun, still held sway, though about to give way to younger men, of whom Seward, Chase, Douglas, and Sumner were the most prominent. Clay spoke fervently in favor of compromise and leaders, Clay and Calhoun. pleaded for concessions on each side that would make possible

Schurz,

Clay,

II, 33I-337.

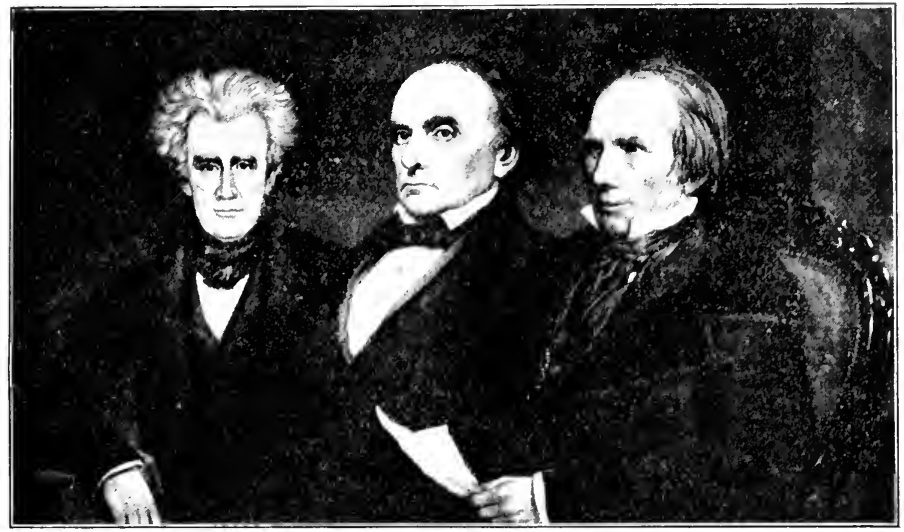

Calingun, Webster, ANi) Clay

a permanent settlement of this dreaderl question. Calhoun Hart, contemalso pleaded for the preservation of the Union, which, in his opinion, had been enclangered by the slavery agitation in the North. He asserted that the Union could be preserverl only by giving the South a share in the government equal to that of the North. This must be done by the North, for poraries, IV, No. I9. the "South has no compromise to offer but the Constitution, and no concession or surrender to make."

In his "Seventh of March speech" Webster claimed that slavery was excluded from California and New Mexico by Webster's and Seward's views the law of nature, and urged that no Wilmot proviso should be applied to those sections when it was unnecessary. The parts of the speech which dealt with the abolitionists and

Rhodes,

United States, I, II9-I3O. 
Hart, Contem- the fugitive slave law gave great offense to many living at foraries,

IV, Nos. $20,22$. the North, but Webster's earnest plea to support the Constitution and prevent secession undoubtedly gained many supporters for the proposed compromise. The position of

Rhodes,

United States, those who opposed the extension of slavery was roiced by I, 162-I68. William H. Seward, senator from New York. He opposed all compromise with slavery and deemed the fugitive slave

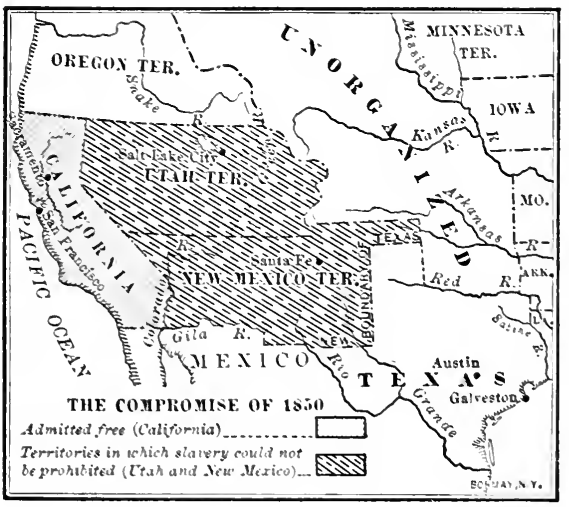
law " unjust, unconstitutional, and immoral." "The Constitution de rotes the domain [i.c. the territories] to union, to justice, to defense, to welfare, and to liberty. But there is a higher law than the Constitution, which regulates our authority over the domain, and devotes it to the same noble purposes." 1

Provisions of the compromise.

Burgess, Middle Period, legislatures being forbidden to restrict slavery. (3) The $3^{62-36}$.

MacDonald, Documents, Nos. So-8 3 .
3II. Completion of the Compromise of $185^{\circ}$. - In its final form the compromise of $\mathrm{I}_{50} \mathrm{O}$ comprised five separate bills: (I) California was admitted as a free state. (2) New Mexico and Ltah were organized as territories, the territorial northwestern boundary of Texas was fixed as at present, a sum of Sio,000,000 being paid to the state for relinquishing. its claims on New Mexico. (4) A fugitive slave act was passed which provided that a master or his agent could take

${ }^{1}$ In April all resolutions on the questions under discussion were submitted to a committee of thirteen. The committee reported one "omnibus bill " covering all subjects in dispute in the Southwest, and separate bills on the other matters. But nothing was done. President Taylor was not friendly to the compromise. but his death in July led to a reorganization of the cabinet under Fillmore who was largely under the influence of Webster. 
a supposed fugitive from the state in which he was residing without a jury trial in that state. It imposed fines on those who interfered with the capture or rendition of fugitive slaves. It compelled all citizens who were summoned to aid in the capture of fugitives to give their assistance, and it provided that the fee received by United States marshals for negroes who were declared to be fugitives should be \$ro, for others \$5. (5) The slave trade was abolished in the District of Columbia.

The radicals of both sections were loud in their complaints that all concession had been made by their side, but the majority of the people were relieved that a settlement was secured which promised to be fairly satisfactory. Conventions were held in the South to consider the question of secession from the Union, but none of these favored separation.

As the majority of the people felt that the question of slavery had been definitely settled by the compromise, the politicians proceeded on that hypothesis by ignoring the subject utterly in campaigns following 1850 . To insure the execution of the laws enacted at that time, Franklin Pierce of New Hampshire, a pro-slavery Democrat, was in $185^{2}$ elected President over Winfield Scott, the Whig candidate, by a very large majority. The Free Soilers polled a vote little more than half as large as in 1848 , for less interest was taken in the topic of slavery in the territories since the status of slavery in all parts of the national domain had been fixed by sacred pledges that were supposed to be irrevocable.

312. The Fugitive Slave Law. - The execution of the Irastic fugitive slave law succeeded in arousing more feeling than the compromise allayed. 'Thousands of fugitives had settled in different parts of the North and had become useful citizens of those communities. Many of them were now reclaimel by their former masters and carried away to the plantations without an opportunity of proving their freedom. The North was aroused as it never had been before at the sight of seizures made on its soil. State after state passed

Direct results.

Rhodes,

Unitid States, I, 189-198.

Election of 1852 .

Burgess, Middle Period, 375-377.

Fugitives, "personal liberty" laws, and the underground railway.

Burgess,

Middle Period, 365-374. 
Rhodes,

United States,

I, 209-2I3, 498-506,

II, 73-78.

Loss to the South.

Cuba.

Ostend

Manifesto.

Foster, Am.

Diplomacy,

326-329,

$3+2-3+7$.

MacDonald, Documents, No. 89. "personal liberty laws," which forbade state officers to aid in the capture of negroes and prevented citizens from taking part in the return of fugitives. The use of the jails was denied to national officers in charge of runaways. Police officers refused to interfere when negroes were rescued by mobs. Channing says truly, " the execution of the Fugitive Slave law did more to arouse the moral sentiment of the northerners than the arguments of the abolitionists had done in twenty years." In many northern states there were established complete routes from the South to Canada, over which fugitires might escape by hiding in the daytime and traveling at night to the next house on the route. These were called " underground railways."

Even if there had been very great need of so severe a measure, the passage of this act would have been a serious blunder. But when it is understood that only the border states lost many slaves and that less than one thirtieth of one per cent of the slares attempted to obtain their freedom in any one year, we realize the magnitude of the mistake. The feeling of the North was intensified by the publication in 1852 of Harriet Beecher Stowe's book, "Uncle Tom's Cabin," which was read by every one and was accepted as a true picture of slavery.

313. Attempts to gain More Slave Territory.-Not only did the pro-slavery leaders wish to extend the limits of slave territory still further, but many expansionists who had farored the acquisition of California and New Mexico desired the extension of our boundaries on the south, especially by annexing the island of Cuba. During Polk's administration we offered $\$_{100,000,000}$ for Cuba. A few years later slavery sympathizers joined in filibustering expeditions to Cuba which accomplished nothing except to involve the United States in difficulties with Spain. France and Great Britain opposed any attempt to transfer Cuba from Spain to the United States and tried to persuade us to join them in a treaty which would have guaranteed to Spain permanent control of the island. In I 854 the Ostend Mani- 
festo, which was issued by our ministers to Great Britain, Smith, France, and Spain, announced the position held by a large number of Americans that we would be justified in seizing Cuba without the consent of Spain if " Cuba in the possession of Spain seriously endangers our internal peace and the existence of our cherished Union." On the eve of the Civil War other offers were made for Cuba, and since that time many persons have desired the annexation of the island.

During this period filibustering expeditions went out from the United States to Mexico and Central America as well as Cuba. The most famous of these was that of Walker which gained control of Nicaragua for a time, only to be driven from the country by the inhabitants. Except in the case of expeditions to Cuba, none of these attempts received the support of a large percentage of the people in the United States.

Parties and Slavery, 82-88.

Central America. Schouler, United States, V, 34I, 364, 400,416 .

Smith,

Parties and Slavery, 88-93, 25I-259

\section{Slavery in Old Territory (1854-1857)}

314. The Kansas-Nebraska Bill (1854). - When it became necessary to organize territories in the region north of the Missouri Compromise line, and lying between the Missouri River and the Rocky mountains, the question of slavery in the territories was again reopened. It would seem as though this subject had been settled by the provision of the Compromise of I 820 which "forever prohibited" slavery within this territory, especially as that was but one of three provisions in a compromise, the other two of which could not now be altered. In the debate, however, it became clear at once that some congressmen believed or pretended to believe that the principle of "popular sovereignty" which had been adopted in the Compromise of 1850 for the territories in the Southwest should be applied to all national territory. This was the view taken by Stephen A. Douglas, Democratic senator from Illinois and chairman of the Senate

Burgess,
Middle Period,

Burgess, 38I-387. Amer. Hist.
Leaftets,
No. $\mathbf{1 7}, \mathbf{I}-8$. Amer. Hist.
Leaflets,
No. 17 , I-8. Amer. Hist.
Leaftets,
No. $\mathbf{1 7}, \mathbf{I}-8$. committee on territories. He reported a bill for organizing a single territory in the country purchased from France north of the line of $36^{\circ} 30^{\prime}$ with " popular sovereignty,"

MacDonald,

Documents,

No. 85 .

Hart, Contemporaries,

IV, No. 34 . No

The original

Nebraska bill. 
because, he said, the Compromise of 1850 had replaced the Compromise of 1820 .

Criticism of Douglas's claim regarding the effect of the Compromise the KansasNebraska bill. of 1850 on that of 1820 was denied emphatically by a large number of senators, and his argument that the territories should decide the question of slavery for themselves was

Smith,

Parties and

Slavery,

98-108.

Rhodes,

United States,

I, 44I-444,

448-452,

463-468.

Amer. Hist.

Leaflets,

No. I7, 9-18. held up to ridicule. Chase of Ohio asserted that there was

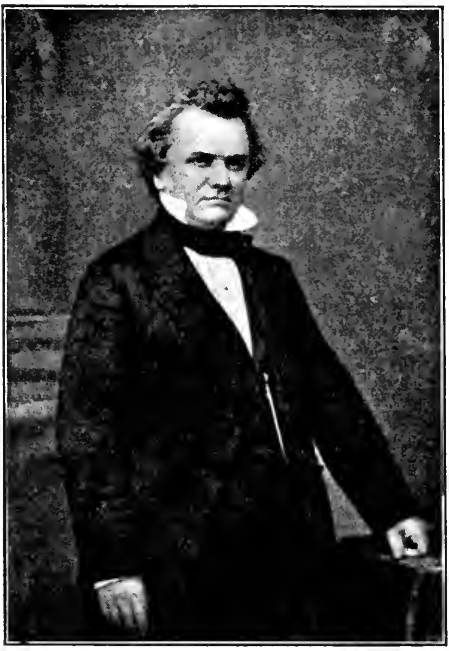

Stephen A. Douglas no more reason for giving this territory home rule regarding slavery than in any other respect and demanded that it be governed as Congress saw fit. Chase and other free soil Democrats protested vigorously in the public press against the $\mathrm{Ne}$ braska bill as a "gross violation of a sacred pledge, as a criminal betrayal of precious rights, as a part and parcel of an atrocious plot to exclude from a vast, unoccupied region immigrants from the old world and free laborers from our own states, and convert it into a dreary region of despotism inhabited by masters and slaves." Throughout the North, while the bill was before Congress, the press and the public expressed themselves in no uncertain way, a large number of public meetings being held to denounce the measure. Several legislatures also petitioned against the repeal of the Missouri Compromise.

Vote on the bill.

315. Passage of the Kansas-Nebraska Act (1854). These demonstrations and demands had considerable influence, for, although the bill was passed by a large majority in the Senate and by a vote of I I 3 to roo in the House, not 
a single northern member in either house aside from the Burgess, Democrats voted for the bill. Northern sentiment is shown further by the fact that only 7 of the 42 members of the Middle Period 398-399. House from that section who voted for the bill were reelected in the fall of 1854 .

The original Nebraska bill had been modified early in the discussion, and it was passed finally in this form. There were to be two territories: one, Kansas, extending from $37^{\circ}$ to $40^{\circ}$ and the other, Nebraska, from $40^{\circ}$ to $49^{\circ}$. The act of $\mathrm{I} 820$ which prohibited slavery in these territories was expressly repealed and the people were left free to permit or exclude slavery not only when the states should be admitted to the Union, but while they were territories as

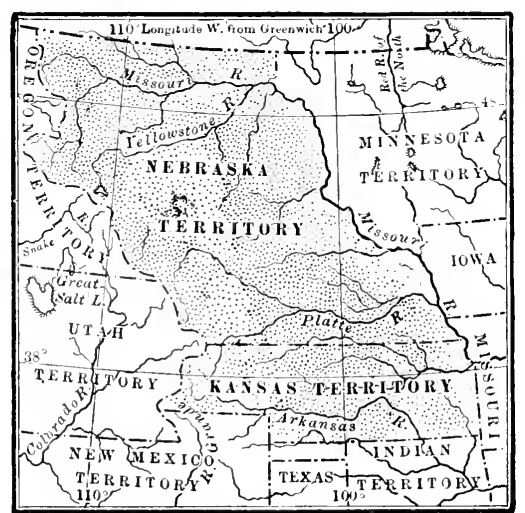

KANSAS AND NEBRASKA (1854) well. It seems to have been the belief that by creating two territories, one would he left open to slavery while the other was devoted to freedom.

As a pro-slavery measure the Kansas-Nebraska Act was a very serious blunder, because the repeal of the Missouri Results of the act. Compromise Act aroused the North as eren the Fugitive Slave law had not done. It led to an organization of the anti-slavery extension forces into a single political party. This would have been accomplished many years later but for the repeal of the Missouri Compromise, a pledge which, in the opinion of the North, Congress had no right to alter. The direct results of the act were (I) the organization of a large political party, made up at first of what were known as anti-Nebraska men, who controlled the North from this time, and (2) the contest, little better than civil war, 
which was waged in Kansas for the control of that territory.

Republican party.

Hart, Contemporaries, IV, No. 35 .

Rhodes, United States, II, 45-49.

Smith, Parties and Slavery, Io9-II4, II 8-120.

Know-nothing party.

Rhodes, United States, II, 50-56.

Johnston, Am. Pol. Hist., II, 258-265.

Smith, Parties and Slavery, I 4 -I 20 , I $45^{-\mathrm{I}} 48$.

Election of I856.

Smith, Parties and Slavery, I6I-I73.

Stanwood, Presidency, Chapter XX.

316. Reorganization of Political Parties. - When the Kansas-Nebraska Bill was passed, the times were ripe for great changes in the political parties. In the election of I 852 the Whigs had been badly demoralized. The party had been split on the slavery question into two factions, neither of which could maintain more than the shadow of an opposition to the now triumphant Democratic party, so that it required only a new issue to produce another party. This issue the Kansas-Nebraska Act provided, for it gave all anti-Nebraska men a chance to unite in opposition to slavery extension. All of the Free Soilers and most of the Whigs of the North joined this new party, which was known after I 855 by the name Republican, and large numbers of freesoil Democrats became members of the same organization. Most of the southern Whigs and large numbers of the voters in the North who opposed any discussion of slavery threw in their lot with the new American party, the members of which were called "Know-nothings" because their affairs were conducted after the manner of secret societies and outsiders were not informed of their doings. The original American party had been organized in order to keep from political power the foreigners who had come to the United States in such numbers after 1845 (\$296). After I 854 the Know-nothing party was composed principally of those who were unwilling to take sides on the question of slavery. In 1855 they carried several states.

The election of 1856 was a test of strength between the old Democratic party and the new Republican party, as the Know-nothings, even with Millard Fillmore as their candidate, carried only one state. The Democrats declared their belief in the principles of the Compromise of $185^{\circ}$ and the Kansas-Nebraska Act, and nominated James Buchanan of Pennsylvania, who had been our minister to Great Britain and therefore had no record on the Kansas question. The Republicans declared that Congress had no 
authority to permit slavery in any territory and clenounced the administration for its attitude toward Kansas. Contrary to the custom of those days they selected both candidates from free states, John C. Frémont of California being nominated for the presidency. The Republicans carried all but four states of the North, but, as three of these were large, Buchanan had I 74 electoral votes to II 4 for Frémont.

317. The Struggle for Kansas (1855-I86I). - Since the fate of Kansas was to be settled on the principle of "popular sovereignty," neither side hesitated long in its attempt to gain the state. An emigration society was formed in New England, by which thousands of "free state" men were sent to the territory by way of Iowa. Some pro-slavery men became actual settlers of the disputed region, but slave owners were unwilling to take their slaves to a region which they knew was little

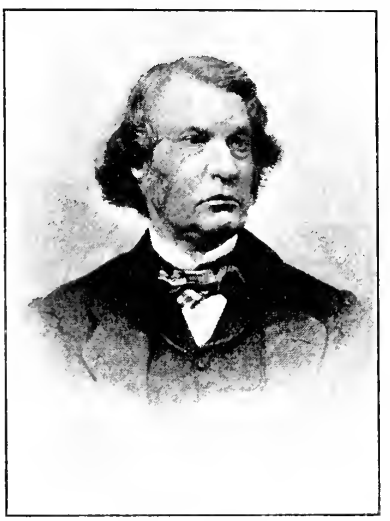

Charles SUMNer adapted to slavery and in which slavery might prove to be a complete failure. As it cost a slaveholder six times as much to establish his home in Kansas as it did a free state man, the population was predominantly anti-slavery from the beginning.

When the first territorial legislature was chosen in March, r855, Kansas was invaded by thousands of Missourians who claimed that they had the same right to vote as free state men sent out by emigrant societies. The free state settlers then took things into their own hands by adopting a constitution and electing a free state legislature. ${ }^{1}$ From

Hart, Contemporaries, IV, Nos. $3^{6-38}$.

Political and civil war in Kansas (1855).

Hart, Contemporaries, IV, No. 39.

${ }^{1}$ During this political struggle, Charles Sumner delivered his famous speech on "the crime against Kansas" in which he criticised in scathing language several senators, notably Butler of South Carolina. Butler's 
Smith, Parties this time the partisans of the two sides came to blows. and Slavery, I2I-135.

Lawrence was sacked by the pro-slavery forces and in retaliation five men were killed on Pottawattamie creek by John Brown and his followers. Bands of armed men roamed over the eastern part of Kansas, destroying crops and houses. About two hundred persons lost their lives in the civil war which gave to the territory the name of "bleeding Kansas." These outrages continued until they threatened to affect seriously the presidential election of I 856 , when the army was used to restore order.

The Lecompton constitution (1857).
Facts of the case.

Burgess, Middle Period, 449-452.
In 1857 a convention was held under the direction of the original pro-slavery legislature at Lecompton. A constitution based on that of Missouri was drawn up and the people were allowed to vote on it, with slavery or without slavery. The free state men, who now controlled the legislature, refrained from roting, so that the constitution was adopted with slavery. Buchanan's administration advocated the admission of Kansas with this constitution, but Douglas maintained that there had not been fair play in Kansas and declared that popular sovereignty had not had a fair test. The people were allowed to vote again on the Lecompton constitution, which they rejected by an overwhelming majority. From this time the free state men, who comprised four fifths of the settlers, controlled the territorial government and in I861 Kansas was admitted to the Union as a free state.

318. The Case of Dred Scott (1857). - Just three days after the inauguration of Buchanan the Supreme Court of the United States rendered its decision in the case of Dred Scott. Scott was a negro who had been taken by his master in 1836 to what was afterward Minnesota, a part of the territory from which slavery had been "forever prohibited" by the Missouri Compromise of 1820 . He had been brought

nephew, representative Brooks, attacked Sumner in the Senate chamber, striking him repeatedly over the head. Brooks resigned from the House, but was elected again by his constituents. The feeling aroused in the North by this brutal attack was intense. 
back to Missouri in ${ }_{1} 838$ and afterward decided to sue for his freedom. He was about this time sold to a citizen of New York, a Mr. Sandford. Scott immediately began suit in the circuit court of the United States, ${ }^{1}$ which decided against Scott. The case was then appealed to the Supreme Court of the United States, whose decision was awaited with great interest in the hope that it might settle the controversy over slavery in the territories.

The court decided that Scott was not a citizen and could not sue in the courts. In supporting this position the chief justice, Taney, made the statement that at the time the Constitution was adopted negroes were not citizens, and unfortunately added that at that time negroes had no rights which white men were bound to respect. The court decided also that the case must be dismissed as the court had no jurisdiction over it. Unwisely the chief justice and a number of his associates believed that this was a favorable time to give their opinions on the question of slavery in the territories and thereby settle that problem for all time. In a most elaborate argument the chief justice stated that the general government had acquired Louisiana territory for the states, that it must protect in that territory all possessions that were legally property in any of the states, and that therefore Congress could not prohibit slavery in any territory acquired after the arloption of the Constitution in 1787 . On this account the law of 1820 , a part of the Missouri Compromise, which prohibited slavery in the territory acquired from France north of $36^{\circ} 30^{\prime}$, was " null and void from the beginning." The influence of this opinion was widespread, for it was very different from the views held by most of the North and contrary to the wishes of the very large number of people who opposed the further extension of slavery ( $\$ 320$ ).

319. Summary. - The period from I 843 to 1848 was one of rapid territorial expansion. At the earlier date our western boundary was virtually the Rocky mountains at

Decision and opinions.

MacDonald, locuments,

No. 9r.

Hart, Contemporaries, IV, No. 4 I-43.

Burgess, Middle Period, 452-459.

Amer. Hist., Leaftets, No. 23.

${ }^{1}$ By virtue of clause in United States Constitution giving national courts jurisdiction of cases between citizens of different states. 

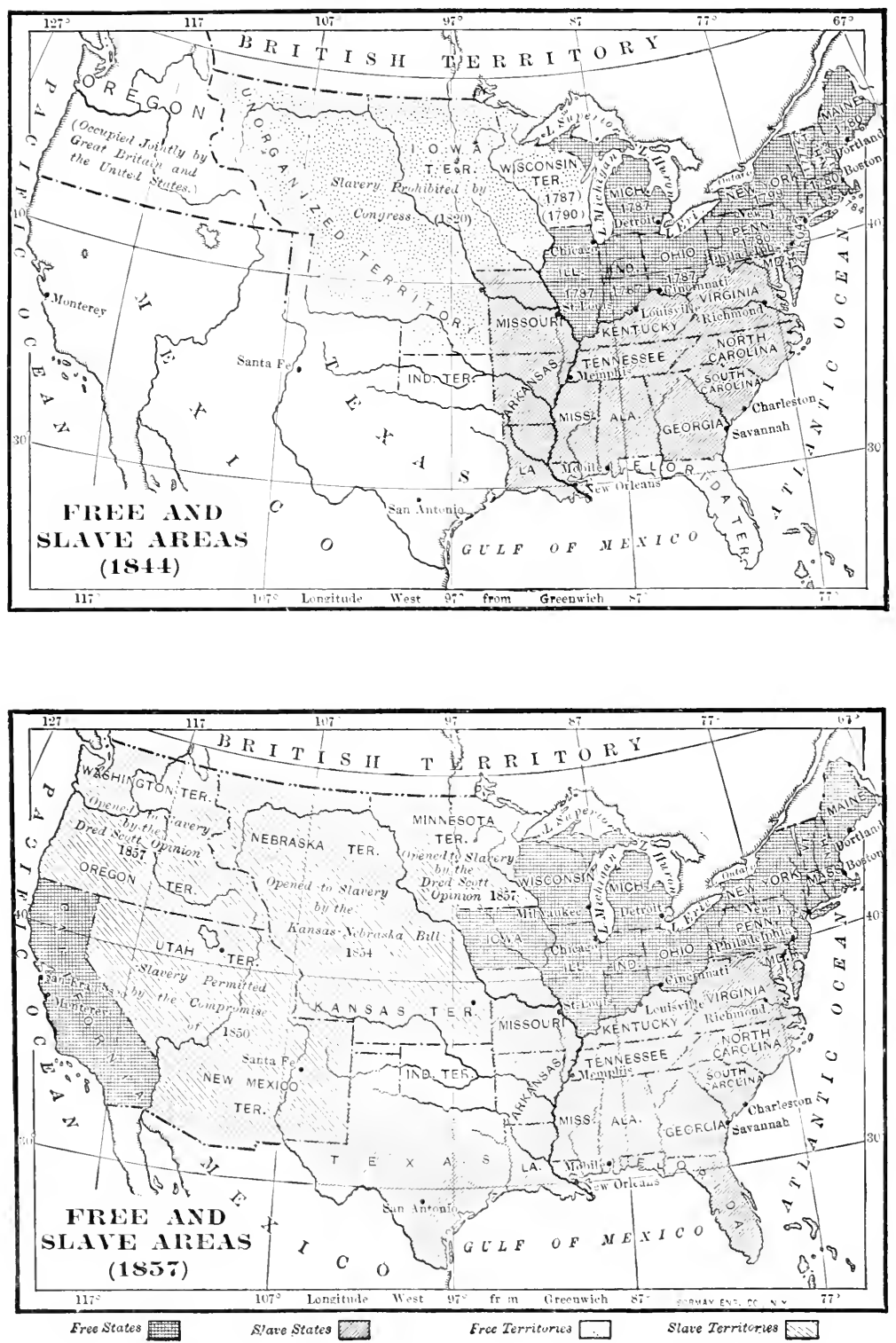
the north and a river about three hundred miles west of the Mississippi at the south, although we occupied Oregon with Great Britain. Most of the people in the United States desired an extension of our territory to the Pacific Ocean, and the return of good times aroused a new spirit of enterprise throughout the nation. The opposition to expansion in the Southwest came almost exclusively from those who did not favor the extension of slavery. Naturally the proslavery leaders, who saw that the slave states were growing less rapidly than those of the North, took the initiative by securing (I845) the annexation of Texas. Disputes over the western boundary of Texas led to the war by which we wrested from Mexico the territory from the Rio Grande to the Pacific. At the same time Oregon was divided. By I 848 our title had been made clear to the entire Pacific coast from parallel 32 to parallel 49 .

The contest over slavery in the territories of the nation may be divided into three parts. (I) The contest over the new territories. This was decided by organizing Oregon as a free territory, by admitting California as a free state, and by forbidding the legislatures of New Mexico and Utah to prohibit slavery. The good results of the Compromise of I850, in which the last two questions were settled, were nullified by the enactment of an unwise fugitive slave law. (2) The repeal of the Missouri Compromise so far as it applied to the territory between the Missouri River and the Rocky Mountains. This opened to slavery two territories in which it had been prohibited, led to a bitter struggle for Kansas, and caused the majority of the voters in the North to unite in a new party, the Republican, in order to oppose the further extension of slavery. (3) The opening of all territories to slavery. This was the natural conclusion of the opinion rendered by the justices of the Supreme Court in the case of Dred Scott. It completed the final though temporary triumph of the faction that was protecting the interests of slavery. 


\section{TOPICS}

I. Fugitive Slave Law: Hart (ed.), "Contemporaries," IV, Nos. 29-33; Rhodes, "United States since I850," I, pp. 192-227, 498-506, II, pp. 73-78; Wilson, "Rise and Fall of Slave Power," II, pp. 29I-337, 352-395, 435-46I ; Sites and Keener, "Growth of the Nation," pp. 295-3I0, 33I-343.

2. Kansas-Nebraska Act: Burgess, "Middle Period," pp. $3^{80-}$ 406; Johnston (Woodburn), "American Orations," III, pp. 3-89; Rhodes, "United States since I850," I, pp. 424-506; Von Holst, "Constitutional History," IV, pp. 280-46r.

3. Struggle For Kansas: Smith, "Parties and Slavery," pp. I 2I-I 35, I 49-I60, 209-222 ; Greeley, "American Conflict," I, pp. 224-251 ; Von Holst, "Constitutional History," V, pp. 70-76, 134185, 284-313; Wilson, "Rise and Fall of Slave Power," II, pp. 462$477,496-507,534-565$; Spring, “Kansas," pp. $24-267$.

\section{STUDIES}

I. Marcus Whitman's ride to Oregon. (Bourne, "Essays in Historical Criticism," pp. 3-99.)

2. The "Pathfinder of the Rocky Mountains." (Appleton's "Cyclopedia of American Biography," under Frémont, John C.)

3. Earliest debate over the Wilmot Proviso. (Benton (ed.), "Debates of Congress," XIV, pp. 643-65г.)

4. The Barn Burners. (Hammond, "Political History of New York," II.)

5. Benton's view of the Compromise of 1850 . (Benton, "Thirty Years," II, pp. 742-769.)

6. Attitude of the United States toward Cuba. (Latané, "Diplomatic Relations with Spanish America," pp. 89-r 37.)

7. Douglas on the Kansas-Nebraska bill. (Johnston (ed.), "American Eloquence," III, pp. 50-87.)

8. Beginnings of the Republican party. (Macy, "Political Parties (i 846-i 860).")

9. Effect of the Dred Scott opinion on the North. (Nicolay and Hay, "Life of Lincoln," II, Chapter IV.)

Io. Kossuth in Boston. ("Old South Leaflets," No. I I I.)

\section{QUESTIONS}

I. What were the advantages and disadvantages of annexing Texas? What was the influence of annexation on sectional sentiment within the United States? on our relations with Mexico? What obligations did we assume with Texas? 
2. What was the purpose of the Mexican War as shown ( $a$ ) by the attitude of northern capitalists? $(b)$ by that of the northern people in general? $(c)$ by the plan of campaign? and $(d)$ by the treaty of peace?

3. Make a table showing the action of Congress regarding slavery in the territories from $I 787$ to $\mathrm{I} 862$. Compare areas closed or left open to slavery. What changes occurred during the period from 1843 to 1857 ?

4. Was a compromise necessary in $185^{\circ}$ ? Which provisions were favorable to the North? which to the South? Did the Compromise of $185^{\circ}$ introduce any new principle of territorial government?

5. Make a careful study of the "Seventh of March" speech. Had Webster changed his position on the slavery question? Were his criticisms of the northern radicals justified? From our point of view was he right or wrong?

6. Has Congress the right to pass irrepealable laws? May Congress repeal part of a compromise when the repeal of the rest is impossible? Could a state in which slavery had been forever prohibited by Congress become a slave state? Why was the Kansas-Nebraska Act a serious mistake?

- 7. Which was more in conformity with our customs and our institutions, popular sovereignty or territorial government by Congress? What was the difference between the provisions for slavery in the territories in the acts of 1850 and 1854 ?

8. Compare the arguments of Taney and Curtis regarding negro citizenship. Which was right? Do you approve Taney's argument in regard to the relation of the nation to the territory acquired from France in 1803 ? 


\section{CHAPTER XVI \\ DISUNION AND CIVIL WAR (I857-I86I)}

Presidents

James Buchanan (I857-I86I) Abraham Lincoln (I86I-I865)

Approaching a Crisis ( $1857-1860$ )

Buchanan. 320. The Situation in 1857 . - It is unfortunate that at this time the presidential chair was occupied by a man as Rhodes, little fitted to prerent disunion as was James Buchanan. C'nited Stutes, A mild, courteous gentleman who disliked controversy, he II, I72-174.

Influence of the Dred Scott opinion. was utterly incapable of acting with decision and vigor to prevent a conflict between the opposing sections, and in fact by his vacillation aided in the development of the slavery crisis.

The chasm between the North and the South which had been growing wider year by year, especially since the enactment of the Kansas-Nebraska law, had been increased to a very great extent by the opinion of the justices of the Supreme Court in the case of Dred Scott. The South was content naturally, not realizing that the adoption of so radical a pro-slavery policy by the courts would react a gainst the institution of slavery not simply in the territories, but in the states as well. The majority of the people in the North were aghast at the conclusion reached in the opinion. Most of them opposed the further extension of slavery in the territories, and were exceedingly indignant over the announcement of the new doctrine that Congress could not prohibit slavery in national territory. People did not stop to consider that this was simply the opinion of justices of the court and not a part of the court's decision. The justices had made clear, they claimed, that a negro had no rights which 
a white man was bound to respect. It was evident that the justices of the Supreme Court, in seeking to settle the question of slavery in the territories, had precipitated the controversy over slavery.

The increase of sectionalism in the years following 1845 is marked not only by the drift in politics, but by the changes in churches and other national organizations. The Methodists and Baptists had divided on sectional lines soon after I845. Fewer southern men attended northern colleges than formerly. In social life and even in business sectional prejudices made themselves felt.

32I. Political Factions and Parties. - It may be inter- Factions in esting to notice at this time the sentiments of the existing the North. factions in the United States. (I) In the North there was a small but exceelingly active group of reformers which demander the total abolition of slavery everywhere. 'To these men the Constitution under which the institution was protected within the states was "a covenant with death, and an agreement with hell." (2) Less radical than the abolitionists but more interested in the restriction of slavery than in any other question was a faction whose attitude may be expressed by the phrase, "let the Union slide." (3) An overwhelming majority at the North believed that slavery was morally wrong and desired to see it excluded from the territories of the nation, although they were not willing to sacrifice the nation to that end. (4) A large minority at the North were opposed to any active discussion of the slavery question and were indifferent probably to its extension in or exclusion from national territories. They were, however, emphatically opposed to any interference with slavery in the states.

To the South the preservation of slavery in the states was a matter of vital importance, that of slavery extension in the territories one of the greatest interest. Seeing that the South was falling behind the North in population, wealth, and resources of every kind, southerners felt that slavery Increase of sectionalism should be protected by the equality of the sections.

Factions in the South.

Smith, Parties and Slavery, 292-304. 
first only a few leaders like Calhoun realized the need of territorial extension. $\mathrm{By}$ I850 this aggressive pro-slavery faction began to demand that one half of the nation should be set aside for slavery. Later they increased their numbers so as to include most of those in the South who were interested in the political future of that section. Their program developed until they demanded that slavery be excluded from those states only where it was prohibited by the wish of the people of the state. (2) Another faction in the South was indifferent to the extension of slavery, provided that the slaves in the states were left alone. (3) Still a third faction, composed of some merchants and of those mountaineers who owned no slaves, had nothing in common with the slave interests. They possessed little political influence. One of their number, Hinton Helper, published in I8 57 a book called the "Impending Crisis" which showed how the South was controlled by three hundred and fifty thousand slave-owners and how slavery had retarded the development of the South. This book was written in a sensational style and created a furore in political circles little less than that made by "Uncle Tom's Cabin."

Lincoln.

322. The Lincoln-Douglas Debates (1858). - One of the most interesting elections in our history was that held in I 858 in the state of Illinois. Members of the legislature were elected who were to choose a successor to Senator Douglas. Both parties selected their senatorial candidates long before the election, the Democrats renominating Douglas and the Republicans naming Abraham Lincoln. Lincoln was little known at this time outside of the central part of Illinois where he enjoyed an excellent reputation as a lawyer of rare honesty and ability. Born in Kentucky, (r8o9) to the heritage of the "poor white trash," he had grown up in Indiana and later in Illinois, with a determination to acquire an education. His experience as rail-splitter and flatboat-man, as well as his study at night by a pineknot fire, is well known. Lincoln had served several terms in the Illinois legislature, and had spent two years in Wash- 
ington as a representative. Very tall and exceedingly ungainly in appearance, Lincoln did not attract at first until one was impressed by his earnestness and the kindness of his homely face, or was won by his never failing humor.

During the summer of $185^{8}$ Lincoln and Douglas held a series of joint debates. By far the most notable of these was held at Freeport, where Lincoln asked Douglas four questions, ${ }^{1}$ the answers to which prevented Douglas from gaining the support of the southern Democracy in the presidential election two years later. Lincoln forced Douglas to choose between his favorite doctrine of popular sovereignty and the opinion expressed by the justices of the Supreme Court in the case of Dred Scott. Douglas tried to reconcile the two by saying that slavery could not exist in any territory if the people did not make local police regulations for its support, and therefore popular sovereignty would decide whether the territory should have slavery or not. Lincoln showed that slavery could exist without these local regulations, and that popular sovereignty and the Dred Scott opinion were incompatible. The South agreed with Lincoln and abandoned Douglas, although the people of Illinois by a narrow margin reëlected Douglas senator.

323. Union and Slavery. - At the beginning of the senatorial campaign Lincoln had made a speech which, in the opinion of many politicians, jeopardized his chances of election. It was a speech worthy of the man, and now classed with the famous speeches of our history. " "A house divided against itself cannot stand.' I believe this government cannot endure permanently half slave and half free. I do not expect the Union to be dissolved - I do not expect the house to fall - but I do expect it will cease to be divided. It will become all one thing, or all the other. Either the opponents of slavery will arrest the further spread of it and

Lincoln's

"Housedivided" speech.

Hart, Contemporaries, IV, No. 44.

Rhodes, United States, II, 3I5-3I 8 .

1 One question was: "Can the people of a United States territory, under the Dred Scott decision, in any lawful way, against the wish of any citizen of the United States, exclude slavery from its limits, prior to the formation of a state constitution?" 
place it where the public mind shall rest in the belief that it is in the course of ultimate extinction, or its adrocates will push it forward till it shall become alike lawful in all the states, old as well as new, North as well as South." This was a statement of the nation's future which no mere politician would have had the foresight or the courage to announce.

Seward's

" Irrepressible conflict" speech.

Hart, Contemporaries, IV, No. 45.

Rhodes, United States, II, 344-346.

In the fall of the same year in which Lincoln made this

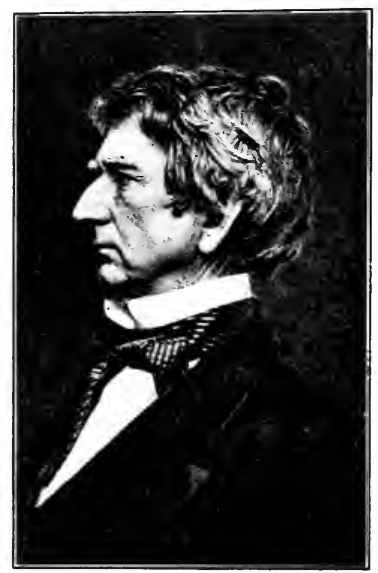

William H. SEWARD prophecy William H. Seward, the most conspicuous man of the Republican party, startled the nation by proclaiming a similar opinion. He stated: "Our country is a thea ter which exhibits, in full operation, two radically different political systems: the one resting on the basis of serrile or slave labor, the other on the basis of voluntary labor of freemen. ... The two systems are at once perceived to be incongruous. But they are more than incongruous, they are incompatible. They never have permanently existed together in one country, and they never can. . . These antagonistic systems are continually coming into closer contact, and collision results. They who think that it is accidental, unnecessary, the work of interested or fanatical agitators, and therefore ephemeral, mistake the case altogether. It is an irrepressible conflict between opposing and enduring forces, and it means that the United States must and will, sooner or later, become either entirely a slaveholding nation, or entirely a free-labor nation."

Influence on southern sentiment.
324. Influence of John Brown's Raid (I859). - Public utterances frequently fix public sentiment, but definite acts make history. The Fugitive Slave law and the repeal 
of the Missouri Compromise had united the North against the further extension of slavery, the John Brown raid united the South for the protection of slavery. Before I859 the South was in no real sense committed to the radical program of its pro-slavery leaders; after that date it identified itself much more closely with the institution of slavery than before. It may seem remarkable that the attack of twenty men on the United States arsenal at Harpers Ferry could have such a potent influence, especially when the attack ended in the capture of Brown and his followers. But the South was impressed by the fact that Brown had collected arms near Harpers Ferry and had planned to free the slaves. That he desired the freedom of all the slaves in the South is certain, and he believed this could be accomplished only by force of arms. This would involve necessarily a servile insurrection which was the nightmare of all classes in the South, slaveholders and others. The danger of such a calamity was enough to unite all southern factions, and to give the impression that the North would stop at no means to destroy slavery. This impression was strengthened by the enthusiasm with which John Brown's attempt was received in many parts of the North. The Republican leaders were very careful, however, to disavow any connection with the affair and to condemn the methods used.

325. The Election of 1860 . - The decisive factor in the election of 1860 was the attitude of the Democratic party. 'This party had a majority of voters in the South and a large minority of those in the North. If they coöperated, success seemed certain. If they were divided on the question of slavery, the Republicans might win. The Democratic convention was held at Charleston, April 23. The southern delegates contended for a platform declaring that not only should the Dred Scott opinion be enforced, but Congress must protect slavery in the territories by every means in its power. They were outvoted, for the northern Democrats succeeded in adopting a plank which stated that the party would "abide by the decisions of the Supreme Court

Democratic convention.

Schouler, United States, V, 454-457,462

Burgess, Civil Har, I, 50-58, 67-70.

\section{Causes of Civil War, 67-89.}

Rhodes, II, $4^{\text {IO- }} 4^{\text {I } 6 .}$

Chadwick,
Causes of
Civil War,
$67-89$.


of the United States on the questions of constitutional law." Most of the southern delegates then withdrew and two Democratic conventions were held later. That comprised chiefly of northern delegates nominated Douglas, while the southern men adopted the platform which they preferred, and named John C. Breckenridge of Kentucky for the presidency. Remnants of the Whig party and conservatives

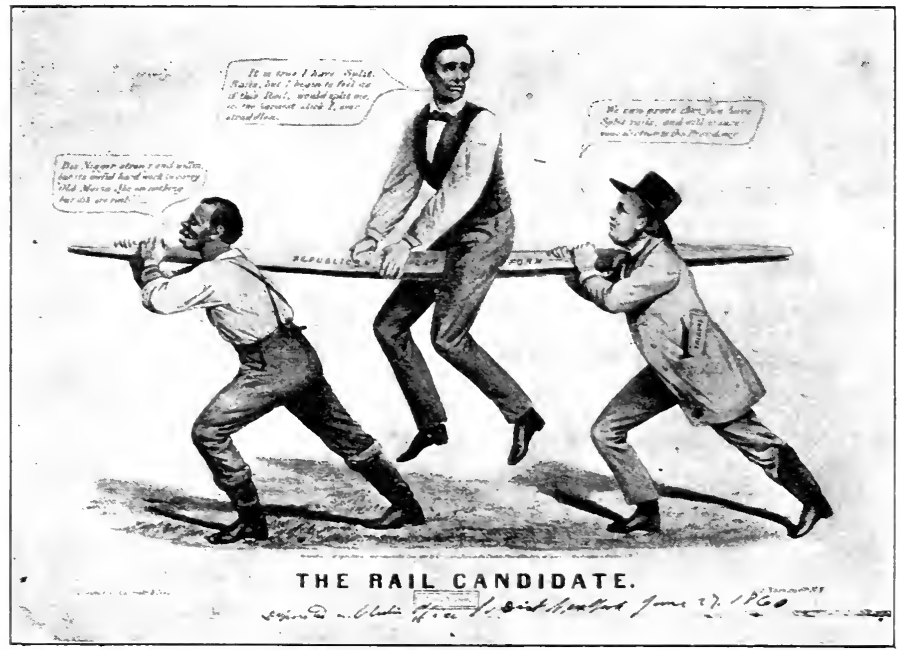

A CARTOON OF i860.

Republican convention.

Burgess, Civil Itiar, I, 58-67.

Chadwick, Causes of Citil biar, II6-I23.

of all parties united under the name "Constitutional Union," and nominated Bell of Tennessee.

The Republicans met in Chicago in May. As the party was composed of numerous elements united chiefly by their desire to prevent the further extension of slavery, the delegates agreed without difficulty on a plank that denied "the authority of Congress, of a territorial legislature, or of any individual to give legal existence to slavery in any territory of the United States." But they maintained especially the right of each state to order and control its own domestic institutions according to its own judgment exclusively. They denounced Buchanan's Kansas policy, and farored 
a protective tariff. Because the party was composed of various elements with different opinions on many questions except the main issue, the convention ignored the more radical candidates, William $H$. Seward, the real leader of the party, and Salmon P. Chase. On the third ballot Lincoln was selected, and, to satisfy the East, Hannibal Hamlin of Maine was chosen for the second place on the ticket.

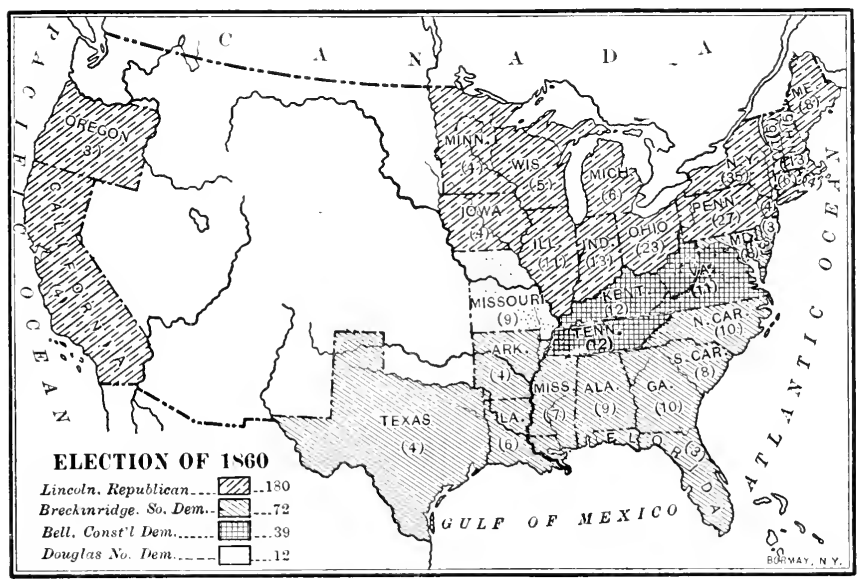

The campaign was full of interest and excitement. When The election. the polls were closed, it was found that Lincoln had carried all of the northern states, ${ }^{1}$ that Breckenridge had been successful in the South, and Bell had secured the rote of three border states. This gave Lincoln 180 of the 303 electoral votes, the others being divided as follows, Breckenridge, 72; Bell, 39; and Douglas, r2. On the popular vote, however, the combined votes of the other three were nearly one million $V, 462-469$. more than those cast for Lincoln.

\section{The Secession Movement (I860-I86i)}

326. Secession in South Carolina (December, I860). - Action before When it was learned that Lincoln had been elected, the legis- Dec. 20.

1 Except three of the seven votes of New Jersey. 
Schouler,

Lnited States,

$\mathrm{V}, 469-47 \mathrm{I}$.

Rhodes.

Lnited States, III, I I 5-I 25 , I92-I00́.

Hart, Contemforiries,

IV, No. 59.

Secession resolutions.

Rhodes, Cnited States, I I I, I96-207.

Larned (ed.), Hist irr Reid: Ret., $3407-3409$.

Aner. Hist. Leariets,

No.I2.

Buchanan's message.

Burgess, Civilltis, I, s2-83. lature of South Carolina called an election for members of a convention which should meet December $I_{i}$ and consider the relations between the state and the Lnion. ${ }^{1}$ There was no doubt in the mind of any one in South Carolina that this result would be secession. In October, when all indications pointed to a Republican victory; the gorernor of South Carolina had sent to most of the other southern governors a letter asking their coöperation. The Lnited States senators from South Carolina and most of the national officials in the state resigned as soon as the convention was called and every preparation was made to serer connections with the Union. Nerertheless the act of the convention on December 20 was a shock to the people of the nation.

In her secession ordinance the state repealed the act of I; SS by which she had ratified the Constitution of the Lnited States and declared that " the union now subsisting between South Carolina and other states under the name of ' the Lnited States of America "is herebr dissolved." A few days later the convention adopted a series of resolutions giving reasons for their action. They reviewed the course of erents during the formative years from $I_{i} ; j$ to $I ; S 9$ to prove that the state was sorereign and the Constitution a compact. Ther maintained that the North had, by personal liberty laws, nullified a law of the Cnion (the Fugitive Slare.$A c t$ ) and that the election of a Republican president threatened the institution of slavery. The arguments of South Carolina probably. did not influence the action in the rest of the slave states, but similar causes led to the calling of conventions in the other states of the South.

327. Attempted Conciliation (December-January). - Until South Carolina had passed an ordinance of secession, the Torth was indifferent. the administration inactive. General Scott, as commander of the army. had urged during Norember that the forts in the states of the South be strengthened, but Buchanan did nothing. As he could not ignore

1 The legislature had been in session to choose presidential electors. This method had given way to popular election in all of the other states. 
in his annual message (December 3 ) the threatened destruction of the Union, he considered the subject in a most extraordinary way. He declared that no state had any right to secede from the Union, but asserted that if a state saw fit to secede, neither the president nor Congress could prevent her from doing so or could bring her back into the Union. Buchanan denounced the anti-slavery agitation in the North as the cause of the whole trouble and recommended constitutional amendments protecting slavery in the states and in the territories.

During the month following this message the President's attitude toward the South changed considerably. Most of the members of his cabinet who favored secession resigned, and their places were taken by ardent Union men. The administration even went so far as to send provisions and troops to Fort Sumter in Charleston harbor, but the relief ship was fired upon and turned back, January 9, I86r.

In Congress committees were appointed by each house early in December to suggest means for preventing disunion. The southern leaders wished to have irrepealable constitutional amendments that would prevent Congress from interfering with slavery in the states or in the territories. The northern leaders were willing to agree that slavery in the states should be free forever from interference, but they refused their consent to slavery at any time in any part of the territories. Other attempts to reach a compromise satisfactory to both sides were made in Congress and out of Congress during the last two months of Buchanan's term (§ 329).

328. The Confederate States of America. - When the southern leaders saw that the northern members in Congress would not accept their terms, they advocated the secession of the other states. Georgia, Alabama, Florida, Mississippi, and Louisiana seceded during January, believing that they could dictate terms if they severed their connection with the Union. There was opposition in these states to secession, especially in Georgia, where Alexander H. Stephens

Change in Buchanan's policy.

Schouler, United States, $\mathrm{V}, 4^{81-485}$.

Larned (ed.), Ready Ref.,

34II-34I2.

Attempted compromise in Congress.

Schouler, United States, $\mathrm{V}$, 504-507.

Hart, Contemporaries, IV, Nos. 63,65 , $66,68,69$.

Secession of the Gulf states.

Hart, Contemporaries, IV, Nos. 58, 6r.

Rhodes,

United States, III, 27I-279. 
Chadwiok, cart? blar. $1+0-150$.

Formation and provisions of the constitution.

\section{Burgess.} cribl bis. I. Ino-rio.

Manonaid. revements No. 9.2.

Hirt, Cinsompurares

IV. No. oz.

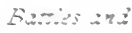
Lesicts: 1 , ou-IIS.

Fresiden: Divis.

B...ㄴ.? (2) $20110 \%$ 1. $119-123$

pleaded against disunion. In none of them was the secession ordinance submitted to the people for ratitication, although the result would have been the same probably in any case.

On the th of February. ISor, delegates from these six seceded states and Texas met at Montgomery, Alabama, and drew up a constitution for the Confederate States of America.

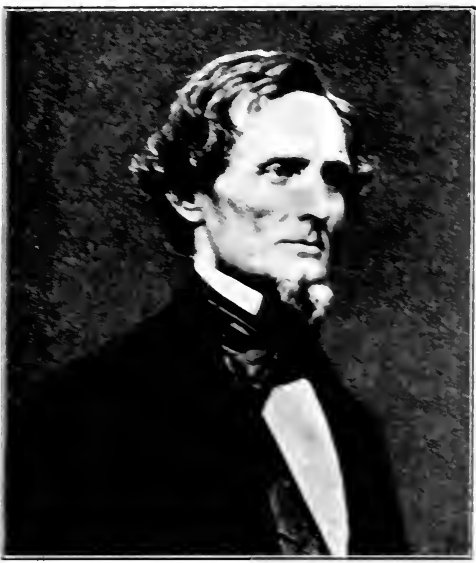

TEFEENON DAME This constitution was in most respects a copy of the national Constitution of $I$-Si. Several important defects or omissions of that document were remedied. and some changes made in the interest of state sovereignty or slavery. Each state was said to act "in its sovereign and independent character." Congress did not have power to give bounties or lay protective duties, but exports might be taxed by a two thirds vote of each house. The president was chosen for a term of six vears, but was not reellicible. The Confederate states might acquire new territury in which slavery was to be "recognized and protected," but no new state should be almitte? to the Confederacy except by a two thirds vote of both houses of Congress, the senate roting by states. There were fewer limitations on the states than in the Constiution of the Únited States.

The govermment. orgumized provisionally in IS6I and permanently in Iミ゙2, included Jef̈erson Davis of Mississippi as president, and stephens of Georgia as vice president. Daris was a man of extomded and varied experience in public life, as he had served in the army, in Congress, and in 


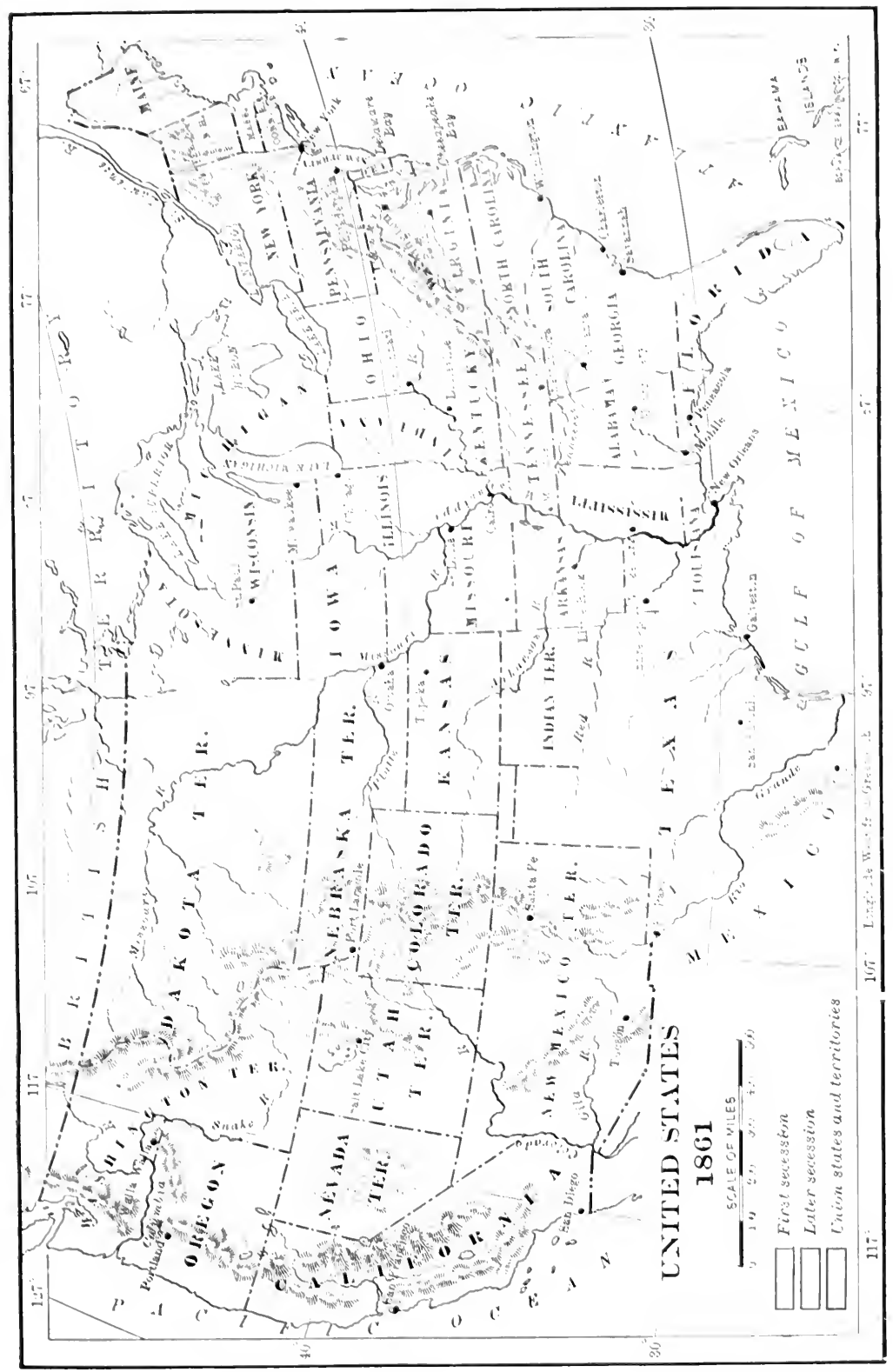




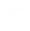


Pierce's cabinet. Although more radical in his views than Stephens, he was not considered an extremist, and administered well the duties of his trying position, although to the satisfaction of very few.

329. Close of Buchanan's Term. - The states in the Confederacy seized the property of the national government which was located within their borders, including numerous arsenals and forts. None of these arsenals manufactured arms - they were simply depots; but large numbers of muskets and a fair quantity of military supplies had been transferred to southern forts or arsenals by Buchanan's secretary of war, perhaps in anticipation of hostilities between the North and the South. The Confederate government selected commissioners to visit Washington and make a treaty of friendship with the United States (February, I86r).

Meanwhile, the discussion of compromise measures continued at Washington. The Senate still considered the Crittenden resolutions which had been proposed originally December 18. They favored irrepealable amendments to the Constitution for the extension of the line of $36^{\circ} 30^{\prime}$, all territories north of that line being free and all south, slave; the admission of states as free or slave as they decided; and the compensation of slave owners for all fugitives not returned to them. During February there was held in Washington a peace conference attended by delegates from two thirds of the states. By a narrow margin the convention voted in favor of the $36^{\circ} 30^{\prime}$ line for all existing territories, the admission of states with the constitutions they selected, no interference by Congress with slavery in the states, and no treaty for annexing territory unless approved by a majority of the senators from the slave states and a majority of those from free states. The House of Representatives also devised a plan for conciliation, one feature of which was accepted by the Senate, the only part of any compromise plan approved by both houses of Congress. This provided that Congress should never interfere with or abolish slavery

Crittenden resolutions. Peace conference, etc.

Burgess, Civil If ar, I, 96-104, I $24-135$.

Rhodes, United States, III, $150-156$, 305-308.

\section{Chadwick, Causes of Civil} War, 184-204.
MacDonald,
Documents,
Nos. $93,95,96$
Documents,
Nos. $93,95,96$


within the states. The adjourmment of Congress, March 4. closed these discussions.

Fuxitity of consitiation.

Two anses.

Deveromen: vinew :n.....

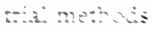
(I)-Zi-Zis).

\section{Siarer} prevents

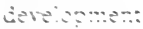
ot ine sion.

Certain moderate men. espectally in the border states. had made every posible effort to preserve the Lnion and mantain peace. But it was to late for compromise. The leaders oppoed to sharer extension would make no concessions permitting slavery permanenty in the territories. The pro-slarery leaders would not yield betause they believed that the system of slavery would lose in the end unless they samed erery demand from the North.

330. Fundamental Causes of Secession. - The secession morement was not the woth of discontented leaders, it wis the clash between scrtions which were radically difierent and whed w retim and devehp their own characteristics. To put it hretiv, there were two fundamental causes of

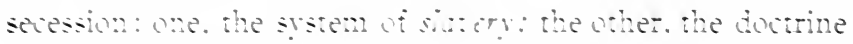

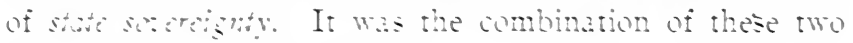
that mate scression pussible.

In the eighty yeats and more since the L'nited States had berome independen. grent changes hat then place within this commy and in the world at lasere (I) Methods of

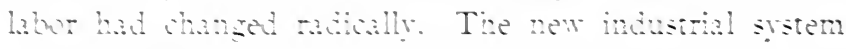
requires stilled labur. intelligens service - in short the frectom of the woringman. a An entirely dizerent set of canse farored the emantipation of those who had been serts or shres. Chet of these was the great derelowment of the ibes of demoracy whith hat been srowing stronger everyhere among civiliad nations but partioularly in the Thited states a This rapid proptess oward industril

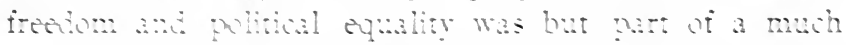
lager moment which hat replact the old orier of things with a new commerial and industial srstem much moe comples tha the ild and a new social order in whith may class Bstinations has been viliterated.

These changes hat aterted the Xorth rery much more than the Souh. Sace the Kevolutionary War. the politicul ideas and ideals of the south hat not changed sreatly. 
Her occupations and business methods were not very different, her social system was practically the same as in 1770 . Amid the wonderful changes of nearly a century of marvelous progress she had mate comparatively litte material progress on account of slavery. Slavery prevented the competition of free labor, yet slaves could not perform any labor except that of the crudest kind. With a system of slavery, democracy, political or social, could not exist.

331. Slavery and State Sovereignty versus Nationality. So closely identified had the South become with the institution of slavery that she felt it necessary to preserve that institution at all costs. To protect and preserve it she had sought new territories. But as slavery could not compete with a system of free labor on equal terms, it required artificial props to protect it in the old territory and in the new from being orerwhelmed by the much stronger system of free labor. 'The South demanded therefore that the North allow her to have an equal share in the government of the United States. But to do this meant the permanent maintenance of two sections, totally unlike and antagonistic. When we consider that the United States had, during the half century following the second war with Great Britain, been growing into a great and powerful nation, we can realize that permanent sectionalization would prevent the further development of nationality.

There were but two alternatives. (I) Either the nation must remain partly developed, or (2) it must complete the development of its nationality by securing a uniform economic, political, and social system; in short, it must abandon slavery or make slavery universal within its borders. Lincoln, Seward, and others had seen this clearly, although the mass of the people did not. As the system of free labor had been growing rapidly, while that of slavery had not, the only hope for slavery was to oppose the growth of nationality. This she could do most effectively by appealing to the political principle that the states are sovereign. State sovereignty had been the chief obstacle in the upward path of the nation,

Antagonism between slavery and the nation.

Why slavery joined forces with state sovereignty. 
and it was natural that when the development of the nation threatened slavery the institution of slavery should join forces with state sovereignty. But state sovereignty, like slavery, belonged to the old order of things, to a past that would never return, and even their union was unable to cope with the young, strong forces of free labor and what Calhoun called, ten years earlier, "a great consolidated national democracy."

\section{Lincoln; "The Three Months' War"}

Inauguration.

332. Lincoln's Policy. - On the $4^{\text {th }}$ of March, I86I, Lincoln was inaugurated quietly at Washington. There had

Rhodes,

United States, been fear that Lincoln's life would be threatened during III, 316-319. his trip to Washington or on inauguration day, but nothing serious happened, for every precaution had been taken to prevent an outbreak. The inaugural address must always

Morse,

Lincoln,

I, 2I 2-228.

Amer. Hist. Leaflets, No. I8.

Lincoln's cabinet.

Larned (ed.), Ready Ref., $3+20$. be ranked among his greatest state papers. He disproved at the beginning that his election was sufficient cause for secession by declaring that he would not interfere with slavery in the states, that he would not oppose a constitutional amendment which prevented the central government from interfering with slavery as a state institution. $\mathrm{He}$ asserted that there could be no right of legal secession, for the Union was older than the Constitution. Having announced his intention of enforcing the national laws in all of the states, as prescribed in his oath, he went on, "in your hands, my dissatisfied fellow-countrymen, and not in mine, is the momentous issue of civil war. The government will not assail you. You can have no conflict without being yourselves the aggressors."

Lincoln was fortunate in being able to gather in his cabinet many of the prominent Republican leaders, for if at first the cabinet lacked unity, it gained for the administration the support of all elements in the North. The secretary of state was William H. Seward, who considered himself the head of the party and sought to dictate the policy of the administration. $\mathrm{He}$ was anxious to subordinate 
sectional questions to an aggressive foreign policy, but this Morse, unwise plan, which would have involved the government in difficulties abroad without lessening its burdens at home, Lincoln I, 234-238. was ignored completely by Lincoln. Seward afterward exhibited a very high quality of statesmanship, and during the eight years he served in the department of state, proved that he was second only to Lincoln among the men of his time. Other notable cabinet officials were Salmon P. Chase, who was secretary of the treasury until I864, and Edwin M. Stanton, a member of Buchanan's cabinet after it was reorganized, who had the war portfolio after I862. Upon these three men devolved the chief duties that affected the success of the Union cause. Yet great as were the services performed by these men and others

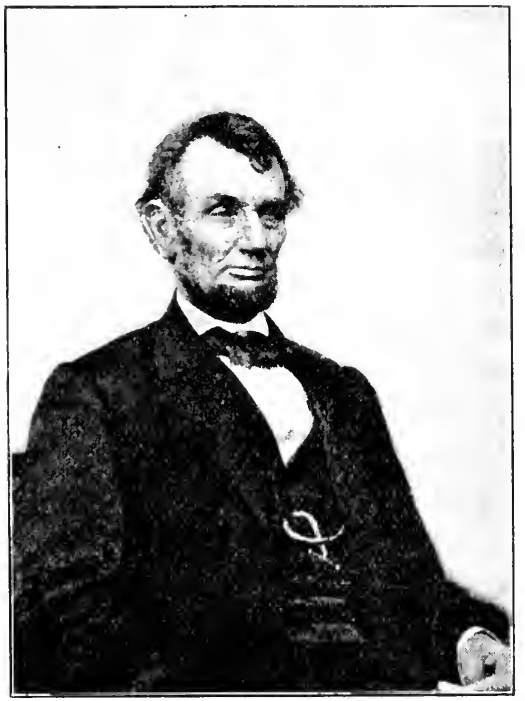

The famous Brady photograph

Abraham LinCOLN of Lincoln's assistants, the policy followed was in the main that of the chief executive. With added experiences and increasing responsibilities, Lincoln acquired a skill in handling men, a soundness of judgment in dealing with difficult problems, and a firmness in carrying through a policy which he believed to be right, that marked him as the greatest American of the nineteenth century.

333. Sumter. - From the beginning Charleston harbor, Negotiations. with its Union force of little more than one hundred men, had been considered the crucial point in the South. Major Anderson, before New Year's, I86r, had withdrawn all the 
Hart, cintem- men from the forts around the harbor, and concentrated his

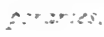

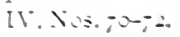
force in Fort sumter in the center of the harbor. The attempt made on Jumuary o to send additional soldiers and supplies in the Star of the II Est had caused the south

Bunes.

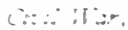

I. IEI-ITI.

Arempied relief, bombarimen:

Tonn forces Apr... ISI)

Butges. C $2:$ it: I. I- $\mathrm{III}$ I ะก-บว.

Rhowes.

7. III, 洂江Carolina forces to fire upon the ressel, and had produced a strong sentiment against disunion throughout the North. Commissioners had been sent to treat with Buchaman in order to gain pussession of sumter, but without avail. Later, commissioners were sent to Washington by the Confederate government to negutiate all matters affecting debts and property in the southern states. Both Buchananand Lincoln refused to treat with these men. for to do so would have been recognition of the Confederacy: but certain notes were lett for them by seward in order that they might understand the attitude of the new administration. From these informal procedings the ofitials of South Carolina gained the impression that no attempt would be made to relieve Sumter. In fact Lincoln promised only that he would notify them of a relief expedition. This was titted out in New Lork. April i. Governor Pickens of South Carolina was notitied immediately. Aiter wo days" consideration of the matter the Confedente government asked for the surrender of sumter. and. when it was reiused. began bombarding the fort. April Iz. On the afternown of the Isth. his ammunition and supplies gone, and the fort on fire. Anderson surrendered and his men were sent North.

334. Preparation for War. - The news of the firing upon Sumter aroused the North from its lethargy. When Limolm. on April Is asked ior 75000 militimen to serve for three months.' the response throughout the free states was enthusiastic. In the slave states however. the governors refused to fumish mops. Within fortyeight hous farm the first call. regiments which had been organized aleady by the "war governoss" were on their way to Washington. In Baltimore on April to, the trops were attacked by mobs, but turther disorder was prevented

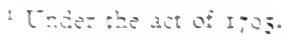


by transporting the soldiers over a nother route. The regular army was demoralized by the withdrawal of nearly one half of the officers, who were southerners, but even at this time the military force of the United States was larger and hetter organized than that of the Confederacy. There was no attempt to organize a large, permanent army, for very few people expected a longr or a serious contlict.

In March the Confederate Congress had authorized the enlistment of one hundred thousind troops, but although that number of recruits offered their services, there were not enough arms or military supplies for them. The Confederacy had also tried to prepare a nary, but their difficulties were increased by the lack of any naval ressels and failure of many southern naval officers to leave the service

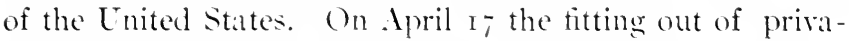
teers to prey upon the commerce of the North was authorized. This action was followed at once by Lincoln's proclamation blockading southern ports (s 3+0).

Lincoln's original call for troops was followed, May 4, by a request for 40,000 volunteers besides regulars and seamen to serve for three years or the war. Legally he had no right to organize this army, but he was supported in this and other ways by the Congress which met in special session, July 4. Congress roted $\$ 250,000,000$ for the prosecution of the war and immediately after the battle of Bull Run (336) roted 500,000 volunteers.

335. The Border States. - Between the Confederacy as it existed on the I 2 th of April and the free states there were two rows of slave states that were still in the Union. The attitude of these border states was a matter of the first importance. If all joined the Confederacy, the two sections would be not far from equal in strength. If all remained in the Union, the early downfall of the Confederacy was assured. When Lincoln issued his call for troops on April ${ }_{5}$. the governors in most of these states refused to send troops.

Confederate army and privateers.

Rhodes, Inited State's III, 320-322, $395-390$.

Larned (ed.), Ridaly Kert., $3+20-3+28$.

Permanently organized torce.

Burgess, Ciill llar, I, 220-232.

Second secession.

Burgess, Ciz'l Hiar,

I, I77, I82-IS6.

Rhodes,

L'nited states,

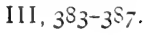
Jackson of Missouri went farther than most of the others, and declared, "Your requisition in my judgment is illegal, 
unconstitutional, and revolutionary in its object, inhuman and diabolical and cannot be complied with." Several of the states immediately took a rote on secession. In the four states of the lower tier, Virginia, North Carolina, Tennessee, and Arkansas, an orerwhelming majority favored separation from the Lnited States. All of these states, of course, joined the Confederacy.

Delaware, Maryland, and western Virginia.

Burgess, Cia.? II: I, I00-205.

Rhodes,

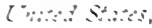
III, 3\$ง-300.

Kentucky and II ssouri.

Rhodes,

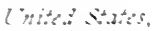
III, 30I-304.

Burgess. (2) $11 \%$, I. 1S0-I05.

Situation in Virsinia (JuY, ISOI).
In the northern tier of the slave states the question was not put to a rote, or was decided against secession. Delaware unhesitatingly sided with the Union. In Maryland, the southern sympathizers were exceedingly active, although in a hopeless minority. The presence of the troops who were protecting Washington, and the arbitrary suppression of disunion efforts by the administration and by the state officials, made the secession of the state impossible. The people of western Virginia were not slaveholders, and objected to being thrust out of the Lnion. They claimed, therefore, to represent the true state and remained in the Union. Afterward, in Is $6_{3}$. without regard to the requirements of the national Constitution, ${ }^{1}$ West Virginia was admitted as a separate state.

Kentucky roted to remain neutral, but found it impossible to do so. In the fall of ristr, when a Confederate force invaded this state. it came out positively on the Lnion side. Missouri was the battleground in which a political and a military contest was waged for the possession of the state. The Lnion men, organized by Blair and commanded by Captain Lron, gained possession of St. Louis and secured control of the state government. deposing the governor, who firored secession. Several battles were fought in Missouri during the fall of rs6r, but the Confederate forces were driven finally from the state and the Union victories made permanent by the battle of Pea Ridge in northwestern Arkansas (February. rsoz).

336. Bull Run. - In Virginia there were three armies on each side, one threatening and one defending Washington, 
two in the Shenandoah valley, and two contending for Larned (ed.), western Virginia. In the mountains of the western part of the state the Confederates, under Robert E. Lee, were driven liécidy lié, $3433^{-}-3+34$. back by George B. McClellan and Rosecrans. In eastern Virginia it was decided to advance from Mashington and attack the Confederate force under Beauregard. This army was stationed at Manassas Junction, where the railway from near Washington to southern and southwestern Virginia met the branch line from the Shenandoah valley, a point valuable for either side, but especially for the Confederates. Patterson, the Union general in the Shenandoah valley, was ordered to engage his opponent, Joseph E. Johnston, while McDowell advanced against Beauregard.

The armies of McDowell and Beauregard met at Bull Run, a short distance from Manassas, and fought well for raw troops. Beauregard was forced back until reënforced by

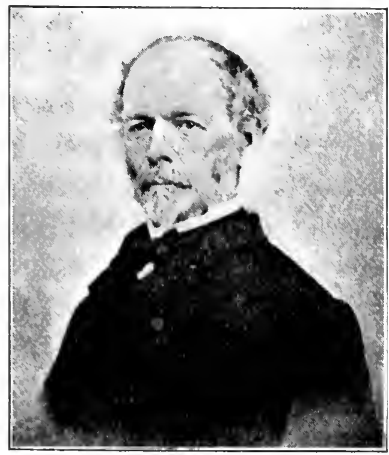

JOSEPH E. JOHNSTON fresh troops brought by rail from the Shenandoah by Johnston. What seemed to be a Union victory became a rout, which turned into a mad scramble to reach Washington. The Confederate force was too badly disorganized to follow and was in fact ready to disband, thinking the war was over. Stung by defeat, the North awakened to the fact that the Dodge, Cizil Iliar. I6-I9.

Rhodes,

United States, III, $4+6-452$. reduction of the South was not a three months' task; that it would require a herculean struggle, to which the North must give unsparingly of her resources. As we have noticed, 500,000 volunteers were roted by Congress the next day, and under the direction of that splendid drill master, McClellan, and other commanders, armies were created that would understand the art of war. 


\section{Conditions affecting Union Success}

Disparity in strength.

Hart, Essays on Am. Gov't, 268-275.

Chadwick, Causes of Civil War, 21-36.
Dependence of the South.

Hart, Contemporaries, IV, No. Io6.

337. Resources of North and South. - Before considering the real campaigns which followed these military preliminaries it will be well to compare the contestants and consider those conditions which affected the final result. We have noticed already how much more rapidly the North had grown than the South, not alone in population but in wealth, general resources, and diversity of industries. In none of these respects were the eleven seceding states a match for the twenty-three states that remained in the Union. Their white population was less than five and one-half millions, that of the loyal states nearly twenty two millions. This disparity of about 4 to $\mathrm{I}^{1}$ may be taken as a fairly true measure of the relative strength of the two parties in other respects than population, for the Confederacy did not have more than twenty per cent of the wealth or commerce of the North, and her industrial output amounted to less than one tenth of that of the loyal states.

The South had large natural resources, but they were undeveloped. She had not attempted to manufacture what she needed, for she had exported almost everything she produced to Europe or to the North, and purchased usually from the North even many necessities of life. At the beginning of the war, she did not have enough factories to supply her people with clothing and shoes. There were no powder plants, no factories for making cannon or small arms, no shipyards. Rolling mills and iron foundries were uncommon. Railways were not particularly plentiful at the South, but they had been equipped with northern rails and supplied with northern locomotives and cars. In short the South was entirely dependent on the outside world, to which she had given her cotton and other products for the articles she needed. ${ }^{2}$

1 Not counting slaves.

2 At this time, however, the exports of cotton comprised about two thirds of the total exports of the entire United States. 
The North possessed an abundance of all of these things. Her factories turned out all the munitions and supplies that she needed. Her farms produced more food than both the soldiers and the workers at home could use. Industry and commerce, instead of being absorbed by the war, were stimulated by it. The strength of the system of free labor increased as the need became greater.

338. The Southern Armies. - With a white population but one fourth that of the North, the South was not able to put as many men in the field. Even in the early part of the war, when southern enthusiasm was greatest, and all desired to present a "stern front to the invader," or, as Davis said, "fight on northern soil," the southern force was only about two thirds that of the North. During the last year of the war it was reduced to less than one half the number of soldiers in the Union ranks. Many from the loyal border states joined Confederate armies, but their number was only a little greater than that of the Union soldiers from east Tennessee and western Virginia. As the northern armies penetrated southern territory, the aid given to the Confederate commanders by the people was of inestimable value. The South was fortunate in most of her commanders, although President Davis interfered constantly by dictating the plan of campaign to be followed.

The South excelled in cavalry except during the last year, and the men who had been accustomed to ride even to their nearest neighbors made the finest cavalrymen in the world. Her artillery and engineering corps were especially inferior to those on the Union side. Her infantry possessed a spirit which went far toward making them excellent soldiers. When they charged, giving their terrible "rebel yell," there was need for the greatest courage among the Union troops. So excellent was her secret service, and so lax the northern methods, that the Union plans were always known and their movements anticipated.

339. The Northern Armies. - To defeat a people so united, so earnest, possessing the advantage of fighting on their

Different branches of the southern service.
Cf. Rhodes, United States, $\mathrm{V}, 43^{\mathrm{I}-447 .}$
Southern milltary policy

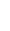

Independence of the North. 
Northern

soldiers and enlistments.

Caring for the troops.

Rhodes,

L'nitcid states, V., $21+-227$.

Government and contractors. own soil, able to move troops from one point to another as each in turn was threatened, required the greatest determination and the highest courage, both of which the Union troops possessed in marked degree. Although the preponderance of numbers on the Union side counted in the end, in most contests the forces were not far from equal. ${ }^{1}$ In the North the soldiers did many things, such as driving teams and building earthworks, which were performed by slaves in the South. The Union armies were recruited to a much larger extent by voluntary enlistment, encouraged by national bounties of $s_{300}$ and supplemented by state and local bounties. The South had no money for this purpose and resorted to drafts early in the war, toward the end permitting young bors and old men to enlist. The North was obliged to draft more than once. During July, I $86_{3}$, the attempt to obtain soldiers by that means led in New York City to terrible draft riots in which nearly a thousand negroes and whites lost their lives.

It took the North longer to discover her best leaders, but toward the close of the war the northern commanders outgeneraled their opponents in almost every contest. During the carly part of the war the northern armies were hampered by interference from Lincoln and his advisers. The northern soldiers were supplied much better than those of the South with ammunition, arms, food, and clothing. At first it was difficult to obtain these articles, as the war department was not able at once to handle so many supplies; but during the last two years of the war the government purchased food and blankets on the principle that it was cheaper to provide new blankets for the men who had discarded them on the march than to hamper the movements of the armies or permit the soldiers to suffer.

This policy was extravagant and led to a great amount of fraud. Large fortunes were made out of government contracts. Men who furnished transports for Union

1 This was not true in the battles of Virginia in which the skill of Lee counterbalanced the greater number of the northern soldiers. 
troops usually doubied their wealth in a few months. Although the government paid a high price for uniforms and blankets, many of them were made of " shoddy," which fell to pieces on slight provocation. The army food, of none too good a quality in the days before canned goods were common, was often inferior stuff on which a good profit was made. Yet few wars have been fought on so large a scale, with so little preparation, in which the soldiers were treated better.

The loss of life from wounds and disease was much sanitary smaller than in earlier wars, partly because of the efficient Commission service performed by a well-organized body called the Sanitary Commission. The northern troops were much more fortunate than those of the South, among whom anæsthetics and other drugs were rare, because the North insisted that they must be considered contraband of war.

340. The Navies; The Blockade. - The American nary Privateering. was small and scattered in I86r. Only three ships were in northern ports, none in those of the South. Since the South realized that it could not get a regular navy, it issued letters of marque and reprisal to privateers and allowed these vessels to prey upon the merchant ships that carried the American flag. As our merchant marine had developed until our ships were found on every ocean this promised to strike a serious blow at the North.

In retaliation Lincoln proclaimed a blockade of the entire southern coast, between 3000 and 4000 miles long, and closed his proclamation by declaring that those engaged in privateering would be treated as pirates. Vessels were purchased to maintain the blockade and in a few months there were only a few ports in the South that could be reached Establishing a blockade.

Cambridge Mod. Hist., VII, 549-552. even by the swift "blockade runners." These steamers usually plied between British ports, the Bermudas or Nassau in the Bahamas, or Havana, and Jacksonville, Savannah, Charleston, and Wilmington. Most of these ports were closed completely early in the war and blockade running became extremely hazardous. Many engaged in the traffic,

Cambridge Mod. Hist., VII, 565-567. 
however. because the protits were so enormous that two rips would pay for the cost of a vessel.

Resines of the bisinte.

Khates

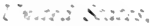

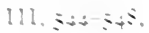
$1.30+20$
Sarmind

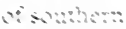

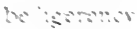
(Max, :sot)

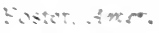
$\because \cdots \cdots$, $\therefore: \therefore$

X.

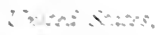
$111+2-23$

$13: \because \cdots$ in:

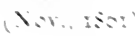

The isolution of the Sumb through the hlokade was an improme cause if met the chet canse of the confeteracy"s tailure. The south hat devoted her energics to rasing cotton umil "Conton was King." before the war she believert that her cotsum orop was of steater real value than all the proxtues of the North. but the south had never

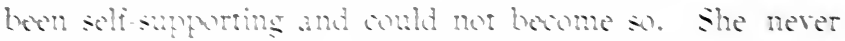

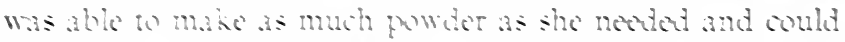
not prowute enuth muscets or ammon. She could raise

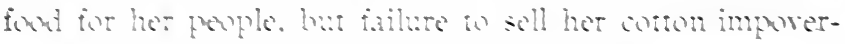

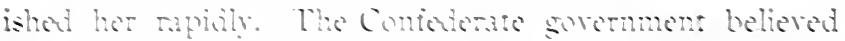

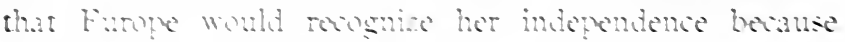

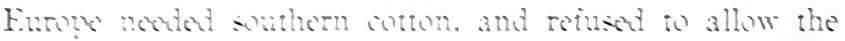

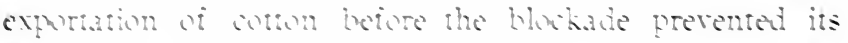
expration alswether, but whom arail. Althugh onton

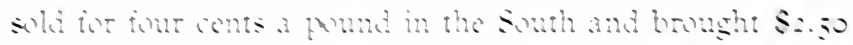

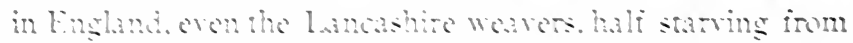

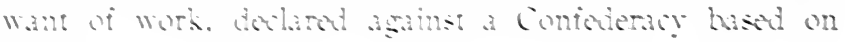
slavers

S4I. Foreign Relations ISOI-ISOS. - The sucres of the

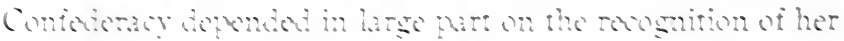

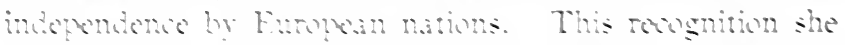

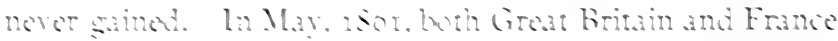

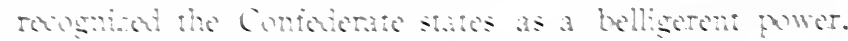
with a well-ursmiot soremment and complete miltary

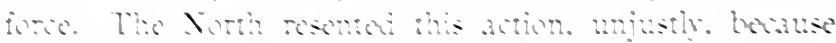

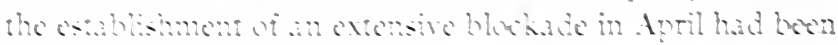

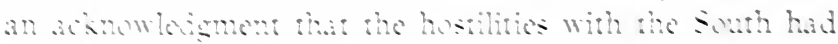

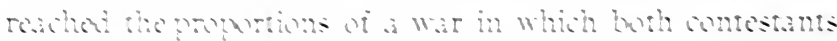

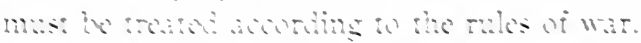

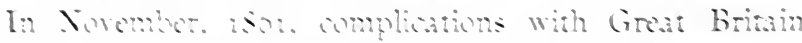

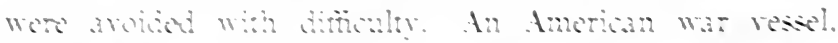

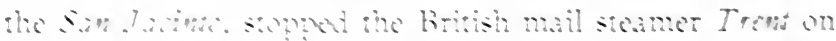

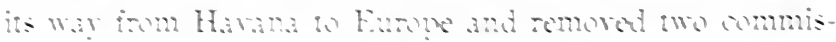

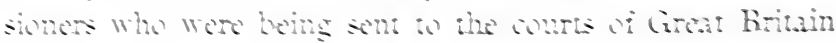


and France by the Confederate govermment. The North applauded this act, but the English gorermment and people were very indignant. When a demand was mate for the surrender of the commissioners. they were released becanse their soizure had been irregular. Secretary seward stated that we compliad cheorfully with the request for the surrender of the commissioners, for we had contended many years against the principle of the " right of search."

The majority of the officials and people of cireat liritain undoubtedly sympathized with the aristocratic south and might not have been mwilling to see the Enion broken up. As the prime minister salid to a northern man, " II de not like slavery, but we want cotton and we dislike very much your Morrill tariff." Although recognition of the Confoderacy was desired he both cireat britain and France. they hesitated to take that action. (1) hecause Russia. still smarting under the defeats of the Crimean war, openly took the side of the L nion and sent a flect to Xew Vork harbor. (2) because the gorernment at IVashington made it clear that if the independence of the south were recognized, our ministers would he withdrawn, and (3) because southerm invasions of the North were always checked casily and quickly. Much of the credit for preventing the recognition of the Confederacy and the fitting out of privaters and other war ressels in European ports belongs to our ministers abroad, especially Charles Francis Adams, who represented us at the Court of St. James.

342. Bonds and a National Banking System. - Money is called appropriately the chicf of the sinews of war, since more wars have failed hecause of lack of money than for any other one reason. The situation of the national government in the spring of Isor did not excite emy. The credit of the government had been declining during the hard times succeding ss a and was almost destroyed in the fall of ssoo, when many feared that the L nion might he dissolved. Nevertheless the nead of money induced Congress in the summer of ISOI to rote a loan of $\$ 250,000,000$ at seven per

Attempts to sain reoosnition of southern independence.

Foster, fmer. I) $37 \mathrm{I}-3 \mathrm{~S}_{4}$.

llosmer. निर्ध一izto $4, n s, 300-322$. Government loans.

Dewey, Finam ital Hist., II 120,130 , $I_{32}, I_{3} 6$. 
cent, with some taxes to pay the interest. This loan could never have been thated but for the lovaly of the banks in the larger northern cities, which disposed of large numbers of bonds. But in December. Isor, the banks were obliged to suspend specie parments, and regular business throughout the rest of the war was done with paper, or with gold at a premium. In February, ISo2, a second loan was voted, this time the enormous sum of $\$ 500,000,000$. Other loans were authorized later, as the gowermments need of money increased comstantly; but

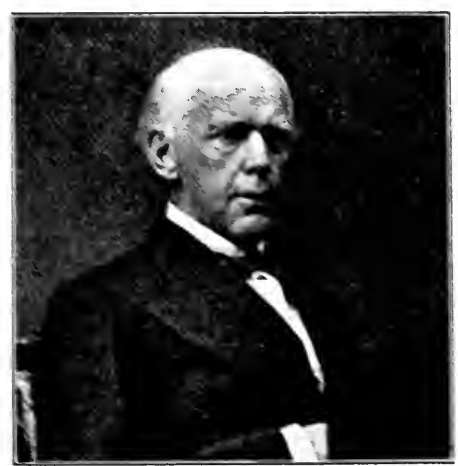

SALU P. CHASE it was not easy to sell the bonds eren on the adrantagenus terms at which they were offered.

In order to provide a new market for the bonds and have a national bank currency which would replace that of the states. a National Banking Act Was passed in Isos. This provided that persons might organize national banks which could issue notes to ninety per cent of the value of Lnited states bonds that they held. Later the state bank notes were forced out of circulation by a tax of ten per cent on their issues. so that most of these state banks were comverted into national banks.

Issues of

343. Greenbacks and Taxes. - Early in the war the steenbacks.

Dewey, Fistar-

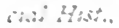
iो $122-125$. sorernment had besun to lery new kinds of taxes, but in Fobruary, Isoz, it supplemented the bonds and taxes by issuing treasury notes which did not bear interest. Many people denied that the government hat the right to issue bills on the credit of the Lnitad states. but the needs of the time werruled all scruples and the notes were issued, tirst to the amount of $S_{150,000,000}$. later to three times that sum. They were called popularly "greenbacks," 
and became the ordinary medium of exchange. Being issued in large quantities, they depreciated naturally. At one time $\$ \mathrm{I}$ in gold was equivalent to $\$ 2 . \$_{5}$ in paper. Becaluse of this cheap) and abundant money high prices prevailed, and a great deal of business was done. Wages were higher, but as they dict not increase in the sime proportion as the cost of living, a large part of this "forced loan" was paid really by those working by the day, week, or month.

Three kinds of taxes were used to gain the money necessary to pay the interest on the national debt and maintain the credit of the government: (1) The tariff, which in $180 \mathrm{I}$ had been male protective in character. The rates were increased considerably in IS62 and much more in IS64 to gatin revenue and to protect from foreign competition the industries which were now obliged to pay national taxes. (2) Manufacturing tases. Part of these were levied on distilled or fermented liquors and tobacco, this tax having been retained to the present. Taxes were levied on almost everything manufactured in the United States from a toy to a locomotive. Often an article would be taxed several times in the process of manufacture. The tax was as nearly universal as it could be male. Even these heary taxes did not interfere with the industry of the North, for manufacturing devetoped continually during the war. (3) Personal taxes, which were levied on all incomes except the very lowest. The rate during the last of the war was five per cent on all incomes between $\$ 600$ and $\$ 5000$ and ten per cent on all above $\$ 5000$, those under $\$ 600$ being exempt. These income taxes were paid cheerfully until peace came, when it was found that taxes of that nature were very objectionable.

344. Southern Finances and Government. - When the South sought to obtain money for carrying on the war, the baleful influence of slavery was very noticeable. As the section had no inchustries and few strong banks, she did not possess the resources for raising revenue or the means for floating her loans. Since the blockade cut off foreign trade, Loans and patper money. no duties could be collected on imports or from the export

Rhodes, Inited .titates, V. 34t-35I. 
Cambridge Mod. Hist., 6ro-6Ig.

Arbitrary government in the South.

\section{Cambridge}

Mod. Hist., 607-6io.

Rhodes,

United States, V, 43I, 453-458, $470-475$.

Some of the dangers. of cotton. The states were too poor to pay heavy taxes of any other kind, so that the government depended on the sale of bonds and the issue of paper money. The earliest bonds were sold for cash, but as the money was expended abroad for military supplies, there was little gold or silver left in the Confederacy. A few bonds were sold later abroad, but most of them were exchanged for food, and netted the government very little. Paper money was issued in large quantities, depreciating rapidly of course in value. Probably the face value of all the notes aggregated more than $\$ 1,000, \infty 00, \infty 00$, besides the issues of the state governments and the banks. Prices rose to enormous figures, even the gold value of everything, including cotton, being higher than before the war. A barrel of flour sold in Richmond during the last year of the war for $\$ 20$ in gold or \$1000 in paper. ${ }^{1}$

As might be expected, the southern jealousy for state rights interfered considerably with the exercise of dictatorial power by the government at Richmond. Yet the necessities of war forced President Davis and the Confederate Congress to use arbitrary means to gain men or money. Attempts were made to regulate prices, needed supplies were seized, the army was recruited by means of forced drafts, and the privilege of the writ of habeas corpus was suspended, although less extensively than at the North. In fact, as President Woodrow Wilson says, " everything gave way, even law itself, before the inexorable exigencies of war."

345. Critical Situation at the North. - The material advantages possessed by the Union over the Confederacy are clearly apparent now, and were understood in part at that time, but the result was by no means certain for at least two years. Had the North been less united than it was, history might give us a very different story. The government at Washington felt it necessary to use every means in its power to preserve the Union, even if that involved the sacrifice of personal rights and compelled officials to disregard the

${ }^{1}$ An ordinary dinner for nine persons, in January, 1865 , cost $\$ 6_{3} 1.50$. Rhodes, United States, V, 249. 
Constitution. Fortunately the people realized the danger to the Union and gave the chief executive their hearty support. It is remarkable that there was so little opposition to the great extension of the president's war power. A few instances will suffice to show how the president became almost a dictator.

At the very beginning of the war President Lincoln suspended the privilege of the writ of habeas corpus around Washington and in some of the border states. When the Supreme Court protested on the ground that Congress alone could suspend the writ, he ignored the order of the court to release persons imprisoned and Congress practically supported his action. Later the writ was suspended throughout the North and many who opposed the work of the government were imprisoned. The draft was used less at the North than at the South, but both governments took engines and cars on the railways when the need arose. There was a partial censorship of the telegraph at the North, and an edition of two New York newspapers was confiscated because they published news which the government wished to keep secret. The national government attempted at first to treat the southerners as rebels and wished to confiscate their property, but in the end treated them as belligerents. Much the most conspicuous instance of dictatorial power, however, was the freeing of the slaves of those engaged in war against the United States by Lincoln in the Emancipation Proclamation, which he issued by virtue of his position as commander in chief.

346. Summary. - After the Dred Scott opinion had opened all of the territories to slavery, there was little chance of avoiding a conflict between the sections, because neither would yield. A strong executive might have prevented or postponed the secession movernent. Buchanan did neither. When the split in the Democratic party (1860) permitter the Republicans to elect Lincoln, South Carolina seceded and six other cotton states followed within six weeks. Buchanan did nothing until forced by public opinion to reorganize

Presidential dictatorship.

Larned (ed.), Ready Ref., 3447-3+48, 3496-3498.

Johnston, Am. Pol. Hist., II, 394-405.

Hosmer, Outcome of Civil War. Chapter I.

Dunning, Civil War and Reconstruction, Chapter I.

The critical period (1857-1861) 
his cabinet. The senators and representatives tried to find some common ground for compromise, the political leaders from Virginia and Kentucky taking the initiative in proposing plans for conciliation, but without result.

Beginning of the conflict (I86I).
A month after Lincoln became president, the fall of Sumter began the war, which, it was thought at first, would last but a few months. Preparations were made for the conflict on a small scale, but the chief contest was over the border states, the lower tier of which joined the Confederacy, while the northern border states were persuaded finally to remain in the Union. The battle of Bull Run showed that the struggle was to be one of large proportions. Both sides then began to prepare in earnest. The North had the advantage of very much greater numbers and industrial and natural resources. It had money that was available for carrying on the war. Its navy was able to cut off the Confederacy from the supplies that were indispensable to the South. The South used her men and resources much more freely than the North found necessary. She had several able commanders and possessed the advantage of fighting on her own soil, being able thus to transport her troops from point to point with comparative ease. Her limited resources and inability to supply herself with necessaries made it impossible to compete with the North on equal terms. Foreign nations refrained from recognizing the independence of the Confederacy, and the conquest of her territory became only a question of time.

\section{TOPICS}

I. John Brown's RaID: Burgess, "Civil War and Constitution," I, pp. 34-44; Von Holst, "United States," VII, pp. I8-59; Rhodes, "United States since I850," II, pp. 383-416; Redpath, "Captain John Brown," pp. 229-407.

2. Election of i860: McClure, "Our Presidents," pp. I54-182 ; Stanwood, "History of the Presidency," Chapter XXI; Stephens, "War between the States," II, Colloquy i 8; Blaine, "Twenty Years of Congress," I, pp. I57-1 72; Rhodes, "United States since I850," II, pp. $440-502$. 
3. Contrast between the Slave and Free States: Wright, "Industrial Evolution of the United States," Chapter XII; Helper, "Impending Crisis," Chapters V, VIII; Hart, "Practical Essays on American Government," No. XI; Sites and Keener, "Growth of the Nation" (N. America, Vol. XIII), Chapter VI; Brown, "Lower South in Amer. Hist.," pp. I 55-190.

4. England and the United States during the War: Foster, "Century of American Diplomacy," pp. 365-400; Adams, "Charles Francis Adams," Chapters IX, XII, XIII, XV, XVII; Rhodes, "United States since I850," IV, pp. 76-95, 337394 .

\section{STUDIES}

I. Lincoln's Freeport speech. (Johnston (ed.), "American Eloquence," III, pp. I84-i94.)

2. Comparison of Davis, Lincoln, and Douglas. (Burgess, "Civil War and Reconstruction," I, Pp. I-27.)

3. Jefferson Davis. (Trent, "Southern Statesmen of the Old Régime," pp. 257-293.)

4. Seward during March and April, r86r. (Lothrop, "William H. Seward," pp. 246-29i.)

5. Reasons for the secession of the Southern States.

6. Formation of the southern Confederacy. (Davis, "Rise and Fall of the Confederate States," I, Pp. 229-242.)

7. Stephen's "Corner Stone" speech. (Johnston (ed.), "American Eloquence," IV, Pp. 39-50.)

8. Washington on the eve of the Civil War. ("Battles and Leaders of the Civil War," I, 7-25.)

9. The secession movement in Missouri. (Carr, "Missouri," pp. 267-323.)

ro. Enlisting in the army. ("Battles and Leaders," I, pp. I49I 59.)

I I. The Sanitary Commission. (Johnson, "War of Secession," pp. $35^{\mathrm{I}-35^{8} \text {.) }}$

I 2. Running the blockade. (Soley, "Blockade and the Cruisers," PP. I 53-167.)

I3. English sentiment for the South. (Rhodes, "United States," IV, pp. 76-95.)

I4. Preventing England from recognizing independence of the Confederacy. (Adams, "Charles Francis Adams," pp. 278-290.)

I5. Debate of the issuance of greenbacks. (Blaine, "Twenty Years of Congress," I, pp. 409-429.)

r6. Civil government of the southern states. (Garret and Hudley, "Civil War from Southern Standpoint" ("North America," .XIV), pp. 485-506.) 


\section{QUESTIONS}

I. As far as possible trace the development of the radical movement at the North and at the South. In which section did the radicals gain control first?

2. What were the questions that Lincoln asked Douglas? How did Douglas answer those that were most important? How did his answers affect his later political career?

3. What is secession? Distinguish from nullification. Why is the Constitution silent on the subject? Could anything but slavery have caused secession? Was the election of Lincoln sufficient reason for secession?

4. Compare the Constitution of the United States with that of the Confederacy. In what respects do they differ most? Were the states sovereign under the Confederacy? Did they enjoy more powers than those in the Union?

5. Trace the growth of slavery as (a) an economic institution; (b) a political institution. In what ways had slavery retarded the growth of the South as shown by social conditions, political ideas and customs, lack of material development, etc.? Show clearly as possible why slavery led to secession. Give the important changes connected with slavery from is 30 to $\mathrm{I} 86 \mathrm{r}$.

6. Compare the Confederacy with the Union in population, value of property and products, size of army and navy, financial resources, and dependence on outside countries for war necessities.

7. Which war powers were exercised by the president? Were any of these unconstitutional? extra-constitutional? Is there a "higher law than the Constitution"; judged by the events from 1850 to 1865 ; judged by the "presidential dictatorship"? 


\section{CHAPTER XVII}

\section{PROSECUTION OF THE WAR (I862-I865)}

\section{President}

\section{Abraham Lincoln (I86I-I865)}

SPRING ANd Summer OF 1862

347. Theater of War in the West. - The result of the Civil War was decided by the western campaigns, and the western campaigns were determined to a great extent by the direction of the great rivers. As the Union forces necessarily assumed the offensive, they followed naturally the Mississippi, which crossed the west-central part of the Confederacy, and the Tennessee, which penetrates the heart of the South. Movements along the Mississippi were impeded by the shallowness of the river, the many turns, and other General character.

Mississippi River.

Semple, Amer. Hist. and its Geog. Conditions, 300-308. obstacles to navigation, and the bordering swamps which prevented the successful coöperation of land and naval forces. When the Union forces had gained possession of the entire river and controlled the railroads which connected the states west of the river with those east, the three western states found it difficult to send men and supplies to the armies across the Mississippi.

The fate of the Confederacy was decided even more in the territory from the Mississippi to the Alleghany mountains. Most of this was comparatively level and not very well settled. The northern part is crossed by the Ohio, which was always in the possession of the Union troops except the very important points where the Ohio meets the Cumberland, the Tennessee, and most of all the Mississippi. Farther Territory between Mississippi and the Alleghanies.

Semple, Geog.

Conditions, 302-308.

south the Cumberland crosses northern Tennessee, and the Tennessee River after crossing the state of that name gives 


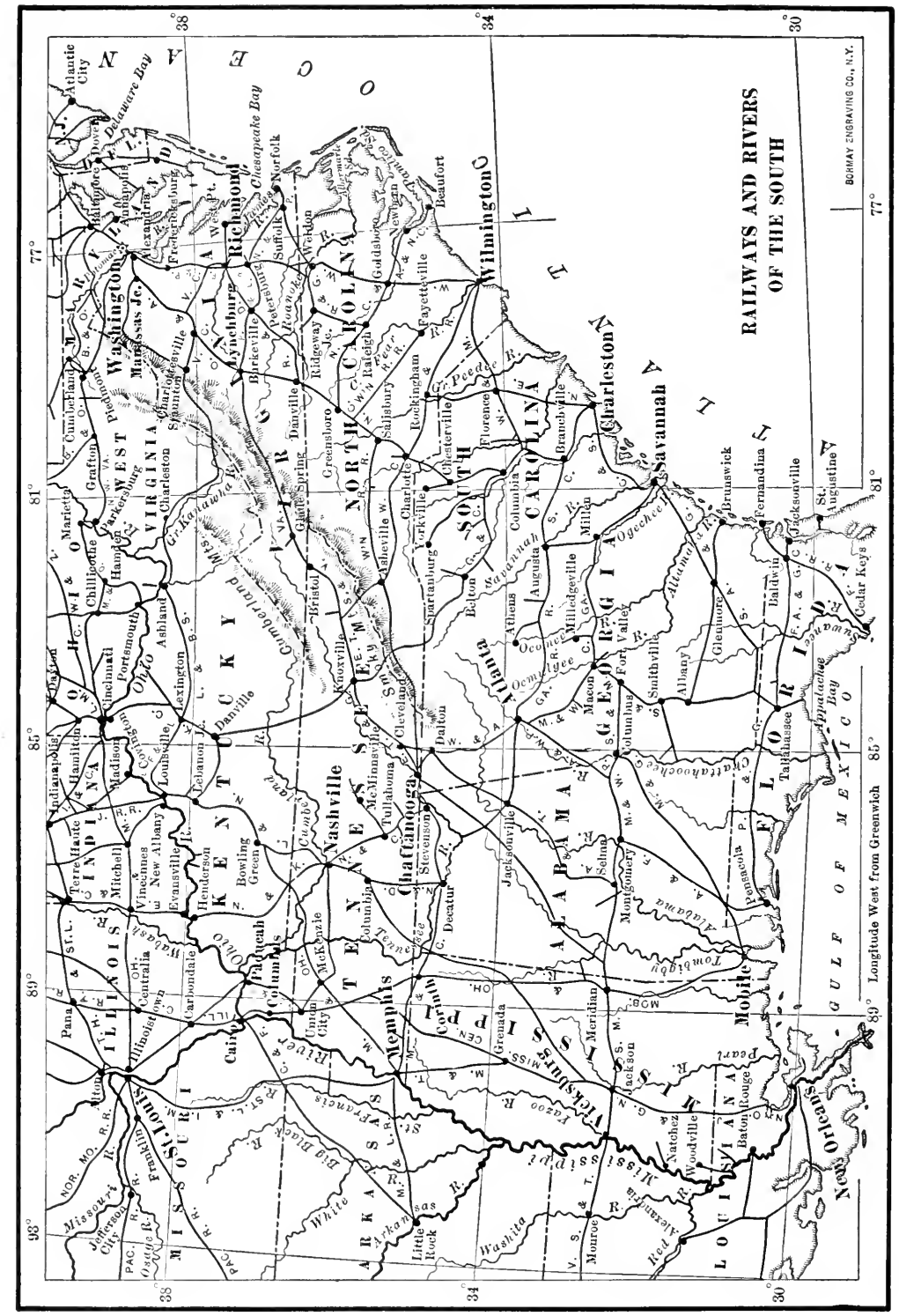


entrance to northern Mississippi and northern Alabama. Railways ran in 1862 from the junction of the Mississippi and the Ohio to New Orleans and Mobile. East and west railways extended from Memphis to Chattanooga and Charleston, and from beyond Vicksburg to Atlanta, Savannah, and Charleston.

The most important points for the attacking Union force

Strategic points in the West.

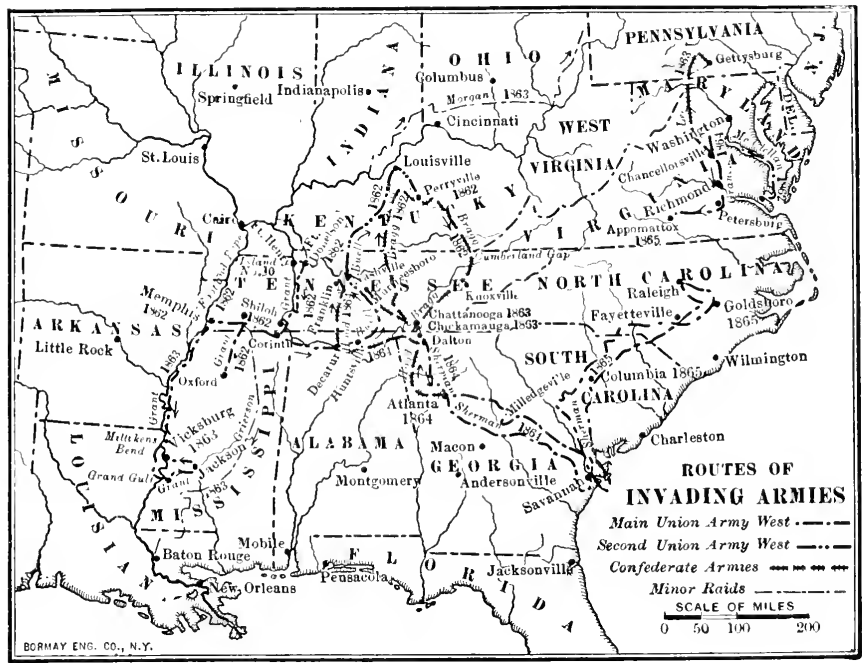

to gain were Cairo and Paducah on the line of the Ohio; Memphis, Corinth, and Chattanooga along the southern boundary of Tennessee; New Orleans and Vicksburg on the lower Mississippi, and the railway center, Atlanta, in north-central Georgia, on the border line between the west and the east. The location of these places should be noted carefully and the maps should be used constantly to ascertain the general routes of the Union forces.

348 Grant's Campaign in the West (to February, I 862). - When the Confederates seized and fortified the bluff at Columbus, Kentucky (September, I86I), General Grant, who had already occupied Cairo, took Paducah also and thus

Seizure of the line of the Ohio.

Grant. 
Rhodes,

United States,

III, 594-598.

Hosmer, $A p$ peal to Arms, 84-9o.
Capture of the first Confederate line.

Dodge, Civil Itar, 25-28.

Fiske, Miss. lalley, 52-66.

gained possession of the entire line of the Ohio. Ulysses S. Grant was a West Point graduate who had done excellent service under both Taylor and Scott during the Mexican War. Before I86I he had been engaged in business without very great success near St. Louis and later at Galena, Illinois. A man of few words, in all his campaigns he acted with a

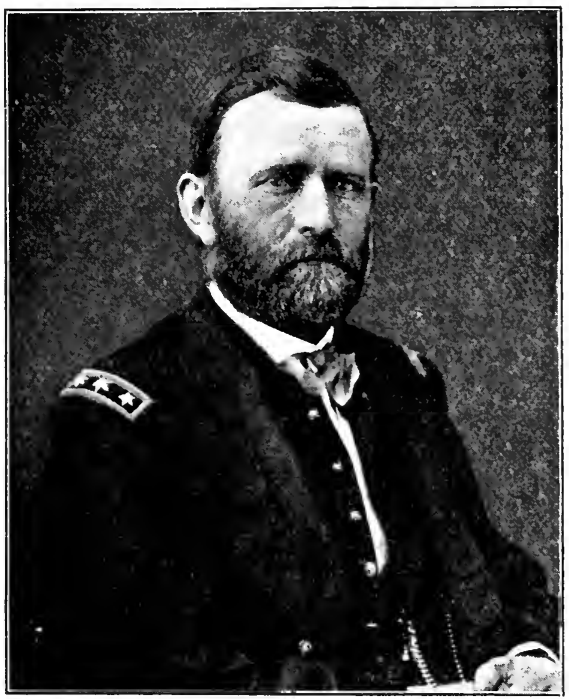

ULYSSES S. GRANT promptness and carried his plans to completion with a determination that brought results. He showed good judgment in the selection of his immediate subordinates, but was often imposed upon by men whose motives he believed to be as pure as his own.

The next forward movement of the army was to capture Columbus, Island No. Io, and forts Henry and Donelson, so as to open the Mississippi, the Tennessee, and the Cumberland by taking the first line of forts. Farther east the Confederates were driven out of Kentucky by Thomas. ${ }^{1} \quad$ Fort Henry was captured by Admiral Foote and his fleet of gunboats, the garrison withdrawing to Donelson, which was much stronger. A combined land and water attack was made on Donelson, during which Grant demanded the "unconditional surrender" of the fort. On February i6 Grant won his first great victory by capturing Donelson, with its garrison of nearly fifteen thousand men. His

1 Battle of Mill Springs, January I9, 1862. 
chief difficulties had been due to the undisciplined character of his troops, the strength of the fortifications, and the severity of the weather. The capture of Donelson left the way open to Nashville and compelled the Confederates to withdraw from Columbus.

349. Completion of the Western Tennessee Campaign. Grant's successes on the Tennessee and the Cumberland

Battle of Shiloh (April, I862).

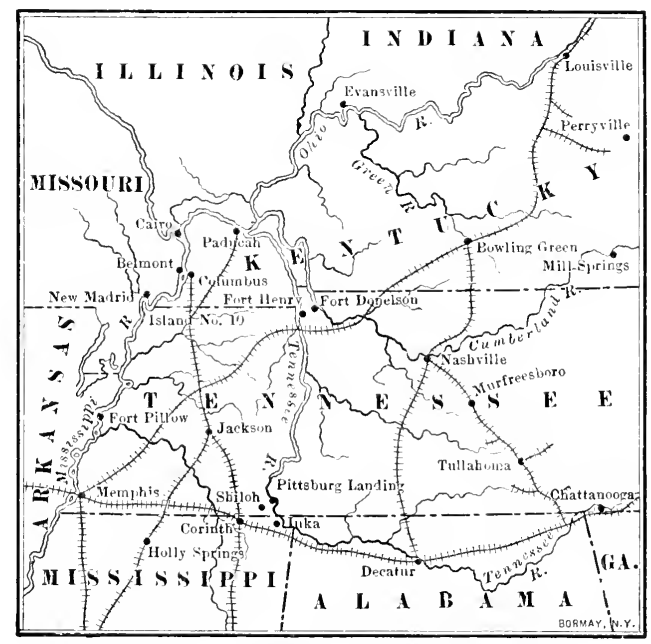

WESTERY KENTUCKY AND TEXNESSEE

Rivers were followed by Pope's capture of Island No. Io after an energetic campaign, March, I862. Grant had at once advanced to Pittsburg Landing on the Tennessee River, the nearest point for an attack upon Corinth, which was at the junction of the north and south railway with that from Memphis to Chattanooga. At this point he waited for reënforcements to arrive from Nashville. His divisions were badly scattered and the army in no condition for advance or defense. Less than thirty miles away was a Confederate Dodge, Civil War, $42-48$.

Johnson, If ar of Secession, I32-I 45 .

Battles and

Leaders, army nearly as large as Grant's under Albert Sidney Johnston, one of the most experienced officers of the old regular army and at that time considered the ablest military leader 
on either side. Suddenly before daybreak, April 6, the Confederates attacked the advanced brigades of Grant's scattered force near Shiloh church. Several thousand prisoners were taken and the Union troops were driven back in the attempt to get between them and the river. That the Union army was not destroyed at the outset was due largely to the courage of the soldiers, and the skill and determination of William T. Sherman, for Grant was absent and at least ten thousand of his soldiers could not report for duty on the field of battle. The death of Johnston and the stubbormness of the Union defense saved Grant's army that day, and the arrival of Buell's army from Nashville and other troops so strengthened Grant that he overpowered the Confederates the next day, although he did not follow up his victory.

Capture of Corinth and Memphis.

Larned (ed.), Reudy Réf., 3+6I-3+69.

Fiske, M/ss. lalley, I3j-137.

Plan of campaign, I862. Progress of the blockade.

Dodge, Cizil Hiar, 33-39.

Johnson, If iar of Secession, 90-98.

General Halleck, who had charge of all western armies, now took command of all the troops at Shiloh and advanced against Corinth. With his greatly superior force he pressed back the Confederates, who abandoned this strategic point without a battle. After he had gained possession of the east and west railway at Corinth and at points east, Memphis surrendered to Admiral Foote, who had defeated the Confederate fleet on the Mississippi.

350. New Orleans (I862). - The advance of the Union armies from the north along the Tennessee and the Mississippi was but part of a much larger plan which included not only the opening of the Mississippi by attacking New Orleans also, but the advance upon Richmond and the capture of important places on the Atlantic or Gulf coasts which could be made the bases of operation for the fleets or blockading squadrons. The United States nary had already gained a foothold on the islands off the coast of North Carolina. A Union fleet had captured Port Royal and had gained control of most of the inlets between Charleston and Savannah. In this way the blockade of those ports and a few others on the south Atlantic coast was made very effective. The capture of New Orleans was desired not simply because it was on the Mississippi, but because its nearness to the cotton belt made 
it easy to ship that staple from the city. On account of the three mouths of the Mississippi it was very difficult to maintain an effective blockade.

The naval expedition against New Orleans was intrusted to Admiral Farragut, a southerner of the greatest ability, who remained loyal to the Union. With a large fleet of wooden vessels, and mortar boats under Admiral Porter, Farragut attacked the forts on opposite banks of the river, which constituted the chief defense of the city. After several days' bombardment, the chain across the river which connected the forts was cut, the Conferlerate fleet was overpowered, and the Union vessels ran past the forts. The city surrendered at once, April 25, and the forts held out only a few days longer.

351. The Theater of War in Virginia. - In the East the advance of the Union armies was as difficult as it was easy in the West. From Washington to Richmond is about roo miles as the crow flies, but the country is as hard to traverse as 500 miles along the Mississippi or the Tennessee. Below the Potomac three rivers cross eastern Virginia, flowing in a southeasterly direction. Farthest north is the Rappahannock, which, at Fredericksburg, is but ten miles from the lower end of the great bend of the Potomac. South of this is the York, and still farther south the James River, with Richmond located at the first scries of falls over roo miles from Chesapeake Bay. Between these rivers the country was wild and almost impassable. Near the coast were swamps, farther inland hills, and everywhere forests. Roads were few, although in 1862 there was a railway from the Potomac above Fredericksburg to Richmond and other southern cities, besides the railway running through Manassas to Lynchburg and Chattanooga.

To these physical difficulties encountered in an advance on Richmond, there was added the problem of defending Washington. On the side of the Potomac there was nothing to fear so long as the Union side had fleets and the Conferlerates had none. The great danger arose from the Shenandoah

Capture of New Orleans.

Larned (ed.), K'eady kef., $345^{8}-3460$.

Johnson, Il ar of Secession, I II-I 26.

Country between Washington and Richmond.

Semple, Geog. conditions, 289-293.

Defence of Washington and Shenandoah valley. 
Semple, Geog. valley. Harper's Ferry, at the confluence of the ShenanConditions, 293-300. doah and the Potomac, is but thirty miles west of Washington and twenty miles north, so that a force crossing the Potomac at this point could threaten Washington from the rear. The upper part of this fertile valley, sometimes called the " gran-

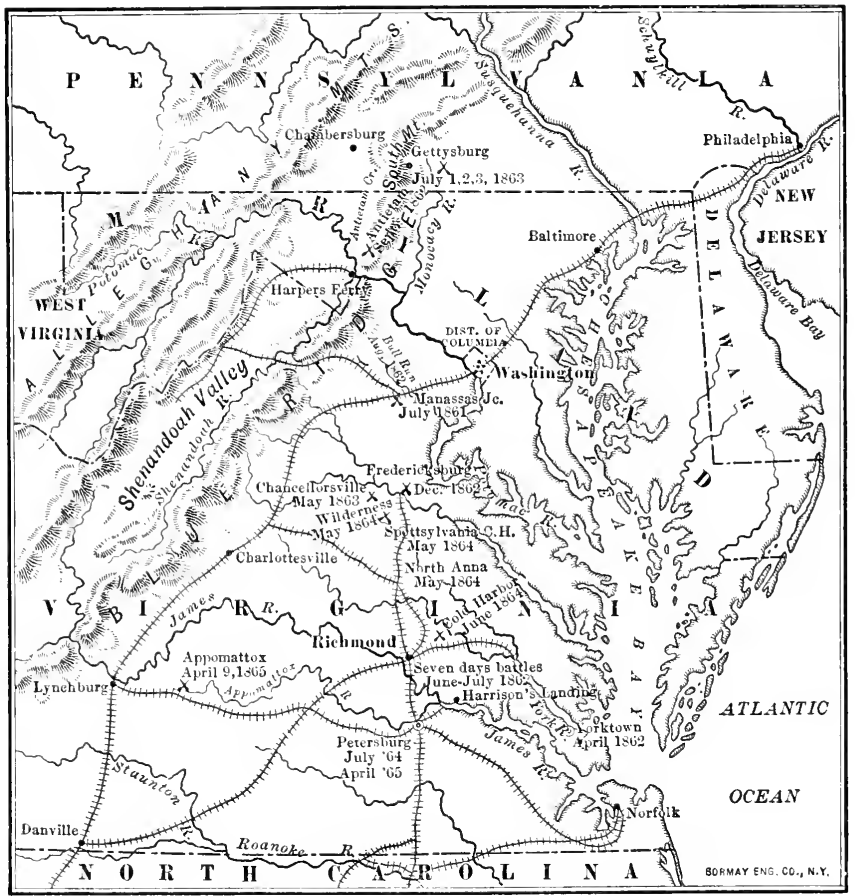

THEATRE OF WAR IN VIRGINIA

ary of the Confederacy," is divided into two parts, a range of hills separating the valley of Cedar creek from that of the upper Shenandoah. A retreating army could withdraw up one of these valleys, cross into the other, and either escape into central Virginia through the many passes of the Blue Ridge or get between Washington and the Union force that had been following them. Because of the geography of northern Virginia a single Confederate army, if it pos- 
sessed a fairly large body of cavalry or rapid-moving troops, might compel the Union commanders to keep one army south of Washington to prevent a direct attack on that city and might at the same time threaten and keep engaged an equally large Union force in the Shenandoah valley.

352. Monitor and Merrimac. - Because of the difficulty of crossing eastern Virginia, it was decided early in 1862 to attack Richmond by transporting the troops to the peninsula formed by the James and York rivers. This plan was no sooner adopted than its execution was endangered by the arrival in the lower Chesapeake of a powerful Confederate ironclad, the Virginia or Merrimac, which threatened to destroy the Union vessels in those waters and all fleets sent to that quarter. This ironclad had been constructed from the hulk of a Union vessel, the Merrimac, which had been sunk in Norfolk navy yarrl, when Norfolk with its many sunken vessels and fine guns had been abandoned hastily the preceding April. 'The new Merrimac, with its coat of heavy armor, attacked first the wooden ships at Hampton Roads. On March 8, I862, she destroyed the Cumberland and the Congress and drove the Minnesota ashore. Alarm spread throughout the North, due to the fear that she might attack Washington or the shipping in New York harbor or even bombard the commercial metropolis.

That night the ironclarl Monitor arrived at Hampton Roads. It had been designed by John Ericsson, a native of Sweden, the chief inventor of the screw propeller for steam navigation. It had been constructed at New York in three months for just this emergency. For two hours on the morning of March 8 these two ironclarl vessels fought each other at close range, until the Merrimac withdrew, not disabled but baffled, never again to be used for offensive purposes. A new era had dawned in the history of naval warfare, an era of steam and steel replacing the old epoch. of canvas and oak.

353. McClelian's Peninsular Campaign. - The destruction of the Merrimac made it possible to carry out McClellan's

First contest between ironclads.

Battles and

Leaders,

I, 70I-7II.

Rhodes,

United States, II I, 608-6I4.

Merrimac.

Battles and

Leaders,

I, 692-70I.

Johnson, War of Secession, I $27^{-1} 3$ I. 
Situation in Virginia

(April, I862).

Vood-

Edmonds, Civil Har, 42-53.

Hosmer, Appeal to Arms, I 25-I32, I $38-153$.

Battles on the peninsula

Cambridge llod Hist., VII, 474-479

Dodge, Civil War, 52-68.

Hosmer, $A p$ peal to Arms, I32-I37, I5t-I66. plan of an advance upon Richmond from the east. Since the beginning of the war the motto of the New York Tribune had been echoed throughout the North, "On to Richmond," to which there came always the same reply, "All quiet on the Potomac." Everywhere the question was asked, "Why doesn't McClellan move?" At last this slow organizer of armies was ready, but delay was caused by friction with the President, who was fearful that Washington

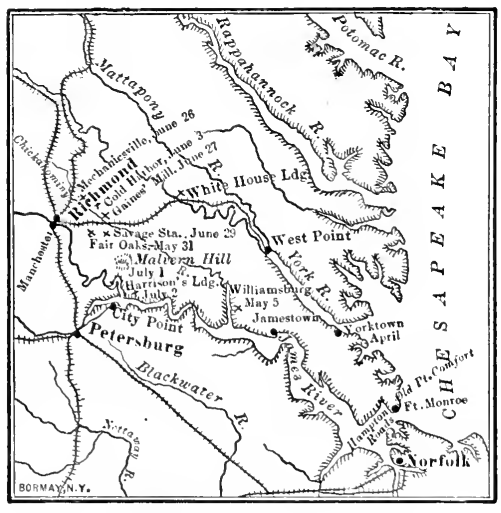

PEAINSULAR CAMPAigN might be captured and wished a large part of the army of the Potomac to be left for its defense. McClellan demurred, especially when McDowell's army was detached from his force. But the danger to Washington seemed real to the politicians, for, in the Shenandoah valley, "Stonewall" Jackson and his light infantry defeated three armies containing nearly three times as many men as his own and finally withdrew almost unharmed to aid in the defense of Richmond.

McClellan felt crippled by the loss of these troops, but he still outnumbered his opponents, at first two to one. But McClellan always orerestimated the size of the Confederate forces and never realized the value of rapid movements. He lost nearly a month besieging Yorktown, defended by wooden guns, and, compared with his own army, a handful of troops, who withdrew as soon as he was ready to attack. In a rather swampy region, in mud that made rapid marching impossible, he finally penetrated to within five miles of Richmond, drove back the Confederates, wounding the commanding general, J. E. Johnston, and waited for reënforcements. Every day saw the defense of Richmond 
stronger and the Confederate army larger. At length, the last week of June, General Robert E. Lee, ${ }^{1}$ who was now in command, attacked the scattered line of the northern army.

With vigorous blows he attacked the Union right so as to cut $\mathrm{Mc}$ Clellan's line of communications with the York River. McClellan easily changed his base of operations to the James River and withdrew to Harrison's landing. For seven days Lee attacked, in many cases his entire army being pitted against a part of McClellan's detached forces. McClellan showed himself skillful in con-

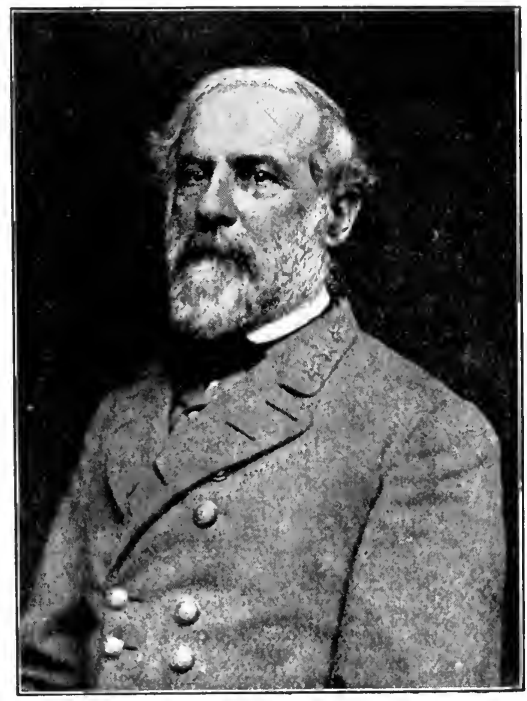

Robert E. LeE ducting his retreat, but failed to take advantage of several opportunities to march on Richmond or to destroy parts of Lee's army which were in perilous positions. Nothing had been accomplished, but the North had discovered the great difficulties of capturing the Confederate capital.

1 Lee was a Virginian who resigned from the United States army when his state seceded. A West Point graduate, he had served with distinction as chief of engineers in the Mexican War and had been superintendent of the academy at West Point for several years. His action in withdrawing from the Union army has been the subject of extended discussion, but was caused by his belief that his allegiance was due to his own state. In western Virginia he did not distinguish himself, but, as he gained more experience, his real military ability became evident. Beloved and respected by his men, he made the army of northern Virginia one of the finest bodies of soldiers in modern times. Probably no man in America during this period, except the great president of the Union, so won the hearts of the people, North and South, as did "Uncle Robert." 
The Middle Period of the War (August, i862JUNE, I863)

Lee's first invasion of the North.

Cambridge Mod. Hist., $480-483$.

Johnson, War of Secession, 173-183.

\section{t}

354. The Fall of 1862 . - General Halleck had now been transferred to the command of all the Union armies. He

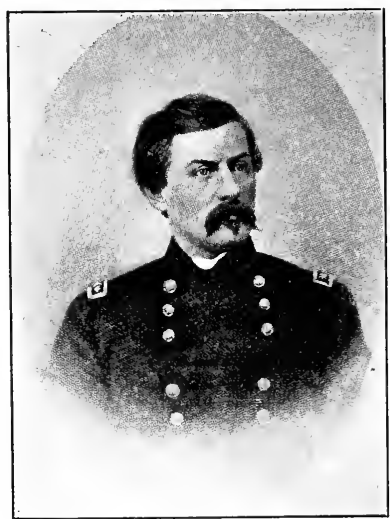

GEORGE B. MCCLELLAN ordered McClellan to withdraw from the peninsula and placed Pope in charge of the forces before Washington. Lee immediately assumed the offensive, and proceeded north rapidly from Richmond. Before McClellan could join Pope, Jackson had gained the rear of the army at Bull Run and Lee attacked in front. Blunder followed blunder, and Lee had little difficulty in winning from a superior force the second battle of Bull Run. This victory remored all possible danger of renewed campaigns against Richmond.

The time seemed propitious for an invasion of the North.

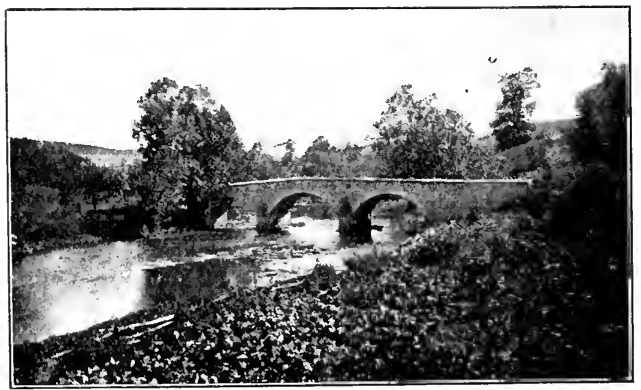

ANTIETAM BRIDGE

Antietam and Fredericksburg.
Maryland had been interested in the Confederacy and there was hope still that she might be detached from the Union, while a successful campaign north of the Potomac would give 
the Confederacy prestige abroad which it had not yet been able to gain. The Union army, again under McClellan, met Lee at Antietam creek. The battle was a Union victory, although Lee with an inferior force outgeneraled his opponent. Lee recrossed into Virginia without pursuit being organized. Burnside was now placed in command of the army of the Potomac, against his own wishes, and in December attacked Lee's fortified position at Fredericksburg on the Rappahannock. The result of a direct assault was to have been expected, but the days following this sickening Union defeat were the darkest of the whole war.

While Lee was leaving McClellan on the Peninsula and marching north, Bragg withdrew part of the Confederate army from before Corinth. Then Bragg assumed an even bolder course than Lee. While the latter was invading Maryland, Bragg dashed past Buell into Kentucky with the hope of seizing Louisville and perhaps Cincinnati and completing the panic which would be caused by a successful invasion in the East. Buell reached Louisville first and a few weeks later drove Bragg from Kentucky by defeating him at Perryville. The last day of the year I 862 these armies came together again at Stone River, and battled this time for the control of central Tennessee. After two days' severe fighting the Union force was left in control of the field.

355. Events Leading to Emancipation. - On January I, I863, President Lincoln issued his famous Emancipation Proclamation. The policy of emancipation had been developed slowly, for since the beginning of the war the government had been troubled by the problem of the negroes. Lincoln had disclaimed from the time of his inauguration that the war was waged to free the slaves, although many people at the North were more interested in the abolition of slavery than in any other national question, and most of the people in Europe believed that the war was essentially a struggle to preserve or destroy slavery. General Butler at Fort Monroe had suggested the best plan for dealing with the negroes who flocked to his camp. He declared that they

Dodge, Civil IVar, IO2-II5.

Battles and

Leaders, II, 663-674.

Bragg's invasion of Kentucky.

Dodge, Civil

Har, 82-88.

Rhodes,

United States,

IV, I73-I8I.

Battles and

Leaders,

III, I-25.

Problem of negro fugitives.

Cambridge Mod. Hist., VII, 580-582. 
were an aid to the enemy in carrying on the conflict, and should be treated as "contraband of war." Colored fugitives were known afterward as " contrabands."

Emancipation before July, I862.

Cambridge, Mod. Hist., VII , 582, 587.

Rhodes, Inited States, IV, 60-66.

Larned (ed.), Ready Ref. V, 3453,3402 , $3464,3+73$.

Hosmer, Athfeal to frms, 20I-2I 2.

Lincoln's views on emancipation.

Cambridge Hod. Hist., 585-59I.

Rhodes, Cinited States, IV, 66-76.

In August, iS6r, Congress passed a confiscation act freeing the slaves who aided the Confederates. Two of the Union commanders, Frémont in Missouri (IS6I) and Hunter in South Carolina and Georgia, applied this by declaring free all slaves in their districts. Their acts were overruled by Lincoln who claimed and exercised the right to deal with the slaves in the seceding states. Lincoln used his influence to persuade Congress to rote money for the compensation of slave owners in the loyal border states and tried to have those states agree to compensated emancipation, but the conservatives in Congress and in these states defeated the plan. Lincoln's purpose was chiefly to attach these states irrevocably to the Union by breaking the only bond that might exist between them and the Confederate states. Congress did, however, free the slaves in the District of Columbia, paying an average of more than \$200 each to their owners. On June I9, IS62, it abolished slavery in the territories without compensation.

356. Emancipation. - Lincoln was among the first of those in authority to realize the need of emancipating the slaves of those in insurrection against the government. $\mathrm{He}$ considered it simply a war measure that would aid the Union cause. On July 22, IS62, he read to his cabinet the first draft of an emancipation proclamation, but the matter was kept secret and postponed because the issuance of the proclamation in the midst of the defeats of the armies in Virginia would appear like a call for help to Europeans who disliked slavery. Lincoln's object was shown clearly when a month later he replied to the unjust criticism of Horace Greeley in the New York Tribune, because the President had not freed the slaves. He wrote, "I would save the Union. I would save it in the shortest way under the Constitution. . . My paramount object in this struggle is to save the Union and is not either to save or to destroy slavery. 
If I could save the Union without freeing any slave, I would do it; and if I could save it by freeing all the slaves, I would do it; and if I could save it by freeing some and leaving others alone, I would also do that."

Soon after the victory at Antietam in September, 1862, President Lincoln issued his preliminary proclamation, Proclamation stating that on January I, I86.3, he would free the slaves

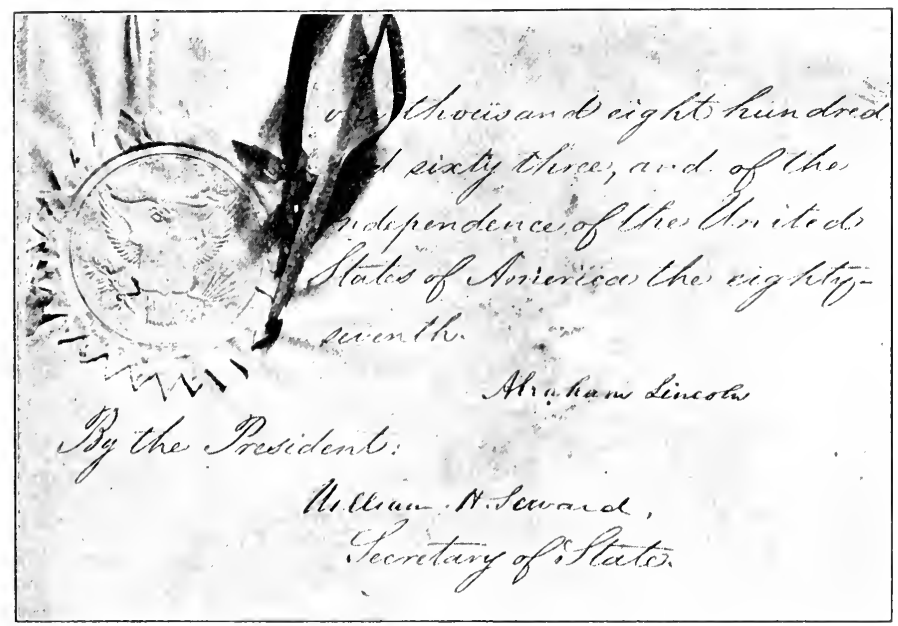

Emanciation Proclamation (Closing Page)

in those states or parts of states that were in insurrection against the United States. This was done by the regular proclamation on New Year's Day. The proclamation did not affect slavery in the loyal parts of the Union, in some of which it was abandoned, however, by state action before the adoption of the thirteenth amendment. It dirl not abolish the institution of slavery even in the states then actual parts of the Confederacy. It intensified the opposition of the South to the invasion of the Union armies, but it almost destroyed hope of recognition by Europe of a Confederacy based on slavery. It did not affect radically the attitude of the people in the Macionald, Statutes, No. 28.

Cambridse Hod. Hist., 59 I- 597 .

Rhodes,

United states, IV, $157-163$. 212-217. North toward the government's policy, although it met with approval in most of that section. 
Chancellorsville (May, I863).

Dodge,

Civil Il'ar, I27-I3I.

\section{Battles and}

Leaders, III, I5t-I 7 I.

Invasion of Pennsylvania (June, I863).

357. Chancellorsville; Lee's Second Invasion. - The series of disasters to the army of the Potomac was to be completed at Chancellorsville, May, I 863. "Fighting Joe" Hooker, who had replaced Burnside, sought to get in the rear of Lee's army by making a long detour to the west. He began this morement successfully, but the rigor with which Lee attacked him paralyzed the Union leader and gave Lee an overwhelming victory over an army much larger than his own. At Chancellorsville,

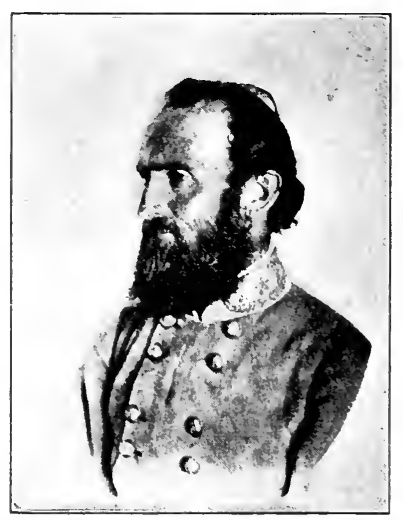

ThOMAS J. JACKSON however, Lee lost Jackson, who had been an invaluable help in executing difficult and dangerous morements whose success depended chiefly upon the rapidity and audacity with which they were made.

Lee now decided to invade the North a second time, hoping that he might seize some of the northern cities and that even if he did not succeed to that extent, he might create a panic throughout the North

Dodge, Civil War, I27-I3I.

Battles and Leaders, III, $244^{-25}$.

that would compel that section to make peace. Lee marched to the west of Hooker's army, separating his divisions so that only the timidity of those in authority at Washington permitted the completion of this difficult movement. The chief duty of the army of the Potomac, according to the views of the chief commander, was to stand between Lee's sixty or seventy thousand reterans and the national capital. Lee was advancing into Pennsylvania when the Union commander was replaced by another, General George Meade, who threatened Lee's communications and hurriedly gathered his scattered army to meet the invasion. Lee turned aside from his march into central Pennsylvania in order to meet Meade marching rapidly from Washington. 
Union Adrance（July, I863-July, I864)

358. Gettysburg. - The two armies came together near July $\mathrm{I}$ and $\mathbf{2}$ the village of Gettysburg, in southern Pennsylvania. Fighting began on July I, only a few divisions being engaged on each side. On July 2, the battle began in earnest, the

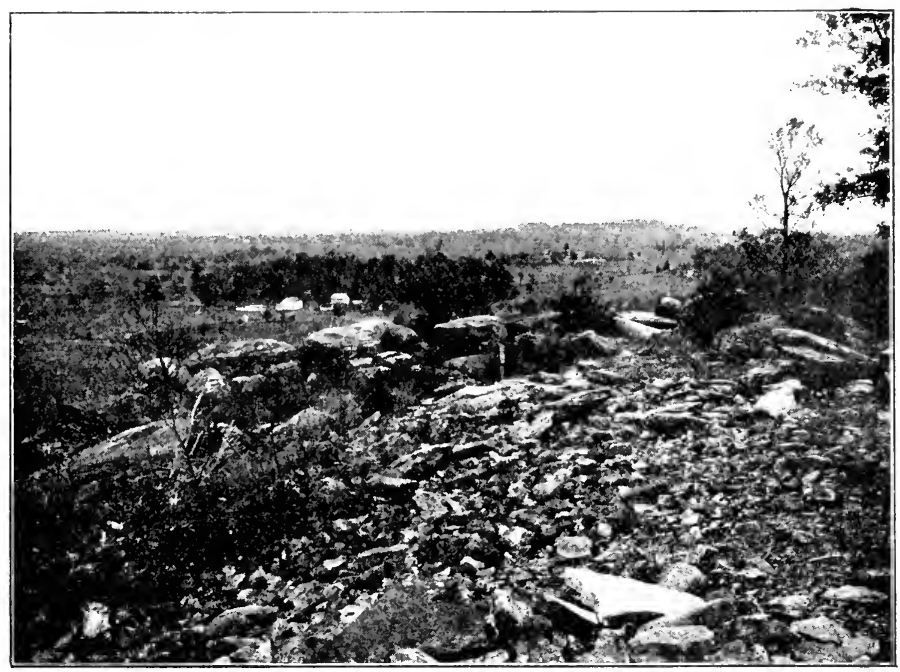

GeTtYSBURG BATtLefiell)

(From Little Round Top)

Union forces having occupied a long ridge which ended in two detached hills known as Round Top and Little Round Top. Across a valley less than a mile wide, the Confederate army

Dodge, Civil IVar, I36-I4I. was intrenched. Other divisions of Lee's force were stationed so that they might attack the right flank of the Union army, and, if successful, get in its rear. The real fighting Hosmer, $A p$ peal to Arms, $287-298$.

of the second day, however, was for the possession of the two Round Tops which commanded the entire Union position. Had the Confederates gained and held these heights, Meade's army must inevitably have retreated. The second day closed with the Union line intact. 
July 3 .

Rhodes, Inited States, IV, 286-290.

Battles and Leaders, III, 309-385.

On the afternoon of the third day began the final struggle in the most spectacular charge of the war. It opened with a tremendous artillery contest, the Confederate fire being concentrated on Cemetery Ridge, the Union center, which Lee desired to seize. When the Union guns ceased fire at length, there appeared from the woods opposite Cemetery hill three long lines of soldiers, the "best fighters of the Confederacy," who marched across the valley against the Union position. Upon them

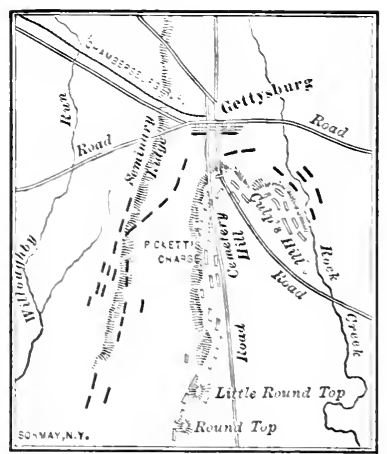

GETTISBLRG BATTLEFIELD-LAST DAY

Cniun furces $\Longrightarrow$ the Union batteries opened with renewed vigor, but they marched on, charged up the hill, even over the embankments, their ranks thinned by the terrible fire from cannon and musket. Futile though it was, for the survivors were beaten back easily, this gallant charge marks the high-water mark reached by the Confederacy. Never again was an invasion of the North attempted, and from this time the fortunes of the Confederacy ebbed steadily, it being a question of time only until the authority of the Union would be reëstablished everywhere in the South.

Difficulties in attacking Vicksburg.

Dodge, (iail lliar, $\mathrm{I}_{4} 2-\mathrm{I}_{4} \mathrm{i}$.

Brigham, Gougrataic Intiuenies, $21 \mathrm{I}-2 \mathrm{I} / \mathrm{z}$.

359. Vicksburg. - The Union victory at Gettysburg on July 3 was accompanied by the capture of Vicksburg on July +. Because of its location on the Mississippi, the strength of its fortifications. and the difficulties of maneuvering in the country around Vicksburg, this campaign was one of the most important and remarkable of the war. Vicksburg is located on a high bluff at the outer end of a huge

${ }^{1}$ Fifty years later the survivors of that terrible charge went up Cemetery Ridge, where the survivors of the Union force again received them warmly, this time with open arms. with hearty hand clasps, and with friendly embraces. Could we have any better proof that the United States of America is a real Union? 
bend of the riverso that batteries on the bluff commanded the Brigham, river for miles in either direction. Attempts were mate in I 862 , and in the spring of $186_{3}$, to reach the city from the (icoscraphic Influenes, 211-217. north, or directly from the west.

Grant tried at first to land north of the city; but when he found that this was impossible, he decided to move his army in a semicircle through the swamps of Arkansas, and, by landing south of Vicksburg to attack the city from the southeast. This movement was attended with great risk, because his long line of communications was exposerl, and because defeat would leave him at the mercy of his foe. He succeeded finally in opening a water route through Arkansas. 'The

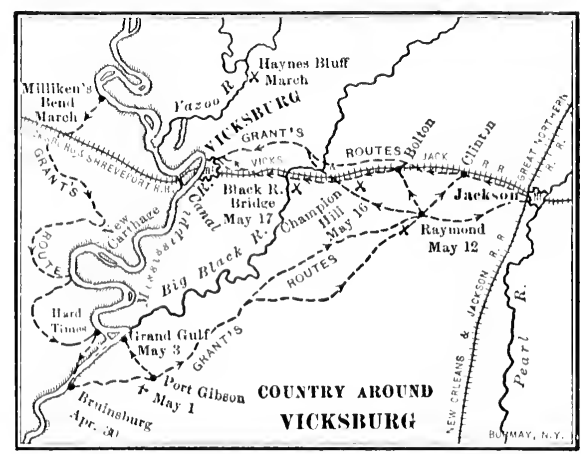

Grant's route against Vicksburg.

Dodge, Cizul IVar. 147-155.

gunboats above Vicksburg passed the batteries so as to aid him in crossing, and, late in April, he landed his army in Mississippi thirty miles below Vicksburg. Grant moved rapidly considering the physiographical difficulties encountered, and by the middle of May hald thrust himself between Pemberton, who commanded the army around Vicksburg, and the forces farther east. Joseph E. Johnston was coming to the aid of Pemberton and ordered that general to abandon Vicksburg and join him, but Pemberton thought his own plan better and kept between Grant and Vicksburg. He was driven back into the city without delay.

Grant tried at once to take the fortifications of Vickshurg, for he feared that Johnston would either unite with PemCapture of berton or would attack Grant's army in the rear. The works were too strong to be captured by assault, but John- 
Dodge, Civil War, I56-I6I.

Chattanooga.

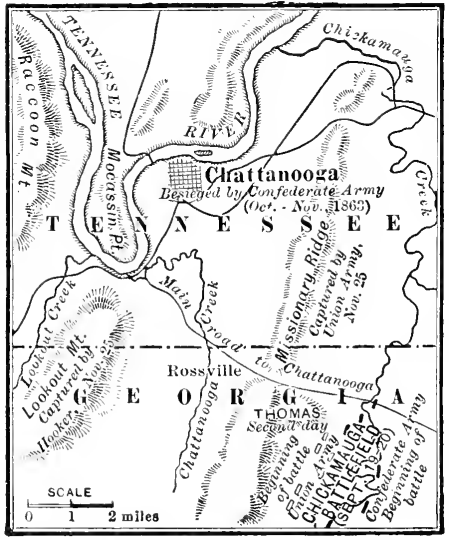

COUNTRY AROUND CHATTANOOGA

Showing Battlefields and Sieges (1863) son less than a week later.

ston remained inactive, and Grant was able to lay siege to the city. A merciless bombardment was kept up by the fleet and army, but the fall of the city after six weeks was due to the scarcity of food. On July 4 Pemberton surrendered with his army of more than thirty thousand men. The Mississippi was opened completely by the fall of Port Hud'-

360. Operations around Chattanooga (I863). - The capture of Vicksburg limited greatly the sphere of hostilities, confining it in the South to the area around Chattanooga and those districts in Alabama and Georgia which could be reached most easily from Chattanooga. ${ }^{1} \quad$ Chatta. nooga, the key to all this region, lies in the narrow valley of the Tennessee with mountains on the northwest, and completely surrounding it on the south. Toward the east a

Dodge, Civil War, I72-I78.

Fiske, Miss. Valley, 248-264.

range several hundred feet high, called Missionary Ridge, commands the city, and on the south a higher mountain, Lookout Mountain, threatens the place. To Chattanooga Bragg was forced to withdraw from near Stone River ( $\$ 354$ ), during the summer of $\mathrm{I}_{86}$, but Rosecrans found it difficult to drive his opponent from the city. He finally sent his divisions over the mountain trails across the ranges south of the city in order to cut Bragg off from his base of supplies.

1 The Confederates still held Mobile, Alabama, and places as far west as Meridian, Mississippi, but this hold was very slight and could have been broken entirely, if the troops had not been engaged in more important enterprises. 
Bragg immediately withdrew from Chattanooga (Sep- Chickamauga tember), but as soon as he was reënforced, fell upon the advanced divisions of Rosecrans's army at Chickamauga Creek (September I9 and 20). The wings of the Union army were driven back in terrible disorder, but Thomas with the center formed his lines in a semicircle and withdrew slowly, holding at bay a force much more than double his own. The firmness of this reliable soldier, himself a southerner, saved the Union army. He was known thereafter as the "Rock of Chickamauga."

Thomas now took command in place of Rosecrans, but was practically besieged in Chattanooga by Bragg, who held both Missionary Ridge and Lookout Mountain. So difficult was it to get supplies that the army was at one time on very short rations. The arrival of Grant with reënforcements from Vicksburg relieved the situation, and plans were made at once to get control of the heights about the town. Late in November, the troops were ordered to seize the rifle pits at the foot of Missionary Ridge. These were taken without difficulty and the elated soldiers without orders rushed up the hill and drove the Confederates from the top of the ridge - a reckless move only justified by its success. The Union army was now in complete control of Chattanooga and its approaches.

36r. Naval Operations (1864). - During I863, no extensive naval operations were undertaken along the seacoast, although the blockade was strengthened and Charleston blockaded more carefully. In I864 two important attacks were made: one at Mobile, the other at Wilmington, North Carolina. The forts of Mobile Bay were captured in August, I864, by a fleet under Farragut. The wooden ships and monitors steamed past the forts at the entrance to the bay, crossed the mines and torpedoes with the loss of a single vessel, destroyed a powerful Confederate ironclad, and closed the port to blockade runners.

The attack on Wilmington was less successful. WilmingMissionary Ridge.

Dodge, Civil War, I79-I83.

Fiske, Miss. Valley, $26+-280$.

Dodge, Civil Itar, 184-189.

Larned (ed.), Ready Ref.,

$\mathrm{V}, 35^{10}-35^{1} 3$.

Mobile.

Cambridge

Mod. Hist., VII, $55 t-556$.

Larned (ed.), Ready Ref., 3537 . ton was defended by a very strong fort called Fort Fisher.

Wilmington. 
Cambriage Mod. Hist., VII, 556-558.

The Alabama.

Larned (ed.), Ready Ref., I, 24-26.

\section{Battles and} Leaders, IV, 600-6I4.

Privateers and shipping.

\section{Cambridge}

Mod. Hist., VII, 565-567.

Johnson, It ar of Secession, 402-4I2.
On account of the two mouths of the Cape Fear River and the strength of that fort, Wilmington had remained open to the blockade runners until this time. ${ }^{1}$ As the Union forces controlled all the railways except those in the Carolinas and southern Virginia, Lee's army was dependent on Wilmington for food and supplies. Fort Fisher was attacked in December, I864, but only after great losses, in February, I865, did it surrender.

In the year I864 the most successful of the Confederate commerce destroyers were sunk or captured. A few of these had been fitted out in southern ports, but those that did the most damage were of British build and in some cases had been allowed to proceed from English ports after the American minister, C. F. Adams, had protested that they were to be used against northern commerce. The Alabama had the most successful career. After a cruise of two years, in which she captured no less than sixty-nine vessels, she fought the American warship, Kearsarge, off the harbor of Cherbourg, France, in June, I864. The ships seemed evenly matched, but the duel was short, and in less than two hours the Alabama sank.

Although only two hundred and sixty-one prizes were taken by all of these privateers, they practicaily drove American merchantmen from the high seas. ${ }^{2}$ Before the war Great Britain and the United States carried an equal amount of shipping, but in I866 American vessels carried only about one half as much as they had in I860. The use of steamers in place of sailing vessels and of steel in place of wood was responsible also for the decline of our merchant marine.

${ }^{1} \mathrm{H}$. W. Wilson, in Cambridge Modern History (Vol. VII, p. 557), gives the following statistics of supplies entering the port at Wilmington between October 26, I864, and January, r 865: 8,632,000 lb. of meat, r,607,000 lb. of lead, r, 933,000 lb. of saltpeter, 546,000 pairs of shoes, 316,000 pairs of blankets, $500,000 \mathrm{lb}$. of coffee, 69,000 rifles, and 43 cannon.

2 By a tribunal held in Geneva, Switzerland, in 1872 , in accordance with an agreement reached in the treaty of Washington (I870) ( $\$ 4 \mathrm{I} 6)$, Great Britain paid the United States $\$$ I $_{5}, 500,000$ for the "Alabama claims." 
362. The Advance on Atlanta (1864). - Grant was called Plan of to Washington in the spring of 1864 to take command of all the Union armies. It was decided to have the army of the campaign (I864). Potomac and that at Chattanooga advance simultaneously so as to prevent the Confederates from shifting divisions to the point attacked, as they had been able to do formerly.

Sherman ${ }^{1}$ commanded the army in the West, whose objective point was Atlanta. Although the distance from Chattanooga to Atlanta is only a little more than one hundred miles, there are several ranges of the lower Appalachian mountains to be crossed, and only one practicable route to be followed. Over this a line of communications must be maintained after the army had passed. Sherman had a fine force of nearly one hundred thousand veterans, but he was opposed to Joseph E. Johnston, a commander but little less able than Lee in conducting a defensive campaign, with

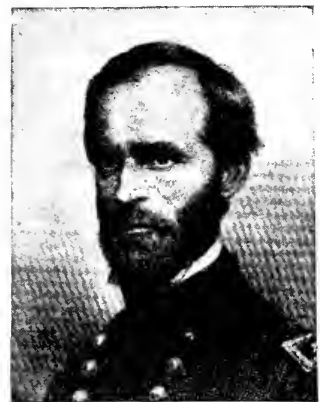

VIllia.i T. SHERMAN an army three fourths as large as his own. On account of his superior numbers Sherman was able to leave part of his force in front of Johnston, and, by moving the balance to one side, threaten his rear and compel him to abandon one fortified position after another. At Kenesaw Mountain Sherman was forced by the impatience of his

${ }^{1}$ William T. Sherman was a brother of the statesman, John Sherman, who was actively engaged in public life for more than forty years. General Sherman had been in the South before the war and understood better than almost any other northern man the character of the conflict that would follow secession. He was appointed in I86I to the district covering most of Kentucky. When he asked for 60,000 troops at once with the idea of increasing his army to 200,000 , the report became general, "Sherman is crazy," and he was removed. Had the war department been wise enough to appreciate the sanity of his views, the war would have been shortened greatly. Sherman combined caution with aggressiveness and displayed as great skill in conducting his campaigns as any other general perhaps on the Union side. 
troops to make a direct attack, which was unsuccessful; but he, as well as Johnston, avoided regular battles. Considering the skill with which both sides conducted all operations, this may be considered the best-managed campaign of the war.

Atlanta. Johnston was finally compelled by equal generalship and superior numbers to take refuge beyond the Chattahoochee

Dodge, Civil War, 255-262. River after a two months' campaign. As Johnston had never had the confidence of President Davis, he was removed and his place filled by Hood, who was preëminently a fighter. Hood attacked the Union army repeatedly, several times when everything seemed favorable to him, but he was beaten constantly. Sherman was detained a month before Atlanta, but when Hood saw that the city was doomed, he withdrew his army. Sherman at once destroyed all of the factories which had provided military supplies for the Confederate armies.

The " hammering campaign."

Rhodes, United States, IV, 440-448.

363. Grant in Virginia (May-July, I864). - Grant's task was of greater difficulty than Sherman's, chiefly because of the great ability of his opponent and the remarkable spirit of Lee's soldiers, although the latter's army was much smaller than that of Grant. In some respects the natural obstacles encountered by Grant were more serious than those of Sherman, but he did not have half the difficulty of maintaining Dodge, Civil communication with his base of supplies. Grant stated that War, 197-208, he would "fight it out on this line if it takes all summer." 213-222.

Battles and

Leaders, He started a "hammering campaign" which began in the Wilderness early in May and continued for about six weeks. IV, II8-I44. With terrific blows he massed his troops and hurled them against Lee's lines, only to be driven back invariably. Combined with these fierce attacks he kept moving part of his

Hosmer, Outcome of Civil War, Chapter VI. army to the east and rear of Lee, forcing him to abandon one position after another. The result was the same in the Wilderness, at Spottsylvania, and at North Anna, until the armies faced each other at Cold Harbor, less than ten miles from Richmond. Here Grant attempted to carry Lee's position by direct assault, but the loss of one tenth of his men in 
ten minutes tells the story of slaughter and defeat. As he could make no headway, Grant moved his army across the James and invested Petersburg, which it was necessary to wrest from Lee before Richmond could be taken. Another direct assault following the explosion of a mine led to further bloodshed. In less than three months Grant lost more men than there were in Lee's army at the beginning of this titanic struggle, but the great Confederate captain had lost only one third as many. Grant had gained ground, but the honors of war were with his opponent.

Close of the War (July, I864-April, I865)

\section{The Shenandoah Valley; Hood in Tennessee. -} During the summer of I 864 , the Confederate leaders tried to loosen Grant's bull-dog grip on the defenses of Richmond ( $\$ 363)$ by threatening Washington. Later they tried to draw Sherman away from Atlanta $(\$ 362)$ by dispatching Hood into Tennessee. Both of these movements failed to divert the determined Union commanders from carrying out their main plan.

In July, i864, Early was sent to the Shenandoah and advanced to the defenses of Washington, which was defended by home guards only. But reënforcements arrived and Early withdrew. Grant sent Sheridan to meet Early and later agreed that he should lay waste the valley, so that it could not be used for military operations. Early was driven from the Shenandoah, which was devastated completely. He returned, however, and nearly succeeded in defeating Sheridan's superior force, the magnetism of Sheridan's personality alone restoring victory after his famous ride from Winchester.

Hood was disappointed when Sherman sent only a part of Nashville. his force to protect Tennessee, while he kept the rest at Atlanta. Hood swung around through Alabama and advanced to central Tennessee. Here he was confronted by Thomas, who was gathering additional troops at Nashville.

Attempts to draw off Grant and Sherman.

Early and Sheridan in the Shenandoah.

Dodge, Civil War, 269-278.

Battles and Leaders, IV, 500-52I. Il ar, 279-285. 293-301. 
When he was ordered to attack Hood, Thomas offered to give up his command, but refused to adrance until he was ready. The middle of December, Thomas attacked. Hood's army was almost annihilated, and all danger to the Union in the West was arerted.

The march to the sea.

Dodge, Civil IIitr, 280-292.

Rhodes. Cnited States, $\mathrm{V}, 7,15-3 \mathrm{I}$.

Hosmer, Outiome of Ciril llitr. Chapter XII.

Dodge, Civil IVir, 302-309.

Rhodes, Crited states, $\mathrm{I}, 85-9 \mathrm{I}$, IOO-IO7.

Sherman in the Carolinas.
365. Sherman in Georgia and the Carolinas. - When Sherman left Atlanta in November, IS64, he did not attempt to maintain a line of communications s'ia Chattanooga, but, starting with a fair supply of provisions, planned to live on the country. His army of 60,000 marched in nearly parallel columns, separating between towns, converging at all important places. All railways along the line of march were destroved, the rails being rendered useless by heating them at bonfires and twisting them into fantastic shapes. Although there was no intention of destroying private property except for food, and positive orders to that effect were issued, the people suffered severely. Not only was their stock driven off and their grain seized or destroyed, but a great deal of damage was done to houses, barns, and furniture. This was inevitable. The march was an act of war to cripple an enemy and it was not always easy to prevent excesses. It was thought that Sherman would reach Augusta and then march north to coöperate with Grant, but no news came from him until he reached the coast near Savannah. That city he captured December 20 , so that, as he said, he offered it as a Christmas present to the President.

Learing Sarannah in January he adranced to Columbia, and after burning the factories, stores, and supplies at that point, proceeded northeasterly into North Carolina. Wilmington had already fallen into Union hands and Charleston was abandoned when Sherman reached Columbia, so that the Confederacy was reduced now to a strip but three hundred miles in length and much narrower. Lee holding the northern end and Johnston, again in command, striving ineffectually with 25.000 men to check Sherman's adrance.

366. The End of the War. - At Petersburg Grant and Lee spent the fall and winter trying to gain some advantage 
over the other, without result. With spring Grant was able to continue his lines farther to the south and west, hoping to cut off Lee's retreat. He accomplished his purpose at length when Sheridan captured Five Forks on the railway in Lee's rear. Lee, forced to abandon Petersburg and Richmond, marched toward the mountains, hoping also to join Johnston; but his soldiers were starving, and at Appomattox Court House, April 9, the 30,000 survivors of his army surrendered to Grant. The simple soldier left to his brave opponents their horses as well as their swords and the close of the campaign was marked by acts of kindliness and unselfishness worthy of two commanders who were not only great captains but noble men. Johnston surrendered to Sherman two weeks later, and with the capture of isolated bands the great struggle came to a close.

In all history

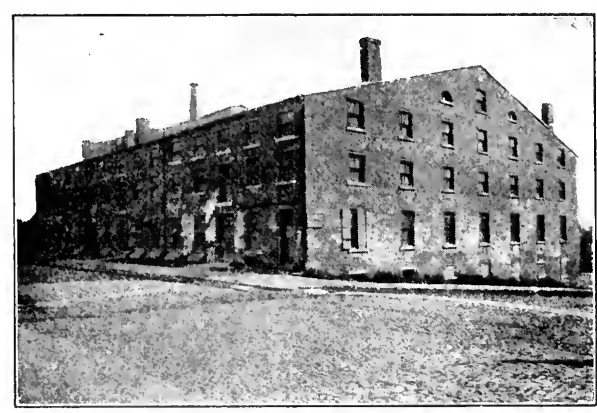

LIBBY PRISON

there is no record of any national contest greater than Results to this. For four years those who wished to preserve the the South. Union had given freely of men and money. With courage and determination they had pressed back their opponents, step by step, until there was nothing left to defend. It has been said that the secession movement was one of leaders and not of the people. If the events of the winter of I 860-I86I do not disprove this, certainly the later years show that the South was united as few nations ever have been. Her soldiers fought with courage equal to that of their brothers in the North. But all of the advantage of inside lines, campaigning on their own soil, and skillful leadership could not counterbalance the greater numbers and the in-

Battles and

Le'aders,

IV, 708-722.

Dodge, Civil

Uar, 310-3I9

Surrender of

Johnston.

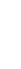


finitely greater resources of the free North. The South had sacrificed everything on the altar of slavery and state sor. ereignty. It was almost a case of all is lost save honor.

Lincoln's supporters and opponents.

Cambriage Mor. Hist., 5/3-575.

Rhodes, L'mitcid States, IV. $223-230$.

367. The People and Lincoln's Government. - During the critical years of the war, Lincoln was fortunate in having the support of Congress and of the North. His wisdom in insisting from first to last that his sole purpose was to save the Union did much to gain the goodwill of the Democrats. The earnestness with which the great body of that party supported the war was due even more to the fervent appeals of Douglas and other Democratic leaders, who insisted that the question was one purely of patriotism and not of politics. Nevertheless there was a large number of persons at the North who desired peace above everything else. Many of these men opposed the arbitrary acts of the President. Prominent among the critics of the government was congressman Vallandigham of Ohio, who was arrested (IS63), denied the privilege of the writ of habeas corpus, tried by a military tribunal, and banished to the South.

Election of ISót.

The election of IS62 had decreased the number of Republicans in the House of Representatives, although it left the Republicans in control of both houses. As the time for Johnson, War election approached (IS64), it became evident that the disof Secission, $+68-750$.

Stanwood,

Presilend, contented members of both parties would try to prevent the reëlection of Lincoln; but as the campaign progressed, party differences were forgotten and from all sides people Chapter XXI. candidate, General George B. McClellan, was nominated on a platform which declared that the war was a failure and that

Hosmer,

Outione of Ciziz His

Chapter IX. peace should be made at once, views which McClellan did not countenance. For the second place on the ticket with Lincoln. Andrew Johnson of Tennessee, a Union Democrat, was selected. McClellan carried only three states, and gained 2 I electoral rotes to 2 I 2 for Lincoln, although Lincoln's popular majority was only 700.000 in a total rote of 4.000 .000 .

Six weeks after the second inauguration, and but five days after Lee surrendered to Grant. Lincoln was struck down by 
an assassin. In the midst of rejoicing over the return of peace, the nation lost the leader who had grown great under the heary duties of his position. Lowell spoke truly when he called Lincoln,

"The kindly-earnest, brave, foreseeing man, Sagacious, patient, dreading praise, not blame, New birth of our new soil, the first American."

368. Summary of the Campaigns. - When the war began First half of the armies of the Confederate states controlled not only the the war. territory of the eleven seceding states, but one half that of Missouri, Kentucky, and western Virginia. The North had possession of Fort Monroe in Virginia and Fort Pickens and Key West in Florida. In the fall of IS6I northern troops occupied the Ohio, which might be called the first line of Confederate defense. Early in the spring of IS62, by victories at Pea Ridge, Island No. Io, and Donelson, they seized the second line of defense and gained entire control of the border states. Later in IS62 they broke through the third line of Confederate defense by capturing Memphis on the Mississippi and Corinth on the railways farther east. At the same time they gained a foothold on the lower Mississippi by capturing New Orleans, but were repulsed before Richmond and compelled to withdraw from the "peninsula." The Confederates then assumed the offensive, Lee defeating the Union troops at Bull Run and then invading Maryland, Bragg at the same time invading Kentucky. These invasions failed, although the Confederates regained some of the territory that they had lost.

After two great victories over the army of the Potomac, Lee again invaded the North, but was defeated at GettysSecond half of the war. burg in July, IS63, at the same time that Grant captured Vicksburg by attacking from the rear. In the fall of IS63 Union troops, after successive defeats and victories, gained possession of Chattanooga, Sherman in IS64 pushing on to Atlanta; while Grant, by hard fighting and maneurering, was forcing Lee south through Virginia. While Grant 
was hammering away at Lee's lines at Petersburg, Sherman gained control of Georgia and South Carolina. Lee and Johnston now attempted to join and aroid being caught between Grant and Sherman, but they were unable to unite and surrendered separately:

Cost of the war. 369. Conclusion. - The question is asked sometimes whether the result justified the cost. As the result must Larned (ed.), be measured by the destruction of slavery and the perfecReady Ref.. V, 3559-3560. tion of national unity, while the cost may be reckoned in human lives ${ }^{1}$ and billions of dollars, ${ }^{2}$ no satisfactory answer

Blaine, Tisenty leurs of Congress, I, 549-562.

Return to peace. can be given. Certainly the unification of the nation was an end beside which the appalling money cost of the war is comparatively insignificant. In human lives the price was too dear if this terrible conflict could by any possibility have been aroided.

Among the most serious results of all great wars are the extravagance they produce and the idleness and recklessness they derelop. The direct wastes of the war, the unRogers, Dot. reasonable prices paid for poor food and inferior uniforms of Norts, $3^{1-34}$. constituted a large item in the gorermment's bill of expenses. After the lavish expenditures of the war it was difficult for the govermment and the people to return to the simple ways of the past. No nation, howerer, has suffered so little from the disbanding of great armies as we did after I 65. Most of the Confederate troops were paroled at once, and before December, IS65, more than 500,000

1 The loss of life on the Union side is reported at $\$ 50.525$; that of the Confederates was probably little less. Besides this number we should count the hundreds of thousands who were crippled for life because of wounds, or diseases due to the hardships of the war.

2 The debt of the United States at the close of the war mas two and three fourths billions: but to this must be added about $\$ ; 50,000,000$ raised by taxation during the war, besides the interest on the debt and amounts paid for pensions since IS65. The aggregate cost to the national government has been nearly eight billions. If we add to this the cost to the separate states of the Union, the cost to the Confederacy, the value of property destroyed, the direct losses due to injury to business, the depreciation of paper currency, and other losses, we should obtain a sum rery much greater than the total assessed raluation of property in the loral states in I\$60. 
Union soldiers had been disbanded, the army being reduced soon after to a peace footing of 25,000 men. Very few of these men joined the ranks of idlers. The southerners returned to their plantations, all of which had been neglected and many of which were practically ruined. The northerners rejoined the ranks of workers and enjoyed the prosperity of a period of unusual business activity. Numerous associations were organized to continue the comradeship begun during the war, notably the Grand Army of the Republic. These organizations of old soldiers have been an important influence in the life of the nation,

\section{TOPICS}

I. Capture of New Orleans: Fiske, "Mississippi Valley in the Civil War," pp. I I I-1 32 ; Mahan, "The Gulf and Inland Waters," pp. 52-90; "Battles and Leaders of the Civil War," II, pp. I 3-IO2.

2. Gettysburg: Burgess, "Civil War and Constitution," II, pp. 157-179; Wood-Edmonds, "Civil War in United States," pp. 2 15-246; Johnson, "War of Seression," pp. 248-269; Doubleday, "Chancellorsville and Gettysburg," pp. 87-210.

3. Vicksburg Campaign: Fiske, "Mississippi Valley," pp. 22 I247; Wood-Edmonds, "Civil War," pp. 247-273; Sherman, "Memoirs," I, Chapter XII ; Grant, "Personal Memoirs," I, pp. 250-337; Greene, "The Mississippi," pp. 9ı-208; "Battles and Leaders," III, pp. $462-598$.

\section{STUDIES}

I. The navy on the upper Mississippi (1862). (Mahan, "Gulf and Inland Waters," pp. 9-5r.)

2. Incidents of a campaign. (Hart (ed.), "Contemporaries," IV, Nos. 86-88, 9o.)

3. Personal experiences in the Civil War. ("Battles and Leaders," II, pp. I53-159, I 89-199.)

4. Morgan's raid. (Cox, "Reminiscences of the Civil War," I, pp. 49I-509.)

5. The draft riots in New York. (Johnson, "War of Secession," pp. 290-306.)

6. The fight for Round Top. ("Battles and Leaders," III, Pp. $318-330$.)

7. Greeley's estimate of Lincoln. (Century, 42 (I891), pp. 37I382.) 
s. Vallandigham's opposition to the government. (Johnston (ed.). "American Eloquence," II, pp. $s_{2-0.2)}$

o. The battle of the Crater. (Wise, "End of an Era," pp. $3+6-$ 3i.

10. Spirit of the North "(I\$64-1\$65). (Hosmer, "Outcome of the Civil War." Chapter $\mathrm{NT}$.)

II. Spirit of the South. (Hosmer, "Outcome," Chapter IVI.)

\section{QUESTIONS}

I. At what points was the South most rulnerable? Was the Tnion plan of campaign the one best suited to the conditions? Show the importance of Cain, Corinth. Vicksburg. Chattanooga.

$\therefore$ Could the war have been ended by the capture of Richmond in ISOZ? Why was the possession of New Orleans of value to the Union amies in Tennessee? Show the importance of the nary in the western campaigns.

3. Why did Lee attempt to invade the North? Why did he fail in each case? Were his northern campaigns conducted with less skill than that in Virginia in Isot?

4. Wore the burning of Atlanta and the devastation of the Shenandoah ralley justified? What was the real importance of Sherman's march to the sea?

5. Could the cost of the war in men or money have been reduced easily? Did the results of the war justify the cost? How was the Union different in ISos from what it had been in IS6I? 


\section{CHAPTER XVIII}

\section{POLITICAL RECONSTRUCTION}

\section{Presidents}

Andrew Johnson (1865-1869) Ulysses S. Grant (I869-1 877 )

370. Lincoln, Johnson, and Reconstruction. - Less than a week after Lee surrendered to Grant at $\Lambda_{\text {plomattox }}$ Lincoln and Congress. Lincoln was dead. His assassination, which wals part of a plot to kill Johnson, Seward, and Grant also, was most unfortunate for the nation, since the problems of reconstruction were but little less serious than those of the war. In Cf. Rhodes, l'nited stute's, V, 139-150. fact there was greater need that the president possess tact and skill in dealing with men after the war than during its prosecution. While there was danger from southern armies, the nation rallied around the President, overlooked his mistakes, and gave him its united support. Congress had acquiescel, gracefully on most occasions, in the unusual acts of Lincoln and had allowed him a free hand even when he used powers that were legislative in character. The close of the war changed the situation radically.

Having been unselfish during the war, Congress was more jealous of its prerogatives in the period following. It did not propose to allow the president to settle questions Situation at the close of the war. which belonged in any respect to the legislative department. When we consider the delicacy of the problems - the way the seceling states should be treated, the attitude of the national government toward those who had taken part in the Civil War, more than all, what should be done for and with the blacks - we can realize that there should have been perfect harmony between the presilent and Congress. Lincoln could have preserved cordial relations with the law-making branch of the government, for he possessed the 
confidence of Congress and the people. He understood the situation as well as any one: he had become preëminently a leader of men. That his reputation may have suffered had he lived is unquestioned. But when he left the great duties of his office to his subordinate, the nation lost as much as his reputation may have gained.

Andrew Johnson.

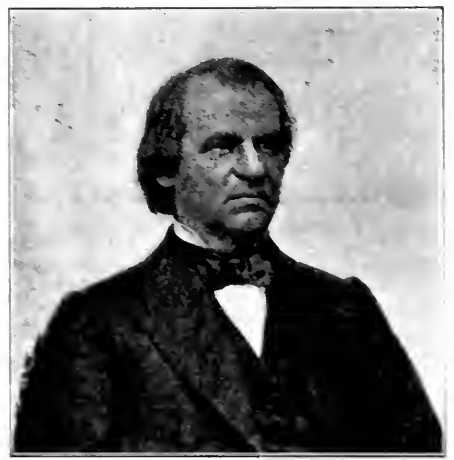

ANTREW TOHXOX

Andrew Johnson had been selected for the second place on the Republican ticket because he was an earnest Union Democrat. a southern man who had been loral. Deprived of early adrantages. he had educated himself late in life, and, by the force of a powerful personality, had risen step by step until accident placed him in the president's chair. But he possessed few qualities to commend him to the

Rhodes. Inited Sintes, V., 5I $7-5200$

Three problems.

The blacks. great ofice even in ordinary times. Although a man of unusual intelligence and will power. he was tactless and vindictive, intemperate in thought. speech. and act. the opposite in almost every respect of the man whose place he took. whose cabinet he retained. whose policy he adopted, whose popularity for a time covered his most glaring defects.

\section{Reconsthtction (ingz-is;o)}

37I. The Problem of Reconstruction. - IThen the war closed, the national government was forced to find solutions for three problems: (I) What should be done with the slaves? (II) How should those persons who had belonged to the Confederacy be treated? (III) How should the Confederate states be restored or reconstructed?

(I) South and North agreed that slavery should be abol- 
ished. The slaves had been freed by the emancipation proclamation $(\$ 35)$ in part of the South, but slavery had not been abolished during the war except in Maryland, although both West Virginia and Missouri had provided for gradual emancipation. The thirteenth amendment to the national Constitution, abolishing slavery throughout the United States, was passed by the necessary two thirds in each house of Congress in January, i $\$ 65$, and ratified by more than three fourths of the states, North and South, by December, IS65. It gave Congress the right to prevent the reëstablishment of slavery. This was only the beginning of legislation for the blacks, as the protection of the freedmen was the ostensible cause of most of the reconstruction legislation.

(II) Most of those who had taken part in the war against the government of the United States were allowed to resume their normal rights as citizens on taking an oath to support the Constitution of the Lnited States and abide by its laws. Those high in civil or military authority were debarred until IS68, when President Johnson declared a complete amnesty for all who had participated in the Civil War. Congress, which had claimed the right to control this subject of amnesties, prevented most of those important persons from holding any office, state or national, until several years later. ${ }^{1}$

(III) Legally and theoretically the greatest difficulties of this period were presented by the questions: What was the status of the Confederate states? Were they in the Union or out of the Union? To admit that they were out of the Union would have been to acknowledge the right of secession, the success of secession, or both. If it was claimed that they were in the Lnion, there was really no "reconstruction" problem, only need of restoration of the states to their normal relations with their sister states.

372. Status of Seceding States. - Sereral theories were developed, soon after ${ }_{1} S_{5}$, presenting different points of view. The southern and the presidential theories agreed

Status of the seceding states.

${ }^{1}$ The fourteenth amendment gave Congress this power.

Theories as to the status. 
Dunning, Reconstruction, 99-I I 2 .

Hart, Contemporaries, IV, Nos. I45-I 49 .

that the states were still parts of the Union, but out of their constitutional relations to the central government. They stated that restoration should take place through action of the people of each state, under limitations prescribed, according to the first, by those people; according to the second, by the president. Charles Sumner held the theory that when a state tries to secede, it commits suicide as a state, and be-

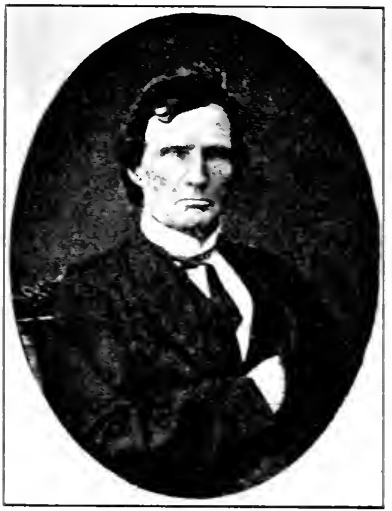

THADDELS STEVENS comes merely a part of the territory of the Union under its control in regard to local, as well as national, affairs, i.e. the states reverted to the condition of territories. Thaddeus Stevens went further, and in the conquered prosince theory adrocated the view that the South was not eren in the condition of territories; that it was a conquered district. $\mathrm{He}$ therefore proposed wholesale confiscation and appropriation of land to negroes. This suggestion was the basis of the doctrine that every freedman should have forty acres and a mule.

Congressional plan of reconstruction.

As none of these theories was acceptable to moderate men, the theory of forjeited rights came to be the basis of final reconstruction. It held that the people of the states had forfeited their rights by attempted secession, and that those rights could be restored to them only on the fulfillment of certain conditions. The judge of what the conditions should be, and when ther had been fulfilled, was Congress, because Congress was instructed by the Constitution to guarantee to each state a republican form of government. This theory was upheld by the Supreme Court of the United States in the case of Texas r. IThite (IS6S).

373. Restoration under Johnson (I865). - President Lincoln and his successor, President Johnson, were anxious 
to have the seceded states restored to their constitutional relations as soon as possible. To this end they used their power as commanders in chief to grant amnesties and pardons, and, in addition, declared that when a state government had been formed by loyal voters equal to one tenth of the whole number of voters in I $\$ 60$, they would recognize

The presidential plan in operation.

Johnston, Am. Pol. Hist., II, $434-439$.

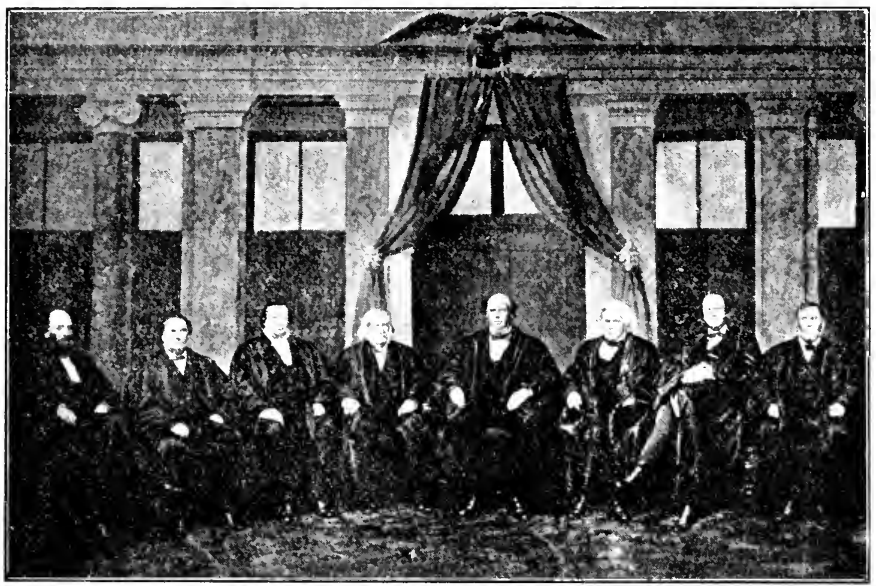

The Supreme Court

(During the Reconstruction Period)

such a government and declare the state fully restored. This plan which Lincoln had formulated Johnson put into Dunning, $\mathrm{Har}$ and Reconoperation. ${ }^{1}$ When Congress assembled in December, I 865, 75-83.

${ }^{1}$ The states of Louisiana, Arkansas, and Tennessee had reorganized their governments in accordance with Lincoln's instructions before the close of the war. In Virginia there had been for years a loyal government which claimed to be the legal government of the state. This was accepted by both Lincoln and Johnson as the regular government of Virginia. In the other states that had attempted to secede from the Union, the President appointed, during the summer of 1865 , provisional governors, under whom the work of reorganization or restoration was to be performed. In most of these states conventions were called without delay. Those persons were allowed to vote who were included in the amnesty proclamations of the president, and the conventions were allowed to decide who might vote thereafter in the state or hold any office. 
Burgess, Re- the president announced that regular state governments had constrution, $35-41$. been restored in all of the southern states but two.

Congress immediately appointed a joint committee on Opposition in reconstruction to decide all questions regarding the states Congress. that had tried to secede. Opposition to the President's Johnston, plan of restoration dereloped at once, not simply because tm. Pol. Hist., Congress believed that it had the right to decide the conII, $4+6-452$.

Rhodes, Cnited states, war if the southern states were restored to the Union and V,549-550. allowed sole control over the blacks. This danger was real to most of the congressmen, for they desired to give the former slaves not only freedom but the suffrage as well. The thirteenth amendment forbidding slavery was adopted in December, IS65. but at the same time came alarming reports from all parts of the South that the restored states were reënslaving the blacks.

Southern apprenticeship laws.

Burgess, Re construition, $45-55$.

374. Freedmen Legislation. - Most of the southern states, proceeding on the assumption that Johnson's plan of restoration had reëstablished their position in the Union, passed, during the fall of $\mathrm{IS}_{5} 5$ and the following winter, apprenticeship and ragrancy laws for the freedmen. All colored minors were to be apprenticed, if possible, to their former masters. All negroes who were not employed, or Hart, ContemAoraries, IV: Nos. 143,151 . who were guilty of attending meetings, were deemed ragrants and their services were sold to the highest bidder. To Congress and to the majority of the people of the North these laws seemed to establish a new form of slavery that would be perfected when the states were unquestionably again in the Lnion. Congress was induced to pass several laws for the purpose of protecting the blacks and to delay reconstruction until definite and permanent guarantees had been secured which would protect the blacks from their former masters.

Second Freed- The first of these laws was the second Freedmen's Bureau men's Bureau Bill. Bill. In Miarch, ISo5, the Freedmen's Bureau had been created for the war and a period of one year thereafter to 
provide food, clothing, and shelter for needy freedmen and to apportion vacant lands for their use. The new bill (February, is66) created an organization that had an agent in every county in the South. No time limit was designated, and the powers of the bureau were enlarged so that its agents looked after not only destitute negroes but every freedman. The agent was really a judicial officer who could try cases where a negro's rights had not been respected by the whites, or where a black had been punished with unnecessary severity. To leave such vague yet extensive power in the hands of an agent of the central government in recently conquered territory was of course a dangerous procedure. The bill was retoed by Johnson, on the grounds that it was a war measure applied to territory in which peace had been restored fully, and that the central government had no authority to exercise juristiction in this way. The bill failed to obtain the necessary two thirds to make it a law at this time, but four months later a more severe bureau bill was passed over the President's reto.

375. Civil Rights Bill and Amendment XIV (I866). Although the radicals in Congress may have desired the humiliation of the South, the majority wished simply to protect the negroes. Those in power in Congress decided that this could be secured only by changes in the national law and Constitution which the states could not alter. This led to the enactment in April, IS66, of a Civil Rights Bill which declared that persons born in the United States were citizens of the United States and that they had the right to make and enforce contracts, to protect themselves in the courts, to acquire and dispose of property. There was to be no discrimination under the civil or criminal law on account of race or color. The President naturally vetoed a bill that not only changed the status of the negroes so materially, but which took from the states powers that had been exercised by them since the formation of the Union. Congress passed the bill over his veto (April, ı866), showing that the Republicans had broken completely with Johnson.

Civil Rights Act.

MacDonald, Statutes,

No. 5 o.

Burgess, Reconstruction, 68-73.

Rhodes, Inited States, $\mathrm{V}, 5^{8} 3^{-587}$. 
Fourteenth amendment.

Johnston, Am. Pol. Hist., II, 454, 467 .

Burgess, Reconstruction, 73-8o.
Provisions of the acts.

MacDonald, Statutes, Nos. 56, 62, 64,67 .

Johnston; Am. Pol. Hist., II, 462-465.

Soon after it was decided to combine in a single amendment to the United States Constitution the principles of the Civil Rights Act and other articles which would embody important results of the recent war. In its final draft this most important amendment was as follows: (I) It defined United States citizenship. "All persons born or naturalized in the United States and subject to the jurisdiction thereof are citizens of the United States and of the state wherein they reside." It protected the rights of these citizens. (2) When a state denied to any men who were citizens of the United States the right to vote, the state should lose a number of representatives in the lower house of Congress in proportion to the number of citizens excluded from voting. (3) Persons who had broken their oaths to support the Constitution of the United States should be allowed to hold state or national office only by a two thirds vote in the loouses of Congress. (4) The validity of the United States war debts was affirmed, those of the Confederacy and seceding states were declared illegal and void.

376. Military Reconstruction (1867-1870). - As the fall elections in 1866 increased the Republican majority in both houses of Congress, the plans of the leaders were perfected and enacted into law early in 1867 . The Military Reconstruction Acts ${ }^{1}$ provided that the ten unreconstructed states $^{2}$ of the South should be divided into five military districts, each of which was to be controlled by a general of the army. (I) These generals were to enroll in each state as voters all men over twenty-one, without regard to color, except those debarred for participation in rebellion. (2) The voters should elect a convention that should adopt a state constitution, one part of which must provide for manhood suffrage. (3) This constitution must be ratified by the registered voters, and approved by Congress. (4) The legislature elected under this constitution must ratify the fourteenth amendment. During this process of recon-

${ }^{1}$ Acts of March 2, March 23, and July 19, I867.

${ }^{2}$ Reconstruction had been completed in Tennessee in 1866. 
struction the general had almost arbitrary power, including even the right to set aside state or local laws or remove officials. When it was completed, the state was "readmitted " to the Union.

It was found that less than ten per cent of the men were excluded from voting, although of course all of the former under the acts. leaders were debarred. The black voters outnumbered the whites in five states, but in only two states did the blacks have a majority of the delegates to the conventions, although the friends of reconstruction controlled the situation in most of the states. Reconstruction was completed before July $\mathrm{I}$, I868, in North Carolina, South Carolina, Florida, Alabama, Louisiana, and Arkansas. The other four states - Virginia, Georgia, Mississippi, and Texas - were obliged to accept the fifteenth amendment as well before reconstruction was $81,82,83,89$. completed and their representatives were admitted to Congress. This unwise amendment made negroes voters on the same terms as whites throughout the United States. In this way the plan of protecting the negroes was perfected, since the thirteenth amendment had given them freedom and the fourteenth had made them citizens.

\section{Incidents of the Reconstruction Period (i867-i877)}

377. The Impeachment of Johnson. - The difference of opinion existing between the President and Congress on the subject of reconstruction developed rapidly into a quarrel, after his veto in February, s866, of the second Freedmen's Bureau Bill. The President publicly criticised Stevens and other reconstruction leaders and by this attitude won not only the dislike of all the leaders in Congress, but lost the support of the moderate Republicans who had been unwilling to break with the President. As the Republicans had a two thirds majority in both houses of Congress, all bills relating to the reconstruction plan of Congress were passed over Johnson's veto. When the election of I866 increased the opposition in Congress to the President, he made a trip through the North, called "swinging round the circle," MacDonald, Statutes,

Johnston, $4 \mathrm{~m}$. Pol. Hist. II, $465-47$ I.

Nos. 68, 69, 76, 
on which he attacked the Republican leaders and declared that Congress was " no Congress," because the southern states were unrepresented. In March, IS6;. Congress had its revenge. (I) It passed the drastic military reconstruction acts over the President's veto. (2) It limited the president's control of the army as commander in chief by compelling him to issue all orders through the general of the army. (3) It passed the famous Tenure of Ofince Act which pre-

Tenure of Otfice Act.

MacDonald, Stazes. No. $5 \%$

Johnston, Atm. Pol. Hist., II, 499-50I.

Impeachment and trial.

MacDona'd, Statutes. No. 00 . vented the president from removing officials from office without the consent of the Senate. ${ }^{1}$ (4) Finally, it adjourned March t. IS67, to meet, the same day, as the fortieth Congress.

The members of Congress believed that without these acts the President would use the great power of his office, especially his control of the patronage, to defeat their reconstruction policy. The more radical members, in fact, de-
EDWIX M. STANTON

sired the remoral of the President, so that the president pro tempore of the Senate might become acting chief executive. The Tenure of Office Act precipitated the quarrel. Johnson attempted to remore his secretary of war. Stanton. who had been dictatorial and refused to resign. Stanton denied that the President might remore him and defeated every attempt to gain possession of his office. The House of Representatives eagerly seized upon the attempt to remore Stanton as a sufficient pretext for impeaching the President, which it did in February, IS68. The trial before the Senate lasted about six weeks, Chief Justice Chase of

${ }^{1}$ The Constitution requires the consent of the Senate in appointments, but is silent on the subject of removals. Since risg the president had exercised sole poter of making removals. 
the Supreme Court presiding, as the Constitution prescribes when a president is tried. The excitement was intense, tremendous pressure being brought to bear on the Republican senators who did not believe the President to be guilty of " high crimes or misdemeanors." When the vote was taken, it was learned that thirty-five senators stood for conviction and nineteen for acquittal, one less than the two thirds required for removil from office.

378. Carpetbag Government in the South. - In almost all of the siates the reconstructed governments were controlled by the negro voters. A large proportion, perhaps a majority, of the offices were held by northerners who had settled in the South at the close of the war. Some of these men were adventurers in search of wealth and power, who, at the beginning, carried their possessions in homemade carpetbag grips. Under the rule of such men, with such supporters, conditions were ideal for misgovernment and corruption. Although the South was impoverished, it furnished rich pickings for these social vultures. Taxes became so heary that they often exceeded the gross value of the crops. Thousands of fine plantations and magnificent halls were sold because the owners were unable to carry the heary burdens placed upon them. The people were often subjected to insult and oppression at the hands of ignorant and greedy rulers.

The young and reckless southerners sought relief by organizing a secret society known as the Ku Klux Klan, the ostensible purpose of which was the intimidation of the negro voters. Nightly visitors robed in white called at negro cabins and terrified the superstitious blacks. But the more violent whites did not stop with that. There was great temptation to end the misrule by resort to torture and murder. At length the national government interfered, passing in I $8_{7} \circ$ and ${ }_{1} 8_{7}$ I two force acts which permitted the use of the United States army to uphold the reconstruction governments and protect them from their enemies.

After $\mathrm{I}_{72}$, when the last of the Confederate leaders

Misgovernment in the South.

Johnston, $1 \mathrm{~m}$. Pol. Hist. II, $47 \mathrm{I}-475$.

Hart, Contemporaries,

IV, No. I57.

Andrews, Our Ozin Times, II 2-1 22.

Ku Klux Klan. Johnston, Am. Pol. Hist., II, 487-492.

Burgess, Reconstruction, 250-261. 
Results of carpetbag government.

Burgess, Reconstruation, $247-249$, $201-204$.

Andrews, Our ()w' Times, I 22-I 30 .

Fraud and extravagance.

were pardoned, the whites gradually regained control of their state and local govermments. South Carolina and Louisiana, both of which had a large majority of negroes, were the last to establish white rule, after several years of bitter partisan warfare. In Virginia and the other state in which the whites predominated, carpetbag government had never secured a serious hold. but in Louisiana, for example, the results of miscrovernment can be measured in part by the terrible financial condition of the state. For several gears the average annual expenditures of the state govermment were six millions, and in four years the debt of the state had increased from less than seven millions to more than forty millions. What those figures represented cannot be imagined easily; they cannot be described in such a text as this at all.

379. City Government and Corruption. - One of the most distinctive political features of American history in the decade following the Civil Mar was the prevalence of corruption in all of our governments, national, state, and city. Aside from the carnival of misrule in the South under carpetbag govermment there was a greater amount of bribery, fraud, and theft in some of our larger northern cities than elsewhere. During these years the cities grew rapidly but the increase in the number of duties they performed far outstripped the increase in population. Franchises were given freely by the cities to private corporations which furnished water or gas, or operated street railways. These franchises were often of great value and continued in force for very long periods. The amount of money required for necessary expenditures was much greater than formerly, and most of our city govermments unfortunately fell into the hands of ignorant and corrupt politicians.

Tweed ring in New York suffered so much more than any other city that New York.

Andrews, Our ():ch Times, I I -10 . she seemed to be in a class by herself. A ring of politicians under the lead of " Boss" Tweed sained control, and. by systematic theft covering a number of years, robbed the city of a sum probably little less than Sio0,000.000. Public 
attention was centered on the ring by the striking cartoons of 'Thomas Nast, which appeared in Harper's Weekly. When the New York Times published definite information

Rhodes,

I'nitid State's.

VI, 392-4IO. regarding thefts by the ring, public-spirited men like Samuel Tilden devoted their attention to bringing the leaders to justice. A number of Tweed's associates were convicted, and the boss died in jail several years later.

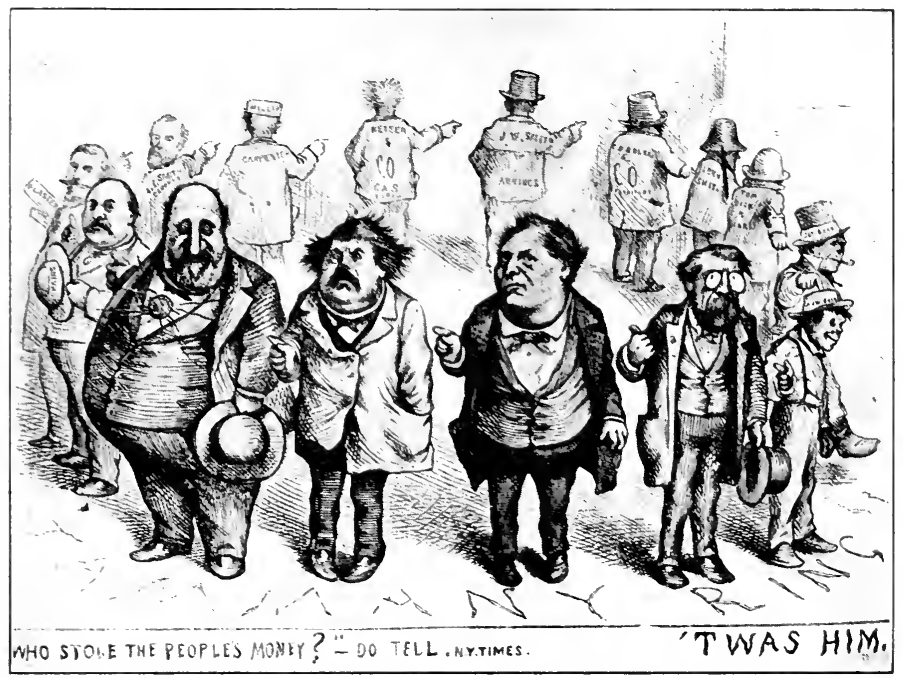

From Harfer's the'en'y, by permission.

Nast's Famots TweEn Rixg Cartoon

380. The Administrations of Grant (I869-1877). - Al- Grant's though General Grant had had no experience in public affiairs policies. he was the unanimous choice of his party in IS6S and was elected almost without opposition. He proceeded to carry out the Congressional policy of reconstruction $(3 ; 6)$ and gave his consent, in a rather half-hearted way, however, to the plan of those that wished hard money instead of an inflated paper currency (390). In dealing with foreign affairs, his administration was quite successful, owing to the skill of his secretary of state. Hamilton Fish; but Grant's farorite 
scheme of annexing Santo Domingo failed, because it did not meet the approval of his advisers or of the people.

Election of IS 72 .

Burgess, Reinstruction, $204-206$.

Stanwood, Presideny. Chapter XXIV.

Andrews, Our Oon Times, $6 S-7 s$.

Civil service under Grant.

Rhodes, Corited Stites, VI, $3 s_{5}-390$.

Credit Mobilier and Whisky ring.

Andrews, Our Ou'n Tincs, IO4-IOO, 200$205,237-242$.
The election of IS;z was interesting chietly because of the attempt of the Democrats to join the reform Republicans and because of the Labor platform. Horace Greeley was nominated by the Liberal Republicans and Democrats, but his campaign was mismanaged and his death soon after election complicated matters. The interesting platform of the Labor party contained several planks that were received with derision in that day, but have found a place in the nation's law. Among these were demands that Chinese laborers be excluded from the United States, that the national government supervise the affairs of railways and telegraphs, that contract labor in prisons be abandoned. They asked for civil service reform, an eight hour day for private contract work on public buildings, lease but not sale of all public lands, and a paper currency issued on the credit of the people but not through the banks.

38r. National Political Scandals. - Grant was so honest himself and had such confidence in the men by whom he was surrounded that he was imposed upon by them. Positions were created to furnish berths for dishonest politicians. The civil service became filled with unfit men. Inefficiency and corruption were prevalent in the national government as nowhere else except in New York City and in the South. In response to a demand for reform, a civil service commission was appointed in I $\mathcal{F}_{\text {I }}$ to select candidates for a few offices on a merit system, but it was not very successful and was abandoned entirely in $I_{5} 5$.

During Grant's administration there were numerous political scandals, some of them of no significance. Perhaps the most discussed of these was that of the Credit Yobilier, an organization created for the purpose of building the Inion Pacitic railway. Stock of this company was sold to many congressmen before the completion of the great highway to the Pacific. It was claimed, probably with truth, that there was no legislation pending which would 



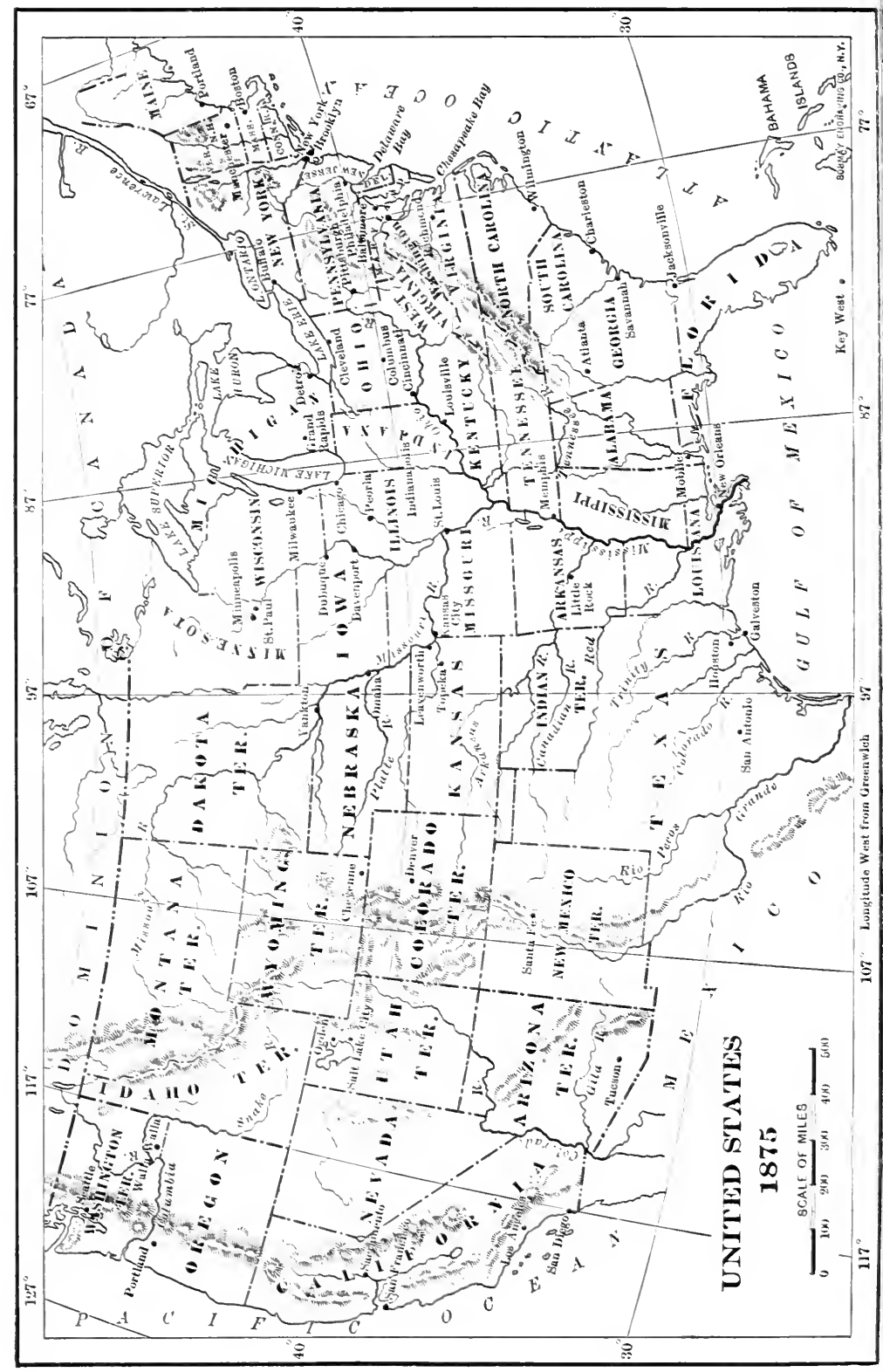


have been influenced in any way by the rote of these Rhodes, congressmen; but the whole affair was condemned without mercy by the awakening public conscience. In I875 a gigantic "whisky ring," with headquarters at St. Louis, which had defrauded the government of several million dollars by connivance with internal revenue officers, was broken up by the effort of B. H. Bristow, secretary of the treasury; but later a ring in California was successful in its fight with the treasury department. The post office department was purged of many abuses by the energy of the postmastergeneral, but, in the war department, Secretary Belknap was found guilty of accepting bribes in making appointments and in letting contracts. Belknap was impeached by the House of Rejoresentatives, but escaped conviction in the Senate by resigning. The President's attitude is shown by his statements: "Turn the rascals out," and, "let no guilty

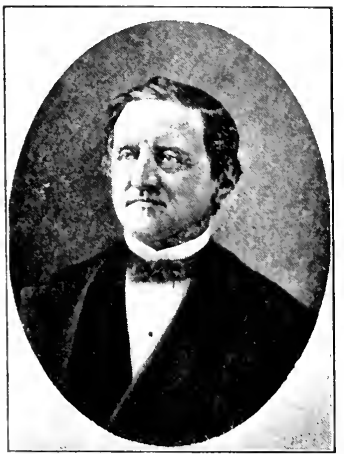

SAMUEL. J. TILDEN man escape." Grant was criticised, however, because he seemed to favor the grafters, as he was loath to believe his friends guilty of wrongdoing.

382. The Disputed Election of 1876 . - The closing scene of the reconstruction tragedy was enacted in connection with the presidential election of November, 1876 . The candidates were Rutherford B. Hayes of Ohio and Samuel J. Tilden of New York. The campaign was rather uninteresting until the day after the votes were polled, when it became evident that both parties would claim the electoral vote of several states. On the face of the returns, as reported originally, Tilden had a fair majority, but the Republicans claimed the electoral vote of the states of Florida, South Carolina, and Louisiana, as well as one elector from Oregon. In these southern states the contest between the carpetbaggers

Cause of the dispute.

Burgess, Reconstruction, 280-283.
United States, VI, I-I8, I82-I9I. 


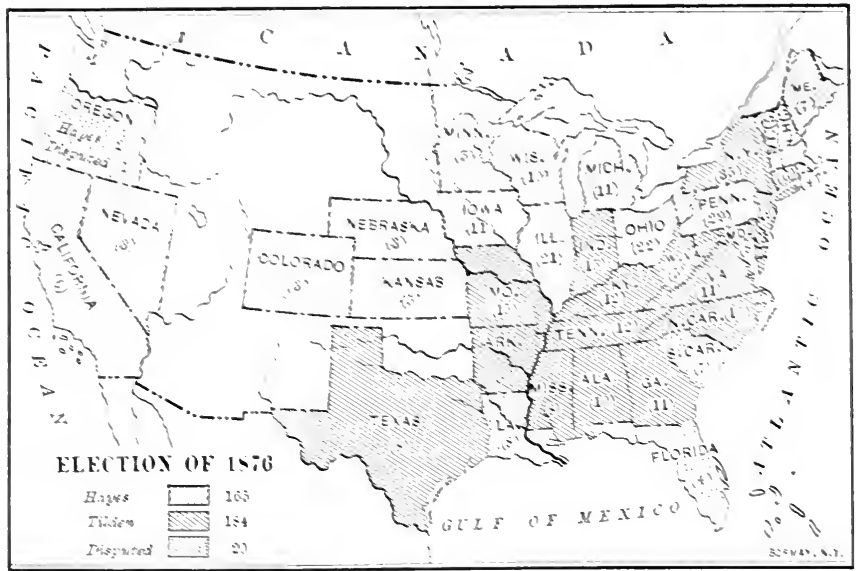

and the native whites made it possible to send in two sets of returns. If all of the votes in dispute were counted for Tilden. he would have 20 ; rotes to roo for Hares. If all were counted for Hayes, he would have Is and Tilden Ist.

Eiectorai commission (IS-)

Burgess in $\therefore$ (n) $2 s^{2}-205$.

Tomston,

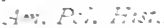
II, $3+4-5: 2$.

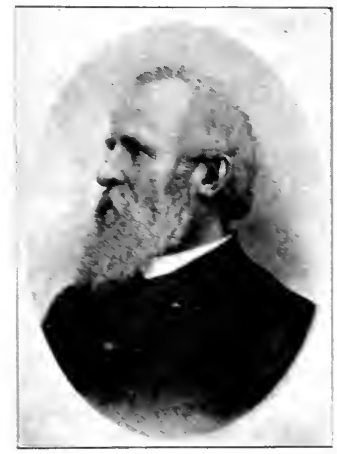

KUMERFORE R. HAYFS cratic. They were opened by the president of the Senate. ${ }^{1}$ but it was decided that he had no authority to count either set of the rotes in dispute, and the matter was referred to an "electoral commission " of fifteen whose recommendations should be accented unless refused by both houses. The commission was to consist of five senators. five representatives. and five justices of the supreme Court. As eight of these elected to the commission were Republicans, all questions in dispute were sottled by a party rote of eight to seren, and, 
on March 2, isit, Hayes was declared to be elected by a majority of one rote.

It was understood but not agreed that, if elected, Hayes would withdraw the troops from the south and allow the former Confelerate states to conduct their own governments without interference from Washington. This was the real end of reconstruction in the South. From this time, normal conditions being restored, the South began to take alliantage of the great resources at her command and dereloped with amazing rapidity.

\section{National Changles (1S6i-1S75)}

383. National Development. - The period of the Civil War and reconstruction - that is, the years from 1801 to I $S_{77}$ - was an era of changes as important as those that hat taken place in the epoch-making Revolutionary period $\left(1775^{-1} 7 S_{0}\right)$. In each case a war which had been brought about by conflict between two different systems of government and society left the United States very different from the country it had found. In each case the war hat exerted an almost inestimable influence in (leveloping a stronger nation.

Before the Civil War the relation of the nation to the states had been a disputed one. A fairly large minority of the people still held that the states were sovereign and believed that Congress should be no more than the agent of the states. This position could no longer be held, since the events of the war and of the reconstruction epoch had shown beyond question that the nation was sovereign and that Congress was not the law-making body of a league of states. The right of the nation to coerce a state which attempted to secede had been proved by the failure of secession. After one hundred years of dispute over the question of whether the nation was sovereign or whether the states were sovereign, there was no longer the slightest doubt as to the supremacy of the nation.

The second great change of the period was the destruction

IIayes's southern policy.

Burgess, Reconstruction, 295-298.

General.

Triumph of national sovereignty.

Johnston, Am. Pol. Hist., II, 3+3-336. 
Destruction of slavery.

Amendments XIII and XV.

Amendment XIV. of the system of slavery which had been the chief factor before the war in developing sectionalism. Freed from the blighting influence of slavery, the South was able to make use of its natural resources and to derote its energies to new occupations; in short, to gain a share in the general progress of the world, from which it had been debarred by slavery before the Civil War $(\$ 320)$.

384. Changes in the Written Constitution. - In spite of the rery radical changes in the relation of the nation to the states, and in the real constitution of the United States, the changes in the written Constitution were comparatively few. Only three amendments had been added to that valuable document. Nominally all of these were for the purpose of protecting the negroes, although they have helped to establish the supremacy of the nation over the states. This is partially the case with the thirteenth and fifteenth amendments, in which the nation decided matters controlled exclusively by the states before the war began. Without the war few states, North or South, could hare been persuaded to surrender to the nation the right which they had had as states to control the question of slavery within their own limits. Without the war it would have been difficult, perhaps impossible, for the nation to have placed limitations on the right of each state to decide for itself who should rote within its limits.

More important than these amendments, from a national standpoint, were the provisions in the first article of Amendment XIV. Before the Civil War those who upheld the doctrine of state sovereignty denied that there was such a thing as real citizenship of the United States. ${ }^{1}$ They contended that erery man owed allegiance to his state only, since he was a citizen of the state only. The reality of United States citizenship, ${ }^{2}$ with its corollary of allegiance to the nation alone, was made clear by the first clause of the

${ }^{1}$ Except in national "territory."

2 On state and United States citizenship and the rights of each, consult Ashley, American Government, \$\$264-266. 
fourteenth amendment. Later clauses prevented the states from interfering with the rights of citizens of the United States or of restricting unjustly the rights of state citizenship.

385. Changes in the Unwritten Constitution.-The constitution of the United States consists not simply of the written Constitution, but of an " unwritten constitution." Increase of national authority. This unwriten constitution includes all important laws or court decisions which explain or supplement the written Constitution. During the war, of course, it had been necessary to use powers that were extra-constitutional. This was justified on the ground that unless the Union was preserved, the Constitution would be destroyed. I) uring the process of reconstruction also extra-constitutional measures were passed because, in the opinion of the nation's rulers, they were demanded by public necessity. At the close of the period of reconstruction, the national government ceased to use these powers which would have been unconstitutional under normal conditions, but it continued to use powers which before the war would have been considered unconstitutional, but which were now deemed legal. It is not surprising that this was done, for the war had dereloped a much stronger national sentiment than had ever existed before. The national government had become so centralized that it could not be expected to give up most of the powers that it had acquired since I860, and the Supreme Court, reflecting popular wishes, gave its support to the doctrine that since the United States was a nation, the Constitution should be interpreted in such a way as to give the central government power to do what was for the best interests of the nation, provided the Constitution did not forbid the use of such a power.

386. The National Government. - In form the national The president. government was changed little; in power it was as different from the government at IVashington before I86I as the nation in 1877 was unlike the nation of two decades earlier. By virtue of the exercise of war powers the president had for 
Rowers a Singas.

a sher the incesse the awhority of his poston immeasur-

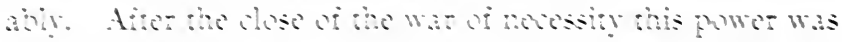

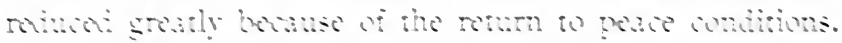

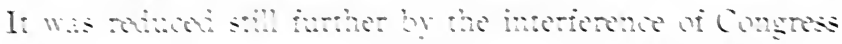

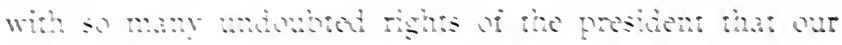

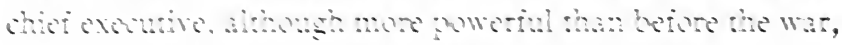

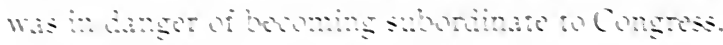

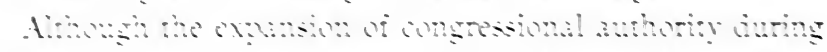

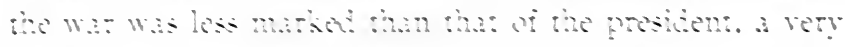
l.

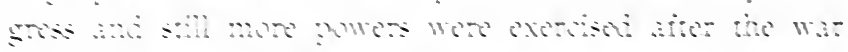

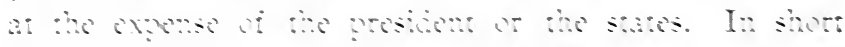

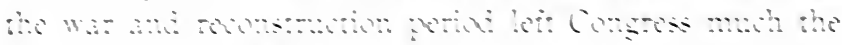

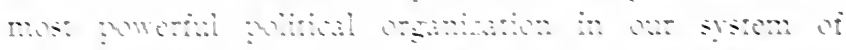

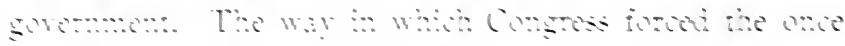

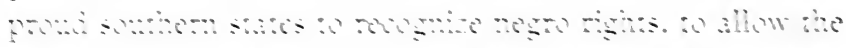

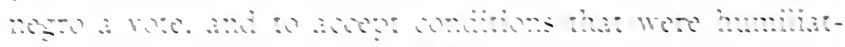

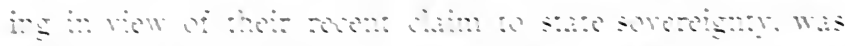
a..... an.

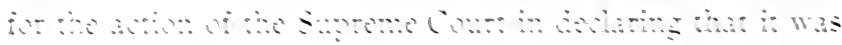

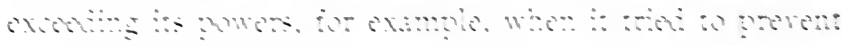

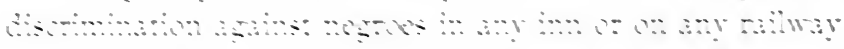

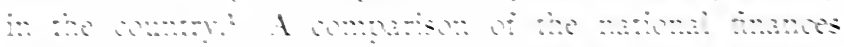

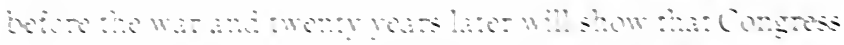

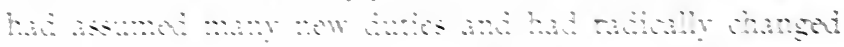

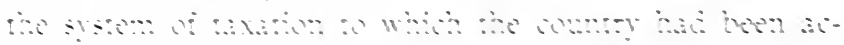
………ㄴ.

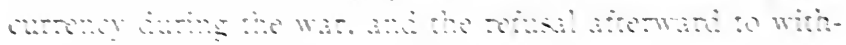

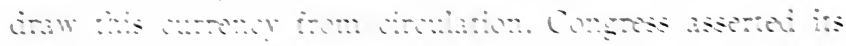

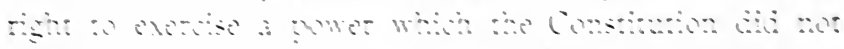

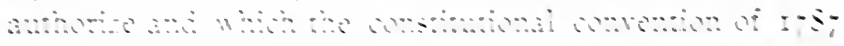

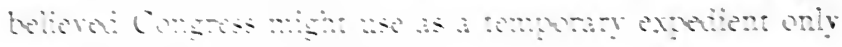
in t......

sesines ה- New Mational Industral Conditions - Fven mose

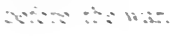

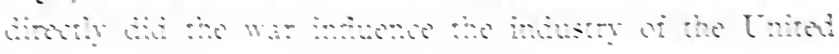
: G. 
States. In isto the people were still deroted almost exclusively to agriculture. 'There was little manufacturing, and almost none at all on what we should consider a large scale. Almost all money in use wats in the form of state bank bills, which did not pass at their face value outsicle of the state where they were issued and often were worth little anywhere, because they were issued in such quantities. This lack of a really national currency prevented the derelopment of interstate trate. In consequence few companies commanded a lare market or exported extensively, whil the value of manufactured imports was large.

During the war manufacturing had been stimulated by the need of providing the troops with necessaries and of furnishDuring the wir. ing materials for the prosecution of military camplagns. The high tariff had more than counterbalanced taxes on pro duction, and this reduction of foreign competition coupled with high prices had proved a boon to mamufacturers.

When peace came, the internal taxes were removed, while Atter the war. the tariff was changed rery little for a quarter of a century. This assured sufticient protection to warrant the investment of still more capital in industry. Large companies were organized. Firms which before had been content with local markets began doing business in several states. New commercial ties were formed by men in different parts of the Union so that many of the old sectional prejudices were forgotten. By this obliteration of state lines in business, the unity of the nation was developed as at no earlier time. The marked difference between the United States, commercially and industrially, hefore the Civil War and after that conflict can be appreciated perhaps by examining the opening sections of the next chapter.

\section{TOPICS}

I. The Process of Reconstruction: Dunning, "Civil War and Reconstruction," PP. $1-6-252$; Burgess, "Reconstruction and

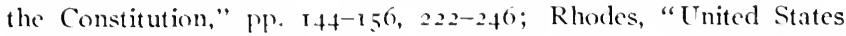
since $1850, " \mathrm{VI}, \mathrm{PP},\left(10-07,108-178,2 S_{4}-305\right.$; Cox, "Three Decades of Federal Legislation," pp. ${ }_{4}$ So-5iz. 
2. Impeachuent of President Johnson: Burgess, "Reconstruction and the Constitution," pp. I $72-192$; Dunning, "Civil War and Reconstruction," pp. 253-303; Blaine, "Twenty Years of Congress," I, pp. $3+\mathrm{I}-3 S_{4}$; Rhodes. "Lnited States since IS 50 ," VI, pp. $98-157$.

3. Disfuted Election of IS;6: Stanrood, "History of the Presidency," pp. 356-393; Cox, "Three Decades of Federal Legislation," pp. 65I-668; Rhodes, "United States since IS50," VII, pp. 206-2SI; Haworth, "Disputed Presidential Election of IS 66 ."

\section{STUDIES}

I. The condition of the South (IS65). (Hart (ed.), "Contemporaries," IV, Nos. ItI-It+.)

2 Powers exercised by the Freedmen's Bureau. (MacDonald, "Select Statutes," No. 5r.)

3. Attempt to remove Stanton from office. (Blaine, "Twenty Years of Congress," II, pp. $3+3-353$.

4. The trial of Johnson before the Senate. (Ross, E. G., in Srribuer's, XI (ISgI), pp. 5I9-524.)

5. Ku Klux morement. (Brown, "Lower South in American Historr:" pp. I I-2:S.)

o. Carpetbag gorernment in South Carolina. (Rhodes, "United States," VI, pp. I+2-I6S.)

i. Political contests in Louisiana. (Andrews, "Lnited States in our Own Times," pp. I52-I6;.)

S. Nast's services in breaking up the Treed ring. (Paine, "Thomas Nast.")

\section{QUESTIONS}

I. Summarize the practical and the theoretical problems of reconstruction as they existed in 1865 . How did the plan that was adopted solve each of these? Do you agree with Professor Burgess that the North should acknowledge that reconstruction was an error as well as a failure?

2. Were the rights of whites and blacks in the South protected by the Freedmen's Bureau and the Civil Rights Bill? What new principles did the latter introduce into our srstem of government? Were those principles incorporated permanently or not?

3. Compare the three amendments to the written Constitution in regard to provisions, importance, and results. Make a complete comparison of the Enancipation Proclamation and Amendment XIII; of the Civil Rights Bill and Amendment XIV.

4. Enumerate the most important changes in the written Constitution during the reconst ruction period. Did the changes (IS6I-IS $i$ ) constitute a revolution? 


\title{
PART V
}

\section{THE NEW NATION (I865-1907)}

\author{
CHAPTER XIX \\ INTERNAL DEVELOPMENT (1865-1886)
}

Presidents

Andrew Johnson (I 865-I869) James A. Garfield (I 88 I-I 88I)

Ulysses S. Grant (I869-IS77) Chester A. Arthur (ISSI-IS85)

Rutherford B. Hayes (I877-I 88 I) Grover Cleveland (IS85-1889)

388. Changes Following the War. - There can be no greater mistake than to imagine that during the Civil War the Business activenergies of the North were entirely absorbed in carrying on that conflict or in supposing that during the succeeding years the reconstruction of the Confederate states engaged the attention of more than a small proportion of the people. When the crisis was past and the preservation of the Union no longer in doubt, the rast majority were aroused by the new business opportunities to improve their financial condition. At the close of the war a million and a half of men, North and South, returned to the ordinary walks of life within a few months. The business of the North, stimulated rather than retarded by the war, increased in rolume manyfold. There probably never has been a period of more numerous radical business changes or greater apparent prosperity than the period of reconstruction. During those years the wealth of the United States nearly doubled. The larger cities engaged in commerce on a large scale. In the smaller towns new factories were started. Immigration from Europe began anew. Into the West flocked a host of sturdy pioneers who settled with their families on the farms which 
the national gorernment sold to them on liberal terms. ${ }^{1}$ Jew lines of railway were built in all parts of the Lnion, especially in the Mest.

Extramagance and panic.

As the country was flooded with the large issues of national paper money - greenbacks and national bank notes. — gold and silver coims were no longer in regular circulation during this perind, high prices prevalled, and spoutation was common. People bousht and sold recklessly. fortunes undreamed of before the war were made within short periods, and private extravagance besan to replace the cautious expenditures of the carlier period. Prosperity sonn led to

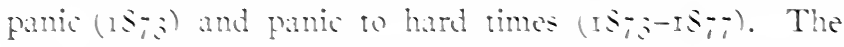
country recovered from this experience about the time that reconstruction was completed in the south. and after Iミ: it settled down to the new methends of business and new standards of living under fairly nomal conditions.

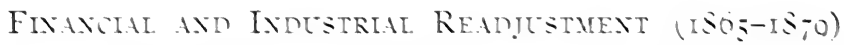

Xationat debt. 3So. Bonds and Taxes after the War. - At the close of the war the debt of the Lnited states was nearly three bilDewey Fom lions of dollars. It inchated more than four hundred millions

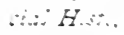

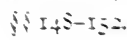

T.uxes. in groenbacks and other notes which bore no interest. but most of the debt was in the form of homds. with interest at five fer cent or six per cont. Some of the bonds were payable in coin only, but the laws authorizing others had not stated in what kind of curreney they were to be paid. As they had been sold for paper money, in almost erery instance, many poople insisted that these latter bonds be paid in sreenbacks. In fact the I) mocratic platiorm ( Isos) contained a plank faroring this method. but the sovermment. in order to maintain its credit and to facilitate the sale of the new bonds that were to replace the old ones. decided to pay all in coin. When peac came in ISos, the govermment sought to retue the taxes as soon as possible. but until the panic of IS: there was a surplus of recoipts over expenditures. The

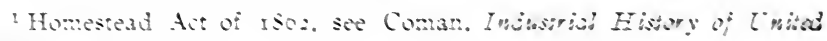

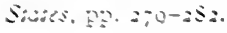


most objectionable features of the internal system were repealed, including the income taxes and the taxes on manufactures, but the excises on liquors and tobaceo were retained, the annual revenue from this source after s s;o being but little less than that from customs duties. No important change was male in the tariff ${ }^{1}$ in spite of the reduction in the internal taxes on manufactured articles which were protected from foreign competition, so that the rates were more than twice what they hat been before the war and the inducement to invest capital in industry was very great.

39o. The Greenbacks. - Is the greenbacks had been intended to help the govermment during the war only, steps were taken by the treasury department as early as I $\$ 65$ to retire them from circulation. Those who desired the withelrawal of the paper money were called "contractionists," their opponents were known as "inflationists." Contraction of the currency proved to be umpopular and wats abantoned in 1 So $\$$, but in 1 \$og the Supreme Court decided that Congress had no power to make those notes legal tender. This decision was reversed two years later when the reorganized court declared that the national government might issue legal-tender paper money in time of war. During the hard times of the 7o's the treasury department issued new greenbacks, and in ISSt, when the Supreme Court was asked to decide whether these issues were constitutional, it gave its opinion that "Congress, as the legislature of a sovereign nation," has the right to issue legaltender notes at its discretion."

In spite of the hard times after i $S_{73}$, repeated attempts were made to resume specie payments. Finally in ${ } S_{75}$ a

${ }^{1}$ In $S_{7} 2$ the duties on tea and coffee were abolished and a horizontal reduction of ten per cent was made on other rates, but the original rates were restored in is 75 , except that tea and coffee were left on the free list.

2 It might do this because of powers specifically conferred on it hy the Constitution (Art. I, s s, cls. I, 2, and 5) and because " the power to make the notes of the government a legal tender in payment of private debts is one of the powers belonging to sovereignty in other civilized nations, and not expressly withheld from Congress by the Constitution."

Issuiance and constitutionality.

Dewey, Financial llist., ईई $15 t^{-1} 5^{\circ}$.

White, Woney, I $34^{-1}+9$, $150-10_{3}$.

Rhodes,

L'nitcid States, VI, 222-225, $25^{8}-273$.

Resumption of specie payments (IS79). 


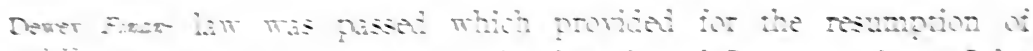

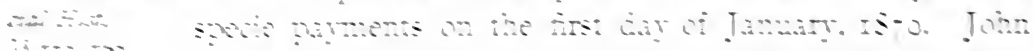

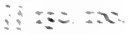

\section{$\mathrm{Bz=}=\mathrm{S}$}

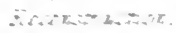

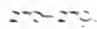

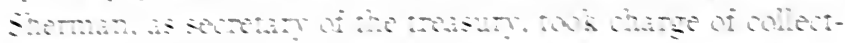

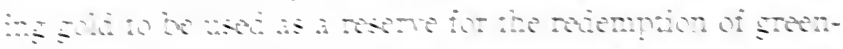

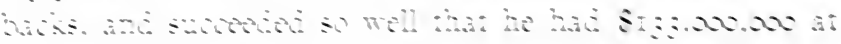

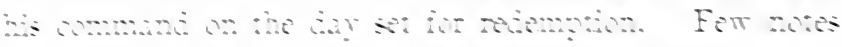
were

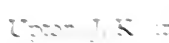
$\therefore-i n=$

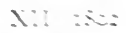

$\because 20-25$

indisis

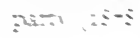

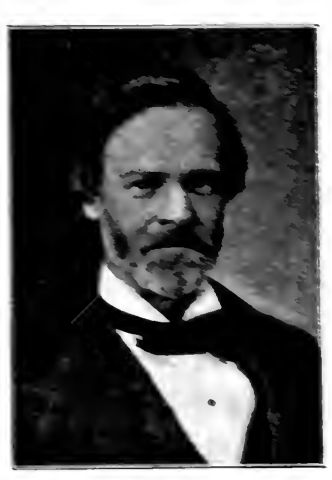

$\therefore \therefore \div \div \div>1$

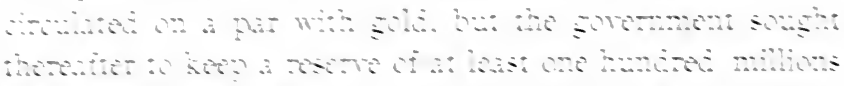

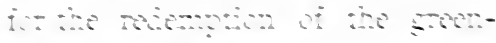

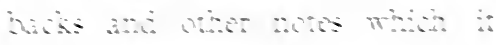

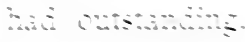

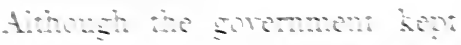

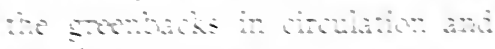

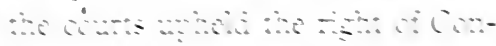

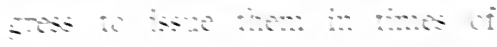

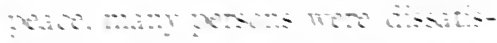

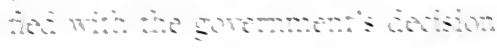

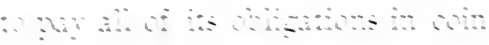

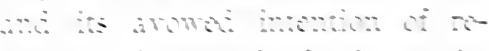

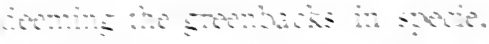

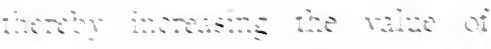

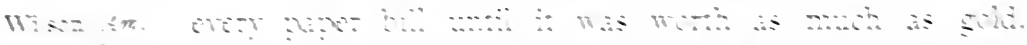

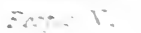

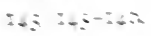

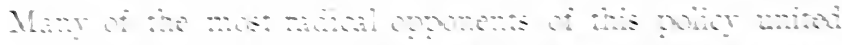

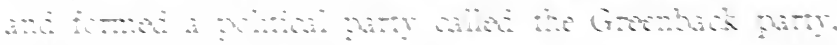

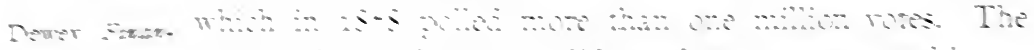

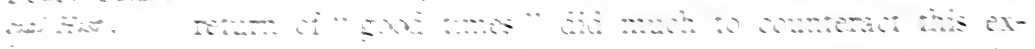
$\therefore: 2$

ins

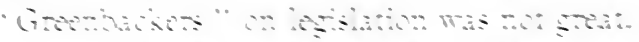

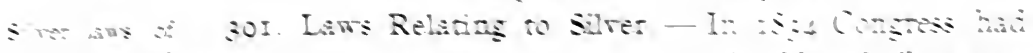

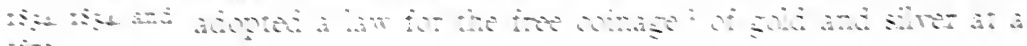
I:

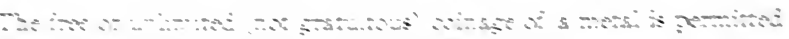
dis a

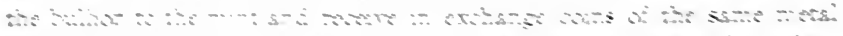

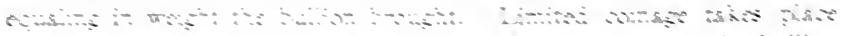
w

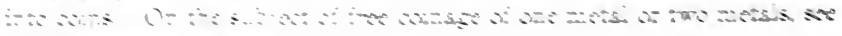

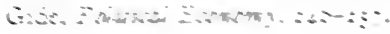




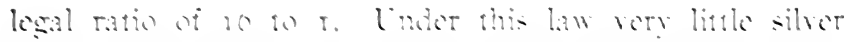

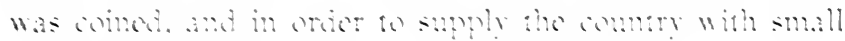

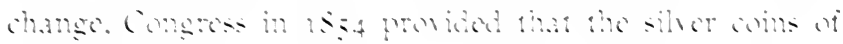

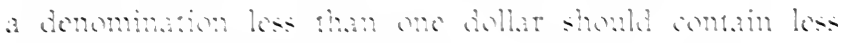

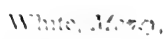
$\therefore:$

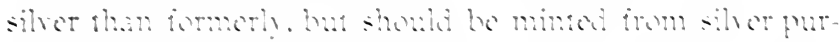

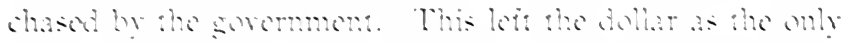

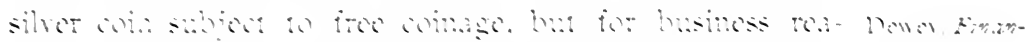

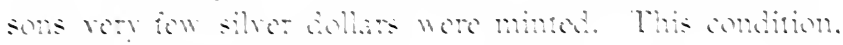

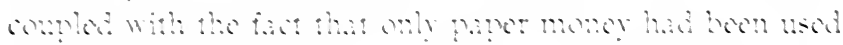

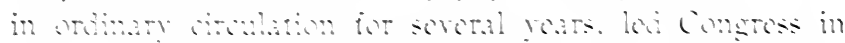

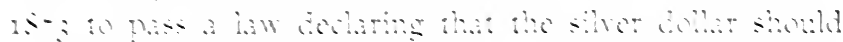

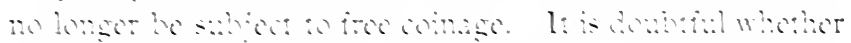

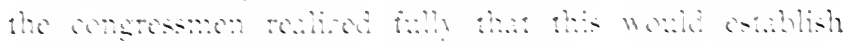

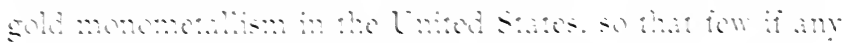

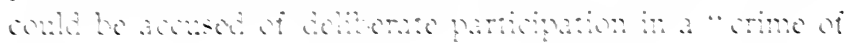
II-

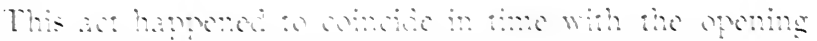

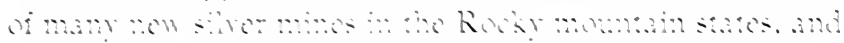

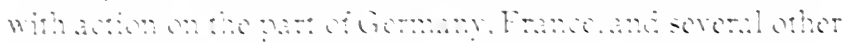

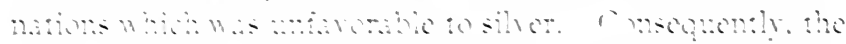

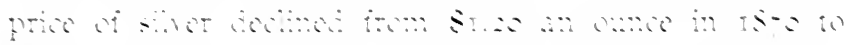
s.

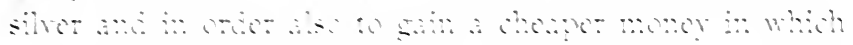

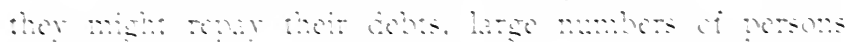

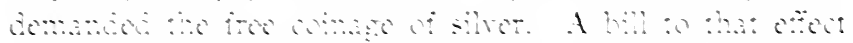

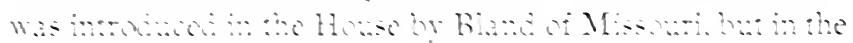

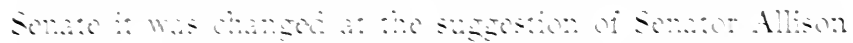

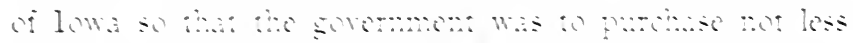

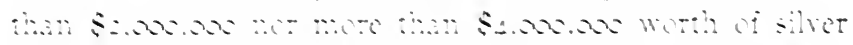

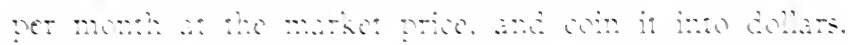

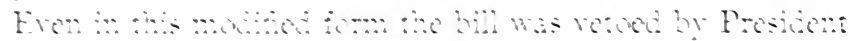

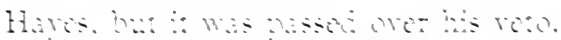

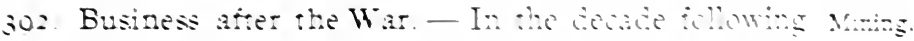

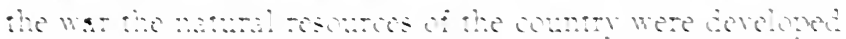

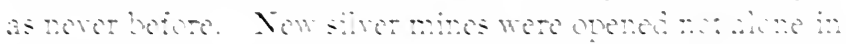

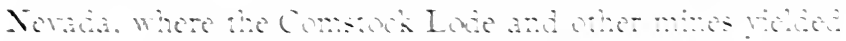

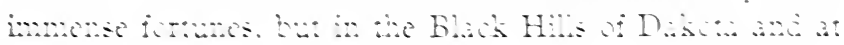

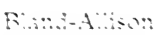
A.: $\because \because-5$.

1) $\therefore$ … 3 in $\therefore: \cdots$

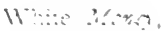
$\therefore: 3-50$.

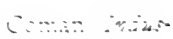

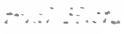
$z:-=-$ 
Leadville, Colorado, to which thousands flocked in search of wealth. Iron and copper were mined much more extensively, particularly in the upper Michigan peninsula, and the coal output of the United States increased five hundred per cent. Especially in northwestern Pennsylvania the production of petroleum drew throngs which sought fortunes

Manufacturing.

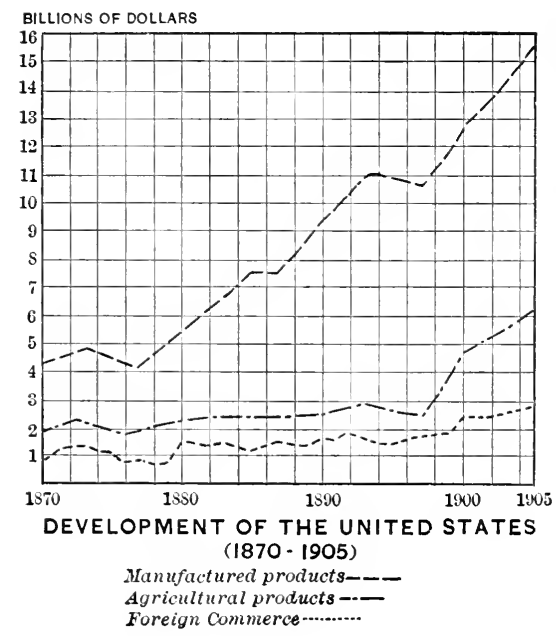
in the oil fields. When this crude oil was refined, it was found to be a very fine illuminant and was sold extensively in the United States and in Europe.

Conditions were especially favorable for manufacturing. The increasing supply of raw materials, the demand for greater conveniences and more luxuries than before the war, Wright, Indus- the extension of the railways and the cheapening of transtrial Evolution, portation, aided in this movement. More than anything else I59-188. the high protective duties, preventing keen competition from abroad, made manufacturing investments desirable. From I 860 to I880 the value of manufactured articles increased from less than $\$ 2,000,000,000$ to nearly $\$ 5,500,000,000$.

Foreign com- Foreign commerce revived very rapidly after the war. merce. In 1865 our total exports and imports amounted to but $\$ 465,000,000$. Eight years later they were nearly three times that figure, and, although the depression from $\mathrm{I} 873$ to 1878 reduced the amount of our foreign trade, it never again fell below $\$ \mathrm{I}, 000,000,000$ a year.

393. Agriculture and the West. - During the period from I865 to I880, which was one of distinctively national growth, 
the United States was fortunate enough to avoid one of the great dangers which are likely to accompany rapid industrial and commercial development, namely, the loss of a sturdy, middle class of farmers. In I 880 there was just twice the number of farms in this country that there were in I860, a truly remarkable change. This can be accounted for in several ways. First, in the South, agriculture was emancipated from the former system of large plantations exclusively, with crude labor, and, although numerous large cotton and tobacco plantations remained, there were now very many small farms devoted to various crops and supporting one family rather than a colony. This was fortunate for the South, as the people did not recover easily from the losses and hardships of the war and reconstruction. Second, in the East more attention was being paid to intensive farming, as it was found difficult to compete with the cheap western lands in the growing of cereals. Near the cities small truck farms conducted on scientific principles were found exceedingly profitable.

Third. Into the West poured hundreds of thousands who were attracted to the rougher life of the frontier, or were drawn on by the offers of cheap land made by the government or the railways. In I 862 Congress had passed the Homestead Act, permitting any one who was a citizen or intended to become a citizen to acquire 160 acres of land by remaining on it five yec rs, the money payment being purely nominal. Last, when hard times after 1873 reduced the demand for labor in industry and commerce, many thousands turned their attention to agriculture, which suffered less from the panic than any other occupation.

Aside from the social advantages derived from the increasing tendency to become a nation of small farmers, the agricultural changes of this period are noteworthy. The quantity which was grown doubled during the fifteen years following the war, and in the case of wheat, the increase was even greater. With the opening of large grain farms in the western part of the Mississippi valley and the

Agriculture in the West.

Coman, Indus. trial Hist., 279-282.

Agricultural development 
construction of railways in that region, we began to export large quantities of flour and other bread stuffs to Europe, the real beginning of our most important modern export trade.

\section{Transportation Problems (I865-i887)}

Railways after the Civil War.

Haynes, Railway Legislation, 82-96.

Johnson, Railway Transportation, 27-28, 3II-3I6.

First transcontinental railway.

Coman, Industrial Hist., 282-286.

\section{Development of the West by Means of Railways.}

We have already noted the care taken by the state governments, particularly in the West, to develop railway communication within their territory ( $\$ 284)$. In I 850 the United States began to take part in this movement by making grants of land to the states to be used as a bonus for railway lines. Much had been done in this way before I860, when the United States possessed 30,000 miles of railway. During the war the need of moving troops or provisions, and after the war the increased demands of the exporters in the coast cities, the eastern manufacturers, the farmers, and the western miners, emphasized the need of better means of communication. This led to an era of railway construction that in eight years (I866-I874) more than doubled the mileage of the country. New sections were thus offered to settlement, inducements being made by the railways which offered to carry settlers and their families at very low rates. Lands were granted almost without cost not only by the government under the Homestead Act, but by railways, which advertised widely the advantages of the farms they had for sale. These lands had been given to the railways as a bonus for building a line through a region that could not possibly support a railway until it was densely populated. The result was, of course, greatly improved means of communication in the Northwest, accompanied by the rapid settlement of the western prairies and an agricultural advance that was marvelous.

The most important railway enterprise of this period was the construction of a transcontinental railway from the Missouri River to the Pacific coast. This was authorized by Congress in I862, the national government making liberal land grants and loaning a large sum of money to the 
railway companies. ${ }^{1}$ The completion of the road in 1869 was an event of great importance from the political as well as the commercial standpoint.

395. Railway Abuses. - In the eastern and central states many of the railways built after the war were unnecessary. (I) Their efforts to secure business led to cut-throat competition between cities which were on more than one line, so that goods were often transported between two points at an actual loss. To make good this deficit, the railways charged an extra amount on local traffic. If a shipper wished to send goods from Chicago to a point in New York or Pennsylvania, it was often cheaper to ship the goods to New York and then reship them back over the same line to the intermediate point. (2) This discrimination between different places was less serious than a second railway abuse; namely, the discrimination between shippers, which became quite common after 1870 . By granting special rates to favored shippers the railways did much to develop the great monopolies which were often able to destroy the business of their smaller competitors, because of the cheaper transportation secured by them. For example, the Standard Oil Company, of Cleveland, Ohio, succeeded in gaining control of most of the refineries in that city and in the oil-producing district of Pennsylvania, partly because it obtained lower freight rates and was able therefore to sell oil for less than its competitors.

By combining, the railways sought to protect themselves from cut-throat competition and to keep the trusts from forcing them into giving large rebates. The object of these combinations was to maintain a uniform system of high rates on all of the railways in the country. But the ordinary

Dillon, S., in Scribner's, $\mathrm{XII}$ ( 1892 ), 253-259.

Two kinds of discrimination in the East.

Johnson, Railway Transportation, 2I7-227.

Haynes, Kailway Legislation, 207-2I3.

Rogers, Devt. of North, I 8 I-I89.

Pools.

Hadley, Railroad Transportation 74-76, 9I-97.

1 The amount loaned was $\$ 16,000$ per mile across the prairies, $\$ 32,000$ on the mountainous plateaus, and $\$ 48,000$ per mile across the mountain ranges. The total sum of over $\$ 6 \mathrm{I}, 000,000$ was loaned at six per cent for thirty years to the main line or branches. This was secured by first mortgage on the railways. Between 1896 and 1899 all of the principal was repaid and in most cases interest was paid also. 
Johnson, Rail- combinations failed to do this because some railway was way Transportation, 228-243. certain to cut rates in order to secure more business. Later a plan was devised to arrange beforehand the percentage of the profits to be received by each of the railways in the combination, or pool, as it was called, so that there would be no temptation to cut rates.

Abuses in the West.

396. The Granger Movement and Railway Legislation.In the West the situation was even more serious. As there was less competition, there was less need of combinations to maintain rates. The railways, having sold most of their

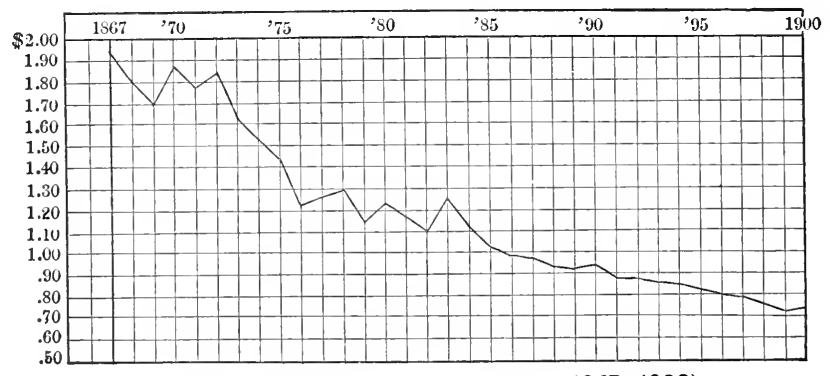

DECREASE IN RAILWAY RATES (1867-1900)

desirable lands by attracting settlers with low rates, began to charge "all the tariff that the traffic would bear." It is probable that most of them could not have paid expenses even by the use of exorbitant rates, but these facts were lost sight of by the shippers who were obliged to find a market for their products. Throughout the West spread a demand for government relief.

Granger

The cry for control of the railways was taken up by the legislation. Farmers' Alliance, which had been originally a non-political body. Hundreds of thousands joined the Alliance in all Wilson, $A m$. parts of the country, and in several state elections during the People, V, 124-128. serenties the question of railway regulation was the principal issue. The chief aim of the Grangers, as the members of the Alliance were called, was to secure lower rates. Largely through their influence state railway commissions were 
appointed which had the right to fix maximum rates and dictate the policy of the railways in other respects. ${ }^{1}$ At first the attempt was made to have all rates as low as those between two places which enjoyed keen, unrestricted competition; but as it was found that this only injured the railways and indirectly hurt the shippers, the commissions later used their powers more carefully.

397. The Interstate Commerce Commission (1887). As the larger part of the freight transported on the railways of the United States is carried between places in different states, legislation by the states did not afford the relief expected even with the drastic methods used. But Congress was slow to take action. In 1878 a bill for the regulation of interstate trade passed the House of Representatives but not the Senate. Nothing was done until, several years later, the Illinois commission tried to apply its laws to certain trade that was carried on between Illinois and the neighboring states. The Supreme Court of the United States declared that the Illinois commission had no right to regulate interstate commerce, as Congress alone had that power.

So widespread a demand had arisen for action by Congress that in 1887 the Interstate Commerce Act was passed, creating a commission of five members which had the power to investigate existing rates and declare them unreasonable. The avowed purposes of the act were to prevent pools affecting interstate commerce by declaring them illegal, to prevent high rates or rates that were discriminating because one person was charged more than another for similar services. or because a greater charge was made for a short haul than for a long one. ${ }^{2}$ Fear that the commission might treat the railways as the earlier state commissions had done led the railways to change their methods radically for a time, not always to the advantage of the public; but the powers of

1 Many former state commissions did not enjoy the right to fix maximum rates. Most of them now have this power.

2 In a case of this kind, the short haul was always a part of the longer one.

Interstate Commerce Act (1887).

Johnson, Railway Transportation, $370-3^{8} 5$. Adams, H.C. in Atlantic, 8I (1898), 433-443. 
the commission were so limited that it acomplished comparatively little.

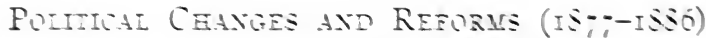

Eevisos of ISE

Ansens gor

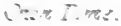
$3+-3 r$

Stanines:

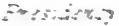
$402+5$

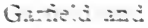
Consting

$A=3-2 w s \quad \%$ $(\because 2 \pi)$ $3+3-3$

3os. Gartield and Arthur. - Not only was busimess reexablished un a numal basis after Is, but the pulitial parties besan winteres themselves in present-day questions.

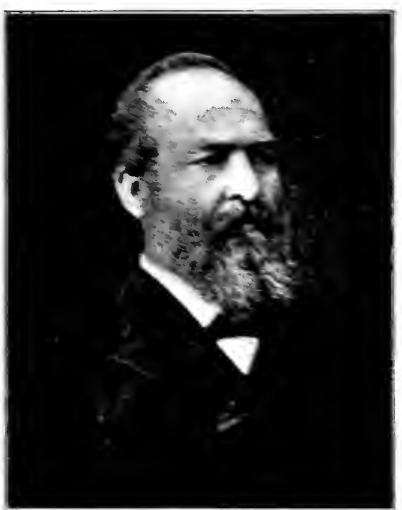

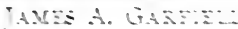

This mas aprorent in all oi the elections atter IB-s. Inierst in the elcution of Isto centers in the Kevublicun conremtion in Chingo rather than in the camping. The

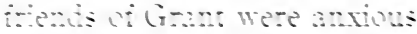
ans he shont be nomimstet. it he and they though that the swalled " thind-term tra-

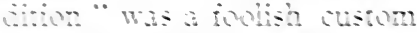
"or santionet by the mation. Giake by Rosue conkling.

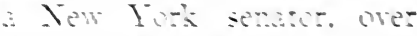

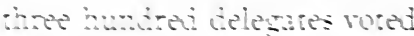

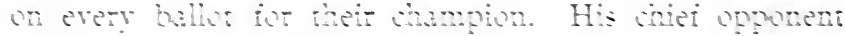

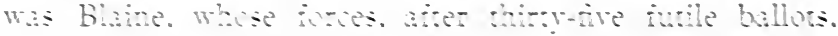

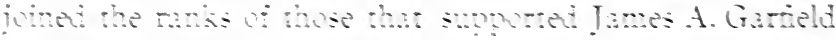

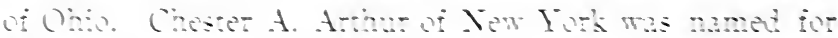

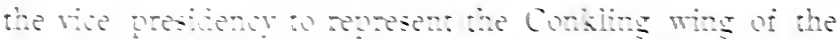

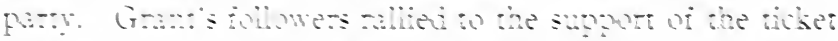

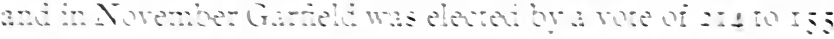

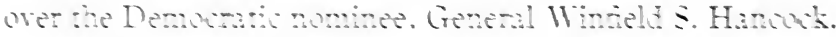

Aler the elewion he breat berwern the Conkling and

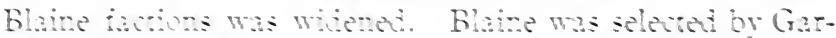

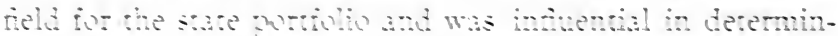
ing the wlioy of the atminimation. When the President

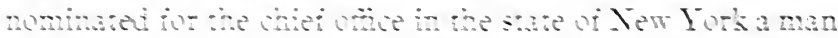

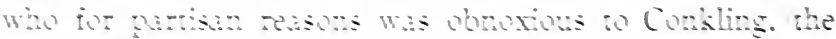

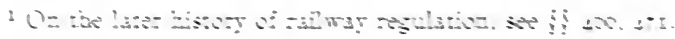


latter resigned from the senate and persuaded his colleague to do the same. It had been the custom, and is still to some extent. for the senators to name the appointes for federal positions in their states, so that Garticht's action was a blow to Conkling's power as well as his pride. The senators expected of course to be triumphantly recelected and were sadly disappointed when others were selected. The incident aroused public sentiment to the evils and dangers of the spoils system. This feeling reached ferer heat when on July 2, ISSr, Garfield was shot by a disippointed office seeker. The lingering illness of this second " martyr president " created a demand for reform in the civil service that found embodiment in law soon after (s tor).

Arthur had been looked upon as a politician of no great ability, but he proved a wise and reliable executive. Few of the measures of his

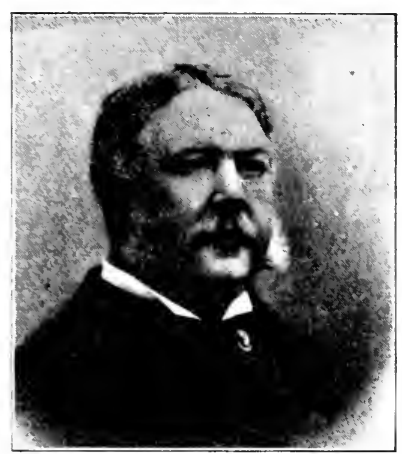

Chester A. Arthur term were partisan acts. so slight was the cohesion in the political parties. The old issues had been dropped, but party lines were not drawn as yet on new political questions.

399. The Election of Cleveland (I884). - The campaign of $I S S_{4}$ was the most interesting that had been held up to Political situation that time since the Civil Mar. The dissensions in the Republican ranks, the lack of any clear-cut Democratic policy, and the rise into prominence of the Prohibition party complicated the situation. So far as any political issues attained prominence, the main question that seemed to be at stake was that of reform, although the politicians of both parties sought to make the tarifi the important issue. In reality, it was more a personal campaign between the two candidates.

The Republicans nominated the most distinguished 
Candidates and election.

Wison, Am. Peifle $\mathrm{I}, \mathrm{I} 5 \mathrm{~g}-\mathrm{I}-\mathrm{0}$.

Stanwood, Presidency, $427-4+9$.

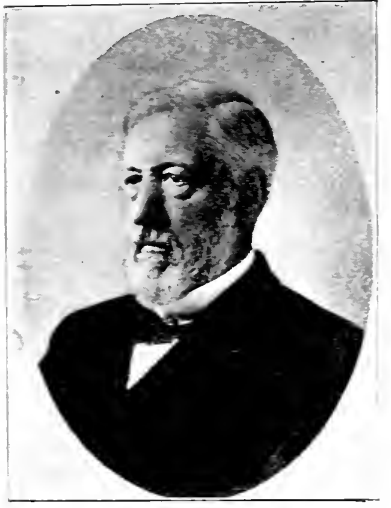

JAMES G. BIAINE

member of their party, James G. Blaine of Maine, a man of magnetic personality who aroused in his followers a greater enthusiasm than any other leader since the dars of Henry Clay. Blaine had unfortunately been connected, while speaker of the House of Representatives, with a transfer of railway stock which his opponents claimed was a bribe. Blaine had answered the charge boldly, but had never satisfied some of the reformers in his party of his innocence. This transaction, in fact, clouded the most brilliant political career of recent times. The reformers refused to support the Republican ticket and worked for the Democratic nominee. This faction of ". Mugwumps," as it was called sneeringly; was, in fact. sufficiently large to decide the election. Grover Cleveland, who represented the Democratic party, had become prominent as governor of New York, because of the immense plurality by which he had been elected in ISS 2 and by the fearless use of the reto to reduce expenditures. He was hailed as the chief reformer then prominent in politics. The campaign was contested hotly and tas marred unfortunately by the bitterness of the personal accusations against the two candidates. The election was decided by the rote of New Fork. in which both the Prohibitionists and Mugwumps were numerous. For several days after the election the rote of New Fork was in doubt, but the official count showed that the state had gone Democratic.

C'ereanan's poticy.

Peck, $7: \cdots$ Iests, $4-50$, 6̆-5̄o.
As Cleveland was the first Democratic president for a quarter of a century the party looked forward eagerly to the return to power. The reformers. on the other hand, expected him to orerlook partisanship in making remorals and appointments. In consequence his position was one of 
great difficulty, and, as is usual in such cases, Cleveland did too little to satisfy the one party and too much to please the other. He left conditions better than he found them and at all times exhibited a firmness that brought results. His administration is noteworthy for the numerous important changes that were made in the law of the nation.

400. The Spoils System and Reform. - For a period of Character of fifty years the majority of the offices connected with the national government had been filled by party workers who had been appointed in return for services rendered to the party during the election campaign. Frequently extensive changes had been made every four years even when the same party remained in power. Thousands of persons were employed whose services had never been engaged according to law. This resulted in a serious demoralization of the civil service which was in-

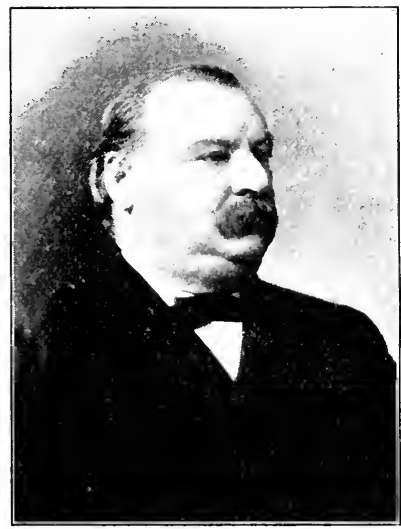

Grover Cleveland creased by the practice of requiring officeholders to contribute to campaign funds and work for their chiefs. Often the entire influence of an administration and its supporters would be devoted to the carrying of primaries; the election of delegates to nominating conventions and the carrying of doubtful states or districts. Pernicious political activity of this kind was even more disgraceful than inefficiency in office.

Even before the Civil War, there had been some demand for the reorganization of the public service on business principles. Nothing of importance was done until, in $187 \mathrm{I}$, a civil service commission of first-class men was appointed by President Grant. The commission was empowered to investigate the character and fitness of a few employees and

Lodge, Hist. and Pol. Essays.

Hart, Actual Gov't, \& 132 .

Civil service under Grant and Hayes.

Larned (ed.), Ready Ref., I, $476-477$. 
Lodge, Essays.

Civil Service Commission $\left(\mathrm{ISS}_{3}\right)$.

MacDonald, statutes,

No. Iog.

Hart, fctual Gov't, \& I3t.

Extension of commission's work.

Larned (ed.), Keady Ref., VI, $\mathrm{I}_{45}-\mathrm{I}_{4} 8$.

Special improvements. might give examinations of an elementary character. After four years Congress refused to rote appropriations for carrying on the work, and, as the results were not particularly gratifying, the commission ceased to exist. President Hayes did much more for the national civil service by insisting on good appointments.

In ISS; Congress passed by a large majority in both houses a bill for the reform of the national civil service. This had been drafted by the Civil Service League and introduced by Senator Pendleton of Ohio. It provided for a commission of three members with power to make rules for the examination of candidates for numerous offices of a clerical nature. These offices were arranged in classes, hence the term " classified "service.

40I. Progress of Civil Service Reform since I883. - As the president was permitted to increase the number of positions to which appointments might be made by the commission, the attitude of the chief executive was a matter of the first importance. All of the presidents since ISS 3 have extended the scope of the commission's work. Intil ISot, however, most of the additions were made after the successor of the executive in office had been chosen. During his second term President Cleveland gave the commission control of large numbers of offices in the treasury, war, nary, and interior departments. During that administration the number of offices in the classified service was more than doubled. Afterward it was claimed that the men appointed by the commission to some positions requiring skill were not fitted for their work, and nearly eight thousand offices were taken from the commission. During the first four years that Roosevelt was president the number again increased nearly one hundred per cent, the offices opened to examination being in many cases of a higher type than those formerly filled by the commission.

Numerous executive orders have modified the civil service rules. Originally persons in the classified service might be removed by those under whom they served. After con- 
siderable agitation President McKinley in I $S_{97}$ declared that none should be removed but for cause which was stated specifically. Changes have also been made for the promotion of officials according to proved ability. Some of the presidents, Roosevelt particularly, have applied this principle to very many offices not controlled by the commission. In general it may be said that, although the method of appointment used by the commission is not ideal, and although there is danger of retaining under the system officials and employees who have outlived their usefulness, it has performed a work of inestimable service to the nation.

The experience of the state and city govermments in regard to the spoils system and reform has been somewhat similar Municipal and state reform. to that of the central government. In our largest cities particularly the abuses of the old system have been more serious than elsewhere. Civil service commissions were appointed in a few states and cities during the nineteenth century. Civil service reform has made more progress since the beginning of the twentieth century, especially in those cities that have adopted the commission form of government. Much still remains to be done.

402. Reform of Elections. - Following close upon the reform in the methods of appointing public officials came a demand for improvement in the methods of election. There had never been any system of providing ballots or any order in polling votes. Each party printed its own tickets, and the parties, by neglecting to provide ballots, might prevent an election. Party workers were allowed to accompany any voter from the time he entered the polling place until he deposited his ballot. There was no secrecy, but every chance for bribery or intimidation. Organized gangs of the roughest element frequently controlled the election. "Stuffing" the ballot box was by no means uncommon. Occasionally those who had the right to count the ballots took the boxes with them to one of their homes. In short, there was every opportunity to defeat the will of the people.

In ${ } S_{7} 7$ agitation for reform began in earnest. England Reform ballots. 
had adopted recently a form of ballot based on that in use in Australia. The reformers urged the selection of this, and in ISSo Massachusetts adopted with modifications the so-called Australian ballot. The movement spread with amazing rapidity, and although no state had used the reform ballot in the presidential election of ISSS more than thirty did so four years later, and all but three had abandoned the older system in I906. These reform ballots are printed by the govermment. Names of all candidates for all offices are printed on a single sheet. Official ballots are not distributed to the roters until they have registered on election day, and the ballot is marked in secret.

Short Ballot.

On account of the large number of names on the old ballots there has been a recent movement to decrease the number of elective offices using a short ballot. ${ }^{1}$

Primary

Reform.

Presidential Succession Act (ISS6).

MacDonald. Statuts.

No. III.

Stanrood, Presidency, $450-452$.

In the old primaries were elected the delegates to nominating conventions. Most of our present primaries are direct primaries which choose candidates directly. ${ }^{1}$

403. Changes affecting the Presidency. - One of the most significant series of laws passed during Cleveland's first term affected the presidency. In ISS5 Vice President Hendricks died. According to the law of that time, in case of the death or disability of both the president and the rice president, the office was to be filled, first by the president pro tempore of the Senate, second, by the speaker of the House. As the Senate was Republican at this time, the accession of its presiding officer to the presidency would have led to a complete reversal of the administration's policy. A new Presidential Succession Act was passed, therefore, proriding that. if both the president and the rice president died, the office should be filled by the members of the cabinet in the order of the creation of the departments, beginning with the secretaries of state, treasury, and war.

President Cleveland had an interesting tilt with the Senate in ISS6 over his right to remove officials without the consent 
of the Senate. It will be remembered that the Tenure of Office Act in $\mathrm{I} 867$ had restricted the president's right of removal. This was replaced by a much milder act in I 869 when Grant took the oath of office, but the Senate had been in the habit of asking for reasons of remoral. Cleveland refused to do this, claiming that the law did not give the Senate a share in making removals. A long debate closed with the yielding of the Senate. This action is typical of a number of others by which Cleveland did much in his relations with Congress to restore the dignity and power of the presidency to the position it had occupied before reconstruction days.

The third change affecting the presidency was the enactment ( ${ } S_{7}$ ) of an Electoral Count Bill. In spite of the difficulties in 1877 in counting the electoral rotes, Congress had done nothing to supplement the omissions of the Constitution in this important respect. The law of $\mathrm{ISS}_{7}$ left the decision regarding what votes should be counted to the states, and if the states neglected the matter, Congress could reach a decision only by the agreement of both houses.

404. Summary. - The years following the war brought to the national government several problems besides that of reconstruction. There was an immense war debt to be refunded and paid. Congress was obliged to decide whether the paper money of the war should be retained, when specie payments might be resumed, and what should be done about silver. By i880 we were again on a specie basis, although a great amount of paper was in circulation and there was no longer free coinage of silver. The nation meanwhile had passed through a period of extreme business activity followed by the great depression in the years after 1873 . One of the prominent characteristics of the time was the rapid expansion of railways. In the East the railways cut rates between competitive points, making good the losses at the expense of intermediate stations. Cut-throat competition led to the formation of pools. In the East, first, and later in the West, state railway commissions sought to restrain the

Dispute over power of removal.

Hart, Actual Gov't, s I3I.

Cleveland, Pres. Problems, 39-76.

Electoral Count Bill.

MacDonald, Statutes, No. II3. Stanwood, Presidency, 397-400, $45^{2-}+56$.

Industrial problems of government and people (I865-I886). 
railways, the granger legislation of the prairie states being so drastic as to injure the railways. Legislation for interstate railways was delayed until i 887 .

Political parties and problems $(\mathbf{1} 877-1886)$.

The election of Hayes put an end to the political confusion of the reconstruction period, and with the election of $\mathrm{I} 880$ new issues were discussed. Some of these were industrial, as was the case with the tariff, which became prominent during the close of this period. From I882 to I 886 more attention was paid to the reform of party politics. The first attack was made on the spoils system, but later the reform of elections and the primaries was demanded.

\section{TOPICS}

I. Constitutionality of the Greenbacks: Bancroft, "Plea for the Constitution"; Knox, "United States Notes," pp. I 56-166, I93-229; Hart, "Salmon P. Chase," pp. 389-4I4; Thayer, "Cases in Constitutional Law," II, pp. 2222-2273.

2. National Control of Railways: Lord, J. W., in North American Review, I83 (1905), pp. 754-766; Haynes, "Restrictive Railway Legislation," pp. 220-233, 243-292; Johnson, "American Railway Transportation," pp. 367-407, 420-427; Meyer, "Government Regulation of Railway Rates," pp. 319-439.

\section{STUDIES}

I. John Sherman and Resumption. (Sherman, "Recollections of Forty Years," II, pp. 629-66o.)

2. Oil craze in Pennsylvania. (Tarbell, "History of Standard Oil," I, Chapter I.)

3. Destruction of Custer's force. (Andrews, "United States in Our Own Time," pp. I86-193.)

4. Building the first transcontinental line. (Warman, "Story of the Railroad," pp. 3I-65.)

5. Transportation in the South. (Bruce, "Rise of New South," pp. 28I-306.)

6. Government grants of land to railways. (Hart, "Practical Essays," No. Io.)

7. Conkling's attempt to nominate Grant. (Dawes, H. L., in Century, 47 (I 894), pp. 34I-344.)

8. The Plumed Knight and his joust. (Andrews, "United States in Our Own Time," pp. 452-480.) 
9. History of removal from national offices. (Cleveland, G., in Atlantic Monthly, 85 (1900), pp. 721-732; 86 (1900), pp. I-14.)

\section{QUESTIONS}

I. Look up the income taxes and taxes on production during the Civil War. Why was there opposition to these taxes? Should they have been retained after the war? If not, should the tariffs have been lowered to correspond to the reduction on the internal taxes?

2. What is meant by "legal tender"? Should Congress be prohibited from issuing a legal tender paper money? What has been the importance of the greenbacks, in supplying the government with revenue? in increasing government expenditures by affecting the price of bonds $(\$ 389)$ and by requiring a gold reserve $(\$ 412)$ in relation to business?

3. Give a summary of the laws regarding gold and silver money from 1792 to 1900 . Compare the Bland-Allison Act and the Sherman Act; the law of 1873 and the law of 1900 .

4. How does our federal system of government complicate the problem of railway control? Has government interference with the railway business protected the shippers? protected the public? affected the railways?

5. Show how the year 1877 marks a return to normal conditions, in the South; in the national government; in political parties; in business.

6. What is meant by the "third-term tradition"? Is it ever likely to be set aside? What change occurred between 1876 and I 885 in the composition of the parties and their policies?

7. What were the chief abuses existing in 1880 in the selection of public officials? Summarize the progress that has been made toward more satisfactory methods of appointment and election. 


\title{
CHAPTER XX
}

\section{THE END OF THE ERA (I886-I897)}

\author{
Presidents \\ Grover Cleveland (I885-I889) Benjamin Harrison (I889-I893) \\ Grover Cleveland (I893-I897)
}

\section{The TARIFF}

General changes of the period.

405. Proposed Reform of the Tariff (1882-1888). - The period from I 886 to I 897 was a period of social unrest ${ }^{1}$ and industrial change. ${ }^{2} \quad$ It was the end of the era of isolation in foreign affairs, for after 1897 the United States occupied a new position as a world power. During the period there were interesting foreign complications, and sharp internal political controversies, first over the tariff and later over free silver.

Tariff of I883. The commercial and industrial changes which took place Dewey, Financial Hist., \& I So.

Taussig, Tariff Hist., 230-237.

Tariff discussion $\left(188_{4-}^{-}\right.$ I 858). during the administrations of Hayes, Garfield, and Arthur made advisable a revision of the tariff, which was in 1882 substantially the same as at the close of the Civil War. A commission of business men appointed by President Arthur recommended a reduction in rates, but Congress passed in I 883 a tariff which raised many of the protective rates.

The tariff was discussed somewhat in connection with the election of $\mathrm{r} 884$ and occupied the attention of Congress during several sessions. In general the Republicans favored

Coman, Industrial Hist.

(rev. ed.), 3133 It. the existing rates and the Democrats sought to obtain a reduction, but a fair minority of Democrats, led by Samuel J. Randall of Pennsylvania, were protectionists. Party lines

${ }^{1}$ On Chinese legislation see $\$ 476$, note $\mathrm{I}$. On the Mormons, $\S 477$, note 2 .

2 On industrial changes see also $\$ \S 467-469,473-476$. 
were not drawn strictly on this issue until after December, I887, when President Cleveland devoted his entire message to a plea for tariff reform. In this document he used the oftquoted statement, "It is a condition which confronts us, not a theory." During the following spring (I888) the Democratic House passed the Mills Bill, providing a tariff for revenue only, but the Senate favored a tariff even higher than that in use.

406. The Election of $\mathbf{1 8 8 8}$. - In the presidential election of I 888 all other questions were subordinated to that of the tariff. Cleveland was renominated by the Democrats, but failed to draw as large a part of the independent vote as in 1884 . Benjamin Harrison of Indiana was elected by a comparatively close rote on a distinctively protectionist platform. ${ }^{1}$ Harrison, a conscientious man, who had been long in public life, was the grandson of President William Henry Harrison. Although

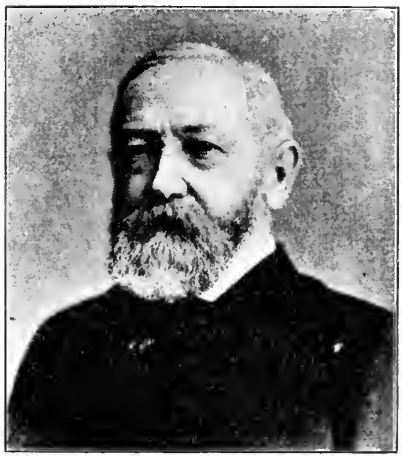

BENJAMIN HARRISON he had few peers in making short addresses to public Peck, Twenty audiences, he possessed little tact and magnetism in dealing with individuals. His most prominent cabinet official was James G. Blaine, who conducted important negotiations with Great Britain and Italy and took a prominent part in Pan-American affairs (\$\$ 4I6-4I8).

The Fifty-first Congress, elected in I888, was one of the most memorable in our history. It possessed a Republican majority in both houses - the first time that any party had been in power since 1876 - but the majorities in both houses were very small. The House selected Thomas B. Reed of Maine as speaker. Since some Republicans were always Years, $\mathrm{I}_{55}-\mathrm{I} 6_{5}$ Stanwood, Presidency, Chapter XXIX. New House rules.

Follett, Speaker of the H. of R., I90-216.

\footnotetext{
${ }^{1}$ The electoral vote was 233 to $\mathrm{r} 68$, but Cleveland's plurality on the popular vote was 98,0 I 7 .
} 
absent the Democrats sought to "filibuster" and prevent the transaction of business by failing to respond to their names when the roll was called. In order to obtain a quorum Reed ruled that any member who was in the Hall of Representatives should be counted as present whether he responded to his name or not. This and other acts destined to destroy the "rights of the minority" were received with protests so loud that the title "Czar" Reed was thereafter applied to the big man from Maine.

Protection and reciprocity.

407. The McKinley Tariff (1890). - This Congress enacted three laws which were of particular importance. One of these was a silver act $(\$ 4 \mathrm{I} 2)$, another the so-called Coman, Indus- Sherman Anti-Trust law ( $\$ 450)$. The third was the Mctrial Hist., 301-302.

Kinley tariff reported in the House by the chairman of the Ways and Means committee, William McKinley. In its final

Dewey, Financial Hist., form it was the most distinctively protective act ever passed $\$ 187$.

by Congress. The rates were especially high on manufactures of wool and cotton. As there had been a large surplus of revenues over expenditures for several years, the free list was Larned (ed.), enlarged greatly, sugar being the most important commodReady Ref., IV, 3085-3089. ity admitted free for the first time. To protect the growers of sugar in the United States a bounty of two cents a pound was to be paid on all sugar produced in this country. The tariff also provided for reciprocity by permitting the president to increase the duties on certain articles imported principally from Latin America, if any country discriminated against our exports. ${ }^{1}$ The tariff was not approved by many moderate Republicans and was one cause of the decided reaction against that party in the following election.

Election of I892.

Stanwood, Presidency, 49I-5I8.
In the election of 1892 the Republicans indorsed their policy of protection and the Democrats came out emphatically for a revenue tariff. Cleveland and Harrison were again the candidates. The campaign was unusually quiet, but it was found when the votes were counted that, as in I 890 , the Democrats had carried a large number of normally Republican states.

${ }^{1}$ These articles were sugar, molasses, tea, coffee, and hides. 
408. The Gorman-Wilson Tariff; the Income Tax Gorman-Wil. (1894). - The Democratic platform in 1892 had contained son tariff. an unequivocal declaration for a revenue tariff. To redeem this pledge a tariff bill was introduced in the House by William L. Wilson, chairman of the Committee on Ways and Means. Rates on protected articles were much lower than in the McKinley Act, although still high; while many articles, such as raw wool, coal, and iron ore were placed on the free list. In the Senate the Wilson Bill was altered by the committee under Senator Gorman so that most of the revenue features were removed and high protective rates were reestablished on many manufactured articles. As the Democratic majority was not united, a combination of members from both parties passed the bill in this form and finally compelled the House to adopt practically the same measure, on the promise that the Senate would consider bills to place coal, wool, and other articles on the free list. President Cleveland was unwilling to sign so un-Democratic a measure, but, believing it to be better than the McKinley tariff, allowed it to become a law without his signature.

The most interesting provision of this act was an income tax of two per cent levied on all incomes in excess of $\$ 4000$. This measure was desired by the South and West, which feared and distrusted the capitalists of the East. It was denounced as a class measure aimed at persons of wealth, but the exemption of incomes below $\$ 4000$ was justified on the ground that capitalists paid less in proportion to their ability than other members of society. The law was set aside by the Supreme Court because it held that all income taxes were direct taxes which must be levied according to population. $^{1} \quad$ Nearly twenty years later the Constitution was amended for the first time in forty years to permit the levying of income taxes $\left(\$_{4} 64\right)$. The loss of revenue, estimated at $\$ 40,000,000$ a year, seriously hampered the national government at a time when the ordinary revenues were reduced

Income tax and its constitutionality.

Dewey, Financial Hist., $\S$ I92.

Larned (ed.), Ready Ref., VI, $554-557$. 
grearly, and there was a constant demand on the gold in the treasury in exchange for paper mone. ${ }^{2}$

Dingley tarif IS:

Lamet ext. Risin $R$

VI. $B$ SI:

Tamsis.

Torin Fis:

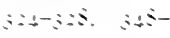
is.
Contioins a:

Covelane"s

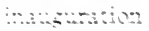
$\therefore \leqslant s$.
400. Recent Tariffs. - As the Republicans were subcessul in the election of $I$ soo $(j+f)$ and desired to revise the tarifi at the tirst opportunity. a special session of Congress was called in Marth. Isor. In July a tariff was adopted which marked a return of many of the rates used in the Mchinley tarifi of Isos, although some of the rates represented a compromise berween the rates adopted in Isoc and those of the Gorman-Wilson turit. This Dingley tariti provides for two forms of reciprocity: (I) The president was authoricet to lery duties on certain imports that otherwise would come in free fom semi-tropicalcountries which discrminutert aguinst American exports. (2) By reciproity treaties the president and Senate, with the approvel of congress, might retue by twenty per cent the rutes on a fell articles in return for concessions made to our trate by foreign powers. Tumerous treaties were negotiated under this dimse but only two of these were ratitied. As the Republicun purty remained in power for several years after so, no whange was made in the tarif until the adop-

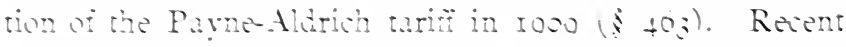
changes in the turiti are treated later as part of the movement of the times.

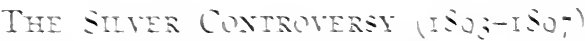

410. Repeal of the Sherman Silver Act - Cletelund began his scond term under uniavorable circumstumes. The thmes of the antionn govermment were in an m-

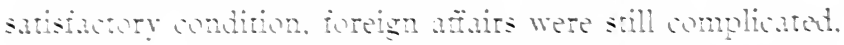
business was unsertich the penple were unensy and the

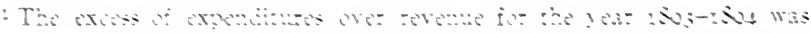

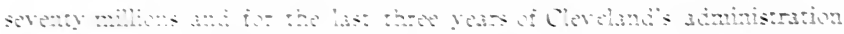

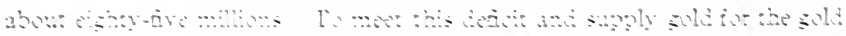

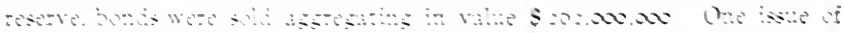

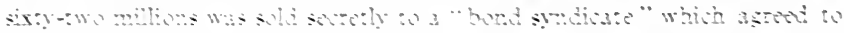

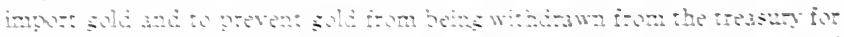

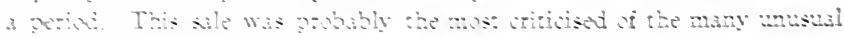

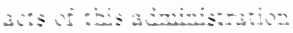


willingness and ability of the gorermment to redeem its Peck. Tirenty obligations in gold were questioned. Cleveland selected as liars, $300-325$. his Secretary of State Walter (Q. Gresham, a former Republican. without experience in diplomatic affiars. Most of the other members of his cabinet were unknown men, although events proved their ability.

In ISoo the Bland-Allison Act (301) had been replaced by a new silver law which was passed by Congress as a Silver law of substitute for a free silver measure desired in the West. This law. called the Sherman silver Act, authorized the treasury department to purchase 4.500 .000 ounces of sil-

Dewey, Financiari Hist., ji ISó.

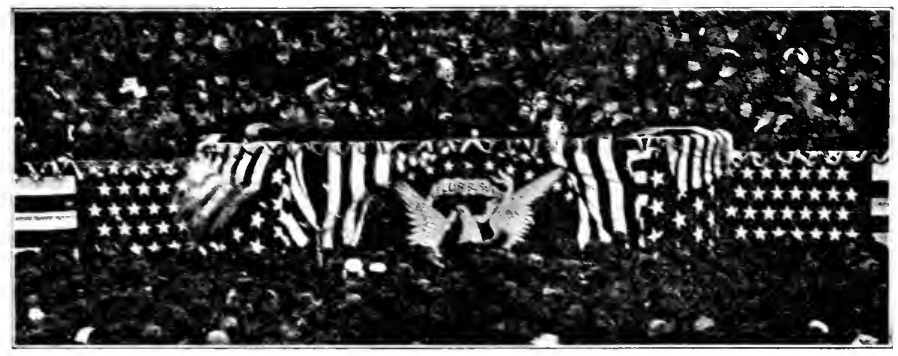

IXALLUKARIN OF CLETELAXN (ISOS)

ver a month. paying for it in certificates which were full legal tender and which were redeemable in either gold or silver at the option of the department.

The passage of this act, coupled with business changes during the years ISoo-ISoz, had a decided influence on the gold reserve of the treasury. Since the resumption of specie parments $(\mathrm{I} ;-0)($; 300$)$, it had been the custom to heep at least \$I00.000.000 in gold always on hand for the redemption of notes issued on the credit of the Lnited States. Comparatively few of these had been presented prior to ISoo, but after ISoo the amount of the gold reserve declined steadily. President Cleveland believed that this unfortunate state of affairs and the uneasiness caused among business men by the low state of the revenue was due chietly to the Difficulty in maintaining the gold reserve.

Dewer, Fin:an. cial Hist., If ISS, ISg. purchase of silver required under the Sherman Act. He did Nores, Thirty Vears of $A m$. Finsuie, $\mathrm{I}_{53}-\mathrm{I} / 3$. 
not call a special session of Congress, however, until more than a month after the commercial unrest had brought on a panic in May, I893 ( $\$ 454)$, until, in fact India closed her mints to the free coinage of silver. The House voted for repeal without delay, but the silver men in the Senate held out over two months before they would permit the Sherman Act to be repealed.

Causes.

Peck, Twenty Years, 448-453.

Development of the silver movement.

Dewey, Financial Hist., $\$ 194$.

Peck, Twenty Years, 453-464.

4II. The Free Silver Movement in the West. - During the years preceding I893 there were numerous indications of a serious movement throughout the West against the commercial interests of the East and against the financial policy of the national government. In I 890 and in 1892 several states had been carried by voters known as "populists," who favored a change. With the hard times that began in I893 and lasted for several years, the movement became more aggressive and almost universal throughout the states from the Missouri River to the Pacific coast. From all parts of the West arose a demand for government relief from the financial ills that oppressed the people. At first the demand was for the redemption of all paper money at Washington in silver as well as gold; but later, especially after the Sherman Silver Act had been repealed, the cry arose for "free silver." In fact, many of the westerners urged the issuance of paper money on an extensive scale.

Thousands of editors, politicians, and public speakers discussed this question until even the children felt that the wrong done to the West by the administration and Wall Street could be righted only by the free coinage of silver at the ratio of sixteen to one. Most of the western farmers were deeply in debt, but had struggled along cheerfully in spite of high rates of interest, heavy charges for transporting their grain to an eastern market, and the manipulation of the market by speculators to the great loss of the grain grower. But natural as was their anger against capital and the administration, it was unfortunate that they should have selected "free silver" as the sole remedy for the conditions existing in that section. 
4r 2. Election of $\mathbf{r} 896$. - So formidable had this free silver movement become that it dominated the political situation in 1896 . The most ardent advocates of free silver were the "Populists," 1 who were preëminently a cheap money party, advocating the free coinage of silver at a legal ratio of sixteen to one and the issuance by the government, without intervention of the banks, of paper money in large quantities. The Republicans, who held their convention earliest, sought to subordinate the question of money to that of protection. They declared their opposition to the free coinage of silver except by international agreement with the leading nations of the world. William McKinley of Ohio was their nominee for the presidency. The Democrats met at Chicago, the silver and the anti-silver men striving for control. The silver men outnumbered their opponents easily and succeeded in adopt-

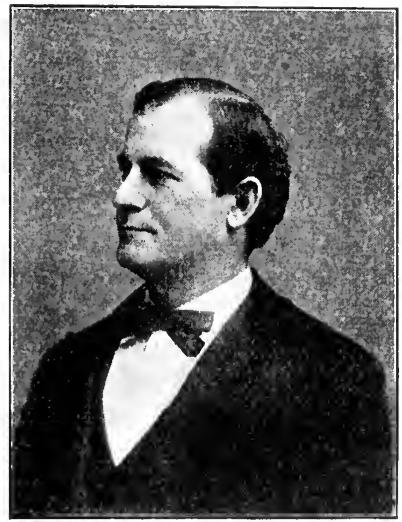

WiLliam J. BRYAN
Party conventions.

Andrews, Our Oun Time, 773-780. ing a free-silver plank for their platform. During the course of the debate on silver a speech of remarkable power was given by William J. Bryan of Nebraska. ${ }^{2}$ Bryan was nominated subsequently not only by the Democratic convention, but by that of the People's party and by the silver Republicans who "bolted" the Republican ticket. The Democrats and the Populists, however, nominated different candidates for the vice presidency. Many gold Democrats supported the Republican

1 This name was given commonly to members of the People's party.

${ }^{2}$ The most dramatic passage in this historic oration was that in which he declared, "We answer the demand for the gold standard by saying, "You shall not press down upon the brow of labor this crown of thorns. You shall not crucify mankind upon a cross of gold." " 
ticket, but others held a convention at Indianapolis and selected nominees of their own.

Campaign and election.

Dewey, Financial Hist., $\S$ I94.
The campaign was one of great vigor and intense interest. Bryan visited almost every state in the Union, making speeches everywhere along the route. The Republicans relied on a "campaign of education," but both sides scattered cartoons and documents broadcast. Each party

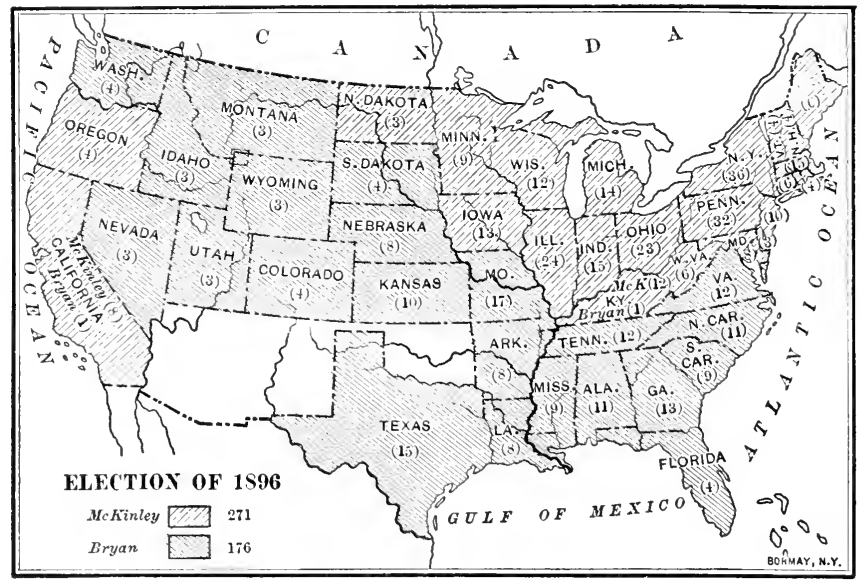

claimed to favor the only form of "sound money." The returns showed that party lines had been abandoned everywhere and that the sections had roted solidly for the candidate that seemed to champion their interests. McKinley carried the North as far west as the Missouri and obtained the electoral rotes of Maryland, West Virginia, Kentucky, and two Pacific states in addition, a total of $27 \mathrm{I}$. Bryan had large majorities in all the mountain, western prairie, or distinctively southern states, I 76 electoral votes in all. The total popular vote polled was larger than that in either I900 or 1904 .

McKinley's policy. 4r3. Republican Policies. - The tidal wave of I 896 gave the Republicans control of all branches of the national government - a control which they maintained and 
strengthened for many years owing to the dissensions in the Democratic ranks. McKinley, who was by temperament fair-minded and conservative, surrounded himself with a cabinet which contained during the first part of his administration men like John Sherman and William R. Day, and later included those exceedingly able statesmen, John Hay and Elihu Root. McKinley sought to conciliate the different interests at home and to prevent unnecessary complications abroad. The shief event of his administrat:on was the conflict with Spain which changed many national policies (\$ $\$ 2 \delta-43$ I.)

No change was made in the inancial system of the United States until in Igoo a law was passed revising part of the system. Gold was declared to be the money standard, and

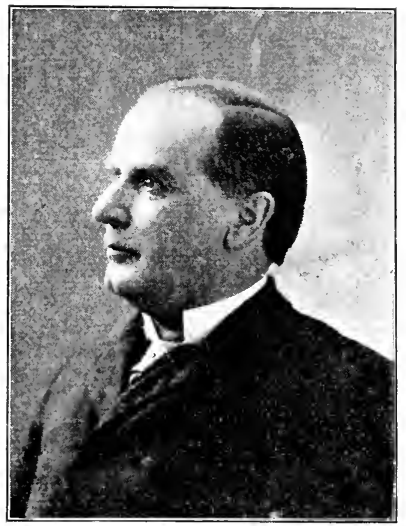

William MCKINLEY
Financial law of 1900 .

Hart, Contemporaries,

IV, No. 172 .

all forms of money are to be maintained at a parity with gold. The national paper currency was reduced in amount and reissued only in exchange for gold. The old bonds bearing three, four, or five per cent interest which had almost reached maturity might be exchanged for new thirty-year two per cent bonds. National banks might be organized more easily and might issue notes on more liberal terms.

\section{Foreign Affairs (I865-I895)}

414. Disputes with England. - During the first administration of Cleveland most of our foreign disputes were with Great Britain. The more acute of these dealt with the northeastern fisheries and was settled at this time; the others were concerned with fur sealing in Bering Sea and with the Larned (ed.), Ready Ref., VI, 639-64I.

Dewey, Financial Hist., $\S \S$ I98-20I. Alaskan boundary. It will be recalled ( $\$$ I 70 ) that at the close of the Revolution the New England states desired

Fisheries disputes.

Cambridge Hod. Hist., VII, 657-659. 
Larned (ed.), a continuance of the profitable fisheries off Newfoundland. Ready Ref., II, The liberal privileges granted to the United States in the II 2 I-II 22 .

Andrews, Our Oun Time, 508-515.

Hart, Contemporaries, IV, No. 173 .

NicGrath, P. T., in New England Mag., 33 (1906), 625630.

Seals in Bering Sea.

Larned (ed.), Ready Ref., V, $35^{8} \mathrm{I}-35^{8}$, VI, 5 I-53.

Dewey, Nat. Problems, 208-2I3.

The Alaskan boundary. treaty of ${ }_{1} 783$ were declared to be forfeited when war broke out in 1812 , and in 1818 , when the matter was readjusted, the United States was obliged to surrender her claim to most of the "inshore" fisheries. There was continued dispute over the interpretation of the convention of $\mathrm{I} 8 \mathrm{I} 8$ and several attempts were made to gain further rights, notably in the important treaty of Washington ${ }^{1}$ ( $187 \mathrm{r}$ ), by which the United States gave a free market to all Canadian fish and gained the right to fish off the coasts of the British colonies for ten years, on payment of $\$ 5,000,000 .^{2}$ When these privileges lapsed, peaceful relations were disturbed by the seizure of American fishing vessels which trespassed on forbidden ground. After much hard feeling the matter was settled by giving special privileges to those American fishermen who took out licenses in Canada. For some years fishing was permitted by special agreements with Newfoundland, but in Igo8 the whole question was submitted to the Hague Court $(\$ 443)$. Al-. though the decisions of the Court in Igro gave Great Britain control of bays less than ten miles wide, it freed American fishermen from petty regulations and annoyances.

The Bering Sea seal fisheries were threatened with destruction because of raids by irresponsible parties. After protracted controversy, it was decided that Canadian sealers should not take furs within a distance of sixty miles of the most important seal islands. In I9I I an agreement was made by the United States, Great Britain, Japan, and Russia for the permanent protection of the seal herds.

The invasion of Alaska by gold seekers after 1898 ( $\$ 437)$ brought into prominence the boundary between Alaska and

1 This treaty of Washington not only settled the controversy over the fisheries, but arranged for the arbitration of the claims due to losses caused by the Alabama and other cruisers ( $\$ 36 \mathrm{r}$, note) and for the arbitration of the boundary line in Puget Sound.

2 This award was made at Halifax in 1877 . 
Canada. ${ }^{1}$ Both sides wished to control the most valuable mines and the bays leading to the interior where the mines were. By submitting the question to arbitration the United States gained most of her contentions, so that she controls practically all of the coast of the "panhandle" of Alaska.

4r5. Samoa. - Harrison's administration is notable not alone for the interest we were beginning to take in our southern neighbors, but because in the south Pacific we were engaging with other nations in a method of political control hitherto foreign to our policy. This was done in the establishment of a joint protectorate over the group of Samoan Islands. In is 878 we had obtained Pago Pago harbor as a coaling station, but our commerce with the islands was not large, and it was not until i 889 that the attempt of Germany to control the king of the island forced the United States into a joint protectorate for Samoa with Germany and Great Britain. This did not work well, and by 1898 a situation had developed that was little better than civil war. By common consent ( 1899 ) the joint protectorate was dissolved, Tutuila Island with Pago Pago harbor being given to the United States and the rest of the islands going to Germany, which compensated Great Britain for her share.

I The relations of Canada and the United States have at all times been very intimate. In 1776 attempts were made to have Canada join the United States, in the invasion of Arnold ( $\$ \mathrm{I}_{42}$ ) and in the Declaration of Independence. In ${ }_{1} 8_{3}$ part of Canada was ceded by Great Britain to the United States $\left(\$_{17}\right)$. In I 8 I 2 one important cause of the war was a design on the part of the West to annex Canada $(\$ 245)$. Later boundary disputes $(\$ 280,303)$, reciprocity for 12 years $\left(1854^{-1} 866\right)$, fisheries questions, renewed talk of annexation, and finally in I 1 I renewed consideration of reciprocity $(\$ 458)$, formed other links in the chain of international relations. So many Canadians have come to the border states during the last half century and so many Americans have gone to the Canadian northwest in the last decade that the boundary line between the two countries is not so important socially as it was. Since Canarla became practically self-governing and in I 867 formed a federation, called the Dominion of Canada, there is tittle difference politically between the two. As we export to Canada more than to any other country except Great Britain, and as we need Canadian raw materials, the commercial relations ought to be still closer than they are. 
United States and Hawaii before I 893 . Andrews, Our Own Time, 700-704.

Foster, $A m$. Diplomacy in Orient, $370-378$.

Revolution of I893.

Cambridge Mod. Hist., VII, 667-668.

United States and Hawaii (I 893-I 898).

Peck, Twenty Years, 243248,33 I-335.

Foster, $A m$. Diplomacy in Orient, $37^{8-385}$. 4r6. - Hawaii.- Americans have been interested in the Hawaiian Islands since the first part of the nineteenth century. After the Civil War there was a growing sentiment in the United States that the islands must never be controlled by any European power. On account of a desire for free trade with Hawaii, a reciprocity treaty was signed in 1876 , but we did not interfere with the government of the islands, which had become more liberal because of the demands of white residents.

Early in 1893 there occurred in the Hawaiian Islands a revolution which drove from the throne the reigning queen,

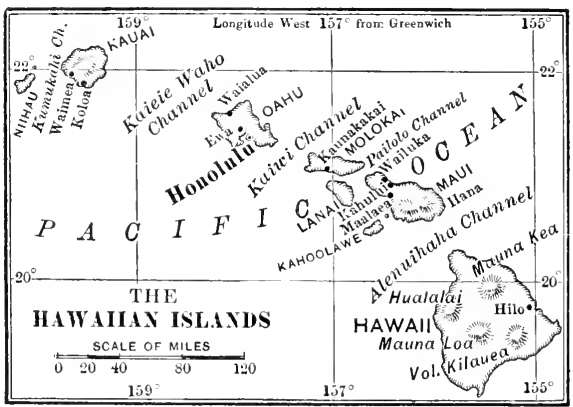

Liliuokalani, who wished to restore arbitrary government. During the confusion accompanying this change, the American minister authorized the landing of marines and raised the American flag. A treaty was drawn up without delay providing for the annexation of Hawaii to the United States and was submitted by President Harrison to the Senate during the closing days of his term.

Before action had been taken in the Senate, the treaty was withdrawn by President Cleveland, and a special commissioner, James $\mathrm{H}$. Blount, was sent to investigate the revolution. By Blount's orders the flag of the United States was hauled down, and, on his recommendations, plans were made for the restoration of the queen. These failed because the new government refused to relinquish its authority and because the queen desired the death of all engaged in the revolt against her. The President's policy was not popular, and in 1894 he recognized the newly organized republic of Hawaii. In 1897 another treaty providing for 
annexation was signed, but it failed of ratification. Not until the events leading to the Spanish-American War forced us to abandon our old policy of semi-isolation from affairs of world-wide importance did Hawaii become part of the United States (1898) through joint resolution of the houses of Congress.

4I7. Pan-American Congresses. - In a sense our most important foreign relations and policies have been those with our southern neighbors. The Monroe Doctrine grew out of attempts to protect them and our interests in Latin America. Beginning with James G. Blaine, several statesmen have attempted to increase our trade with Latin America and establish a better feeling between the United States and countries south of us. The first Pan-American congress was held at Panama in I 826 for the purpose of forming an alliance of the Latin-American states in their contest with Spain. The United States was asked to send delegates, although it was expected that we should have no share in the alliance ; but many Americans objected to sending commissioners. The proposed alliance came to naught. Later congresses of Latin-American states were held, without important results.

The United States did not take part in the work of any congresses until I889. Delegates from the republics in the new world met in conference at Washington in October, I889, and selected as chairman Secretary Blaine, who had tried to secure a Pan-American conference in $\mathrm{I} 88 \mathrm{I}$. This conference was followed in I 900 by one held in the city of Mexico. The third Pan-American conference met at Rio Janeiro in I9o6, and the fourth in Buenos Ayres in I9io. The results of the meetings have been important, although the delegates have made no laws and the different countries have not always acted on the suggestions offered. Because of these conferences a better understanding exists among the nations of the new world. Commerce has been promoted, especially by the establishment of a bureau of the American republics which collects and publishes information regarding

Pan-American Conferences (I 889-I 9o6).

Andrews, Our Own Time, $566-574$.

Casasus, J. D., in Annals of Am. Acad. Pol. Sc., Sup. May (I906), 5-13. 
trade. ${ }^{1}$ Most of the countries have agreed to use every effort to preserve peace and the most important nations have given their consent to a plan for the compulsory arbitration of debts owed by any government to citizens of another country.

Two applications of the Monroe Doctrine.

The French in Mexico (is 660 ). Foster, $A \mathrm{~m}$. Diplomacy, $401-403$.

Lothrop, Setiard, ${ }_{3} \mathrm{~S}_{7-}$ 395.
4I8. The Monroe Doctrine and Mexico after the Civil War. - During the last half century there have been two conspicuous instances of European interference with the affairs of the Latin-American republics to which we have objected. The first of these occurred in Mexico during the Civil War, the second grew out of the boundary dispute in Venezuela. During the Civil War Napoleon III of France, under pretext of collecting certain debts, forced upon the Mexicans an Austrian prince named Maximilian, who was maintained as Emperor of Mexico by the use of the French army. Being fully occupied with the prosecution of the war, and anxious to aroid difficulty with France, the government at Washington felt it unwise to do more than refuse to recognize Maximilian's government and mildly protest against $\mathrm{Na}$ poleon's course. After Appomattox the case was different. An army of observation under Sheridan was dispatched to the Rio Grande, and disapproval of French actions was clearly expressed. Finally, on December Io, is65, Secretary Seward sent to France a peremptory note, stating that the policy of friendship for France would " be brought into immediate jeopardy, unless France could deem it consistent with her interest and honor to desist from the prosecution of armed intervention in Mexico to overthrow the domestic republican. government existing there, and to establish upon its ruins the foreign monarchy which has been attempted to be inaugurated in the capital of that country." After a little hesitation Napoleon agreed to withdraw his troops: and when that was done, the Mexican Empire came to an end, Maximilian being put to death.

419. Dispute over the Boundary of Venezuela (I895).

Since the early part of the nineteenth century, there had been

${ }^{1}$ It has a building at Washington built chietly with money donated by Mr. Carnegie. 
a dispute over the location of the boundary line between British Guiana and Venezuela. This had never been located, although repeated attempts had been made, especially after I $S_{4}$, to reach some agreement. The disputed territory included a large area in the interior, in which gold had been discovered, and a strip along the mouth of the great ()rinoco River. Venezuela proposed arbitration, but the British government refused at first such a settlement of the question, and later agreed to that method only on condition that Venezuela should admit the validity of most of England's claims before submission to arbitrators.

The disparity in strength between Great Britain and Venezuela, the danger that Venezuela might be forced to surrender some of her territory to (ireat Britain, as well as the interest of the United States in the controversy, seemed to President Cleveland and Secretary of State Olney sufficient ground for interference. Secretary Olney accordingly wrote to Lord Salisbury ( 1895 ), explaining at length the nature of the Monroe Doctrine and asserting our right to protect Venezuela from the forcible seizure of the territory in dispute. Lord Salisbury answered that the Monroe Doctrine was simply a policy of the United States, that it was not a part of the law of nations, and that, in any case, it was not a sufficient reason for American interference.

420. Settlement of the Venezuela Controversy. - Soon after receiving this reply, President Cleveland sent a special message to Congress (December I 7 ). He stated that since Great Britain had been unwilling to submit the dispute to impartial arbitration, it was now the duty of the United States to determine the location of the true boundary line. He recommended a commission appointed by the executive

Correspondence over Venezuela.

Hart, Contemporaries, IV, No. I 79.

Latané, $U . S$. and $S p . A m$., $272-277$.

Dewey, Nat. Problems, 304-307.

Cleveland's message.

Dewey, Nat. Problems, 307-312. 
Cleveland. Pres. Problems, 209-273.

Decision regarding Venezuela boundary:

Cleveland, Pres. Problems. $273-28 \mathrm{~s}$.

Larned (ed.). Reudy Rej.. II, 000-093.

Debt collection in Venezuela and Sinto Domingo.

Larned (ed.). Riady Rej.. IIII, $5 \mathrm{~S} z-5 \mathrm{~s}$. $0 s_{4}-05_{5}$.

Latané, $A m$. as a Horld Powier, $271-$ $28+$.

The dilemma of the Monrue Doctrine.

Bingham, $\mathrm{H}$. in - Atiuntic. Wh, III (I9I3), ;2I-j34. to investigate the question and render a report. "When such report is made and accepted it will, in my opinion, be the duty of the United States to resist, by every means in its power, as a willful aggression upon its rights and interests, the appropriation of any lands or the exercise of governmental jurisdiction over any territory which after investigation we have determined of right belongs to Venezuela."

This forceful language aroused great enthusiasm in America, but for a few days there was considerable excitement because of the belief that war with Great Britain might follow. After the commission was appointed, Great Britain agreed to arbitrate the dispute, on condition that each country could have the lands which its citizens had occupied for fifty years. This gave a large part of the inland territory in dispute to Great Britain without further controversy. The tribunal which fixed the line decided, however, that Venezuela should control the territory on both sides of the Orinoco.

42I. The Monroe Doctrine since i895. - The Venezuela dispute emphasized the fact that the Monroe Doctrine is not simply the doctrine announced by Monroe in $\mathrm{IS}_{23}$. Since ISos the doctrine has been changed still further. In I 002 Germany, Great Britain, and Italy tried to collect from Venezuela by " peaceful blockade " debts due to citizens of those countries. When the United states insisted that a peaceful blockade was contrary to the Monroe Doctrine. the powers declared a war blockade. The question was settled by submission to the Hague Court, which gave preference to the three powers over other creditor countries. Later, in Santo Domingo, President Roosevelt took charge of the customs of that country in order to protect American interests and to aroid European interference.

As the Monroe Doctrine is the policy of the President of the United States, it raries with each executive. President Roosevelt favored a very great extension of the doctrine. Other chief executives would restrict it. Continued misgovernment in a Latin-American republic, coupled with interference with foreigners and foreign property rights, certainly calls for supervision by the United States, as Roosevelt 
insisted, or interference by European powers, if American diplomacy and moral suasion fail. But the more progressive Latin-American countries fear Uncle Sam's interference rather than that of Europe. 'The Monroe Doctrine arouses the hostility of these people and interferes with their friendship for us and their trade with us. We must expand the doctrine, or we must limit it to unwarranted interference by Europe, or we must abandon it.

In spite of this indefiniteness the Monroe Doctrine may be said to include the following principles. No European power can colonize any Imerican territory, with or without the consent of the American republic whose territory is taken. No great European power shall decide territory controversies with the weaker American states to its own advantage. We Principles of the Monroe Doctrine.

No. Am. Rev, 1 so (r 1905$)$, 586-601. do not permit one of the great nations to occupy or retain the territory of a republic of this continent to guarantee the payment of debts owed in Europe. On the other hand, we do not object to the use of force if necessary to collect debts that a Spanish-American state may refuse to pay, nor do we interfere in ordinary disputes between the nations of the old world and the new, although we always offer our services in the settlement of the controversy.

422. Summary. - The decade which closed with $\mathrm{IS}_{97}$ is General. noteworthy as a transition period. It was the end of an era of glowth mainly national. It was a time of change in politics, in business, and in society. People were dissatisfied with their political parties and their government's methods in dealing with internal and foreign questions.

Politically the period may be divided into two parts. Political issues (I) The dominant issue from I 886 to $\mathrm{r} 894$ was the tariff. In 1890 a high protective tariff was adopted. (2) From i 894 to i 896 the free-silver movement obscured every other.

The foreign questions of the period were more important than at almost any other time since isis. Nost of our ordinary disputes were settled without great difficulty. Two questions, those of Samoa and Venezuela, showed a desire on the part of the officials and people to take an active part in world affairs from which we had heretofore held aloof. 


\section{TOPICS}

I. The Silver ACt OF I89o: White, "Money and Banking"; Noyes, "Thirty Years of American Finance," pp. I $58-($ r $S I)$; Taussig, "The Silver Situation," pp. +S-7r; Sherman, "Recollections of Forty Years," pp. I06I-I071, II75-1 200.

2. The Venezuela Controversy: Peck, "Twenty Years of the Republic," pp. 4I2-436; Larned (ed.), "History for Ready Reference," VI, pp. 684-693, 557-560; Cleveland, "Presidential Problems," Pp. $173-273$.

3. Election of ISg6: Stanwood, "History of the Presidency," Chapter XXXI; Peck, "Twenty Years of the Republic," pp. 465$5^{1} 7$; Larned (ed.), “History for Ready Reference," VI, pp. 563-574.

\section{STUDIES}

I. Kearney and the sand lot riots. (Andrews, "The United States in Our Own Time," pp. 360-3Sr.)

2. Thomas B. Reed. (Knight, E., in New England Magazine, 30 (I904), pp. 2 I 5-224.)

3. Populist platform (IS92). (Stanwood, "History of the Presidency," pp. 509-513.)

4. Government sales of bonds. (Cleveland, "Presidential Problems," pp. I $2 \mathrm{I}-\mathrm{i} ; 2$.)

5. Bryan's "Cross of Gold" speech. ("Masterpieces of Eloquence," Vol. 25 , pp. 10735-10745.)

\section{QUESTIONS}

I. Make a table showing the changes in the tariff since the Civil War. Would it be better if business men rather than politicians decided tariff rates? What are the chief objections to a highly protective tariff? to one exclusively for revenue?

2. What was the purpose of the Panama Congress ( 1826$)$ ? How has the object of the later congresses been different? To what extent do the American countries trade with one another? To what extent have they a community of political interests?

3. What European countries have income taxes? Was the tax of I $89+$ a class measure? Should not some of our taxes be progressive, i.e. with a higher rate for those whose assessment is large?

4. What is the chief cause of agitation for cheap money? To what extent was the free-silver movement in I 894 similar to the greenback morement of $\mathrm{IS}_{77}$ ? What was the result of the movement in each case?

5. Place in the notebook a complete summary of each of the following topics, showing the sections of the test in which details may be obtained; the tariff, laws relating to money, Monroe Doctrine. 


\section{CHAPTER XXI}

\section{EXPANSION (I897-I904)}

\section{Presidents}

William McKinley (I897-1901) Theodore Roosevelt (I90I-I909)

423. Fundamental Changes in the United States after 1897. - The years 1897 and 1898 marked the transition from Readiness for the old era to the new. The old nation, which had emerged triumphant from the long struggle with state sovereignty twenty years earlier, had completed the task of destroying slavery and most of the other dangers which threatened the development and continuance of a true nation. It had attacked and in many cases had solved temporarily pressing political problems, such as the tariff, silver, and civil service difficulties. New industrial and commercial methods were coming into use. The nation, instinct with life and energy, needed new outlets for its products, sought new fields of activity, political and commercial, demanded new policies that were based on recognition of our real position as a nation and not on precedent. For several years there had been evidence of a readiness to abandon our former position of semi-isolation from the affairs of the world powers. The opportunity to adopt a new international policy came when we felt impelled not alone for self-protection but in the interests of humanity to intervene in Cuba.

The war which followed gave the new American spirit New imperial a chance to express itself in many ways. We annexed new policy. territories which were densely populated by people of races alien to our own, by people who were inexperienced in the art of self-government. A new colonial policy was formulated to meet the needs of these dependencies, although this policy involved on a large scale imperial principles which 
we had considered odious hitherto and which we had used reluctantly. The establishment of this colonial policy involved a new construction of the Constitution which will react inevitably on the government of the United States proper by increasing centralization and by decreasing the right of the states and of individuals.

Industrial consolidation.
Importance of Cuba to the United States.

Cf. Mahan, America in Sea Power, 27I-3I4.

The Ten Years' War (I868-I879).
The new imperial policy of the United States was of scarcely greater importance than the industrial changes which took place at this time. With the great consolidation of capital engaged in industry or commerce in the form of great trusts or railway combinations, the country began a new period marked by limited competition, extensive production, and wider markets. To protect the public from the exorbitant changes or unjust methods of these combinations has been and is now one of the chief problems of our national government and of the governments in many of our states.

\section{The Spanish-American War}

424. Our Relations with Cuba before 1895. - The location of Cuba has made that island of the first importance in the history of the United States, since we acquired territory in the Mississippi basin and along the Gulf of Mexico. Standing at the entrance to those two inland seas, the Gulf and the Caribbean, both of which become of infinitely greater value to us with the construction of an isthmian canal, Cuba has interests inseparable from those of the United States. We could permit Cuba to remain a Spanish colony because Spain was no longer a factor in the world's affairs, but we could not and cannot permit Cuba to become the dependency of any of the great European nations. To many people the annexation of Cuba by the United States has been considered the only safe solution of this vexed problem.

Among the colonizing nations of the world Spain has been notorious for the wretched government of its provinces. Cuba suffered most of the abuses borne by Spanish colonies, due to harsh laws, arbitrary administration, failure of justice, 
official greed, and universal corruption. Many revolts had occurred in order to gain greater liberty and lower taxes. 'The greatest of the revolts before 1895 was the so-called "Ten Years' War," an insurrection that started in I868, but was confined almost exclusively to the eastern part of the island. When the United States protested against the fruitiess struggle, Spain's captain-general in Cuba, Campos, agreed to grant autonomy. But after the insurgents had laid down their arms, the Spanish government refused to carry out the promises of Campos. During this struggle war was averted narrowly when the Virginius was captured on her way to Cuba, and Cuban officials shot many of her crew who were Americans.

\section{United States and Cuban Insurrection (1895-1896).-} In February, I895, insurrection again broke out. This time all Cuba was affected and the cry of Cuba Libre was echoed from every part of the island, for few longer put faith in the promises of the Spaniards. Spain sent large numbers of troops who could accomplish little against the guerrilla bands of the Cubans, although they outnumbered the insurgents regularly in the field at least four to one. The difficulty was to find an enemy whom they could strike. In despair General Weyler sought to crush the rebellion by ordering (1896) the concentration of all non-combatants in camps near the larger cities. Through this " reconcentrada" policy the insurgents were crippled somewhat, but the suffering of the innocent women and children, huddled together without means of earning enough for food, defeated not only the immediate purpose of Weyler, but was the signal for the overthrow of Spanish rule in America. In the interest of humanity the United States was compelled to assert herself.

From the beginning of this insurrection there was a pronounced sentiment among many Americans in favor of recognizing the belligerency of the Cubans if not the independence of the Cuban republic. This sentiment was reflected in Congress, both houses of which desired to have President Cleveland use his good offices for the recognition of both

Insurrection of 1895 .

Larned (ed.), Ready Ref., VI, I7I-I75.

Titherington, Sp.-Am. II ar, $43-56$.

Cleveland and Cuba.

Lodge, Ifar with Spain, I3-23. 
belligerency and independence. The President did not see fit to take any action and when (December, I896) Congress was on the point of declaring that Cuba was independent, Cleveland and Olney made it clear that they should disregard any resolution passed in Congress to that effect. In his last message to Congress, however, the President stated that a prolongation of the war might require our intervention in Cuba.

McKinley and Cuba.
426. Dangers to American Interests in Cuba (1897I898). - President McKinley took nearly the same view of

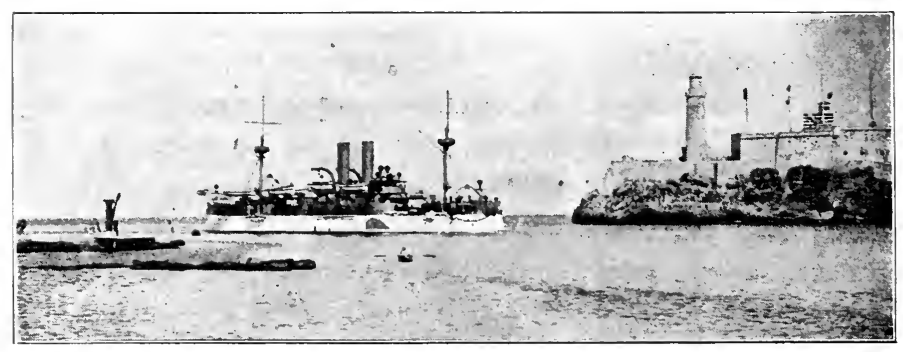

THE Waine ENTERING HAVANA HARBOR

Lodge, Wiar with Spain, $23-28$.
Destruction of the Maine.

Larned (ed.), Ready Ref., VI, 583-585. the Cuban question as his predecessor, although his efforts in behalf of American prisoners afforded better protection to those who had business in Cuba. During 1897 the Spanish prime minister was assassinated and a Liberal ministry was formed under Sagasta, which recalled Weyler and endeavored to pacify the island by offering home rule to the Cubans. This offer was spurned, and by the middle of January, I898, the disorder in and around Havana had increased to such an extent that the battleship Maine was sent to Havana harbor in order to protect American interests.

On the morning of February i 6 the world was shocked to learn that the Maine had been blown up at ten o'clock the preceding evening, 266 of her officers and crew being dead. For five weeks, with rare self-control, the nation waited. On March 2I a committee of inquiry reported to the President that the disaster had been caused by the 
explosion of a mine outside the vessel. Although the Spanish officials must have known that they had stationed the Maine over a mine, no blame was attached to the Spanish government. Even then the people waited for the government to decide when and in what way it would act. Pressure was brought to bear upon Spain to make reparation for this outrage, without result of course.

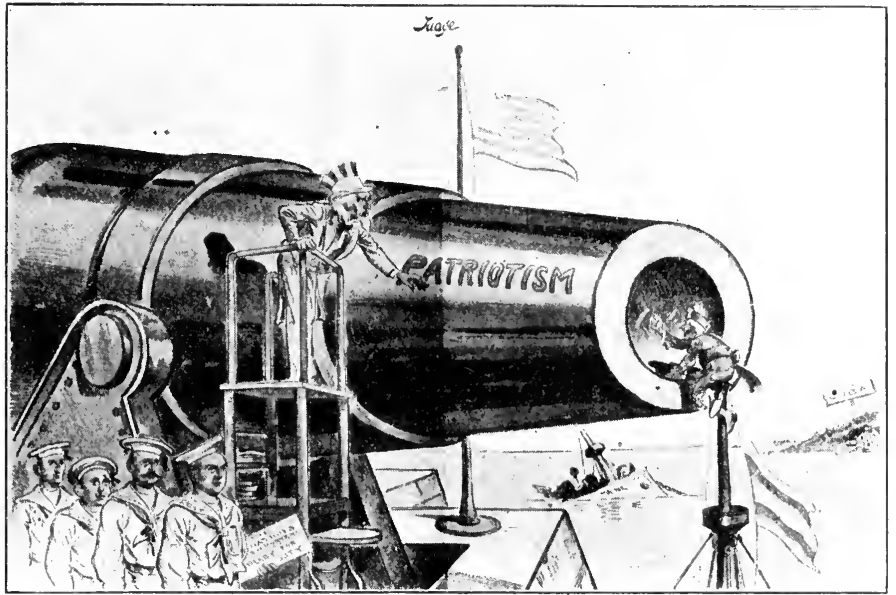

By courtesy of $7 u d g e$. Copyrighted.

"Be Careful"

427. The Situation during the Spring of 1898 . - Meanwhile active preparations were made for the war which Preparations for war. was to be the last resort. On March 9 Congress had voted $\$ 50,000,000$ for the national defense, to be expended at the discretion of the President. When it became evident that Spain would do nothing, the patience of the people was Titherington, Sp.-Am. Har, $70-95$. exhausted. President McKinley sought to prevent hostilities, but, on April I I, he was forced by public sentiment to send to Congress his "war message " asserting that " the war in Cuba must stop." After a few days' debate on the exact form of intervention, Congress, on the historic Igth of April, adopted four resolutions: (I) that the people of $2 \mathrm{~K}$ 
Cuba were and of right ought to be free and independent; (2) that Spain must withdraw from Cuba; (3) that the President might use force to free Cuba; and (4) that the United States was freeing the island for the Cubans and not for herself. Spain at once severed diplomatic relations with the United States and war actually began April 21, although it was several days before Congress declared that a state of war existed between Spain and the United States.

Attitude of European powers.

The attitude of the United States toward Cuba had been

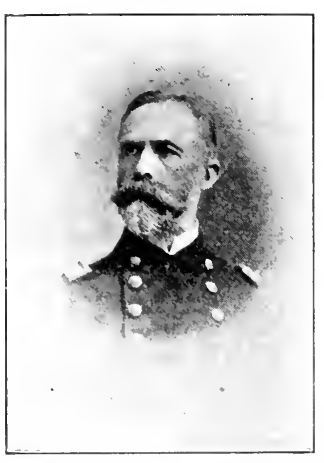

WilliaM T. SAMPSON watched carefully by the European powers, who had tried to prevent armed conflict between Spain and America. Most European statesmen believed that the United States was interfering in Cuba in order to advance American interests. They thought therefore that our interference was not justified. On the continent it was expected that Spain would have no difficulty in overpowering our nary, and the attitude of many was distinctly

Peck, Twenty hostile to the United States, until repeated victories silenced Iécars, $5+5-554$. opposition. England, however, gave proof of her goodwill from the beginning and used her influence in winning friends for us on the continent.

Comparison of the combatants.

Titherington, Sp.-Am. II irr, 96-IIf.
428. The Beginning of War. - On paper the adrantage at the beginning lay with Spain rather than the United States, but the Americans of necessity assumed the offensive. Spain had large numbers of seasoned troops under arms in Cuba, whereas the regular army of the United States consisted of but 25,000 men, many of whom could not be spared for foreign service. Spain's nary consisted of several armored cruisers of high speed and modern equipment, although the nay as a whole was inferior to that of the United States, which included several large battleships.

After the destruction of the Maine, the nary was pre- 
pared for possible war. Two fleets were gathered in the Preparing the north Atlantic. One of these, with most of the battleships fleets. and monitors, was commanded by Admiral William T. Sampson; the other, composed of faster cruisers and called the "flying squadron," by Admiral Winfield S. Schley. ${ }^{1}$ All vessels in the Pacific were ordered to Hong Kong, where Hart, Contemporaries, IV, No. I83. Admiral Dewey made preparations to capture the fleet at Manila in case of war.

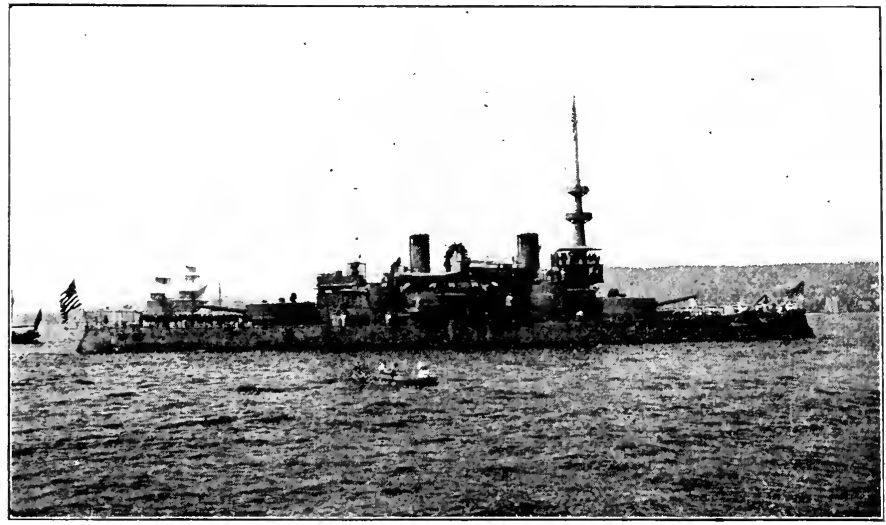

Copyright (1898) by Wm. H. Rau.

THE BATtLeship Oregon

After war was declared Dewey was obliged to leave Manila. the British port at Hong Kong, as he could not remain in the harbor of a nation that had declared itself neutral. He proceeded at once to the Philippines and advanced early on the morning of May I against the Spanish fleet. The Spanish were not well prepared for an attack, although their vessels were more numerous than ours and were protected by the batteries located at Cavite and along the Larned (ed.), Ready Ref., VI, 596-599, $617-620$. shore. A few hours sufficed for the complete destruction of $36.4-378$.

1 The battleship Oregon was ordered from San Francisco to join the Atlantic fleet and made a remarkable voyage around Cape Horn, the ship covering fourteen thousand miles in sixty-seven days, and reporting for duty without delay, since it arrived in perfect condition. 
Lodge, Hiar with Spain, $48-67$.

all the enemy's ressels, but no attempt was made at this time to capture Manila, since Dewey could not spare the marines necessary for holding the city. Later in May the first transports left San Fran-

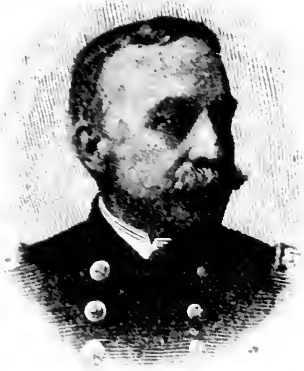

GeORGe DrWe.' cisco with troops for the Philippines, but Manila was not besieged until late in July after fresh reënforcements had arrived. A combined land and naval attack under General Merritt and Dewey led to the surrender of the city August $\mathrm{I}_{3}$, one day after peace articles had been signed at Washington. As the Spanish had controlled a very small part of the islands, their rule in the East was practically over.

Cuba.

Lodige, His with vizin. Chapters VIvill.

429. War on the Atlantic. - At the beginning of the war a blockade of most of the important ports of Cuba was established, in the hope of starring Harana into submission. A sharp lookout was kept for the fleet under Cervera which, it was feared, might attack one of our unprotected coast cities. The fleet was discorered later at Santiago de Cuba, the harbor of which is deep and narrow, with a bottlelike entrance which the blockading tleet sought unsuccessfully to close by sinking a collier, the $/ \mathrm{cr}$ -

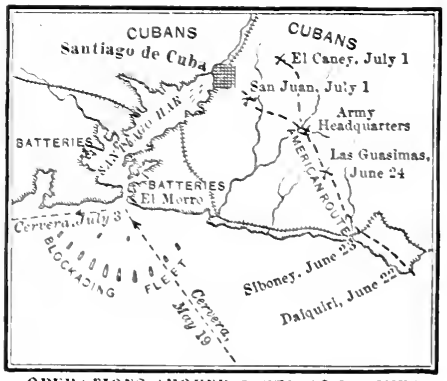

OPEKA RIOAS AROCND SATTIAGO DE CLBA rimac, in the entrance. The American fleet now waited outside the harbor until the army threatened the capture of the city. Owing to the difficulties in organizing and transporting the troops, only a few thousand were ready 
to sail from Florida at this time. After some delays and considerable suffering through lack of proper food and shelter, the regulars and Roosevelt's "rough riders" captured the enemy's strongholds at El Caney and San Juan Hill. Cervera then left the harbor about nine o'clock on the morning of July 3 . One after another his vessels were forced ashore and destroyed by the accurate fire

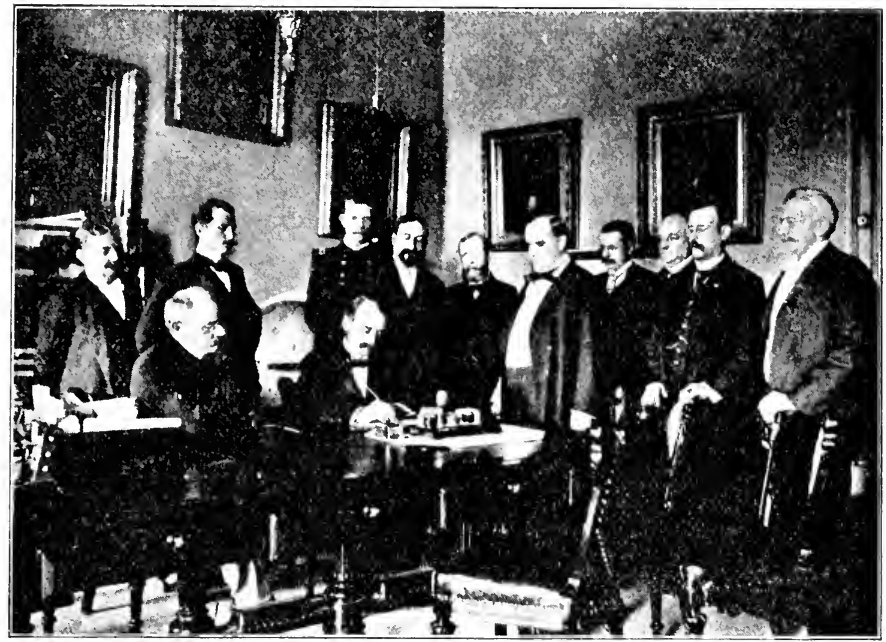

SIGNING THE PEACE PROTOCOL

of the Americans. Again, practically without loss, an American fleet had destroyed its Spanish opponent. ${ }^{1}$ Soon after, the city was surrendered with all of the troops in eastern Cuba, on condition that they should be transferred tree to Spain.

Later in July an American force under General Nelson A. Miles proceeded against Porto Rico. By a well-planned Porto Rican campaign. and brilliantly executed campaign the subjugation of Porto Rico was nearly completed when preliminaries of peace were Larned (ed.), Ready Ref., signed and hostilities ceased.

1 The sole remaining fleet of Spain, which had passed through the Suez canal on its way to the East, now turned back to Spain, 
Preliminaries of peace.

Lodge, Hiar with Stain, $222-220$.

Loans and new taxes.

Dewey, Financial Hist., ई 197 .

West, M., in Reri. of Rei'. IS (ISOS), $+5-52$.

Inefficiency of the war department.
The decisive naval rictories of the Americans at Manila and Santiago, followed by preparations for active campaigns against Porto Rico and the city of Manila, convinced the Spanish government that further prosecution of the war was unwise. On July 26 the French ambassador at Washington was requested to ask for terms of peace and on August I2 a peace protocol was signed. Spain relinquished all claim to Cuba, ceded Porto Rico and her other West Indian islands to the United States, and gave us one island in the Ladrone group in the Pacific. The Lnited States was to hold the city and harbor of Manila pending the final disposition of the Philippines.

430. War Finance. - To meet the extraordinary expenses of the war, Congress raised large sums of money. Immediate needs were satisfied by a loan of $\$ 200,000,000$ at three per cent interest. So patriotic was the response to the government's request for money that more than 300.000 persons subscribed to the loan, offering a total sum of Si, $, 00,000,000$. Profiting by the lesson of the Civil IVar, the government wisely sought to pay most of the military and naral expenses through taxation. The old rates on tobacco and fermented liquors were increased one hundred per cent. New schedules were created by placing a stamp tax on patent medicines, chewing gum, and other articles. Stamps were to be placed on all checks, drafts, deeds, notes, and many other papers involving business transactions. Several lines of business were obliged to pay business taxes, the total revenue from the new excise and business taxes amounting to about $s ;_{;}, 000,000$ a year. A new kind of national tax was levied on legacies, the rate varying from less than one per cent for direct heirs to fifteen per cent for those unrelated to the deceased who inherited large sums.

As the increase of the army and nary expenses was not limited to the four months of the war, ${ }^{1}$ most of these war

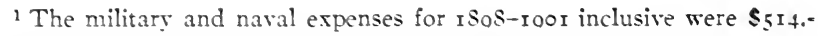
000.000 more than for the preceding four years, an increase of more than one hundred and tifty per cent. 
taxes were retained for several years. Both the stamp taxes and the inheritance tax were repealed during I902.

431. Army Administration and Reform.- Even before the Larned (ed.) Ready Ref., VI, 63I-634. war began the serious condition of the war department became painfully evident. Not only was the department unprepared for war, but so defective were its methods that it could not do satisfactorily even a small part of the work assigned to it. Troops were furnished with the wrong kind of materials for tropical campaigns; there were few modern rifles obtainable and smokeless powder was provided only on rare occasions. The volunteers were huddled in unsanitary camps. If sent

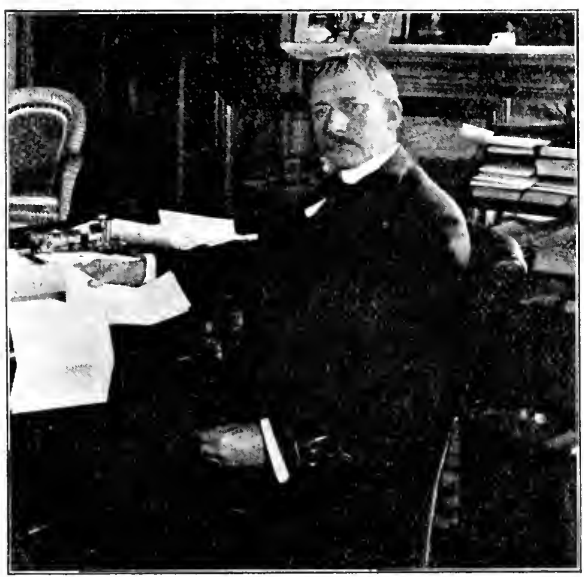

ELIHU RoOT

to the front, they were delayed at every point by lack of transports or other facilities. Six weeks after war was declared, a time sufficient in I 866 for the complete humiliation of Austria by Prussia, the new army was still disorganized. The department failed most completely in providing food for the troops. Serious sickness and death were caused by this scarcity or by the inferior quality of the supplies. Contracts were made by the department under which "embalmed" beef that was unfit for food was furnished in large quantities. An investigation in I899 exonerated Alger, the secretary of war, but the public was not satisfied that the defects of the system were understood or the proper officials blamed for neglect of duty.

As the preservation of order in the new colonies required 
Reorganization of the army.

Larned (ed.), Ready'Ref., VI, 678-68o.

The question of expansion.

Negotiations regarding the Philippines. a larger standing army than that existing before $\mathrm{I} \delta 98$, a new law was passed by Congress in I90r enlarging the army to a total of not less than 57,000 nor more than roc,000. Under the guidance of that able and energetic administrator, Secretary of War Root, the entire system was modernized and reorganized, and a general staff created to take charge of army affairs. Since we had decided to keep the outlying islands which came into our possession in 1898 and construct an isthmian canal, plans were made and have been carried out partially to enlarge and strengthen the nary, which will be of especial value in protecting our interests in all parts of the globe.

\section{The Care of Wider Auerican Interests}

432. The Problem of the Pacific. - During the three months following the conclusion of hostilities the administration was obliged to decide definitely what its policy should be in regard to the annexation of distant lands in the Pacific. There was no doubt that the nation was willing to follow a new policy that would open to us new ports in the far East and permit us to use our political influence in the Pacific to greater advantage. During the war Hawaii had been annexed to the United States by joint resolution of both houses of Congress. Although many arguments in faror of Hawaiian annexation could not be used of islands near Asia - the nearness of the Hawaiian group, their commercial dependence on the United States, the comparatively large white population of Hawaii, the danger to us from their acquisition by a European nation - nevertheless the possession of Hawaii was a reason for going a step farther and acquiring islands which would give us commercial advantages in the great struggle that had already begun for supremacy in the west Pacific and in eastern Asia.

At first President McKinley authorized the peace commissioners to acquire the island of Luzon only, with trade concessions in other parts of the Philippines. Later, howerer, the President reached the conclusion that " the cession 
must be of the whole archipelago or none. The latter is wholly inadmissible and the former must therefore be required." As Secretary Hay telegraphed to the peace commissioners, "The sentiment in the United States is almost universal that the people of the Philippines, whatever else is done, must be liberated from Spanish dominion. In this sentiment the President fully concurs. Nor can we permit Spain to transfer any of the islands to another power. Nor can we invite another power or powers to join the United States in sovereignty over them. We must either hold them or turn them back to Spain. Consequently grave as are the responsibilities and unforeseen as are the difficulties which are before us, the President can see but one plain path of duty - the acceptance of the archipelago."

433. The Treaty of Paris (1898-1899). - While the administration was deciding what should be done in reference to the Philippines, negotiations for a peace treaty were begun at Paris, October, IS98. The United States was represented by five able commissioners ${ }^{1}$ who succeeded in gaining all of the concessions we desired. The chief discussions were caused by Spain's desire to make us responsible for Cuba and the Cuban debt and to retain the Philippines for herself. On both points Spain yielded finally. According to the completed treaty Spain relinquished her sovereignty over Cuba, ceded to us Porto Rico and her other West India possessions and the Island of Guam, and transferred her rights in the Philippines for a sum of $\$ 20,000,000$ paid to her for public works and improvements which belonged to the Spanish government.

Although most of the people of the United States approved the acquisition of the Philippines, an active minority opposed it. Anti-imperialist leagues were formed which sought to arouse public sentiment, especially by harping on the word "imperialism." They called attention to the great change which we should make if we abandoned our traditional

Negotiation and provisions,

Hart, Contemporaries, IV, No. 185 .

MacDonald, Statutes,

No. I3I.

Debate over ratification.

\section{Larned (ed.),} Ready Ref., VI, 634-638.

1 The commissioners were William R. Day, Cushman K. Davis, William P. Frye, George Gray, and Whitelaw Reid. 
policy. They maintained that the acquisition was not only contrary to the principles of the Declaration of Independence and the Constitution, but was unjust to the Filipinos and dangerous to the perpetuation of our democratic institutions. Many of the adrocates of amexation did not desire to hold the Philippines permanently, but believed any other course to be unwise. Probably the majority of the American people, even at this time, farored not only the retention of the islands

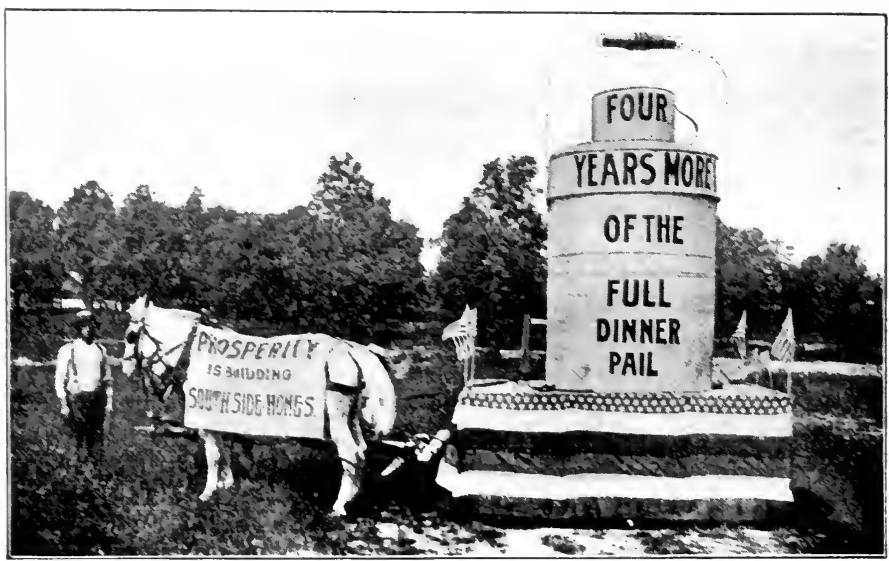

By courtesy of Le'sic's Hect.y. Copyrighted.

A Replilicax Appeal to Voters (I900)

Aguinaldo's insurrection.

Andrews, ( ): () $\approx$ (x) rim:e, $s_{42}-s_{52}$.

but the adoption of an imperialist policy involving tropical colonies. The treaty was submitted to the senate early in Jamuary, ISoo. After a month of discussion it was adopted by a very narrow margin, the rote being 57 to 28 , only one more than the constitutional two thirds.

434. The Philippine Insurrection and the Election of I9oo. - The problem of controlling the Philippines was complicated because of an insurrection against the authority of the American government. For several years before the Spanish-American War there had been armed opposition in the islands to the rule of Spain. After the transfer of the Philippines in the treaty of peace these forces which had rebelled, led by Aguinaldo, attacked the American troops, 
and it was more than two years hefore the disorder was finally suppressed by the capture of Agumaldo and the suppression of minor rebellions in the smaller islands of the group.

In the presidential election of rooo interest in the freesilver discussion of 1806 was revived hecause of the unwillingness of the Democratic candiclate, William J. Bryan, to run on any other platform than that of the free coinage of silver at a legal ratio of 10 to $\mathrm{s}$. The Democratic platform, however, stated that imperialism was " the paramount issue of the campaign." 'The Republican convention endorsed the attitude of the McKinley administration in its dealings with our dependencies and renewed its "allegiance to the principle of the gold standard." William McKinley was renominated for President and Theodore Roosevelt of New York was selected for Vice President in response to popular demand. Although many eastern states gave Mckinley much smaller pluralities than during the abnormal campaign of $1 \$_{90}$, his total popular plurality was much larger than in I $S_{96}$, and he carried five states more than in his first election.

\section{The Development of a Colonial Policy. - The} Republican victory in 1900 might be construed as an endorsement of the colonial plans of that party. That policy followed the usual methods for controlling new territory, that is, to appoint military governors until it was possible to organize a civil government. Provisional civil government was changed into permanent civil government, in Porto Rico in 1000, and in the Philippines in 1902. This permanent government was not like that of our " organized territories," however, since Congress and the President did not believe that " the Constitution follows the flag." They held on the contrary that Porto Rico and the Philippines were colonies, that Congress might decide how they should be governed, and that Congress might lery taxes on the colonies, in spite of the provision of the Constitution that "all duties, imports and excises shall be uniform throughout the United States." In the earlier "Insular cases" (I90I) the Supreme Court

Larned (ed.), Redaly Ref., $\mathrm{V} 1,3 \mathrm{i}$, 383 , $38_{5} \cdots 387$.

Election of 1900.

Andrews, Our (a'n Time, $\mathrm{SO}_{5}-\mathrm{S}_{7} \mathrm{~S}$.

Larned (ed.), Realy Ref., II, 0.70-000.

Lalané, America as a llorld Poier, I $20-132$.

Republican policy before 1902.

The Insular cases. 
Larned (ed.), decided that, since the colonies were neither foreign soil nor Ready Ref., VI, 669-674, 68 $2-683$.

Burgess, J. W., in Pol. Sc.

Quar., I6

(I9OI), 486504.

integral parts of the United States, Congress might levy such tariffs as it pleased. Later decisions (I904) denied the right of trial by jury and the right to bear arms within the Philippine Islands, even to former citizens of the United States. These decisions gave Congress absolute control of the colonies, since Congress might rule them as it wished until it Rowe, L. S., in Annals $\mathrm{Am}$. Acad., I 8

(I9OI), 226250.

Porto Rico. Larned (ed.), Hist. for Ready Ref., VII, 50I503 .

Abbott, L., in Outlook, 92 (1909), 45I462 .

Liberty and government.

Taft, W. H., in Outlook, 7I (I902), 305 et seq. limited its own power by extending constitutional rights and privileges to inhabitants of the colonies.

Porto Rico was allowed to have complete civil government earlier than the Philippines, and the powers granted to the people were greater. Universal suffrage was given in the act of I 900 , and the Porto Ricans had a legislature from the first. Porto Rico was subject to a special tariff for a short time only. The United States (I909), however, asserted its right to make appropriations if the Porto Rican legislature failed to do so. The most important agitation among the islanders during recent years has been the demand for United States citizenship.

436. The Philippines since I900. - The Philippine Islands were at first under a military governor who was the commander of the army in the Philippines. In I900 a civil government was established, a commission of five being appointed by the President to control the islands under the laws of Congress. This commission was replaced in 1902 by a complete government, consisting of a governor, four comJenks, J. W., in Rev. of Revs., 26 (I 902 ), 5 So-58s.

Willoughby, Territories, I 84-20I.

Larned (ed.), Ready Ref., VII, 492-498. missioners, and other colonial officials selected by the President and Senate, of an upper legislative house composed of the Philippine commission with several Filipinos, and of a lower house of from fifty to one hundred members chosen by roters who own property or can speak, read, and write Spanish or English. ${ }^{1}$ In local government the people were allowed a greater share than in the tropical colonies of any European power. Congress did not deem it wise to grant to the inhabitants of the islands all of the civil rights exercised by citizens of the United States, but it did give them all the

1 The first assembly did not meet until 1907. 



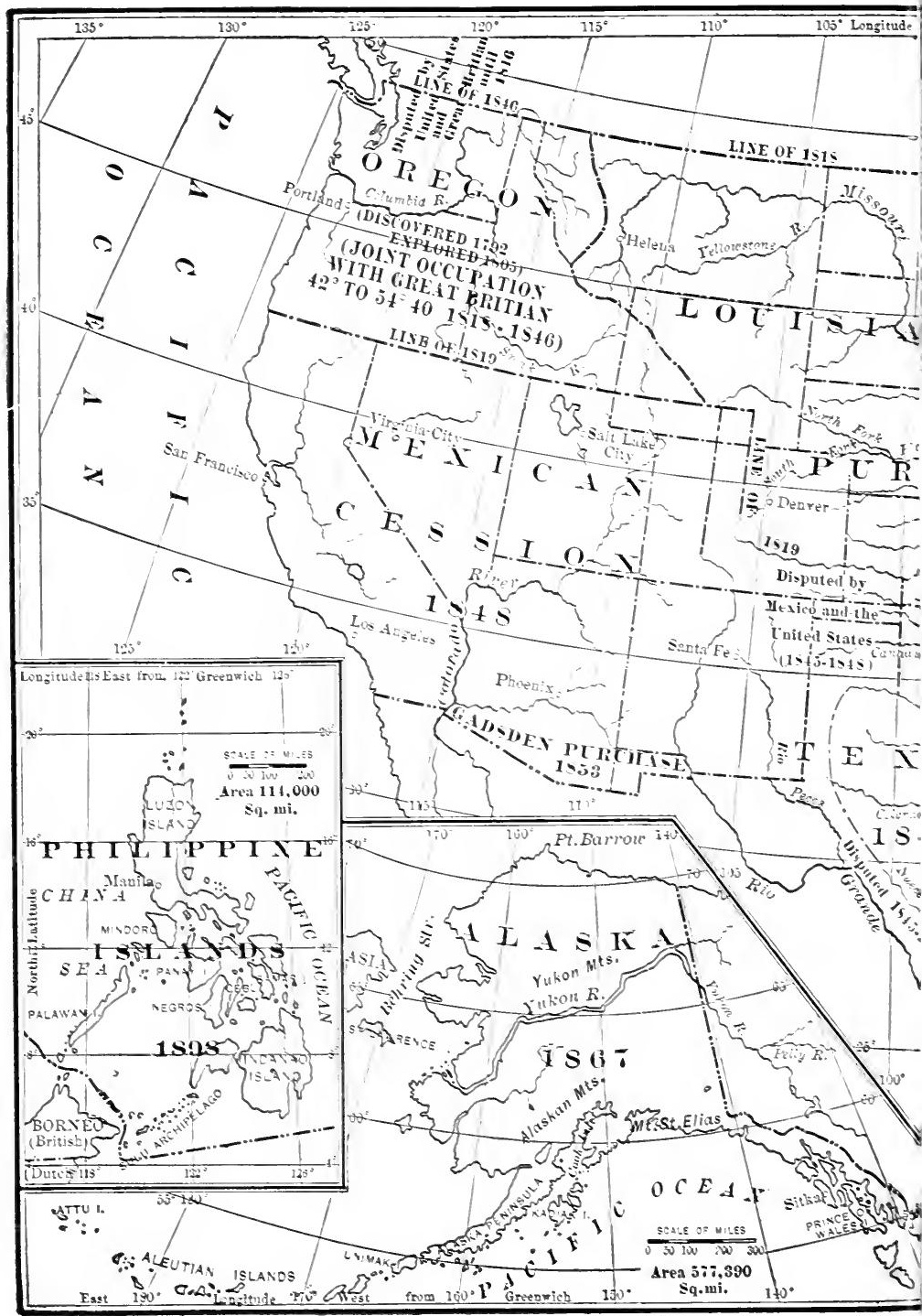

(The different Scales used shou 


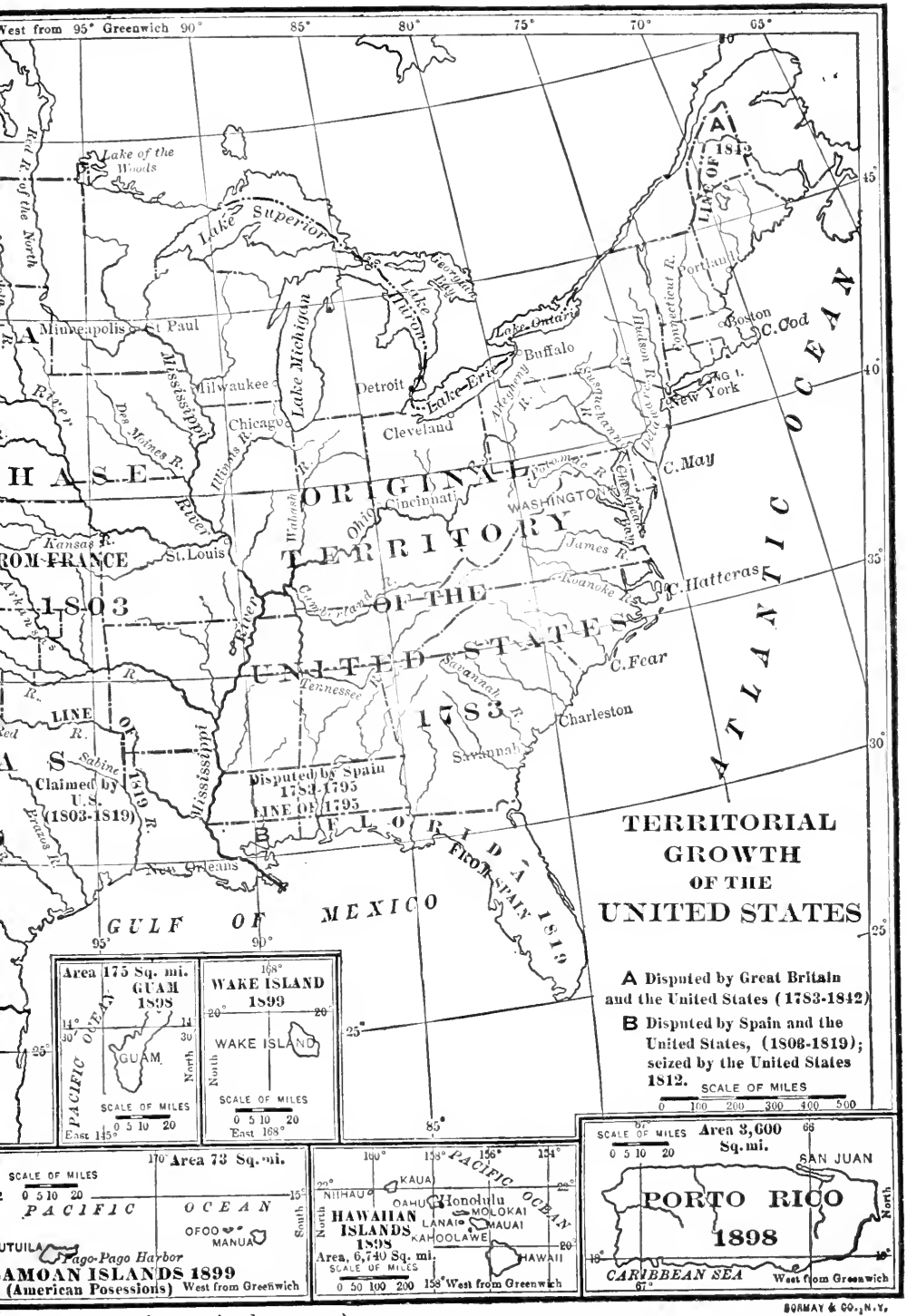

be noted with particular care.) 

rights enumerated in the amendments of the Constitution except the right of trial by jury and the right to bear arms.

In many ways the United States has been able to settle difficulties which prevented the development of the islands. Among these have been the problems of schools, which have been opened everywhere on the islands; that of roads, which have been built near the large cities; those of sanitation and public improvements; and, most trying of all, that of the friars lands, which was settled through the help of the pope, by the purchase of the friars' lands and by depriving the friars of much of their previous political control. Apparently the islands have made good progress under American control, but many of the inhabitants and others desire Philippine independence, and consider the work which has been done by the Americans to be of comparatively little value. Before rgog imports to the United States from the islands paid a duty equal to seventy-five per cent of our regular tariff, but since that date there has been practically free trade between the islands and the United States for the products of either.

437. Alaska. - The last American territory to have a government of its own was Alaska, which until ig 2 had no law-making body. However, Alaska was the first territory that we acquired which was not contiguous to the United States proper. It had been held by Russia which had sought about 1820 to acquire possessions farther south than Sitka in order to keep the British from the Pacific. This threatened aggression by the largest country of the old world was an immediate cause of the proclamation of the Monroe Doctrine in 1823 ( $\$ 262)$. In ${ }_{2} 8_{24}$ Russia agreed to remain north of $54^{\circ} 40^{\prime}$. After the United States gained undisputed possession of southern Oregon in I846 (\$303) offers were made to Russia for Alaska. These seem to have been considered favorably lecause of Russia's hatred and fear of England, particularly in the years following the Crimean War (IS54). During the Civil War Russia gave proof of her friendship by sending a fleet to New York. In I867, when

Social and industrial problems.

Ide, H. C., in No. Am. Rer., 186 (1907),

$510-524$.

Ireland, A., in Atlantic, 94 (I904), 577594.

Forbes, IV. C. in Atlantic, 103 (1909), 200-209.

Willis, H. P., in Phil. People.

Relations with Russia before I 868 .

Foster, $A m$.

Diplomacy, 404-410. 
the suggestion was made that Russia should cede us Alaska. terms were agreed upon and the treaty ratified within twenty-four hours. Russia had gained such great areas in Asia that she feared (ireat Britain and wished our friendship, as Xapoleon had sixty years earlier (\$2,2).

Development and problems of Mlaska.

\section{Lamed (ed.).} Reculy Ke . Vil. o-10.

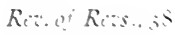
(1000). $00 ;-$ $702.40(1000)$. 40-02.

Halbert. II D. in ()atkenk. ou (1011). $051-002$

IIeems, (C.. in Horlds II or? zs (IOIz). $4: 2-430$.

Early attempts.

Taylor. B.. in lineticnth Cintury. 4 (1000). $507-500$.

Latané. $L^{\circ}$. S. and Epantish Anctiol, INO-:20. Necessary preliminary steps for construction of an American cansl.
There was little opposition to the acquisition of this rast territory. but few people appreciated the richness of the resources in that region. In fact it was not until the discovery of large quantities of gold near the Yukon River in Isos that much interest was taken in Alaska. The location of raluable mines near the boundary line and the use that was made by the gold-seckers of bays and roads which were claimed by both the Lnited States and Great Britain caused the settlement in Ioo: of the boundary dispute between Alaska and Camada. Aliska is well supplied not only with sold but with coal and other minerals. The attempt of corporations and speculators to scize coal lands and harbor frontage in I goo caused sevore criticism of President Taft's Secretary of the Interior. Richard Ballinger $(\$+\$)$. Later Mliska : resources were tied up until, after ior 2 , the government at IVashington proposed a govermment railway. provided some self-groverment for the territory, and permitted further development of Alaskias resources.

\section{Attempts to secure an Isthmian Canal before I902.} - With American possessions in the Pacific, a canal across Central America became a necessity. Plans were proposed three centuries ago to connect the Atlantic and the Pacitic. When the United States gained California, this discussion was revived, and. in order to secure the coöperation of Great Britain. which possessed capital and controlled the best canal route, the Cnited States agreed to the Clayton-Bulwer treaty in $\mathrm{s} s: 0$.

In order to construct a canal under American auspices, it was necessary to complete four preliminary steps. (I) $\mathrm{Me}$ must socure the abrogation of the Clayton-Bulwer treaty which required the copperation of Great Britain in the construction of a canal; (2) Congress was obliged to select a 
route and authorize the construction of a canal by that route; (3) the President and Senate must agree with the country in which the canal was to be located on the terms under which we should dig the canal; and (4) if the Panama route were selected, we must purchase the rights and property of the French company that had done considerable excarattion for a canal at Panama.

The United States and Great Britain finally agreed (1901) on the Hay-Pauncefote convention, which superseded the Clayton-Bulwer treaty. It expressly stated that the United States might construct a canal, directly or indirectly, and gave us the exclusive right of providing for the regulation and management of the canal. The canal was to be neutral on the same conditions as the Suez canal, giving the United States the right to police the district traversed, but not allowing any nation to blockade the canal or commit an act of war in it.

439. Securing a Satisfactory Route for the Canal. The Nicaragua route was favored by most of the engineering commissions that examined this subject, and by the House of Representatives. The last commission (1901) reported in faror of Panama. The Senate farored Panama, but authorized the President to choose the other route if no terms could be made with Colombia or the French company. This was accepted by the House, and the Isthmian Canal Act of June 28 , ro02, contained that provision. ${ }^{1}$

Without great difficulty Colombia was persuaded to make a treaty giving us the use of a strip ten miles wide as a canal zone. Compensation was fixed at $\$ 10,000,000$, but the Colombian Congress desired a larger sum, \$25,000,000, and refused to ratify the treaty. Panama then took matters into her own hands and seceded from Colombia. Her independence was recognized at once by President Roosevelt, an act

1 The Canal Act also stated that the President might expend $\$$. $0,000,000$ for the franchises and property of the French company, and might appoint an isthmian canal commission which would have charge of the construction of the canal. The sum of $\$_{135}, 000$, ooo was authorized for the completion of the work. 
Bishop, J. B., which caused considerable comment, and the new Republic in International, 9 ( 1904$)$, $247-260$. of Panama agreed to give us perpetual rights in a canal zone and the right to construct a canal for the amount originally Mahan, A. T., accepted by Colombia. As the French Company had in No.Am.Rev., already accepted our offer of $\$ 40,000,000$, the way was I96 (I9I 2), $5+9-568$.

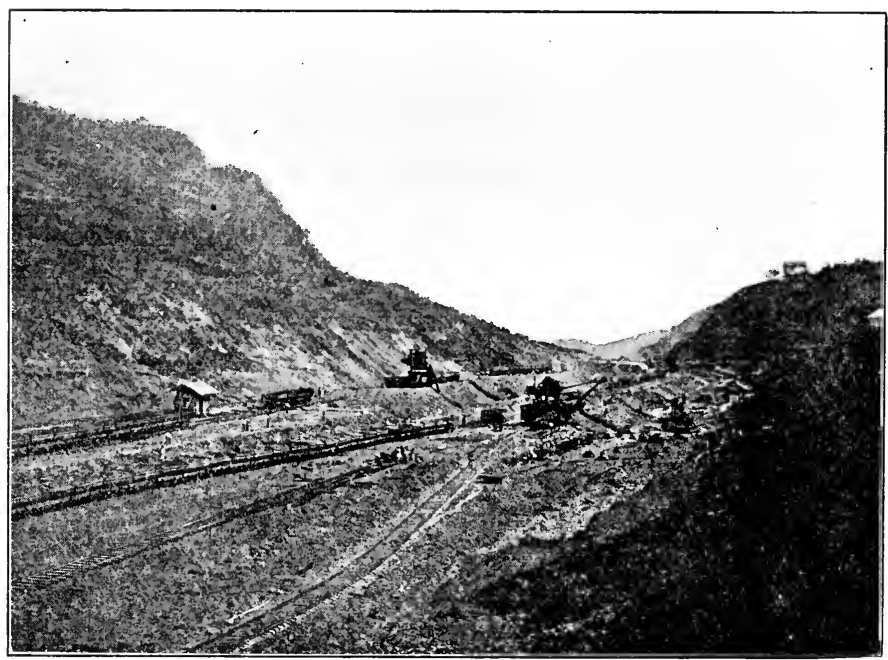

Culebra Cut, Panama Canal

(Work done by French Companies.)

cleared for actual construction by the national government.

Work

440. Construction of the Canal. - When we came to accomplished. examine the property that we had purchased, we found that Taft, W. H., in only a small part of the work of necessary excavation had Present Day

Problems, 95-122. been completed, much of this being rendered valueless by the refilling of the cuts. Most of the old machinery was Authier, G. T., worthless. It was not until I906 that the President of the in Rev. of Revs., United States and Congress decided that a lock canal would 43 (I9I), $49-6$ I be better than one at sea level. ${ }^{1}$ This decision was reached

${ }^{1}$ The construction of the locks presented a very serious engineering problem, which was solved satisfactorily. One grave defect of the lock system arises from the fact that already our great ocean liners are almost too large for the canal locks. 
because of the smaller original cost of a lock canal, the World's Work, shorter time required for its construction, and the saving of time for vessels. ${ }^{1}$ The canal was completed at a cost of

24 (I9I 2 ), 389-402, 4144 I 7 .

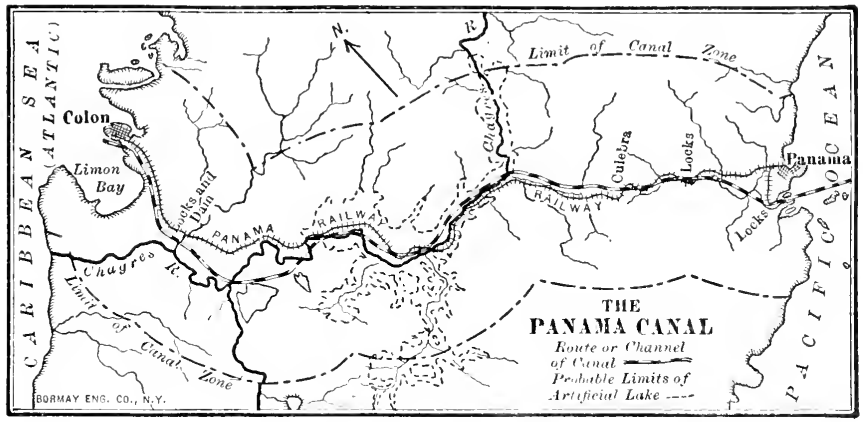

more than twice that of the original estimates, but it is much larger and better than the canal that was planned originally. The success of this great undertaking is largely a personal triumph for the chief engineer, Colonel G. W. Goethals.

The work accomplished by the Department of Sanitation was of first importance, since the canal zone was originally very unsanitary. By draining swamps, cleaning up the cities, using screens and other preventive measures against

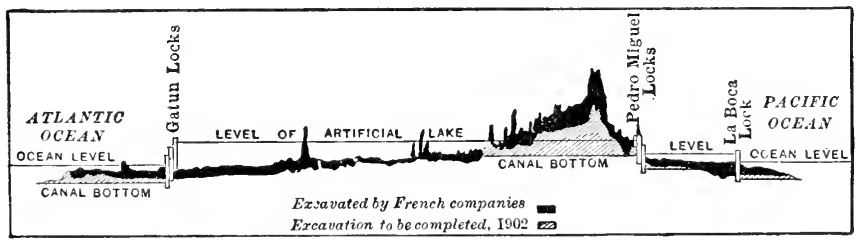

PROFILE OF THE PANAMA CANAL

yellow fever and malaria, the zone has been made as healthy as the average American city. An entirely different kind of protection has been that afforded against foreign enemies, for it was decided in I9 I to fortify the canal.

In rgr 2 Congress passed an act providing for the government of the canal zone after the completion of the canal.

Scientific Am., IO7 (I9I 2),

385-399.

Scribner's, 54 (I9I3), 7-36.

Sanitation and fortification.

Scientific Am., 107 (I9I2), $385,392-393$.

Bishop, J. B., in Seribner's, 53 (19I3), 234-25I. Stimson, H. L., in Scribner's, 54 (I9I 3), I-6.

1 This is due to the greater width of the canal between locks. 
Question of tolls.

Root, E., in Independent, 74 (I9I3), 285-289.

Military and naval

importance.

Mahan, A. T., in Century, 82, (I9II), $240-248$.

Commercial benefits of the canal.

Ballard, G. A., in Contemporary, 94 (I908), 73I-742.

World's Work, 24 (I9I2), 403$414,418-433$.

Johnson, E. R., in Annals A m. Acad., I 9 (I902), I-23, and in Scribners, 54 (I9I3), $37-43$.
This act provided that tolls should be charged on all traffic except American vessels engaged in the coastwise trade, which are to be exempt. Great Britain protested this act on the ground that it violated the Hay-Pauncefote treaty, and the question of tolls was reconsidered.

44I. Importance of the Canal. - The canal is not only notable as a great engineering feat. It is important from both the naval and the commercial points of view in binding the East to the West. The military importance is so great, in the opinion of Colonel Goethals, that the entire cost of the canal should be considered as an item in our military expenses, the running expenses of maintaining the canal alone being paid by the traffic through the canal. In these days of brief wars, time is an important element, and the canal has almost doubled our naval strength by permitting our naval vessels to proceed quickly from one ocean to the other.

The importance of the canal in binding the East to the West commercially will be very great. At the present time the cost of transporting freight by rail over the Rocky mountains and the great distance around Cape Horn hamper the development of this trade. Since transportation by water is cheaper than that by rail, the shortening of the water route from the Atlantic ports to those of the Pacific will give an immense impetus to the industries of the Pacific coast, the products of which can now be sold profitably only in the local market. Of equal advantage will be the opportunities given to the eastern cities to trade with the Orient, and with the South American countries on the Pacific coast. At present they cannot compete with the European merchants who enjoy a shorter water route. Our trade with western South America should be developed by the opening of the canal. The products of the Mississippi valley and the Gulf states will be benefited particularly, because of the great decrease in the cost at which they can be marketed, especially if a ship canal is built from the Gulf of Mexico to Lake Michigan, and the branches of the Mississippi are improved. 


\section{Our New Position among the Nations}

\section{The United States as a World Power. - The} position of the United States as a world power has long been suggested by her preëminence in the western hemisphere. It has become more conspicuous with the changes in foreign relations during the last two decades, not only in more clearly defining our headship among the republics of the New World, but in the acquisition of scattered colonial possessions, in new and important activities in the Far East, and in participation with other great powers in affairs of world-wide significance. More than all else it has been shown by our commercial and diplomatic position as a power second to no other.

Our place as a world power has come naturally and inevitably, as the Pacific Ocean has become more and more the sphere of world action, because we are the only great nation touching both the Atlantic and the Pacific. It was observable in our acceptance of a joint protectorate over Samoa, I 889 , and in our joint action with other great powers in the movement on Peking during the Boxer revolt in 1900. Usually our policy has been marked by moderation so far as our own demands are concerned, and by a disinterested, but sincere, determination to protect the territory, revenues, and rights of the non-Caucasian countries that have been unable to withstand the aggressions of the " civilized world."

443. American Influence on World Peace. - From the beginning of its history the United States exerted its influence to secure the rights of neutrals against the aggressions of belligerents. The proclamation of neutrality, issued by Washington ( 1793 ), furnished not only an example of firm and moderate action under trying circumstances, but was a model copied by older nations that wished to declare their neutrality.

The United States has long been an advocate of arbitration as a means of solving international difficulties, having Efforts made to protect neutrals.

Foster, Century of $\mathrm{Am}$. Diplomacy, 93, 154-157, 347-349.

International arbitration. used that method repeatedly since the adoption of the Con- 
Moore, J. B., stitution, especially in the settlement of disputes with Great in Harper's

Magazine, I 10 (1905),

610-6ig.

Larned (ed.),

Ready Ref., VI, $577^{-580,}$ VII, 708-7II.

Taft, W. H., in Century, 83 (I9I 2), $459-466$.

Living Age, 277 (1913), $688-690$.

Britain. In the recent movement for arbitration, however, the government of the United States acted rather tardily. This was due not to lack of interest in the subject but almost entirely to the complicated machinery, chief executive and Senate, through which our foreign affairs are managed. A general arbitration treaty with Great Britain in 1897 was defeated by the Senate's failure to coöperate with the President. When the Hague Peace Conference in 1899 made provision for a permanent court of arbitration, proposing a form of treaty under which disputes should be submitted, the United States found it impossible to join the other nations in this great movement until, in I908, several treaties were ratified. In I9ix, through the influence of President Taft, much more general arbitration treaties with Great Britain and France were ratified. Still later Secretary of State Bryan distinguished himself for his attempt to procure treaties with all countries, by which even questions involving national honor were to be submitted to arbitration if they were not settled by diplomacy.

America and

Americans have been very active in the promotion of the future of world peace.

Larned (ed.), Ready Ref., VII, 715-725. peace, ${ }^{1}$ holding national conferences, seeking to keep peace in the western hemisphere, and securing a second Peace Conference at the Hague in I907, but they have not always been unselfish enough to arbitrate. As the only great power with direct access to both the Atlantic and the Pacific; as the most disinterested spectator of European political maneuvers, and of contests in the Orient for territorial, policical, or commercial advantage, - the United States will undoubtedly have in the future a still greater share in the maintenance of the world's peace.

Military

444. Relations with Cuba since r898. - The question of Cuba after the war with Spain was one of great delicacy and difficulty. At the beginning of the war we had justified interference on the grounds that Cuba deserved to be free

${ }^{1}$ The Nobel peace prize has been awarded to two Americans, Theodore Roosevelt and Elihu Root. 
and that Spain's methods of control were morally wrong and injurious to American interests. We were pledged practically to establishing in Cuba a government that would be not only independent, but would reëstablish order in the island and maintain satisfactory relations with other nations. The fulfillment of this pledge required the military occupation of the island for more than two years, during which the American commanders did much toward improving municipal government in Cuba and aiding in the reëstablishment of business prosperity.

In I9or a constitutional convention completed a constitution providing a complete government for the Republic of Cuba and embodying several articles regarding the independence of Cuba and the relations to exist between Cuba and the United States. ${ }^{1}$ On the basis of this amendment we took charge of the Cuban republic in 1906, when insurgents prevented President Palma from executing the laws. Palma's resignation forced the United States to govern the island until I909, when the Cuban republic was again left in charge, but in I 9 I 2 President Taft was obliged to warn the Cuban government that affairs must be managed better.

As soon as the Cuban republic was established, the United States was asked to aid the Cuban planters by giving them especially low rates on goods imported from Cuba. Free trade between the two countries was advocated by a few, but was not considered seriously. After numerous delays, largely due to the opposition of the beet-sugar interests of the United States, the Senate ratified (I903) a reciprocity treaty with Cuba.

445. Relations with Mexico. - Our relations with Mexico

1 In the most important of these articles Cuba agreed to maintain her independence, financial and political, to accept the work done during the military occupation by the United States, and if necessary to permit interference by the United States for the purpose of preserving the independence of Cuba and fulfilling the obligations which we assumed for Cuba in the treaty of Paris. The United States was allowed to have coaling stations in the island, which we agreed never to use for the purpose of dominating Cuban affairs.

Larned (ed.), Ready Ref., VI, $182-I 87$.

Latané, $A m$. as a World Power, I 75-178, I $81-183$.

Permanent rights in Cuba. Larned (ed.), Ready Ref., VI, I 87-I90, VII, $174-178$.

Conant, C. A., in No. Am. Rev. I 8 (1907), I $41-146$.

\section{Reciprocity} with Cuba.

Latané, $A m$. as a World Power, I 83-19o.

Willis, H. P., in Annals Am. Acad., 22 (I903), I 29I 47. 
Mexico under have been very interesting and are likely to be as important Diaz. as those with Cuba. In I867 Maximilian was overthrown Lummis, C. F., in Mexico by Benito Juarez (\$4I 8$)$. A few years later in Outlook, 69 Juarez was succeeded in the presidency of Mexico by Porfirio (r9or), $536-$ 545 .

Diaz, who ruled the republic until I9I . During that period of forty years of benerolent despotism, Mexico developed rapMartin, P. F., idly, building railways, opening mines, constructing buildings, in Quar. Rev., 2 I I, 526-549. and developing agriculture. Diaz encouraged the investment of foreign capital, so that, at the close of his " reign," a billion dollars of American capital was invested in the Lyle, E. P., Jr., country. Although he looked after the material interests in World's IIork, If (I907), 9 7 79-9 196 .

Rule of Madero and Huerta, I 9 I I-I 9 I 4 .

Welliver, J. C., in Tech. Horld, I 8 (I9I 2), $376-387$.

Uncle Sam's Mexican problem. of Mexico by promoting peace and prosperity, Diaz did not give the Mexicans political freedom, and he often sacrificed individual rights and liberty to national progress. He was denounced as a tyrant who oppressed the people and denied the right of free elections.

In I9ro Diaz defeated Francesco Madero for the presidency, but soon after Diaz was forced to resign and leave Mexico. As president, Madero was not strong enough to maintain order, several insurrections being started in the states of northern Mexico. In I9I3 Madero's government was overthrown. Madero was forced to resign and was shot, after he had surrendered to acting President Huerta. Insurrections followed in the northern states, but Huerta maintained himself a dictator. The United States did not recognize Huerta's government in Mexico.

For several years United States troops have been maintained along the Mexican border in order to protect residents of that territory and to maintain the neutrality laws. On several occasions intervention seemed probable, but was avoided. In I9I3 President Wilson sent John Lind as his personal representative to Mexico to study the situation and work for peace and order. In accordance with Lind's suggestions, the Wilson administration followed a waiting policy. American citizens in Mexico were urged to leave the country and attempts were made to force Huerta's resignation by preventing him from getting money. This policy 
was supported by most of the powers. As Mexico has great natural resources which attract foreign investors, as the Mexican people are incapable of true self-government, and as they have not yet developed a national consciousness, Mexico is likely to have troubles for some years to come. If Uncle Sam tries to act as either censor or guardian for unhappy Mexico, our relations with our turbulent southern neighbor are also likely to be unsettled for a similar period.

446. Relations with China. ${ }^{1}$ - In 1898 we added Hawaii and the Philippine Islands to Alaska as Pacific Ocean possessions. These changes compelled us to interest ourselves in the Far East, particularly in China. For years the feeling in China against foreigners had been growing, especially at the invasion of graveyards and the acquisition by foreign governments of spheres of influence. Inder the learl of a secret organization whose members were known as "Boxers," foreigners were attacked everywhere in I 900.2 "To protect our minister and other Americans in China, the United States joined the European powers in sending troops against the Chinese capital, Peking. The Chinese government was forced then to punish the leaders of the revolt, to give assurance that there would be no recurrence of the difficulty, and to simplify and improve its methods of dealing with foreign nations. The Chinese government was forced to pay the allies an indemnity equal to more than $\$ 350,000,000$, but the United States effectually prevented any further partition of the empire or the possibility of any nation's seizing territories in lieu of the amounts due to it.

The influence of the United States at this time and later was exerted very effectually by the Secretary of State, John

${ }^{1}$ Our early relations with China were cordial, partly through the personal influence of Caleb Cushing and Anson Burlingame, ministers to China. Even the drastic Chinese exclusion laws $(\$ 476$, note I $)$ did not destroy this friendship, which has been strengthened by the demand of the United States that there should be fair dealings with China among foreign powers.

2 The German minister was killed and the other ministers were besieged in one of the legations. The Chinese government, which had been unable to preserve order for many years, sided with the Boxers. 
United States ; Hay, to preserve the integrity of China and to remove unjust and the integrity of China. trade restrictions. Early in the Russo-Japanese War (I904) Secretary Hay secured the consent of the combatants and all European powers to the "administrative entity" of China and a limitation of the field of hostilities.

The Chinese Republic.

Hart, A. B., Obrious Orient, 208-220. Colquhoun, A. R., in Fortnightly Rev', 96 (I9II), IO32-1043. Annals $\mathrm{Am}$. Acad., 39 (I9I 2), 1-3S. McCormick, F., in Scribner's, 50 (I9I I), 349-355.

Changes in Japan after Perry's visit in I 854 .

Coolidge, $L$. S. as World Power, $3+1-3+4$.

The danger of the partition of China among the great powers is by no means past, since China became a republic

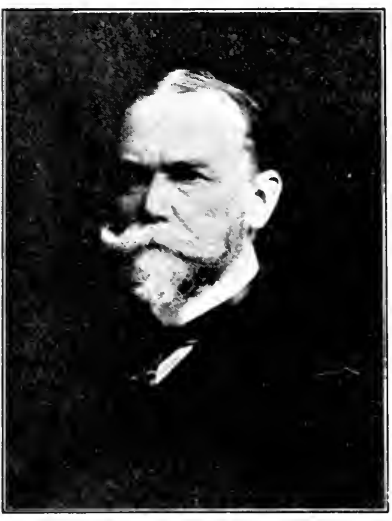

JOH: HAY (igri). The organization of the republic was the culmination of numerous reforms, giving China a western system of education, provisional congresses, and a national assembly. In igi i the reform movement became a revolution in which the ruling dynasty of the Manchus was driven out of China. A parliament was held in I 9 I 3 and Yuan Shi Kai was elected president, one of his acts of his first year in office being to abolish the parliament and rule China with the help of an administrative council. Whether China will be permanently a republic, and whether as a republic she will be able to resist foreign aggressions remains to be seen. ${ }^{1}$

447. Relations with Japan. - In the immediate fature our relations with Japan are likely to be much more important than those with China, because China is still half-asleep, and the Japanese are wide-awake. Our relations with Japan

${ }^{1}$ As the Chinese government has needed money, it has borrowed from foreigners. In the "four-power" loan and later in the "six-power" loan conditions were imposed on China which would have threatened to deprive China of her independence. Because of this fact and because President Wilson was unwilling to aid American capitalists in China and elsewhere by the use of our national authority, he withdrew (I9I3) the support of the American government from the "six-power" loan. Later the Chinese Republic was recognized. 
began with the visit of Commodore Perry to the islands in I854. Japan soon opened several ports to foreign commerce, but these concessions to foreigners, like those in China nearly a half century later, caused a domestic revolution. Out of this domestic revolution emérged finally a modern. Japan, with a constitution and parliamentary government. Japan has adopted western methods in business, in education, and in war. As the Japanese are keen, ambitious, courteous, exceedingly industrious, and intensely patriotic, Japan has rapidly come to the front among the nations of the world.

As Japan is small and her resources are limited, while her population is one half that of the United States, she has required an outlet for her surplus population. This she has found partly in Formosa, obtained from China in $1894 .{ }^{1}$ Another outlet is Korea, occupied after the successful war against Russia. Japanese laborers are found in large numbers in the Philippine Islands, in Hawaii, and in Latin America. So many began to come to the United States that the people of the Pacific coast were alarmed, as they were by the Chinese immigration nearly a half century earlier $(\$ 476$, note 1$)$. The Japanese live on much less than Americans can, and work many more hours a day. Americans therefore cannot compete with the Japanese on equal terms. For economic and racial reasons the San Francisco school board (Igo6) and the California legislature (I907, I9I3) legislated against the Japanese. Japan protested against these acts as violations of treaty agreements. The earlier problems were settled by a compromise which permitted the Japanese to attend regular schools, and the Japanese government restricted the immigration of laborers to this country. These Japanese questions and trouble with Italy in $\mathrm{I} 89 \mathrm{I}^{2}$ illustrate the difficulty encountered by the na-

${ }_{1}^{1}$ In 1894 , after her brilliant campaigns against China, Japan freed herself from the humiliating treaties which Caucasian nations had forced on her before. Since that time foreigners in Japan have been under Japanese law and not under treaties.

${ }^{2}$ A similar difficulty over the conflict between national and state authority occurred in $189 \mathrm{I}$ when citizens of New Orleans lynched several citizens of 
tional government in negotiating with foreign countries concerning subjects left exclusively to the states.

Real and imaginary dangers of the future.

Shaw, A., in Rers of Rers., 47 (IgI3). $043-650$.

The war with Spain.

Problems growing out of the war.

Japan's progressiveness and her aggressiveness have aroused fears that she wished to attack the United States. Friction due to incidents like those in California has produced in the "rellow journals" and among the " jingoes" of both nations a great deal of "war talk." Japanese leaders and well-informed Americans do not share in this feeling, although it is well understood that there cannot be emigration of Japanese laborers to America without race antagonism, and that, in the future, Japan and the United States will be keen rivals in the Pacific and may even come to blows.

448. Summary. - When afiairs in Cuba became unendurable in $\mathrm{ISO}_{06}$ and $\mathrm{ISO}_{\mathrm{T}}$, the government of the Lnited States indicated that it must interfere unless order was restored at once and American interests protected. The battleship Mainc was sent to Havana harbor in January, ISoS, to insure this protection. Its destruction in February, and the report of the commission of inquiry in March that it was blown up from the outside, left no way open but complete submission by Spain, or war. As Spain refused to admit that she was in the wrong, war began on April $2 \mathrm{r}$, I Sos, after a specific statement by Congress that its purpose was not conquest but the freedom of the Cubans. The decisive victories at Manila Bay and at Santiago de Cuba showed that Spain could not hope for the least degree of success, and peace was made by Spain's relinquishing her sorereignty over Cuba, and by surrendering Porto Rico and the Philippines to us.

The erents of the war forced upon us recognition of the fact that we were one of the great powers of the Pacific, and must decide important problems, not only in connection with the government of distant colonies, but in regard to our

Italy who had terrorized that community. Italy demanded reparation Secretary Blaine stated that Louisiana had entire jurisdiction of the matter. Although the state did nothing. the matter was settled by the payment of indemnity by the Lnited States. 
attitude in the East toward the other world powers. Colonial problems we solved, theoretically by asserting the authority of Congress to govern the colonies as it deemed best, practically by leaving the people of our new possessions a fair share in their own government and training them for the assumption of a larger number of duties. By constructing an Isthmian ship canal, we have sought to link more firmly the Atlantic slope with our Pacific states and possessions.

Owing to her position between the Atlantic and the Pacific, to her headship among the nations of the new world, to the great development of her marvelous natural resources, and to her skillful and aggressive foreign policies, the United States has taken a position in recent years second to none of the great world powers. She has used this position to promote peace and sometimes extend international arbitration. She has taken a rather arbitrary attitude toward Cuba and other Latin-American states $(4+4,+4)$. On the other hand she has submitted to many indignities rather than intervene in Mexico. As a rule, and especially in China, her leadership has been marked by disinterestedness and by consideration for weaker peoples. In her relations with aggressive Japan, she has found it necessary to follow a moderate course in order to avoid antagonism.

\section{TOPICS}

i. Cuba and the United States before isos: The American Nation, XXI, I7I-I73; XXV, 3-28; Hart, "American Foreign Policy," pp. I I 3-132: Latané, "United States and Spanish America," pp. So-r 75 ; Callahan, "Cuba and International Relations:" Chadwick.

2. Destruction of Cerver.'s Fleet: Nation, 69 (IS99), p. 406 ; Warren, A.. in Engineering. ILagazine, I6 (I S99), pp. 533-548; Long, $\mathrm{J}$., in Outlook, it (1902), +10-426,603-620; Century .Hagazine, $5^{\mathrm{S}}$ (IS99), pp. 50- IIS.

3. Controversi over Retention and Government of PhilippiNes: Latané, "Am. as a World Power," 60-8I, I53-I04; Larned (ed.), "History for Ready Reference," VI, pp. $63+-638,6+1-6+5,660-$ 666; Vest, G. G., in North American Revieu', I68 (IS99), pp. I I 2-1 20 ; Denley, C., in Forum, 29 (I900), pp. toI-to8; Taft, W. H., in Out- 


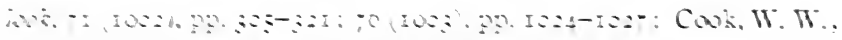

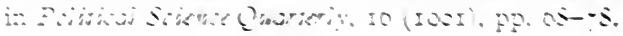

\section{SIUDIES}

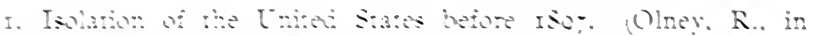

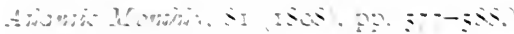

$\therefore$ ()

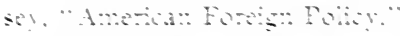

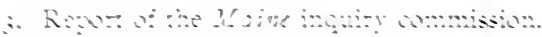

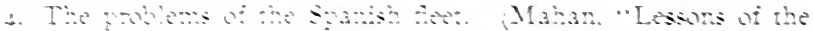

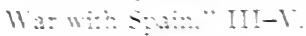

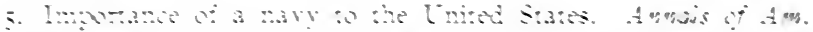

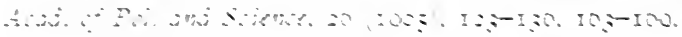

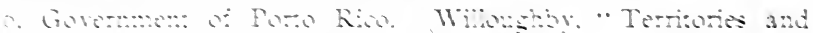

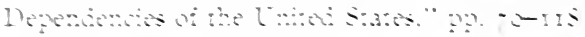

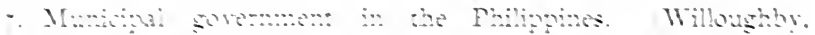

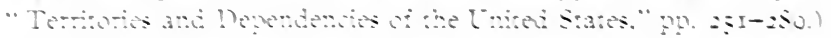

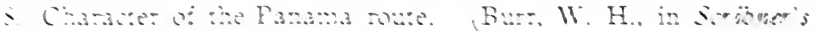

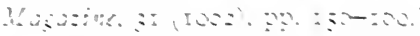

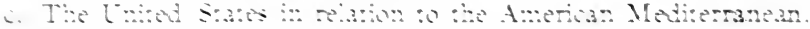

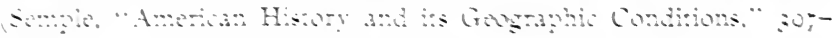
$\therefore \therefore$.

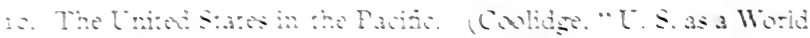
Pw:?

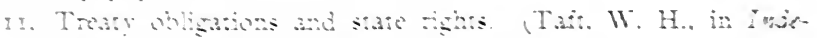

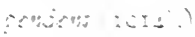

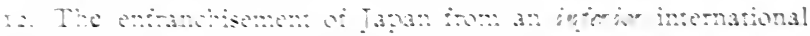

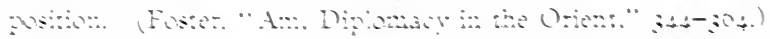

\section{DEESIONS}

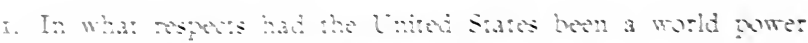

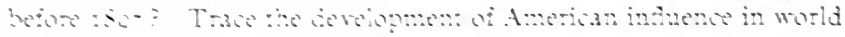

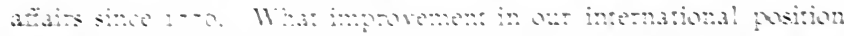

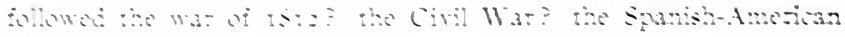
$11: \div:=$

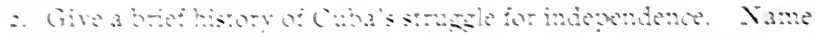

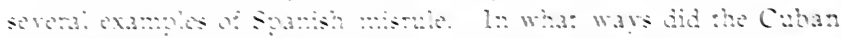

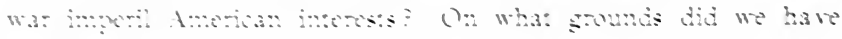

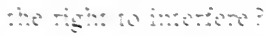

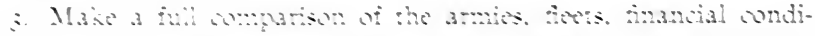

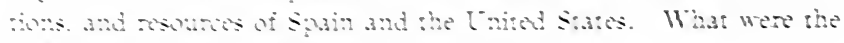

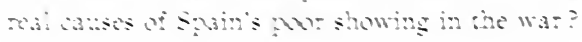


4. Compare the acpuisition of Porte kive and the Philippines with

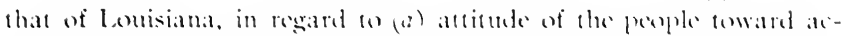

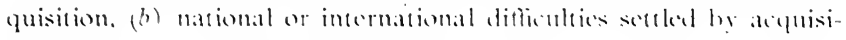
tion. (6) prohkms of government in the new territory. and (d) in Huence of the acepusition on the lenited states as a world power.

5. What difficulties were conountered in selecting a rome for the lsthmian canal? in deciding what hind of ianat should be con structed? How should the canat atfort the latitie coast? the com meree of the Atlantic cities with south Imerieat and lsia?

c. State with exactmess our rightes in (yhal after sises and our ohligations toward cuha. To what extem did we proted cubats interests rather than our own in the military ocompation (1 by the Platt amendment? hy commential treaty? hy interference in 1005? Must we tinally annex ('uha?

7. Towhat extent has the lunted states money interests in .lexien?

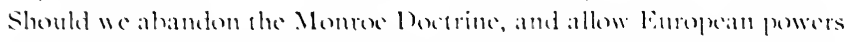
to protect their interests or should we intervene when a 1 at in . Imerican crisis oceurs like that in Mexio, 1011-101t?

s. What is the great problem of the Paritic? Is there a "yellow peril," now from Japan, in future, from china? Should we restriet or prohibit Asiatic immigration? Why? Should we give dsiaties citizenship? 


\section{CHAPTER XXII}

\section{RECENT CHANGES (I9OI-IgI4)}

\section{Presidents}

Theodore Roosevelt (Igor-I909) William H. Taft (Igo9-IgI2) Woodrow Wilson (1912-)

\section{The Roosevelt Policies (igoi-igog)}

Contrast between the two men and their policies.

449. McKinley and Roosevelt. - William McKinley was mortally wounded in Buffalo, September 6, I90I, by

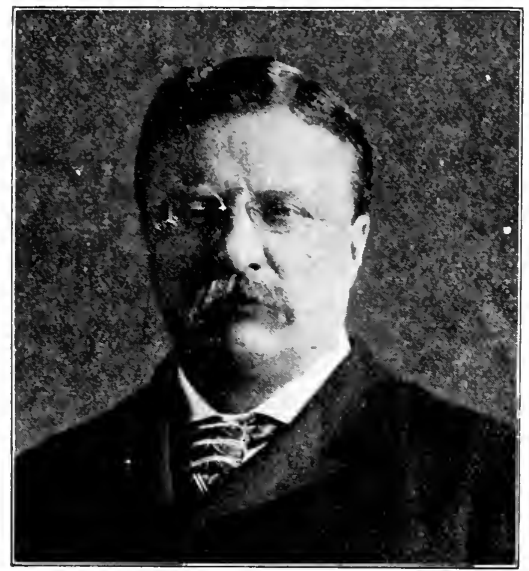

Copyright by Pach Brothers (rgo4).

THEODORE ROOSEVELT a Polish anarchist. With his death a few days later, Theodore Rooserelt became President. ${ }^{1}$ In general Roosevelt attempted at first to carry out the policies of McKinley, but they were men of different character, methods, and ideas. In spite of his fine personal character, McKinley had been the tool of " big business," "the ad-

vance agent of prosperity," in the words of the political managers. McKinley was largely under the domination

${ }^{1}$ Roosevelt's first experience in politics was in the New York legislature in ISSI. He was later (ISS6) the Republican candidate for mayor of New York, served (1SS9-IS95) on the naticnal Civil Service Commission, was 
of the Republican boss, Mark Hanna. Roosevelt was a much more skillful politician than his predecessor, a man of wider knowledge, and infinitely more aggressive. He understood better that the people would not permit capital and the great corporations to rule them indefinitely. Roosevelt did not break at once with the party " machine," but Hanna's death in February, I904, left him in control of the party. The changes in policy that followed McKinley's death will be understood from the following sections.

450. Roosevelt's "First Term." - Among the measures that became law at this time largely through the personal support of the President was the law for the reclamation of lands in the arid West by the building of huge dams for reservoirs. This was called the Irrigation Act (1902). In the improvement of the civil service Roosevelt contributed greatly to the reform movement of the time. Postal frauds in Cuba and elsewhere were investigated and several "grafters" were punished. More positions were placed under the Civil Service Commission by Roosevelt than had been set aside by his predecessors during the twenty years since the commission had been created.

The Panama Canal had been opposed by the railways for years. With Roosevelt's support the Canal Act was passed in $1902(\$ 439)$. When negotiations failed to secure from Colombia a right of way across Panama, Roosevelt recognized the state of Panama as an independent Republic, and a canal zone was acquired from Panama.

Had there been doubt about the popularity of Roosevelt and his policies, there was no question after the election of 1904. The Democratic party held an exciting convention, which was controlled by the conservative Democrats.

Land laws and reforms.

Van Hise, Conservation of Nat. Resources, I93-197.

Newell, F. H., in Outlook, 83 (1906), 933-941.

Blanchard, C. J., in Nat. Geog. Mag., $2 \mathrm{I}$ (igro), 333-360.

The Panama Canal.

Larned (ed.), Ready Ref., VII, $467-470$.

The election of I 90.4 .

Larned (ed.), Ready Ref., VII, 669-67I.

police commissioner in New York City under a reform administration, and served as assistant secretary of the navy. When the Spanish-American War broke out, he resigned and helped organize the "Rough Riders." His popularity made him governor of New York and his aggressiveness made him an enemy of the New York boss, "Tom" Platt. In r 900 Platt, by appealing to the people, forced Roosevelt to accept the vice presidency, in spite of the opposition of Mark Hanna and of Roosevelt himself. 
Bryan prevented the insertion in the platform of a plank

Latané. Am. ds a llorld Poretr.

$2=4^{-2+1 .}$

Stanmood.

Hist. of the

Presidency

(Isiot-I000).

$i i-I+0$

General.

Latané. Atm. as a Ilorle Forecr. ISt-ISO, $215-$ $220,2=4-22 \%$.

Scott, J. B., in Ottlook. gI (I000). $350-357$

The end of RussoJapanese IVar (I005). Santo Domingo.

() $64600 k, 00$ (I OOS),

100-104.

Moore, J. B., in $R_{\text {ers oi }} R_{\text {ets., }}$ $3 \mathrm{I}(\mathrm{I} 905)$, $203-203$.

New restrictive legislation.

Res. of Ress. if $(1000)$. I $30-$ If $2,05-; 0$; $33(1000)$, $555-500$. faroring the gold standard, but the Democratic candidate. Judge Alton B. Parker of Jew York, came out tatly for gold. In spite of this "safe and sane "position of the Democrats, Parker stood no chance against Roosevelt. who carried all of the northern states and two of those in the "Solid South." his popular plurality being about two and one half millions.

\section{I. Foreign Affairs under Roosevelt. - During most of} Roosevelt s " first term " foreign affairs were conducted by Iohn Hay. and during most of the second term by Elihu Root. In the conduct of foreign affairs during this period, howerer. we usually notice the hand of Rooserelt and the "big stick." This is true from the first. Not only did the recognition of Panama show Roosevelt's arbitrary method, but the forcing of reciprocity with Cuba through the Senate in special session ( I00 $)$ ( $+4 t)$ shows the same spirit.

When Rooserelt tendered the good offices of the United States in the settlement of the Russo-Japanese IVar (1005) he performed a notable service for the world. which brought him the Nobel peace prize the next vear. By intervention in Santo Domingo for the purpose of collecting debts due to American merchants ( $+2 \mathrm{I}$ ) Rooserelt prevented intervention by European powers similar to that in Venezuela three years earlier.

452. Internal Policies of Roosevelt's " Second Term." The Congress which was elected in root made a record for restrictive and reform legislation. The most important of the measures was the Interstate Commerce Act $(i \mathrm{I})$, which gave the Interstate Commerce Commission the right to fix maximum rates and so changed the methods of regulating railways that the commission was able to protect shippers and the public. Among the measures was a pure food law against which the manufacturers of foods and drugs had fought successfully for several years, a law to proceed with the construction of the Panama Canal, and a law reforming the consular service. 
The legislation of this Congress included a law for the preservation of Niagara Falls. This was one of the earliest Conservation of the special laws made for the conservation of our national resources. Already a large forest reserve had been established. Pending revaluation, President Roosevelt withdrew from sale more than $70,000,000$ acres of coal lands. As there was no law providing for this act, his successors placed policy.

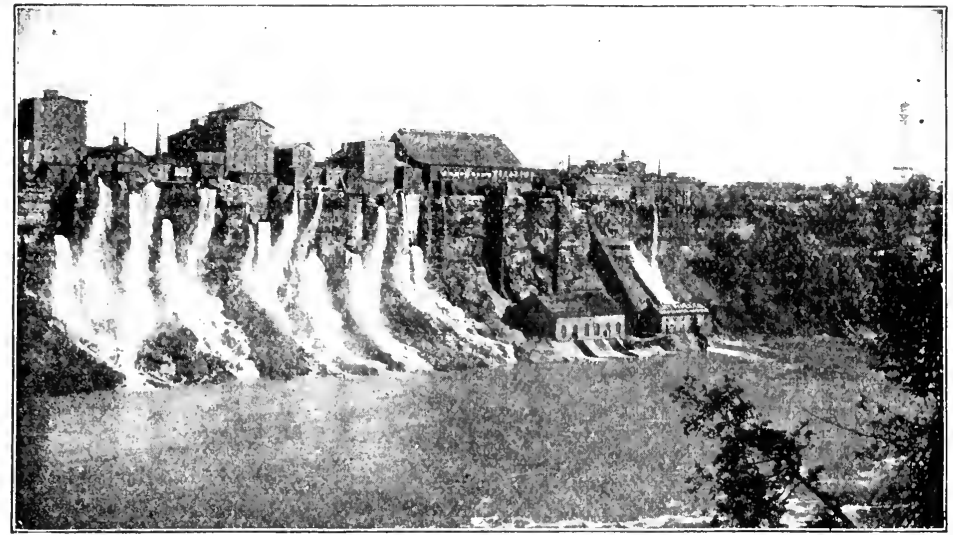

Water Power, Niagara Falls

them again on the market, but after the Ballinger-Pinchot controversy $(\$ 458)$, the lands were withdrawn legally. President Roosevelt aroused great interest in the conservation of waterways by his trip down the Mississippi (1907) and by securing a conference of the state governors to consider the subject of conservation in Washington, in 1908.

Anti-trust investigations which were made by the Bureau of Corporations and suits which were brought by the government against trusts formed a very important part of the "Roosevelt policies." In his earlier messages President Roosevelt urged the need of better supervision of the railways and the trusts. Suits were begun against combinations that were believed to be contrary to the Sherman anti-trust law $(\$ 468)$, although none of these important cases except that against the Northern Securities Company was decided

Roosevelt's Anti-trust policy.

Hill, G. G., in No. Im. Rev., I 85 ( I 907 ), 759-765. 
Garfield, J. R., during the first administration of Roosevelt. Later, in public in Outlook, 9I (I909), 389-393. addresses and in suits at law, Roosevelt attacked these great corporations. He decried " predatory wealth," and abused the "malefactors of great wealth " who exploited the people. The public was aroused against the great corporations and became interested also in Roosevelt's policy of conservation.

The panic of I907.

Holt, B. W., in Rev. of Revs., 36 (I907), $672-677$. Laughlin, J. L., in $\mathrm{W}$ orld Today, I3 (r907), I 220-I 224 .

Noyes, Forty Years of $A \mathrm{~m}$. Finance, 355380 .

The election of I908.

Larned (ed.), Ready Ref., VII, 674-678. International Year Book, I 908 ,

579-594.

Stanwood, Hist. of the Presidency, (I897-1909), I 4 I-2 I3.

General.
453. Panic. The Election of I908. - Many people attributed the business panic which occurred in October, I907, to attacks made by Roosevelt on the trusts. Others saw an attempt by certain great capitalists to precipitate a panic so that the Roosevelt policies might be discredited and that the competitors of the capitalists might be injured by the depression which followed. These were undoubtedly minor causes, for, as in the case of previous panics, this panic was due to over-speculation and too much extravagance. It was due in part also to a national banking system that did not give an elastic currency and to the speculations of the trust (banking) companies. The depression which followed the panic was comparatively short-lived. It did not destroy the popularity of Roosevelt or the prestige of the Republican party.

Roosevelt selected William H. Taft of Ohio to carry out the "Roosevelt policies." Taft and James S. Sherman were nominated by the Republican convention on a platform that called "unequivocally" for a revision of the tariff so that rates should equal the difference between the cost of production abroad and at home. The Democrats nominated William Jennings Bryan with a platform that demanded tariff reform and the adequate control of trusts. Bryan polled a much larger popular vote than Parker in 1904, but was beaten in the electoral college by a vote of 326 for Taft to 157 for Bryan.

\section{The Rule of the People (igo6-1913)}

454. The War against Political Misrule. - The movement against the domination of the political world by "big business " started first in the West, especially in the pop"list 
states and later in Wisconsin under Robert La Follette. It did not become a national movement until Theodore Roosevelt moved into the White House. Another nation-wide movement which has been characteristic of the last decade is a reform and uplift movement, especially in our cities and our central and western states, which demands that the people should have a larger share in the government and that the activities of the government should promote the welfare of the people.

In order that the people might rule, it was necessary that they be aroused to the corruption and graft that were prevalent in our governments, especially those of the cities. This was not done easily. Gradually, however, people began to realize that the police of our cities frequently protected vice and crime if they were paid enough by the lawbreakers. It was found that councilmen were bribed to give away valuable franchises. In many instances these grafters were brought to trial, and, in a few cases, they were convicted and sentenced to imprisonment. When graft cases came to trial, however, it was found that these officials were usually part of a great political system which would not endure having its members punished. It was found further that the laws were not designed so much to protect the public as to look after favored interests. More and more insistent became the demand that new means should be devised to give the people control of their own governments.

455. The Insurgent Movement. - The movement against domination of the government by special interests may be called the insurgent movement, although that name is sometimes used for a small part of this general movement. It was not simply a protest against graft; it was a demand that the people should have a chance to elect their own representatives, and that these representatives should not be hampered by precedent or by political machines. It sought to introduce new methods which would give the people a direct share in their government. Among the first results of t'ie insurgent movement proper was the overthrow in the

Bingham, T. A., in Century, 78 (1909), $725-728$.

The national insurgent movement.

Arena, 35

(I906), 63I640.

Steffens, L., in Everybody's, is (I 908$), 723-$ 736.

Pinchot, A., in McClure, 35 (1910), 58I-590. 
White, W. A., national House of Representatives of the arbitrary rule by in American, 7I (1910), $170-174$.

Baker, R. S., in American, 69 (I gro), $435^{-448}$.

The "insurgents" in the House of Representatives.

Hinds, A. C., in $\mathrm{McClure}$, 35 (I9ro), 195-202.

Murdock, V., in 1 o. $A \mathrm{~m}$. Res., I9I (I910). 510-5 I6. Hale, W. B., World's Work 19 (1910). I $2 \mathrm{SO}^{2}-\mathrm{I} 2 \mathrm{SI} 2$. The old-time primary and nominating convention.

Hart, Actual Goo't, 457 , 46,48 .

Merriam, Primary Elections, I 8-39.

Dallinger, Nominations for Elective Office, 95-1 26 . the Committee on Rules. Widespread and more important than these were the reform methods in the states known as the direct primary, the initiative and the referendum, and the recall.

Before igio the work of the House of Representatives had been controlled by the "big three," that is, by the majority members of the Committee on Rules. The leader of these was the speaker of the House, who appointed the committees and decided who might speak before the House. Later speakers had been more dictatorial if not more arbitrary than "Czar" Reed (\$ 406). By a union of Democrats and " insurgent "Republicans the speaker lost his power to appoint committees and was removed from the Committee on Rules (I9I0), the committee being composed thereafter of ten members, six from the majority and four from the minority. This committee controls the work of the House, but the Democrats in IgI and in I9I3, fearing that it might gain too much power, allowed the Committee on Ways and Means to appoint the other committees.

456. Reform of Political Party Methods. - A change that was of infinitely greater importance than the reform in the House of Representatives has been the gradual abolition of the political party convention and the substitution of the direct primary as a means for the nomination of party candidates. Under the old, or convention, system, primaries were held to elect delegates to the conventions. These primaries were either mass meetings of voters in a small precinct who came together and elected delegates to a local convention, which in turn elected delegates to a larger convention; or the primary was an election in which the voters of each party elected its delegates to the convention. In either case the delegates were usually selected by the political party " organization " or " machine," and the candidates whom the convention chose were regularly machine men.

In order that the candidates might be the choice of the people rather than the tools of the " machine," the direct 
primary has been introduced. During recent years it has spread to almost all of the states, being used for the nomination of local and state candidates, and, in several states, for the selection of the state's delegates to the national party convention, which nominates the party candidates for President. The adoption of these methods has brought the choice of the candidates close to the people; but now a campaign is necessary before the direct primary election, and sometimes a bewildering number of names of prospective candidates is placed on the ballot. After all, then, with the direct primary, as in the case of the convention, we need some political party organization, and the "organization" or "machine" may have as much power as formerly. The old party bosses and machines are usually opposed to the direct primary, however. ${ }^{1}$

In order to reduce the number of names on both the primary ballot and the final election ballot, a reluction in the number of elective offices has been proposed, and in some states this change has been made. This is known as the "short ballot."

State and national laws have forbidden contributions by the corporations to party campaign expenses. The people rather than the corporations therefore theoretically may control both the parties and the elections.

457. The Initiative, the Referendum, and the Recall. For fear that these devices should not give the people adequate control of the governments, there has been widespread extension of the right of the people to propose and make their own laws. The means by which legislation is made direct are the initiative and the referendum. The " initiative" is the right of the people to propose laws which

${ }_{1}$ The experience of New York shows this. In I9I 3 the struggle between Governor Sulzer and Tammany for real control of the state politics centered around the direct primary law. As the other party leaders and bosses opposed Sulzer, he was impeached and removed from office. In the following municipal election in New York City in November Tammany Hall was overwhelmingly defeated. Popular pressure will in time give New York and other states the direct primary. 
Munro, Gov't of Am. Cities, $321-350$.

The recall.

Beard, $A m$. City Gov't, 68-75.

Annals Am. Acad., 43 (I9I2), 215236.

Munro (ed.), Initiative, Ref., and Recall, 298-320. the lawmaking branch of the government must pass or must submit to the voters. The "referendum" is the right of ratifying laws. As lawmaking is naturally a subject that demands special knowledge and special training, the extension of this privilege to the public shows that the people have come to distrust their governments very thoroughly. Direct legislation has been in use for local laws a great many years, but its scope has recently been so extended that, at the close of the year I913, eighteen states had the "initiative" and the "referendum " for state laws as well." The "referendum " had been used generally for the ratification of state constitutions and for state constitutional amendments for about a century, but its use in connection with the initiative for the making of state laws has been the result of the recent demand that the people should rule.

The recall is a further means of controlling public officials; it is not a method of popular or direct legislation. Where the recall has been adopted, ${ }^{2}$ a certain percentage of the voters may demand that another election shall be held in order to ascertain whether an official whom the petitioners distrust shall be retained in office. If he polls a larger vote than any of his opponents, he is retained.

\section{The Movement toward Economic Reform (igo9-igi4)}

458. The Beginning of the Taft Administration. - The new popular movement for a larger share in the government

I For a summary of recent changes in the status of popular government see the American Year Book (I9I4), table p. 69. This table will undoubtedly be brought down to date in later issues.

2 This method is used much less widely than the initiative and the referendum, being applied to judicial state officials in but three states in rgra. In fact, there is very great opposition among conservatives to the application of the recall to judges, whose decisions might then be influenced by fear of removal. When New Mexico and Arizona were admitted to the Union in I9I 2, President Taft refused to sign the resolution admitting Arizona until Arizona eliminated the provision of the state constitution which permitted the recall of the judiciary. Ex-President Roosevelt advocated the recall of judicial decisions as a substitute, but it has been received with less favor than the recall. 
and more benefits from the government for the common people had not made great headway when Taft was elected President $(\$ 453)$ in I 908 . Taft was looked upon then as a progressive, but his temperament and his long experience on the bench made him quite conservative. ${ }^{1}$ He made himself unpopular in the West the first year by indorsing the reactionary PayneAldrich tariff (\$ 463) as the "best ever." His attempt to apply literally the law for the sale of coal lands caused Taft and Secretary Ballinger to offer coal lands for

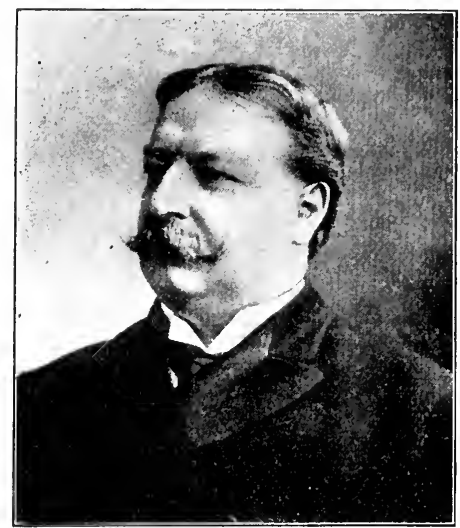

Whiliam H. TAFT sale at the old ridiculously low prices. ${ }^{2}$ A popular protest, the so-called Ballinger-Pinchot controversy, led to the enactment of laws which permitted the withdrawal from sale of valuable coal, oil, and other mineral lands.

President Taft earnestly desired to promote peace and international good will. He earnestly advocated a reciprocity agreement with Canada by which trade in grains and raw materials would be promoted between the two countries. For twelve years (I854-I866) the United States had tried reciprocity with Canada, but, although in I9I I Congress voted in favor of reciprocity, Canada, at a general election,

1 William H. Taft is a graduate of Yale, where he holds at present a professorship. From I 88 I to 1892 he held several political positions, and in 1892 was appointed judge of the United States Circuit Court. After I900 he served as governor of the Philippine Islands, and (I904-I908) as Secretary of War under Roosevelt. Because of his extended administrative experience Taft was exceptionally well prepared for the duties of chief executive.

${ }^{2}$ Roosevelt had withdrawn coal lands from sale, pending the revaluation of these lands, although no law permitted this action. Ballinger made preparations to give patents to lands in Alaska, which Pinchot thought contrary to a wise policy of conservation.

The conservative position of the Taft administration on tariff and conservation. Lowery, E. G, in $\mathrm{No} . \mathrm{Am}$.

Rev., I9I (I910), 289301.

Turner, G. K., in McClure, 35 (I9IO), 2I I-22I .

Reciprocity and international arbitration. Rev. of Revs., 43 (I9II), 278-283, 737738 . 


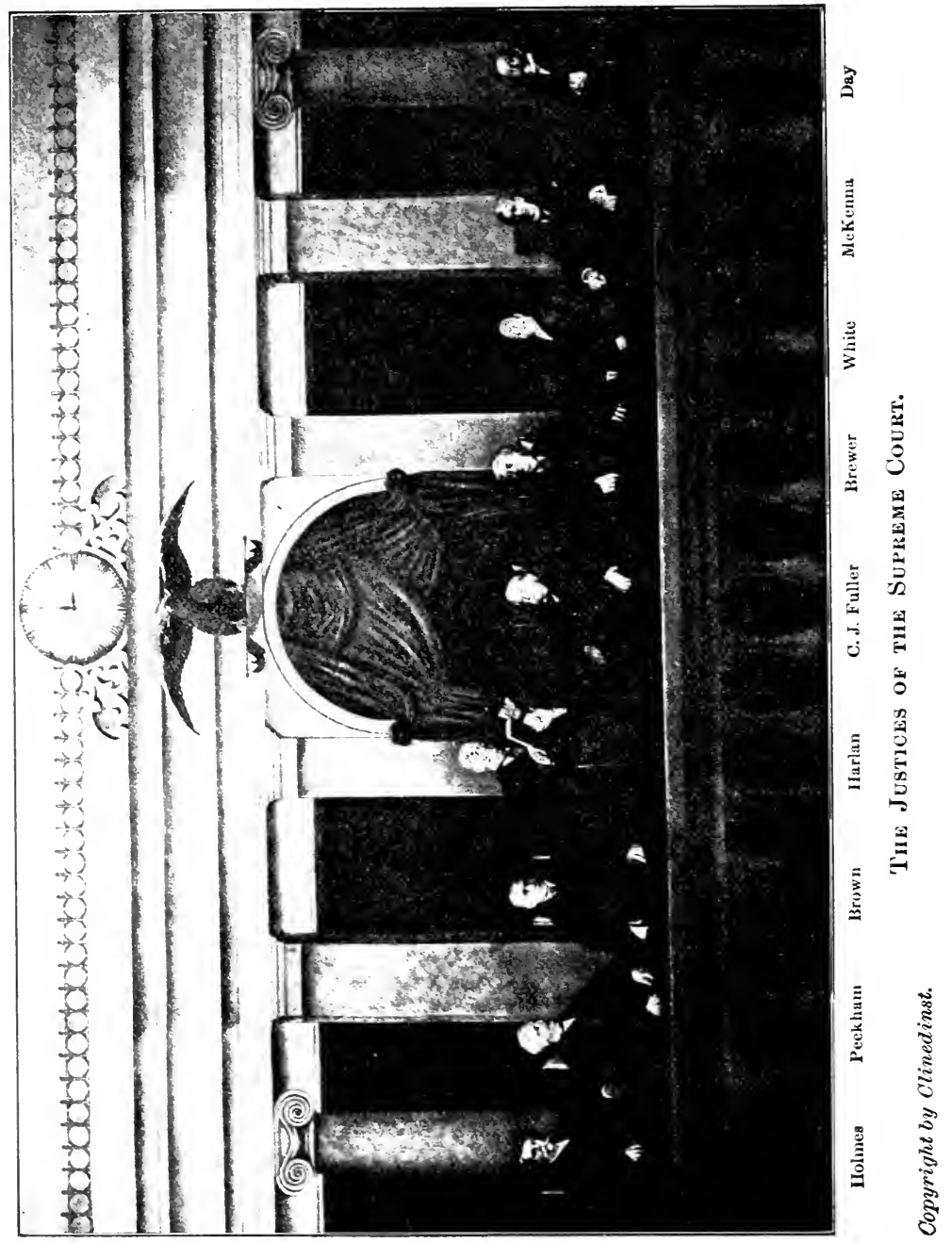


decided overwhelmingly against it, evidently fearing absorption by the United States. President Taft was more fortunate in securing very liberal arbitration treaties with France and Great Britain ( $\$ 443)$.

That action of Taft's administration which has been most approved and will in future be of most importance was the appointrnent of national judges made by President Taft. For the first time in fifty years a majority of the justices of the Supreme Court were appointed by one president. More than forty per cent of the judges in the inferior national courts were also selected by Taft. The work of these judges will constitute the chief contribution of Taft to the history of this period. ${ }^{1}$

459. Reform Legislation. - Because of the great popular movement described above $(\$ 454-457)$ there was a great deal of reform legislation in state and nation during the Taft administration. In I 9 I 0 Congress established a postal savings bank system, and in r 912 a parcel post was authorized. The postal savings bank is used in a majority of the post offices, where depositors more than ten years of age can deposit from $\$_{1}$ to $\$ 500$. It reaches sections which before had no banks and brings into circulation money that had been hoarded. The parcel post gives opportunity to send good-sized packages at rates varying with weight and distance. It is hoped that the parcel post may facilitate the marketing of products, and, by eliminating middlemen, may reduce the high cost of living $\left(\$_{4} 65\right)$.

The period from 1908 to I 913 was one of progressive legislation for the protection of labor. The national government established (I9I3) a separate Department of Labor and two years earlier created a Children's Bureau. Child-labor laws, laws limiting the hours of labor for women, improved employer's liability laws, industrial and compensation laws, and minimum wage measures are among the humanitarian measures enacted by the states during that period.

1 The attitude of the courts on the anti-trust law is considered below $(\S 468)$. 
The Republican primary campaign.

Woodburn, J. A., in $A m$. Year Book, I 912, I-IO.

Dunn, A. W., in Rev. of Revs., 45 (I9I2), 427-433. Blythe, S. G., in $\mathrm{McCl}$ Clure, 39 (I9I2), 205-214.

The Republican convention. Woodburn, J. A., in $A m$. Year Book, I9I 2, IO-I4. Rev. of Revs., 46 (I9I4), I32I4I, I9I-I 95 . Davis, R. H., in Scribner's, 52 (I912), 259-273.

Democratic convention. Woodburn, J. A., in $A m$. Year Book, I 9 I 2, I4-2O. Outlook, Iо I (I9I2), 557-561.

The Progressive convention. Woodburn, J. A., in $A m$. Year Book, I $912,20-27$.
460. The Election of I9I2. - Reform movements and programs played a considerable part in the presidential election of I9I2. The election was opened by a spectacular primary campaign. Roosevelt had declared in 1904 that under no circumstances would he seek reëlection after that date. He was so disappointed with the conservative policies of the Taft administration that in I 9 I 2 he came out openly as a candidate against President Taft, who was seeking renomination. As several states provided by law for the election of delegates in the primaries, and, as several others actually chose their delegates in that way, a great deal of vigorous campaigning was done in order to win control of the Republican convention in Chicago.

Because Taft controlled the regular Republican machinery and the delegates from the southern states, he was able to control the Chicago convention by a small majority. Roosevelt protested in vain against the "steam-roller" methods which excluded his delegates, maintaining that the majority had been robbed. His followers remained silent while the convention renominated Taft and Sherman, and adopted a platform which was liberal in many respects but which was conservative in others.

The Democratic convention met in Baltimore, June 25. A struggle immediately began between the conservatives and the progressives, the latter winning through the unqualified support of William Jennings Bryan. The convention adopted a liberal platform with especial emphasis on a revenue tariff, an income tax, opposition to the trusts, and a single term for the President. Woodrow Wilson of New Jersey and Thomas R. Marshall of Indiana were nominated.

The Republican Roosevelt delegates called a convention in Chicago, August 5, and organized the Progressive party. The primary purpose of the new party was to destroy boss rule, but its platform was an extended summary of social, political, and economic reforms. Roosevelt gave the convention his " confession of faith," concluding with the words: "We stand at Armageddon and we battle for the Lord." 


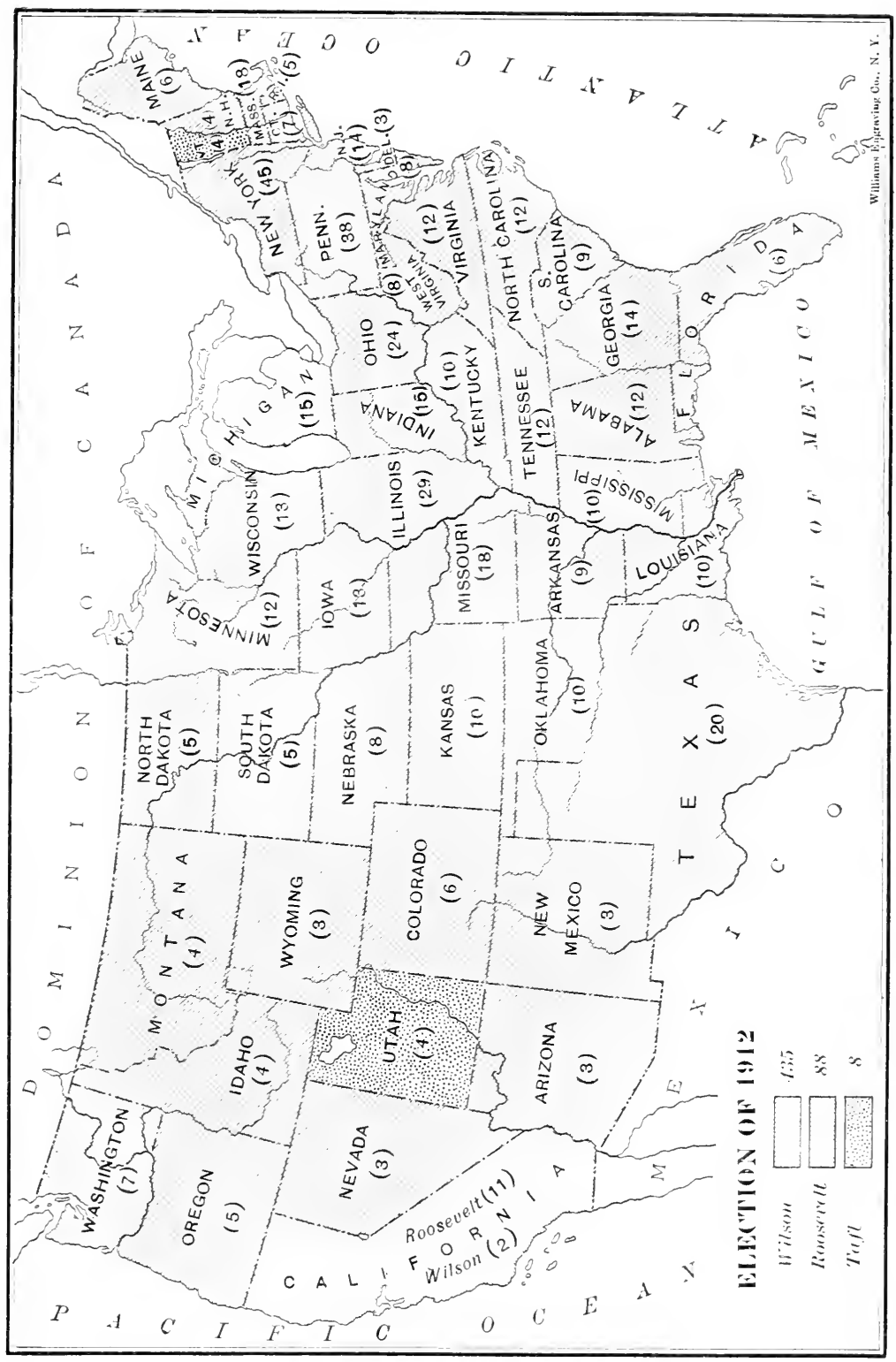


Abbott. E. H.. With Roosevelt was nominated Hiram WV. Johnson of Caliin Outlook. Ior

(IOT2).

$8_{5 i}-804$

Menkel, II: in $K_{e}$ is of Kiss.

40 (IOIZ).

jIO-BIT.

Result of the election.

Noodburn.

J. A., in $4 m$.

Fiar Book.

IOI 2, 27-47.

Iforld's If ork.

25 ( I OI 2 ).

$137-150$.

The Income

Tax

amendment. fornia.

The result of the election was predetermined by the split in the Republican party, the campaign being comparatively dull. ${ }^{1}$ When the rotes

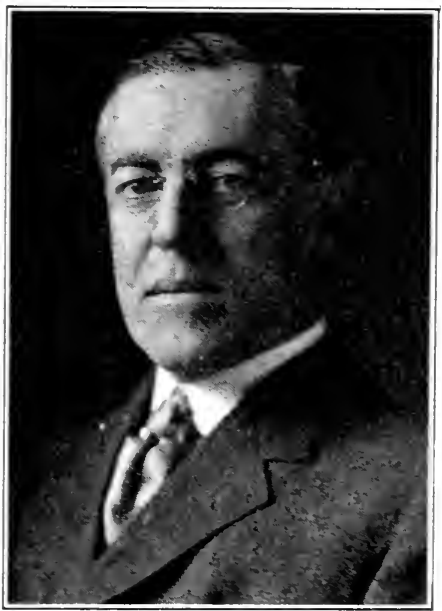

Copyright by Harris and Fwing.

MOONROW MILSW

were counted, it was found that Wilson had carried forty-one states, including three states that had been very progressive before iqi2. Roosevelt had a plurality in five states and Taft in two. Milson's popular rote was less than Bryan's in I oos, and a million and a quarter less than the combined rote of Roosevelt and Taft in Igr2. The socialist rote was nearly one million, being more than double the rote of that party in roos. showing that many people demanded a much more radical reform of social and economic abuses than either the Progressive party or the Democratic party was likely to give."

46I. Constitutional Changes. - Twice in the year IgI 3 was the Constitution of the Lnited States amended in order

${ }^{1}$ In Milwaukee. October If a fanatic attempted to assassinate Roosevelt. Roosevelt's courage in addressing an audience immediately afterwards, although sererely wounded. aroused nation-wide sympathy and enthusiasm.

"The socialist party platform in $10 \mathrm{r}$ a declared that "society is divided into warring groups and classes, based upon material interest." It demanded that the rule of the capitalist class shall be replaced by that of the workers. It asked for collective ownership of railways and other means of social communication. of banks and of land held for speculation or exploitation. It demanded relief for the unemployed. the better conservation of human resources and direct government by the people in the national as well as the state and local governments. 
to make it correspond more nearly with the wishes of the people. These were the first changes in our witten fundamental law in more than forty years. The sixtecnth amendment provides for an income tax, so that such a tax may be levied without being declared unconstitutional as was the tax of IS94 $(\$+8)$. An income tax was levied in I9I3 $($ to 4 ).

The serenteenth amendment was the result of an even more determined demand of the people. Several times Houses of Representatives had passed resolutions in faror of the direct election of senators, but the senate always failed to concur. As some senators were considered too conservative for the popular taste, many states had followed the Oregon plan, which provided that the people might advise the legislature of their choice for senator, at the same time that the roters elected legislators who agreed to abide by the people's wish. The result of the new amendment must be a decided change in the character of the Senate.

In the states constitutional amendments have been as common as the national amendments were rare. Among notable changes in the fundamental law of the states in recent years has been the admission of women to rote in five new states, making nine states in all (1913), the adoption of provisions for direct primaries, the initiative and referendum, those that provide for better taxation and control of corporations, and those which take hetter care of men, women, and children who work with their hands.

\section{The Beginning of the Wilson Administration. -} The election of Woodrow Wilson to the presidency brought to the chief magistracy a distinguished scholar and student of public affairs. Wilson showed from the first that he intended to be the leader of the party and the head of the administration. He broke precedent after precedent. For

Constitutional amendments in the states.

Direct election of senators.

Jones, Readings on Parties and Elcotions, I $25^{-1}+0$. $325-327$. Brooks. S., in No. Am. Rer', 107 (1013), $5+2-555$. the states.

Character and policies of Wilson.

McAdoo, IV. G., in Century. $\mathrm{S}_{5}$ (I913), $7+4-753$.

1 Distinguished as author, teacher, and college president, Wilson had served as governor of New Jersey, giving to that state a clean and progressive administration. He selected Bryan as his Secretary of State, and filled his cabinet with progressives. 
Hale, W. B., in I'orld's Work, 26 (I9I3), 69-77. Low, A. M., in Living Age, 278 (I913), I $7-22$.

Wilson, his party, and business policies.

Harvey, G. B. $\mathrm{McC}$., in $\mathrm{No}$. Am. Rev., 198 (I9I3), 577-608.

The maximum and minimum tariff (I 909).

Dewey, Finan. Hist. of $U$. S., $48.3-487$.

Taussig, F. IV., in Quar. Jour. Econ., 24 (I909), II -38 . example, he read his first message as Washington and John Adams had done. He has not hesitated to go to the Capitol nor does he hesitate to advise congressmen freely. He refused to be bothered with office-seekers. He abandoned "dollar-diplomacy," 1 in connection with the China loan $(\$ 446$, note) and Latin-American affairs. In relation to Mexico he followed a waiting policy more censorious but not radically different from that of President Taft.

The first year of the Wilson administration saw the enactment of a comparatively low tariff and an important banking act. Against trusts and other combinations of capital, the administration enforced the Sherman anti-trust law more thoroughly than previous presidents had done. Combinations that controlled prices and interlocking directorates $(\$ 465)$ were especially the objects of law enforcement, but the attempt was made also to control the capitalization of great companies as well. Although the Democratic party had been noted for its factions from 1896 to 1913 , President Wilson united the party and succeeded during his first year in carrying through a comprehensive program of reforms, designed to benefit the "common people."

463. The Payne-Aldrich Tariff. - From I897 to 1909 there had been no real changes in the tariff. In I 909 a special session of Congress passed a protective tariff, the PayneAldrich, and in I9I3 another special session passed a revenue tariff. Demand for tariff reform before I 909 had come from those who wished lower prices, from those who believed that our tariff schedules were antiquated because of the great industrial changes of recent years, and from those who were opposed to protection. The Payne-Aldrich tariff in 1909 provided for a larger free list, reductions on some trust-made articles, and a rearrangement of schedules which left the rates nearly as high as before, the general principles

${ }^{1}$ Dollar diplomacy was the name given to the method, used especially by Secretary Knox in the Taft administration, to promote commerce through the diplomatic service and to let the extension of business, especially in Latin America, aid diplomacy in return. 


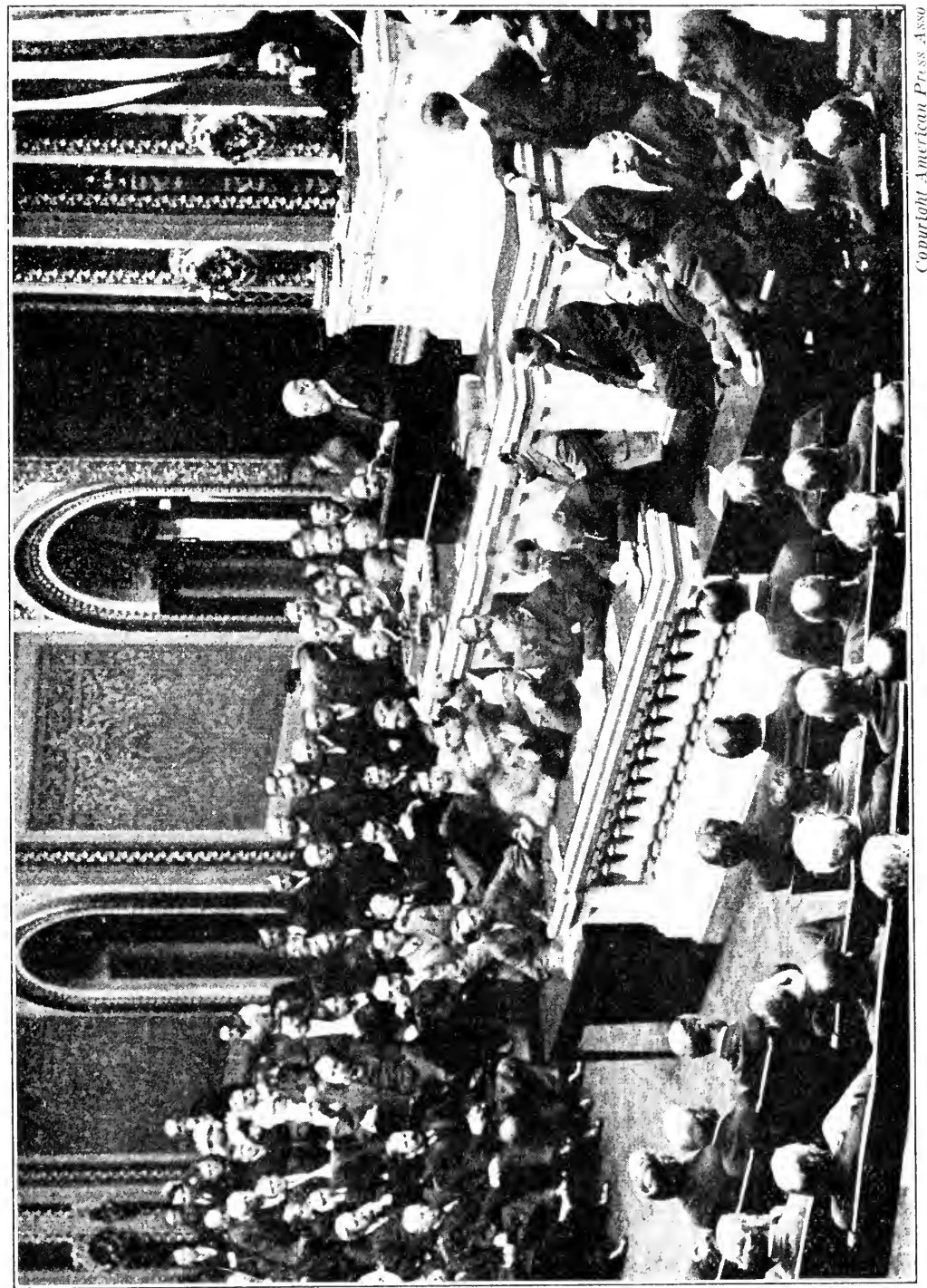


of the Dingley tariff $(409)$ and the Payne-Aldrich tariff being the same. The law provided for what is called a double tariff. ${ }^{1}$ It also provided for a special board of appraisers and a Custom Court of Appeal, before whom disputes about rates were settled finally, and a temporary tariff board. ${ }^{2}$

The corporation tax.

Conant, C. A., in No. Am.

Rev., I90

(I 909), 231-240.

Proposed tariff bills (I9I II9I3).

Rev. of Revs., H+ (I9II), 259-264. Am. Feur Book, I9I I, $48-52$.

The Underwood tariff (I9I3).

Wickware, T. G., in $A m$. Year Book, I $9 I_{4}, 2 \mathrm{~S}-3 \mathrm{~S}$.
After suggesting an inheritance tax and an income tax as supplementary to the tariff, Congress agreed (I gog) on a corporation tax of one per cent on the net revenue of all corporations, every corporation being exempted from payment on the first $S_{5} 000$ of its revenue.

464. Democratic Tariff Measures. - The election of a Democratic House of Representatives in I gro gave that party a chance (IgII) to propose bills for reducing the tariff. With the aid of progressive Republicans in the Senate a wool bill and a cotton bill were passed in Congress, both of which reduced the existing rates. President Taft vetoed both bills, and they were not passed over his veto. In I9I3 a special session of Congress was called by President Wilson to enact a revenue tariff and other financial measures. The House was overwhelmingly Democratic and that party had a slight majority in the Senate. The Underwood tariff was passed at this session.

The Underwood tariff provides for a substantial reduction on all protective rates. It enlarges the free list by including free wool, and after three years, free sugar. It retains high rates and in some cases increases the rates

${ }_{1}^{1}$ The regular rates formed what was called the minimum list, the minimum rates being granted to all countries which made the United States substantial trade concessions. If there were any others, they were obliged to pay the maximum rates, which were obtained by adding to the minimum rate twenty-five per cent of the cost of the imported articles.

2 The tariff board was created for the purpose of studying the cost of producing similar commodities at home and abroad. Having ascertained these differences, it was expected that the tariff rates would be changed so that the American manufacturers would be protected by rates just high enough to make the foreign costs equal to the costs at home. The board's reports show such varying costs in America and abroad that no conclusion could be drawn, except this, perhaps, that American manufacturers with old equipment and poor organization had been able to continue as producers because of the protective rates. 
on luxuries, reducing the rates on those articles that are used most commonly by the public. Although it does not abandon the principle of protection, it will seriously cripple, if it does not destroy, those factories or industries which have depended entirely upon protection in order to compete with foreign producers. Theoretically it is a consumers' tariff, just as practically all of the tariffs since the Civil IVar have been producers' tariffs.

In order to secure sufficient revenue for the national government without adding further to the taxes already paid by consumers, Congress in I9I 3 passed an income tax measure which provides rates from I to 7 per cent. The first $\$ 3000$ of every income is exempt, ${ }^{1}$ thus freeing from the tax nine tenths of the heads of families. This has been attacked as class legislation. To any one who has observed that the national government has been supported in the past chiefly by those whose incomes have been small, this law seems fairer than any other national tax that we have.

465. Other Financial Reform Measures. - The trusts and the railways have been blamed for part of the increased cost of living in recent years, and the public has tried to protect itself by laws that will restrict or regulate business. The tariff also was held responsible on the ground that it has fostered industry, - that is, the producer at the expense of the consumer, - and therefore made monopoly possible. Finally complaint has been made that all capitalists stand together and amass wealth at the expense of the public. Prices have been going up ever since 1895 . This is due chiefly without doubt to the increased production of gold, ${ }^{2}$

1 Married men are exempt to the amount of $\$ 4000$.

Income $\operatorname{tax}$ (I9I3).

The high cost of living.

Fisher, I., in No. Am. Rev., I 96 (I9 I 2), $740-758$.

Streightoff, Standard of Living, $44^{-68}$. Annals Am. Acad., July, I9I 3.

2 The amount of gold produced each year after igro was more than double the annual output of gold from i 890 to 1895 . As the purchasing value of gold depends largely on the amount in existence, prices go up as the amount increases. Wages, of course, do the same in time, but changes in wages occur slowly. The high cost of living is not simply the result of high prices; for, if wages increase at the same rate as prices, a man's income will go as far with high prices as with low prices. It has been said very truly that a fair part of the high cost of living is the cost of high living. At least it is due in part to an improvement in the standard of living. 
to the expansions of our system of credit, ${ }^{1}$ and to the improvements in the standard of living; but it is due in part also to the special opportunity which the protected industries have had of raising prices.

Money trust investigation.

Litcrary Digest, 46 (I9I3), I63I66, 261-263.

The national banking act of I9I 3 .

Wickware, T. G., in $A m$. Year Book, I914, 38-53.
Among the numerous investigations of combination of capital that were supposed to be responsible for high prices and business monopoly was that of the head "trust" of all, the so-called "money trust." The investigation did not show the existence of any organization, but it showed that i 80 men, each of whom held positions on a great many directorates (interlocking directorates), had great influence over corporations with resources amounting to about $\$ 25,000,000,000$. Many of these corporations were engaged in banking.

Fear that great capitalists would control still more the banking of the country and its business interests delayed the adoption of necessary banking reforms until i9r3. In that year Congress amended the national banking act $(\$ 342)$. The new act provides for a better concentration of banking reserves, a more elastic currency, and a better system of bank credit. National banking in reserve centers is no longer to coöperate chiefly with the stock market, but with business, domestic and foreign. Loans to farmers are made easier, a general plan of agricultural credit being worked out later. The bank act provides for a national reserve board which supervises reserve banks. ${ }^{2}$ This is selected by the president. There are from eight to twelve " regional reserve banks " controlled by bankers of that region, which can issue emergency currency and therefore furnish extra money when crops are to be moved or a money stringency occurs. It is hoped that this new banking plan will give a needed flexibility to our national banking system, will help to prevent panics, and will keep organized capital from dominating business.

${ }^{1}$ See Fisher, I., in American Economic Reriew, 2 (I9I 2), 43I-558.

${ }^{2}$ It is composed of seven members, two of whom are the Secretary of the Treasury and the Controller of the Currency. 
466. Summary. - In the later years of the nineteenth General. century large railway and industrial corporations had great influence over our governments. The protest of society against business domination in politics was expressed in the Roosevelt policies in national affairs, and in the demand that the people should rule in city, state, and national governments. As a result of these two movements numerous changes occurred in the laws affecting labor, the currency, the tariff and others.

Roosevelt followed McKinley's policies at first, especially in foreign affairs, but urged more drastic action against the trusts and favored conservation. After his election in 1904 he came out more strongly for railway regulation, conservation, and the punishment of " malefactors of great wealth." Even the panic of 1907 did not shake the faith of the Roosevelt supporters, and in roos William H. Taft was elected as his successor to carry out his policies.

The same forces that were working to overthrow husiness domination of politics were working against corruption in The rule of the people. government and for popular control of all public affairs. In the House of Representatives, the insurgents overthrew ihe oligarchical sway of the Committee on Rules. In the states, especially in the West and South, were established the direct primary, the initiative, the referendum, and the recall by which the people were able to keep the politicians from managing politics against the wishes of the public.

At the beginning of the Taft administration (rgo9I913) many valuable coal, oil, and mineral lands were withdrawn from sale, no longer being offered at even low prices. Later postal savings banks and a parcel post system were established by Congress. 'The period was one of numerous changes in state laws for the benefit of labor. In the election of I9I2 there were sharp contests between the conservative and liberal factions of each of the old parties. The more conservative members controlled the Republican party, nominating Taft; the liberal wing organizing as the Progressive party and nominating Roosevelt. 'The Democrats

Movement toward economic reform 
elected Woodrow Wilson on a liberal platform. Immediately following the election two liberal measures were incorporated in the United States Constitution as the sixteenth amendment (income tax) and the seventeenth (direct election of senators). The Wilson administration was more liberal than was even expected. The conservative PayneAldrich tariff was replaced by lower protective tariff, a new banking act was passed to give greater elasticity to our currency and credit, and action was taken to break the control of "interlocking directorates" over business.

\section{TOPICS}

i. Conservation: Ashley, "Am. Federal State" (rev. ed.), ch. XXIX; Coman, "Industrial History of the U. S." (rev. ed.), pp. 375413; National Conservation Commission, "Summary of Report"; Annals of the Amer. Academy, 33 (1909), 3-226; Van Hise, "Conservation of Natural Resources."

2. Corruption and Reforir, Municipal: Bliss (ed.), "New Encyclopedia of Social Reform,” pp. 318-327; Larned (ed.), “History of Ready Ref.," VII, pp. $43^{\mathrm{I}-4+2}$; Beard, "American City Gov't," pp. 192-217; Flint, "The World of Graft," pp. 9-SS; Myers, "History of Tammany Hall," pp. 252-350; Steffens, "Shame of the Cities."

3. Initiative and the Referendum: Munro (ed.), "The Initiative, Referendum, and Recall," pp. I 26-193; Wilcox, "Gor't by All the People," pp. гі-і66, 229-3іг; Annals Amer. Academy, +3 (1912), 3-31, 65-109, 203-215; Oberholtzer, "The Referendum in America" (rev. ed.), pp. ${ }_{73}-217,368-453$; Lowell, "Public Opinion and Popular Gor't," pp. I69-235, 368-398.

4. The Recall of Judges and Judicial Decisions: Roosevelt, in Outlook, I00 (1912), 61 S-626; ror, 855-857, 1004-1007; Wilcox, "Gov't by All the People," pp. 2II-22s; Cleveland, "Organized Democracy," pp. 426-437; Annals of Amer. Academy, 43 (I9I 2), 239-325; Acad. of Pol.Sc., Proceedings, January, r913, 76-гі6.

\section{STUDIES}

I. Roosevelt and civil service reform. (Shaw, W. B., in Revieit of Review's, 3I (1905), 317-324.)

2. Campaign funds and campaign scandals. (Carr, J. F., in Outlook, 8I (1905), 549-554.)

3. Conservation of Niagara Falls. (Spencer, J. W. W., in Popular Science Monthly, 73 (1908), 289-305.)

4. Mismanagement of insurance companies before igo6. (Larned (ed.), “History for Ready Reference," VII, pp. 326-329.) 
5. La Follette of Wisconsin. (Roe, G. E., in Independent, 64 (I908), $717-725$.

6. New York police force. (Roe, W. J., in Popular Science Monthly, So (I I 2 2), 46I-475.)

7. Publicity of campaign funds. (Jones, "Readings on Parties and Elections," pp. 302-321.)

8. Municipal research bureau. (Annals of Amer. Academy, $4 \mathrm{I}$ (1912), 235-278.)

9. Regulation of political campaigns. (Cleveland, "Organized Democracy," pp. 243-260.)

ı. The function of parties. (Lowell, "Public Opinion and Popular Gov't," Part II.)

11. Socialist party in election of rgi 2. (Hoxie, R. F., in Jol. Pol. Econ., 20 (I91 2), 205-223.)

12. The tariff board and tariffs. (Am. Economic Review, 2 (I gr 2), March Sup., i 9-4I.)

\section{QUESTIONS}

I. Place in your notebook a complete summary of the following topics, showing the sections of the text in which details may be obtained: Federalist party, old Republican party, Whig party, Democratic party, Republican party.

2. What were some of the favors received by the great corporations from our governments? Why did the trusts and the railways wish to control the governments? What was the danger of capitalistic control? By what means and to what extent has capitalistic control been averted?

3. Compare the policies and methods of Roose velt, Taft, and Wilson. To what extent did the personalities of these men enter into the work of their administrations? Show how they represent three types of party leadership.

4. Compare the foreign, anti-trust, and conservation policies of Roose velt. Which features of these policies were original with him ? Are his permanent contributions to American history connected with these original features or the other features?

5. Show the relation between the revolt against capitalistic domination and the revolt against boss rule.

6. In what ways may the people control their governments that were not generally in use twenty years ago? Show the advantages and disadvantages of each method of popular control.

7. Show how the movement for popular rule affected the state and national legislation of the period from 1909 to I9I 2.

8. Compare the tariffs of 1909 and 1913 with those of 1890 and I894. Does a return to the principles of the tariff of 1909 seem probable in 1917 ? 


\section{CHAPTER XXIII}

\section{PROGRESS AND PROBLEMS}

\section{Commerce AND Indestry}

Causes and results of industrial combination. Jenks, Trust Problem, 2 I-55. Taussig, Principles of Economics, II, $+19-+42$.

Haney, Bus. Organization cnd Combination, I28-ith.
467. Industrial Progress since I880. - During the last third of a century the industrial adrance of the United States has been very rapid. The capital invested in manufacturing and the value of manufactured products have increased fourfold. This derelopment has been accompanied by changes which we have already noted in part - the combination of companies engaged in the same line of industry, with a resulting loss of competition, and the combination also of employees engaged in similar occupations. The adrantages of production and exchange on a large scale are evident. Improved machinery and processes may be employed, finer products may be secured by deroting the energies of an entire plant to a special form of manufacture, and immense sums are sared by preventing the unaroidable wastes of separate plants. By controlling most of the output in its line, a trust need ship into a particular territory only the amount that can be sold easily. It can lower its prices in a district in which a rival is dangerous and drive its competitor from business. it can afford to develop new markets, domestic or foreign, which may be unprofitable at first, for the sake of the future. Whether these advantages from the industrial standpoint are sufficient compensation to the public for the loss of competition, which in the past has hept prices low, depends partly on the policy of the trust, partly on the attitude of our governments toward the trusts, and partly on the willingness or ability of the people to keep prices low.

The adrantages of combination were apparent long before the Spanish-American War, and many trusts were 
organized during that period, ${ }^{1}$ but the movement for industrial or commercial consolidation was far more conspicuous from r $S_{0} S$ to I 902 than at any earlier time..$^{2}$ Several hundred trusts were organized, many of them powerful enough to be considered monopolies. The largest of these was the United States Steel corporation, with capital stock of

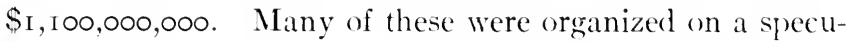
lative basis and either collapsed or suffered from over-capitalization within a short time. The railways of the United States adopted similar methods, and most of the mileage is controlled now by a few corporations. In fact some of the largest combinations control the mines or other sources of raw material which they use, manage their manufacturing plants, and own or control the railways by which the materials are hrought to their plants or their products are shipped to market.

468. Anti-Trust Legislation in the States. - Inder the present system of law in the United States these great companies do not receive charters from the national government, but are chartered in some state. and then do business in the other states under that charter. The other states, however, may limit the activities of the corporations within their own boundaries, and, in fact, may prohibit them from doing business in their state. The earliest form of state control, as we have observed already $(\$ 396)$, was in connection with railways. Most of the early granger legislation was

1 The earliest and still one of the most notable trusts is the Standard Oil Company, which, as early as is 88 , controller the output of over ninety-five per cent of the refined oil in the United States.

2 There have been in general four historical forms of combinations. (I) The earliest was the pool, in which earnings were pooled and then distributed among the members of the pool according to agreement. (2) The second was the trustee form, from which we get the word "trust." The stock of the companies in the combination was held by trustees who managed the affairs of the combination. (3) The third form was the holding company. One company was organized which owned the majority of the stock in the subsidiary companies. The Standard Oil Co. was a trust of this kind until igri. (4) The latest form of trust is the great corporation, the lesser companies being really absorbed by the single great company. The steel trust is the best example of this kind of corporation. 
Huebner, G. G., in Annals Am. Acad., 32 (1908), $138-$ 156.

Industrial antitrust laws.

Sayers, J. D., in $\mathrm{No} . \mathrm{Am}$.

Rev., I69

(1899), $210-217$.

Clark, Control of Trusts, $7 \mathrm{I}-95$.

Outlook, so (1905), 42743I ; 9I (I909) $320-322$.

Stimson, Popular Law Making, I 73-189.

Provisions. The problem of national control.

MacDonald, Statutes, No. 120. repealed after a few years' experiment, but in almost all of the states, railway commissions are maintained to supervise rates and the other business of railways. Most of these state commissions have the power to fix the maximum rates that shall be charged by the railways, a few still depend upon publicity, and some are public service commissions which supervise not only the steam railways, but electric railways, water and power plants, and other public utilities.

About 1890 the organization of a large number of trusts led to the enactment of numerous state anti-trust laws; and the so-called Sherman Anti-Trust Act which was passed by Congress. In many of the states monopolies were forbidden entirely: in other states the laws were intended to restrict the trusts from charging excessive rates or otherwise injuring the public. More perfect laws were passed later by many states, that of Texas being a good example of the severe anti-monopoly law. It has not been easy to enforce these laws against the great corporations, but some success has attended the efforts of the states west of the Mississippi. In 1904 Kansas engaged in a war on the Standard Oil Company by building a refinery of its own. Two years later Missouri forced the same company to admit that the lesser companies doing business in that state were nothing more than parts of the great monopoly. Texas as well as Missouri was rather successful in dealing with the Standard Oil monopoly before the Supreme Court of the United States declared that monopoly illegal. Both states levied heavy fines on the subsidiary companies of the Standard Oil Company.

469. The Sherman Anti-Trust Law of $1890 .{ }^{1}$ - In response to a popular demand, Congress in 1890 decided that "every contract, combination in the form of trust or otherwise, or conspiracy, in restraint of trade or commerce among the several states, or with foreign nations, is hereby

${ }^{1}$ In connection with this and succeeding sections the student should review $\$ \$ 394-397$. 
declared to be illegal." This act was intended to supplement the Interstate Commerce Act ( $\$ 397)$ which had been passed three years earlier. We should notice carefully that the only provision of the United States Constitution which deals with the power of the national government over commerce or industry within the United States is contained in the words, "Congress shall have power . . . to regulate commerce... among the several states." 1 When the Constitution was adopted in 1787 , even interstate commerce was not particularly important. The fact that for one hundred years there was no real attempt to regulate this commerce from Washington is sufficient evidence of the recent development of interstate trade. But the expansion of large corporations, which have plants in several states and do business in many others, presents a problem of commercial and industrial control which cannot be solved by the separate state governments. The interest of the public therefore must go unprotected or be secured by the national government. For this reason the interpretation placed upon the Sherman Act by the courts is of the first importance. If this act has been construed narrowly, the power of Congress over commerce will be very limited. If it has been construed liberally, the national government may not only control industry under it, but Congress may pass supplementary legislation extending its powers still further.

At first comparatively little attention was paid to the law either by the government or the corporations. It was invoked in I894 ( $\$ 474)$ to prevent labor organizations from interfering with the movement of trains engaged in interstate commerce. Later the Supreme Court broke up several illegal combinations. ${ }^{2}$ The most interesting case until recent years was that of the Northern Securities Company. This company was organized to hold the stock and manage the interests of several railways, the Northern Pacific, the

Application of the Sherman Act to 1904 . Ripley (ed.), Trusts, Pools, and Corporations, 263-272. Garner, J. W., in Annals Amer. Acad., 24 (I904), I 25-1 47 .

1 United States Constitution, Art. I, $\$ 8, \mathrm{Cl} .3$.

2 Trans-Missouri Freight Case (1897) and Joint Traffic Case (1898) especially. 
Great Northern, and the Burlington lines. The Supreme Court prevented the Securities Company from carrying out this plan by deciding (1904) that its acts would be in restraint of interstate trade. The court made clear its position that the restraint was not necessarily unreasonable in order to be illegal.

Bureau of corporations (I903).

Reinsch (ed.), Readings in Am. Fed. Govt., 529-538.

Curbing of corporation powers.

Larned (ed.), Ready Ref., VII, I I 7-I 27. Annals of $\mathrm{Am}$. Acad., 32 (1908), 3-94, $235^{-258 ; 42}$ (I9I2), 219269.

Wickersham, G. IV., in Century, $8_{3}$ (19I2), 616-622.
470. Recent Anti-Trust Activity. - In I903 Congress organized a new cabinet department known as the Department of Commerce and Labor, which was later (19i3) separated into a Department of Commerce and a Department of Labor. One of the bureaus created for the Department of Commerce was that of Corporations, the head of which was authorized to investigate " the organization, conduct, and management" of any company other than railways which was engaged in interstate commerce, reporting direct to the President. This bureau has issued valuable reports on combinations like the steel trust, the tobacco trust, and the monopoly of railway and steamship terminal sites. It may be made a powerful weapon for the supervision of great corporations, particularly if these corporations are compelled to take out national charters. It has been proposed that this bureau be superseded by an interstate trade commission.

Mạny suits have been instituted against the trusts by the national government. In general, the results obtained in the courts have been favorable to the government, although these suits have not interfered particularly with the business operations of the large corporations. The right of Congress to control the actions of trusts engaged in interstate commerce has been upheld by the courts fully. On the other hand, the right of a trust to defend itself by refusing to show its books or give evidence in court on the ground that it might incriminate itself has been denied corporations. The courts have held that private cars cannot be used by railways to injure the business of any person or section, and that a railway company cannot engage in any business like that of mining coal, in which it can haul its own coal cheaper than that of its competitors. Many of the important trusts 
have been compelled to abandon some of the most flagrant of the practices which they had used for controlling the market.

The position of the courts toward the trusts was made clear in the Standard Oil and Tobacco Trust cases (I9I I). The court held that they were monopolies and were breaking the Sherman anti-trust law which forbade interference with interstate trade, and they were ordered to dissolve. The court held that a "rule of reason" should be applied in order to determine whether any trust restrained interstate trade to such an extent that the government should interfere with the trust, or prohibit its business, if it were a monopoly. As it is impossible to return to the competition which existed before the trusts were formed, the attitude of the state and national governments toward big business will be one of the most interesting questions of the future, as it has been of the past. ${ }^{1}$

471. Railway Rate Regulation. - So closely connected are the industrial corporations and the railways that any action taken by the government in dealing with one almost always involves the other. This has been true in most of the investigations mentioned in the preceding section. Since the laws dealing with railways and with the powers of government over railways are concerned almost exclusively with "common carriers," we should note how the railways have been kept from injuring the public either alone or in coöperation with the trusts. The importance of the railways in the development of industry and in the maintenance of those healthful business conditions under which alone prosperity is possible cannot be overestimated. Since almost all of the trunk lines in the United States have come into the control of a limited number of persons, who

1 At this time Congress has under consideration several anti-trust measures. One prohibits interlocking directorates $\left(\$_{4} 65\right)$. Another proposes an interstate trade commission to look after industries that produce goods for interstate trade. A third seeks to define terms and powers of the Sherman anti-trust law. Others deal with irregular or undesirable practices in interstate trade and give the Interstate Commerce Commission control of the issues of stocks and bonds on interstate railways. 
are more interested in other business than that of transportation, the need of governmental control has increased.

Provisions of the present law.

Ripley (ed.), Railway Problems, 53I-556.

Smalley, H. S., in Annals Am. Acad., 29

(I907), 292-309.

Dixon, T. H., in Quar. Jour. Econ., 24

( I910), 539-633.

Great development of export trade.

Whelpley, J. D., Trade of the IVorld (last chapter).

Waldron, G. B., in Chautauquan,

3 I (I 900$)$, 499-504.
After years of agitation, ${ }^{1}$ both houses of Congress agreed (I9o6) on a new Interstate Commerce Act (amended I910), which replaced that of 1887 . The new commission, composed of seven members appointed by the President and Senate, has the power not only to declare rates " unreasonable," but to fix the maximum rate that shall be charged for the transportation of freight or passengers on interstate lines. It brings under the supervision of the commission all interstate " common carriers." 2 No railway may carry, except for its own use, articles of which it is the owner; nor, if a railway reduces rates to meet water competition, may it restore the old rates when the water competition has been removed.

472. Commerce and Shipping. - The industrial and commercial development of the period following the war with Spain naturally affected our foreign trade very much. The increase in our exports from I 896 to I9I 3 was almost 200 per cent, and the excess of exports over imports for each of these years was little less than five hundred million dollars. This great " balance of trade" in our favor was due principally to the great demand, particularly in Europe, for our agricultural products, such as cotton ${ }^{3}$ or breadstuffs for our meat products; and to the great exports of mineral products, especially refined petroleum, ${ }^{4}$ and iron, steel or copper

1 In I903 the Elkins anti-rebate law supplemented the Interstate Commerce Act of $\mathrm{r}_{88}$ by defining the character of the punishment that should be meted out to the railways which give rebates, and by making shippers liable to fine for accepting rebates. This act furnished the Interstate Commerce Commission a more effective means of preventing rebates.

2 This term is defined to include railways, private refrigerator cars, Pullman cars, express companies, and pipe lines (except for gas and water). In addition the Interstate Commerce Commission supervises interstate telephone and telegraph companies.

${ }^{3}$ Our exports of raw cotton for the year ending June 30 , I9I3, were $\$ 547,357$, I 95 ; of live stock or meat products, $\$ 139,271,542$; and of grain and flour, $\$ 184,214,756$.

${ }^{4}$ The figures for petroleum for 1913 were $\$ 137,237,762$; for iron, steel, and copper manufactures, $\$ 444,870,7$ Io. 


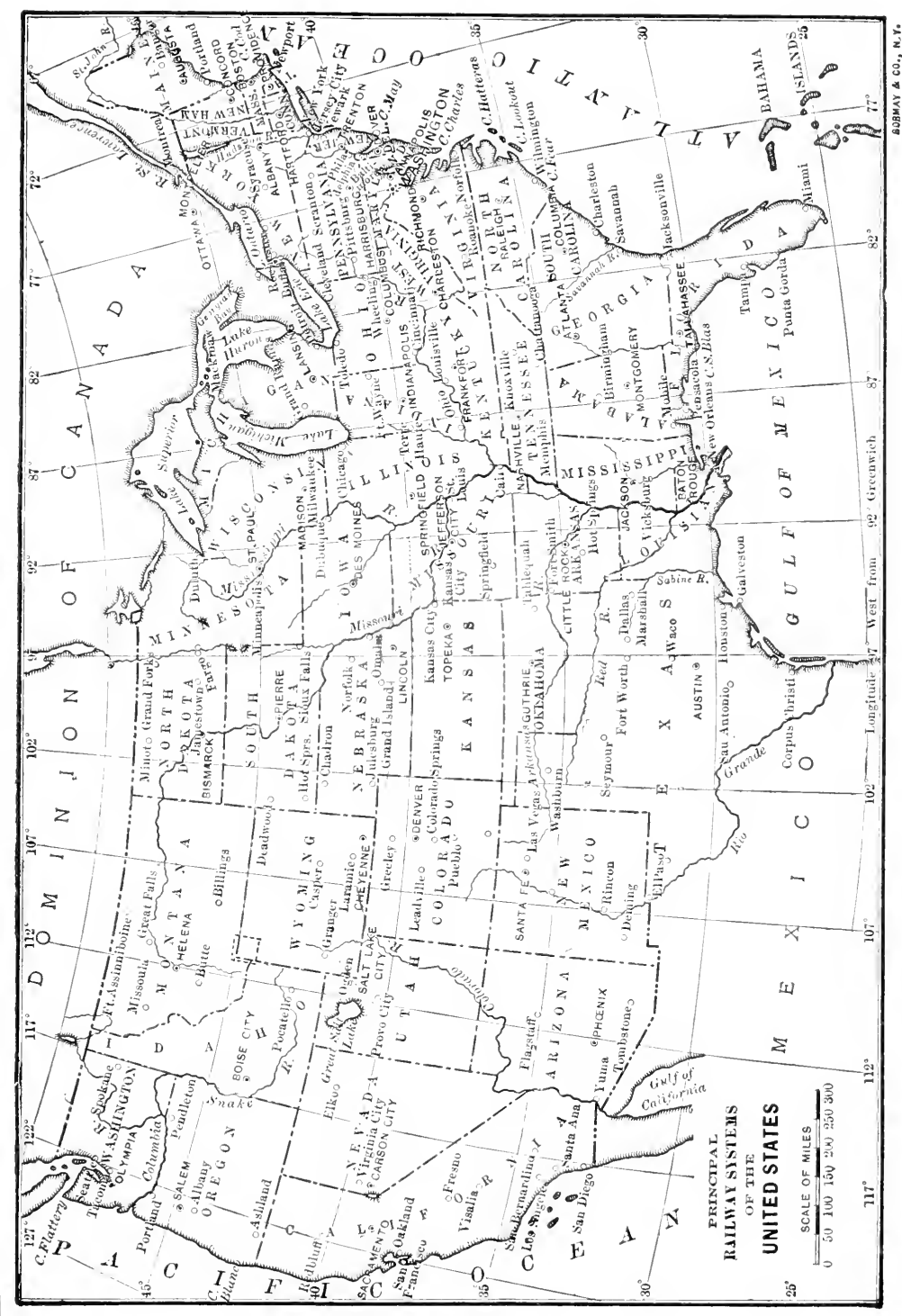




\section{$\cdots$}


manufactures. The United States has in fact become an Digby, W. P., exporter of manufactured articles rather than an exporter of raw materials. Our market for machinery has expanded perhaps as rapidly as that of any of our other exports. In many cases machines have been sold abroad for much less than the price in the United States, in order to open the way for later sales. American locomotives have competed successfully with those of foreign make in distant Russia and Japan, and America now leads all other countries in its exports of automobiles. The trade with Cuba and Porto Rico has grown rapidly, and that of the Pacific coast is increasing constantly, but we still enjoy but a small proportion of the exports to South American countries, the Philippines, and eastern Asia.

Although our favorable position commercially among the nations of the world is a matter of pride to us, the dependence of the United States upon other countries to carry our exports and imports is not pleasing. We have found other occupations more profitable than that of shipping, and, therefore, have neglected to build ships for foreign trade. On this account large sums are paid annually to foreign shippers. Our merchant marine has declined so that less than one tenth of our foreign trade is carried in American vessels and our flag is seen comparatively little in the ports of the world. ${ }^{1}$ To remedy this unfortunate though not serious state of affairs, to provide fleets of vessels that can be turned into transports or auxiliary cruisers at short notice in time of war, to build up again a large merchant marine, ship subsidies have been suggested. Several bills have been passed by one house of Congress during recent years, but have failed to receive the approval of the other house.

1 The tonnage of American vessels is greater than ever before, about six and a half million tons; but the tonnage of vessels engaged in foreign trade is less than one million tons. As our foreign shipping in 1856 represented two and one half million tons, the decline has caused very serious criticism.

in Engineering

Mag., 29

(I905), 32I$333,508-518$, $673-682$.

Root, F. D., in Independent,

73 (I9I 2), I $457-1460$; 76 (I9I3).

Annals Am. Acad., 37 (I9II), 50-59, 70-84.

Shipping and ship subsidies.

Review of

Reviews, 2I (I 900), 319-328.

Raymond, A., in Forum, 49 (I9I3), $447-456$.

Garner, J. W., in No. Am.

Rev., 180 (I905), 360-374. 


\section{BUSINESS AND LABOR}

Panic of 1873.

Coman, Industrial Hist., 286-289.

Burton, Crises, 286, 289 .

Larned (ed.), Ready Ref., V, 3574-3576.

Panic of 1893 .

Burton, Crises, 292-296.

Noyes, $A m$.

Finance,

I 82-196.

Lauck, Panic of $1893,97^{-}$ I 22.

473. Prosperity and Panics since 1865. - Since the Civil War there have been successive waves of business prosperity and depression. The excessive expansion of business during the years from ${ }_{1} 86_{5}$ to 1873 caused one of the worst panics in our history in 1873 . Speculation had been conspicuous in manufacturing, in railway extension, in purchase of public lands, and in commerce. Collapse followed the manipulation of the stock market. The failure of Jay Cooke of Philadelphia started the panic, which affected every line of industry. There was no sale of property, and prices fell everywhere. The gravity of the situation increased as the years passed, for the number of failures in I 877 and 1878 was much greater than in 1873 . In 1879 there was a return to normal business conditions, and times continued prosperous until I885. After a slight depression, business revived and continued very active until I 892 .

The immediate cause of the panic which occurred in I 893 was undoubtedly the fear among business men that the government might not be able to redeem its notes in gold (\$4IO). ${ }^{1}$ To this cause was added the doubt about possible changes in the tariff. The underlying cause was undoubtedly the abnormal inflation of values and the increase of speculation. The first serious failures occurred in May, I893. Banks, factories, and railways were affected. In many cases business houses were forced into bankruptcy simply because they were asked to pay their debts and could not collect from those who owed them money, their assets often being much greater than their liabilities. ${ }^{2}$ Factories

${ }^{1}$ If the government were obliged to use silver for this purpose, the business of the country would then be transacted on a silver basis. As the intrinsic value of the silver in a dollar was only about fifty cents, the loss to merchants who sold on time would be appalling.

2 The total indebtedness of those that failed during 1893 reached the enormous total of nearly $\$ 350,000,000$. Receivers were appointed for railway companies that owned more than twenty-five thousand miles of railroad. 
closed or reduced their output so that many hundreds of thousands were added to the ranks of the unemployed. ${ }^{1}$ This condition of affairs continued with comparatively little improvement for two years, and, as in the great panic twenty years earlier, normal conditions were not restored for four or five years, but, about the time of the war with Spain business became more active than at any preceding time.

The years from I 897 to I 913 were exceedingly prosperous except for a slight stock panic in 1903 , which was the result of too much "high finance" in the organization of trusts, and the panic of $1907(\$+53)$, which was far less disastrous than those of ${ }_{1} 873$ and 1893 . There was a worldwide depression in 1913 .

474. Labor Unions and Strikes (1877-1894). - Periods of marked industrial development or depression are usually accompanied by conflicts between caprital and labor. When times are exceptionally good, the workers believe they are not receiving a just share of the unusual profits. When hard times come, the employers feel that they cannot afford to pay as high wages as formerly. The hard times of the 70 's caused a reduction of wages which in time led in several cases to strikes. The greatest of these began on the Baltimore and Ohio Railway in July, 1877 . Railway strikes occurred at the same time on the Pennsylvania Railway and other lines. Pittsburg was the center of the rioting and disorder, and the molos in that city were dispersed only by the use of Gatling guns. A large amount of property was destroyed, order being restored finally when United States troops were ordered to Pittsburg.

After 1877 more interest was taken by the workers in the formation of labor organizations. Many joined the Knights of Labor, the largest of the unions, which in 1885 had a half million members. The American Federation of Labor was

Labor union movement.

Wright, Industrial Evolution, $273^{-282 .}$

1 The winter of $1893^{-1894}$ was very trying to the laboring classes. Hundreds of thousands had been thrown out of employment by the business depression, and the suffering of their families during the winter months was very great. 
Stimson, Lubo" in Relition to La.. I-IO.

The Pullman strike.

Andrews ( () (1). 5 Ting,

$\because: 2-7: 30$.

Wright. Indwisrid His.. SIS-SI Clevelund. Pres. Froficons. idetio

Intivisual barsining or ollective bargaining. Carlion.

() LAs , I I II organized in ISSI, and several other national labor organizations have been formed since. The principal objects of these bodies have been to raise wages and reduce the hours of labor. through coupperation. by strikes if necessary. More than one half of the strikes undertaken by the unions have been won by the workers, although they have lost many of the larger strikes. Among the prominent strikes after Is: were those occurring in Isso on the Gould railways in the southwest. the one in Chicago in connection with which the Haymarket riot ocurred. one at Homestead in Pennsylramia in 1 Soz. strikes in the mining regions of the West. and those considered in the following paragraphs.

In sout there ocured perhaps the greatest strike in the history of the Lnited states. A strike among the employees of the Pullman Car Company spread to all railways on which Pullman cars were used. For several weeks few trains were operated on the railways from Lake Erie to the Pacitic. Rioting occurred in Chicago and at other points, the lowal authorities in many cases being unable to preserve order or protect property. President Cleveland ordered Cnited States troops to Chicago to prevent interference with the carrying of the mals or with interstate commerce. Against this action Governor Altgeld of Illinois protested. as he maintained that the national government had no right to send troops unless he called for them. He was unable to see that the troops were enforcing simply national law. The strike collapsed eventually without gaining any concessions from the emplovers.

475. Recent Labor Problems. - In the period since ISot the organization of lator has not kept pace with the combinations of capital. The problem of protecting labor is therefore a serious one, since no single employee can make stccessful terms with a corporation which employs tens of thousands of laborers: and, naturally, the government cannot dictate who shall be employed or what wages shall be paid. Wages have, nevertheless, increased during the last 
two decales, as in previous decaldes, but they have gone up . Mams and less rapidly than prices have risen since 1 s'os. 'This means that laborers were able constantly to improve their standard of living before sosos and have been mable to improve it since that time. One of the problems of the future is so to reform unions as to make them more representative and to

summer, labor l'roblims, iol io5.

laussig, Principles of licollomics, II, 201 28., luclustrial

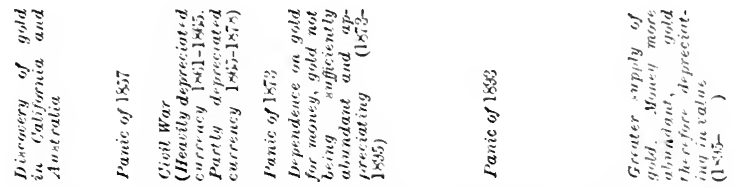
(ommission Riport, XIX, Sis $3-8.17$.

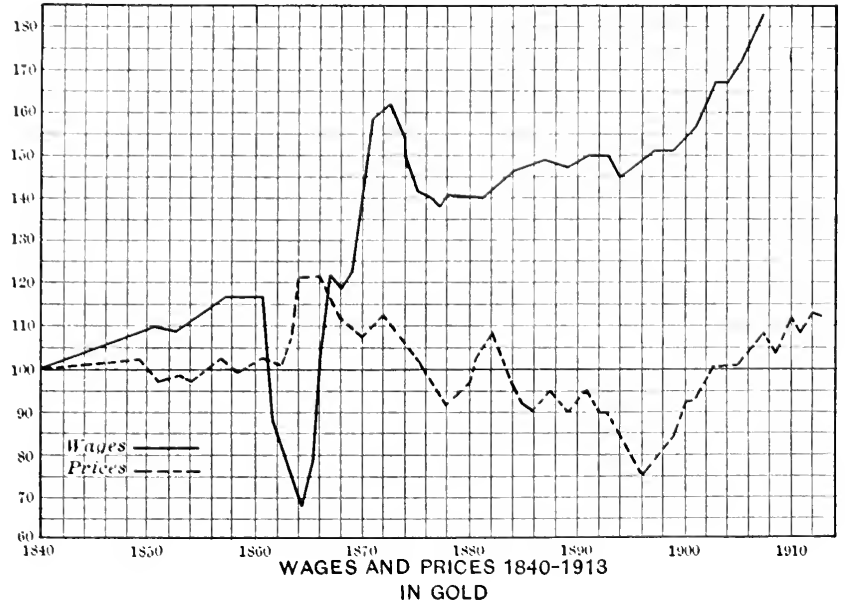

secure collective bargaining where labor must serve combinations of capital.

Labor has sought to protect itself chiefly by strikes, or by the threat of striking. The loss to the public where strikes involve a public utility, as a railway, or a public necessity, as coal, is so great that some other way should be devised. To have arbitration after month of dispute, as in the great anthracite coal strike of 1902, is unsatisfacArbitration and conciliation.

Carlton, Organizid Labor, $232-2+3$. tory. The trade agreement reached in the bituminous coal 
controversy of 1905 without a strike was a decided improvement. Where no public necessity is involved, strikes are less objectionable, but more peaceful methods are much preferable, and many of our states as well as the national government have sought to substitute conciliation or voluntary arbitration for industrial warfare.

Industrial

warfare.

Baker. K. S., in MiClure, 23 (I904), $+3-57$.

Carlton, Organized Labor, $s_{2}-s_{4}$.

Marshall, IVright, and Field, Materials for Study of Economics, 700-704.

Legislation during the last quarter of the nineteenth century:

Wright, Industrial Evolution, 273-2S2.

Stimson, Labor in Relation to Lai, I-IO.

Adams and Sumner, Labor Problems, +00-tio.

Since rooo several disputes between capital and labor have really resulted in warfare. In Colorado mine difficulties led to the banishment of strikers, to the use of troops on the one side and dynamite on the other. Dynamite has also been used as a means of intimidation when there was no strike, as in a series of dynamitings of iron structures culminating in the destruction of the plant of the Los Angeles Times, an ardent enemy of the unions. The I. II. W. (Industrial Workers of the World), who distrust the labor unions, believe thoroughly in the use of warfare as a means of securing the rights of labor from capital. Nevertheless, the vast majority of the workers and a still larger percentage of the general public prefer more peaceful means of settling labor problems.

476. Labor Legislation. - In a republic which has universal manhood suffrage, it is strange that the demands of labor for legislative protection hare been less strenuous and have been granted more tardily than in either semi-republican England or monarchical Germany. During the period of formation of great national labor unions thirty years ago, the unions persuaded Congress to exclude not only the Chinese ${ }^{1}$ but all laborers who were under contract to work in the United States. Comparatively few of the other demands of the unions were granted at that time. However, factory laws were passed in many states, and most of the in-

${ }^{1}$ Agitation against Chinese coolie immigration started soon after IS;O in California, where a large number had come under the Burlingame treaty, which encouraged trade and migration between the two countries. In ISS: a law forbidding the immigration of Chinese laborers was passed by Congress and was supplemented by later laws and by treaties. These laws have been enforced harshly, so that there are fewer Chinese in the L'nited States to-day than there were a quarter of a century ago. 
dustrial states had labor bureaus that investigated industrial questions, but had little power to act.

Within recent years changes have been rapid. Laws for the protection of women and children have been passed in a majority of the states. A large number of states have protected employees better by requiring more sanitary conditions for workers or by prohibiting the use of dangerous materials, as phosphorus, in the making of matches, or of unprotected machinery. In case of accident, injured employees can now secure either damages or compensation in a majority of the states, ${ }^{1}$ whereas, ten years ago an injured workman bore the entire cost of accidents. The twentieth century has been called the century of the child. It has also been called the woman's century. It is likely to be the century of the proletariat. The legislation of the present may be conservative compared with that which probably will come.

\section{Political and Social Chaxges 2}

477. Population and Race Problems. - It the present time the continental United States has nearly one hundred million inhabitanss. Our dependencies add another ten millions to this number. This is an increase of twenty-five fold since the adoption of the Constitution. When Washington was inaugurated, even Ireland had more people than

IIn some cases the injured workman is allowed to sue his employer for damages and the employer is no longer allowed to escape payment unless the employee was to hlame. In other cases the states provide a scale of compensation for death, or for different degrees of injury, the compensation being paid chiefly by the employer, but presumably by the public, which must pay more for the commodities which the employers produce.

2 An important social problem is that connected with marriage and livorce. The increase of divorce has been one of the most conspicuous social changes of the last quarter century. A phase of the marriage question that has entered into our history is represented by the plural marriages of Mormonism. Mormonism was founded by Joseph smith nearly a century ago. Having been driven from Illinois and Missouri, the Mormons settled in Ltah in s 8.76 . Although there was a national law against polygamy in the territories after I $\$ 62$, no persons were punished until a new law was passed in I \$\$2. Later ( $18_{7}$ ) the Mormon Church was dissolved, although it was restored as soon as the leaders agreed that all Mormons would obey the law, 
the entire United States. To-day only Russia has a larger white population. Of this great number, only a little more than half are native-born whites whose parents were natives of the United States. More than one fifth are the children of European immigrants, and more than one seventh were born in Europe. About one in ten is a negro, and a few are Asiatics.

The negro problem.

Washington, B. T., in

Independent, 74 (1913), 695-697.

Commons,

Races and

Immigrants in America, 22-62. Annals Am. Acad., 49 (1913), 47-66.

Foreign Immigration.

Carlton, Hist. and Problems of Organized Labor, 322352.

Adams and Sumner, Labor Problems, 6875, I07-III.
This mixture of races is no new thing in American history. The percentage of colonials of the English race was hardly higher in $175^{\circ}$ than that of native-born Americans of native parentage at present, while there were proportionally twice as many negroes a century and a half ago. Yet the race problems of the present are very much more complicated than those of the past. The negro is no longer a subject and a slave, but he is a citizen, with legal rights and the power of the rote except in a few states. ${ }^{1}$ The economic problems of the negro and the question of his education, his social status, and his future place in our great country are problems of the first magnitude.

478. Foreign Immigration. - Hardly less important are the problems of assimilating the great numbers of immigrants from southern and eastern Europe that are pouring into our cities. These people are of different races, ideals, and capacities from those Teutonic and Celtic races that founded and developed this republic. As their standard of living is lower than ours, and as they are inexperienced in political affairs, we may be compelled either to restrict further immigration of this character or to change radically our standard of living; we may be forced to abandon many of our older

1 In the South, the whites have struggled with the problem of how to disfranchise the negroes without violating the fifteenth amendment of the United States Constitution. Mississippi was the first state to pass a law with this in view, when in I $\$ 90$ she prescribed an educational test for voters which disfranchised many more blacks than whites. South Carolina does not deprive those intellectually unfit if they own property assessed at $\$ 300$. Virginia, North Carolina, Alabama, and Louisiana have special qualifications but exempt those who voted or whose ancestors were voters or soldiers before I\$67. The operation of these "grandfather clauses" is the practical disfranchisement of the negroes without debarring the whites from voting. 


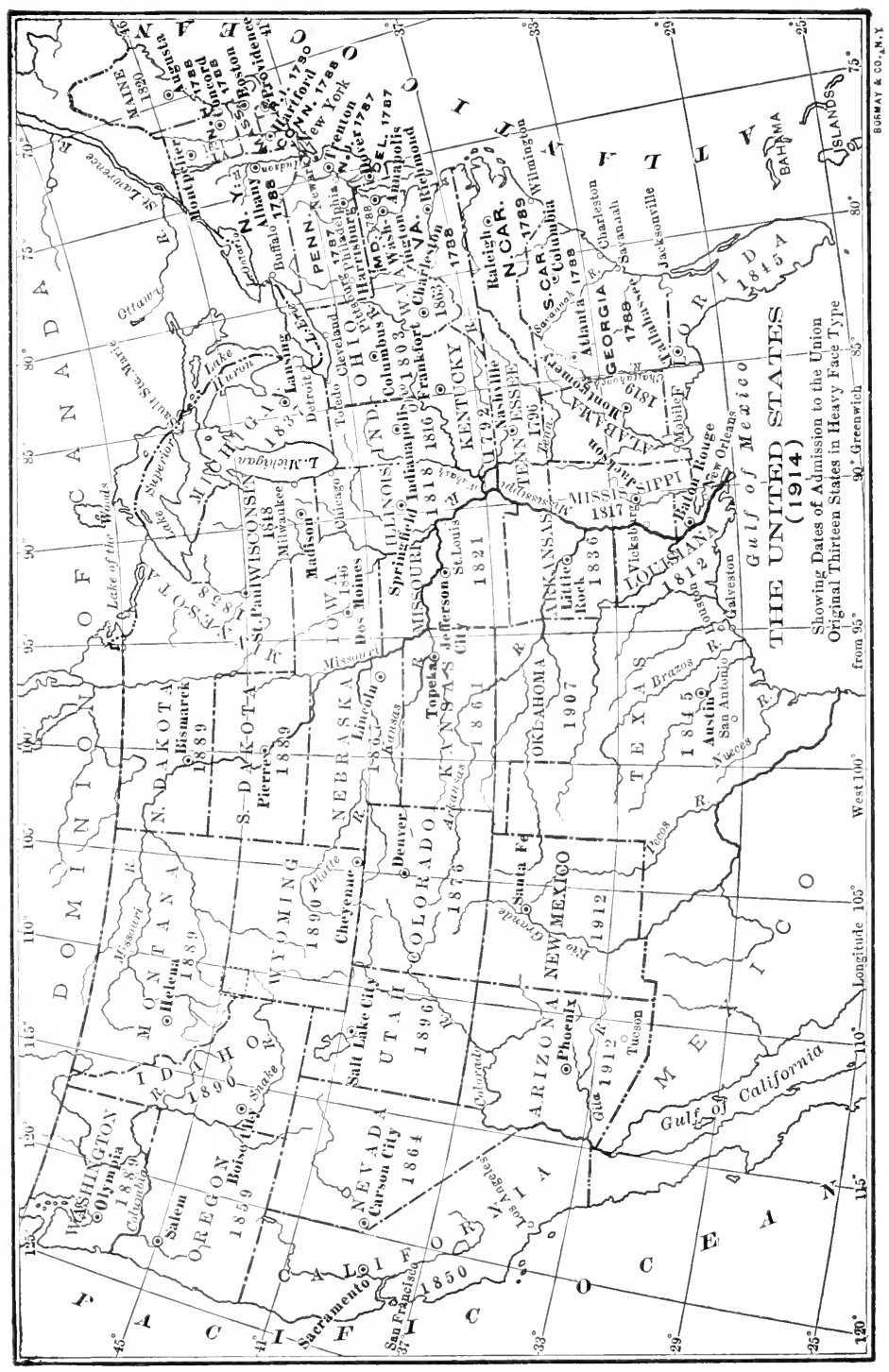




$$
-
$$


political methods and our new devices which give more power to the people. ${ }^{1}$

Thirty years ago the majority of the foreigners who came to America were Germans or Irish, people with ideas and customs which differed somewhat from our own, but capable of assimilation with the native stock. Since r 890 a much larger percentage of Italians, Hungarians, and Russians have come to America. Instead of settling, as most of their predecessors did a half century ago, on small farms (s. 296), they have congregated in cities, forming race clusters which retain their old language and customs and often threaten the unity of our national life. A large proportion of these people from eastern and southern

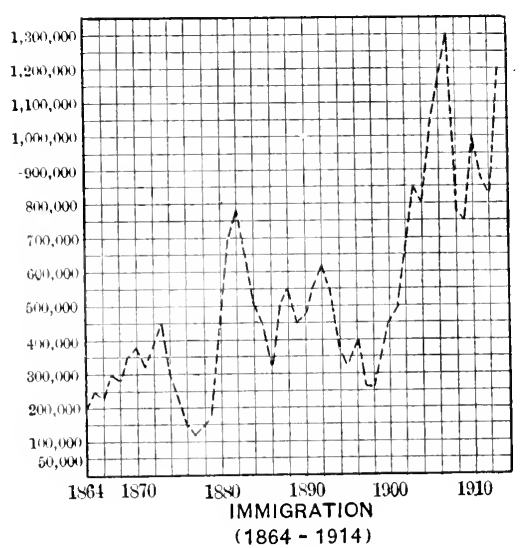

Europe are illiterate
Extent and character of recent immigration.

Hall, Immigration, 36-66.

Commons, Races and Immigrants, 63-106.

Fairchild, Immigration, I 23-I 43 . and incapable of performing a high grade of work. Their children are usually anxious to learn, so that they frequently adopt American ways and show pride in their American citizenship.

The immigration laws of the past have debarred from

1 A problem which involves a much smaller number of people, but which may be quite as serious in the future, is that of the Chinese, who will not be abused in the future as they have been in the past ( $\$ 476$, note 1$)$, and that of the Japanese $(\$+17)$. As these people belong to a radically different race from that of Americans, and have standards of living very much lower than ours, their admission to the United States in large numbers will cause social and economic crises of great magnitute. Absolute prohibition of immigration of Chinese and Japanese laborers may seem unfair and contrary to the spirit of American institutions; but it certainly is the simplest solution of a great problem, and perhaps the only solution that it is wise for America to attempt. 


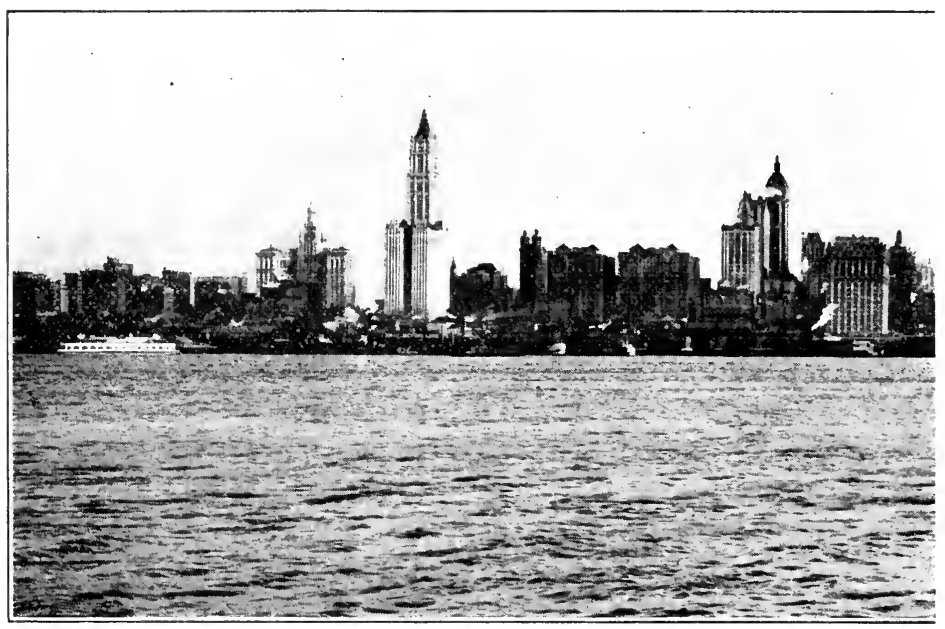

LOWER NEW YORK

Immigration laws.

Marshall, Wright, and Field, Materials for Study of Economics, I $52-150$.

Fairchild, Immigration, I OO-I 22.

Extent of urban development. Beard, $A m$. City Gor't, 3-6. the United States Chinamen, paupers, insane people, people with certain contagious diseases, and persons under contract to labor. In order to restrict the immigration from southern and eastern Europe a literacy test has been considered carefully in Congress. Many people believe that a literacy test is al poor test, and that we should have either a better physical test, since we need liborers, or a character test.

479. Growth of Cities. - One of the most significant changes of our history has been the growth of our cities. At the beginning of the Civil War only one sixth of the people of the United States dwelt in cities, the largest city being New York, which boasted 805,657 in- 


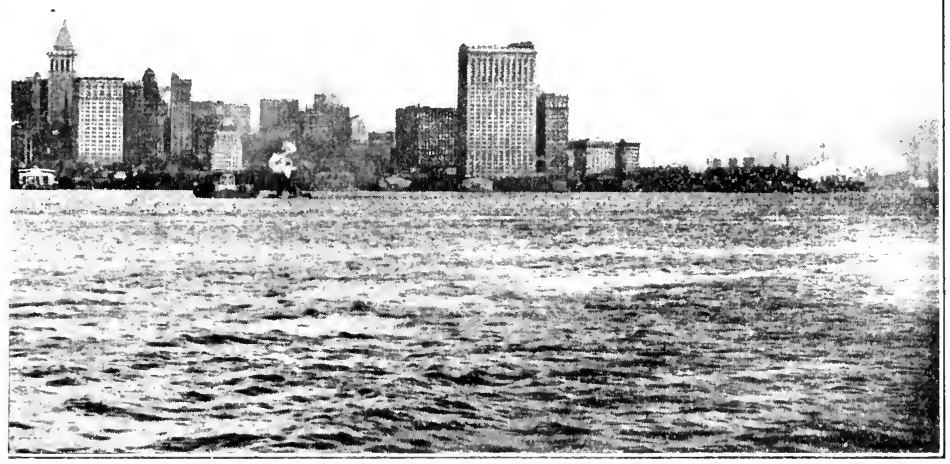

SKV-LINE, 1914

habitants. Only eight other cities contained too,ooo people Marshall, each. At the present time nearly 50 per cent of our population is urban. Greater New York, with more than 5,000,000, is second only to London in numbers, and forty-nine other Wright, and Field, 1I aterials for Study cities had reached the 100,000 mark in 1910. Chicago, 134-136. which in I 860 was a straggling western town of barely

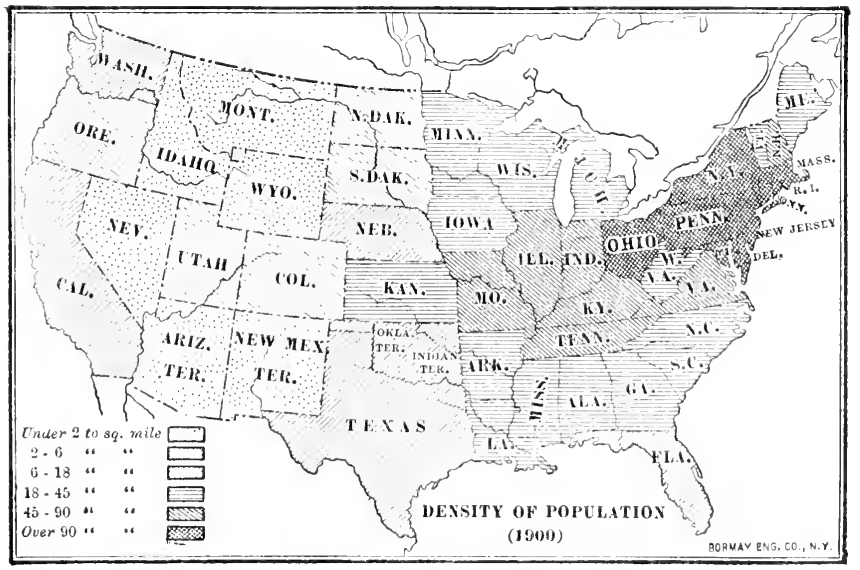


Commons, Races and Immigrants, I60-I 68 .

Changes in standards of living.

100,000 , is now the great commercial center of the interior, with more than $2,500,000$. The concentration

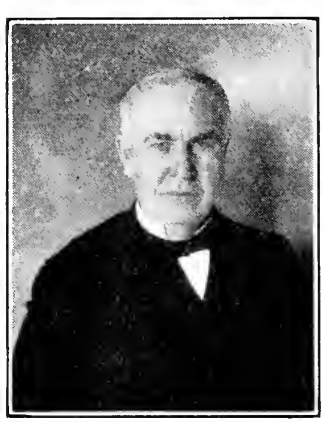

ThOMAS A. EDISON of population is more marked in the northeastern states than elsewhere, nearly two thirds of those in that section living in cities of more than 8000 inhabitants. Even the Pacific coast has developed fairly large cities, seven having attained 100,000 in I9I4.

The movement from country to city is due principally to the social and business advantages which cities The Nineteenth offer. It indicates the growing tendency of the nation Century, $417-430$.

Munro, Gov't of Am. Cities, $29-52$.

to obtain wealth, and to use that wealth extravagantly in the satisfaction of social desires. The simple standards of a half century ago no longer satisfy. Every one lives on a grander scale. The luxuries of yesterday become the necessaries of to-day. With the cheapening of articles manufactured by improved machinery, material

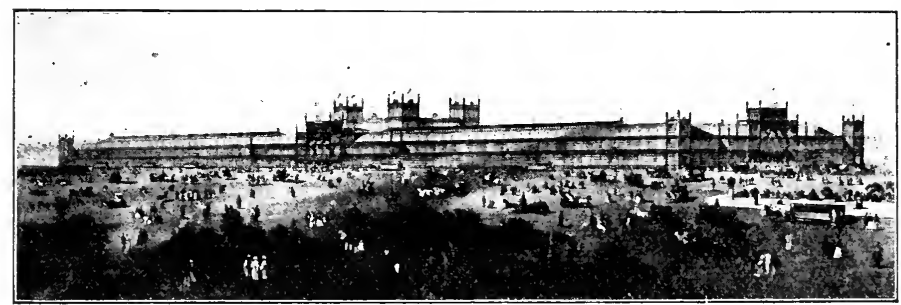

Main Building, Centennial Exposition, 1876

comforts are brought within the reach of all. Telephones are found in a large proportion of city homes and in many well-settled rural districts. Electric lights reach the Beard, $A m$. City Gov't, majority of the people in the United States. Electric railways penetrate in every direction the territory adjacent to our cities and towns. Truly the last century has been an 
era of material advancement unequaled before in the history of the world. ${ }^{1}$

480. City Problems. - This rapid development has The slum not been unaccompanied by dangers. The segregation of problem. people gives opportunities for crime unknown in rural dis- Riis, Battle tricts. The problem of preserving order is one of the most with Slum, serious confronting our city governments. The large proportion of foreigners in cities is often a menace to civil I- 35 .

Riis, Ten Years' War,

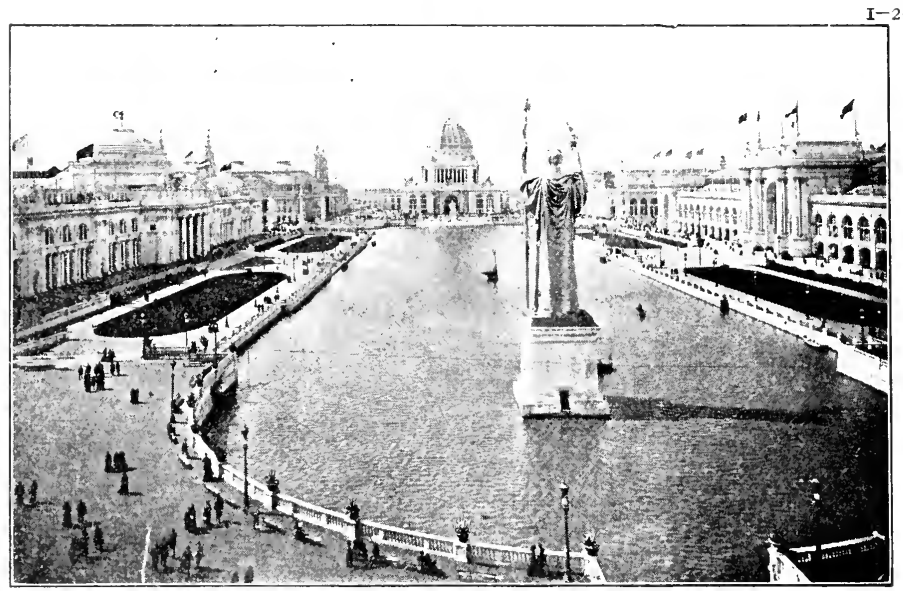

Court of Hoxor, Chicago (iS93)

progress, and one of the chief problems in securing good government. The growth of the slum is the greatest of the specific problems of the city, and represents the worst form Beard, $A m$. City Gov't, 287-3ro. of congestion. Legislation in favor of good tenements, the demand for more air-shafts and light-shafts, the limiting of the percentage of the land area that shall be covered with buildings, provisions for fire escapes, for clean streets, for parks and playgrounds near congested districts, the prohibition of sweatshop) work, the opening of trade schools;

1 The holding of the "Centennial exposition" at Philadelphia in 1876 was an important means of uniting the people and breaking down the barriers of provincialism. Later expositions have had a broadening effect on our social and industrial life. 
these and many others are but surface measures that at best can afford slight relief, for they do not cure the real disease.

Protests

There has been a sirong movement during the last two against misrule decades to remove the worst evils of city government. in cities.

Ford. H. J., in Pol. Sc. Qutur., I9 (1904). 673-684. Many of our larger cities have been controlled by bosses or rings which have not governed them in the public interest. These politicians have usually been able to maintain their control because of the large number of positions which they

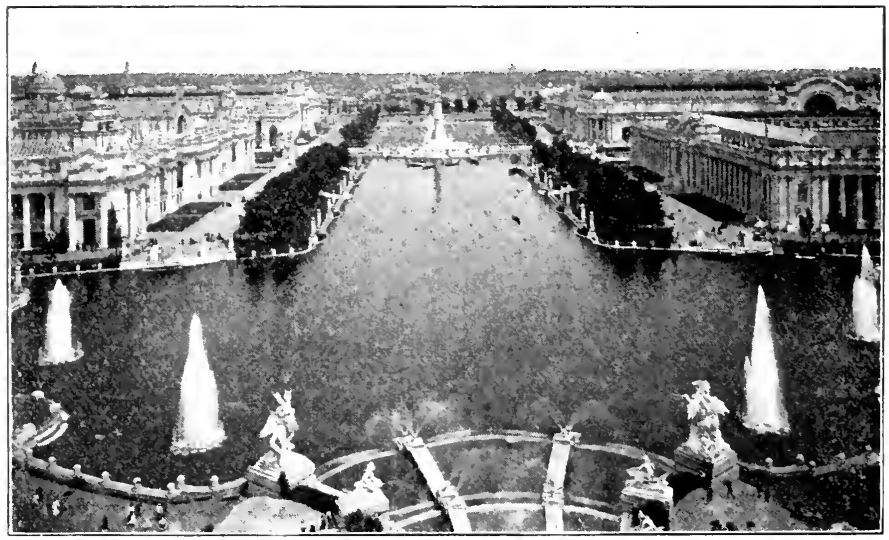

Grani Basin, St. Louls (I904)

Nunro, Gov't may fill with their appointees and the inmense sums of of $4 \mathrm{~m}$. Cities, public money that they handle, because also men of busi$35^{8}-383$. ness have not been interested sufficiently to insist upon reform. At times the public has rebelled, and, for a time it mar have abolished the worst features of ring rule, but organization is necessary in the successful administration of any government, and the forces of reform usually fail to remain united. In general, however, our cities are governed better than formerly. As an illustration of the old state of affairs we may note the prevalence of corruption in and blackmail by the police department of New York unearthed during the Lexow investigation ( $\mathrm{IS}_{94}$ ), and the victories of Cir- 
cuit Attorney Folk in St. Louis (1903) and of Mayor Weaver of Philadelphia.

The most recent movement for reform has been the change from the mayor-council type to the commission form of government, which was used first in Gialveston, Texas, after the great disaster of r goo. 'The commission consists of from three to nine members who are elected from the city at large and are heads of different administrative departments as well as commissioners. The commission form of government has been adopted by most of our smaller Commission form of government.

Beard, $1 \mathrm{~m}$. Cily Gov't, 92-97.

Munro, Gov't of Am. Cities, $294-320$. cities and by many of medium size. In $191+$ more than

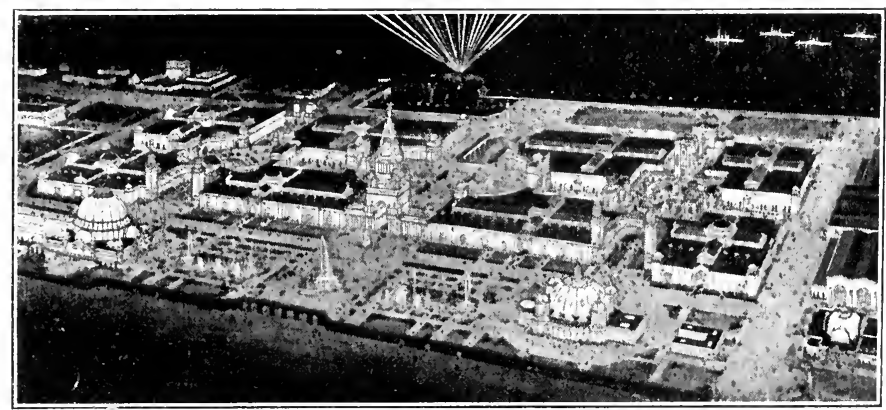

Copyright Panama Pacific Intern. Exp.

General View, San Francisco, I9I 5

20 per cent of our urban population lived under the commission form. It seemed to be quite successful at that time.

48I. Legal Rights of Women. - The first half of the nineteenth century was notable for the rapid increase in the number of political and legal rights of men $(\$ 292)$. The last half century marks almost as complete a change in the legal status of women. In I 850 women did not vote for candidates for public office anywhere. In many states married women did not have the right to hold property. Both law and custom prevented them from engaging in any of the professions except that of teaching. About the middle of the Women's rights a half century ago.

Bliss (ed.), New Encyc. of Social Reform, I 290-I 29I, I3OI-1303.

Hecker, $H$ ist. of I'omen's Rights, century a few earnest women sought to arouse interest I $57-$ I 74 . 
in the legal disabilities of women, especially of those who were married. Because many of them believed that woman's rights were to be obtained only through woman's suffrage, they devoted most of their attention to securing the ballot for women. This attempt was not particularly successful, but the desire to improve the legal position of women has produced remarkable results.

Increase in number of political and civil rights.

Abbot, L., in World's Work, 8 (I904), 5033-5042.

The Nineteenth Century, I 79-204. Harper, J., in Rev. of Revs., 46 (r9I 2), 700704.

Cleveland, Organized Democracy, I 5 I-I 68.

Results of the changes.

Giddings, Democracy and Empire, 165-I 76 . Nearing, W'oman and Social Progress, 21 7-239, 256-264.

In 1913 women voted, on the same terms as men, in nine states, Wyoming, Colorado, Utah, Idaho, Washington, California, Kansas, Oregon and Arizona. ${ }^{1}$ In several states women who own property may vote on all questions directly involving taxation. In about one half of the states in the Union all women over twenty-one years of age are allowed to vote at school elections. Married women are now allowed to own separate property, and in most of the states have complete control of its disposal. In many states all that is earned and saved after marriage becomes the joint property of husband and wife, who are supposed to have contributed equally in bearing the family burdens. Many civil rights which were denied to women formerly now enable them to protect themselves. Unfortunate as many of the results of our lenient divorce laws have been, these laws have been an important factor in freeing women from the unequal and unjust burdens which marriage formerly placed upon many of them.

The so-called emancipation of women has been aided by the new occupations opened to them. They have entered all the professions. Several colleges are devoted exclusively to women, and most of the others admit men and women on the same terms. Certain occupations are filled almost exclusively by women, and in several others they have compelled men to work for lower wages, this being one of the serious disadvantages of a movement which has made women "independent." As ordinary wage earners, moreover, women, and children as well, are protected by the laws which limit the number of hours per week that they

I In Illinois women vote for presidential electors and for local officers. 
may be employed, and in some cases the laws have provided for a minimum wage $(\$ 459)$.

482. The Distribution of Wealth. - It has seemed necessary to protect labor because our wealth has increased rapidly, and it has not been distributed as evenly as in former years. On account of the organization of great corporations which the laws have created and protected, and sometimes aided as well, great fortunes have been amassed by a number of people. It is estimated that I per cent of the people of the United States hold more than one one half of the wealth.

At the same time poverty has increased, largely on account of the congestion of population in our large cities, where the people frequently cannot get employment. Unemployment is much more common to-day than it was two generations ago. The fact is not generally understood, however, that the ordinary wage earner has nearly doubled his wages in the last seventy-five years. This is not only true of the money wage, that is, the wage in dollars and cents; it is true also of the purchasing power of the wage, for general prices have not increased materially during the last three quarters of a century. ${ }^{1}$ The high wages in the United States have been due to our boundless natural resources, to improvements in our machines and in the organization of our businesses, to the efficiency of the American laborer and to the organization of labor.

The wages would be still higher and our great wealth would be more evenly distributed had we not parted with our valuable timber and coal lands, our iron deposits and supplies of oil, fine water power sites, valuable water rights and terminal facilities, for little or nothing. By keeping for the public the immense resources which still belong to the people, by adopting corporation, inheritance, and income taxes that will make those wealthy citizens contribute more nearly accord-

Conservation and the distribution of weaith.

Howe, Privi-

lege and

Democracy, $28-44$.

${ }^{1}$ Prices of food and some other necessaries have increased, however, and the laborer is not twice as well off as he was in 1840 , although his standard of living has improved. 
ing to their ability instead of learing the burden of taxation on the poorer members of society. and by placing upon society the burden of industrial accidents, much has already been accomplished toward a better distribution of wealth.

Adrantages of our land policy in the past.

Bullock, Reudings in Public Finunce. O4-72.

Disadrantages in general.

Humphrey, L. K., in Atlantic Mo.. IO: (1008). $\mathrm{I}-\mathrm{O}$.

Human life.

Van Hise. Conseration. $304-372$.
483. The Past and the Future. - Nothing has affected more vitally the political development of the L nited States, as well as the economic progress and the social life of the people, than the disposal of our agricultural lands. During the closing years of the Rerolution the public lands in the West produced the chief bond of union among the states. In the West the possibility of acquiring title to public lands was a very important factor in the rapid development of the section east of the Mississippi between ISIs and I $\$ 60$. and west of the Mississippi after the War for the Lnion. Our public land policy helped to keep us a nation of small farmers. It aided in the development of a real democracy, not simply political, but ecomomic and social. It helped us to absorb as true American citizens multitudes of foreigners who have come to us.

Just as the establishment of small farms, three quarters of a century ago, created a West in which political equality was the rule and great distinctions the exception, so in later years the liberal grants of agricultural, mineral, and forest lands helped to develop a class which, through the misapplication or maladministration of these land laws. grew rich and powerful at public expense. In parting with its greatest natural asset, its rich agricultural lands, the Lnited States has made a great blunder. so far as the lands did not become the permanent homes of a numerous and thrifty class of small farmers.

A more important subject, little, as yet. under the supervision of our govermments, is the conservation of human life. When we notice the appalling losses due to our haste in the search for wealth, to our carelessness or indiffetence, we must recognize the need of remedial action to ward off accidents, disease, and death. We must expect in the future a much greater amount of governmental supervision, pos- 
sibly of direct interference, for the conservation of life and health. What shall it protit our nation, if it shall conserve its natural resources and sacrifice the lives of its perople?

Marshall, IVright, ant Ficht. Matirials for study of Economics, I 21 - 13.4 .

\section{The NATION AND ITS GONERnMent - A COMPIRISON}

484. Changes of a Century and a Third. - Is we look back over the years since the Lnited states first dectared themselves independent of Grealt Britain, we camnot lail to be impressed with the great changes that have taken place. It is not simply the fact that the America of that day consisted of only thirteen states with but two millions and a kalf inhabitants. The people then lived really in a different work from that which we know. Before the daty of steam and electricity and machinery, life was simple and narrow. Their political deleas and ideals impress us ats being conservative and provincial. (One standard of life, its purpose and its methods, prevailed in the North; others, elsewhere. Their political standards were alike only in their intense hatred for monarchy, their equal distrust of real democracy.

Difficult as it is to measure and compare views and abstract qualities, we must content ourselves with the contrast presented by institutions and forces that can be studied easily. We can see how the territory of the United States, which in 1770 covered only the Melantic slope, with vague claims to the interior, expanded in 178,3 to the Mississippi then extended to the Rockies, the (iulf of Mexico, and finally the Pacific, stretching across the finest part of the continent and washed by the waters of the two great oceans of the globe. We can note the acpuisition of outposts in different parts of the world that bind us closer to the rest of the human family. The two millions and a half have grown to nearly' one hundred millions, excluding those living in our insular possessions. Our total wealth, measured then by the hundred millions, is now estimated at much more than one hundred billions. Our foreign commerce has expanded

Territorial and indust rial expansion since $177 \%$.

The Imerican people of 1770 . 
fifty-fold. Then we had no manufactures except the humble shops that employed but few hands. Now single corporations employ almost as many men as there were in any state in those days. We can cross the continent in less time than our ancestors could go from New York to Boston and with less discomfort than they could go from town to town. But we need not multiply illustrations. Certainly it must be clear to every one that the material progress since 1776 has revolutionized the world of that day.

Three great political contributions to the world.

Changes in American government.
485. Important Characteristics of American Political Development. - Yet it is not in material development but in the political field that we must look for those characteristics which distinguish the United States from other nations. We have developed certain political ideas and influenced the world by persuading other nations to adopt the principles which we have proved satisfactory in practice. Of these, three deserve especial attention: (I) The United States has proved not simply that a republic of a really democratic nature may be developed, but that it may be developed on a large scale. The republics of history were small and aristocratic. (2) The United States has furnished the first example of a nation governed in accordance with a written constitution, an example which most of the other nations have followed. (3) The United States was the first nation to prove that a federal system of government can be used to advantage, combining complete autonomy of the states in matters of local interest with the supremacy of the national government in public questions of national importance. ${ }^{1}$

The political success of the American nation has been due in a great degree to the combination of these three principles: democracy, the written constitution, and a federal system. But the development of the nation, as we have noticed in detail elsewhere, was a process completed only

${ }^{1}$ On the nature of federalism in America, see the author's American Government, or for a fuller account, his American Federal State, Chapter X. 
after a long, bitter struggle. Although there have been but seventeen amendments to the written Constitution, that great document has been modified constantly through a liberal construction of its provisions, through the enactment of laws on new subjects, and the adoption of new methods. These important court decisions, statutes, and customs that have supplemented the written Constitution are called the unwritten constitution. ${ }^{1}$

Popular government in the United States under a written constitution involves a system of representation, as practically all people in the United States are citizens and most men and women are voters. As the people cannot act directly in the conduct of many public affairs, they must depend on political parties. These parties not only are the means through which the American people govern themselves, but the political party has done an inestimable service in uniting the people. The parties are largely responsible for the harmonious working, not only of different branches of any one government, but of our two great sets of government, state and national.

486. The People, the Nation, and the Government. In 1789 the United States was governed by classes. People could not vote unless they owned a certain amount of property and had been for a long time residents of the state and district. Officials were by law usually required to own a much greater amount of property, and by custom they were ordinarily drawn from certain families. Except in the New England townships the local government was by no means popular, for elsewhere the town, parish, and county officers were either appointed by the state governments or chosen by a few persons.

To-day manhood suffrage is practically universal and woman suffrage is gaining ground. Religious qualifications The democracy of to-day. were abolished long ago, when State and Church were separated, but the nation has become more rather than less

1 On the unwritten constitutions and the changes in government which it supports, see Ashley, American Government, \$§ 206-2 I I. 
religious. The few restrictions of time, residence, and citizenship for electors are essentials of good government. Officeholding is open to any one who has the personal qualities needed for winning popular faror. All of the chief positions in national, state, and local governments are filled by popular election, and changes in fundamental law must meet with the approval of voters. The people may propose laws in a great many states and may insist that the proposed laws be ratified by them. The people coöperate in government largely through parties, but the control of those parties belongs to them: for no one that seeks to become a party dictator or "boss" can maintain his position in the long run without popular support. We have now as truly a government "of the people, by the people, for the people" as ever existed, with most of the benefits and most of the faults inherent in democratic rule.

The nation and its social problems.

Although our governments respond rather slowly to the popular will, a situation not without many advantages in a democracy, in the long run our laws and our constitutions register the sober second thought of the nation. The adoption of new political devices to make more real the rule of the people and the enactment of laws for social betterment are but signs of the times. The twenticth century is certain to bring us epoch-making social changes. If we consider the new position of woman, or the hetter provision for those that lahor with their hands, or the control by the public through its government of great resources and businesses, we see that the nation is trying to adjust itself to the newer need of a society which cannot exist under eighteenth-century conditions, and will not follow the models of the nineteenth. Since nationality and democracy were the great products of the century that is just past, in America and in Europe, we can no longer look forward to them as goals: but we must look forward to a new national democracy that demands social progress and seeks to work out better ideas of social welfare. 


\section{TOPICS}

I. INDustrill Arbitration: Bliss (ed.), "Now Encyclopedia of Social Reform," p). 5s-0.4; National Industrial commission, "Final Report," XIX, Pl. \$3,3-\$O2: Carlton, "History and Problems of Organized Liblor," 22S-202.

2. Chiln L.ABok: Adams and Sumner, "Labor Problems," pp. 2037, 5-67; Bliss, "New Encyclopedia of Social Reform," pl. r7oISı; Lovejoy, (). R., in lmals of Imer. Icademy, is (1012), sup. 31-35; Carlton, "History and Problems of Organized Labor," Pl. 3So-30s: Mangold, "Child Problems," 150-217; Nearing, "Child Labor."

3. Emlloyers" Liability : Carlton, "History and Problems of Organized Labor," pl, 202-310; Seager, "Social Insurance," plp. 24S3; Eastman, "Work Accidents and the law," pp. 100-220; .1 muals of imer. Academy, is (1011), It4-220; Camploll, "Industrial Liability," Rubinow, "Social Insurance," pp. $28-45,80-107$.

4. Commission Form of City ( Borkenume : Bruère, "New City" Government," Pl). 1(1-0); Bradford, "Commission Cov't in Ancr. Cities," Pl). 127-1 fo, 1S1-213, 201-300; Hamilton, "I)thronement

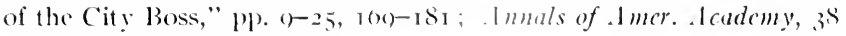
(10I1), Pl). $071-0+3$.

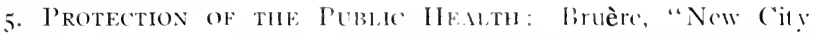
Government," pp. tor-413; Beard, "Amer. City (iovernment," pp. 201-280; Mccirath, IV. M., in Surey, 27 (1012), 1501-1514; Almals of Amer. Academy, 37 (1011), 3-12, 12.3-120, 102-220, 250260; Allen, "Civies and Health."

\section{STUDIES}

1. Growth of manufactures in the U.S. (R.encers, "I) velopment of the North" ( North America, XVIII), ple. 2.35-250.)

2. Development of the South since the Civil War. (Bruce, "Rise of the New South" (North America, XXVIl), ply. 45.5-472.)

3. The Mann-Elkins Railway Act of 10 10. (Ripley. "Railroads: Rates and Regulation," 5.57-5So.)

4. Control of railways by a state (Texas). (Haney, I. II., in Iour. Pol. Economy, ro ( I I I ), 4.37-455.)

5. The relation of state to interstate railway regulation. (Litcrary Digest, $\left.4^{6}(1013), 13^{61-13} 3^{0} 3.\right)$

6. The anti-trust policies of the Taft administration. (WVickersham, G. W., in Century, $8_{3}$ (1012), 610-622.)

7. Our "Bumper" crops.

8. Commercial invasion of Europe. (Vanderlip, F., in Scribner's Magazine, 3 I ( (902).)

9. The American Federation of Labor. (Carlton, "History and Problems of Organized Labor," $7+-\$ 2$. 
Io. The need of a minimum wage. ("O. Henry," in McClure, 35 (г9 го), 688-690.)

II. The problem of the African. (Shaler, "The Neighbor," pp. I26-I9I.)

I2. The new problem of immigration. (Fairchild, "Immigration," $369-380$.)

I3. Five American contributions to civilization. (Eliot, "American Contributions to Civilization," pp. I-3S.)

I4. Some reasons why the American republic may endure. (Eliot, "American Contributions to Civilization," pp. 39-70.)

I 5. Geographic distribution of immigration. (Semple, "American History and its Geographic Influences," pp. 310-336.)

I6. The American intellect. (Wendell, Barrett, in "Cambridge Modern History," pp. 723-75r.)

\section{QUESTIONS}

I. Place in your notebook a complete summary of the following topics, showing the sections of the text in which details may be obtained: territorial growth, railway development and control, foreign relations in general, social changes after the (I) Revolutionary War, (2) during the first half of the nineteenth century, (3) during the last half century.

2. What are the chief advantages of economic consolidation? What are the disadvantages of the policy? Why do not trusts raise prices indefinitely if they have no competition?

3. Should there be more restraint of corporations than at present? What are the chief difficulties in railway regulation? How does our federal system of government complicate the railway problem? What are the advantages and disadvantages of government ownership of railways?

4. What has been gained through organization of labor? Should there be compulsory arbitration of some, or all, labor disputes? How does labor legislation affect industry? the workers? society?

5. Compare the immigration of to-day with that of former years, noting races represented, places where immigrants settle, immigration problems to be solved. If present non-Teutonic immigration continues, how long before the United States will cease to be an "Anglo-Saxon" nation?

6. What are the advantages of universal suffrage? the disadvantages? Is the franchise of to-day likely to become more or less restricted? Was the fifteenth amendment a mistake? Give arguments for and against woman suffrage.

7. What are the chief problems for the nation to solve? What solutions have been suggested for each? 


\section{APPENDIX}

\section{THE DECLARATION OF INDEPENDENCE}

\section{(Adopted by the Continental Congress, July 4th, I776.)}

题 C C thirteen united States of America.

When in the Course of human events, it becomes necessary for one people to dissolve the political bands which have connected them with another, and to assume among the powers of the earth, the separate and equal station to which the Laws of Nature and of Nature's God entitle them, a decent respect to the opinions of mankind requires that they should declare the causes which impel them to the separation.

We hold these truths to be self-evident, that all men are creaied equal, that they are endowed by their Creator with certain unalienable Rights, that among these are Life, Liberty and the pursuit of Happiness. That to secure these rights, Governments are instituted among Men, deriving their just powers from the consent of the governed, - That whenever any Form of Government becomes destructive of these ends, it is the Right of the People to alter or to abolish it, and to institute new Government, laying its foundation on such principles and organizing its powers in such form, as to them shall seem most likely to effect their Safety and Happiness. Prudence, indeed, will dictate that Governments long established should not be changed for light and transient causes; and accordingly all experience hath shewn, that mankind are more disposed to suffer, while evils are sufferable, than to right themselves by abolishing the forms to which they are accustcmed. But when a long train of abuses and usurpations, pursuing invariably the same Object evinces a design to reduce them under absolute Despotism, it is their right, it is their duty, to throw off such Government, and to provide new Guards for their future security. Such has been the patient sufferance of these Colonies; and such is now the necessity which constrains them to alter their former Systems of Government. The history of the present King of Great Britain is a history of repeated injuries and usurpations, all having in direct object the establish- 
ment of an absolute Tyranny over these States. To prove this, let Facts be submitted to a candid world.

He has refused his Assent to Laws, the most wholesome and necessary for the public good.

He has forbidden his Governors to pass Laws of immediate and pressing importance, unless suspended in their operation till his Assent should be obtained; and when so suspended, he has utterly neglected to attend to them.

He has refused to pass other Laws for the accommodation of large districts of people, unless those people would relinquish the right of Representation in the Legislature, a right inestimable to them and formidable to tyrants only.

He has called together legislative bodies at places unusual, uncomfortable, and distant from the depository of their public Records, for the sole purpose of fatiguing them into compliance with his measures.

He has dissolved Representative Houses repeatedly, for opposing with manly firmness his invasions on the rights of the people.

He has refused for a long time, after such dissolutions, to cause others to be elected; whereby the Legislative powers, incapable of Annihilation, have returned to the People at large for their exercise; the State remaining in the mean time exposed to all the dangers of invasion from without, and convulsions within.

He has endearoured to prevent the population of these States; for that purpose obstructing the Laws for Naturalization of Foreigners; refusing to pass others to encourage their migration hither, and raising the conditions of new Appropriations of Lands.

He has obstructed the Administration of Justice, by refusing his Assent to Laws for establishıng Judiciary powers.

He has made Judges dependent on his Will alone, for the tenure of their offices, and the amount and payment of their salaries.

He has erected a multitude of New Offices, and sent hither swarms of Officers to harass our people, and eat out their substance.

He has kept among us, in times of peace. Standing Armies without the Consent of our legislatures.

He has affected to render the Military independent of and superior to the Civil power.

He has combined with others to subject us to a jurisdiction foreign to our constitution, and unacknowledged by our laws; giving his Assent to their Acts of pretended Legislation: 
For quartering large bodies of armed troops among us:

For protecting them, by a mock Trial, from punishment, for any Murders which they should commit on the Inhabitants of these States:

For cutting oft our Trade with all parts of the world:

For imposing Taxes on us without our Consent :

For depriving us in many cases, of the benefits of Trial by Jury :

For transporting us beyond Seas to be tried for pretended oftences :

For abolishing the free System of English Laws in a neighbouring Province, establishing therein an Arbitrary government, and enlarging its Boundaries so as to render it at once an example and fit instrument for introducing the same absolute rule into these Colonies:

For taking away our Charters, abolishing our most valuable Laws, and altering fundamentally the Forms of our Governments :

For suspending our own Legislatures. and declaring themselves invested with power to legislate for us in all cases whatsoever.

He has abdicated Government here, by declaring us out of his Protection and waging War against us.

He has plundered our seas, ravaged our Coasts, burnt our towns, and destroyed the lives of our people.

$\mathrm{He}$ is at this time transporting large Armies of foreign Mercenaries to compleat the works of death. desolation and tyranny, already begun with circumstances of Cruelty \& perficly scarcely parallel in the most barbarous ages, and totally unworthy the Head of a civilized nation

He has constrained our fellow Citizens taken Captive on the high Seas to bear Arms against their Country, to become the executioners of their friends and Brethren, or to fall themselves by their Hands.

He has excited domestic insurrections among us, and has endeavoured to bring on the inhabitants of our frontiers, the merciless Indian Savages, whose known rule of warfare. is an undistinguished destruction of all ages, sexes and conditions.

In every stage of these Oppressions We have Petitioned for Redress in the most humble terms: Our repeated Petitions have been answered only by repeated injury. A Prince whose char acter is thus marked by every act which may define a Tyrant, is unfit to be the ruler of a free people. 
Nor have We been wanting in attentions to our Brittish brethren. We have warned them from time to time of attempts by their legislature to extend an unwarrantable jurisdiction over us. We have reminded them of the circumstances of our emigration and settlement here. We have appealed to their native justice and magnanimity, and we have conjured them by the ties of our common kindred to disavow these usurpations, which would inevitably interrupt our connections and correspondence. They too have been deaf to the roice of justice and of consanguinity. We must, therefore, acquiesce in the necessity, which denounces our Separation, and hold them, as we hold the rest of mankind, Enemies in War, in Peace Friends.

aile, therefore, the REPRESENTATIVES of the atnitro states of Antrica, in Geseral Cosgress, Assembled, appealing to the Supreme Judge of the world for the rectitude of our intentions, do, in the Name, and by Authority of the good People of these Colonies solemnly PUBLish and DECLARE, That these United Colonies are, and of Right ought to be fres and indepenont States: that they are Absolved from all Allegiance to the British Crown, and that all political connection between them and the State of Great Britain, is and ought to be totally dissolved; and that as Free And Independent States, they have full Power to levy War, conclude Peace, contract Alliances, establish Commerce, and to do all other Acts and Things which INDEPExDExt States may of right do. And for the support of this Declaration, with a firm reliance on the protection of divine Providence, we mutually pledge to each other our Lives, our Fortunes, and our sacred Honor.

JOHN HANCOCK.

${ }^{1}$ [New Hampshire.]

Josiah Bartlett,

WilliaM Whipple,

Matthew ThorNton.

[.Massachusetts Bay.]

Samuel Adams, JOHN ADAMS.

Robert Treat Paine, Elbridge Gerry.
[Rhode Island.]

STEPHEN Hopkins, Williay Ellery.

\section{[Connecticut.]}

Roger Sherman, Samuel Huntington, William Wulliams, Oliver Wolcott.

1 This arrangement of the names is made for convenience. The States are not mentioned in the original. 


\section{[New York.]}

WilliaM Floyd,

Philip Livingston,

Francis Lewis,

LEWIS MORRIS.

\section{[New Jersey.]}

RICHARD STOCKTON, JOHN WithERSPOON, Francis Hopkinson, JOHN HART, Abraham Clark.

[Pennsylvania.]

RoBert Morris, Benjanin Rush, Benjamin Franklin, JOHN MORTON. George Clymer, JAMES SMITH, GEORGE TAYLOR, JAMES Wilson, GEORge Ross.

[Delaware.]

Cesar Rodney, George Read, ThOMas M'KeAN.

[.Maryland.]

SaneEl Chase, Willian PACA,
Thomas Stone, Charles Carroll of Carrollton.

[Virginia.]

George Wrthe, Richard Hexry Lee, Thomas JefFerson, BenjaMin Harrison, Thomas Nelson, Jr., Francis Lightfoot LeE, Carter Braxton.

\section{[North Carolina.]}

William HoOper, Joseph Hewes, John Pexn.

\section{[South Carolina.]}

Edward Rutledge, Thomas Herward, JR., Thomas Lyech, JR., Arthur Middleton.

[Georgia.]

Button Gwinnett,

Lyman Hall.

Geo. Walton. 


$$
\text { ' }
$$




\section{CONSTITUTION OF THE UNITED STATES}

We the people of the United States, in Order to form a more Preamperfect Union, establish Justice, insure domestic 'Tranquility, provide for the common defence, promote the general Welfare, and secure the Blessings of Liberty to ourselves and our Posterity, do ordain and establish this Constrtution for the United States of America.

\section{Article. I.}

Section 1. All legislative Puwers herein granted shall be vested in a Congress of the United States, which shall consist of a Senate and Iouse of Representatives.

Section 2. [1] The Ilonse of Representatives shall be composed of Members chosen every second Year by the People of the several States, and the Electors in each State shall have the Qualifications requisite for Electors of the most numerous Branch of the State Legislature.

[?] No Person shall be a Representative who shall not have attained to the age of twenty-five Years, and been seven Years a Citizen of the United States, and who shall not, when elected, be an Inhabitant of that State in which he shall be chosen.

[:3] [Representatives and direct Taxes shall be apportioned among the several States which may be included within this Union, according to their respective Numbers, which shall be determined by adding to the whole Number of free Persons, including those bound to Service for a Term of Years, and excluding Indians not taxed, three fifths of all other Persons.] The actual Enumeration shall be made within three Years after the first Meeting of the Congress of the United States, and within every subsequent Term of ten Years, in such Manner as they shall by Law direct. The Number of Representatives shall

Congress. Two houses.

House of Representatives. Term and election.

Qualificationsage, citizenship, residence. Method of apportioning representatives. (Part in brackets superseded by Sec. 2 of Amendment XIV.) 
not exceed one for erery thirty Thousand, but each State shall Tempo- have at least, one Representative; and until such enumeration

rary

appor-

tionment.

Vacancies.

Officers.

Senate.

Election

and term.

Division of Senators into three classes.

Qualifications age, citizenship, residence. Vice-president.

Officers.

Trial of impeachments. shall be made, the State of New Hampshire shall be entitled to chuse three, Massachusetts eight, Rhode-Island and Proridence Plantations one, Connecticut five, New York six, New Jersey four, Pennsylvania eight, Delaware one, Maryland six, Virginia ten, North Carolina tive, South Carolina five, and Georgia three.

[t] When racancies happen in the Representation from any State, the Executive Authority thereof shall issue Writs of Election to fill such Vacancies.

[0] The House of Representatives shall chuse their Speaker and other Officers; and shall have the sole Power of Impeachment.

Vacancies. erery second Year; and if Vacancies happen by Resignation, or otherwise during the Recess of the Legislature of ans State, the Executive thereof may make temporary Appointments until the next Meeting of the Legislature, which shall then fill such Vacancies.

Section 3. [1] The Senate of the United States shall be composed of two senators from each state, chosen by the Legislature thereof, for six Years; and each Senator shall hare one Vote.

[-2] Immediately after they shall be assembled in Consequence of the first Election, they shall be divided as equally as may be into three Classes. The Seats of the Senators of the first Class shall be racated at the Expiration of the second Year, of the second Class at the Expiration of the fourth Year, and of the third Class at the Expiration of the sixth Year, so that one-third may be chosen [3] No Person shall he a Senator who shall not have attained to the Age of thirty Years, and been nine Years a Citizen of the United States. and who shall not, when elected, be an Inhabitant of that State for which he shall be chosen.

[t] The Vice President of the I'nited States shall be President of the Senate, but shall have no Yote, unless they be equally divided.

[5] The Senate shall chuse their other Officers, and also a President pro tempore, in the Absence of the Vice President, or when he shall exercise the Office of President of the United States.

[6] The Senate shall have the sole Power to try all Impeachments. When sitting for that Purpose. they shall be on Oath or Affirmation. When the President of the United States is tried, 
the Chief Justice shall preside: And no Person shall be convicted without the Concurrence of two thirds of the Nembers present.

[7] Judgment in Cases of Impeachment shall not extend further than to removal from Otlice, and disqualification to hold and enjoy any (Otfice of honor, Trust or Profit under the United States: but the Party convicted shall nevertheless be liable and subject to Indictment, Trial, Judgment and Punishment, aceording to Law.

Section 4. [1] The Times, Places and Namer of holding Elections for Senators and Representatives, shall be preseribed in each State by the Legislature thereof; but the Congress may at any time by Law make or alter such Regulations, except as to the Places of chusing Senators.

[2] The Congress shall assemble at least once in every Year, and such Neeting shall be on the first Monday in December, unless they shall by Law appoint a different Bily.

Section 5. [1] Each Howse shall be the Julge of the Elections, Returns and Qualifications of its own Members, and a Majority of each shall constitute a Quorum to do Business; but a smaller Number may adjourn from day to day, and may be anthorized to compel the attendance of absent Members, in such Manner, and under such Penalties as each House may provide.

[2] Each Ilonse may determine the Rules of its Proceedings, punish its Members for disorderly Behaviour, and, with the Concurrence of two thirds, expel a Nember.

[3] Each Honse shall keep a Journal of its Proceedings, and from time to time publish the same, excepting such Parts as maly in their Judgment require Secrecy; and the Yeas and Nays of the Members of either House on any question shall, at the Desire of one fifth of those Present, be entered on the Journal.

[4] Neither House, during the Session of Congress, shall, without the Consent of the other, adjourn for more than three days, nor to any other Place than that in which the two Houses shall be sitting.

Section 6. [1] The Senators and Representatives shall receive a Compensation for their Services, to be ascertained by law, and paid out of the Treasury of the United states. They shall in all Cases, except Treason, Felony, and Breach of the Peace, be privileged from Arrest during their Attendance at the Session of their respective Houses, and in going to and returning from the same; and for

Judgment in eises of impeachment.

Both Houses. Times, places, and method of electing members. Time of meeting.

Membership regulations. Quorum.

Rules of each house.

Journals.

Special adjournments.

Members.

Compensation and privileges of members. 
any Speech or Debate in either House, they shall not be questioned in any other Place.

Disabilities of members.

Bills and resolutions.

Revenue bills. Veto of President on bills.

Veto on resolutions.

[:] No Senator or Representative shall, during the Time for which he was elected, be appointed to any civil Office under the Authority of the United States, which shall have been created, or the Emoluments whereof shall have been encreased during such time; and no Person holding any Office under the United States, shall be a Member of either House during his Continuance in Office.

Section 7. [1] All Bills for raising Revenue shall originate in the House of Representatires; but the Senate may propose or concur with Amendments as on other Bills.

[2] Every Bill which shall have passed the House of Representatives and the Senate, shall, before it become a Law, be presented to the President of the United States; If he approve he shall sign it, but if not he shall return it, with his Objections to that House in which it shall hare originated, who shall enter the Objections at large on their Journal, and proceed to reconsider it. If after such Reconsideration two thirds of that House shall agree to pass the Bill, it shall be sent, together with the Objections, to the other House, by which it shall likewise be reconsidered, and if approved by two thirds of that House, it shall become a Law. But in all such Cases the Votes of botin Iouses shall be determined by Yeas and Nars, and the Names of the Persons roting for and against the Bill shall be entered on the Journal of each House respectively. If any Bill shall not be returned by the President within ten Days (Sundays excepted) after it shall have been presented to him, the Same shall be a Law, in like Manner as if he had signed it, unless the Congress by their Adjournment prevent its Return, in which Case it shall not be a Law.

[3] Every Order, Resolution, or Yote to which the Concurrence of the Senate and House of Representatives may be necessary (except on a question of Adjourmment) shall be presented to the President of the United States and before the Same shall take Effect, shall be approved by him, or being disapproved by him, shall be repassed by two thirds of the Senate and House of Representatices, according to the Rules and Limitations prescribed in the Case of a Bill.

Pozers of Section 8. The Congress shall hare Power [1] To lay and Congress. collect Taxes, Duties, Imposts and Excises, to pay the Debts and 
provide for the common Defence and general Welfare of the Taxation. United States; but all duties, Inyosts and Excises shall be uniform throughout the United States;

[2] To borrow Money on the credit of the Luited States;

[3] To regulate Commeree with foreign Nations, and anong the several states, and with the Indian Tribes;

[t] To establish an uniform Riule of Naturalization, and uniforn Laws on the subject of Bankruptcies throughout the United States;

[5] To eoin Money, regulate the Value thereof, and of foreign Coin, and tix the Staulard of Weights and Measures;

[i] To provide for the Punishment of counterfeicing the Securities and current Coin of the Lnited States;

[7] To establish Post Offices and post Roads;

[s] To promote the Progress of Science and useful Arts by securing for limited Times to Authors and Inventors the exclusive Right to their respective Writings and IDiscoveries;

[9] To constitnte Trimnals inferior to the smpreme Court;

[10] To define and punish Piracies and Felonies committed on the high Seas, and ()ffences against the Law of Nations;

[11] To declare War, grant Letters of Marque and Reprisal, and make Rules concerning Captures on Land and Water;

[12] To raise and support Armies, but no Appropriation of Money to that Lse shall be for a longer Term than two Years;

[1:3] To provide and maintain a Navy;

[1t] To make Rules for the Government and Regulation of the land and naval Forees;

[15] To provide for calling forth the Militia to execute the Laws of the Lnion, suppress Insurrections and repel Invasions;

[16] To provide for organizing, arming, and disciplining, the Militia, alid for governing such Part of them as may be employed in the Service of the Unit States, reserving to the States respectively, the Appointment of the Officers, and the Authority of training the Militia according to the discipline prescribed by Congress.

[17] To exercise exclusive Legislation in all Cases whatsoever, over such I)istrict (not exceeding ten Miles square) as may, by Cession of particular States, and the Acceptance of Congress become the Seat of the Govermment of the United States, and to exercise like Authority over all Places purchased by the Consent of the

Borrow.

ing.

Regulat-

ing

coinmerce

Natural-

ization

and bankruptey.

Coins, weights, and measures. Counterfeiting.

Post offices.

Patents and copyrights. Inferior courts. Piracies. War. Army.

Navy.

Land and naval forces. Militia, in service. Militia, organization.

Seat of government, and stations. 
Legislature of the State in which the Same shall be, for the Erection of Forts, Magazines, Arsenals, dock-Yards, and other needful Buildings; - And

Supplementary legislation.

\section{Limita-} tions on powers of Congress.

Slave trade.

Habeas corpus. Bills of attainder and $\mathrm{ex}$ post facto laws.

Direct tax.

Tax on exports.

Uniform commercial regulations.

Finance.

Titles of nobility and presents.

\section{Limita-}

tions on powers of States.
[18] 'To make all Laws which shall be necessary and proper for carrying into Execution the foregoing Powers, and all other Powers vested by this Constitution in the Government of the United States, or in any Department or Officer thereof.

Section 9. [1] The Migration or Importation of such Persons as any of the States now existing shall think proper to admit, shall not be prohibited by the Congress prior to the Year one thousand eight hundred and eight, but a Tax or duty may be imposed on such Importation, not exceeding ten dollars for each Person.

[2] The Privilege of the Writ of Habeas Corpus shall not be suspended, unless when in Cases of Rebellion or Invasion the public Safety may require it.

[3] No Bill of Attainder or ex post facto Law shall be passed.

[4] No Capitation, or other direct, tax shall be laid, unless in Proportion to the Census or Enumeration hereinbefore directed to be taken.

[5] No Tax or Duty shall be laid on Articles exported from any State.

[6] No Preference shall be given by any Regulation of Commerce or Revenue to the Ports of one State orer those of another: nor shall Vessels bound to, or from, one State, be obliged to enter, clear, or pay Duties in another.

[7] No money shall be drawn from the Treasury, but in Consequence of Appropriations made by Law; and a regular Statement and Account of the Receipts and Expenditures of all public Money shall be published from time to time.

[8] No title of Nobility shall be granted by the United States: And no Person holding any Office of Profit or Trust under them, shall, without the Consent of the Congress, accept of any present, Emolument, Office, or Title, of any kind whatever, from any King, Prince, or foreign State.

Section 10. [1] No State shall enter into any Treaty, Alliance, or Confederation; grant Letters of Marque and Reprisal; coin 
Money; emit Bills of Credit, make any Thing but gold and silver specific Coin a Tender in Payment of Debts; pass any Bill of Attainder, prohibiex post facto Law, or Law impairing the obligation of Contracts, or grant any Title of Nobility.

[2] No State shall, without the Consent of the Congress, lay any Imposts or Duties on Imports or Exports, except what may be absolutely necessary for executing it's inspection Laws: and the tions. net Produce of all Duties and Imposts, laid by any State on Imports or Exports, shall be for the Use of the Treasury of the United States; and all such Laws shall be subject to the Revision and Controul of the Congress.

[3] No State shall, without the Consent of Congress, lay any Duty of tonnage, keep Troops, or Ships of War in time of Peace, enter into any Agreement or Compact with another State, or with a foreign Power, or engage in War, unless actually invaded, or in such imminent Danger as will not admit of delay.

Limitations on imposts.

Prohibitions removable with consent of Congress.

Article. II.

Section 1. [1] The executive Power shall be vested in a President of the United States of America. He shall hold his Office during the Term of four Years, and, together with the Vice President, chosen for the same term, be elected, as follows:

[2] Each State shall appoint, in such Manner as the Legislature thereof may direct, a Number of Electors, equal to the whole Number of Senators and Representatives to which the State may be entitled in the Congress: but no Senator or Representative, or Person holding an Office of Trnst or Profit under the United States, shall be appointed an Elector. [The electors shall meet in their respective States, and vote by hallot for two Persons, of whom one at least shall not be an inhahitant of the same State with themselves. And they shall make a List of all the Persons voted for, and of the Number of Votes for each; which List they shall sign and certify, and transmit sealed to the Seat of the Government of the United States, directed to the President of the Senate. The President of the Senate shall, in the Presence of the Senate and House of Representatives, open all the Certificates, and the Votes shall then be counted. The Person having the greatest Number of Votes shall be the President, if such Number be a Majority of the whole Number of Electors appointed; and if there be more than

PresiDENT. Term. Presidential electors and method of choosing President.

(Part in brackets superseded by XII amendment.) 
one who have such Majority, and have an equal Number of Votes, then the House of Representatives shall immediately chuse by Ballot one of them for President; and if no Person have a Majority, then from the five highest on the List the said House shall in like Manner chuse the President. But in chusing the President, the Votes shall be taken by States, the Representation from each State having one Vote; A quorum for this Purpose shall consist of a Member or Members from two-thirds of the States, and a Majority of all the States shall be necessary to a Choice. In every Case, after the Choice of the President, the Person having the greatest Number of Votes of the Electors shall be the Vice President. But if there should remain two or more who have equal Votes, the Senate shall chuse from them by Ballot the Vice President.]

Dates of elections.

Qualifications, citizenship, age, and residence.

Presidential succession.

Compensa. tion.

Oath of office.
[3] The Congress may determine the Time of chusing the Elector's, and the Day on which they shall give their Votes; which Day shall be the same throughout the United States.

[4] No Person except a natural born Citizen, or a citizen of the United States, at the time of the Adoption of this Constitution, shall be eligible to the Office of President; neither shall any Person be eligible to that Office who shall not have attained to the Age of thirty five Years, and been fourteen Years a Resident within the United States.

[5] In Case of the Removal of the President from Office, or of his Death, Resignation, or Inability to discharge the Powers and Duties of the said Office, the same shall devolve on the Vice President, and the Congress may by Law provide for the Case of Removal, Death, Resignation, or Inability, both of the President and Vice President, declaring what Officer shall then act as President, and such Officer shall act accordingly, until the Disability be removed, or a President shall be elected.

[6] The President shall, at stated Times, receive for his Services, a Compensation, which shall neither be encreased nor diminished during the Period for which he shall have been elected, and he shall not receive within that Period any other Emolument from the United States, or any of them.

[7] Before he enter on the Execution of his Office, he shall take the following Oath or Affirmation:- "I do solemnly swear (or affirm) that I will faithfully execute the Office of President of the United States, and will to the best of my Ability, preserve, protect and defend the Constitution of the United States." 
Section 2. [1] The President shall be Commander in Chief of the Army and Navy of the United states, and of the Militia of the several States, when called into the actual Service of the United States; he may require the Opinion, in writing, of the principal Officer in each of the executive Departments, upon any Subject relating to the Duties of their respective Offices, and he shall have Power to grant Reprieres and Pardons for Offences against the United States, except in Cases of Impeachment.

[2] He shall have Power, by and with the Advice and Consent of the Senate, to make Treaties, provided two-thirds of the Senators present concur; and he shall nominate, and by and with the Advice and Consent of the Senate, shall appoint Ambassadors, other public Ministers and Consuls, Judges of the supreme Court, and all other Officers of the United States, whose Appointments are not herein otherwise provided for, and which shall be established by Law: but the Congress may by Law vest the Appointment of such inferior Officers, as they think proper, in the President alone, in the Courts of Law, or in the Heads of Departments.

[3] The President shall have Power to fill up all Vacancies that may happen during the Recess of the Senate, by granting Commissions which shall expire at the End of their next Session.

Section 3. He shall from time to time give to the Congress Information of the State of the Union, and recommend to their Consideration such Neasures as he shall judge necessary and expedient; he may, on extraordinary Occasions, convene both Houses, or either of them, and in Case of Disagreement between them, with Respect to the Time of Adjournment, he may adjourn them to such Time as he shall think proper; he shall receive Ambassadors and other public Ministers; he shall take Care that the Laws he faithfully executed, and shall Cornmission all the Officers of the United States.

Section 4. The President, Vice President and all civil Officers Liability of the United States, shall be remored from Office on Tinpeachment for, and Conviction of, Treason, Bribery, or other high Crimes and Misdemeanors. impeachment.

\section{Article. III.}

Section 1. The judicial Power of the United States, shall be JuDICIvested in one supreme Court, and in such inferior Courts as the 
Judges: Congress mar from time to time ordain and establish. The term and compensation.

Jurisdiction. Judges, both of the supreme and inferior Courts, shall hold their Otfices during good Behariour, aud shall, at stated Times, receive for their Serrices, a Compensation. which shall not be diminished during their Continuance in Otfice.

Section 2. [1] The judicial Porer shall exteud to all Cases, in Law and Equity, arising under this Constitution, the Laws of the United States, and Treaties made, or which shall be made. under their Authority; - to all cases affecting Ambassadors, other public Ministers and Consuls; - to all cases of admiralty and maritime Jurisdiction: - to Controversies to which the L'nited States shall be a party; - to controrersies between two or more States:- between a State and Citizens of another State; - between Citizens of different States - between Citizens of the same State claiming Lands under Grants of different States. and between a State, or the Citizens thereof, and foreign States. Citizens or subjects.

Original

and

appellate jurisdiction of supreme Court.

Jurs trial. Place of trial.

[2] In all Cases affecting Ambassadors, other public Ministers and Consuls, and those in which a State shall be Party, the supreme Court shall have original Jurisdiction. In all the other Cases before mentioned. the supreme Court shall have appellate Jurisdiction, both as to Law and Fact, with such Exceptions, and under such Regulations as the Congress shall make.

[3] The Trial of all Crimes except in Cases of Impeachment. shall be by Jury: and such Trial shall be held in the state where the said Crimes shall have been committed: but when not committed within any State, the Trial shall be at such Place or Places as the Congress mas by Law hare directed.

Treason: Section 3. [1] Treason against the Lnited States. shall condefiuition, sist only in lerving War against them. or in adhering to their Enemies, giring them Aid and Comfort. No Person shall be convicted of Treason unless on the Testimony of two Witnesses to the same orert Act, or on Confession in open Court.

punishment.

Nation AND States.

[-2] The Congress shall have Power to declare the Punishment of Treason, but no Attainder of Treason shali work Corruption of Blood, or Forfeiture except during the Lite of the Person attainted.

\section{Article. IV.}

Section 1. Full Faith and Credit shall be giren in each State to the public Acts, hecoras, and judicial Proceedings of erery 
other State. And the Congress may by general Laws prescribe the Manner in which such Acts, Records and Proceedings shall be proved, and the Effect thereof.

Section 2. [1] The Citizens of each State shall be entitled to all Privileges and Immunities of Citizens in the several States.

[2] A Person charged in any State with Treason, Felony or other Crime, who shall flee from Justice, and be found in another State, shall on Demand of the executive Authority of the State from which he fled, be delivered up, to be remored to the State having Jurisdiction of the Crime.

[3] No Person held to Serrice or Labour in one State, under the Laws thereof, escaping into another, shall, in Consequence of any Law or Regulation therein, be discharged from such Service or Labour, but shall be delivered up on Claim of the Party to whom such Service or Labour may be due.

Section 3. [1] New States may be admitted by the Congress into this Union; but no new State shall be formed or erected within the Jurisdiction of any other State; nor any State be formed by the Junction of two or more States, or Parts of States, withont the Consent of the Legislatures of the States concerned as well as of the Congress.

[2] 'The Congress shall have Power to dispose of and make all needful Rules and Regulations respecting the Territory or other Property belonging to the United States; and nothing in this Constitution shall be so construed as to Prejudice any Claims of the United States, or of any particular State.

Section 4. The United States shall guarantee to every State in this Lnion a Republican Form of Government, and shall protect each of them against Invasion; and on Application of the Legislature, or of the Executive (when the Legislature cannot be convened) against domestic Violence.

\section{Article. $\nabla$.}

The Congress, whenever two thirds of both Houses shall deem it necessary, shall propose Amendments to this Constitution, or, on the Application of the Legislatures of two thirds of the several AMENDMENT OF Covsiritu. TION. States, shall call a Convention for proposing Amendments, which, in either Case, shall be valid tc all Intents and Purposes as Part of .

Admission of new States.

Government of national territory.

Protection of States. 
this Constitution, when ratified by the Legislatures of three fourths of the several States, or by Conrentions in three fourth thereof. as the one or the other Mode of Ratitication may be proposed by the Congress; Prorided that no Amendment which may be made prior to the Year One thousand eight hundred and eight shall in any Manner affect the first and fourth Clauses in the Ninth Section of the first Article; and that no State, without its Consent, sinall be deprived of its equal suffrage in the Senate.

\section{Article. VI.}

NISCELLANEOUS. Preëxisting national debt. Supremacy of Constitution, treaties, and national law.

Oaths of national and state ofticials.

[1] All Debts contracted and Engagements entered into, before the Adoption of this Constitution, shall be as ralid against the United States under this Constitution, as under the Confederation.

[-2] This Constitution, and the Laws of the Lnited States which shall be made in Pursuance thereof: and all Treaties made, or which shall be made, under the Authority of the Lnited States, shall be the supreme Law of the Land; and the Judges in every State shall be bound therebs. any Thing in the Constitution or Laws of any State to the Contrary notwithstanding.

[3] The Senators and Representatives before mentioned, and the Members of the several State Legislatures. and all executive and judicial Officers, both of the Luited states and of the sererai States, shall be hound by Oath or Attirmation. to support this Constitution; but no religious Test shall ever be required as a Qualification to any ()fice or public Trust under the Lnited States.

\section{Article. Tit.}

Ratifica- The Ratification of the C'onrentions of nine States, shall be suffiTION. cient for the Establishment of this Constitution between the States so ratifying the same.

Done in Conrention by the I'nanimous Consent of the States present the Serenteenth Day of September in the Year of our Lord one thousand seren hundred and Eighty seven and of the Independence of the Inited States of America the Twelfth Is Witxess whereof We have hereunto subscribed our Names.

G. Washisgtox-

Presidt. and Deputy from Virginia [and thirty eight members from all the States except Rhode Island.] 


\section{ARTICLES IN ADITION TO, AND AMENDMENT OF,}

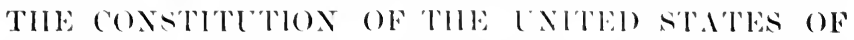

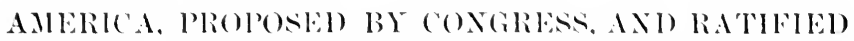
BY THE LEGISLATLRE OF THE SEVRRAL STARS PERSANT TO THE FIETH ARTICLE OF THE ORIGIN.TL, CONSTITLTION.

\section{[ATTCLE $\left.\mathrm{I}^{1}\right]$}

Prohibitions on

Congress shall make no law respecting an establishment of reli-

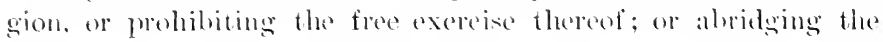
ireedom of sperels. of of the press: ar the right of the prople peaceably to assemble, and to petition the Gorermment for a redress of grievances.

$$
[\text { Iritel: } 111]
$$

Congress respecting religion, sperech, and the press.

A well regulated Militia, being netessiry to the security of a Right to free state. the right of the prople to lieep and bear Ams, shall not bear arms. be infringed.

\section{[ARTLLE III 1$]$}

No Soldier shall, in time of peace be quartered in any house, Quarterwithout the consent of the (Owner, nor in time of war, but in a ing of manner to be preseribed by law.

soldiers.

\section{[IRTICLE IV']}

The right of the people to be secure in their persons, houses, Right of papers, and elfects, agitinst mureasonable searehes and seizmres, seareh. shall not be riolated. and no Warrants shall issue, but upon probable cause, supported by Oath or affimation, and particularly descriling the place to be searched, and the persons or things to be seized.

\section{[ARTICLE $\left.\mathrm{I}^{+}\right]$}

No person shall be held to answer for a capital, or otherwise infamous crime, unless on a presentment or indictment of a Grand

${ }^{1}$ First ten amendments proposed by Congress, Sept. 25, 1759. Proclaimed to be in foree Dee. 15, 1791.

Protection of aceused in eriminal cases. 
Jury, except in cases arising in the land or naval forces, or in the Militia, when in actual service in time of War or public danger; nor shall any person be subject for the same offence to be twice put in jeopardy of life or limb; nor shall be compelled in any Criminal Case to be a witness against himself, nor be deprived of life, liberty, or property, without due process of law; nor shall private property be taken for public use, without just compensation.

\section{[ARticle VI']}

Rights of In all criminal prosecutions, the accused shall enjoy the right to accused regarding trial. a speedy and public trial, by an impartial jury of the State and district wherein the crime shall have been committed, which district shall have been previously ascertained by law, and to be informed of the nature and cause of the accusation; to be confronted with the witnesses against him; to have compulsory process for obtaining Witnesses in his favor, and to have the Assistance of Counsel for his defence.

\section{[Article VII $\left.{ }^{1}\right]$}

Jury trial In suits at common law, where the value in controversy shall in lawsuits. exceed twenty dollars, the right of trial by jury shall be preserved, and no fact tried by a jury shall be otherwise re-examined in any Court of the United States, than according to the rules of the common law.

\section{[ARTICLE VIII ${ }^{1}$ ]}

Bail and Excessire bail shall not be required, nor excessive fines imposed, punishment. nor cruel and unusual punishments inflicted.

\section{[ARTICLE IX ${ }^{1}$ ]}

Unenu- The enumeration in the Constitution, of certain rights, shall merated rights. not be construed to deny or disparage others retained by the people.

\section{[Article X $\mathrm{X}^{\mathbf{1}}$ ]}

Undelega- The powers not delegated to the United States by the Constituted pow- tion, nor prohibited by it to the States, are reserved to the States ers. respectively, or to the people.

1 First ten amendments proposed by Congress, Sept. 25, 1789. Proclaimed to be in force Dec. 15, 1791 . 


\section{Article XI ${ }^{1}$}

The Judicial power of the United States shall not be construed to extend to any suit in law or equity, commenced or prosecuted against one of the United States by Citizens of another State, or by Citizens or Subjects of any Foreign State.

Exemption of States from suit.

\section{Article XII}

The Electors shall meet in their respective states, and vote by ballot for President and Vice-President, one of whom, at least, shall not be an inhabitant of the same state with themselves; they shall name in their ballots the person voted for as President, and in distinct ballots the person voted for as Vice-President, and they shall make distinct lists of all persons voted for as President, and of all persons voted for as Vice-President, and of the number of votes for each, which lists they shall sign and certify, and transmit sealed to the seat of the government of the United States, directed to the President of the Senate; - The President of the Senate shall, in presence of the Senate and House of Representatives, open all the certificates and the votes shall then be counted;-The person having the greatest number of votes for President, shall be the President, if such numler be a majority of the whole number of Electors appointed; and if no person have such majority, then from the persons having the highest numbers not exceeding three on the list of those voted for as President, the Honse of Representatives shall choose immediately, by ballot, the President. But in choosing the President, the votes shall be taken by states, the representation from each state having one vote; a quorum for this purpose shall consist of a member or members from two-thirds of the states, and a majority of all the states shall be necessary to a choice. And if the House of Representatives shall not choose a President whenever the right of choice shall devolve upon them, before the fourth day of March next following, then the Vice-President shall act as President, as in the case of the death or other constitutional disability of the President. . The person having the greatest.number of votes as Vice-President, shall be the Vice-President, if such number be a majority of the whole number of Electors appointed, and if no person have a majority, then from the two

1 Proposed September 5, 1794. Declared in force January 8, 1798. 
highest numbers on the list. the Senate shall choose the Vice-President; a quorum for the purpose shall consist of two-thirls of the whole number of senators, and a majority of the whole number shall be necessary to a choice. But no person constitutionally ineligible to the office of President shall be eligible to that of VicePresident of the Luited States.

\section{Article XIII}

Abolition Section 1. Teither slavery nor involuntary serritude, except as of slavery. (Proposed Feb. 1, 1865. Declared in force Dec. 1s, 186i5.)

Citizens of the Lnited States protection of. (Proposed June 16,1866 .

Declared in force July :s, 1868.)

New basis of representation in Congress. (Superseding part of Art. I. see. 2, cl. 3.) a punishment for crime whereof the party shall have been duly convicted, shall exist within the Lnited states, or any place subject to their jurisdiction.

Section 2. Congress shall have power to enforce this article by appropriate legislation.

\section{Article XIV}

Section 1. All persons born or naturalized in the Lnited States, and subject to the jurisdiction thereof. are citizens of the L nited States and of the state wherein they reside. No state shall make or enfore any law which shall abridge the privileges or immunities of citizens of the Luited states; nor shall any state deprive any person of life. liberty, or property. without lue process of law: nor deny to any persou within its juristiction the equal protedtion of the laws.

Section 2. Representatives shall be apportioned among the several States according to their respective numbers counting the whole number of persons in each state. exeluding Indians not taxed. But when the right to rote at any election for the choice of electors for President and Vice President of the Lnited States. Representatives in Congress. the Executire and Judicial otlicers of a State, or the members of the Legislature thereof. is denied to any of the male inhabitants of such state, being twenty-one years of age, and citizens of the Lnited States, or in any way abridged, except for participation in rebellion, or other crime, the basis of representation therein shall be redneed in the proportion which the number of such male citizens shall bear to the whole number of male citizens twenty-one years of age in such State.

Section 3. No person shall be a senator or Representative in Congress, or elector of President and Vice President, or hold any 
office, eivil or military, under the Inited States, or moder any state, who, having previously taken an oath, as a member of con gress, or as an officer of the United states, or as a member of any state legislature, or as an exeentive or julicial oflicer of any State, to support the C'onstitution of the Cinited States, shall have engaged in insurrection or rebellion against the same, or given aid or eomfort to the enemies thereof. But Congress may hy twothirds rote of each Ilouse, remove such disability.

Section t. The valielity of the public debt of the United States, anthorized by law, including debes incurred for payment of pensions and lounties for serviees in suppressing insurrection or rehellion, shall not be questioned. But neither the United states nor any State shall assume or pay any debt or ohligation incurred in aid of insurrection or rebellion against the Inited states, or any claim for the loss or emancipation of any slare; bit all such dehts, ohligations and claims shall be held illegal and voir.

Section 5. The Congress slall have power to enfore, by appropriate legislation, the provisions of this article.

\section{Artiche $\mathrm{XV}^{1}$}

Section 1. The right of citizens of the Linited States to rote shall not be denied or abridged by the United States or by any State on account of race, color or previous condition of servitude.

Section 2. The Congress shall have power to enforce this article by appropriate legislation.

\section{ARTILLE XVI}

The Congress shall have power to lay and collect taxes on in- Income eomes, from whatever sonree derived, withont aplontiomment tax. among the several states, and withont regard to any census or enumeration.

\section{ArTHLe XVII}

The Senate of the Enited States shall be composed of two Sena- Direct tors from rach state, elected by the people thereot. for six yeals; and each senator shatl have one vote. The electors in aidel state

Validity of war debt.

\section{Voting} riwhts of ritizens of the U.S. clection of seniators

1 Proposed February 27,1869 Denlared in forese March :30, 1850. 
shall have the qualifications requisite for electors of the most numerous branch of the State legislatures.

Yethod of When vacancies happen in the representation of any State in election. the Senate, the executive authority of each State shall issue writs Temporary of election to fill such vacancies: Provided that the legislature of appoint- any state may empower the executive thereof to make temporary ments. appointments until the people fill the vacancies by election as the legislature may direct.

This amendment shall not be so construed as to affect the election or term of any senator chosen before it becomes valid as part of the Constitution. 
TABLE I. PRESIDENTS

\begin{tabular}{|c|c|c|c|c|}
\hline Name & State & PARTY & $\begin{array}{l}\text { YEAR IN } \\
\text { OFFICE }\end{array}$ & Vice President \\
\hline I George Washington & Va. & (Fed.) & $1780-1797$ & John Arlams \\
\hline 2 Jobn Adams & Mass. & Fed. & I 797-ISOI & Thomas Jefferson \\
\hline 3 Thomas Jefferson & Va. & Rep. & I SoI-I Sog) & Aaron Burr \\
\hline 4 James Madison & Va. & Rep. & $1809^{-}-1817$ & George Clinton \\
\hline 5 James Monroe & $\mathrm{Va}$. & Rep. & I $817-18_{25}$ & Daniel D. Tompkins \\
\hline 6 John Q. Adams & Mass. & Rep. & $1825-1820$ & John C. Calhoun \\
\hline 7 Andrew Jackson & Tenn. & Dem. & $1829-1837$ & $\begin{array}{l}\text { John C. Calhoun } \\
\text { Martin Van Buren }\end{array}$ \\
\hline 8 Martin Van Buren & N.Y. & Dem. & $1837-1841$ & Richard M. Johnson \\
\hline 9 Wm. H. Harrison & Ohio & Whig & $18+1-1841$ & John Tyler \\
\hline Io John Tyler ${ }^{1}$ & Va. & (Whig) & $18+1-18+5$ & \\
\hline i I James K. Polk & Tenn. & Dem. & $1845-1849$ & George M. Dallas \\
\hline 12 Zachary Taylor & La. & Whig & $1849-1850$ & Millard Fillmore \\
\hline I3 Millard Fillmore ${ }^{1}$ & N.Y & Whig & I 850 I 85.3 & \\
\hline It Franklin Pierce & N.H. & Dem. & I $85 j-I 857$ & William R. King \\
\hline 15 James Buchanan & $\mathrm{Pa}$. & Dem. & $1857-1801$ & J. C. Breckenridge \\
\hline I6 Abraham Lincoln & Ill. & Rep. & $1801-1805$ & $\begin{array}{l}\text { Hannibal Hamlin } \\
\text { Andrew Johnson }\end{array}$ \\
\hline 17 Andrew Johnson I & Ten & (Rep.) & I 805 I 809 & \\
\hline Is Ulysses S. Grant & Ill. & $\mathrm{Re}$ & $1809-1877$ & $\begin{array}{l}\text { Schuyler Colfax } \\
\text { Henry Wilson }\end{array}$ \\
\hline is Rutherford B. Hayes & Ohio & Rep. & $1877-1881$ & IVm. A. Wheeler \\
\hline 20 James A. Garfield & Ohio & Rep. & I $88 I-I S S I$ & Chester A. Arthur \\
\hline 2 I Chester A. Arthur ${ }^{1}$ & N.Y. & Rep. & $188 I-I 885$ & \\
\hline 22 Grover Cleveland & N.Y. & Dem. & $1885-1889$ & Thomas A. Hendricks \\
\hline 23 Benjamin Harrison & Ind. & Rep. & $1889-1893$ & Levi P. Morton \\
\hline 24 Grover Cleveland & N.Y. & Dem. & $1893^{-1897}$ & Adlai E. Stevenson \\
\hline 25 William McKinley & Ohio & Rep. & I $897-1901$ & $\begin{array}{l}\text { Garrett A. Hobart } \\
\text { Theodore Roosevelt }\end{array}$ \\
\hline 26 Theodore Roosevelt & N.Y. & Rep. & I $901-1909$ & Chas. IV. Fairbanks \\
\hline 27 William H. Taft & Ohio & Rep. & $1909^{-1913}$ & James S. Sherman \\
\hline 28 Woodrow Wilson & & Dem. & $1913^{-}$ & Thomas R. Marshall \\
\hline
\end{tabular}

TABLE II. PRESIDENTIAL ELECTIONS

\begin{tabular}{|c|c|c|c|c|}
\hline YEAR & $\begin{array}{l}\text { Successful } \\
\text { CANdidate }\end{array}$ & $\begin{array}{c}\text { Chief } \\
\text { Opponent }\end{array}$ & Popular Vote & $\begin{array}{c}\text { Electoral } \\
\text { Vote }\end{array}$ \\
\hline I 789 & Washington & & & Unanimous \\
\hline 1792 & Washington & & & Unanimous \\
\hline 1796 & Adams & Jefferson & & 7 I to 68 \\
\hline 1800 & Jefferson & Arlams & & 73 to $65^{2}$ \\
\hline I $80_{4}$ & Jefferson & C. C. Pinckney & & I62 to 14 \\
\hline I 808 & Madison & C. C. Pinckney & & I 22 to 47 \\
\hline ISI 2 & Madison & De W. Clinton & & I 28 to 89 \\
\hline 1816 & Monroe & King & & I83 to 34 \\
\hline 1820 & Monroe & & & 2.31 to $\mathrm{I}$ \\
\hline 1824 & Adams & Jackson & 105,321 to 155,872 & $8_{4}$ of $26 I^{2}$ \\
\hline 1828 & Jackson & Adams & $6.47,2,31$ to 500,007 & I 78 to 83 \\
\hline 1832 & Jackson & Clay & 687,502 to $5.80,180$ & 219 to 49 \\
\hline
\end{tabular}

I Raised from the vice presidency. $\quad{ }^{2}$ Elected by House of Representatives. 
PRESIDENTIAL ELECTIONS.-- Continuei

\begin{tabular}{|c|c|c|c|c|c|}
\hline YEAR & $\begin{array}{l}\text { SuCCESSFUL } \\
\text { CANDIDATE }\end{array}$ & $\begin{array}{c}\text { Chief } \\
\text { Opponent }\end{array}$ & POPULAR & Vote & $\begin{array}{c}\text { ELECTORAL } \\
\text { VOTE }\end{array}$ \\
\hline $8_{3} 6$ & Van Buren & Harrison & $761,5+9$ to & $736,65^{1}$ & 170 to 73 \\
\hline ISto & Harrison & Van Buren & $\mathrm{I}, 275$, OI 7 to & $\mathrm{I}, \mathrm{I} 2 \mathrm{~S}, 702$ & $23+$ to 60 \\
\hline ISt+ & Polk & Clay & $\mathrm{I}, 337,243$ to & I, 299.068 & 170 to 105 \\
\hline I $S_{4} S$ & Taylor & Cass & $\mathrm{I}, 360, \mathrm{IOI}$ to & $1,220,5+4$ & 163 to 127 \\
\hline IS52 & Pierce & $S \cot t$ & $\mathrm{I}, 60 \mathrm{I}, 47+$ to & $1,380,576$ & $25+$ to +2 \\
\hline 1856 & Buchanan & Frémont & $\mathrm{I}, 8_{3} 8, \mathrm{I} 69$ to & $1,3+1,26 t^{2}$ & I 74 to II 4 \\
\hline I 860 & Lincoln & Douglas & I. 866,352 to & $\mathrm{I}, 375, \mathrm{I}_{5} 7^{3}$ & I $S 0$ to I 23 \\
\hline 1864 & Lincoln & $\mathrm{McCl}$ & $2,216,067$ to & $\mathrm{I}, \mathrm{SOS}, 725$ & $2 \mathrm{I} 2$ to $2 \mathrm{I}$ \\
\hline 868 & Grant & 5 & $3,015,071$ to & $2,709,6$ I 5 & $2 \mathrm{I} 4$ to $\mathrm{So}$ \\
\hline $\mathrm{I} \mathrm{S}_{72}$ & Grant & $\mathrm{G}$ & $3,597,070$ to & $2, S_{34,079}$ & 286 to $63^{4}$ \\
\hline I 376 & Hay & $\mathrm{Ti}$ & 4,033, & $4,28_{4}, 88_{5}$ & $\mathrm{IS}_{5}$ to $\mathrm{IS}_{4}$ \\
\hline I $8 S 0$ & Garfield & $\mathrm{H}$ & 3 to & 4.4 & $21+$ to 155 \\
\hline $3 S_{4}$ & Cleveland & Blai & $4,9 \mathrm{II}, 0 \mathrm{I} 7$ to & $4,848,334$ & $2 \mathrm{I} 9$ to $\mathrm{IS}_{2}$ \\
\hline 888 & Harrison & Cleve & $5,4+0,2$ I 6 to & $5,538,233$ & 233 to I $6 \mathrm{~S}$ \\
\hline I S92 & Clevelan & Harrison & $5,556,9$ IS to & $5,176,10 S^{5}$ & 277 to $\mathrm{I}+5$ \\
\hline 896 & $\mathrm{Mch}$ & $\mathrm{Br}$ & $7,104,779$ to & $6,502,925$ & 271 to 176 \\
\hline 00 & McKinley & Bry & $7,207,923$ to & $6,35^{8}, 133$ & 292 to I 55 \\
\hline 1904 & Roosevelt & Parker & $7,023,4^{86}$ to & $5,077,97 \mathrm{I}$ & 336 to $1+0$ \\
\hline I 908 & Taft & & $7.078,908$ to & $0,409,104$ & $32 \mathrm{I}$ to 162 \\
\hline I91 2 & Wilson & Rooseve & $6,293,019$ to & 4, I I 9,507 & 435 to $8 \mathrm{~S}$ \\
\hline
\end{tabular}

TABLE III. CONGRESS SINCE I 865

\begin{tabular}{|c|c|c|c|c|c|c|}
\hline \multirow{2}{*}{$\begin{array}{l}\text { Nujuber } \\
\text { of } \\
\text { Congress }\end{array}$} & \multirow{2}{*}{ YeARS } & \multicolumn{2}{|c|}{ SENATE } & \multicolumn{2}{|c|}{ House } & \multirow{2}{*}{ SPEAKER } \\
\hline & & Rep. & Dem. & Rep. & $\overline{\text { Dem. }}$ & \\
\hline 39 & I $865-$ I 867 & +I & II & I 45 & 40 & Schuyler Colfax \\
\hline to & I $867-$ I $\$ 69$ & 42 & I I & $1+3$ & t9 & Schuyler Colfax \\
\hline $4 \mathrm{I}$ & I $869-$ I $S_{7} I$ & 58 & I I & $\mathrm{I}_{5} \mathrm{I}$ & 78 & James G. Blaine \\
\hline 42 & I $S_{71-}-18_{73}$ & 57 & I 7 & 138 & 103 & James G. Blaine \\
\hline+3 & I $873-$ IS 75 & 47 & 20 & I94 & 92 & James G. Blaine \\
\hline 44 & I $875-1877$ & 43 & 29 & 107 & 168 & $\begin{array}{l}\text { Michael C. Kerr } \\
\text { Samuel J. Randall }\end{array}$ \\
\hline 45 & I $877-1879$ & 36 & 39 & 142 & I5I & Samuel J. Randall \\
\hline+0 & I $879-$ ISSI & 32 & 44 & I 29 & 148 & Samuel J. Randall \\
\hline 47 & $\mathrm{ISSI}-\mathrm{I} \mathrm{SS}_{3}$ & 37 & $3^{8}$ & $I_{4} 6$ & I3 $\mathrm{S}$ & John W. Keifer \\
\hline $4^{8}$ & I $S_{3}-1 S_{5}$ & 40 & 36 & 124 & I9S & John G. Carlisle \\
\hline 49 & I $885-1887$ & $t^{2}$ & 34 & I 20 & 204 & John G. Carlisle \\
\hline 50 & $1887-1889$ & 39 & 37 & I 53 & I0S & John G. Carlisle \\
\hline $5^{\mathrm{I}}$ & I $S 89-$ I $S 9$ I & 39 & 37 & I 66 & I 59 & Thomas B. Reed \\
\hline 52 & I 89 I-I 893 & 47 & 39 & SS & 236 & Charles F. Crisp \\
\hline 53 & $1893-1895$ & 38 & th & I 26 & 220 & Charles F. Crisp \\
\hline $5+$ & I $S_{95}-\mathrm{I} S 97$ & +2 & 39 & $24^{6}$ & 104 & Thomas B. Reed \\
\hline 55 & I $S_{97}-$ IS 99 & 40 & 34 & 206 & I34 & Thomas B. Reed \\
\hline 56 & IS99-I 90 I & 53 & 26 & 185 & 163 & David B. Henderson \\
\hline 57 & I $90 \mathrm{I}-\mathrm{I} 903$ & $5^{6}$ & 29 & IgS & I 53 & David $\mathrm{B}$. Henderson \\
\hline $5 \mathrm{~S}$ & $1903-1905$ & $5^{8}$ & 32 & 206 & 174 & Joseph G. Cannon \\
\hline 59 & $1905-1907$ & $5^{8}$ & 32 & 250 & 136 & Joseph G. Cannon \\
\hline 60 & $1907-1909$ & $6 \mathrm{I}$ & 29 & 222 & 164 & Joseph G. Cannon \\
\hline $6 \mathrm{r}$ & I909-I9I I & 60 & 32 & 219 & 172 & Joseph G. Cannon \\
\hline 62 & I $911-19 I_{3}$ & $5 \mathrm{I}$ & $4 \mathrm{I}$ & 162 & 228 & Champ Clark \\
\hline 63 & I9I3-I9I5 & +5 & $5 \mathrm{I}$ & $127^{6}$ & 290 & Champ Clark \\
\hline
\end{tabular}

1 Entire Whig opposition, 4 candidates.

${ }^{3}$ Breckenridge, $8_{45}, 76_{3}$, Bell, 589-5 $\mathrm{sx}$.

5 Weaver, $\mathrm{I}, \mathrm{O}+\mathrm{I}, \mathrm{O} 2 \mathrm{~S}$.
${ }^{2}$ Fillmore, $8_{7}, 538$.

4 Total opposition vote.

${ }^{6}$ is Progressives. 
TABLE IV. CHIEF JUSTICES OF THE SEPREME COLRT

\begin{tabular}{|c|c|c|c|}
\hline NaWe & State & APPOINTED BY & $\begin{array}{c}\text { Years } \\
\text { in Office }\end{array}$ \\
\hline $\begin{array}{l}\text { I John Jay } \\
2 \text { John Rulledge } \\
3 \text { Oliver Ellsworth } \\
4 \text { John Marshall } \\
5 \text { Roger B. Taney } \\
6 \text { Salmon P. Chase } \\
7 \text { Morrison R. Waite } \\
8 \text { Melville W. Fuller } \\
9 \text { Edward D. White }\end{array}$ & $\begin{array}{l}\text { New York } \\
\text { South Carolina } \\
\text { Connecticut } \\
\text { Virginia } \\
\text { Maryland } \\
\text { Ohio } \\
\text { Ohio } \\
\text { Hllinois } \\
\text { Louisiana }\end{array}$ & $\begin{array}{l}\text { Washington } \\
\text { Waashington } \\
\text { Washington } \\
\text { Adams } \\
\text { Jackson } \\
\text { Lincoln } \\
\text { Grant } \\
\text { Cleveland } \\
\text { Taft }\end{array}$ & $\begin{array}{l}1789-1795 \\
1795-1795 \\
1796-1800 \\
1801-1835 \\
1836-1864 \\
1864-1873 \\
\text { I } 874-1888 \\
\text { I } 888-1910 \\
\text { I010- }\end{array}$ \\
\hline
\end{tabular}

TABLE V. THE STATES

\begin{tabular}{|c|c|c|c|c|c|c|c|c|c|}
\hline \multirow[b]{2}{*}{ State } & \multirow[b]{2}{*}{$\begin{array}{c}\text { BECAME } \\
\text { MEMEER } \\
\text { OF } \\
\text { UNION }\end{array}$} & \multirow[b]{2}{*}{$\begin{array}{l}\text { LAND } \\
\text { AREA. } \\
\text { SQU } \backslash R E \\
\text { MILES }\end{array}$} & \multirow[b]{2}{*}{$\begin{array}{c}\text { Population } \\
\text { IOIO }\end{array}$} & \multirow[b]{2}{*}{ 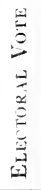 } & \multicolumn{5}{|c|}{ RANK IN I9IO } \\
\hline & & & & & 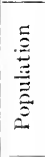 & 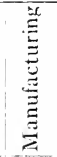 & 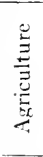 & 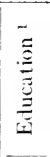 & 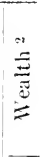 \\
\hline Alabama & 1819 & 51,279 & $2,138,093$ & I 2 & I8 & 30 & 17 & 48 & 27 \\
\hline Arizona & I9I 2 & I 13,354 & 204.354 & 3 & +5 & +2 & 47 & 30 & $4^{6}$ \\
\hline Arkansas & 1836 & 52,525 & $1,57+, 4+40$ & 9 & 25 & 35 & 32 & +3 & iI \\
\hline California & I 850 & 155,652 & $2,377,5+9$ & I 3 & 12 & I I & 25 & + & 6 \\
\hline Colorado & 1876 & 103,$6 ; 8$ & 799,024 & 6 & 32 & 31 & 29 & 9 & $2 \mathrm{I}$ \\
\hline Connecticut & 1788 & 4,820 & 1, I I $4.75^{6}$ & 7 & 31 & 12 & 40 & 5 & 19 \\
\hline Delaware & I 787 & 1,965 & 202,322 & 3 & to & +1 & th & 35 & 47 \\
\hline Florida & I $8+5$ & 54,861 & $752,6 \mathrm{ro}$ & 6 & 3.3 & 37 & 38 & 34 & 41 \\
\hline Georgia & I 788 & 58,725 & $2,609,121$ & If & Io & 24 & 5 & 44 & 22 \\
\hline Idaho & I 890 & 83,354 & 325,594 & 4 & $4+$ & 43 & 34 & 19 & 43 \\
\hline Illinois & 1818 & 56,043 & $5,638,591$ & 29 & 3 & 3 & I & 8 & 3 \\
\hline Indiana & 1816 & 36,045 & $2,700, S_{7} 6$ & 15 & 9 & 9 & 8 & 10 & I 2 \\
\hline Iowa & I $\delta_{4} 6$ & 55,586 & $2,224,771$ & 13 & 15 & 18 & 2 & $2 \mathrm{I}$ & 7 \\
\hline Kansas & I 86 I & $8 \mathrm{I}, 774$ & $1,690,049$ & IO & 22 & 14 & 0 & 24 & I 5 \\
\hline Kentucky & I 792 & $40, I S_{1}$ & $2,289,905$ & I I & I4 & 20 & $2 \mathrm{I}$ & 42 & 17 \\
\hline Louisiana & 18 & 45.709 & $1,65^{6,388}$ & 10 & 24 & 19 & 27 & 39 & 26 \\
\hline Maine & I 820 & 29,895 & $7+2,37 \mathrm{I}$ & 6 & 34 & 27 & 35 & 22 & 33 \\
\hline Maryland & I 788 & $9,9+\mathrm{I}$ & I, $295,3+6$ & s & 27 & 15 & $3 \mathrm{I}$ & 36 & 18 \\
\hline Massachusetts & I 788 & $8,0,39$ & $3,366,416$ & IS & 6 & 4 & 37 & 2 & 5 \\
\hline Mich & 1837 & 57,480 & $2,810,173$ & I 5 & S & 7 & It & 17 & IO \\
\hline Minn & I 85 & So, 85 & $2,075,708$ & I 2 & I9 & I 3 & 10 & 20 & 9 \\
\hline Mississippi & I 8 I 7 & 46,362 & I, 797, IIt & 10 & $2 \mathrm{I}$ & 34 & 15 & 45 & 36 \\
\hline Missouri & I $\sum_{21}$ & 68,727 & $3,293,335$ & I 8 & 7 & 10 & 7 & 32 & 8 \\
\hline Montana & ז 889 & I $46,20 \mathrm{I}$ & 376,053 & t & to & $3^{6}$ & 36 & I6 & 34 \\
\hline Nebraska & I 857 & $7^{6}$, So & $1,102,214$ & 8 & 29 & 25 & 9 & 25 & I6 \\
\hline Nevada & 1864 & 100,821 & 81,875 & 3 & 48 & $4^{n)}$ & $4^{6}$ & 27 & 48 \\
\hline New Hampshire & 1788 & $0,0.31$ & $4.30,572$ & 4 & 39 & 28 & +1 & I 3 & 39 \\
\hline New Jerse & 1787 & $7,5 \mathrm{It}$ & $2,537, \mathrm{I} 67$ & It & I I & 6 & 32 & 7 & I I \\
\hline New Mexic & 1912 & $122,50,3$ & 327,301 & 3 & 43 & 47 & 45 & 40 & 44 \\
\hline New York & I 788 & 47,654 & $9,113,614$ & +5 & I & 1 & I 2 & 3 & I \\
\hline North Caro & $17 S_{9}$ & $48,7+0$ & $2,206,287$ & 12 & $1^{6}$ & 23 & 20 & $7^{6}$ & 29 \\
\hline North Dakota & 1889 & $70,18_{3}$ & 577,056 & 5 & 37 & 44 & II & 18 & 35 \\
\hline Ohio & I $S \circ 3$ & 40,740 & $4,767,12 \mathrm{I}$ & 24 & 4 & 5 & 4 & 6 & 4 \\
\hline
\end{tabular}


THE STATES. - Continu'd

\begin{tabular}{|c|c|c|c|c|c|c|c|c|c|}
\hline \multirow[b]{2}{*}{ State } & \multirow[b]{2}{*}{$\begin{array}{c}\text { BECAME } \\
\text { MEMBER } \\
\text { OF } \\
\text { UNION }\end{array}$} & \multirow[b]{2}{*}{$\begin{array}{c}\text { LAND } \\
\text { AREA, } \\
\text { SqUARE } \\
\text { MILES }\end{array}$} & \multirow[b]{2}{*}{$\begin{array}{c}\text { Population } \\
\text { I9Io }\end{array}$} & \multirow[b]{2}{*}{ 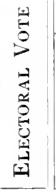 } & \multicolumn{5}{|c|}{ RANK IN I9IO } \\
\hline & & & & & 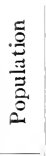 & 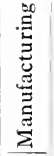 & 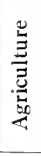 & 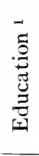 & $\underbrace{\infty}_{i}$ \\
\hline Oklahoma & I 907 & 69,414 & I $, 657,155$ & 10 & 23 & 40 & I9 & $3 \mathrm{I}$ & \\
\hline Oregon & I 859 & 95,607 & 672,765 & 5 & 35 & 33 & 30 & I5 & \\
\hline Pennsylvania & 1787 & $4+, 832$ & $7,665,7$ I I & 38 & 2 & 2 & I3 & 23 & \\
\hline Rhode Island & 1790 & 1,067 & 542,610 & 5 & 38 & I 6 & 48 & I I & \\
\hline South Carolina & 1788 & 30,495 & $\mathrm{I}, 5 \mathrm{I} 5,400$ & 9 & 26 & 32 & I 6 & 47 & \\
\hline South Dakota & I 889 & 76,868 & 583,888 & 5 & 36 & 45 & 22 & 26 & \\
\hline Tennessee & 1796 & $+1,687$ & $2,184,789$ & 12 & 17 & 26 & 24 & 37 & \\
\hline Texas & $18+5$ & 262,398 & $3,896,542$ & 20 & 5 & 17 & 3 & 38 & \\
\hline Utah & I 896 & $82,18_{4}$ & $373.35 \mathrm{I}$ & + & $4 \mathrm{I}$ & 39 & $4 \mathrm{I}$ & It & \\
\hline Vermont & I $79 \mathrm{I}$ & 9,124 & 355,956 & 4 & $4^{2}$ & 38 & 39 & 12 & \\
\hline Virginia & 1788 & 40,262 & $2,061,612$ & I 2 & 20 & 22 & 26 & $4 I$ & \\
\hline Washington & I 889 & 66,836 & $\mathrm{I}, \mathrm{I}+\mathrm{I}, 990$ & 7 & 30 & $2 \mathrm{I}$ & 28 & I & \\
\hline West Virginia & 1863 & 24,022 & I, 22I, II 9 & 8 & 28 & 29 & 33 & 33 & \\
\hline Wisconsin & 1848 & 55,256 & $2,333,860$ & I3 & I3 & 8 & I 8 & 28 & \\
\hline \multirow[t]{2}{*}{ Wyoming } & I 890 & 97,594 & I 45,965 & 3 & 47 & 48 & 43 & 29 & 45 \\
\hline & & $2,973,8_{30}$ & $9 \mathrm{I}, 6+1, \mathrm{I} 97$ & $53 \mathrm{I}$ & & & & & \\
\hline
\end{tabular}

${ }^{1}$ Report of Russell Sage Foundation.

${ }^{2}$ Census report for 1904 .

TABLE VI. THE TERRITORIES

\begin{tabular}{|c|c|c|c|}
\hline \multirow{2}{*}{ Territory } & \multirow{2}{*}{$\begin{array}{c}\text { Area, } \\
\text { Square Miles }\end{array}$} & \multicolumn{2}{|c|}{ Population } \\
\hline & & 1910 & 1900 \\
\hline $\begin{array}{l}\text { Alaska } \\
\text { Hawaii } \\
\text { Porto Rico } \\
\text { Philippine Islands }\end{array}$ & $\begin{array}{r}590,884 \\
6,449 \\
3,435 \\
\text { I } 5,026\end{array}$ & $\begin{array}{r}64,356 \\
191,909 \\
\text { I, I } 18,012\end{array}$ & $\begin{array}{r}63,590 \\
154,001 \\
953,243 \\
7,635,426^{1}\end{array}$ \\
\hline
\end{tabular}

11903.

TABLE VII. THE SECTIONS (I790-I 860 )

\begin{tabular}{|c|c|c|c|c|c|c|}
\hline \multirow{2}{*}{ DATE } & \multicolumn{2}{|c|}{ Population } & \multicolumn{2}{|c|}{ SENATE } & \multicolumn{2}{|c|}{ House ${ }^{1}$} \\
\hline & Free States & Slave States & Free & Slave & Free & Slave \\
\hline 1790 & $1,968,455$ & $1,961,372$ & $\mathrm{I}_{4}$ & 12 & 55 & 46 \\
\hline I Soo & $2,68_{4}, 6$ I 6 & $2,62 \mathrm{I}, 3 \mathrm{I} 6$ & I 6 & I6 & 76 & 65 \\
\hline I910 & $3,75^{8,910}$ & $3,4 \mathrm{So}, 9 \circ 2$ & I 8 & I6 & 103 & 78 \\
\hline I 820 & 5, I 52,372 & $4,485,8$ I 9 & 24 & 24 & I 23 & 90 \\
\hline I 830 & $7,006,399$ & $5,8,8,3$ I 2 & 24 & 24 & $I+1$ & 99 \\
\hline 1840 & $9,733,922$ & $7,334,433$ & 26 & 26 & I35 & 88 \\
\hline I 850 & I $3,599,488$ & $9,663,997$ & 32 & 30 & I 44 & 90 \\
\hline I 860 & I $9,128,4$ I 8 & I $2,315,372$ & 36 & 30 & I 55 & $9 \mathrm{I}$ \\
\hline
\end{tabular}

1 The representation in the House is that based on the census of the year mentioned, including only states in the Union in that year. 


\section{INDEX}

Abolitionists, the, $335^{-336}, 34^{2}$, American Association, 150. 367 ; see also Slavery.

Acadia, 87, 90, 94, 98 .

Acts of trade, see Navigation acts.

Adams, C. F., 39I, 420.

Adams, John: before $1797, \mathbf{3} 35,146$, $158,18_{3}, 1 S_{5}, 223$.

biography of, 243 .

portrait of, $2+2$.

president, $2+2-2+7$.

Adams, John Q.: before 1824, 261 , $275,288,290$.

portrait of, 296.

president, 295, 296, 297, 298, 305.

Adams, Samuel, 146, 147.

Admission of new states, 220, 334, map opposite page 5.38 .

Agriculture: in colonial times, tro I I I.

after Civil War, 458-460.

chart of, $45^{8}$.

American Federation of Labor, 559.

American party, $35 \mathrm{~s}$.

Ames, Fisher, 236.

Amnesty, after Civil War, 433,435 .

Anderson, Major Robert, $3 \mathrm{~S}_{\mathbf{l}-3} \mathrm{~S}_{2}$.

Andre, Major John, i 80.

Andros, Sir Edmund, 70. So, Si .

Anglo-Saxons, in colonies, see Colonies, English, people of.

Annapolis Conference ( 786$), 200$.

Annexations of territory, I $8,3-186$, $253-256, \quad 288-289, \quad 33 \mathrm{I}-332$, $341-344,502,509$.

intietam, battle of, tro-tII, fI3.

Anti-Federalists, 203.

Inti-Masonic party, 300 .

Anti-rebate laws, $55^{6} n$.

Anti-trust laws, of the states, 55I ; of the [.S., 529, 552-557, $555 \mathrm{n}$.

Appalachian mountains, 7,9 .

exports of products of, $460,55^{6}$.

Aguinaldo, 507 .

Aix-la-Chapelle, treaty of (I 748 ). $94,95$.

Alabama, $285,375,418,419,439$, $5+1$.

Alabama, the, $t 20$.

Claims, 420.

Alaska, 509.

boundary, ${ }_{4} 84$.

Albany Congress, 97.

Alexander of Russia, 275 .

Alexander VI, Pope, 26.

Alger, Russell A., 507.

Algonquin Indians, $12,44,55,78$, 260.

Alien acts ( 7998$), 2+4$.

Allegheny River, French forts on, 95.

Alliance, French (I778), I74-175, 24.

Farmers', 462-463.

Holy, 280-29o.

Altgeld, Governor, 560 .

Amendments, see Constitution.

America, naming of, 29 (maps).

Appointments to public office, $3 \mathrm{II}^{-}$ $302,+67-469$.

Appomattox, +25 .

Apportionment of representatives, 202.

Arbitration, industrial, 56 I.

national, 48S-490, 535 .

treaties, 515 .

Aristotle, views of, 21 .

Arkansas, 334, 384, 417, 435, 439 .

Armada, Spanish, $33,34,36$.

Armstrong, John, 262.

Army : after i Sor, 250.

American dread of, $138,192$.

in 1763,137 .

in Civil War, $38_{2}-3 s_{3}, 38_{7}-38_{9}$, 429.

in Revolutionary IVar, 162-164, I 75, I92-I0.3.

in $\mathrm{Nl}$ ar of $\mathrm{I} S \mathrm{I} 2,270,277$.

since $\mathrm{I} S 9 \mathrm{~S}, 49 \mathrm{~S}, 503,504$.

Arnold, Benedict, $155,10_{3}, 172$.

treason of, r79-rSo.

Arthur, Chester A.

portrait of, 405 .

president, 465,476 . 
Articles of Confederation, see Confederation.

Ashburton treaty (I $S_{42}$ ), 3I 3-3I4.

Asia, trade with, 19-20, 225, 5It, 557.

Assemblies: beginnings of, 43,49 , 52,60 .

development of, 92-93, $14+4$.

Assistance, writs of, $\mathrm{I} 34-\mathrm{I} 35, \mathrm{I}+5$.

Assumption of state debts, $23 t^{-235}$.

Atlanta, capture of, $42 \mathrm{I}-422$.

Atlantic slope, 7, 8, 9, I6I ; see also England, colonies of.

Austerlitz, battle of, 260 .

Australian ballot, $469-470$.

Austria, 289.

Ayllon, Lucas de, 3 I.

BACoN's rebellion, 74 .

Bahama Islands, 26, 389 .

Balboa, Vasco de, 30.

Ballinger, 510, 529, 535 .

Ballot, reform of, $469-470,533$.

Baltimore, city of, 219, 274, $3 S_{2}, 53 \mathrm{~S}$.

Baltimore, Lords, 59, 60-6 I, $82-8_{3}$.

Bank: first U.S., 236-237, 279-280. second L.S., 279-2S0, 307-310.

Banks, colonial, i It. present national, $391,4{ }_{5}$.

Western state, 230, 309, 328.

Baptists, see Churches.

Barbary war, 276-277.

Bear Flag Republic (I $8+6$ ), $3+6$.

Beauregard, Gen. P. G. T., 385 .

Beef, embalmed, 503.

Belknap, IV. IV., ++5 .

Bell, John, 372-373.

Bemis Heights, battles of, I $72-173$.

Bennington, battle of, 171 .

Bering Sea controversy, 484

Berkeley, Sir John, 69.

Berkeley, Sir William, 73-75.

Berlin Decree (ISo6), 264.

Bermuda Islands, $3 \mathrm{~S} 9$.

Bill of rights (I689), Si. national, 208. state, I60.

Black Hawk War (1832), 303 .

Black Hills, gold in, 457 .

Blaine, James G.: character of, 466 . political leader, 464-466. portrait of, 466 .

Blair, Montgomery, 384 .

Bland-Allison Silver Act (1878), 457,479 .
Blockade: in Civil IVar, $38_{3}, 380-$ 390.

in War of ISI 2, 272, $2 S_{2}$.

Blockade runners, $389,+20$.

Blount, James H., 486 .

Blue laws of Connecticut, 57 .

Board of Trade, $S_{4},{ }_{2} 28,130$.

"Body of Liberties," 53.

Bonds, sale of: in Civil War, 39I392.

in war with Spain, 502.

Bonne Homme Richard, the, I77.

Bonus Bill, 282.

Border states, $354, \quad 377-378,383^{-}$ $384,412$.

Boss, political, 301,570 .

Boston: city, S1, IOS, I35, I 40,146 , It, I 49, 2 I9.

in Revolution, $15 t^{-1} 55$, I 56.

map of, 154 .

massacre, $\mathrm{I}+6$.

port bill, i 4 S.

tea party, I 48 .

Boston Neiis Letter, 120.

Boundaries of U.S., $185,255^{-256}$, 289, 343-344, 347, 502, 509.

Bounties: paid by England, 132, I34, I3 S.

paid on sugar ( 1 S9o), +76 .

Boxer movement in China (1900), 5 I 5,5 I9.

Braddock's defeat, 9 S.

Bradford, Governor William, 49.

Bragg, General Braxton, 4II, 4I8tig.

Brandywine, battle of, I70-17 I.

Brazil, Portuguese in, 27.

Breckenridge, John C., 372-373.

Brewster, William, +8 .

Bristow, B. H., +45.

Brooklyn Heights, battle of, I67.

Brooks, Preston, 360.

Brown, General Jacob, 273.

Brown, John, 360.

Bryan, William J., $+\mathrm{SI}_{\mathrm{I}}+\mathrm{S}_{2}, 507,5 \mathrm{I} 6$, 538 .

Buchanan, President James, 358, $360,366,372,374-375,377$, 382,395 .

Buell, General D. C., 404, 4I I.

Buena Vista, battle of, 345 .

Buffalo, Pan-American exposition at, 526,560 .

Bull Run, battles of, $384-385,396$, 410. 
Bulwer (Clayton) treaty ( $\left.18_{50}\right)$, Census, 202; see Population. 5IO-5II. Centennial exposition, 548 .

Bunker Hill, battle of, I $54^{-1} 55$.

Burgoyne's expedition (I 777 ), I69, I 7 I-I 73 .

Central America, 28, 30, 355, 487, 5 IO- 5 It 4

Cervera, Admiral, 500-501.

Burlingame treaty (1869), 562 $n$.

Burnside, General A. E., ti I.

Burr, Aaron, 246, 256-257.

Business, see Commerce, Industry, Panics, Prosperity, Tariff.

CABInet, the president's, $2 \mathrm{I}_{3}$.

Cable, submarine, 323 .

Cabots, the, 28.

Cabral, 27.

Cabrillo, 3 I.

Calhoun, John C.: 279, 288. and extension of slavery, 34 I, $35 \mathrm{I}$. and nullification, 305, 306 . portrait of, $35 \mathrm{I}$.

California: admission of, 349-352. conquest of, $325,334,346-347$.

Calverts, the, 59-61, $82-83$.

Camden, battle of, I 79 .

Campos, General, 495.

Canada: attempted conquest of ( 1812$), 271,272$. conquest and government of, 99-I01, I 37, I49, I 55-I 50. disputes with, $483,484,485 n$. reciprocity with, 535 . settlement of, $87-88,93$.

Canals: Erie, 3 IS, 32 I. other state, 318-319, 32 I. proposed national, see Isthmian Canal.

Canary Islands, 25.

Canning, George, 290.

Cape Verde Islands, 26, 27.

Capital of the U.S., 234-235; see also Washington.

Caravel of Columbus (picture), 26.

Carleton, Sir Guy, I56.

Carolina, 75-76; see North Carolina, and South Carolina.

Caroline, Ft., 34-35.

Carpet baggers, $44 \mathrm{I}-44^{2}$.

Cars, private, and the public, 554 , $55^{6} \mathrm{nl} .2$.

Cartier, explorations of, 32 .

Cass, Lewis, $34^{8}$.

Catholics, see Churches.

Caucus, use of, 295, 300 .

Cavite, 499.

Cemetery Ridge, Gettysburg, 4I 6 .

Champlain: Samuel de, $S_{7}-88$. portrait of, 87 .

Champlain, Lake, 94, I55, I56, I6 I, I 69, I 7 I, 273.

Chancellorsville, battle of, 414 .

Channing, Edward, 354.

Charles I, and the Puritans, 46, 5o$5 \mathrm{I}$.

Charles II, 63, 74, 77, 79 .

Charles V, of Spain, 33 .

Charleston, $7^{6}$, Io\&, I $48,1_{56}, 1_{7} 8$, $371,375,381,389,424$.

Charlestown, Mass., I $54-155$.

Charter colonies: control of, I $28-$ I 29.

map of, opp. 82 .

Charter of Privileges, Pa. (I 70I), 7 I.

Charters: of $1606,40,44$. revocation of, 44, 78-79, I 28-I 29. sea-to-sea, 42, 5o, 56, 75 .

Chase, Salmon P., 206, 356, 373, 3SI, 440 .

impeachment of, $25 \mathrm{I}-252$.

Chatham, Lord (IIm. Pitt), 98, 99, I42.

Chattanooga, campaigns around, 4 I 8-4ig.

map of, 4 I 8 .

Checks and balances in U.S. government, 205-207.

Cherokee Indians, 302.

Cherry Valley massacre, I 78.

Chesupeake, the, 259, 200.

Chicago: exposition at (IS93), 569. strike in ( 1894$), 560$. see also, 372, 48I, 536, 538, 567 .

Chickamauga, battle of, 4 I 9 .

Children's Bureau, 537.

China: Boxer movement in, 5 I 5, 5 I 9. loan, and "dollar diplomacy," 542 and $n .2$.

integrity of, 5 I 9 .

republic of, 520 .

trade with, I9, 225 .

treaties with, $510 n$.

Chinese exclusion, $2 n$.

Churches: Anglican, 77, 80, II5, I 10 .

before Civil War, 367 .

Catholic, 60, 8I, II6, 223, 224. 
Churches: early national, 223, 225. other colonial, 53 , I 16 .

Puritan, 46, 50-5I, 53-54, 8o, I $14-116,224$.

Cibola, seven cities of, 3 I .

Cincinnati, 220.

Cincinnati, Society of, 193.

Cities: colonial, ros.

diagram of, 566 .

government of, 33I, 442-443, 569 .

growth of, $219,33 \mathrm{I}, 566$.

Citizenship, 190, 240, 361, 448.

Civil Rights acts, ( 1866 ) 437, ( 1875 ) $450 \mathrm{n}$.

Civil Service reform, 444, 467-469, 527.

Civil War: causes of, $378-380$.

changes during, $447-45 \mathrm{I}$.

conditions affecting, 386-395.

cost and results of, $425,+28-429$, $447-45 \mathrm{I}$

prosecution of, 399-429.

summary of campaigns of, $427^{-}$ 428.

Clarendon, Earl of, 63,75 .

Clark, expedition of Lewis and, 255.

Clark, George R., i 78 .

Clay, Henry: as political leader, $275,279,288,296,297,305$, $307,308,3+2,35 \mathrm{I}$.

character of, 270 .

compromises of, $287,307,350-35 \mathrm{I}$. portrait of, $35 \mathrm{I}$.

Clayton-Bulwer treaty (i $8_{5}$ o), 5 Io.

Clermont, the, $3 \mathrm{I} 7$.

Cleveland, President Grover: first term of, 465-467, 468, 470$47 \mathrm{I}, 475,486$.

portrait of, 467 .

second term of, $478,479,480-482$, $486,489-490,495-496,560$.

Climate, 3, 4 (map).

Clinton, De Witt, 3 I 8.

Clinton, Sir Henry, I56, I73, 177 , I 78,182 .

Coaches, I $21,228-229$.

Coal: labor controversies, $56 \mathrm{I}$. production of, $45^{8}$.

Cod fisheries, see Fisheries.

Coinage, see Silver.

free, $227-228,457,4 S_{1}$.

Cold Harbor, battle of, 422 .

Coligny, Gasper de, 34 .

Colleges, I 19-1 20, 572 .
Colombia, negotiations with (1903) 5 I I, 527.

Colonial policy, American, 507-508.

Colonies: American, 508-509.

Dutch, 65-68.

English, government of, 92-93, I 24 .

industry in, IIO-II4.

other conditions in, I I 5-1 22.

people of, IO4-I Io.

relations of, to Great Britain, $70,8_{3}, 127^{-1} 5^{2}$.

settlement of, $36,41,48-50$, $5^{6-57}, 59,64-65,70,91$.

French, 32, 34, 86-89, 93, 100.

Spanish, 31, 35, 289.

Colonists and Indians, see Indians.

Colorado, 562, 572 .

Columbia, District of, see District.

Columbia river, 343,344 .

Columbia, S.C., 424 .

Columbian exposition ( 1893 ), 569.

Columbus, Christopher, $21,24^{-28}$.

portrait of, 25 .

Columbus, Ky., 401.

Commerce, Dep't of, 554 .

Commerce: colonial, I IO-I I 2, I3 II 35 .

diagrams of, 258,458 .

early national, 202, 232, 325 .

interstate, I99, 317-322, 463-464, $55^{2-553 .}$

interstate commerce act, $463-464$, $528,553,556$.

later national, $450,457^{-4}-48,556$. neutral, 240, 257-266.

under Confederation, 197-198, 225. see also Panics, Railways.

Commission government, $57 \mathrm{I}$.

Commission, $55^{2}$.

Committees of Correspondence, 147.

Committee on Rules, 532.

Common carriers, see Railways.

Commons, house of, $143^{-144 .}$

Communism in colonies, $4 \mathrm{I}, 49$.

Compact theory of the Constitution, $205,245,303,374$.

Compromises: in Constitutional Convention, 20I-203.

Missouri (1820), 286-288.

over nullification ( $\mathrm{I}_{333}$ ), 306-307.

over slavery, (I 850 ) 350-353. (I 861 I) $375,377$.

Comstock Lode, 457.

Concord, battle of, 154 . 
Conestoga wagons, 121, 122.

Confederacy, Southern: character of, $376,383,386,387,390$, 393-394.

failure of, $+25,+47-448$.

formation of, $375^{-376}$.

leaders of, after $\mathrm{I} \mathrm{S}_{55}, 433,43 \mathrm{O}$.

restriction of territory of, map opp. 427 .

Confederation: Articles of, ${ }_{5} 58$, I $_{80}-$ 192.

character of, 190-192.

critical conditions under, s92- I00. formation of, I 59, I So.

Confederation, New England, 57-50.

Congregationalists, see Churches, Puritan.

Congress: Albany (I 754), 97-c; 8

during Confederation, ${ }_{1} 8_{3}, \quad$ I $89^{-}$ 190, 191, 102, 195, 196, 198, $200,204$.

First Continental ( $177+$ ) , I 19 .

Second Continental ( 1775$)$, $157^{-}$ I60, $163,165,176$.

Stamp Act (1765), I4I.

Congress, under Constitution: Appendix.

and colonies, 512 .

and reconstruction, $434^{-}+41,4+5^{-}$ $4+7,450$.

creation and organization of, $20 \mathrm{I}^{-}$ 202, 206, 210-212, appendix, table III.

increase of powers of, $227,279^{-}$ $28_{1}, 4+7.450,506,553,554$.

powers of, over slavery, $287,3.36$. $356,36 r, 371-372,+12,450$.

Conkling, Roscoe, $464-465$.

Connecticut: colony of, I6, $55-56$, $58,64,73,77,80,8_{3}$.

state of, I60, I93, I95, I99.

Connecticut Compromise, 20I-202.

Conservation: Policy, 520; and the Distribution of wealth, 57.3 ; of Human Life, 574 .

Constitution of the Inited States: first twelve amendments of, $208,2+7$.

formation of, $200-203$.

implied powers of, $237,28 \mathrm{I}, 449^{-}$ 450.

later amendments of, (1 3 th) 4.36 , $4.8 ; \quad(1+$ th) $438,448-4+9$; (I5th) $439,44^{8}$; (I6th) $5+1$; (i 7 th) $54 \mathrm{t}$. method of amendment of, 207-208.

ratification of, $203^{-204}$.

sources of, 208-209.

theories concerning, 204-206, 303, $304,314-315,+47$.

see also Unwritten constitution.

Constitution, the, 272 .

Constitution, written, I6o, IS9, 204-200, 448, 576 .

Constitutional Union party (is6o), 371 .

Constitutions of the states, 160,328 , $53+n .2$.

Continental congresses, see Congress.

"Continental line," 163 .

Continental money, I65-I66.

Contraband of war, $240,257,412$.

Convention: nominating, $300,3+2$, $371-372$.

of $1787,201-203$.

state, 160 .

Convicts in colonial times, ro6.

Conway cabal, i 76 .

Couke, Jay, 558.

Corinth, Miss., 401, 404.

Corn, see Maize.

Cornwallis, General C., I69, I79, I $80-182$.

Coronado, F. V. de, 3 I.

Corporations: bureau of, 554 .

control of, $55 \mathrm{I}^{-5} 55$.

development of, 550-551, and n.2. tax, $5+4$.

Correspondence, see Committees.

Corruption, $530-53 \mathrm{I}, 570$.

Cortez, Hernando, 32.

Cosmographie Introductio, 29.

Cotton, importance of, 339-340, $386,390,55^{6} \mathrm{n} .3$.

Cotton gin, 222, 3.39.

Councils of the colonies, 123 .

County government, 122-123.

Courts, colonial, 123. national, see Supreme Court. state, $25 \mathrm{I}$.

Cowpens, battle of, $\mathrm{I} S \mathrm{I}$.

Crater, at Petersburs, 123.

Crawford, WV. H., 288, 296.

Credit Mobilier, $4+4^{-}+45$.

Creek Indians, 274, 302 .

Criminals, i 17 .

Crittenden compromise, 377.

Cuba: American protectorate over, 516-5I7.

insurrections in, $494^{-496 .}$ 
Cuba : other relations with, 26 . proposed annexation of, $35 t^{-355}$. recent relations with, 502, 505, 5 I6-5I 7 .

war in, ${ }_{49}-502$.

Cumberland Road, $2 \mathrm{~S}_{2}-2 \mathrm{~S}_{3}, 3 \mathrm{I} S$.

Currency: before Civil War, II3${ }_{11} 4,227-228,2 \mathrm{So}$.

since Civil War, 392-393, 455$456,479,483$.

Currency Act (1913), 546 .

Customs, collection of, 132-135. I +5 ; see also Tariff.

DAGUERREOTYPE, 323.

Dartmouth College case, 28I.

Davis (explorer), 35 .

Davis, Jefferson : as president of Confederacy, $376,387,394,+22$. biography of, $376-377$. portrait of, 376 .

Day, William R., $+8_{3}$.

Debt : imprisonment for, 329. national, $232,233-235,391-302$. +54 .

Debtors' laws, 329.

Declaration of Independence, $157^{-}$ I6o.

Declaration of Rights, (I66I) 77 . ( I 765) I+I, ( I 774) I 49-I 50.

Declaratory Act ( 766 ), $1+2$.

Delaware, $67,72,204,384$.

Demarcation, line of, 27 .

Democracy: in colonial times, 52$53,56,92$, I $22-123$, I 29.

in early national period, $284,292$. 299, 326-320.

in recent times, $563-565,577$.

Democratic party, see Parties.

Deposit of public moneys, 309.

De Soto, F., 32.

Detroit, 94 .

Dewey, Admiral George, 499-500. portrait of, 500 .

Diaz, 5 I 8 .

Dickinson, John, ISg.

Dingley Tariff ( 1807 ), 478 .

Dinwiddie, Governor, 95.

Diplomacy : after I8zo, 2S9-29r, $3+\mathrm{I}, 347,35+-355,4 \mathrm{~S}_{3}-49 \mathrm{I}$.

before I $S_{20}$, IS $4-\mathrm{IS}_{5}, \quad 2+0-2+3$, $252-255,263,275$.

Direct primary, 532-533, constitutional amendment, $54 \mathrm{I}$.

Direct taxes, 202, 236.
Discovery of America, 24-30, 37 .

District of Columbia, 234-235, 273$27+336,350-353,412$.

Disunion, see Secession.

Doctors, colonial, it 4 .

"Dollar diplomacy," $520 n$.

Dollars, see Silver and Currency.

Dominion of New England, 79.

Donelson, Fort, 402-403.

Dongan, Governor, 69.

Dorchester Hcights, 156.

Dorchester venture, 49 .

Douglas, Stephen A., 355-356, 360, $368-369,372-373,426$.

portrait of, 356 .

Drafts, $388,394,305$.

Drake, Sir Francis, 34, 35, 36 .

Dred Scott decision, 360-361, 363, $360-367,369,37$ I, 395.

Duane, II. J., 300.

Duquesne, Ft., 95, 97, 98 .

Dutch: commercial rivalry of, with England, 34, 63-64, 67. in Connecticut, 55. in Delaware, 67 . in New York, 65-68.

Dutch West India companies, 65 .

E.ARLy, General Jubal, +23 .

East, trade with, I9.

East India Company, 34, I4S.

Edison, Thomas A., portrait of, 568.

Education: after I $800,329-330$. in colonial times, I I 8-I 20.

Educational land grants, 330 ,

El Caney, battle of, 501.

Elections: qualifications for. I 23 , $327-328$; see also Suffrage. reform of, $469-470$.

Elections, presidential, appendix, ( I $\left.7 \mathrm{~S}_{9}\right)$ 209, ( ( 7966$) 2+2$, ( I SooI SOI) $246-2+7$ (map), (I $824-$ IS25) $295^{-297}$ (map), (IS2S) 29S-300, (I $\left.S_{32}\right)$ 308, ( $\left.S_{3} 6\right)$ 3 II, (I $8+0) 3$ II-3I3, (IS+4) 342 (map), (1 $8+8) 3+8$, (I 852 ) 353 , (I 856$) 358$, (I 860 ) 37 I373 (map), (1 864$)+26$, (I 868 ) $4+3,($ I 872$)$ 44t, (IS76) 445+47 (map), (I 880 ) 46+-465, (18S4) $+65-467$, (I $88 S) 475$, (I $\left.\mathrm{SO2}_{9}\right) \quad 476,(\mathrm{I} 896) \quad 48 \mathrm{I}-4 \mathrm{~S} 2$ (map), (1900) 507, (1904) 527, (I 00 S) 530, (I912) 538, and map, 539 . 
Electoral "college," 207, 209. Electoral Commission ( 1870 ), 445$+46$.

Electoral Count Act (I886), 47 I.

Electricity, use of, 322, 568 .

Elizabeth, Queen, 33, 47 .

Elkins Anti-Rebate law, $556 n$.

Emancipation: after I $829,335,4$ II, $4 \mathrm{I} 3$.

before 1829,221 .

completion of, 433 .

proclamation of ( $\mathrm{I}_{363}$ ), 4I3.

Embargoes: 260-262.

results of, $262-263$.

Emigrant aid companies, 359.

Emigration, see Immigration.

England: after $1760, \mathrm{I}_{35^{-1}} 37, \mathrm{I} 43^{-}$ I 44, I5O-I5I, IS3, 240, $39 \mathrm{I}$.

colonies of, $9,36,40-159 ;$ see Colonies.

conditions in, before I760, I9, $33,63-64,80-81,127$.

contests of, with France, so, 88, 89-90, 94-IOI.

dispute of, with colonies, I35-I5I. first war of, with U.S., I $51-186$.

government of colonies of, 92 , I $22-123$.

minor controversies of, with U.S., before War of I812, 198, 226, $232,239^{-242}, 257-265$.

second war of, with U.S., 260275 .

since I $860,343-344,390-391,420$, $455,483-4 S_{4}, 488-490,510$.

treaties of, with U.S., $183-186$, $2.40-2+2,275$.

Enlistments, $163,387,388$.

Enumerated articles, colonial, 64, I32, I33.

Eratosthenes, views of, 2 I.

Ericsson, John, 3 I 7 .

Erie Canal, 318, 32 I.

Erie, Lake, battle of, 271.

Erskine treaty, 263.

Essex, the, 272.

Europe, see names of different countries.

Eutaw springs, battle of, I 82.

Excise taxes, 235, 250, 393, 455, 502 .

Executive departments, 2 I 2-2 I 4.

Expansion, 575-578; see also Territorial growth.

Exploration, in America, 30-36, $37,87-89,255$.
Expositions, $569 n$.; see also Pictures, 568, 569, 570, $57 \mathrm{I}$.

Expunging resolution (I 835), 309 .

FACTORY system after i $810,323$.

Farmers' Alliance, $462-463$.

Farms, number of, see Agriculture.

Farragut, Admiral David G., 405, 4 Io.

Federalist, the, 204.

Federalists, 204, 237-238; see Parties.

Federal system of government, 205$206,4+7-450,576$.

Ferdinand I of Spain, 25.

Ferguson, Major, I 80 .

Field, Cyrus IV., 323.

Filibustering in Congress, 476 .

Filibusters, in Cuba, etc., $354-355$.

Fillmore, President Millard, 348, 352,358 .

Finance: in Civil War, $38_{3}, 39 \mathrm{I}^{-}$ $394,+28-429$.

in Spanish war, 502 .

in times of peace, 212, 233-237, $454^{-457}, 478-483$.

in war of 1812,280 .

Revolutionary, I64-I 66.

under Confederation, I9I, I98I99, 236 .

see also Debts, Paper money Tariff, Taxation.

Fiscal bank bill, $3 \mathrm{I}_{3}$.

Fiscal corporation, 313 .

Fish, Hamilton, 443.

Fisher, Ft., +19-420.

Fisheries, northeastern, 6, 49, 90, I I I, I 83, I 84, I $85,483-484$.

Fiske, John, quoted, 99.

Five Forks, 425.

Five Nations, see Iroquois Indians.

Flag, first American, I59.

Florida: exploration in, 30, 31, 32 . state of, $303,334,439,445$.

territorial changes of, Ioo, I96I 97, 253, 255, 288-289, 332.

Folk, and corruption, $57 \mathrm{I}$.

Foote, Admiral A. H., 40.4.

Force Acts, (I 808 ) 261, ( 1833 ) 307, (I 870 ) 44 I.

Foreign affairs, see Diplomacy.

Forts, French, in West, 88, 94.

Forty-niners, 349.

Fox, Charles, 183 .

Fox, George, 69. 
France: ally during Revolution, I 73-175, I 82, I 83, I 85 .

Civil War and since, 390, 391, 488. colonization by, 87-89, 93 .

during early national period, 225, $238-239, \quad 243-244, \quad 253-254$, $260,265,289$.

European, I8, 33, 86, 93, 96, I73, 238.

explorations by, Iо, I6, 87-89.

wars of, with England, 86, $89^{-0} 9$, 94-101, 136.

Franklin, Benjamin: after 1775,158 , I 73-I 75, I $83-\mathrm{I} 85,20 \mathrm{I}, 229$.

before Revolutionary War, 98, $\mathrm{I}_{39}, \mathrm{~J}_{4} 2$.

biography of, I 73-I 74 .

portrait of, 174 .

Franklin, "state" of, 196.

Fredericksburg, battle of, 4I I.

Frederick the Great, I60.

Free coinage, see Silver, 475 .

Freedmen's Bureau, 436-437, 439 .

Freeport debate, 369 .

Free silver movement, 480.

Free Soil party, see Parties.

Free trade, 305-306, 324-325.

Frémont, John C., 346, 359, 4I 2.

French and Indian wars, $89^{-} 90,94^{-}$ IOO.

Friars' lands, control of, 509.

Friends, see Quakers.

Frobisher, Martin, 35 .

Frontenac, Count of, 90.

Frontier, 219-220, 326-327.

Fugitive Slave Act (I 850), 350, 352354 .

Fulton's steamboat, 317 .

Fur trade, 6, 88, 94.

G.tge, General, I 54-I 55 .

"Gag resolutions," 336.

Gallatin, Albert: 250, 275, 283, 3 I 8 . portrait of, 250 .

Galveston, commission government, $57 \mathrm{I}$.

Gama, Vasco da, 20.

Garfield, President James A., 464465 .

portrait of, 464 .

Garrison, William Lloyd, 335. portrait of, 335 .

Gaspee affair (1773), I 47.

Gates, General Horatio, I72, 176, I 79 .
Genet, Edward, 239.

Geneva award, $420 n$.

Genoa, commerce of, I 9 .

Geography, influence of, 2-II, I6I, 399, 405-407.

maps showing, I, 4, 5, II .

George III, I00, I36-I37, I 50, 159 , 162.

portrait of, I 36 .

Georgia, 9I, I 78, I94-195, 302--303, 375 .

Civil War and Reconstruction in, $42 \mathrm{I}-422,424,439$.

Germans, immigration of, 333 .

Germantown, battle of, I $7 \mathrm{I}$.

Germany, 19, 457.

Gerry, Elbridge, 243.

Gettysburg, battle of, 415-416 (map).

Ghent, treaty of (I8I4), 274-275.

Gilbert, Sir Humphrey, 36 .

Gin, cotton, 339 .

Goethals, Col. G. WV., 513, 514 .

Gold, mining of, $325,457,510,542$ $n 2$.

Gold Democrats (I 896), 48I.

Gold reserve, 479 .

Gorges's lands, 57, 78-79.

Gorman-Wilson tariff act (I 894$), 477$.

Gourgues, de, 35 .

Government: development of national, sínce $1787,447-450$, 484-486; see also Congress, President, and Courts.

during the Revolution, I60-I6r.

local, I 22-I 23, 328.

national, in $1787,206-207$.

of the colonies, 92-93, 123.

present colonial, 508 .

state, since $1787,328,533,534 n$., 563.

territorial, 195-196, 348, 354, 356 . under the Confederation, I90-I91.

Governors: colonial, 92-93, I 22, I 29, I44.

French colonial, 93.

state, r6o, 328 .

"Graft," see Corruption.

Grand Army of the Republic, 429.

"Grandfather" clauses for voters, $564 n$.

Granger railway laws, $462-463,55 \mathrm{I}$.

Grant, President Ulysses S.: biography of, 402 .

campaigns of, 401-404, 416-419, $422-425,431$. 
Grant, President Ulysses S. : political career of, 443-445, 464, 467 .

portrait of, 402 .

Grasse, rle, Admiral, i 82.

Great Britain, see England.

Great Lakes, 8.

Greeley, Horace, 330, 41 2, 444.

Greenback party, sec Parties.

Greenbacks: constitutionality of, $455^{-456 .}$

issuance of, $392-393,455,483$.

sec also Paper money.

Greene, General Nathanael, I03, I $81-182$.

portrait of, $\mathbf{I} S \mathbf{I}$.

Green Mountain Boys, 155.

Grenville, George, I37, I38, I39, 142.

Gresham, Walter Q., 479.

Guilford Court House, battle of, I $8_{I}$.

Habeas Corpus, writ of, $8_{3}, 394$, $395,426$.

Hague Peace Conference, 5 I 6 .

Halifax award, $4 S_{4} n$.

Halleck, General Henry, 404, 4 I 0.

Hamilton, Alexander: biography of, $2 \mathrm{I}_{3}$.

general, 200, 20I, 204, 237, 24I, $242,256$.

portrait of, 213 .

secretary of the treasury, $2 \mathrm{I}_{3}$, $226,233-237,265$.

Hamilton, Andrew, 120.

Hamilton, General (British), i 78 .

Hancock, General Winfield S., 464 .

Hanna, Mark, 527.

Harper's Ferry, 406.

Harper's II'eekly, 443.

Harrison, President Benjamin, 475, 485,486 .

Harrison, President William Henry, I 7, 269, 27I, 3I I-3I3.

Hartford Convention, $277-278$.

Harvard College, i 19 .

view of, I I 9 .

Havana, 100, 496, 522.

Hawaiian Islands, $486,508$.

Hawkins, Sir John, 35 .

Hay, John, 482, 505, $520,528$.

Hayes, President Rutherford B., $445^{-4}+4$.

Haymarket riot. Chicago, $5^{6}$.

Haynes, Senator Robert, 30.3-304.
Hay-Pauncefote treaty (1901), 51 I, 514.

Helper's Impending Crisis, 368.

Hendricks, Thomas, 470.

Henry, Ft., 402.

Henry, Patrick, I3 I, I 40. portrait of, r 40.

Henry, Prince, of Portugal, 20.

Henry IV of France, 86.

Henry letters, 200.

Hessians, in Revolutionary War, I 58, I 62, I 68, I 7 I.

High cost of living, 545 .

Hobkirk's Itill, battle of, i 8 I.

Holding company, $55 \mathrm{I} n .2$.

Holland: colonies of, $6,65-68$.

general, $48,177,183,225$.

Holy Alliance, $289-290$.

Homestearl Act of I 862, 459-460.

Hong Kong, 499.

Hood, General John, 422, 423-424.

Hooker, General Joseph, 4I 4 .

House of Representatives, 202, 206, $285-286,296$.

Houses, colonial, ro8-i ro.

Houston, General Sam, 34I.

Howe, Adniral, I67, I 75 .

Howe, General William, I 55, I 56 , I 67, I 68, I69, I 70, I 7 I.

Howe's sewing machine, 323 .

Hudson Bay Co., 65, 343, 344.

Hudson Bay territory, 90 .

Hudson, Henry, 65, 87 .

Hudson, Port, 4 i 8 .

Hudson river, 65, I61, I67-168, I 69,179 .

Huerta, 5 I 8 .

Huguenots in America, 76 , 105.

Hull, General, 27 I.

Hunter, General, 412.

Huron-Iroquois Indians, 87 .

Hutchinson, Governor Thomas, I 40 , I 46 .

Hutchinson, Mrs. Anne, 54.

IDAHO, 540, 543 .

Illinois, $28.4,368,475$.

Imago Hundi, $2 \mathrm{I}$.

Immigration : diagram of, 565 .

during colonial times, 52, 92 . $104-105$.

early nineteenth century, 333 .

recent, $521,5^{6} 4-560$.

Impeachment of President Johnson, 439-44I. 
Impeachments, 25I-252, $533 n$.

Impending Crisis, 368 .

Imperialism, 497-498, 507 .

Implied powers of Congress, 237, 255, $263,28 \mathrm{I}, 449,450,508,553$.

Impressment of seamen, 240, 259, 270.

Inaugurations, ( 7789 ) $2 \mathrm{IO}, \quad$ (I $80 \mathrm{I})$ 247-248, (I 86I) 380, (I 893$)$ (cut) 479 .

Income taxes, $393,455,477,54 \mathrm{I}, 545$.

Indented servants, Io6.

Independence: achieved, $184^{-1} 85$.

Declaration of, $157-160$.

results of, $22 \mathrm{I}-225$.

second war of, 269-275.

Independent treasury, 309, 3 I I .

India, contest for, 96,100 .

Indian territory, 303.

Indiana, 282,284 .

Indians: and Whites, I4-I7, 36, $302-303$.

important conflicts with, I6-I7, $77-78,100,220,269,274$

location of tribes of (map), 12. minor wars with, I6-I7, 55, 87 , 303.

numbers and character of, II-I 4 .

removal of, 17,303 .

see also under names of tribes.

Indies, trade with, I9.

Indigo, I I .

Industrial Workers of the World, 562 .

Industries: colonial, I I 2-I I 3.

early national, 226-227, 262, 278, $304,323-325,378$.

recent, $450-45 \mathrm{I}, 453-454,457$, $460,55^{\circ}, 55^{8-563}, 572$.

Inheritance, laws of, I 24, 224, 329 .

Inheritance taxes, 502 .

Initiative, 533 .

Insular cases, 507 .

Insurgent movement, 531 .

Intendants, French, 93.

Intercolonial wars, 89-90, 94-100.

Interlocking directorates, $546,555 n$.

Internal improvements, ${ }_{2} \mathrm{~S}_{2}-2 \mathrm{~S}_{3}$. 328 .

Internal revenue, see Excise taxes.

Interstate commerce: I99, 317-322.

Acts regulating, (I 887 ) 463-464,

$$
556 ; \quad \text { (1890) } 556 ; \text { (I906) }
$$$$
528,555-556 \text {. }
$$

Commission, 528, $556 n$.

Intolerable Acts (1774), I $48-149$.
Inventions, 322-323, 568 .

Iowa, 334.

Irish, immigration of, 333.

Iron, manufacture of, $133,323,45^{8}$, $55 \mathrm{I}, 556 \mathrm{n} .4$.

Iroquois Indians, I 2, 1 5, 67, 69, 87, 9o, 97, 193 .

Irrepressible conflict speech, Seward's, 370 .

Irrigation, national law (I902), 527 .

Isabella, Queen, 25.

Island No. Io, capture of, 403.

Isthmian canal, 510-5I4, 527.

diagrams of, 5 I 3 .

tolls, 5 I4.

view of, 5 I 2 .

Italy, dispute with (1891), $521 \quad n .2$.

JAckson, President Andrew, military career of, 17, 274, 282, 288.

political career of, 296, 297, 298302, 306-310, 3 I 4 .

portrait of, 299.

views of, 297.

Jackson, General T. J. ("Stonewall"), 408-410.

Jackson, Governor, of Missouri, quoted, 383 .

James I, 40, 43, 47 .

James II (Duke of York), 68, 69. $70,79,8 \mathrm{r}$.

Jamestown, 4I-42, 74 .

Japan, relations with, 520-522, $565 n$.

Jay, John, I 83 , I 84, I97, 204, 214.

portrait of, $24 \mathrm{I}$.

treaty by, 240-242.

Jefferson, Thomas: biography of, $248-249$.

general, 147, I58, I59, I95, 2 I 3 , $222,224,227,237$.

party leader, 237-238, 242, 245 .

portrait of, 249 .

president, 246-249, 253, 254, 257, $259,26 \mathrm{I}, 263$.

Jena, battle of, 260 .

Jesuits, 88, 93.

Jews, 223.

Johnson, President Andrew: and Congress, 431, 432, 433, 43444 I.

character of, 432.

impeachment of, 439-441.

portrait of, 432 . 
Johnston, General A. S., 403.

Johnston, General Joseph E., 385, $408,417^{-}+18,42 I^{-}+22,424$, 425 .

portrait of, 385 .

Joliet, Louis, 88.

Jones, Commodore Paul, I 77.

Judges, I 23, I30, 144, 207.

Judiciary, national, see Supreme Court.

Judiciary act of I 789, 214; of I SOI, $247,250$.

KALB, Baron de, I 79.

Kansas-Nebraska Act (I854), 356358,363 .

Kansas: struggle for, 359-360. trusts in, 552 .

Kaskaskia, Ft., I 78 .

Kearsarge, the, 420 .

Kenesaw mountain, battle of, $42 \mathrm{r}$.

Kentucky: in Civil War, $384,4 \mathrm{I}$. resolutions of (1798-1799), 246. settlement of, I 78, 220-22 I .

Kidd, Captain, I 12.

King, English: and colonies, 53. and parliament, 50-5 $\mathrm{I}, 8 \mathrm{I}$. and Puritans, 43-44, 47, 50-5I.

King George's War, 94.

King William's War, 89-9o.

King's friends, I37.

Kings Mountain, battle of, $\mathbf{S}$ I.

Kitchen cabinet, Jackson's, 302.

Kitchen, colonial, rog.

Klondike, see Alaska.

Knights of Labor, $55 \%$.

"Know-notning" party, 358; see Parties, political.

Kosciusko, I63.

"Ku Klux Klan," 44 .

LABOR: Department of, 537, 554. Disputes of, with capital, $559^{-5} 5_{3}$. in colonial times, I 13 .

legislation regarding, 562-563.

Labor party, platform of ( 1872$)$, $4+4$.

Labor unions, 559-560.

LaFayette, Marquis de, $163,182$. portrait of, 182 .

LaFollette, R., 53 I.

Lake Erie, battle of, $27 \mathrm{I}$.

Land cessions of the states, I94-I95. map of, opp. i 85 .

Land laws of colonies, 124.
Lands, public, 124, 282, 309-310, 3 I $5,320,325-326,529,535$ and $n, 2,573$.

Lane, Ralph, 36.

La Salle, R. C., Sieur de, 88-89.

Laud, Archbishop, 5 I.

Law: colonial, I $23-124$. early state, $222,223,224,327-329$. recent state, 532-534, 54I, 55I, 563.

Lawrence, Kan., 360.

Law's Mississippi Bubble, 89 .

Lawyers, colonial, I I 4.

Leadville, Col., 458.

Lecompton constitution ( 1857 ), 360 .

Lee, General Charles, I 77.

Lee, General Robert E., biography of, $409 n$.

campaigns of, $385,409^{-411}, 4^{1-}$ 4 I $6,422-425$.

portrait of, 409.

Lee, R. H., I $58,203$.

Legal Tender Cases, 455-456.

Legislature: colonial, 92, I 23, I 4 I. state, I0o, 328.

Leisler s rebellion ( 1689 ), 82 .

Leon, Ponce de, 30.

Leopard, the, 250.

Lewis and Clark expedition (1805) 343 .

Lexington, battle of, I54.

Lexow investigation, 570 .

Libby prison, view of, 425 .

Liberal Republicans ( 1872 ), 444.

Liberator, the, 335 .

Liberty: civil, 53, 83, r 20. political, see Suffrage.

religious, see Religious freedom.

Liberty party, see Parties.

Liberty, seizure of the, I 46 .

Liliuokalani, Queen of Hawaii, 486.

Lincoln, General Benjamin, i 78 , I 99 .

Lincoln, President Abraham: biography of, $368-369$.

death of, 426-427.

debates of, with Douglas, 309.

emancipation by, $+\mathrm{II}^{-} 4 \mathrm{I}_{3}$.

portrait of, frontispiece, $38 \mathrm{I}$.

president, 37.3, 380-38I, 382, $38_{3}$, $395,306,408,4 \mathrm{II}^{-} \mathrm{II}_{3}, 426-$ 427 .

views of, on union and slavery, $369-370,380,412-4$ I.3.

Little Belt affair, 269. 
Livingston, Edward, 307 .

Livingston, R. R., I5S, 253-254.

Loans, government, see Finance.

Local government, sce Cities and Government.

Locke's Fundamental Constitutions, 75 .

London Company (I 606), 40, 4I, 4344.

Long Island, battle of, 167-168.

Lookout Mountain, battle of, 4IS, 419.

"Loose construction" of the Constitution, see Implied powers.

"Lords of Trade," $S_{4},{ }_{2} 8$.

Louisburg, 94, 98 .

Louisiana: changes in $\left(1_{7} 6_{3}-1 \mathrm{SO}_{2}\right)$, IOO, 232, 253, 274 .

French colony of, $\mathrm{Sg}$.

purchase of, $253^{-256}, \quad 286-28 S$, 332,361 .

state of, $375,435,439,442,+45$, $564 n$.

Louis XIV of France, $S_{9}, 90$.

Louis XV of France, 94.

Louis XVI of France, 238 .

Lovejoy, Elijah, 335 .

Lowell, J. R., quoted, 427.

Loyalists, revolutionary, $164,{ }_{17} 8$, I 79, I So, I 84 , I $8_{5}$, I $97-198$.

Lundy's Lane, battle of, 273.

Lyon, Capt. N., $3 S_{4}$.

Lyon, Matthew, 245.

MacDonough, Captain Thomas, 273.

Machine, political, 300, 532-533, 570; see also Spoils system.

Macon Bill, No. 2, 264.

Madero, 5 I 8 .

Madison, President James, before I $S 09,200,201,204,212,224$, $234,236,249$.

president, 263, 264, 270, 274, 2 SS.

Magellan, Fernando, 30.

Mails, 1 22, 229, 330.

Maine: boundary dispute of (map). colony of, $57,5 \mathrm{~S}, 7 \mathrm{~S}-79$.

state of, 286,3 I $3-314$.

Maine, destruction of the, 522 .

Maize, Indian, 5-6, I 5, I 10.

Manassas Junction, Va., 385 .

Manila, 499, 500, 502.

Mann, Horace, 330.
Manufactures: chart of, 458 . colonial, I I $2-113,133$. early national, 262, 324. protection of, 279, 304-305; see also Tariff, after I $\$ 60$.

recent, $45 \mathrm{I}, 453,45 \mathrm{~S}, 556-557$.

taxes on, 393.

March to sea, Sherman's, 424.

Maria Theresa, 96.

Marion, General Francis, I 79.

Marquette, Father, SS.

Marshall, John, C.J., 243, 247 , $25 \mathrm{I}, 2 \mathrm{~S}, 302$.

portrait of, 251 .

work of, $25 \mathrm{I}$.

Mary, Queen, see William III.

Maryland: in Civil War, $3 s_{4}, 411$, 433.

settlement of, $59-6 \mathrm{I}, 72, S_{2}-S_{3}$, I $89,200,209,224$.

Mason, John, 57.

Mason and Dixon's line, 72.

Massachusetts: colony of, 56, 57, $59,76-S_{2}$.

in revolutionary period, $141,1_{4} 6$, I 4 S-I 49 , I 50, I 5 I, I $54-156$.

settlement of, 50-54.

state of, 160, 193, 195, 199, 204, 219.

Massachusetts Government Act, 148 .

Massacre, Boston, 146.

Matches, friction, 323 .

Maximilian, Emperor of Mexico, 488,5 I 8 .

Mayflower, t $^{8}$.

Mayflower compact, ${ }_{4} 8$.

McClellan, General George B., ${ }_{3} S_{5}, 408-411,426$.

portrait of, tro.

McCullock is. Maryland, 28I, 308.

McDowell, General Irvin, $385,408$.

McHenry, Ft., 274.

Mckinley, President William, 469, ${ }_{4} \mathrm{SI}_{\mathrm{I}}-4 \mathrm{~S}_{3}, 507-509$.

character of, 526 .

portrait of, 483 .

McKinley Tariff (I89o), 476.

McMaster, John B., quoted, 2 I $9 n$.

Meade, General G. G., 4I 4, 4I 5 .

Memphis, Tenn., capture of, 404 .

Menendez, Pedro, 34-35.

Merchant adventurers, 48 .

Merchant marine, see Shipping.

Merrimac, the (I $9 S$ ), 500. 
Merrimac and Monitor (1862), 407. Merritt, General Wesley A., 500.

Mexican War, $3+4^{-} 3+7$.

Mexico, $341,343,344^{-347,} 487,518$, $5+2$.

Michigan, 27I, 320, 334, $45^{8}$.

Midnight judges, 247.

Milan Decree (I 806), 260, 264.

Miles, General N. A., 5or.

Military Reconstruction Acts, 438$+39$.

Militia, use of, I38, I5I, I54, 235, 382.

Mills Tariff Bill, 475 .

Mining, 457-458; see also Gold, etc.

Ministers, colonial, II 4 .

Ministries, English ( $1660-1782$ ), I37, $142,1+5,183$.

Minnesota, 360 .

Minute men, 154 .

Missionary Ridge, battle of, 4 I 8 .

Missions among Indians, 32, 88.

Mississippi basin: contest orer, in colonial times, 94-95, 100 .

during early national period, 178 , $184,232,252-257,274$.

French in, Io, 88-89

geography of, 4, 5, 7-8, 32 .

in Civil llar, 399-405, 410-419 (maps).

Mississippi Bubble, 8y.

Mississippi River, navigation of, I 84, I $85,196$.

Mississippi (state), 284, 375, to.4, $+16-418,+39$.

Missuuri, $284-286,334, \quad 383-384$, 433,529 .

Missouri Compromise line, 287,348 , $355^{-}-357,362,377$.

Missouri compromises, 280-288 (map).

Mobile, battle of, 4 I 9 .

Molasses Act (I733), I 33 .

Money, see Currency, Paper money, and Silver.

"Money trust," see Trust.

Monitor and Merrimac, 407.

Monmouth, battle of, I 77 .

Monopolies, see Trusts.

Monroe, President James, 253, 254, 289-29I.

portrait of, 290.

Monroe Doctrine: original, 277, 289-29I.

present, 488-49I, 509 .
Montcalm, Marquis de, $98,99$.

Monterey, Cal., 346.

Montgomery, Ala., 376 .

Montgomery, General Richard, 155.

Montreal, 33 .

Monts, de, 87 .

Morgan, General Daniel, I63, I73, I $S_{\text {I. }}$.

Mormons, $563 n$.

Morrill tariff (I 860), 391, 393.

Morris, Gouverneur, 201, 203.

Morris, Robert, 20I, 227.

portrait of, I9I.

Morse, S. F. B., 322 (portrait).

"Mugwumps," +66.

Murfreesboro, battle of, 4 II .

Muskhogean Indians, I 3.

NAPOLEON I, 244, 253-254, 264, 266, $273,289$.

Napoleon III, 488 .

Narragansett Indians, 78 .

Narvaez, P. de, 31 .

Nashville, battle of, $+23-424$.

Nast, Thomas, 443 (cartoon).

Nation, American: 2, 205, 576-578.

after Civil War, 447-45I.

relation of, to states, $205^{-200}$, 578 .

National Banking Act, ( $180_{3}$ ) 392, (I9I3) $5+6$.

Nationality: contest of, with state sovereignty, 20.4-205, 340, $378,379-380,+47$.

increase of, after $\mathrm{I}_{\mathrm{I}} 5,275^{-28} 4$, $292,298-300$.

National road, $28_{2}-28_{3}, 32 \mathrm{I}$.

Naturalization Act ( 1798 ), 244.

Natural resources of the United States, 3, 6-7; sce Mining, Agriculture, etc.

Navigation Acts, colonial, $63-64,74$, 78, I $31-135$, I 57 .

Navy: in Civil War, 389-390, 402, $404-405,407,+19-420$.

in Revolutionary War, 176-177, I 82 .

in Spanish War, 496-502.

in War of $1812,271,272-273$.

Nebraska Bill, 355.

Negroes, 432-433, 436-437, 438, $4+1-4+2, \quad+48 ;$ see also Slavery.

Negro suffrage, $439,564 n$.

Netherlands, see Holland. 
Neutrality: proclamation of, 239 . rights of, $240,257-265,276$.

Nevada, 457 .

New Amsterdam, 66, 67-68. view of, 66 .

New England: colonial conditions in, IO4, IO5, IIO-II3, II 5 , II 6 , I I9, I $22-123$.

during national period, 221, 224, $261,277-278,345$.

during revolutionary period, 150 , I 58 , I 60, I 69 .

first settlement of, $44^{-59}$.

map, 58 .

political problems of (I660-I69I), 76-83.

New England Confederation, 57-59.

New France, 87-88, 93, Ioo; see also Canada.

New Hampshire, 57, 79, I60, 308.

New Haven, 56.

New Jersey, 69, I30, I68-169, I78, I 99,2 Io.

New Mexico, 334, 347, 350, 352, $534 n 2$.

New Netherland, 65-68.

New Orleans, 89, I00, 253, 274 (map), 52 I $n 2$. capture of, 404-705.

New Sweden, 67.

New York: colony of, $65-69,73,82$, $8_{3}$, I I 4 , I 20 , I $22, I_{3}$, I 45 .

since I 783 , I9I, I93-I94, I99, 209, $224,318,319,466$.

state of, in Revolution, I6o, I67I68, I69, I 7 I-I 73, I 79; map of, 167 .

New York City: before 1775 , Io8, I 12 , I 4 I, I 48 .

corruption in, $4+2-4+3,570$.

in Revolution, I6I, I67-I68, I69. since $178_{3}, 210,331,566-567$, 570.

New York Sun, 330; Tribune, 330, 408, 4I2; Times, $4+3$.

Newburgh address, I 93.

Newfoundland, 9o, $48_{4} ;$ see also Fisheries.

Newport, R. I., I 77.

Newspapers, 229, 329-330.

Niagara, 94, 273.

Nicaragua canal, see Isthmian canal.

Nicholson, Governor, 82.

Nicollet, Jean, 88.

Nobel Peace Prize, $516 n ., 528$.
Nominating conventions, 300 .

Non-importation agreements, I42, I 46.

Non-intercourse acts, 263-264.

North: and state sovereignty, 255, $278,303-304$.

border wars of, 89-90, 94-100.

colonial problems of, $76-84$.

comparison of, with South (I86I), 386-395.

industrial development of, since I $865,457-460,550$.

industry in (colonial), I Io-I It.

opposition of, to slavery extension, 285-288, 347, 352, 357, $359,366-367$.

Revolutionary War in, I54-157, I $67-173,177$.

settlement of, $44^{-59}, 65^{-73}$.

transportation problems of, $46 \mathrm{I}-$ +64 .

war in (1812-1814), 270-273; map, $27 \mathrm{I}$.

North, Lord, I45, I 5 I, I 75, I 83 .

North Carolina, 28, I8I, I93, I95, I 96, 204, 234, 439 .

Northern Securities Case (I904), $529,553$.

statistics of (I790-1860), appendix, Table VII.

Northwest territory, I95-196.

Nueces River, 34I.

Nullification, (I 799) $246, \quad$ (I 8 I 4 ) $278,($ I 828$) \quad 306-307,($ I 832$)$ 315 , (after I 850 ) 354 .

OfFiceholders, I 29-I30, $223,328$.

Oglethorpe, James E., 9I.

Ohio, 220, 27I.

Ohio valley, struggle for, 94, 95, 98 I 78 .

Oil, see Petroleum.

Olney, Richard, 489.

Ontario, Lake, 94, 272.

Orders in Council, English (I 806I 807 ), 260.

Ordinance of $178_{7}, 195^{-196,223 .}$

Oregon: state of, 445 .

territory of, $343-344,348$.

Oregon, the, $499 n$. view of, 499.

Orinoco River, 28, 490, 492.

Orleans, Isle of, Iоo, 253.

Ostend Manifesto, 354-355.

Oswald, Richard, I84. 
Oswego, 94.

Otis, James, I35.

portrait of, 135 .

PACIFIC OCEAN : commerce of, 5 I4. control of coasts of, $35,291,343^{-}$ 344,346 .

in colonial times, 30,35 .

recent political problem of, 521 , 522 .

Pacific railways, $444,460-461$.

Paducah, Ky., tor .

Paine's Common Sense, 58.

Pakenham, General, 274.

Palma, President of Cuba, 5 I 7 .

Panama, Republic of, 5 I I-51 2, 527.

Panama Canal, see Isthmian canal.

Pan American Congresses, 487.

Panics, (I8I0) 32.4, (I837) 3IO-3II, $324,($ I 857$) 325,($ I 873$) 454$, 55 , ( (189.3) 558, ( ( 907$) 530$, 55 S.

Paper money: Civil War, 392-30.3, 455 .

colonial, I 44, I $_{3}$ I.

Confederation, 198-199.

present, $455^{-} 45^{6}, 481,483$.

Revolutionary, I65-I 66.

Parcel post, 537.

Pardon, see Amnesty.

Paris, treaties of, (I76.3) 99-100, ( 7783$)$ I $83-186,($ I 898$) 505$.

Parker, Judge Alton B., 528.

Parkman, Francis, quoted, I3-I4.

Parliament: and the colonies, $83^{-}$ 84, I 31-133, I 38, I 39-I 40 , I $44^{-1} 45, I_{4} 8-I 49$.

and the king, 50-51, $8 \mathrm{I}$.

Parson's Cause, I30-I3I.

Parties, political: Anti-Federalist ( $787-1788), 203$.

Anti-Masonic, 300 .

Constitutional Lnion, 372-373.

Democratic (I828-I854): history of, 298, 301, 308, 31 I$313,314,342,348,353,357$.

principles of, $297-298$.

Democratic, since I 854 : general history of, $359,37 \mathrm{I}-373,426$, $444,445^{-447}, 454,464-467$, $476-480,48 I-482,507,528$, 538,544 .

on slavery, $358,360,37 \mathrm{I}$.

position of, on tariff, 464-465, 474,544 .
Federalist: fall of, $277-278$

formation of, $237-238$.

history of, $242-243,245,246-$ $247,254,26 \mathrm{I}$.

Free Soil, 348, 353, 358.

Greenback, 456 .

Know-nothing, 358 .

Labor, 444.

Liberty, 342 .

"Nugwumps," 456.

National Republican, 297, 298; see also Whig.

Old Republican (to 1828 ) : formation of, $237-2.38$.

history of, $242-243,245,246-$ $252,255,263,270,279,295-$ 297.

People's (Populist), 48 I.

Prohibition, 466.

Republican : formation of, $35^{8}$.

general history of, $359,37 \mathrm{I}-373$, $426,443,444,445^{-447}, 4^{64}$ $407,474,48 \mathrm{x}-484, \quad 507-509$, $534^{-539}$.

position of, on slavery, $35^{8-359}$, $371,372$.

position of, on tariff, $464-465$, $476-478$.

Whig: principles of, 297.

history of, $308,3 \mathrm{II}^{-3} \mathrm{I3}, 314$, $342,348,353,358$.

see also Elections, presidential.

Parties and the government, 577 .

Patroon system, 65-66.

Paulus Hook, capture of, i 78 .

Payne-Aldrich tariff, 535, 542.

Peace Congress (i 86I), 377: see also Hague Peace Conference.

Pea Ridge, battle of, 384 .

Pemberton, General J. C., 4I 7-418.

Pendleton Act, 468.

Peninsular campaign (1862), 408409 .

map of, 408.

Pensacola, Fla., 89, 288.

Penn, William, 70-71.

portrait of, 70 .

Pennsylvania: boundaries of, 72-73 (map).

colony of, 70-73, 105, II4, II6, I 7, I 20.

rebellion in ( 1794$), 235$.

state of, $221,235,319,415^{-416}$, 458.

“Pennsylvania Dutch,” I05. 
People of colonies, 104-106.

People's Party, see Parties.

Pepperell, William, o4.

Pequod Indians, 55.

Perdido River, $28 S$.

Perry, Commodore, and Japan, $52 \mathrm{I}$.

Perry's victory on Lake Erie, 271.

Perryville, battle of, +II .

Personal liberty laws, 354. 374 .

Pet banks, 309-310.

Petersburg, siege of, $+24-425$.

Petitions, slavery, 336.

Petroleum, 456, $55^{\circ}$ n. $f$; see als? Standard Oil Company.

Philadelphia, 7I, I4S, I 49, 219, 235. during Revolutionary War, I57. I 69-I 7 I, I 77.

exposition in, 560 n. $I$.

Philip II of Spain, 33, 34, 35.

Philip, King (Indian), 16, $77-78$.

Philippine Islands: acquisition of. 503-504, 506-508, 500.

discovery of, 30 .

government of, 508-509.

Pierce, President Franklin, 353.

Pilgrims, +8-49.

Pinchot, $53 \mathrm{~S}$ and $n, 2$.

Pinckney, C. C., 201, $243,246,247$.

Pinckney, Thomas, 2+2, 252.

Pine tree shillings, 77 .

Piracy in colonial times, 112.

Pitt, William, see Chatham.

Pittsburg, 220, 550.

Pittsburg Landing, 403.

Pizarros, 32.

Plassey, battle of (India), roo.

Platt Amendment (Cuba, I90I). $5 \mathrm{ro} n$.

Plattsburg, battle of, 273 .

Plymouth colony, $4 \mathrm{~S}-49,7 \mathrm{~S}, \mathrm{~S} 2$.

Plymouth Company, to, +4 .

Polk, President James K., 3+2, 345 . $3+7,354$.

portrait of, $3+0$.

Polygamy, 563 n. 2.

Pontiac, conspiracy of, 16, 100, 138.

Pools, railway, 55 I $n .2$.

Pope, the, and America, 26.

Pope, General John, to3, 4 Io.

Popham colony, +4 .

Popular sovereignty, $348,355^{-356}$. $359,360,369$.

Population: (I 750) IO4, (ISOO) 2 IS. 325. 326. (i $S_{50}$ ) 33I-333, ( I 86 I ) 386 . (1910) 566-567.
Population, density of (maps), ( 1750 ) 104. (ISOO) 2IS, (IS50) 332, 567.

Port Hudson, tis.

Port Royal, S.C., 404.

Portages, Indian, I0, I I.

Porter, Commodore David D., 405.

Porto Rico, 505. 506. 507-508.

Portugal, 20, 26, 27.

Postal savings bank, 537 .

Post Office: administration of, 122 , 220,330 .

corruption in, 445,546 .

extended service, 466,537 .

Potomac River, 200.

Poverty, 573 .

Prescott, Colonel William, I5i.

President: election of, 206, Appendix, Tables I, II.

powers of, 207, 300, 395, 449450 .

President, the, 260.

Presidential dictatorship, 395 .

Presidential elections, see Elections, presidential.

Presidential Election Act, 470 .

Press, free, I 20.

Prices, 545 n. I.

Primary reform, 532-533.

Princeton, battle of, I69.

Princeton college, 120.

Printing press, 323, 330.

Prisons, 320.

Privateering, 272, 3S9, 419-420.

Proclamation line (i 763$)$, гоo, I93. 2 I9.

Proclamation of Emancipation, +13.

Professions, I I 4 -I I 5 .

Proprietary government, 59, 70, 75.

Prosperity, 324-325, 55S.

Providence, colony of, 54-55; see Rhode Island.

Prussia, 96, 225, 289.

Ptolemy, views of, 2 I

Public debt, sce Debi, public.

Public lands, see Lands, public.

Public Oicurrences, 120.

Public schools, see Education.

Puget Sound boundary, ${ }_{4} s_{4} n .2$.

Pullman strike (i $S_{94}$ ), 500 .

Puritans: in England, 43, 46-47, 50-5 $\mathrm{I}$.

in New England, 50-59, 76-79, IO4.

Pỵthagoreans, views of, 21 . 
QuAKers, 69-71, 76, $222,336$.

Quartering Act, (I765) I40, (I774) I 49.

Quebec Act (I774), I49, I93.

Quebec (city), capture of ( 1759$), 99$.

Queen Anne`s War, 9o.

RAILWAYS: consolidation of, 320 , 55 I, 555, map opp. 556 .

control of interstate, $463-404,47 \mathrm{I}$, 553,555 .

control of state, $46 \mathrm{I}-463,47 \mathrm{I}, 553$. earliest, 3 I 9-320, 386, 400 .

importance of, 322 .

West and, 444, 460-46I.

Rainfall, 4 .

Raisin River, massacre at, $27 \mathrm{I}$.

Ralegh, Sir Walter, 36 (portrait).

Randall, Samuel J., 476.

Randolph, Edward, 79.

Randolph, John, 252.

Rates, railway, diagram of, 462 ; see also Railways, control of.

Reapers, first, 323.

Rebates, railway, 461,556 and $n$.

Recall, 534.

"Reciprocity," +78, 480, 51 7, 535 .

Reconcentrado policy, 495.

Reconstruction: and Congress, 436438.

military, $438-439$.

presidential, $434^{-}+36$.

problems of, $432-434$.

results of, $44 \mathrm{I}-44^{2}, 447-45 \mathrm{I}$.

Redemptioners, 106.

Reed, Thomas B., 532.

Referendum, 534 .

"Regulators" (I774), I $47 n$.

Religious freedom, $5 t^{-55}, 60,7$ I, 76,9 I, II6, I96, $224^{-225}$, 329 .

Religious intolerance, colonial, 53$54,76,8$ I, 9 I, I I 6 .

Removals from office, $249,301-302$, $440,470-47$ I.

Representation and taxation, I4I, I 43 - 144.

Repressive acts (I774), I 48 -I 49 .

Republican party, see Parties, political.

Requisitions on states, I65, I9I.

Resolutions, Kentucky, $245^{-2} 4^{6}$.

Restoration (I660), 63-65, 73 .

Resumption of specie payment, $455^{-} 456$.
Revenue, sce Finance, Tariff, Taxation.

Revolution, American: causes of, I 35 -I 52 .

chief military events of, I67-I73, I $7 \mathrm{~S}-\mathrm{I} S 2$.

conditions affecting, I6I-I66, I73I 75 .

results of, $223-225$.

treaty concluding, I83-I 86 .

Revolution of i688, English, 8r.

Revolutions of I689, American, 8o, $8 \mathrm{I}-8+$.

Rhode Island: colony of, 54-55, $58,64,77,78,80,83$, I 47 .

state of, $160,198-199,203,204$.

Ribaut, Jean, 34,35 .

Rice, 6 , I33.

Richelieu, Cardinal, 88.

Richmond, campaigns against, 407$409,422-425$.

Rivers in Civil War, 399-40r, (map) 400.

Roads, local, I $21,228,320,321$. national, $32 \mathrm{I}$.

Roberval's colony, 33 .

Rockingham ministries, $\mathrm{I}_{4} 2, \mathrm{I}_{3}$.

Rocky Mountains, the, 7, 255, map and $n$.

Roosevelt, Theodore: character of, 526-527.

portrait of, 526 .

president, 507, 526-530.

presidential candidate, 538 .

Root, Elihu, 504, 528.

portrait of, 503 .

Rosecrans, General William S., 385 , 4 I $8-419$.

"Rough Riders," 505.

Round Top, Gettysburg, 4I5.

Royal colonies, control of, 92, I 29.

"Rule of 1756 ," $240,258$.

Rum, III, I39.

Russia, 289, 343, 391, 509-510.

Russo-Japanese War, 528.

Ryswick, treaty of (I697), 90 .

SALEM, witchcraft, II 7 .

Salisbury, Lord, 4 So.

Samoa, 485 .

Sampson, Admiral IV. T., 499.

portrait of, 49 S.

San Domingo, 26, 254, 444 .

San Francisco, I9 5 , exposition view, $57 \mathrm{I}$. 
San Jacinto, battle of, $34 \mathrm{I}$.

San Juan, battle of, 501 .

Sandford $v s$. Scott, 360-362; see also Scott, Dred.

Sandys, Sir Edwin, 43.

Sanitary Commission, 389 .

Santa Anna, President of Mexico, 340, 341, 346 .

Santiago de Cuba, 500 (map).

Santo Domingo, 490.

Saratoga, surrender at, I73.

Savannah, I78, 424 .

Savannah, the, 3 I 7 .

Schley, Admiral IV. S., 499.

Schools, see Education.

Schuyler, General P., I 7 I, I 72.

Scotch in America, 76 .

Scotch-Irish in America, 105.

Scott, Dred, case of, $360-362,363$. 366-367.

Scott, General Winfield, 345, 346 , 353,374 .

Seal fishery, Alaskan, 484 .

Sea to sea charters, $42,50,64,75$, 9I, I93.

Search, right of, $240,259-260$.

Secession, causes of, $339-340,378-$ 380 .

early suggestions of, 255.307 .

failure of, 433-434.

progress of, $373-377,3 s_{3}-38_{4}$.

Sections, Appendix, Table VIII.

Sedition Act (I 798 ), 245.

Seminole Indians, 303.

Senate: organization of the, 202, 206.

powers of, in appointments, 440, $47 \mathrm{I}$.

powers of, in treaty, 285,286 .

Senators, direct election of, $54 \mathrm{I}$.

Separatists, 46, 47, 48-49.

Seven Years' War, 95-100.

Seward, William H. : political leader, $373,380-382,391,431,488$.

speeches of, on slavery, $35^{\mathrm{I}-35^{2}}$, 370.

Sewing machine, 328 .

Shays's Rebellion, 199.

Shelburne, Lord, I 83 , I 84 .

Shenandoah Valley, in Civil War, 405-407, 408, 423 .

Sheridan, General P. H., 423, 425, 488.

Sherman John, 42 I $n$., 456, $48_{3}$.

Sherman, Roger, I 58, 201.
Sherman, William T., character of, $42 \mathrm{I}$.

campaigns of, 404, 42I-422, 423425 .

Sherman Anti-Trust Act (I 890), 552-554.

Sherman Silver Act (IS9o), 478-479.

Sherman's march to the sea, 424 .

Shiloh, battle of, 403-404.

Ship-building, colonial, I I I-I I 2, I I 3 , I32.

Ship-money, 5 I.

Shipping, I I I-I I $2, \quad 420, \quad 55^{6-557}$, and $n$.

Short ballot, 533 .

Silver: Act of $1873,456,457$.

Bland-Allison Act ( $\left.{ }^{8} 88\right), 457$, 479.

coins before Civil War, 228.

first coinage act, 227.

Free Silver movement, $480-482$.

law of 1900,483 .

mining of, 457 .

Sherman Act (I 890$), 478-480$, $55^{8}$.

Six Nations, see Iroquois.

Slave trade, $350,353$.

Slavery: abolitionists and, 335336,367 .

abolition of ( 1865 ), 432-433.

colonial, 107-108.

discussion over, in convention, 202-203.

during Civil War, 4II-4I3.

emancipation, after $1776,22 \mathrm{I}^{-}$ 222, 335 .

extension of (1844-1857) (maps), 362 .

importance of, to South, 339340.

in compromise of $1850,35^{\circ}-353$.

in connection with Civil War, $369^{-}$ $370,377-380$.

in Dred Scott case, 360-362, 363, 366-367.

in Kansas-Nebraska Act, 355$35^{8}$.

in Missouri discussion, $284^{-2} 88$.

introduced, 42 , 91 .

question of extension of, to territories, 195, 196, 340, 345, $347-363$.

see Fugitive slaves, Emancipation.

Sloat, Commodore, 346 .

Slum problem, 569 . 
Smith, Captain John, $4 \mathrm{I}^{-4^{2}}$. portrait of, $4 \mathrm{I}$.

Smith, Joseph, 475 .

Smuggling, colonial, I.34, 146, 148 .

Social conditions, (I 750) 105-107, (isoo) $218-223,($ I 850$) \quad 320^{-}$ 3.34 , (later) $563-575, \quad 563$ n. $I$.

Social reforms, 221-225, 329, 537 .

Soldiers: American, I0.3, I92.

British, I 62.

Northern, 388-389, 429 .

Southern, 387, 429 .

Sons of Liberty, $1+1$.

Soto, Hernando de, 32.

South: and secession, $307,373^{-} 376$, $378-380,447-448$.

and slavery, $335^{-3} 36, \quad 339^{-} 340$. $347,35 \mathrm{I}, 354^{-}-355,357,350$, $36 \mathrm{I}-363, \quad 367-368, \quad 37 \mathrm{I}-37.3$, $378-379,448$.

and state sovereignty, $245^{-24} 6$, $303-307,379-3$ So, 447.

and the tariff, 305-306.

conditions in, IIO, I I9, I $21,123$.

railway map of, 400 .

recent progress of, 459 .

reconstruction in, $43^{-}+42,4+5^{-}$ 447.

resources of, in war, 386-391, 393394.

Revolutionary War in, I56, i78I 82 ; map, I 80 .

settlement of, $34^{-37}, 40^{-44}, 59^{-}$ $61,73-76,9 \mathrm{I}$.

social classes in, 105-107.

statistics of (1790-1860), Appendix, Table VII.

war in, $38 \mathrm{I}-429$.

war maps of, 40I, 403, 406, 4I 7 , $418,428$.

South America, 27, 28, 29, 487,489 , 490,557 ; see also Monroe Doctrine.

South Carolina, colony of, 76,107 , IOS, III.

in Revolutionary War, $156, \mathrm{I}_{44}$, I 78-179, I $80-182$.

nullification in, 305-307.

general, 193, 195, 382, 439, 445. $56+n$.

secession of, $373-374,395$.

South Carolina Exposition, 305 .

South Dakota, 458 .

South Sea, see Pacific.
Sovereignty, disputed between national and state, see Nation.

Spain: colonies of, $3 \mathrm{I}, 289$.

controversy with, over Florida, I $97,232,288,280$.

discoveries by, 24-30.

dispute with, over Mississippi River, $196,25^{2-253}$.

European, 18, 25, 33, 343 .

explorations by, 30-32.

treaties with, (I795) 252, (I 8 I9) 289, ( ( 898$) 502$.

wars of, with England, 90, 91, 94, I00, 177.

war with, 494-504.

Spanish-American Republics, 290, ${ }_{4} 87$.

Speaker of the House, Appendix, Table III.

Specie circular, 3 io.

Specie payments, resumption of, $45^{6}$.

Sproils system, 301, 3I 4, 467 .

Spottsylvania, battle of, 424 .

Stage coaches, 1 22, 220.

Stamp Act (I 765 ), I39-I43.

Stamp Act Congress, I+I.

Stur of the II est, the, 382 .

St. Augustine, 35.

St. Clair, General, 220.

St. Lawrence Basin, 8, го, 87, 99, 100.

St. Leger, Colonel, I 7 1-I 72.

St. Louis, 384,571 , 570 (view of exposition).

Standard Oil Company, 46I, 55I $n$. $I$ and 2, 552 .

Standish, Captain Miles, 49.

Stanton, Edwin M., $381,4.0$.

Stanwix, Ft., seizure of, I 72.

Stark, General John, I 7 I.

"Star-Spangled Banner," $27+$.

State sovereignty, I90, 204-205, $245^{-246}, 303-304,376, \quad 379^{-}$ 380,447 .

States: admission of new, 220-22I, $334,534 n$.

constitutions and governments of, I60-I $61,328,53+n ., 55 \mathrm{I}$.

first organized, i 60 .

local governments of, 328 .

political and social changes in, $22 \mathrm{I}-225,320^{-}-320,55 \mathrm{I}, 533^{-}$ 5.34, 541 .

position of, under Confederation, I90-19I, I99. 
States: reconstruction of southern, 432-439.

relation of, to nation, $205,447^{-}$ 448 .

statistics of, at present, Appendix, Table V.

Steamboats, 31 7, 31 S, 32 I.

Steel trust, $55 \mathrm{I}$; see also Iron.

Stephens, Alexander H., 375, 376, 377.

Steuben, Baron, I63, I 76 .

Stevens, Thaddeus, 434 (portrait).

Stevenson's engine, 3 I 9.

Stocks, punishment by, i 6 .

Stockton, Commodore, 346.

Stone River, battle of, 4 I I.

Stony Point, capture of, 178 .

Stowe's Uncle Tom's Cabin, 354 .

"Strict Construction," see Constitution.

Strikes, $559-562$.

Stump speaking, 312 .

Stuyvesant, Governor Peter, 67, 68 .

Subsidies, proposed ship, 556-557.

Suffrage: in colonies, 52, 56, 77 , I 23,144 .

in England, I 43 .

movement toward universal, 223, $327,328,331,439$; map of, 327 .

recent restrictions on, 438, 439, $577-578$.

woman, 572 .

Sugar Act $\left(1_{7} 64\right)$, I $_{3} 8-139$.

Sullivan, General John, I68.

Sulzer, Governor, $533 n$.

Sumner, Charles, 359 n., 434. portrait of, 359 .

Sumter, Ft., $375,3 S_{1}-3 S_{2}, 396$.

Sumter, General Thomas, 179.

Superstition, I 6 .

Supreme Court: chief justices of, Appendix, Table IV.

creation of, 207, 2I 4.

during war and reconstruction, $395,434,435,446,449,450$. early decisions of, $2 \mathrm{I}_{4}, 28 \mathrm{O}, 2 \mathrm{SI}$, 361.

photograph of, 536 .

recent decisions of, 476, 479, 507, 553.

Taft appointments, 537 .

Surplus, distribution of, 3 IO.

Survey of public lands, 326 .

Swedes in America, 67.
"Swinging round the circle," Johnson's, 439.

TAFT, William H., $534-537$ and $n$., 538 .

portrait of, 535 .

Talleyrand (French minister), 254

Tallmadge Amendment, 285 .

Tammany, 300, 442.

Taney, Roger B., C. J.. 309, 36r.

Tariff: Board, 544, n. 2.

changes, 455, (I $882-$ I 888 ) 474.

compromise tariff ( 1833 ), 474 .

Custom Court of Appeal, 544.

Dingley tariff ( $\mathrm{I}_{97}$ ), 478 ,

double tariff, $544 n$.

earliest, ( (789) 212, ( (1812) 279,

(I 8 I6) 278-279, (I 824$) \quad 304$,

(I 828$) 304-305,($ I 832$) \quad 305$,

( 1842$) 324$.

general, 494 .

Gorman-Wilson tariff (I894), 478 .

McKinley tariff (I890), 476.

Morrill tariff (I86I), 39I, 393.

Payne-Aldrich tariff, 542 .

proposed (Confederation), I9I.

tariff in politics (1880- 1892 ), 464 , $465,475,476$.

Underwood tariff, 544 .

Walker tariff, (I846) 325, ( 1857 ) 325 .

war tariffs (1 862-1864), 393.

Tariffs, special, for colonies, 5 I 2 .

Tarleton, Colonel, i $8 \mathrm{I}$.

Taxation: early national taxes, 2 I 2 , $235^{-236,265 .}$

England's dispute with colonies over, I35, I39-143, I44-146, I 47 -I 48 .

since I $860,393,454-455,502$.

see Tariff, and under names of different kinds of taxes.

Taylor, President Zachary, 345, 348, $349,350,352$.

Tea, tax on, I $47^{-1} 48$.

Teachers, colonial, II4.

Tecumseh, I 7, 269, 27 I.

Telegraph, electric, 322-323.

marine, 323.

Telephone, 568 .

Tennessee: I96, 220, 284, 435, 438 . Civil War in, 399-404, 4II, 418419.

map of (IS62), 403.

Tennessee River, 399-404. 
Tenure of Office Act (I867), 440, $470-471$.

Territorial changes before ${ }_{1} 7 \delta_{3}$, 67-68, 90, 100.

Territorial growth since $\mathrm{I}_{7} 8_{3} ;$ map between 508 and 509 .

Alaska (i S67), 509 .

boundaries (I $\left.78_{3}\right), \quad$ I $8_{5}$ (map) 313-314, 33I.

California, etc. (1 $8+8), 3+7$; map of, 345 .

Floridas (1 795-1 821 ), 288-289.

General, 331-332, 363, 575 .

Hawaii, 486 .

Louisiana (1803), 253-256; map of, 255 .

Oregon (I 846), 343-344.

Philippines, Porto Rico, etc. ( 1898 ), 502, 505, 506 .

Samoa (i 899 ), $48_{5}$.

Texas ( $18+5$ ), 3+0-343; map of, $3+4$.

Territories : government of, 105-106, 508 .

present statistics of, Appendix. Table VII.

slavery in, see Slavery.

Texas: controversy over, 256, 299 , $341,343,344,350,35^{2}$.

state of, $332,334,439,552$.

Texas i's. White, 344 .

Thames, battle of, $27 \mathrm{I}$.

Thomas, General George H.. +02, + I 9.

Three-fift hs compromise, 202.

Ticonderoga, Ft., I 55-157, I 7 I.

Tilden, Samuel J., 443, 4.45-447. portrait of, 445 .

Tippecanoe, battle of, 260.

"Tippecanoe and Tyler too," 313

Tobacco: cultivation of, 42 , IIO.

regulations about, 64,74, II I, 132 . trust, 555 .

use of, as currency, I13, I30.

Toleration Act of $\mathrm{I} 649$ (Md.), 6I.

Tonnage Act, 2 I 2.

Tordesillas, treaty of, 27 .

Tories, see Loyalists.

Toscanelli, 24 . map of, 24 .

Towns, New England, 56, I 22.

Townshend, Charles, 137, 144, 145 .

Townshend Acts (1767), I44-146.

Trade, see Commerce.

Trade routes with East before 1492, I9-20.

map of, 20 .
Trafalgar, battle of, 260 .

Transportation, see Roads, Canals, Steamboats, Railways.

Travel, I 2 I-122, $228-229,317-322$.

Treasury, department of, 2 I 3 .

Treasury notes, see Paper money.

Treaty: Aix-la-Chapelle (France) ( 748$), 94$.

Arbitration (1 897$), \quad(1903-1905)$, 500-510.

Chinese (1 $\left.869^{-1} 894\right), 562 \mathrm{n}$.

Clayton-Bulwer (England), 5105 I I.

Colombian (I903), 5 I I.

Cuban reciprocity (1903), 517 .

Erskine (England) ( 1 Sog), $26_{3}$.

Florida (Spain) ( I $89 \mathrm{I}-\mathrm{I} 82 \mathrm{I}), 289$; see map, 255.

Guadalupe-Hidalgo

(Mexico) ( 1848 ), $3+7$; map of, 345 .

Hawaiian (1 876$), \quad(1893), 486$; map of, 486 .

Hay-Pauncefote (Fngland) (I90I), $5 \mathrm{II}, 5 \mathrm{It}$

Jay (England), 240-24I.

Louisiana (France) ( 1803 ), 254256 ; map of, 255 .

of alliance with France (1778), I 7 - 75 .

of Ghent (England) (I $\mathrm{SI}_{4}$ ), 274275.

of Ryswick (France) (r607), oo.

of San Il tefonso (France and Spain), 253.

of Washington (England) ( 1870 ), ${ }_{4} S_{+}$and $n$.

of Westminster (Holland) (I675), 68.

of I 800 (France), 244.

Paris (France) ( 763 ), 99-100, map opp. 100.

Paris (Spain) ( 1898 ), 505; see map opp. 505 .

Paris $\left(\mathrm{I}_{7} \delta_{3}\right)$ (England), $\mathbf{1} 8_{3}-\mathbf{1} 86$, map opp. 185 .

Pinckney's (Spain) (I 795), 252.

Texan annexation (IS44), 34I ; map of, 344 .

Utrecht (France) (I7 I3), 90, map opp. 90 .

Webster-Ashburton (I $8+2), 313^{-}$ 3It; map, 3I.t.

with Panama (190.3), 5II; map of, 513 .

Trent, affair, 390-39I. 
Trenton, battle of, ros.

Trevett as. Ileeden ( 17 So), ros.

Trusts: control of. 5.40 .

"money trust," 5.40 .

organization of, 550,551 and $n, I$ and $:$.

see also Railwats.

Turgot (French minister), 17.8.

Turner s insurrection, .3.5.

Tweed king, Hz-4ti: cartoon of. t+3.

Tyler, President John, 300, 312, 31 itis.

"Tyramny of Andros," so.

Cnele Tom's Cabin. 35.4 .

luconstitutional liws, 302, 450 n.. $+7 i$.

" Endersround railroad," 35.

Enderwood Tarift, 5.4.

Unemployment. 5is.

Cnion: Albany plan of, o7-os.

during Revolutionary peried, $1+1$. $147,1+0-150,157$.

under the Confederation, roo-ror. 100.

under Constitution, see Nation.

Enited states, se' Comstitution. Congress, Nittion, President. supreme Court, States, ete.

University of Pennsylyamia, r 20.

linwritten constitution, 2:31, 440, 577.

Ltah. $50,312.572$.

Etrecht, treaty of $(1713), 00$.

Vica, Cabeza de. it.

Vallandigham, C. L., +20 .

Villey Forge, 171,$1 ; 0$.

Van Buren, President Martin. zos,

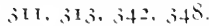

portrait of. $\$ 1$.

Vancouver, explorations of. 3.4.

Venezuclan boundary controwersy. $48 S-480$

Venice, trade of, ro, zo.

Vera Cruz, Mexico, ito.

Vergennes (French minister), i7. ist.

Vermont, 221.

Verrazano, G. da, 32.

Vespucius, Americus, 20.

Vetoes, presidential, sos, 4.37, 4.30. 40.

Vickshurg, campaisn against, fiofIS: map of $f 17$.
Vincennes, 175.

Virsinia: ("ivil Mar in. 3st. 40,$+11,+22+23+424-425$. colonial conditions in, 107, 110, $11,3,110$.

colony of, $30,40-4,7,3-75,05,1,30$. during Revolution and Confederation, 100, 104, 181, 182. 18. (1), $10.3,10.4$.

later state of, $200,20 \%, 200,240$, 4.5. 4.50, 4.42.

map of $(1 S 01-1505), 400$.

Virginia plan of union, 201.

lirsinius, fos.

Virtual representation, $1+3$.

Voltaire, quoted, 7 .

Voters, set suffirage.

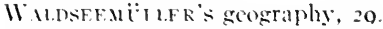

Walker, Tariff (1Sfo), 325.

II alpele, Ilorace, 134, 1,30.

Wages. $5454 ., 57$.

IVar: (Civil, sio tze).

Indian. see under Indians.

Revolutionary, $15+1$ 心2.

sccond with England. 200-275.

with french, so-00, 04-100.

with Mexico, $3+4^{-} 3+7$.

with spain, fo+-504.

sec also under separate names.

IVar department, defects of, 502-504.

"War Hawks," Clay"s, zoo.

Was shingt on: Ft., 108.

map of (1St), 272 .

state of 572 .

treity of $\left(1 s_{7}\right), 484$.

Washington, city of : creation of, $2.34^{-2.35}$.

capture of, $27.3-274$.

defense of in Civil II:ar, 3ist. 405 407. tos. tio. tit.

IVashingtom, (ieorge: portrait of. zII.

character of, $10,3,210$.

in comvention of 1787,201 .

military leader, 05, 150, 107-171, $170,170,182$.

president, 210, 21, 21, 21, 23.3-243.

Wiate rloo, battle of, 270,278 .

Wiane, General Anthony, 17, 178, 220 .

Wralth, distribution of, 57.3 .

Webster, Damiel, 270, 30,3, 313, 331, $3.5 \mathrm{t}$.

port rait of. $35 \mathrm{x}$. 
Webster: views of, on union, 303 $304,35 \mathrm{I}-352$.

Webster-1-bburton treaty (1 $8+2)$, $313-314$.

West, the: agriculture in, $4.5^{8-460}$. Chinese in, $56,2 \mathrm{n}$.

(ivil llar in, 300-105, $4: t, 410$.

Clark's conquest of, 178 .

remocracy in, $326-328$.

disputes over navigation of $\mathrm{Mi}$ sissippi in, 16f) $197,252-25 \%$.

early settlement of $10,0,2$ Ir, -220 , $281-282$.

free silver movement in, $480-4 \times 2$. government of territory in, $195^{-}$ Ig6, 220.

importance of, $256,28.3-28.4,482$.

internal improvement in, $282-28,3$, $32 \%$.

land cessions in, 19.3-195.

legislation in. $328-320$.

mining in, $349,457-4.5 \%$.

Normons in, $56,3 n$.

problems in ( $17.5(9), 2.32$.

public lands in, see Lands, public.

railway problems of, $4^{(j 0-4 t}+3$.

settlements excluded from, 100 .

slavery conteoversies in, $28+258$, $3+1-3+3,3+7-361$.

states formed in, $221,3.34$.

strikes in, 560 .

territorial acquisitions in, see Territorial growth.

transportation in, $317^{-3} 32$.

war in $(1812-1814), 270-271$.

West Indies: English, trade with, IJ I, 1.3.3, I.39, I98, 241 .

French, 100, $240,258$.

Spanish, 100, 197; see also Cuba and Syain.

West Point, 1 79-180.

West Virginia, 384, 433 .

Weyler, General, 495, 496.
Whiz:, Engli-h, 137, 150.

Whio- see Parties.

Whisky in-urrection, 235 .

Whisky King, $4+5$.

White, (F) vernor, 37.

White Pains, battle of, if 68 .

Whitman, Rev. Marcus, $3+4$.

Whitney's cotton gin, 222.

Wildernes, battles in, 422 .

William IJI of England, 81.

IVilliam and Nary College, I 19.

Milliam: Rogerer, 5.3-5.5.

portrait of , 54.

Wilmington, N.C., 380, +10-720.

Wilmot P'roviss, $3+7-3+8$.

Winthrop, Governor John, 51.

Wilesn, James, 202 (portrait).

Wilson, Woodrow, quoted, 394.

portrait, 2.

elerted to presidency, 5.38 .

chararter and policies, $5+\mathrm{I}$ and $n$.

party and busines prolicies, 542 .

II ilsoll (sorman) tariff I $89+4), 477$.

Wil-r, W. H., quoted, $400 \mathrm{n}$.

Wioronsin, 3it.

Wit heraft, $116,117$.

Wolfe, Cieneral James, 93 .

Wroman legal position of, 329, 571 .

Woman suffrage, 571 .

Writs of assistance, $134-135,145$.

Wyoming, 572 .

Wyoming Valley, 7.3, 178.

"X.Y.Z." letters, 244.

Yate College, I 20.

"Yazos claims," 195.

Yeardley, Governor, 43.

York, Duke of, see James II.

Yorktown, capture of, 182, 108.

Yuan Shi Kai, 520.

Zenger case (free press), I 20. 


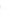


THE following pages contain advertisements of a few of the Macmillan books on kindred subjects. 


\title{
American Government
}

\section{TEXT-BOOK FOR SECONDARY SCHOOLS}

\author{
By ROSCOE LEWIS ASHLEY, A.M.
}

\author{
Author of "The American Federal State""
}

nlustrated Cloth I2mo $\$ 1.00$ net

- In this wels-considered manual we have a clear and succinct account or the character and functions of the American Government; its development, its inter-relations, its limitations, its influence upon the pecple, and its demands upon them as citizens are clearly described. It is well adapted for use in secondary schocls, and would be useful in any consideraticn of the principles of ctizenship." - Fournal of Education.

"The book, while intencled as a text-book, is thoroughly interesting, as well as instructive, and will do as well for general reading as for class work. It is especially valuable in the number of its references." - St. Paui Dispaich.

«I have examined the book and am frank to say that it is the most com. plete book on its subject that I have yet examinel for class work. The maps, illustrations, and appended bibliography are very commendable features. As this is the text arlopted by the West High School, it will be the text in use here." - E. P. Reynolds, Principal East High School, Jackson, Mich.

"I have examined the book with great interest, and think that for scope, clearness, and general interest it can hardly be surpassed The young man or woman whe studies this book cannot fail to be a better American citizen after having completed the same." - Charles S. Chapman, Vice-Chairman Boara of Education, Waterbury, Conn.

- In my opinion, it is the most comprehensive and concise work wit which I am acquainted." - Miss L. Epps, High School, Athol, Mass.

\section{THE MACMILLAN COMPANY}

66 FIFTH AVENUE, NEW YORK 


\title{
American Government and Politics
}

\author{
BY CHARLES A. BEARD \\ Associate Professor of Politics in Columbia University
}

New and Revised Edition, Cloth, crown 8vo, index, $\$ 2.10$ net

A work designed primarily for college students, but of considerable interest to the general reader. Full attention has been paid to topics that have been forced into public attention by the political conditions of the present time. A special feature is the page references made to the author's "Readings in American Government and Politics."

In this revised erlition the author has recorded the leading changes of the last four years, with special emphasis on local tendencies and general principles.

"The great merit of the work is its absence of dogmatism. It gives exactly what it pretends to give, a clear, scholariy review, first of the history of our political system and secondly of its practical operation. . . The book can be highly recommended." - The Nation.

"The citizen who gives it a careful reading will arise from it a better citizen. ... . It is, in brief, a truly notable bouk, and one that was long needed." - Baltimore Sun.

\section{Readings in American Government and Politics}

New and Revised Edition, Cloth, crown 8vo, $\$ 1.90$ net

A collection of interesting material illustrative of the different periods in the history of the United States, prepared for those students who desire to study source writings.

The author has brought the work abreast of current questions by adding extracts from the party platform of 1912 an 1 selections illustrating presidential preference primaries, changes in the procedure of the House of Representatives, the recall, and the recall of judicial decisions. The Constitution, with the latest amendments, has been included.

"The volume will be useful as a textbook and convenient for reference by those who wish to have an intelligent conception of uur political life and histury." - Education.

"The book affords a very valuable adjunct to the work of instruction in American history and political science." - The Dial.

"The work is well planned and well executed." - The Nation.

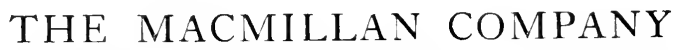

Publishers

64-66 Fifth Avenue

New York 


\title{
A NEW HIGH SCHOOL TEXT IN ECONOMICS
}

\section{Elements of Economics for High Schools}

\author{
By HENRY REED BURCH, PH.D.
}

Director of the School of Commerce in the West Philadelphia High School for Buys

AND

SCOTT NEARING, Pн.D.

Instructor in Economics in the University of Pennsylvania, Philadelphia

Cloth, $12 \mathrm{mo}, x v i+363$ pages, $\$ 1.00$ net

This book is written for the high school course in Economics from the high school standpoint. It is live, concrete, and suggestive, and it will appeal to the high school student as no book prepared from a different point of view can do.

The Burch and Nearing text is, moreover, thoroughly American and thoroughly up-to-date. Here we find a live treatment of such vital questions as the conservation of natural resources, the problems of immigration, the trust and the railroal, the effects of monopoly on price, and finally, the various experiments and programs of economic reform embracing such movements as profit-sharing, government regulation, and the socialization of land and capital.

While economic principles are given proper $t$ mphasis and careful treatment, the beginner is not lost in a maze of theory. The book is filled with living realities.

Professor J. Lynn Barnard of the School of Pedagogy, Philadelphia, says : "I consider this book remarkable for its clearness, simplicity, and inclusiveness." This clearness of thought and simplicity of expression are apparent even in the discussion of such alstract phases of the subject as value, price, and the theories of distribution. Throughout the whole book a sund and thorough comprehension of economic principles has been combinel with such simplicity of treatment as to fit the work especially for high school conditions.

From a pedagogical standpoint, a distinctive and almirable feature of this text book is the outline precerling each chapter and the marginal notes throughout the chapter corresponaling to the topics in the outline. It is difficult to conceive of a method of presentation more conducive to logical study, clearness of thought, and ease of comprehension.

\section{THE MACMILLAN COMPANY




\section{High School Texts in History}

\section{Medieval and Modern History}

By George Burton Adams. Professor of History in Yale University: Cloth. I2mo. Illustrated. xxviii +474 pages. \$1.10 net

\section{European History}

By George Burton Adays. Half leather. I2mo. Illustrated xxviii +577 pages. \$I.40 net.

\section{The Growth of the French Nation}

By George Burton Adans. Cloth. i2mo. Illustrated. ix + 350 pages. \$1.25 net.

\section{A History of England}

By Katharine Comax, Ph.B., Professor of Economics in Wellesley College, and Elizabeth Kimball Kexdall, M.A., Professor of History in Wellesley College. Cloth. I 2mo. Illustrated. xvi + $50 \mathrm{I}$ pages. \$I.25 net.

\section{Source-Book of English History}

Edited by Elizabeth Kimball Keviall, M.A., Professor of History in Wellesley College. Cloth. I2mo. xxii $+4 \delta_{3}$ pages. So cents net.

\section{THE MACMILLAN COMPANY}

64-66 Fifth Avenue, Now York

BOSTON CHICAGO DALLAS SAN FRANCISCO 



LIBRARY OF CONGRESS

|||||||||||||||||||||||||| 00114480617 